\title{
MULTILAYER BIODEGRADABLE ACTIVE FILMS BASED ON PHBV FOR FOOD PACKAGING
}

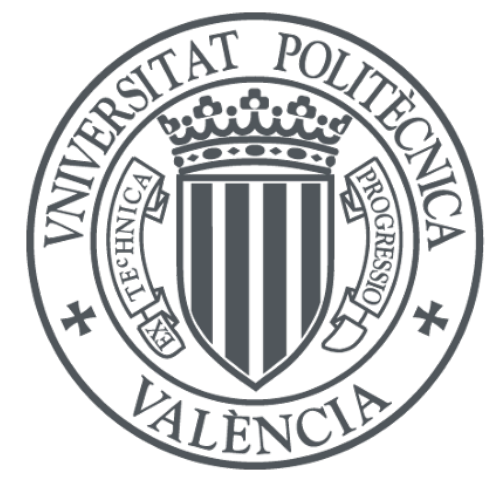

\section{UNIVERSITAT POLITÈCNICA DE VALÈNCIA}

Instituto Universitario de Ingeniería de Alimentos

para el Desarrollo

Raquel Requena Peris

Supervisors:

Amparo Chiralt Boix María Vargas Colás

Valencia, September 2018 


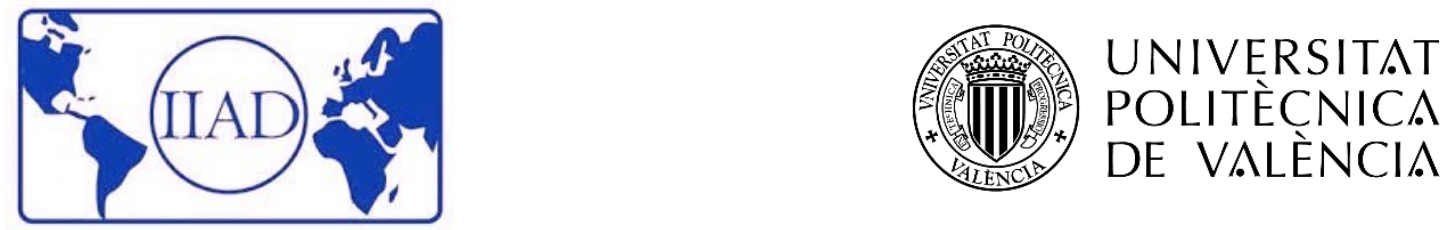

Dra. Amparo Chiralt Boix, Catedrática de Universidad, perteneciente al Departamento de Tecnología de Alimentos de la Universitat Politècnica de València.

Dra. Maria Vargas Colás, Profesora Titular de Universidad, perteneciente al Departamento de Tecnología de Alimentos de la Universitat Politècnica de València.

Hacen constar que:

La memoria titulada "MULTILAYER BIODEGRADABLE ACTIVE FILMS BASED ON PHBV FOR FOOD PACKAGING" que presenta Da Raquel Requena Peris para optar al grado de Doctor por la Universitat Politècnica de València, ha sido realizada en el Instituto de Ingeniería de Alimentos para el Desarrollo (IUIAD - UPV) bajo su dirección y que reúne las condiciones para ser defendida por su autora.

Valencia, September 2018

Fdo. Amparo Chiralt Boix

Fdo. María Vargas Colás 

A mí famílía, Y en especial a jorge 



\section{ACKNOWLEDGEMENTS}

Hace cuatro años, antes de empezar me preguntaba si esto sería para mí y sín duda ahora sé que lo es, la investigación me ha cautivado. Termina una etapa llena de experiencias y recuerdos, pero me llevo conmigo todo lo aprendido y sobre todo personas maravillosas que han ido apareciendo a lo largo del camino.

A Amparo, gracias por darme la oportunidad de formar parte de este maravilloso grupo de investigación y sobre todo por compartir conmigo todos tus conocimientos. Siempre serás un ejemplo a seguir en cuanto a tu dedicación e infinito entusiasmo por la investigación.

A María, gracias por confiar en mí y apoyarme a la hora de adentrarme en el mundo de la investigación. Siempre atenta y cercana.

A Fran gracias por dejarme formar parte de tu grupo de investigación y por tu hospitalidad durante mi estancia en Estocolmo. A Amparo Jiménez gracias por toda tu ayuda en el lab durante mi estancia en $K T H$, pero gracias también por ser una amiga.

A Alberto, gracias por acogerme al llegar y compartir conmigo todos tus conocimientos, sin ti el comienzo hubiese sido diferente. Pero sobretodo, gracias por estar ahí cuando lo he necesitado durante toda la tesis a pesar de que nuestros caminos se separaran pronto. Espero que siga siendo así por muchos años más.

A mis chicas del lab Ángela, Amalia, Anna, Emma, Susana, sin vosotras no hubiese sido tan divertido. Gracias por esos buenos momentos dentro y fuera del laboratorio, nunca los olvidaré. A Emma también, gracias por tu paciencia y toda tu ayuda con la tesis, eres un sol. $Y$ en especial a Olga y Justine, gracias por todo vuestro apoyo y vuestra amistad. Independientemente de lo que nos depare el futuro, siempre habrá tiempo para volver a estar juntas allá donde estemos. También a vosotras Alina, Caro, Johana, Mayra, Sofía, que a pesar de llegar más tarde también dejáis un bonito recuerdo.

A mis amigos y en especial a Paula, Carlos, Euge y Lidia, que aunque la mayoría de las veces no entiendan lo que les explico cuando me preguntan que hago en el trabajo sé que están orgullosos de que haya llegado hasta aquí.

A mi familia, quien ha hecho posible que esté hoy aquí siendo la persona que soy, sin ellos no hubiera sido posible. Gracias por todo vuestro apoyo incondicional. $Y$ en especial a mi madre, gracias por haber estado siempre ahí ayudándome y animándome cuando más lo he necesitado, eres una madre ejemplar. 
Por último, a Jorge. Sin tu apoyo y comprensión nada hubiese sido igual. Gracias por estar siempre ahí, por confiar en mi cuando yo he dudado de mi misma y por saber siempre que decir. Las cosas no han sido fáciles, tu allí y yo aquí, después yo allí y tu aquí, y ahora otra vez nos separamos, pero por muy grande que sea la distancia nadie nos separará. 
Biodegradable active films based on PHBV, combined with other biopolymers (PLA and starch) and different antimicrobial compounds, such as essential oil compounds, were developed and characterized as to their functional and structural properties to obtain materials that better meet food packaging requirements. Plasticization of PHBV was analysed by using five different biodegradable compounds to enhance the PHBV mechanical performance. Likewise, different active compounds (oregano and clove essential oils, as well as their respective main compounds, carvacrol (CA) and eugenol (EU)) were incorporated into PHBV bilayer films by spraying the active compounds between two thermo-compressed PHBV monolayers, and their antimicrobial properties and release kinetics in food simulants were analysed. The potential synergy between different essential oil compounds and their applications to different food real systems when incorporated into PHBV films was also analysed. Multilayer antimicrobial films combining polar (starch) and less-polar (polyester) sheets, incorporating carvacrol, either by spraying it between both layers or incorporating it in the polyester casting solutions, were developed to optimise the material functionality (barrier and mechanical properties), together with the active release kinetics and antimicrobial action. Bioactive xylans and cellulosic fractions from rice husk by-product, which are useful for food packaging applications, were obtained by using an eco-friendlier valorization process based on sequential subcritical water extraction.

The used plasticizers led to apparently homogeneous PHBV-based matrices, as supported by DSC analyses, but crystallization of stearic acid in the films occurred. Although the addition of polyethylene glycol (PEG) of different molecular weight and lauric acid significantly decreased the stiffness and the resistance to break of PHBV films, only PEG1000 yielded more extensible films. Nonetheless, additional strategies would be required to adapt PHBV mechanical properties to certain packaging requirements.

Spraying active compounds at the interface of both PHBV monolayers produced antimicrobial films with appropriate tensile, optical and water vapour barrier properties, with good compound miscibility and thermal stability. The release of the active ingredients from the films was adequate to control the growth of $E$. coli and L. innocua in culture media, which were more sensitive to oregano essential oil and its main compound, carvacrol. Both actives, CA and EU diffused through the polymer layers and were effectively released into different food simulants. The release rate was enhanced when the polarity of aqueous systems decreased, but it fell markedly in fatty systems.

The most remarkable synergistic effect for the essential oil compounds was observed for $\mathrm{CA} /$ cinnamaldehyde blends for both bacteria but using different compound ratios. Thus, the 
obtained results allowed for the optimization of the dose of active compounds used for food application, thus minimizing their sensory impact. PHBV films with active essential oil compounds were highly effective against $L$. innocua and $E$. coli in the in vitro tests, but they were much less effective in the foods tested. Likewise, no correlation between the amount of active that migrated to the food and the antibacterial effect was observed in the different matrices, which reflected that many compositional factors affect the availability of the active compounds to exert their antibacterial action on a specific food composition.

The 75:25 PLA-PHBV formulation with PEG1000 exhibited the best properties in terms of extensibility and water vapour permeability and, thus it was used to be the carrier of carvacrol by casting and to develop bilayer assemblies with starch sheets. Incorporating CA by spraying it between the polyester and starch sheets was not effective at retaining this active compound in the bilayers. However, the incorporation of CA into casted polyester films was highly effective at providing practically total CA retention, which led to a notable antimicrobial activity. Moreover, these active bilayers exhibited highly improved tensile and water vapour barrier capacity with respect to the starch monolayer.

The rice husk valorization, based on sequential subcritical water extraction, allowed for obtaining better preserved hemicellulose fractions, with antioxidant and antibacterial activity, useful as additives for food or food packaging applications, and cellulosic reinforcing agents to develop biocomposites with enhanced mechanical performance. 


\section{RESUMEN}

Se desarrollaron películas biodegradables activas a base de PHBV, combinadas con otros biopolímeros (PLA y almidón) y diferentes compuestos antimicrobianos, tales como compuestos de aceites esenciales, las cuales se caracterizaron en cuanto a sus propiedades funcionales y estructurales a fin de obtener materiales que satisfagan mejor los requisitos de envasado de alimentos. La plastificación del PHBV se llevó a cabo mediante el uso de cinco compuestos diferentes con el objetivo de mejorar el rendimiento mecánico de los films a base de PHBV. Asimismo, se incorporaron diferentes compuestos activos (aceite esencial de orégano y clavo, así como sus respectivos compuestos mayoritarios, carvacrol (CA) y eugenol (EU)) en películas bicapa de PHBV pulverizando los compuestos activos entre dos monocapas de PHBV obtenidas por termocompresión y se determinarion sus propiedades antimicrobianas, asi como la cinética de liberación en simulantes alimentarios. También se analizó la potencial sinergia entre diferentes compuestos de aceites esenciales, asi como sus aplicaciones a diferentes alimentos cuando se incorporan en películas bicapa de PHBV. Se desarrollaron películas antimicrobianas multicapa donde se combinaron láminas polares (almidón) y otra menos polar (poliéster) y carvacrol, ya sea pulverizado entre ambas capas o incorporado en la solución filmogénica de poliésteres, a fin de optimizar la funcionalidad del material (propiedades mecánicas y barrera), asi como la cinética de liberación del activo y su acción antimicrobiana. El proceso de valorización de la cáscarilla de arroz, basado en extracción secuencial con agua subcrítica, permitió obtener xilanos bioactivos y fracciones celulósicas, los cuales presentan potenciales aplicaciones en el envasado de alimentos.

Los plastificantes utilizados dieron lugar a matrices de PHBV aparentemente homogéneas, tal como demuestran los análisis de DSC, aunque el acido esteárico tendió a cristalizar en las películas. Pese a que la adición de polietilenglicol (PEG) de diferente peso molecular o ácido láurico disminuyó significativamente la rigidez y la resistencia de las películas de PHBV, solo el PEG1000 dio lugar a películas más extensibles. No obstante, estrategias adicionales fueron necesarias a fin de adaptar las propiedades mecánicas de los films de PHBV a ciertos requisitos de envasado.

La pulverización de compuestos activos en la interfaz de ambas monocapas de PHBV generó películas antimicrobianas con adecuadas propiedades tanto mecánicas, como ópticas y de barrera al vapor de agua. Además, la liberación de los activos desde las películas permitió controlar el crecimiento de Escherichia coli y Listeria innocua en medio de cultivo liquido, las cuales fueron más sensibles al aceite esencial de orégano y su principal compuesto, carvacrol. Ambos activos, CA y EU, difundieron a través de las capas de PHBV y se liberaron de manera efectiva en diferentes simulantes alimentarios. En este sentido, la tasa de liberación mejoró 
cuando disminuyó la polaridad de los sistemas acuosos, pero disminuyó notablemente en los sistemas grasos.

El efecto sinérgico más notable para los compuestos de aceites esenciales se observó para las mezclas CA/cinnamaldehído para ambas bacterias, pero usando diferentes proporciones de compuestos. De esta forma, los resultados obtenidos permitieron la optimización de la dosis de compuestos activos utilizados para la aplicación de alimentos, minimizando así su impacto sensorial. Las películas de PHBV con compuestos activos de aceites esenciales fueron altamente efectivas contra L. innocua y E. coli en las pruebas in vitro, pero fueron mucho menos activas en los alimentos probados. Asimismo, no se observó ninguna correlación entre la cantidad de activo que migró desde el film al alimento y el efecto antibacteriano en las diferentes matrices, lo que refleja que existen numerosos factores composicionales que afectan a la disponibilidad de los compuestos activos a la hora de ejercer su acción antibacteriana sobre un alimento de composición determinada.

La formulación 75:25 PLA-PHBV con PEG1000 exhibió las mejores propiedades en términos de extensibilidad y permeabilidad al vapor de agua y, por lo tanto, se utilizó como soporte del carvacrol mediante casting, asi como para desarrollar estructuras bicapa con láminas de almidón. La incorporación de CA pulverizarlo entre las láminas de poliéster y almidón no fue eficaz a la hora de retener el compuesto activo en las bicapas. Sin embargo, la incorporación de CA en películas de poliésteres mediante casting fue altamente efectiva, proporcionando una retención de $C A$ prácticamente total, lo que condujo a una notable actividad antimicrobiana. Además, estas bicapas activas exhibieron una capacidad de barrera al vapor de agua y a la tracción altamente mejoradas con respecto a la monocapa de almidón.

La valorización de la cáscara de arroz, basada en la extracción secuencial con agua subcrítica, permitió obtener fracciones hemicelulósicas mejor conservadas, con actividad antioxidante y antibacteriana, útiles como aditivos para aplicaciones de envasado de alimentos o en la formulación de alimentos, así como agentes de refuerzo a base de celulosa para desarrollar biocomposites con un rendimiento mecánico mejorado. 


\section{RESUM}

Es van desenvolupar pel-lícules biodegradables actives a base de PHBV, combinades amb altres biopolímers (PLA i midó) i diferents compostos antimicrobians, com ara compostos d'olis essencials, les quals es van caracteritzar quant a les seues propietats funcionals i estructurals a fi d'obtindre materials que complisquen millor els requisits d'envasament d'aliments. La plastificació del PHBV es va dur a terme per mitjà de l'ús de cinc compostos diferents amb l'objectiu de millorar el rendiment mecànic dels films a base de PHBV. Així mateix, es van incorporar diferents compostos actius (oli essencial d'orenga i clau, així com els seus respectius compostos majoritaris, carvacrol (CA) i eugenol (EU)) en pel-lícules bicapa de PHBV polvoritzant els compostos actius entre dos monocapas de PHBV, obtingudes per termocompressió, i es determinaren les seues propietats antimicrobianes, així com la cinètica d'alliberament en simulants alimentaris. També es va analitzar la potencial sinergia entre diferents compostos d'olis essencials, així com les seues aplicacions a diferents aliments quan s'incorporen en pel-lícules bicapa de PHBV. Es van desenvolupar pel·lícules antimicrobianes multicapa on es combinaren làmines polars (midó) i altres menys polars (polièsters) i carvacrol, ja siga polvoritzat entre ambdós capes o incorporat en la solució filmogénica de polièsters, a fi d'optimitzar la funcionalitat del material (propietats mecàniques i barrera), així com la cinètica d'alliberament de l'actiu i la seua acció antimicrobiana. El procés de valoració de la corfeta d'arròs, basat en extracció seqüencial amb aigua subcrítica, va permetre obtindre xilans bioactius i fraccions cel-lulòsiques, els quals presenten potencials aplicacions en l'envasament d'aliments.

Els plastificants utilitzats van donar lloc a matrius de PHBV aparentment homogènies, tal com demostren els anàlisis de DSC, encara que l'àcid esteàric va tendir a cristal-litzar. A pesar que l'addició de polietilenglicol (PEG) de diferent pes molecular o àcid làuric va disminuir significativament la rigidesa i la resistència de les pel-lícules de PHBV, només PEG1000 va donar Iloc a pel-lícules més extensibles. No obstant això, estratègies addicionals varen ser necessàries a fi d'adaptar les propietats mecàniques dels films de PHBV a certs requisits d'envasament.

La polvorització de compostos actius a la interfase d'ambdós monocapes de PHBV va generar pel-lícules antimicrobianes amb adequades propietats tant mecàniques, com òptiques i de barrera al vapor d'aigua. L'alliberament dels actius des de les pel-lícules va permetre controlar el creixement d'Escherichia coli i Listeria innocua en assajos in vitro, les quals van ser més sensibles a l'oli essencial d'orenga i el seu principal compost, carvacrol. Ambdós actius, CA i EU, van difondre a través de les capes de PHBV i es van alliberar de manera efectiva en els diferents simulantes alimentaris. La taxa d'alliberament va millorar quan va disminuir la polaritat dels sistemes aquosos, però va disminuir notablement en els sistemes grassos. 
L'efecte sinèrgic més notable per als compostos d'olis essencials es va observar per a les mescles de CA/cinnamaldehído per a ambdós bacteris, però utilitzant diferents proporcions de compostos. D'esta manera, els resultats obtinguts van permetre l'optimització de la dosi de compostos actius utilitzats per a l'aplicació en aliments, minimitzant així el seu impacte sensorial. Les pel-lícules de PHBV amb compostos actius d'olis essencials van ser altament efectives front $L$. innocua i $E$. coli en les proves in vitro, però van ser molt menys efectives en els aliments provats. Així mateix, no es va observar cap correlació entre la quantitat d'actiu que va migrar des del film a l'aliment i l'efecte antibacterià en les diferents matrius, la qual cosa reflectix que hi ha molts factors composicionals que afecten la disponibilitat dels compostos actius per a exercir la seua acció antibacteriana sobre un aliment de composició determinada.

La formulació 75:25 PLA-PHBV amb PEG1000 va exhibir les millors propietats en termes d'extensibilitat i permeabilitat al vapor d'aigua i, per tant, es va utilitzar com a suport del carvacrol per mitjà de càsting, així com per a desenvolupar estructures bicapa amb làmines de midó. La incorporació de CA polvoritzat entre les làmines de polièsters i midó no va ser eficaç per a retindre el compost actiu en les bicapas. No obstant això, la incorporació de CA en pel-lícules de polièster per mitjà de càsting va ser altament efectiva, proporcionant una retenció de CA pràcticament total, la que va conduir a una notable activitat antimicrobiana. A més, estes bicapas actives van exhibir una capacitat de barrera al vapor d'aigua i a la tracció altament millorades respecte a la monocapa de midó.

La valoració de la corfa d'arròs, basada en l'extracció seqüencial amb aigua subcrítica, va permetre obtindre fraccions hemicelulósiques millor conservades, amb activitat antioxidant $\mathrm{i}$ antibacteriana, útils com a additius per a aplicacions d'envasament d'aliments o en la formulació d'aliments, així com agents de reforç a base de cel-lulosa per a obtindre biocomposites amb un rendiment mecànic millorat. 



\section{DISSERTATION OUTLINE}

This Doctoral Thesis was organized in five sections: Introduction, Objectives, Chapters, General Discussion and Conclusions. The Introduction section discusses the state of the art concerning the use of bioplastics in the food packaging area, focusing on the development of materials based on biopolymers, such as polyhydroxyalkanoates, poly(lactic) acid and starch. Different strategies aimed to improve functional properties of polyhydroxyalkanoates packaging materials, such as plasticizer addition, polymer blends, multilayer systems and composites, have also been reviewed in a book chapter entitled "Plastics from bacteria (polyhydroxyalkanoates)" in Sustainability of Plastic Materials. The properties of essential oils (EOs) and their main compounds, which were used as antimicrobial compounds in this study, have been examined when incorporated into biopolymer materials in a review entitled "Biopolymers carrying essential oils, or their compounds, for food antimicrobial packaging".

The Objective section presents the general and specific objectives of the Thesis. The obtained results were shown in four main Chapters, which were divided into seven scientific publications with the usual sections: introduction, material and methods, results and discussion and conclusions.

The most relevant results obtained in the different chapters were analysed together, from a global perspective, in the General Discussion section. Finally, the last section compiled the most relevant conclusions of the Thesis.

Of the different biodegradable polymers, polyhydroxyalkanoates (PHAs) are those gaining attention due to the broad chemical variety of their radicals, which provides PHAs with physical properties as good as the ones exhibited by conventional polymers. Nevertheless, PHAs show some drawbacks related with their use. Specifically, poly[(3-hydroxybutyrate)-co(3-hydroxyvalerate)] films are brittle, stiff, relatively permeable to oxygen and expensive. In this sense, different strategies such as the addition of plasticizers and/or active compounds, polymer blends, multilayer systems and composites can be implemented in order to enhance their functional properties as packaging materials

Thus, Chapter 1 deals with those strategies aimed to improve the functional properties of PHBV films. To improve the extensibility of PHBV films, plasticizing substances were incorporated and their effect on the film properties was analysed. In this sense, Chapter 1. I entitled "Effect of plasticizers on thermal and physical properties of compression-moulded poly[(3-hydroxybutyrate)-co-(3-hydroxyvalerate)] films" compares the neat and plasticized PHBV films with different substances, in terms of structural, thermal, optical, mechanical and barrier properties. Polyethylene glycol was the most effective at plasticizing PHBV films, and 
it was the only plasticizer that partially mitigated the ageing effects. Chapter $\mathbf{1}$. II entitled "Poly[(3-hydroxybutyrate)-co-(3-hydroxyvalerate)] active bilayer films obtained by compression moulding and applying essential oils at the interface" studies the effect of four active components (oregano essential oil, clove essential oil and their respective main compounds carvacrol and eugenol), sprayed at the interface between two layers of PHBV, on the resulting PHBV bilayer films in terms of their functional properties (tensile, barrier and optical properties, as well as thermal behaviour), and antimicrobial activity against Escherichia coli and Listeria innocua. Although the tensile properties of the films were not improved with respect to pure PHBV films by the addition of the active compounds, more transparent materials with better water vapour barrier capacity were obtained. Moreover, PHBV active films controlled the microbial growth of the two tested bacteria in in vitro tests. In order to predict the antimicrobial activity of these active films in foods, in Chapter 1. III, which was entitled "Release kinetics of carvacrol and eugenol from poly(hydroxybutyrate-cohydroxyvalerate) (PHBV) films for food packaging applications", the release kinetics of carvacrol and eugenol in food simulants of different polarity were analysed. The release rate increased when the polarity of aqueous simulants decreased, but it markedly fell in fatty systems.

Chapter $\mathbf{2}$ covers those studies related to the antimicrobial activity of EO and their application in real food systems. The concentrations of the EOs or their constituents that are required to inhibit bacterial growth in foods can modify the taste or exceed the acceptability of food products. In this sense, the potential synergistic activity of these EO compounds was considered as an alternative means of reducing the active doses needed to achieve antimicrobial effects in food. Thus, Chapter 2. IV entitled "Study of the potential synergistic antibacterial activity of essential oil components using the thiazolyl blue tetrazolium bromide (MTT) assay" analyses the potential interactions between carvacrol, eugenol, cinnamaldehyde, thymol and eucalyptol, which were used as antibacterial agents against Escherichia coli and Listeria innocua. In this sense, the minimum inhibitory concentration of each active compound and the fractional inhibitory concentration index for the binary combinations of essential oil compounds were determined by the MTT assay. The most remarkable synergistic effect was observed for carvacrol-cinnamaldehyde blends for both $E$. coli and $L$. innocua but using different compound ratios (1:0.1 and 0.5:4, respectively, for each bacteria). Nonetheless, significantly higher EO amounts are required to achieve similar antimicrobial effects when applied to food matrices, probably due to the interactions between the active compounds and different food components, which could limit their effectiveness as antimicrobials. Thus, in Chapter 2. V entitled "Eugenol and carvacrol migration from PHBV films and antibacterial action in different food matrices", the antibacterial effect of PHBV films with the two different actives was analysed in food matrices of different composition (cheese, chicken breast, pumpkin and melon). Moreover, the migration of carvacrol and eugenol in the different food matrices was determined to analyse the food matrix effect on the antimicrobial 
effectiveness of the film. There was no correlation between the antimicrobial activity and the migration of the active compounds, which reflects that many compositional factors affect the availability of the active compound to exert its antibacterial action in a specific food.

Developing multilayer structures where materials with complementary properties are combined in a multilayer assembly is also an interesting approach to overcome the shortcomings of PHBV films. In this sense, starch is widely available at low cost and provides biodegradable films with great oxygen barrier capacity, whereas PHBV films have good water vapour barrier and high tensile strength. Therefore, the combination of both biopolymers could offer packaging materials with interesting properties due to their complementary characteristics. However, their lack of compatibility made their blend difficult, since blends yield heterogeneous film structures, or they require compatibilizers, which can compromise their use for food applications. The starch-PHBV combination in bilayer assemblies was also challenging due to a limited adhesion between both layers. Thus, Chapter $\mathbf{3}$ deals with the improvement of the functionality of packaging films by obtaining multilayer films. On the basis of a greater adhesiveness between PLA and starch, in Chapter 3. VI entitled "Obtaining antimicrobial bilayer starch and polyester-blend films with carvacrol", PLA-PHBV blends previously optimized in terms of mechanical, barrier and thermal properties, were used to develop multilayer structures with starch sheets. Likewise, the incorporation of an active compound (carvacrol) has also been considered in order to obtain antimicrobial films. Two different approaches were analysed for carvacrol incorporation: spraying it between melt blended and compression moulded sheets or incorporating it into the chloroform polyester solution that is used to obtain polyester casted films. Incorporating carvacrol by spraying it between the polyester and starch sheets was not effective at retaining the compound in the bilayers. However, the incorporation of carvacrol into casted polyester films was highly effective at providing practically total carvacrol retention, which led to a notable antimicrobial activity. Moreover, these active bilayers exhibited highly improved tensile and water vapour barrier capacity with respect to the starch monolayer.

Alternative active agents to EOs have been considered in order to obtain active packaging materials without impact on the sensory profile of the packed foodstuffs. In this context, bioactive xylans obtained from lignocellulosic by-products can be a promising option. Thus, Chapter 4 covers the rice husk valorization for obtaining products useful in food packaging applications. Specifically, in Chapter 4. VII entitled "Valorization of rice husk into bioactive xylans and cellulose nanocrystals by using sequential subcritical water extraction", a greener process to obtain bioactive hemicelluloses and cellulose nanocrystals (CNCs) was proposed from the rice husk, by using sequential subcritical water extraction, bleaching and acid hydrolysis. The yields and properties of the obtained fractions were compared to those reached using a more conventional process, involving alkali treatment as the first process step. In this way, it was possible to fractionate polymeric hemicelluloses (xylans) with bioactive 
properties and to obtain CNCs useful as reinforcing agents, which can be used to develop packaging materials with enhanced functional characteristics. 


\section{DISSEMINATION OF THE RESULTS}

\section{INTERNATIONAL JOURNALS JCR}

\section{Published}

"Effect of plasticizers on thermal and physical properties of compression-moulded poly [(3hydroxybutyrate)-co-(3-hydroxyvalerate)] films". Raquel Requena; Alberto Jiménez, María Vargas; Amparo Chiralt. Polymer Testing (2016) 56, 45-53.

"Poly [(3-hydroxybutyrate)-co-(3-hydroxyvalerate)] active bilayer films obtained by compression moulding and applying essential oils at the interface." Raquel Requena; Alberto Jiménez; María Vargas; Amparo Chiralt. Polymer International (2016) 65, 883-891.

"Release kinetics of carvacrol and eugenol from poly(hydroxybutyrate-co-hydroxyvalerate) (PHBV) bilayer films for food packaging applications". Raquel Requena; María Vargas; Amparo Chiralt. European Polymer Journal (2017) 92, 185-193

"Obtaining antimicrobial bilayer starch and polyester-blend films with carvacrol". Raquel Requena; María Vargas; Amparo Chiralt. Food Hydrocolloids (2018) 83, 188-133.

Review. "Biopolymers carrying essential oils, or their compounds, for food antimicrobial packaging". Raquel Requena; Maria Vargas; Lorena Atarés; Amparo Chiralt. Current Organic Chemistry (2017) 21, 1-16

Chapter. "Food hydrocolloids as matrices for edible packaging applications". Alberto Jiménez; Raquel Requena; María Vargas; Lorena Atarés; Amparo Chiralt. Role of Materials Science in Food Bioengineering (2018) 263-299. Ed. Elsevier.

Chapter. "Plastics from bacteria (Polyhydroxyalkanoates).". Raquel Requena; María Vargas; Amparo Chiralt. Sustainability of Plastic Materials". Ed. DeGruyter publishing company. (Accepted).

\section{Submitted}

"Study of the potential synergistic antibacterial activity of essential oil components using the thiazolyl blue tetrazolium bromide (MTT) assay". Raquel Requena; María Vargas; Amparo Chiralt. Applied and Environmental Microbiology

"Eugenol and carvacrol migration from PHBV films and antibacterial action in different food matrices". Raquel Requena; María Vargas; Amparo Chiralt. Food Chemistry.

"Valorization of rice husks into bioactive xylans and cellulose nanocrystals by using sequential subcritical water extraction". Raquel Requena; Amparo Jiménez; Rosana Moriana; María Vargas; Amparo Chiralt; Francisco Vilaplana. Bioresources Technology. 


\section{COMMUNICATIONS IN INTERNATIONAL CONGRESSES}

Poster: "Physical properties of plasticized PHBV films". Raquel Requena; Alberto Jiménez; María Vargas; Amparo Chiralt. " 3 rd International meeting on Material/Bioproduct Interaction. MATBIM 2015" Zaragoza, Spain (2015).

Poster: "Incorporation of essential oils in PHBV bilayer films and study of their antimicrobial activity". Raquel Requena; Alberto Jiménez; María Vargas; Amparo Chiralt. " 5 th International Conference on Biobased and Biodegradable Polymers. BIOPOL-2015". San Sebastian, Spain (2015).

Poster: "Antimicrobial PHBV films with active compounds of essential oils". Raquel Requena; María Vargas; Amparo Chiralt. "2 ${ }^{\text {nd }}$ International \& $3^{\text {th }}$ National Student Congress of Food Science and Technology". Valencia, Spain (2016).

Oral communication: "Release kinetics of carvacrol from PHBV films for food packaging applications". Raquel Requena; María Vargas; Amparo Chiralt. "4 ${ }^{\text {th }}$ International ISEKI_Food Conference. ISEKI_Food 2016". Viena, Austria (2016).

Poster: “Obtaining active high-barrier starch-polyester bilayer films". Raquel Requena; María Vargas; Amparo Chiralt. "6" International Symposium on Food Packaging: Scientific Developments Supporting Safety and Innovation". Barcelona, Spain (2016).

Poster: "Antibacterial properties of PHBV films with carvacrol or oregano essential oil in different food matrices". Raquel Requena, María Vargas, Amparo Chiralt. "International Conferences in Food Innovation. Food Innova 2017". Cesena, Italy (2017).

Oral communication: "Release kinetics of eugenol from PHBV films and antimicrobial activity in food system". Raquel Requena; María Vargas; Amparo Chiralt. "4 ${ }^{\text {rd }}$ International meeting on Material/Bioproduct Interaction. MATBIM 2017". Porto, Portugal (2017).

Poster: "Functional and antimicrobial properties of starch-polyester bilayer films with carvacrol, as affected by the film processing method". Raquel Requena; María Vargas; Amparo Chiralt. "6 6 th International Conference on Biobased and Biodegradable Polymers. BIOPOL 2017". Mons, Belgium (2017).

Poster: "Combined application of active compounds from essential oils against foodborne bacteria using MTT assay". Raquel Requena; María Vargas; Amparo Chiralt. " $31^{\text {st }}$ EFFoST International Conference: Food Science and Technology Challenges for the 21st Century Research to Progress Society". Sitges, Spain (2017). 


\section{COMMUNICATION IN SCIENTIFIC EVENTS}

Oral communication: "Biodegradable active bilayer films for food packaging based on polyesters and starch". Raquel Requena; María Vargas; Amparo Chiralt. "III Meeting of PhD students of the Universitat Politècnica of València". Valencia, Spain (2016)

Oral communication: "Sequential subcritical water extraction for rice husk valorization, obtaining bioactive xylans and cellulose nanocrystals". Raquel Requena; Amparo Jiménez; Rosana Moriana; María Vargas; Amparo Chiralt; Francisco Vilaplana. "Latest developments in A\&l packaging and Opportunities for communication of ActInPak. COST Action FP1405 WGs Workshop". Riga, Latvia (2018).

Poster: "Antimicrobial bilayer films of starch and polyester-blend with carvacrol". Raquel Requena; María Vargas; Amparo Chiralt. "Latest developments in A\&l packaging and Opportunities for communication of ActInPak. COST Action FP1405 WGs Workshop". Riga, Latvia (2018).

\section{PREDOCTORAL STAYS AT FOREIGN INSTITUTIONS}

Division of Glycoscience, School of Biotechnology, KTH Royal Institute of Technology, (Stockholm, Sweden). From $1^{\text {st }}$ September 2017 to $30^{\text {th }}$ November 2107 under the supervision of Professor Fransico Vilaplana. Short Term Scientific Mission granted by COST Action FP1405 (ActInPack) entitled "Sequential subcritical water extraction for rice husk valorization, obtaining bioactive xylans and cellulose nanocrystals". 



\section{TABLE OF CONTENTS}

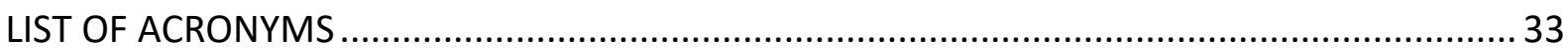

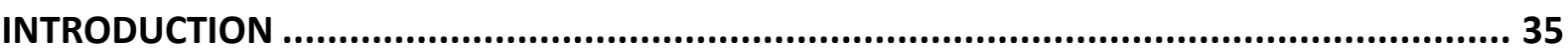

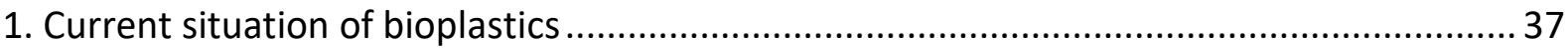

2. Bio-based biodegradable materials for food packaging .................................................. 40

2.1. Plastics from bacteria (polyhydroxyalkanoates). In Sustainability of Plastic Materials

(2018). Ed. DeGruyter. Raquel Requena; María Vargas; Amparo Chiralt. .......................... 40

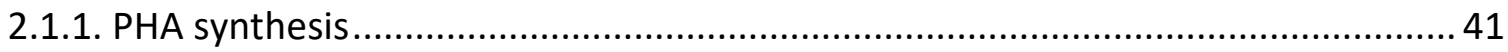

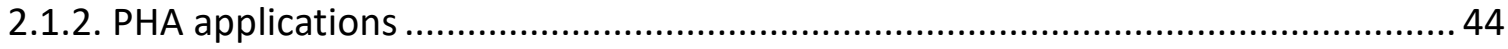

2.1.3. Properties of PHA-based packaging materials....................................................... 49

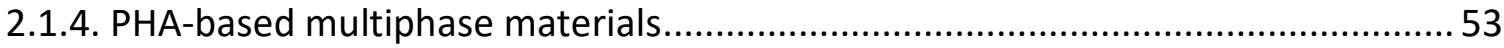

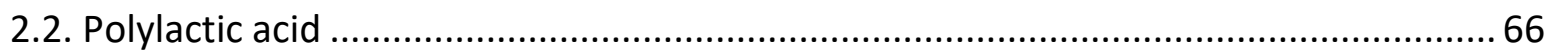

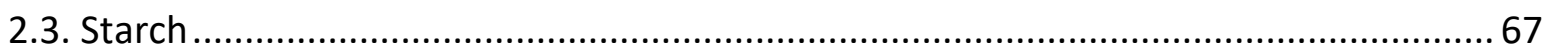

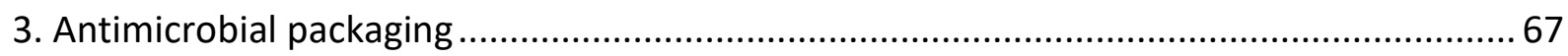

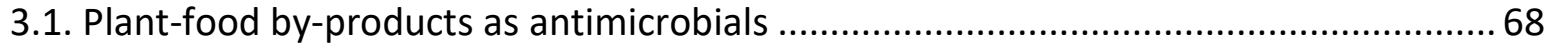

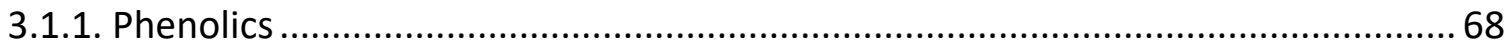

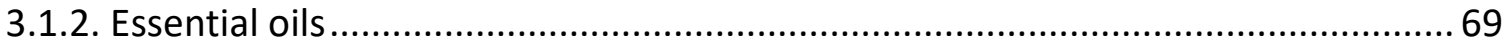

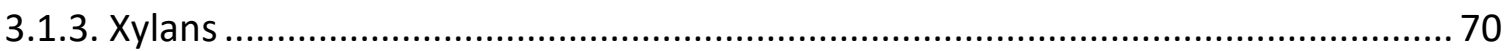

3.2. Biopolymers carrying essential oils for food antimicrobial packaging. Current Organic Chemistry (2017) 21, 1-16. Raquel Requena; Lorena Atarés; María Vargas; Amparo Chiralt.

3.2.1. Antimicrobial properties of essential oils .71

3.2.2. Incorporation methods of essential oils into polymer matrices ........................... 77

3.2.3. Impact of essential oils on the film functional properties.................................... 81

3.2.4. Release of essential oils from the polymer matrices into food or food simulants 85

3.2.5. Food applications of active biopolymer films containing essential oils ................. 90 
I. Effect of plasticizers on thermal and physical properties of compression-moulded poly[(3-hydroxybutyrate)-co-(3-hydroxyvalerate)] films........................................127

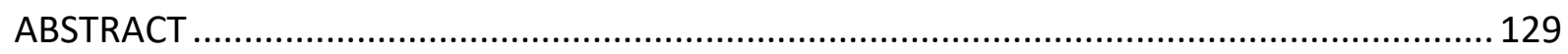

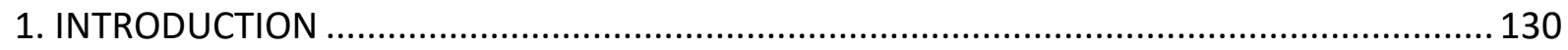

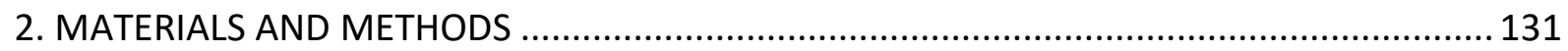

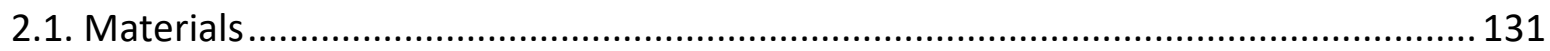

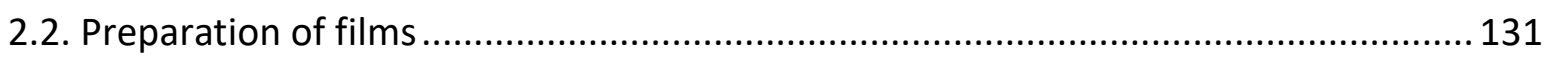

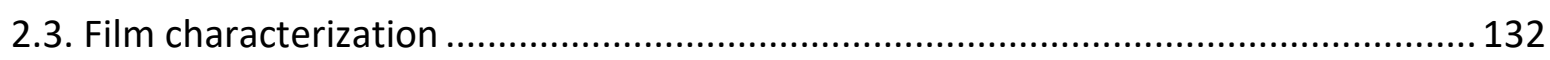

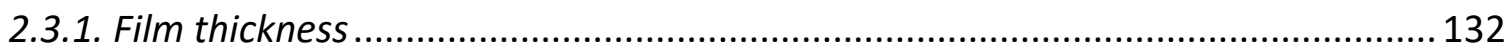

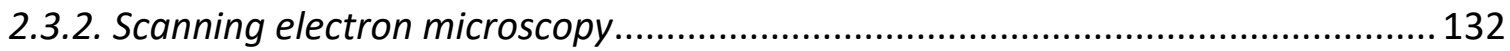

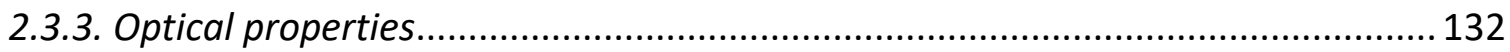

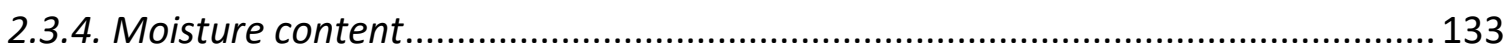

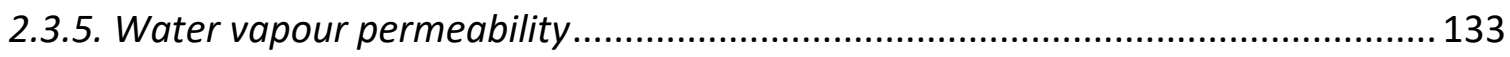

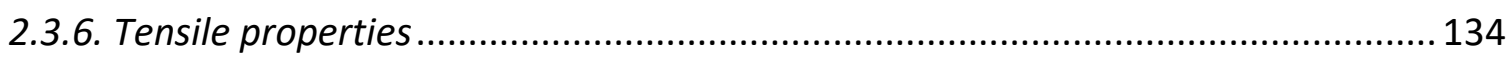

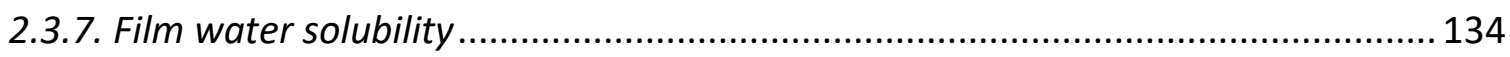

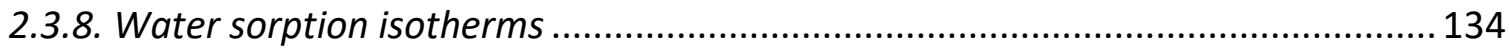

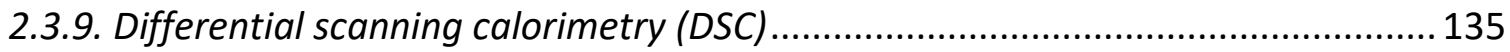

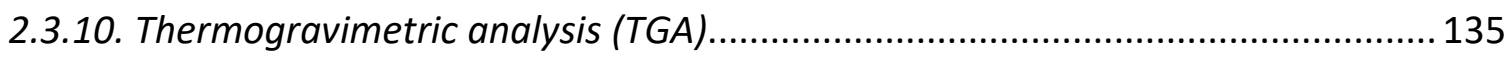

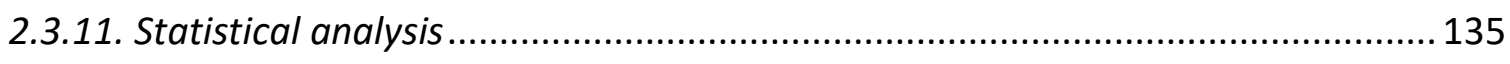

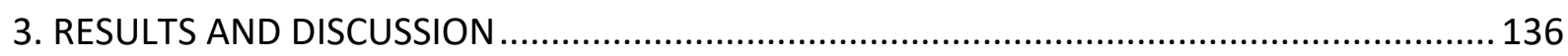

3.1. Microstructure and thermal behaviour of plasticized and non-plasticized films. ...... 136

3.2. Effect of plasticizers on tensile properties of the films ........................................... 141

3.3. Effect of plasticizers on water affinity of the films.................................................... 142

3.4. Optical properties of plasticized and non-plasticized films ..................................... 144

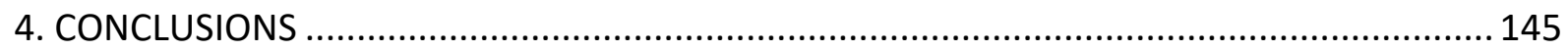

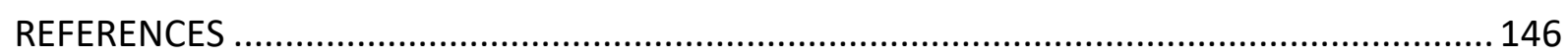

II. Poly[(3-hydroxybutyrate)-co-(3-hydroxyvalerate)] active bilayer films obtained by compression moulding and applying essential oils at the interface ..............................149

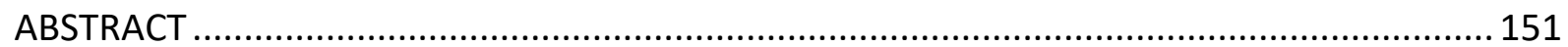

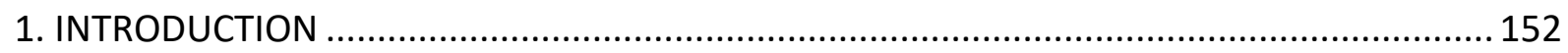

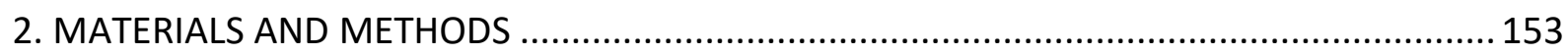

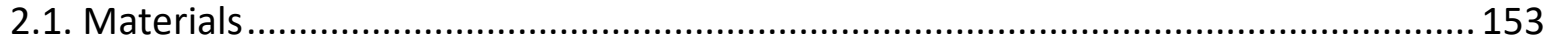




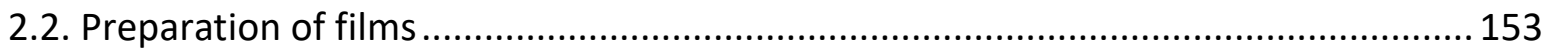

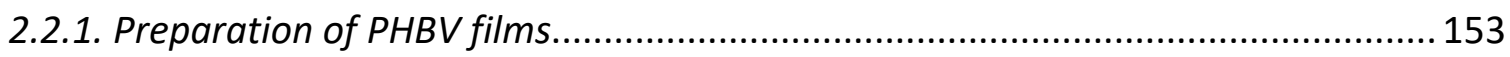

2.2.2. Incorporation of active compounds into bilayer structures.................................. 153

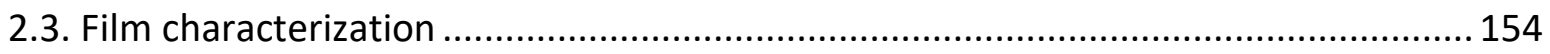

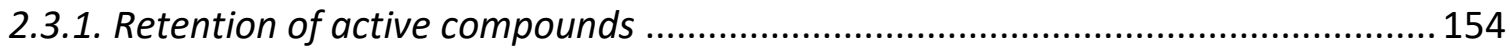

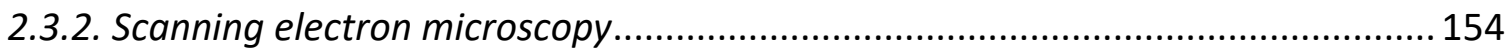

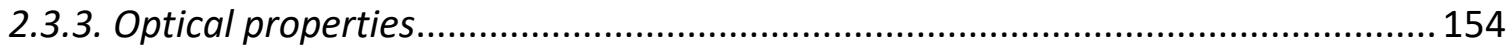

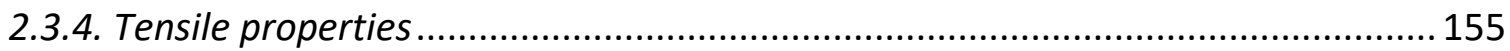

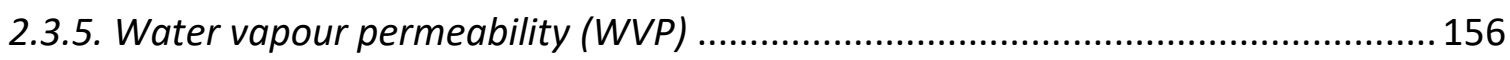

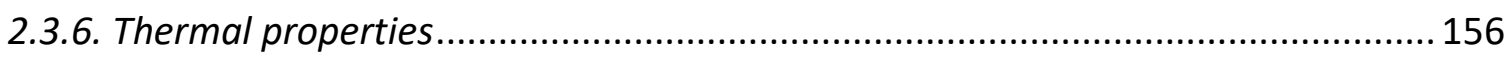

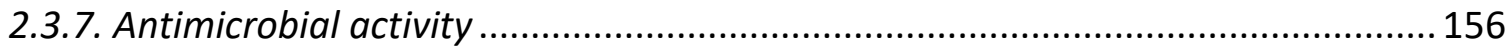

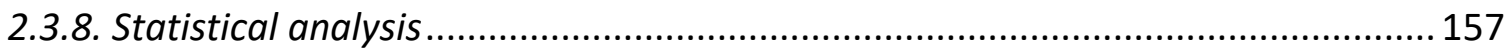

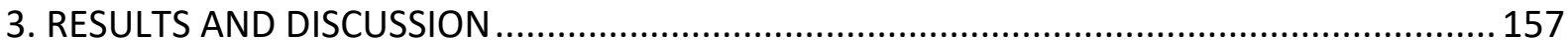

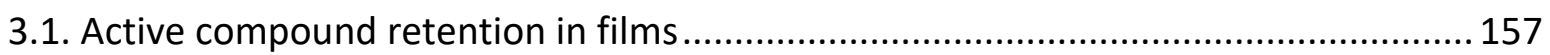

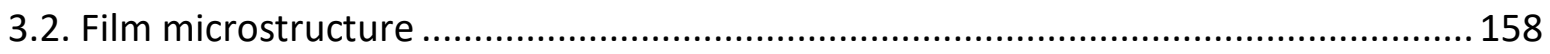

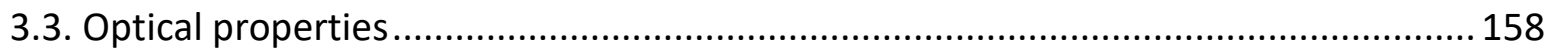

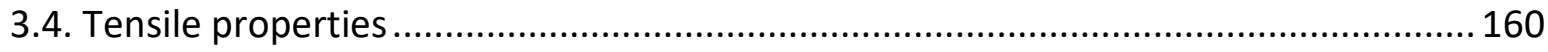

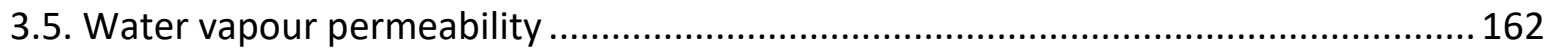

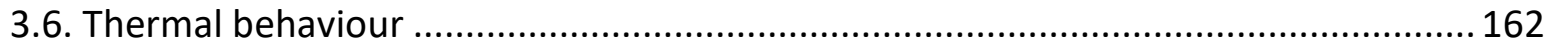

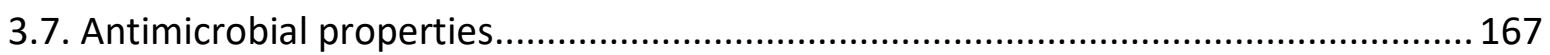

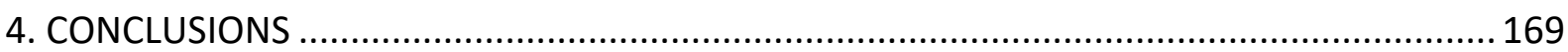

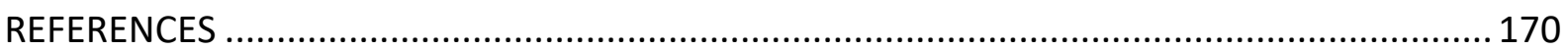

III. Release kinetics of carvacrol and eugenol from poly (hydroxybutyrate-cohydroxyvalerate) (PHBV) films for food packaging applications ..................................173

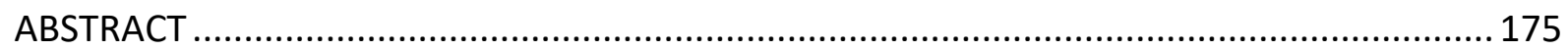

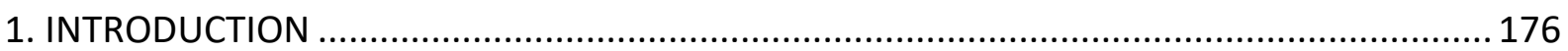

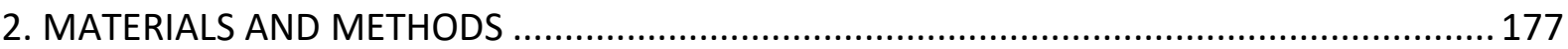

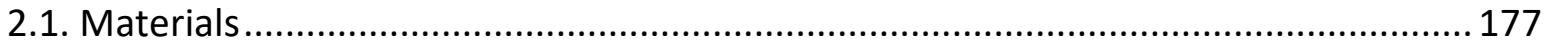

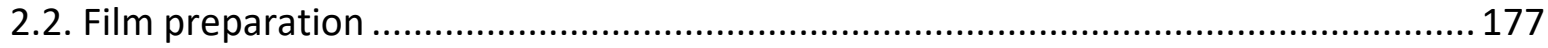

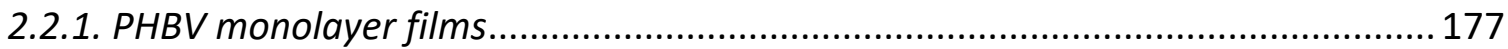

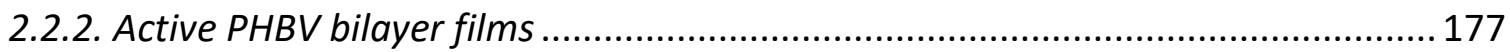

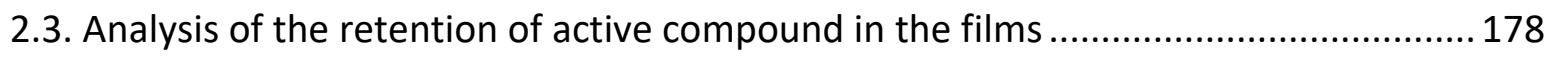


2.4. Kinetics of CA and EU release in food simulants

2.4.1 Mathematical modelling of CA and EU release ................................................ 179

2.4.2. Prediction of antimicrobial action of the films from release kinetics. .................. 180

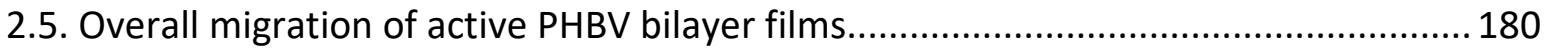

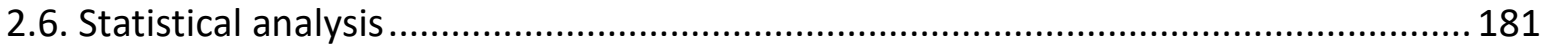

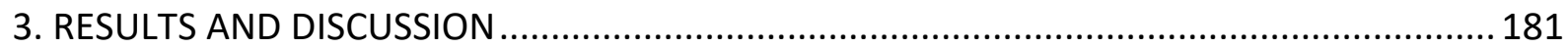

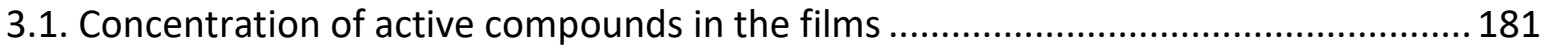

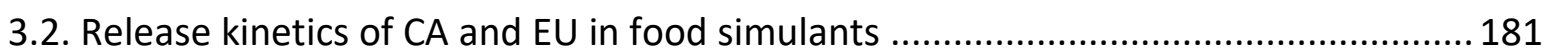

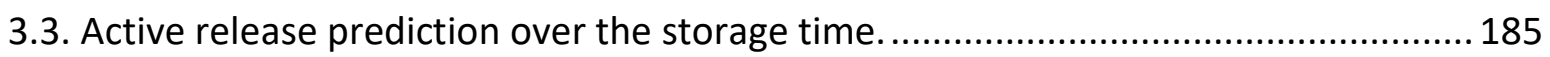

3.4. Overall migration of active PHBV bilayer films.................................................... 187

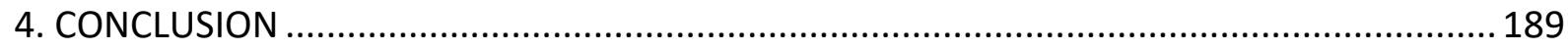

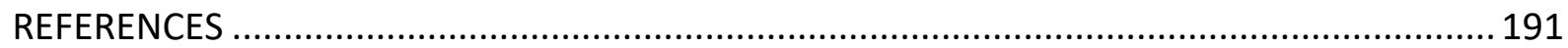

IV. Study of the potential synergistic antibacterial activity of essential oil components using the thiazolyl blue tetrazolium bromide (MTT) assay ........................................195

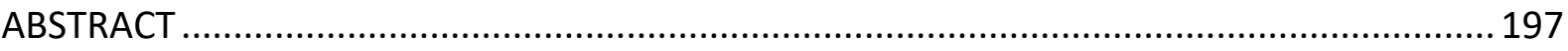

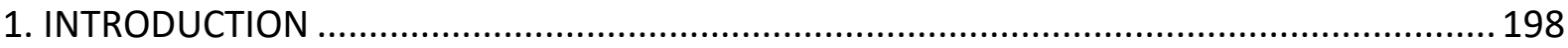

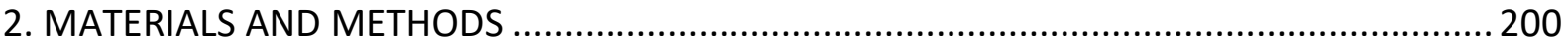

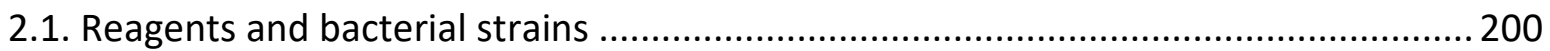

2.2. MIC assessment and combined antimicrobial effects............................................. 200

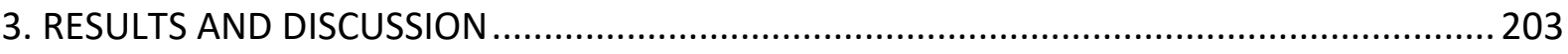

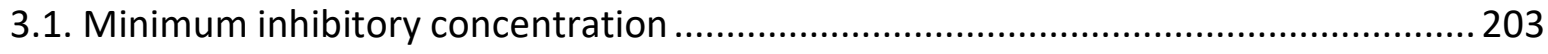

3.2. Interactions between components in binary active compound mixtures .................. 204

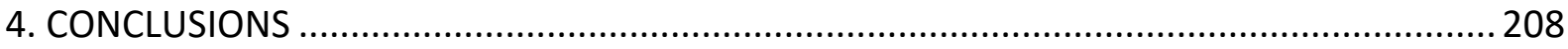

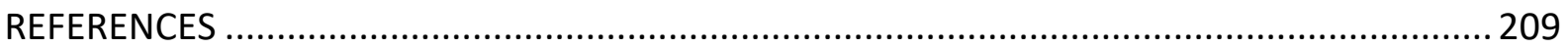

V. Eugenol and carvacrol migration from PHBV films and antibacterial action in different

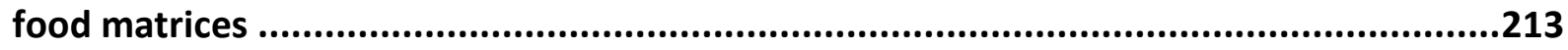

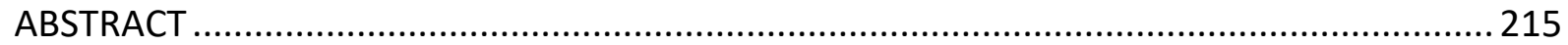

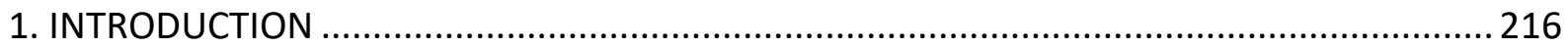

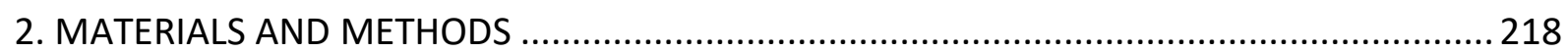

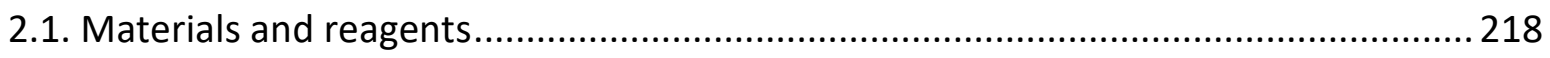

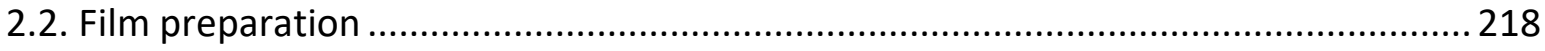

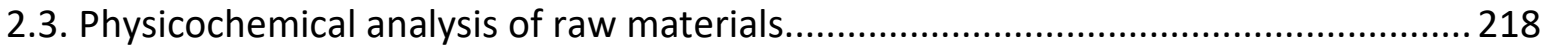


2.4. Antibacterial effectiveness of active films: in vitro and in vivo tests

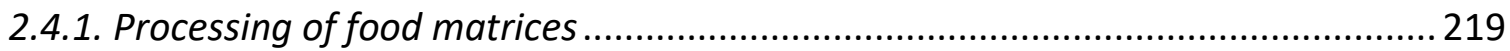

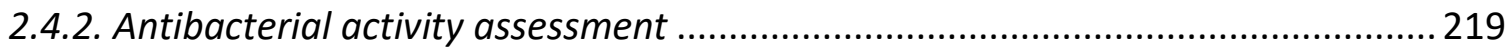

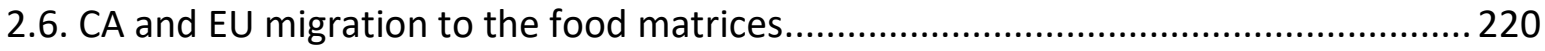

2.6.1. Quantification in the films by methanol extraction ............................................. 220

2.6.2. Analyses in the food matrices by Gas chromatography-mass spectrometry (GC$\mathrm{MS})$

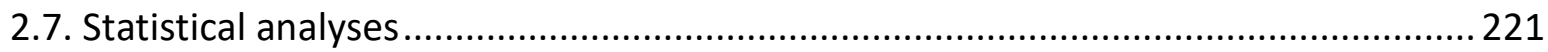

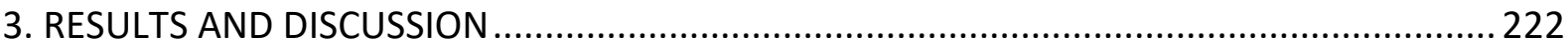

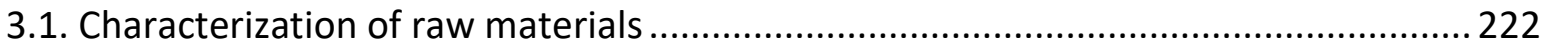

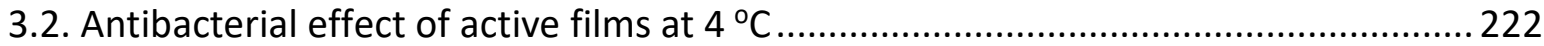

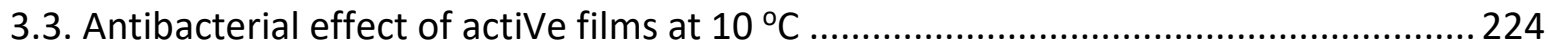

3.3.1. Antibacterial effect of active films in high-protein food ....................................... 224

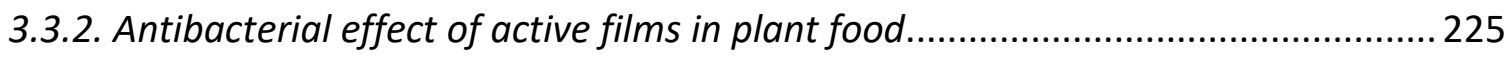

3.4. Cuantification of CA and EU migration to the food matrices ...................................228

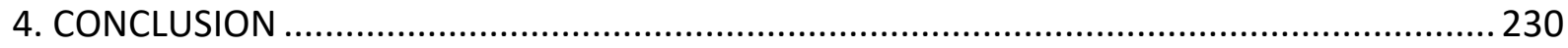

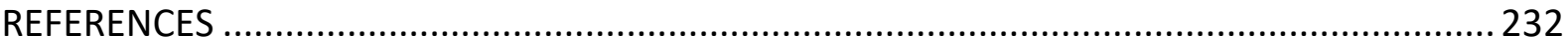

VI. Obtaining antimicrobial bilayer starch and polyester-blend films with carvacrol.......237

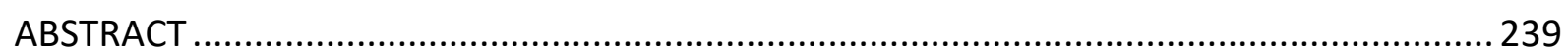

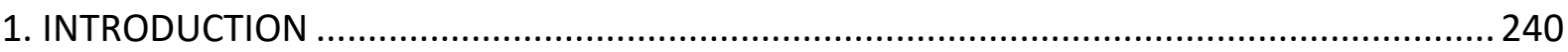

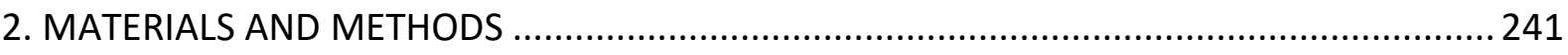

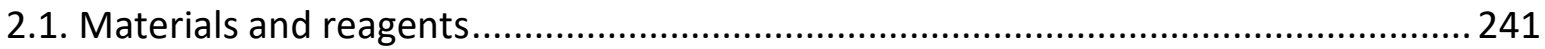

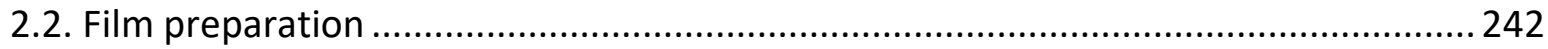

2.2.1. Preparation of polyester monolayer films by thermo-compression ( $T$ PLA:PHBV:PEG).

2.2.2. Preparation of polyester monolayer films by casting (C-75:25:15 and C-75:25:15-

CA).

2.2.3. Preparation of starch monolayer films by compression-moulding (S).................. 243

2.2.4. Preparation of active starch-polyester bilayer films (TP-S, TP-CA-S, CP-S, CP(CA)-S)

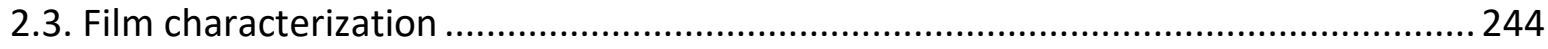

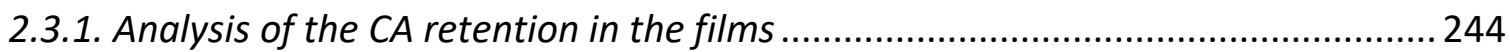

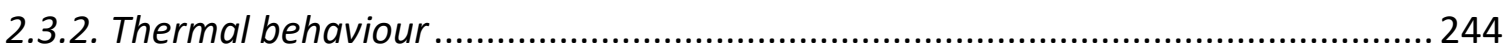




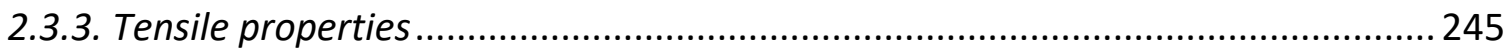

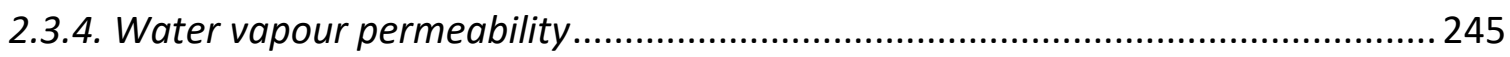

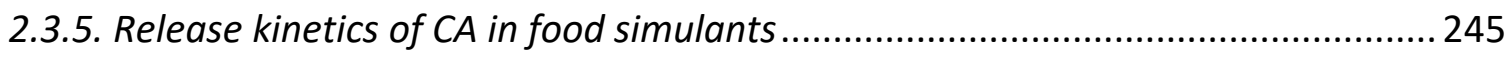

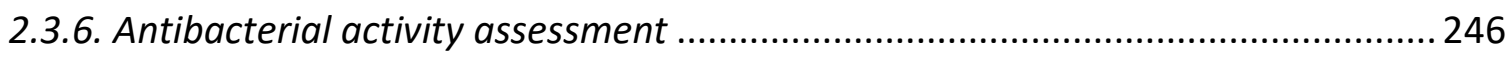

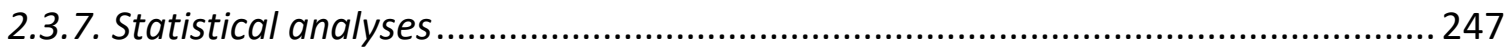

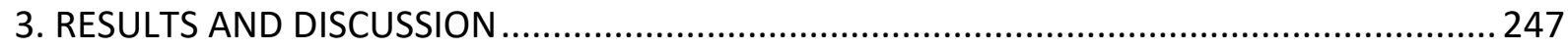

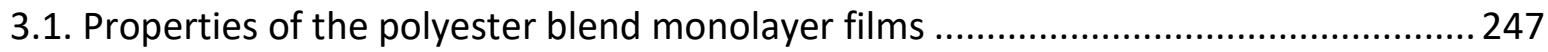

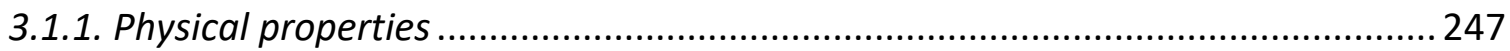

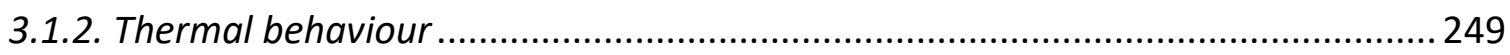

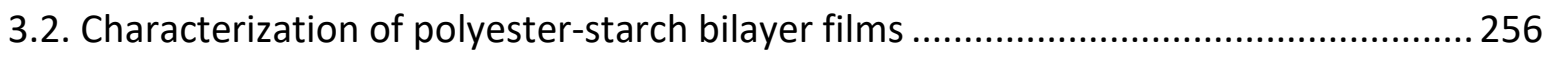

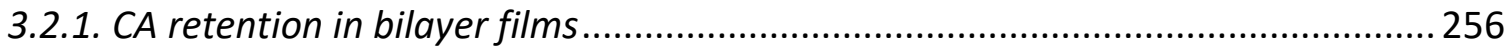

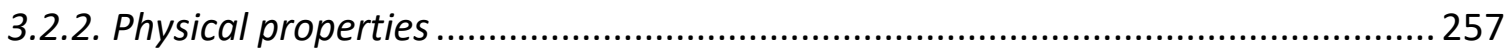

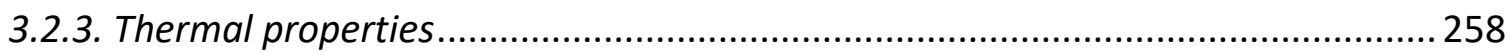

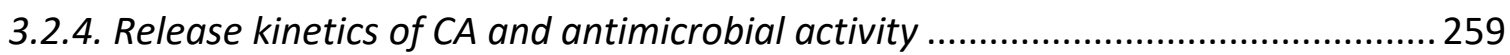

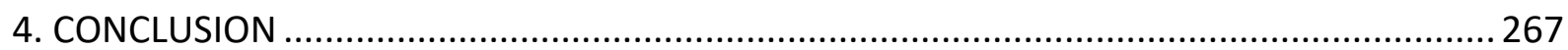

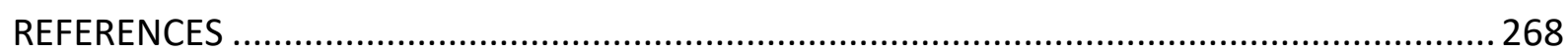

VII. Valorization of rice husks into bioactive xylans and cellulose nanocrystals, using

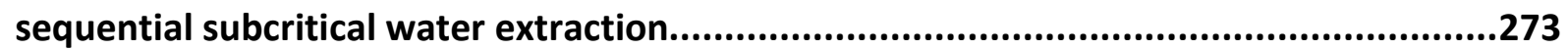

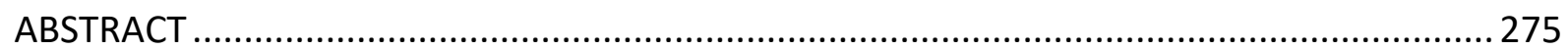

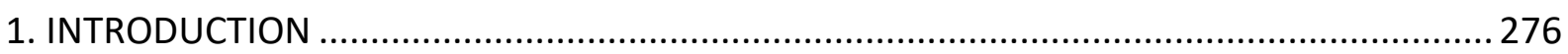

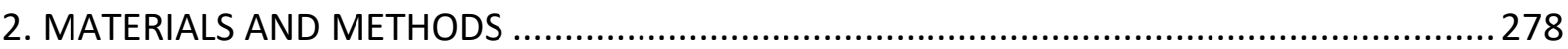

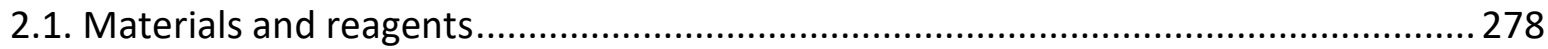

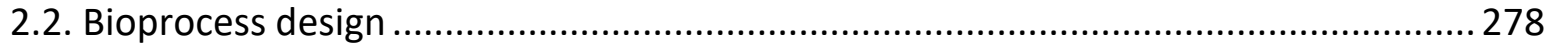

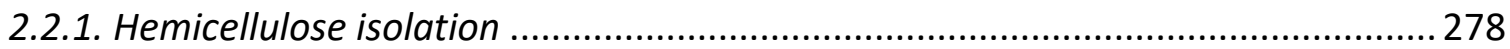

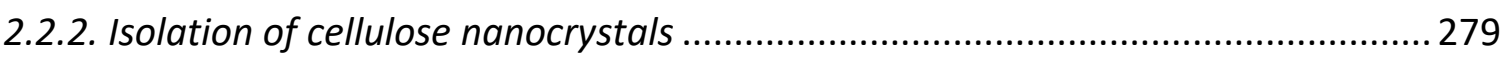

2.3. Characterization of the materials obtained throughout the valorization processes.. 280

2.3.1. Characterization of the alkali and SWE soluble extracts ................................... 280

2.3.2. Characterization of the insoluble fractions from macro to nano dimensions ...... 282

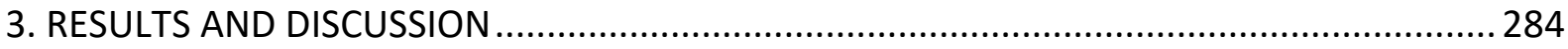

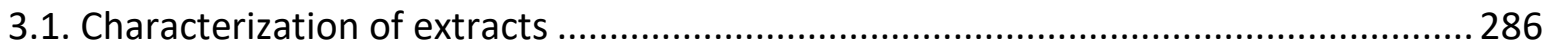

3.1.1. Chemical composition of the hemicellulosic extracts ........................................... 286

3.1.2. Functional properties of the hemicellulosic extracts ............................................ 288 
3.2. Characerization of the insoluble fraction from macro to nano dimensions 290

3.2.2. Chemical composition of the insoluble fractions ................................................ 290

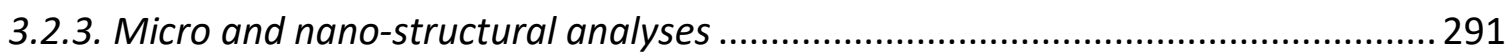

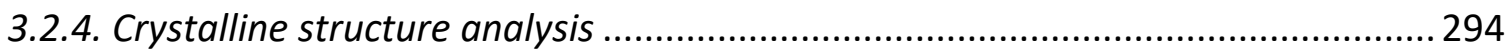

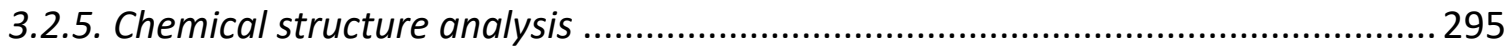

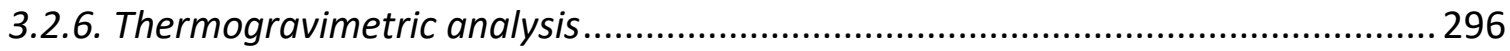

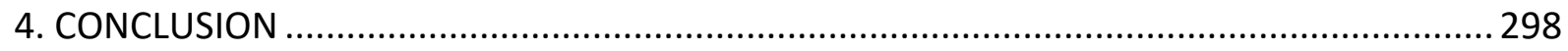

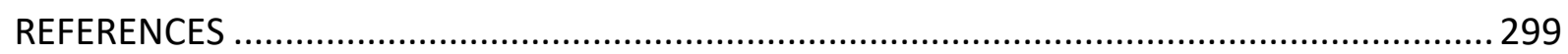

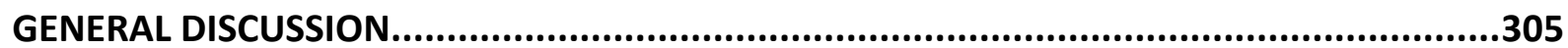

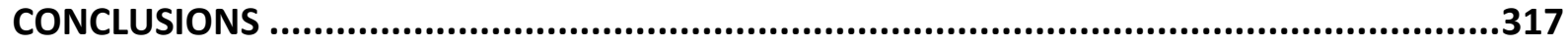





\section{LIST OF ACRONYMS}

\%E: Percentage of elongation at break AgNP: Silver nanoparticles ASTM: American Society for Testing and Materials

ATBC: Acetyl Tri-n-Butyl Citrate

$\mathrm{C}_{\mathrm{ab}}$ *: Chroma

CA: Carvacrol

CFU: Colony Forming Unit

$\mathrm{CIN}$ : Cinnamaldehyde

CLO: Clove

CNC: Cellulose nanocrystal

CNF: Cellulose nanofibre

CNW: Cellulose nanowisker

CO: Castor oil

D: Diffusion coefficient

Da: Dalton

DBP: Dibutilphtalate

DBS: Dibutylsebacate

DCM: Dichloromethane

DOS: Dioctylsebacate

DPPH: 2,2-Diphenyl-1-pikryl-hydrazyl

DSC: Differential Scanning Calorimetry

DTG: Thermal weight loss derivate

$\mathrm{EC}_{50}$ : Half maximal effective concentration

EM: Elastic Modulus

EO: Essential Oil

ESO: Epoxized Soybean Oil

EU: Eugenol

EUCA: Eucalyptol

EVA: Polyethylene-co-vinylacetate

FDA: American Food and Drug Administration

FFD: Film-forming dispersion

FTIR: Fourrier Transform Infrared Spectroscopy

GC-MS: Gas Chromatography-Mass

Spectrometry

GD: Golden delicious

GRAS: Generally Recognized As Safe

$\mathrm{h}_{\mathrm{ab}}{ }^{*}$ : Hue
HDPE: High Density Polyethylene

HPDSP: Hydroxypropyl distarch phosphate

HPMC: Hydroxypropyl methylcellulose

IVT: In vitro test

$\mathrm{k}$ : Rate constant of Korsmeyer-Peppas model

$\mathrm{k}_{1}$ : Kinetic constant of Peleg model

$\mathrm{k}_{2}$ : Constant of the Peleg model

$\mathrm{L}^{*}$ : Luminosity

LA: Lauric acid

Icl-PHA: Long chain length PHA

LCNF: Lignocellulose nanofibrils

LDPE: Low Density Polyethylene

LSD: Least Significant Difference

$M_{\infty}$ : Amount of active compound released at equilibrium

MA: Maleic Anhydride

mcl-PHA: medium chain length PHA

MIC: Minimum Inhibitory Concentration

MWCNT: Multiple-walled carbon nanotube

$\mathrm{n}$ : Difussional exponent of Korsmeyer-Peppas model

OLA: Oligomer lactic acid

OML: Overall Migration Limit

OMMT: Organically modified montmorillonite

OP: Oxygen Permeability

OR: Oregano

OTR: Oxygen Transmission Rate

PA: Polyamide

PBAT: Polybutylene adipate-co-terephthalate PBS: Polybutylene succinate

PBSA: Polybutylene succinate-co-adipate

PC: Polycarbonate

PCL: Polycaprolactone

PE: Polyethylene

PEA: Polyethylene adipate

PEF: Polyethylene furanoate

PEG: Polyethylene glycol

PEG200: Polyethylene glycol $200 \mathrm{Da}$ 
PEG300: Polyethylene glycol $300 \mathrm{Da}$

PEG1000: Polyethylene glycol 1000 Da

PEG4000: Polyethylene glycol $4000 \mathrm{Da}$

PEG-PE1400

PEGDO: Polyethylene glycol 400 dioleat

PES: polyether sulfone

PET: Polyethylene terephthalate

PG: Propylene Glycol

PHA: Polyhydroxyalkanoates

PHA-g-MA: Maleic anhydride-grafted

polyhydroxyalkanoate

PHB: Poly- $\beta$-hydroxybutyrate

PHBV: Poly(3-hydroxybutyrate)-co-(3-

hydroxyvalerate)

PIB: Polyisobutylene

PLA: Poly(lactic) acid

PMMA: Polymethyl methacrylate

PP: Polypropylene

PS: Polystyrene

PVC: Polyvinyl chloride

PVOH: Polyvinyl alcohol

RD: Red delicious

RH: Relative Humidity

S: Starch

SA: Stearic Acid

scl-PHA: Short chain length PHA

SEM: Scanning Electron Microscopy

SO: Soybean oil

$\mathrm{t}$ : time
$\mathrm{T}_{\mathrm{c}}$ : Crystallization temperature

TEC: Triethyl citrate

$\mathrm{T}_{\mathrm{g}}$ : Glass transition temperature

TGA: Thermogravimetric Analysis

THY: Thymol

Ti: Transmisttance

$\mathrm{T}_{\mathrm{m}}$ : Melting temperature

$\mathrm{T}_{\max }$ : Maximum decomposition temperature

Tonset: Onset Temperature

TPS: Thermoplastic starch

TS: Tensile Strength

TSA: Tryptone Soy Agar

TSB: Triptone Soy Broth

UV: UltraViolet

UV-VIS: UltraViolet-Visible Spectroscopy

W-G: Whey-gelatin

WG: Wheat gluten

WPI: Whey protein isolated

WVP: Water Vapour Permeability

WVTR: Water Vapour Transmission Rate

$\mathrm{X}_{\mathrm{c}}$ : Degree of crystallinity

XRD: X-Ray Diffraction

ZnONP: Zinc oxide nanoparticles

$\Delta \mathrm{H}_{0}$ : Melting enthalpy of $100 \%$ crystalline polymer

$\Delta \mathrm{H}_{\mathrm{c}}$ : Crystallization enthalpy

$\Delta \mathrm{H}_{\mathrm{m}}$ : Melting enthalpy 



\section{Current situation of bioplastics}

Plastics are the material par excellence of the modern economy with a worldwide production of 335 million tonnes in 2016, due to their unequalled features, such as low cost, low density, high impact resistance and versatility. Owing to these advantages over other materials, their use has increased twenty-fold in the last fifty years, and it is expected to double in the coming decades. In terms of plastic production, the European Union ranks second with 60 million tonnes in 2016, ahead of North America, while Asia is the largest producer. Of the different market sectors in Europe, the packaging industry accounts for $40 \%$ of the total plastic demand (Neufeld et al., 2016; PlasticsEurope, 2017).

Despite their benefits, there are two main growing concerns related with the use of plastic packaging: the first is the critical economic dependence of this sector on the price and availability of crude oil and natural gas, and the second is the associated environmental problems, such as the degradation of natural systems and greenhouse gas emissions that result from plastic production and disposal (Neufeld et al., 2017). Moreover, only a small share of the plastic packaging materials can be recycled because such materials are often contaminated with food and/or biological substances (Malathy et al., 2014). For these reasons, a great effort is being made to develop environmentally-friendly alternatives to petroleum-based plastics, such as the bio-based and biodegradable materials. The term biobased is used to describe those plastics derived from biomass sources, which are not necessarily biodegradable, having a short carbon cycle as compared to the much longer carbon cycle of fossil-based materials. Biodegradable plastics, on the other hand, can be either made of natural or fossil sources and refer to materials that can be degraded quite quickly by biological agents in a natural environment, whereas traditional plastic materials are considered non-biodegradable due to their low degradation rate (Ross et al., 2017).

In this scenario, the concept of bioplastics corresponds to those materials that are either biodegradable, bio-based or both. They are mainly applied in the packaging market, accounting for almost 60 percent (1.2 million tonnes) of the bioplastics market in 2017. Bioplastics provide a promising replacement for traditional synthetic plastics, such as polypropylene (PP) and polystyrene (PS), since they possess comparable functional properties and can mitigate the environmental issues associated with synthetic plastics. Currently, bioplastics constitute about one percent of the global plastic production, and their market is continuously growing due to their increased demand. Thus, the global bioplastic production capacity is set to increase from around 2.05 million tonnes in 2017 to approximately 2.44 million tonnes in 2022 (European Bioplastics, 2017). 
The bioplastics that are relevant for food packaging applications are classified into three different groups (Figure 1) (Piergiovanni \& Limbo, 2016; Ross, et al., 2017; Geueke, 2014):

1. Bio-based, or partially bio-based, non-biodegradable plastics, which are obtained wholly or partly from bio-based intermediates, such as bio-based polyethylene (PE), PP and polyamides (PA).

2. Plastics obtained from fossil resources, which are biodegradable due to their inherent properties and medium molecular weight, such as polycaprolactone (PCL), thermoplastic polyvinyl alcohol (PVOH) and aliphatic copolyesters (PBSA).

3. Plastics that are both biodegradable and bio-based, such as poly(lactide acid) (PLA) and polyhydroxyalkanoates (PHAs), which are obtained through different strategies. This group also includes naturally occurring carbohydrate-based macromolecules, such as starch and cellulose derivatives.

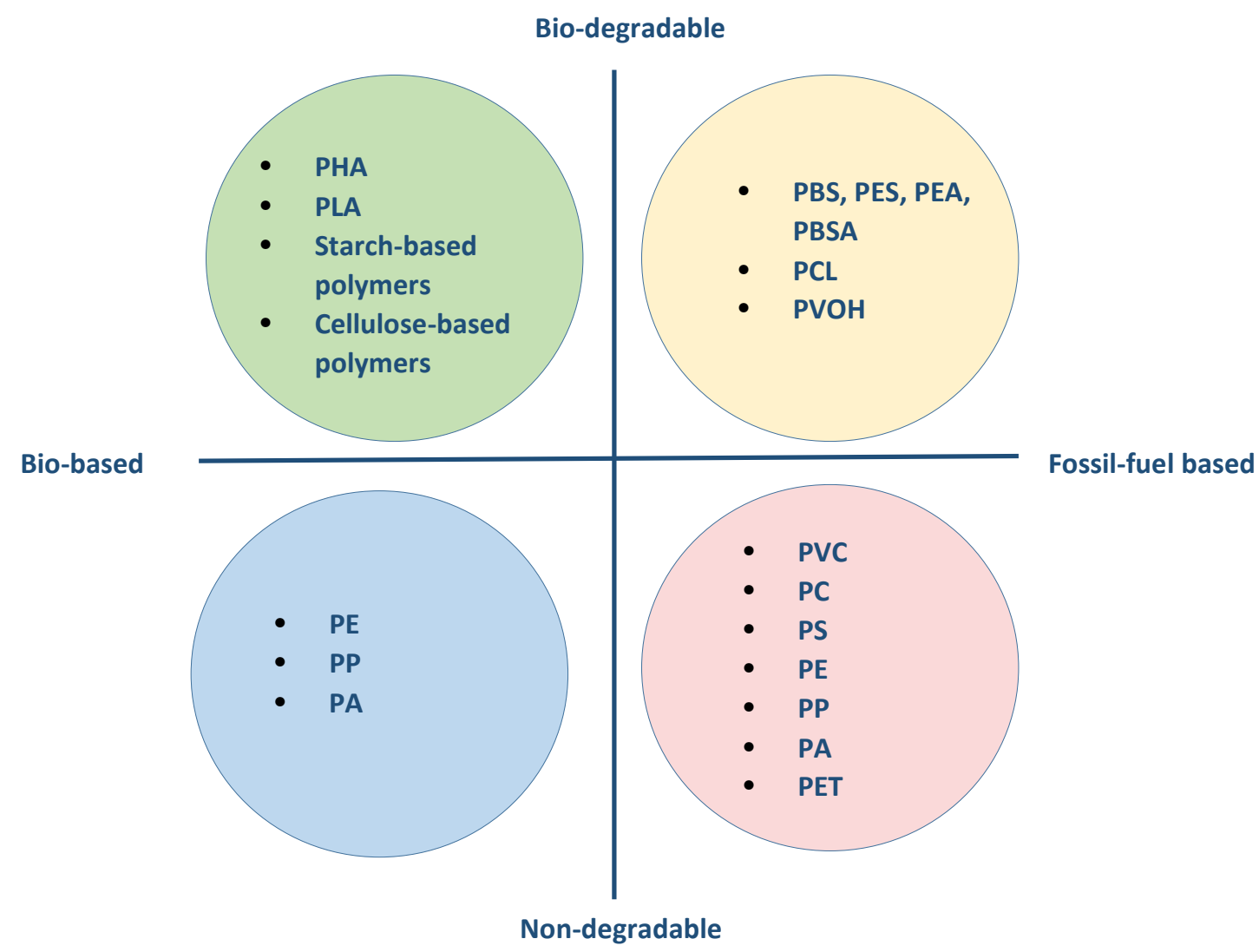

Figure 1. Overview of biobased and fossil-fuel based plastics as a function of their degradability (Adapted from Geueke, 2014). 
As shown in Figure 2, bioplastics are either directly extracted from biomass (e.g. starch, cellulose) or produced in vivo by bacteria in fermentation processes, using suitable carbon sources (e.g. PHA). Moreover, plant biomass can be either chemically or biocatalytically transformed into building blocks to obtain bioplastics by chemical polymerization processes (e.g. PLA, polyolefins). As concerns the biomass, carbohydrate-rich food crops, such as corn or sugar cane (first generation feedstock) are the most common sources used to obtain bioplastics. Although nowadays it is not profitable, non-food crops (second generation feedstock), such as lignocellulosic residues can also be used to obtain bioplastics by previous transformation into suitable chemical building blocks. Furthermore, oil- or protein-plant biomass has been widely studied for bioplastic production, as has the biomass coming from animal waste (e.g. chitosan, whey) (Xu \& Guo, 2010; Geueke, 2014).

\section{Plant biomass}

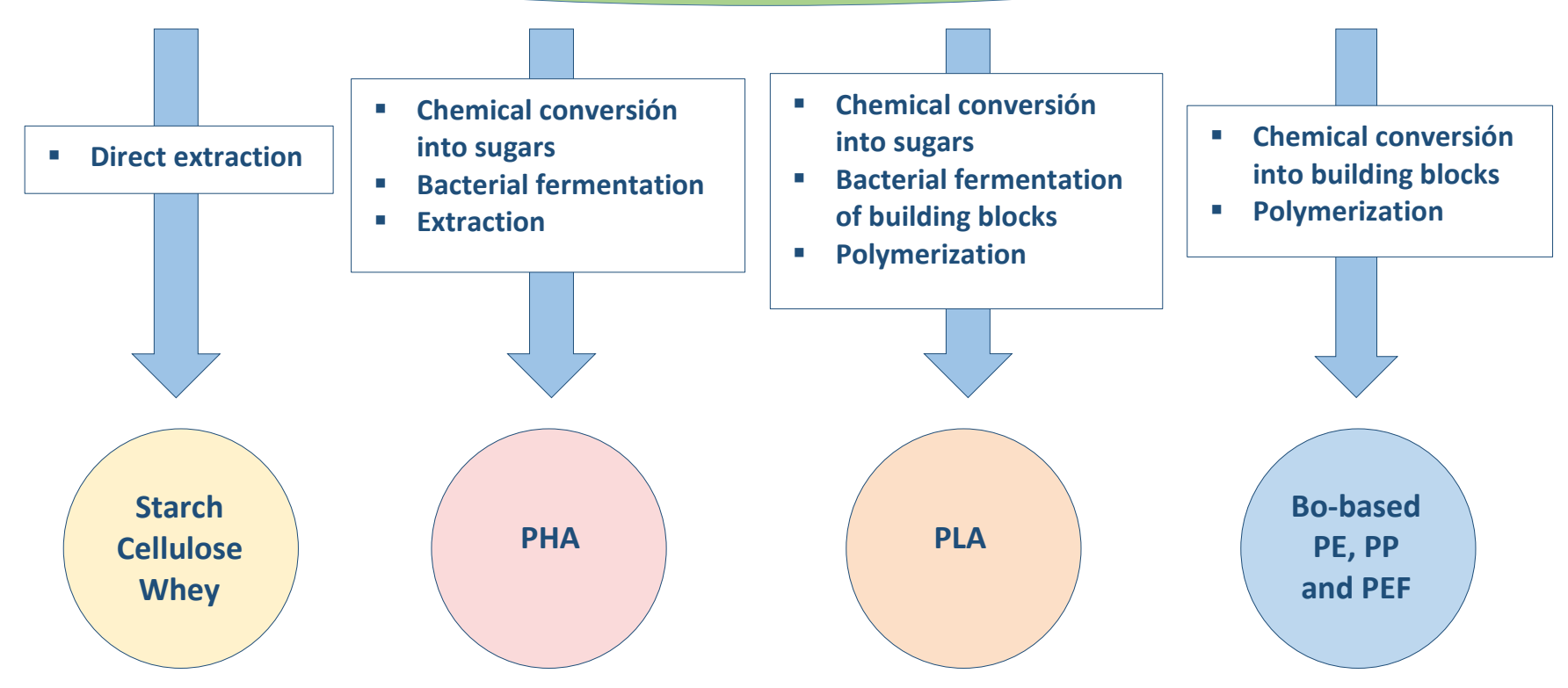

Figure 2. Production pathways of bioplastics based on plant biomass (Adapted from Geueke, 2014) 


\section{Bio-based biodegradable materials for food packaging}

2.1. Plastics from bacteria (polyhydroxyalkanoates). In Sustainability of Plastic Materials (2018). Ed. DeGruyter. Raquel Requena; María Vargas; Amparo Chiralt.

Polyhydroxyalcanoates (PHAs) are a family of linear polyesters of (R)-3-hydroxy fatty acid monomers with the general structural formula shown in Figure $\mathbf{3}$. They are the only family of polymers that acts as energy/carbon reservoirs for more than 300 species of Gram-negative and Gram-positive bacteria as well as a broad variety of archaea (Laycock et al., 2014). PHAs are synthetized intracellularly as discrete inclusions when an essential nutrient, such as nitrogen, phosphorous, magnesium, sulphate or phosphate, is available in limiting concentrations in the presence of an excess of carbon source. These inclusions of 0.2-0.5 $\mu \mathrm{m}$ in diameter are localized in the cell cytoplasm and can comprise up to $80 \%$ of the dry cell weight. It is known that PHA in vivo is not a crystalline solid, indeed, it is a mobile amorphous polymer. However, what hinders PHA crystallization still remains doubtful. Some authors support the hypothesis of the plasticizing effect of the water present in the PHA inclusions, which could form hydrogen bonds with the carbonyl groups of the polyester backbone between adjacent polymer chains (Sudesh et al., 2000). Owing to their high refractivity, native PHAs can be visualized with a phase contrast light microscope and stained with Sudan Black B, which indicates that they are lipid in nature (Khanna \& Srivastava, 2005; Sudesh et al., 2000).

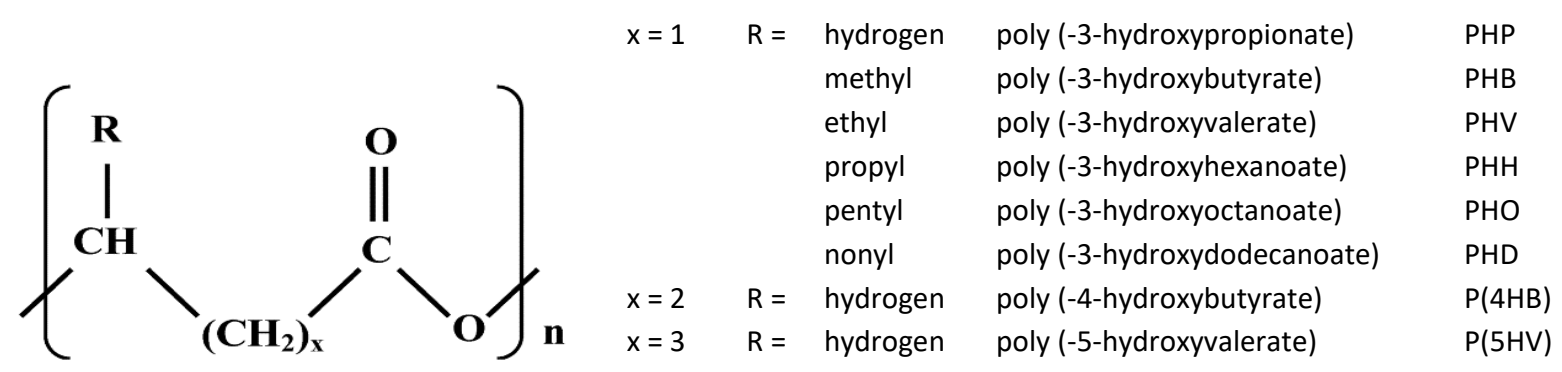

Figure 3. The general molecular structure of polyhydroxyalcanoates (PHAs). In the figure, $R$ side chains consist of hydrogen or alkyl groups up to 13 carbon atoms in length, $x=1-4, n=600-35000$ (Adapted from Muhammadi et al., 2015).

The molecular weight of these polymers ranges from 200,000 to 3,000,000 Da, depending on the microorganism and growth conditions. Thus, PHAs can be divided into two main groups depending on their chain length. Short-chain-length PHAs (scl-PHAs), such as poly(3hydroxybutyrate) (P(3HB) or PHB), contain monomer units with less than five carbon atoms, whereas the medium-chain length PHAs (mcl-PHAs) contain monomer units of 6-14 carbon 
atoms. There is also a third group with monomer units containing more than 14 carbon atoms, which is uncommon and little studied, called long chain length PHAs (Icl-PHAs) (Raza et al., 2018). This difference with regard to the chain length is caused by the substrate specificity of the PHAs synthases (Laycock et al., 2014; Khanna \& Srivastava, 2005; Sudesh et al., 2000).

PHAs are also classified depending on the types of monomers: homopolymers (only one type of monomer) or copolymers or heterocopolymers (different monomers in the chain). More than 150 different (R)-3-hydroxy fatty acid monomers have been identified in this heterogeneous family of homo or copolyesters, thus resulting in polymer materials with a wide spectrum of properties. While scl-PHAs lead to thermoplastic materials that are highly crystalline and, therefore, brittle and barely stretchable, mcl-PHA are more flexible and less crystalline materials with lower melting temperatures (Xu \& Guo, 2010; Piergiovanni \& Limbo, 2016). The most common PHA are PHB and poly(3-hydroxybutyrate-co-3-hydroxyvalerate) ( $\mathrm{P}(3 \mathrm{HB}-3 \mathrm{HV})$ or $\mathrm{PHBV})$, since they possess properties that are similar to conventional polymers, such as PP and PE (Laycock et al., 2014).

\subsubsection{PHA synthesis}

PHAs are naturally occurring polymers, which are synthetized by bacteria utilizing common carbon sources (i.e. glucose). Based on the requirements for PHA production, bacteria are divided into two different groups. The first group consists of bacteria, such as Alcaligenes eutrophus, Protomonas extorquens and Protomonas oleovorans, require the presence of excess carbon, while an essential nutrient is available only in limiting concentratrions. This group can only accumulate PHAs during starvation periods, since once the bacteria are provided with the limiting nutrient, the reservoirs are depolymerized to recover the stored carbon. In contrast, the second group of bacteria, which includes Alcaligenes latus (a mutant strain of Azotobacter) and recombinant Escherichia coli, does not need nutrient limitation for PHA synthesis and can accumulate PHAs during growth (Khanna \& Srivastava, 2005). In its simplest approach, PHA production by pure cultures, with bacteria belonging to the first group, consists of a two-stage batch cultivation process, in which the bacterial inoculum is introduced into a sterile solution containing an available carbon source (first stage). After a desired biomass concentration is obtained without nutrient limitation, the carbon source and an essential nutrient in limiting concentratrions should be fed at an optimal ratio to allow an efficient PHA synthesis (second stage) (Laycock et al., 2014).

In order to reduce the PHA production costs, several alternative approaches have been proposed, such as the use of mixed cultures adapted to complex waste feedstock, which does not require reactor sterilization. In this way, real fermented agricultural or industrial waste can be used as low-cost feedstock, thus reducing the high cost of the bacterial fermentation associated with the substrate cost. In this way, many different fermented wastes, such as 
effluents from fruit and tomato cannery, sugar cane molasses, effluents from olive oil, saponified sunflower oil, bio-oil (a pyrolysis by-product) and waste waters from the food industry and households, have been used as substrate for the PHA production (Laycock et al., 2014). Alcohols, such as methanol, are also cheap, available carbon sources, which can be used to synthetize PHAs by using methylotrophs, although their productivity still needs to be enhanced (Khanna \& Srivastava, 2005; Laycock et al., 2014). Bacteria can use different carbon sources to synthetize PHAs, since the PHA synthase enzyme shows a broad substrate spectrum, polymerizing a wide variety of monomers. The main factor that determines PHA composition is the type of carbon source used (Sudesh et al., 2000; Raza et al., 2018).

The use of recombinant strains that utilise cheap carbon sources is another alternative means of lowering the cost of the PHA production. PHA biosynthesis in E. coli by introducing $\mathrm{PHA}$ synthase genes allows for a cost-effective production, since many different cheap carbon sources can be used as substrate and the extraction process is easier and less costly. Moreover, because $E$. coli is not a natural PHA producer, it does not require the limitation of essential nutrients. In addition, since $E$. coli does not have PHA depolymerase, PHA accumulation could reach $80-90 \%$ of the dry cell weight (Khanna \&Srivastava, 2005; Sudesh et al., 2000).

Transgenic plants expressing bacterial genes have also been considered to synthetize PHAs in a more cost effective way. Novel metabolic pathways either in the cytoplasm, plastid or peroxisome have been engineered in the model plant Arabidopsis thaliana to obtain different PHAs. Moreover, PHA production has been successfully performed in agriculturally relevant crops, such as tobacco, Brassica napus, cotton and corn (Snell \& Peoples, 2002). However, adverse effects, like stunted growth and infertility, have been observed because of high expression levels of the acetoacetyl-CoA reductase, which hinders their large-scale cultivation. Nonetheless, this problem can be minimized by regulating the tissue specificity, the timing of expression and the cellular location of the PHA-producing enzymes (Hempel et al., 2012; Khanna \& Srivastava, 2005; Sudesh et al., 2000). High levels of PHB (up to $18 \%$ PHB of the cellular dry weight) in plants with fertile offspring are obtained in the plastid of Nicotiana tabacum (Bohmert-Tatarev et al., 2011). For large-scale production, oilseed crops, such as rapeseed, have been proposed as ideal PHA producers, since the results obtained in the closely related species Arabidopsis thaliana are directly applicable (Khanna \&Srivastava, 2005; Sudesh et al., 2000).

Despite the high interest of the plant-based expression systems that do not need external organic sources, the use of these systems is limited because of competition with subsistence crops in cultivation areas. Moreover, the application of transgenic plants is restricted in many countries due to ethical concerns and strict legislation regarding their dissemination. In this sense, algae or microalgae, which have emerged as a by-product of the bio-refinery processes, show the same advantages as transgenic plants: high growth rates, ease of handling and ability 
to grow in a wide range of environments (Hempel et al., 2012). Furthermore, this approach enables the use of carbon, thus neutralizing greenhouse gas emissions. According to Bugnicourt et al. (2014), two stages are distinguished for the algae polymer production: a first stage, in which the algae growth is initiated, and a second phase in which PHA accumulation is promoted. Hempel et al., 2012 demonstrated for the first time that the PHB production is feasible in a microalgal system by introducing the bacterial PHB pathway of Ralstonia eutropha $\mathrm{H} 16$ into the diatom Phaeodactylum tricornutum (PHB levels up to $10.6 \%$ of algal dry weight).

PHAs can also be produced by chemical synthesis or by chemical modifications of natural PHAs, as described by Abe et al., 1995 for the chemical synthesis of PHB by the ring-opening polymerization of a mixture of ( $R$ )- and ( $S$ )- $\beta$-butyrolactone in the presence of aluminium or zinc alkyl catalysts. This group of synthetic PHAs cannot be produced by microorganisms, since the monomer units are toxic or cannot be taken from the culture broth by bacteria, due to the PHA synthase specificity. Nevertheless, this approach is not economically profitable for largescale production and requires the use of toxic reagents (Xu \& Guo, 2010; Laycock et al., 2014).

The PHA recovery process should also be taken into account, since it is a determining factor in PHA production costs. Owing to its simplicity and ease of operation, solvent extraction has been the most commonly used PHA recovery method. Solvent extraction consists of a previous treatment based on cell disruption to liberate the PHA granules contained within bacteria, followed by the solubilisation of PHA granules with organic solvents, and a final precipitation with non-solvents (Gumel et al., 2013; Raza et al., 2018). This is the preferred extraction method when high purity is required, since it does not degrade the polymer and removes cell endotoxins (Gumel et al., 2013; Jacquel et al., 2008). The flotation method, a modification of the solvent method that avoids the last step, is also used to extract PHAs by the shelf-flotation of the cell debris with high purity and recovery efficiency (Raza et al., 2018). Enzymatic or chemical (hypochlorite or surfactants) digestion methods have emerged as alternatives to solvent methods with good PHA recovery. Two-phase aqueous extraction and supercritical fluid extraction are the latest and most innovative strategies for PHA extraction, due to their sustainability and low cost. Aqueous two-phase system is comprised of two polymers at low concentrations (or of one polymer and an inorganic salt) that display incompatibility and coexist as two immiscible phases when are mixed (Kunasundari \& Sudesh, 2011). Meanwhile, the supercritical fluid extraction uses supercritical fluids for the isolation, purification and recovery of PHAs, such as carbon dioxide ammonia and methanol (Gumel et al., 2013; Raza et al., 2018). For in vivo PHA applications, some impurities, like endotoxins, can cause inflammation even when PHAs are obtained by solvent extraction (Koller et al., 2013a, b). Supercritical solvent extraction is recommended in these cases since it allows impurity-free PHAs to be obtained for medical applications (Raza et al., 2018). 


\subsubsection{PHA applications}

Of the different biodegradable polymers, PHAs are those gaining attention due to the broad chemical variety of their radicals, which provides physical properties as good as the ones exhibited by conventional polymers (Albuquerque \& Malafaia, 2017). In this sense, tailormade PHAs can be produced by selecting the proper bacteria, as well as the appropriate culture conditions and carbon sources. Moreover, PHA variability can be increased by the chemical modification of the natural PHAs (Hazer \& Steinbüchel, 2007). Thus, depending on the PHA monomer composition, these biopolymers could vary from rigid and brittle plastics to soft elastomers, rubbers and adhesives (Albuquerque \& Malafaia, 2017).

PHA applications in the material industry have been related with the development of cosmetics containers, shampoo bottles, shopping bags, cups, pens, combs, bullets, and disposable items such as razors, feminine hygiene products, moisture barriers for nappies and sanitary towels (Xu \& Guo, 2010; Keshavarz \& Roy 2010; Madison \& Huisman, 1999). Moreover, in the last three decades, numerous patented applications for the PHAs have been developed such as flavour delivery agents in foods (Yalpani, 1993a), dairy cream substitutes (Yalpani, 1993b), fibres for non-woven fabrics (Steel \& Norton-Berry, 1986), latex for paper coating (Marchessault et al., 1995) and hot-melt adhesives (Kauffman et al., 1992).

\section{Food packaging materials}

Although some mcl-PHAs can be elastomeric materials in a narrow temperature window, sclPHAs, such as PHB, PHBV or poly(3-hydroxyvalerate) (P(3HV) or PHV), are thermoplastic polyesters and are used as bioplastics, which can replace petroleum-based polymers in packaging and coating applications, with the food sector being the principal target (Albuquerque \& Malafaia, 2017; Madison, \& Huisman, 1999; Siracusa et al., 2008). Table 1 shows several studies that analysed the impact of packaging materials based on $\mathrm{PHB}$, the most common PHA, on the quality of the packaged foodstuffs.

Despite the acceptable results regarding the impact on the food quality of PHB based materials, its application as food packaging has been hindered because of its brittleness, stiffness, thermal instability, limited gas barrier properties as well as high cost and limited availability (Albuquerque \& Malafaia, 2017; Modi et al., 2011). In this sense, different strategies have been investigated to improve PHA functional properties as packaging material in order to extend their applicability. Copolymerizing approaches have been effective alternative means of improving thermal stability, mechanical performance, gas and water vapour barrier capacity of these biopolymers, through decreasing both their brittleness and melting temperatures (Albuquerque \& Malafaia, 2017; Gumel et al., 2013; Modi et al., 2011; Siracusa et al., 2008; Peelman et al., 2013; Petersen, 1999; Zhang \& Thomas, 2011; Cao et al., 
2005). In this sense, several copolymers have been developed using different monomer units, such as 3-hydroxyvalerate, 4-hydroxybutyrate or 3-hydrohexanoate, thus improving the physical properties of the PHB homopolymer (Choi \& Park, 2004). PHBV obtained by different levels of copolymerization of 3-hydroxyvalerate leads to less stiff, tougher materials with improved thermal stability and barrier properties, with a broadened application range in the food packaging sector (Gumel et al., 2013; Modi et al., 2011; Siracusa et al., 2008; Peelman et al., 2013; Petersen, 1999; Savenkova et al., 2000).

Table 1. Impact of polyhydroxybutyrate based packaging on food quality.

\begin{tabular}{|c|c|c|}
\hline Food & Impact on food quality & Reference \\
\hline Sour cream & $\begin{array}{l}\text { PHB based films were suitable for maintaining the quality of the } \\
\text { dairy product in terms of colour, } \mathrm{pH} \text { and secondary lipid } \\
\text { oxidation products. }\end{array}$ & $\begin{array}{l}\text { Muizniece- } \\
\text { Brasava \& } \\
\text { Dukalska, } 2006\end{array}$ \\
\hline $\begin{array}{l}\text { Mayonnaise, } \\
\text { margarine and } \\
\text { cream cheese }\end{array}$ & $\begin{array}{l}\text { PHB films were found suitable for storage of fat-rich products, } \\
\text { according to physical, mechanical, sensorial, and dimensional } \\
\text { analyses. }\end{array}$ & $\begin{array}{l}\text { Bucci et al., } \\
2005\end{array}$ \\
\hline $\begin{array}{l}\text { Meat salad in } \\
\text { mayonnaise }\end{array}$ & $\begin{array}{l}\text { PHB films could be successfully used for Sous vide thermal food } \\
\text { treatment at a temperature no higher than } 63^{\circ} \mathrm{C} \text {. }\end{array}$ & $\begin{array}{l}\text { Levkane et al. } \\
2008\end{array}$ \\
\hline $\begin{array}{l}\text { Orange juice } \\
\text { simulant and a } \\
\text { dressing }\end{array}$ & $\begin{array}{l}\text { PHB based cups were equivalent to those of high density } \\
\text { polyethylene in terms of colour changes, primary and } \\
\text { secondary lipid oxidation products and reduction of } \alpha- \\
\text { tocopherols, during storage of samples with light exposure. }\end{array}$ & $\begin{array}{l}\text { Haugaard et al., } \\
2003\end{array}$ \\
\hline Tomatoes & $\begin{array}{l}\text { PHB-coated paperboard trays maintained tomato quality as } \\
\text { good as that of those stored in low density polyethylene bags, } \\
\text { in terms of weight loss, moisture content, colour, firmness and } \\
\text { flavour. }\end{array}$ & $\begin{array}{ll}\text { Kantola } \& \\
\text { Helén, } 2001\end{array}$ \\
\hline
\end{tabular}

In the field of food applications, PHA-based packaging materials have also been used as carriers of antimicrobial or antioxidant compounds, which can extend the shelf-life of the packaged foodstuffs, maintaining their quality. To impart antimicrobial action to PHA materials, antimicrobial agents can be incorporated into the packaging structure during manufacturing. Thus, the antimicrobial activity can be achieved by direct contact with the foodstuff (the antimicrobial compound can be absorbed or immobilised into the polymeric matrix), or by modifying the headspace of the package by the controlled release of the active compound from the packaging structure (Sanchez-Garcia et al., 2010b). In this sense, many studies have been performed aiming to provide this added functionality to PHA based materials (Table 2). 
Table 2. Antimicrobial packaging materials based on polyhydroxyalkanoates.

\begin{tabular}{|c|c|c|c|}
\hline Active agent & Film processing & Main results & Reference \\
\hline $\begin{array}{l}\text { Silver } \\
\text { nanoparticles } \\
\text { (AgNPs) obtained } \\
\text { in an aqueous } \\
\text { solution of PHBV. }\end{array}$ & $\begin{array}{l}\text { Melt blending of the } \\
\text { PHBV/AgNPs } \\
\text { nanocomposites (8\%) }\end{array}$ & $\begin{array}{l}\text { PHBV-AgNPs films showed a strong } \\
\text { and sustained (even after seven } \\
\text { months) antibacterial activity } \\
\text { against Salmonella enterica and } \\
\text { Listeria monocytogenes. }\end{array}$ & $\begin{array}{l}\text { Castro- } \\
\text { Mayorga } \\
\text { et al., } \\
2016\end{array}$ \\
\hline $\begin{array}{l}\text { Hexagonal- } \\
\text { pyramid zinc } \\
\text { oxide } \\
\text { nanoparticles } \\
\text { (ZnONP) }\end{array}$ & $\begin{array}{l}\text { Nanocomposites based } \\
\text { on PHBV and ZnONP } \\
\text { obtained by three } \\
\text { different methods: (i) } \\
\text { melt-blending, (ii) melt- } \\
\text { blending of pre- } \\
\text { incorporated ZnO into } \\
\text { PHBV electrospun fibres } \\
\text { and, (iii) coating of the } \\
\text { electrospun PHBV/ZnO } \\
\text { fibres on the compression } \\
\text { moulded PHBV. }\end{array}$ & $\begin{array}{l}\mathrm{ZnO} \text { contained in electrospun fibre } \\
\text { mats, as coatings of the film outer } \\
\text { layer increased the } \mathrm{Zn} \text { availability } \\
\text { and, thus, its antimicrobial } \\
\text { performance (reduction of } 3 \mathrm{CFU} \\
\text { log units). }\end{array}$ & $\begin{array}{l}\text { Castro- } \\
\text { Mayorga } \\
\text { et al., } \\
2017\end{array}$ \\
\hline ZnONP & $\begin{array}{l}\text { Nanocomposites based } \\
\text { on ZnONP }(1,2,5 \text { and } 10 \\
\text { wt \%) and PHB, obtained } \\
\text { by casting method from } \\
\text { chloroform solutions. }\end{array}$ & $\begin{array}{l}\text { PHB-ZnONP films showed } \\
\text { antibacterial activity against both } \\
\text { Staphylococcus aureus and } \\
\text { Escherichia coli, which was } \\
\text { progressively improved upon } \\
\text { increasing ZnO concentration. }\end{array}$ & $\begin{array}{l}\text { Díez- } \\
\text { Pascual \& } \\
\text { Díez- } \\
\text { Vicente, } \\
2014\end{array}$ \\
\hline Eug & $\begin{array}{l}\text { PHB active films, obtained } \\
\text { by casting from the } \\
\text { chloroform solutions, } \\
\text { with eugenol at different } \\
\text { concentrations (10-200 } \\
\mu \mathrm{g} / \mathrm{g} \text { of } \mathrm{PHB})\end{array}$ & $\begin{array}{l}\text { PHB films containing eugenol ( } 80 \\
\mu \mathrm{g} / \mathrm{g} \text { ) inhibited the growth and the } \\
\text { sporulation of moulds, i.e., } \\
\text { Aspergillus niger, Aspergillus flavus, } \\
\text { Penicillium sp., and Rhizopus sp., } \\
\text { until } 7 \text { days. Significant } \\
\text { antibacterial activity was observed } \\
\text { against Salmonella typhimurium, } \\
\text { Staphylococcus aureus, Escherichia } \\
\text { coli and Bacillus cereus. }\end{array}$ & $\begin{array}{l}\text { Narayanan } \\
\text { \& Ramana, } \\
2013\end{array}$ \\
\hline Vanillin & $\begin{array}{l}\text { PHB active films were } \\
\text { obtained by casting from } \\
\text { chloroform solutions with } \\
\text { vanillin at different } \\
\text { concentrations }(10-200 \\
\mu \mathrm{g} / \mathrm{g} \text { of PHB) }\end{array}$ & $\begin{array}{l}\text { The minimum concentration of } \\
\text { vanillin required to exhibit } \\
\text { antimicrobial activity was } \geq 80 \mu \mathrm{g} / \mathrm{g} \\
\text { PHB for bacteria and } \geq 50 \mu \mathrm{g} / \mathrm{g} \text { PHB } \\
\text { for fungi. }\end{array}$ & $\begin{array}{l}\text { Xavier et } \\
\text { al., } 2015\end{array}$ \\
\hline
\end{tabular}




\begin{tabular}{|c|c|c|c|}
\hline Active agent & Film processing & Main results & Reference \\
\hline $\begin{array}{l}\text { Cinnamaldehyde } \\
(\mathrm{CIN})\end{array}$ & $\begin{array}{l}\text { Electrospun zein-CIN layers } \\
\text { were applied to obtain } \\
\text { PHBV multilayer films by } \\
\text { compression moulding: (1) } \\
\text { PHBV + zein-CIN; (2) PHBV + } \\
\text { zein-CIN + PHBV; (3) PHBV + } \\
\text { zein-CIN + alginate. }\end{array}$ & $\begin{array}{l}\text { The active multilayer structures showed } \\
\text { antibacterial activity against L. } \\
\text { monocytogenes, the PHBV/zein- } \\
\text { cinnamaldehyde/PHBV system being the } \\
\text { one that showed the greatest } \\
\text { antibacterial activity. }\end{array}$ & $\begin{array}{l}\text { Cerqueira } \\
\text { et al., } \\
2016\end{array}$ \\
\hline $\mathrm{CIN}$ & $\begin{array}{l}\text { Trilayer structures with PHB } \\
\text { outer layers were obtained } \\
\text { by compression moulding } \\
\text { including an electrospun } \\
\text { inner layer of zein-CIN. }\end{array}$ & $\begin{array}{l}\text { Multilayer films containing CIN }(2.60 \\
\left.\mathrm{mg} / \mathrm{cm}^{2}\right) \text { completely inactivated feline } \\
\text { calicivirus, while murine norovirus titers } \\
\text { were reduced by } 3 \text { log. Both are enteric } \\
\text { viruses, causing foodborne illnesses. }\end{array}$ & $\begin{array}{l}\text { Fabra et } \\
\text { al., 2016a }\end{array}$ \\
\hline $\begin{array}{l}\text { Catequin } \\
\text { (antioxidant) }\end{array}$ & $\begin{array}{l}\text { PLA-PHB }(75: 25) \text { films } \\
\text { containing } 5 \text { wt } \% \text { catequin } \\
\text { were prepared by melt } \\
\text { blending. }\end{array}$ & $\begin{array}{l}\text { Polyester films containing catequin } \\
\text { showed significant antioxidant activity } \\
\text { coherent with the catechin release. }\end{array}$ & $\begin{array}{l}\text { Arrieta et } \\
\text { al., 2014a }\end{array}$ \\
\hline $\begin{array}{l}\text { N-halamine } \\
\text { precursor }\end{array}$ & $\begin{array}{l}\text { Electrospun fibre } \\
\text { membranes based on PHB } \\
\text { and the } \mathrm{N} \text {-halamine } \\
\text { precursor were chlorinated } \\
\text { to obtain antimicrobial } \\
\text { materials. }\end{array}$ & $\begin{array}{l}\text { The chlorinated membranes had } \\
\text { excellent antimicrobial functions, which } \\
\text { could inactivate } 92 \% \text { S. aureus and } 85 \% E \text {. } \\
\text { coli within } 30 \text { min of contact time. }\end{array}$ & $\begin{array}{l}\text { Fan et al., } \\
2015\end{array}$ \\
\hline Nisin & $\begin{array}{l}\text { PHB-PCL (50:50) films were } \\
\text { obtained by melt blending } \\
\text { and compression moulding. } \\
\text { Antimicrobial films were } \\
\text { obtained by nisin } \\
\text { adsorption. }\end{array}$ & $\begin{array}{l}\text { PHB-PCL nisin activated films were } \\
\text { effective against Lactobacillus plantarum } \\
\text { inoculated on sliced ham, thus extending } \\
\text { its shelf-life. }\end{array}$ & $\begin{array}{l}\text { Correa et } \\
\text { al., } 2017\end{array}$ \\
\hline $\begin{array}{l}\text { Montmorillonite } \\
\text { organoclays } \\
\text { (Cloisite }^{\circledR} \quad 30 \mathrm{~B} \\
\text { and } \\
\text { Claytone APA) }\end{array}$ & $\begin{array}{l}\mathrm{P}(3 \mathrm{HB}-4 \mathrm{HB}) \\
\text { nanocomposites with } 5 \text { and } \\
10 \text { wt\% of each type of } \\
\text { organoclays were obtained } \\
\text { by casting. }\end{array}$ & $\begin{array}{l}\mathrm{P}(3 \mathrm{HB} 4 \mathrm{HB}) \text { exhibited antimicrobial } \\
\text { activity against } S \text {. aureus but not against } \\
\text { E. coli. Films containing Claytone APA } \\
\text { showed higher antimicrobial properties } \\
\text { compared to those containing } \\
\text { Cloisite }{ }^{\circledR} 30 \mathrm{~B} \text {. Stronger antimicrobial } \\
\text { effects were observed as the clay } \\
\text { concentration in the film increased. }\end{array}$ & $\begin{array}{l}\text { Hema et } \\
\text { al., } 2013\end{array}$ \\
\hline
\end{tabular}




\section{Medical applications}

The biocompatibility and the biodegradable nature of PHAs have attracted much interest in the medical sector (Xu \& Guo, 2010; Gumel et al., 2013; Raza et al., 2018). Thus, PHB and PHBV have been widely used in tissue engineering as matrices (scaffolds) for the proliferation of different human cells, such as endothelium cells, isolated hepatocytes, fibroblasts (Sevastianov et al., 2003) and neurons (Chen \& Tong, 2012). PHAs have also been used for the tissue regeneration of bones (Porter et al., 2013) and eyelids (Zhou, 2010). Based on the results obtained for orthopaedic implants and bone replacement in animals, PHAs could be used as biomedical implant materials in the human body (Raza et al., 2018). PHAs have also been used in the repairing damaged nerves in rates as an alternative to the conventional nerve graft (Bugnicourt et al., 2014) and for wound dressing (Shishatskaya et al., 2016) and scaffols (Volova, 2004).

The use of PHAs as drug delivery carriers is also receiving more and more attention, since the micro or nanospheres of PHAs containing drugs allow for a prolonged release of the encapsulated compounds, as the polymer degrades (Xu \& Guo, 2010; Gumel et al., 201; Raza et al., 2018). Thus, PHAs have been tested as drug or vaccine carriers on several animals, such as mice, rabbits, sheep or dogs, and even in the gingivitis treatment in humans (Valappil et al., 2006; Valappil et al., 2007). Specific drug targeting systems based on PHA nanoparticles for cancer therapy have been successfully developed by the linkage of specific ligands, whose effectiveness has been proven in both in vitro and in vivo studies (Kiliçay et al., 2011; Wang el al., 2008a; Yao et al., 2008).

Both D-3-hydroxybutyrate (D-3HB), which is the most common PHA degradation product, and D-3HB derivatives showed inhibitory effects on cell apoptosis, which explains the PHA biocompatibility and suggests their application as neural protective agents (Xu \& Guo, 2010; Xiao et al. 2007). These products improved neural capacities, such as learning and memory, since they enhanced neural communication (Zou et al. 2009).

\section{Biofuel}

The use of PHAs as precursors of green biofuels has recently been suggested, since the hydrolysis of PHAs followed by methyl esterification gives 3-hydroxyalkanoates methyl esters, whose combustion energy is comparable to that of bioethanol (Gao et al., 2011; Wang et al., 2010; Zhang et al., 2009). However, PHA conversion into biofuel is more expensive than the direct fermentation of sugars into bioethanol (Gumel et al., 2013). Nevertheless, the interest in PHA-based biofuels is enhanced by the fact that they are biodegradable and produce low greenhouse gas emissions, in contrast with fossil fuels. Moreover, other biofuels are obtained from biomass, whereas PHAs can be produced from waste water or activated sludge, dealing with the controversial use of agricultural crops as fuels (Xu \& Guo, 2010; Chen, 2009). 


\section{Other industrial applications}

PHB and PHBV can be used as carriers of herbicides, such as ametryn, for agricultural applications, due to their capacity to deliver the agents contained inside micro or nanoparticles progressively, thus reducing the requirement of successive applications as well as the negative effects on non-target species (Grillo et al., 2011; Gumel et al., 2013). Due to their hydrophobic nature, PHA composites can be used as biomimetic adsorbents for the removal of lipid-soluble organic pollutants from water (Zhang et al., 2010). PHB granules in feed have also been applied as pathogenic bacterial growth inhibitors in some aquaculture applications (Defoirdt et al., 2011; Wille et al., 2010).

\subsubsection{Properties of PHA-based packaging materials}

The physical properties of PHA can be as good as those of synthetic plastics, due to the wide chemical variety of their radicals. Thus, depending on the monomer composition, PHAs can range from brittle, stiff plastics to soft elastomers, rubbers and adhesives. Moreover, some PHA packaging materials offer good resistance to moisture, because of their hydrophobic nature (Bugnicourt, et al., 2014), and gas barrier properties comparable to polyvinyl chloride (PVC) and polyethylene terephthalate (PET) (Albuquerque \& Malafaia, 2018), with the advantage of being biodegradable at worst in 6 weeks in a microbiologically active environment (Siracusa et al., 2008). Compared to polysaccharide-based materials, PHAs films exhibit much better moisture barrier properties, whereas the gas barrier capacity is inferior (Petersen, 1999).

\section{Physical properties}

PHB homopolymer based films are brittle and stiff, with poor impact resistance, due to their high degree of crystallinity and the secondary crystallization that occurs after film processing with ageing (Bugnicourt, et al., 2014; Laycock et al., 2014). PHA film properties are known to be dependent on the polymer composition and film processing, particularly so when they are obtained by melt blending or solvent casting (Laycock et al., 2014; Fabra et al., 2013). Table 3 reviews the range of reported values for the properties of PHB-based films obtained by both processing methods. As shown in Table 3, PHB films prepared by solvent casting show higher elongation at break and greater impact resistance than those obtained by melt blending and compression moulding, probably due to the finer spherulitic morphology associated with the low crystallization temperature, which results in high nucleation density (Holmes, 1998). Similar results have been observed for copolymers, such as poly(3-hydroxybutyrate-co-3hydroxyhexanoate) $(\mathrm{P}(3 \mathrm{HB}-3 \mathrm{HH})$ or $\mathrm{PHBH})$, where the solvent cast films were more stretchable than those obtained by compression moulding (Laycock et al., 2014). As regards 
thermal properties, PHB solvent cast films exhibit lower glass transition temperature $\left(T_{g}\right)$ and melting temperarture $\left(T_{m}\right)$ values than those obtained by melt blending and thermocompression. However, the film barrier capacities are in the same order of magnitude for PHB films obtained either by solvent casting or thermoprocessing.

As previously mentioned, the brittleness and the thermal instability of PHB-based materials are what mainly limit practical applications. Therefore, different approaches, such as the use of copolymeric materials, have been investigated as a means of improving PHA applicability. As shown Table 3, compared to PHB, PHBV-based packaging materials exhibit less stiffness and brittleness, and improved stretchability and tensile strength as the content in the copolymer increases (Laycock et al., 2014; Savenkova et al., 2000), since 3-hydroxyvalerate units hinder the formation of hydroxybutyrate crystals (Orts et al., 1990). Likewise, as the second monomer fraction increased in the copolymeric materials, such as PHBV, poly (3hydroxybutyrate-co-3-hydroxypropionate) (P(3HB-3HP) or PHBP), poly (3-hydroxybutyrateco-4-hydroxybutyrate) ( $\mathrm{P}(3 \mathrm{HB}-4 \mathrm{HB})$ ) and poly (3-hydroxybutyrate-co-6-hydroxyhexanoate) $(\mathrm{P}(3 \mathrm{HB}-6 \mathrm{HH}))$, their glass transition and melting temperatures dropped, thus broadening the processing window, since there was improved melt stability at lower processing temperatures (Sudesh et al., 2000; Modi et al., 2011). Savenkova et al. (2000) reported that $\mathrm{T}_{\mathrm{m}}$ values of PHBV films decreased from $180{ }^{\circ} \mathrm{C}$ to $123{ }^{\circ} \mathrm{C}$ and $\mathrm{Tg}$ from $3.1{ }^{\circ} \mathrm{C}$ to $-6.3^{\circ} \mathrm{C}$ as the $3-$ hydroxyvalerate content in the copolymers increased from 0 to $20 \mathrm{~mol} \%$, with elongation at break values of $180 \%$ for the PHBV film with $20 \mathrm{~mol} \% \mathrm{HV}$.

As concerns the effect of the method used for the PHBV film processing, Fabra et al. (2013) reported that the PHBV/PHBV bilayer films obtained by thermoprocesing exhibited greater mechanical resistance and lower water vapour permeability (WVP) and transparency, as compared to the corresponding multilayer obtained by casting. 


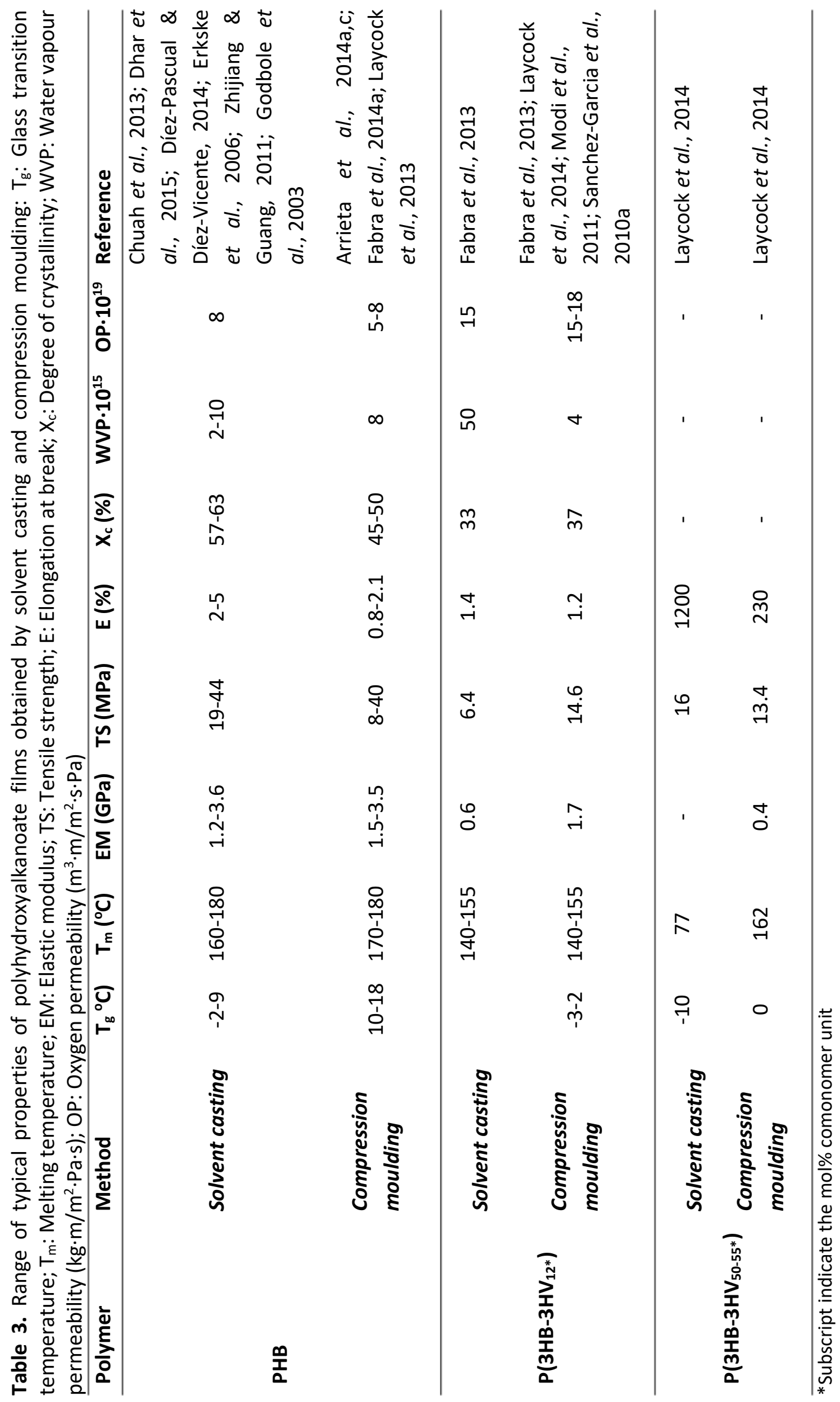




\section{Biodegradability}

PHAs based materials are degraded in biological media, giving rise to harmless products: carbon dioxide and water in aerobic conditions or methane and water in anaerobic environments (Boyandin et al., 2013; Siracusa et al., 2008; Volova et al., 2017). Bacteria, actinomycetes and micromycetes have been described as PHA degraders in soil, compost, activated sludge, and river and sea water, since they produce extracellular PHA depolymerases, which hydrolyse the polymer by surface erosion to water-soluble monomers and/or oligomers used as substrates by other microorganisms (Boyandin et al., 2013). The main advantage of PHAs as compared to other biodegradable polymers is that they do not need specific environmental conditions to be degraded (Muhammadi et al., 2015). Moreover, PHAs can be recycled like petrochemical thermoplastics (Madison \& Huisman, 1999).

The degradation rate and the mechanism of PHA biodegradation are influenced by several factors, including PHA chemical composition and properties (crystallinity, molecular mass, polydispersity), type of polymer and processing method, physicochemical conditions of the environment (oxygen availability, temperature, $\mathrm{pH}$, moisture, acidity, salinity), weather and climate and, to a larger extent, by the composition and metabolic activity of the microbial community (Boyandin et al., 2013; Volova et al., 2017). In this sense, Lee (1996) reported that PHBV was completely degraded after 6 and 75 weeks in anaerobic sewage and soil, respectively, which reflects the great influence of the type of media where the biodegradation takes place. As regards the molecular weight of the polymer, Thellen et al. (2008) reported the fastest degradation rate for the PHB films with the lowest polymer molecular weight, whereas the film with the highest PHB molecular weight had the slowest degradation rate. Volova et al. (2017) found a negative correlation between the degree of crystallinity of PHAs and their biodegradation rate: $\mathrm{P}(3 \mathrm{HB}-4 \mathrm{HB}$, which had the lowest degree of crystallinity $(50 \%)$, showed the highest degradation rate $(1.63 \mathrm{mg} /$ day) and the most crystalline (78 \%) PHB was degraded at the slowest rate $(0.61 \mathrm{mg} /$ day $)$, whereas the polymer with intermediate crystallinity, PHBV, exhibited an intermediate degradation rate.

Compared to other biodegradable polyesters, such as PLA, PHBV-based packaging materials have been reported to degrade faster; and an improved biodegradability of PLA-PHBV blend films has been achieved by adding hydrophilic plasticizers, such as polyethyleneglycol (PEG). These kinds of hydrophilic substances promote the matrix swelling required for the hydrolysis reactions (Wang et al., 2008b). However, the addition of other plasticizers in PHA-based matrices, such as laprol, was reported to halve the biodegradation rate of PHB films compared to pure films, probably due to the fact that laprol partially encapsulated the PHB component, thus retarding the biodegradation of the blend (Savenkova et al., 2000). 


\subsubsection{PHA-based multiphase materials}

A great deal of effort has gone into improving the brittleness and stiffness of PHB-based packaging materials that result from their high degree of crystallinity and ageing recrystallization (Bugnicourt, et al., 2014; Laycock et al., 2014); this effort has focused on different strategies aimed at reducing the crystallinity and improving the thermal stability and stretchability of the final packaging materials.

\section{Plasticizers}

In biopolymer film production, plasticizers are essential additives since they reduce the intermolecular forces along polymer chains, which improves the flexibility and chain mobility, at the same time as they provoke a decrease in the $T_{g}$ and changes in the crystallization behaviour, thus enhancing the functional properties of the packaging materials (Vieira et al., 2011). The effect of different kinds of plasticizers on the mechanical and thermal properties of PHA-based matrices has been studied in depth (Table 4). Jost \& Langowski (2015) reported that as the plasticizer concentration increased, the $T_{m}$, the elastic modulus (EM) and the tensile strength (TS) decreased, whereas the elongation at break (E) and the degree of crystallinity $\left(X_{c}\right)$ of the plasticised film increased. Moreover, the plasticizers significantly increased the water vapour and oxygen permeability, but to a different extent.

In general, medium molecular weight substances with oxygen atoms (e.g. ethers or ketones), which are accessible for interactions with the polymer matrix, such as polyethyleneglycol with $M_{w}$ of 1000 Da (PEG1000), triethyl citrate (TEC) or dibutilphtalate (DBP), have effectively improved the film stretchability (Choi \& Park, 2004; Jost \& Langowski, 2015). Conversely, glycerides with long fatty acids and low $\mathrm{M}_{\mathrm{w}}$ substances with hydroxyl groups do not lead to a plasticising effect in PHBV films (Jost \& Langowski, 2015). The addition of some plasticizers, such as acetyl butyl citrate (ATBC) and sophorolipid, hindered the PHBV and PHB crystallization, respectively, in line with the interruption of interactions among the polymer chains (Branciforti et al., 2013; Solaiman et al., 2015). In contrast, some other compounds, such as propylene glycol (PG), PEG1000 or epoxidised soybean oil (ESO), promoted molecular mobility, thus favouring the crystallization process (Jost \& Langowski, 2015).

There is increasing interest in the application of natural plasticizers, such as castor oil (CO), ESO, soybean oil (SO), DBP or TEC. Natural pasticizers show low toxicity and migration and improve both the thermal and mechanical properties of PHBV films (Choi \& Park, 2004; Jost \& Langowski, 2015; Vieira et al., 2011). Some other biodegradable additives, such as dodecanol, lauric acid, tributyrin and trilaurin, were miscible with PHB and enhanced its molecular mobility, thus decreasing both the glass transition and crystallization temperatures $\left(T_{c}\right)$ of PHB films (Yoshie et al., 2000). 
Table 4. Plasticizer effects on the functional properties of polyhydroxyalkanoate-based films.

\begin{tabular}{|c|c|c|c|}
\hline Plasticizer & $\begin{array}{l}\text { Polymer } \\
\text { (Process) }\end{array}$ & Main results & Reference \\
\hline $\begin{array}{l}\text { Propylene glycol (PG) } \\
\text { Glycerol (G) } \\
\text { Poly(ethyleneglycol) } \\
\text { with } \mathrm{M}_{\mathrm{w}} \quad 1000 \quad \mathrm{Da} \\
\text { (PEG1000) } \\
\text { Castor oil (CO) } \\
\text { Epoxidised soybean } \\
\text { oil (ESO) }\end{array}$ & $\begin{array}{l}\text { PHBV } \\
\text { (extrusion) }\end{array}$ & $\begin{array}{l}\text { In general, as the plasticizer concentration } \\
\text { increased, } T_{m}, E M \text { and TS decreased, whereas } E \\
\text { and } X_{c} \text { of the plasticised film increased. } \\
\text { PEG1000 and TEC improved the film } \\
\text { stretchability. Conversely, glycerides with long } \\
\text { fatty acids (PG and G) and low } M_{w} \text { substances } \\
\text { with hydroxyl groups (CO and ESO) did not lead } \\
\text { to a plasticising effect. All the plasticizers } \\
\text { significantly increased the WVP and OP of the } \\
\text { films, but to a different extent. }\end{array}$ & $\begin{array}{l}\text { Jost \& } \\
\text { Langowski, } \\
2015\end{array}$ \\
\hline $\begin{array}{l}\text { ESO } \\
\text { Soybean oil (SO) } \\
\text { Triethyl citrate (TEC) } \\
\text { Dibutilphtalate (DBP) }\end{array}$ & $\begin{array}{l}\text { PHBV } \\
\text { (casting) }\end{array}$ & $\begin{array}{l}\text { TEC and DBP were more effective at plasticizing } \\
\text { PHBV matrices, since they led to significantly } \\
\text { lower } T_{m} \text { and } T_{g} \\
\text { Likewise, stretchability and impact resistance of } \\
\text { PHBV-TEC and PHBV/DBP blends were also } \\
\text { greater than PHBV-SO and PHBV-ESO blends, } \\
\text { since the solubility parameter, and the polar and } \\
\text { hydrogen-bonding components of TEC and DBP } \\
\text { were closer to the corresponding values of PHBV. }\end{array}$ & $\begin{array}{l}\text { Choi \& } \\
\text { Park, } 2004\end{array}$ \\
\hline $\begin{array}{l}\text { Acetyl butyl citrate } \\
\text { (ATBC) }\end{array}$ & $\begin{array}{l}\text { PHBV } \\
\text { (extrusion) }\end{array}$ & $\begin{array}{l}\text { The addition of ATBC significantly shifted both } \mathrm{T}_{\mathrm{g}} \\
\text { and } \mathrm{T}_{\mathrm{m}} \text { as the plasticizer concentration } \\
\text { increased. Moreover, ATBC led to less crystalline } \\
\text { films and less stable crystallites. }\end{array}$ & $\begin{array}{l}\text { Branciforti } \\
\text { et al., } 2013\end{array}$ \\
\hline $\begin{array}{l}\text { PEG300 } \\
\text { Laprol } \\
\text { Dioctylsebacate } \\
\text { (DOS) } \\
\text { Polyisobutylene (PIB) } \\
\text { Dibutylsebacate } \\
\text { (DBS) }\end{array}$ & $\begin{array}{l}\text { PHB } \\
\text { (casting) }\end{array}$ & $\begin{array}{l}\text { All the additives progressively enhanced the E of } \\
\text { the PHB film from concentrations that ranged } \\
\text { from } 15 \% \text { to } 33 \% \text {. Laprol, DOS and DBS led to } \\
\text { better mechanical behaviour, whereas PIB } \\
\text { showed the mildest plasticizing effect. Laprol } \\
\text { was selected as plasticizer based on the greatest } \\
\text { improvement of the PHB film stretchability. }\end{array}$ & $\begin{array}{l}\text { Savenkova } \\
\text { et al., } 2000\end{array}$ \\
\hline Sophorolipid (SL) & $\begin{array}{l}\text { PHB } \\
\text { (casting) }\end{array}$ & $\begin{array}{l}\mathrm{SL} \text {, a kind of glycolipid produced by the } \\
\text { fermentation broth of Candida bombicola, } \\
\text { significantly hindered the PHB crystallization } \\
\text { (decrease in } \Delta \mathrm{H}_{\mathrm{m}} \text { and } \mathrm{T}_{\mathrm{m}} \text { ) by the interruption of } \\
\text { inter-molecular interactions. }\end{array}$ & $\begin{array}{l}\text { Solaiman et } \\
\text { al., } 2015\end{array}$ \\
\hline
\end{tabular}




\begin{tabular}{|c|c|c|c|}
\hline Plasticizer & $\begin{array}{l}\text { Polymer } \\
\text { (Process) }\end{array}$ & Main results & Reference \\
\hline $\begin{array}{l}\text { Dodecanol } \\
\text { Lauric acid } \\
\text { Tributyrin } \\
\text { Trilaurin }\end{array}$ & $\begin{array}{l}\text { PHB } \\
\text { (casting) }\end{array}$ & $\begin{array}{l}\text { All the compounds acted as plasticizers, since } T_{g} \text { and } \\
T_{c} \text { of the mixtures were lower than those of the neat } \\
\text { PHB films, but to a different extent. The miscibility } \\
\text { between PHB and the different plasticizers was } \\
\text { greater in the order of tributyrin }>\text { dodecanol lauric } \\
\text { acid > trilaurin. }\end{array}$ & $\begin{array}{l}\text { Yoshie et } \\
\text { al., } 2000\end{array}$ \\
\hline PEG200 & $\begin{array}{l}\text { PHB } \\
\text { (casting) }\end{array}$ & $\begin{array}{l}\text { The incorporation of PEG200 (15\%) led to a reduction } \\
\text { in both TS ( } 30 \text { to } 22 \mathrm{MPa} \text { ) and } \mathrm{EM} \text { ( } 1180 \text { to } 537 \mathrm{MPa} \text { ), } \\
\text { and enhaced the film extensibility (from } 6 \text { to } 12 \% \text { ). } \\
\text { Moreover, } \mathrm{T}_{\mathrm{m}} \text { decreased from } 175^{\circ} \mathrm{C} \text { to } 156^{\circ} \mathrm{C} \text {. }\end{array}$ & $\begin{array}{ll}\text { de } & 0 \\
\text { Patrício et } \\
\text { al., } 2013\end{array}$ \\
\hline
\end{tabular}

$T_{g}$ : Glass transition temperature; $T_{m}$ : Melting temperature; EM: Elastic modulus; TS: Tensile strength; $E$ : Elongation at break; $X_{c}$ : Degree of crystallinity; WVP: Water vapour permeability; OP: Oxygen permeability

\section{Polymer blends}

Unlike the development of new polymer materials, the blending strategy is a cheap and rapid method to improve plastic functional properties. Therefore, this approach has been applied to obtain PHA-based blends with improved film properties as compared to that of the neat polymer films. Table 5 summarizes different studies dealing with the blending of PHAs with other polymers. PHAs have been widely used to improve both the mechanical properties and barrier capacity of PLA films (Armentano et al., 2015; Arrieta et al 2014a,b; Ma et al., 2017). Nonetheless, Ferreira et al. (2001) reported immiscibility between both polyesters, since PLAPHBV blends showed two different $T_{g}$ and $T_{m}$ values, which did not vary in relation to the blend composition. Therefore, additives, such as plasticizers and/or compatibilizers, are necessary to improve the ductile properties of the polymer blends and to achieve the stretchability required for their application, as well as the compatibility of the polymer blends, which renders better functional film properties. As seen in Table 5, lactic acid oligomer (OLA), limonene, PEG300, acetyl tributyl citrate (ATBC) and poly(butylene adipate-co-terephthalate) (PBAT) have enhanced the functional properties of PLA-PHB blend films (Armentano et al., 2015; Arrieta et al 2014a,b; Ma et al., 2017). As reported by Jost \& Kopitzky (2015), 20-35 \% of PHBV is the suitable concentration range for PLA-PHBV blend films in terms of polymer interactions, phase separation and barrier properties. WVP and OP decreased by $46 \%$ and $40 \%$, respectively, in PLA-PHBV (75:25) films with respect to the neat PLA films. 


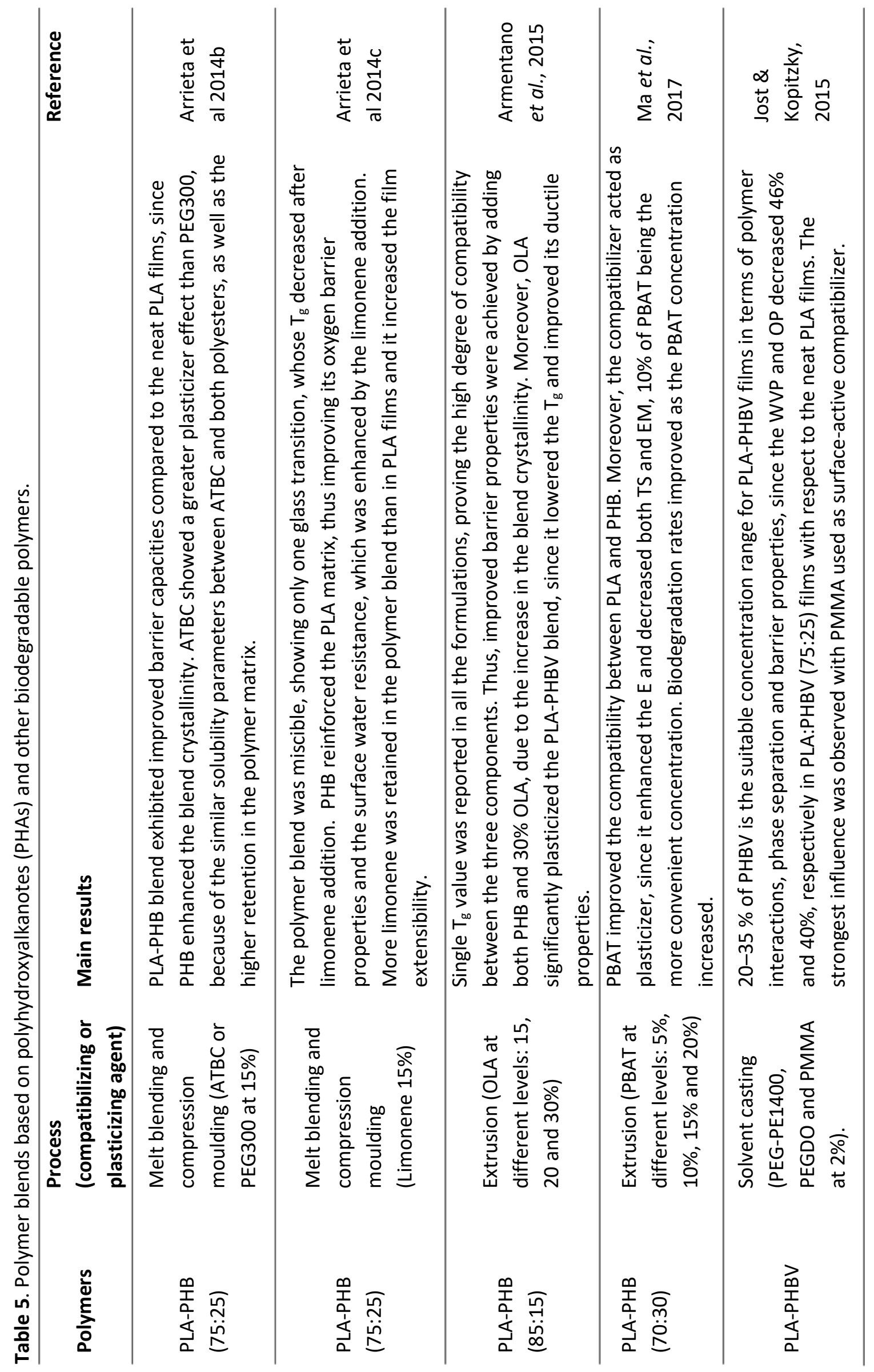




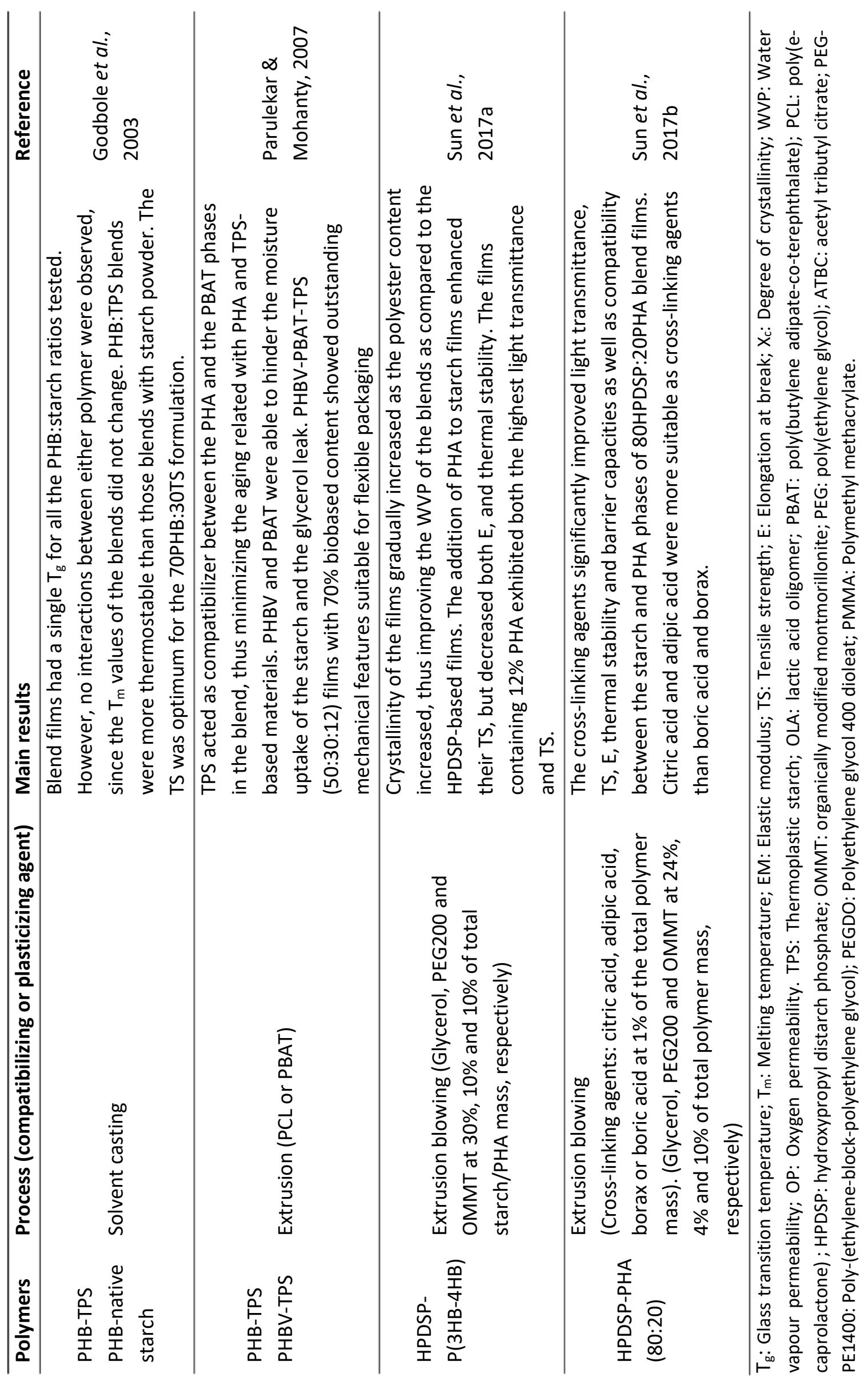


PHA-starch blend films have been proposed as a means of lowering the costs associated with the use of neat PHA and accelerating their biodegradation, because starch is cheaper and faster to degrade than PHA. However, in order to use starch as packaging material, it should be gelatinised and plasticised, usually by using water and/or non-volatile plasticizers, such as glycerol or other polyols, obtaining thermoplastic starch (TPS) (Parulekar \& Mohanty, 2007). Thus, PHB-TPS blends were more thermostable and exhibited better mechanical performance than those blends prepared with native starch granules (Godbole et al., 2003). Likewise, Parulekar \& Mohanty (2007) successfully developed PHBV-PBAT-TPS films by extrusion with $70 \%$ biobased content and outstanding mechanical features, which were suitable for flexible packaging, since both hydrophobic materials, PHBV and PBAT, were able to delay both the high moisture uptake of starch and the glycerol leach. Moreover, the aging process related with PHA and TPS based materials was significantly reduced due to the compatibilizing effect of the TPS in the PHBV-PBAT-TPS blend. Likewise, Sun et al. (2017a) recommended starch-PHA blend films based on hydroxypropyl distarch phosphate (HPDSP) and $\mathrm{P}(3 \mathrm{HB}-4 \mathrm{HB})$ in a polymer ratio $88: 12$ by using extrusion blowing and glycerol, PEG200 and organically modified montmorillonite (OMMT) at $30 \%, 10 \%$ and $10 \%$, respectively, since this blend formulation showed improved TS and water vapour resistance. HPDSP-PHA (80:20) blend films were obtained by using different cross-linking agents, with improved light transmittance, TS, E, thermal stability and barrier capacity as well as compatibility between the starch and the PHA phases. The different cross-linking agents were citric acid, adipic acid, boric acid and borax; the first two being more suitable than boric acid and borax (Sun et al., 2017b).

\section{Multilayer systems}

Although improved film properties can be obtained by blending PHA with other biodegradable polymers, this strategy involves reactive processes, which, in turn, could lead to reactant residues in the films, whose food safety needs to be proven. Conversely, the bilayer or multilayer systems provide an easier approach to combine biopolymers with complementary properties and no great effort to enhance the interfacial compatibility between the polymers is needed, since the polymer interactions only take place at the layer interface. In addition, as regards the barrier capacity, multilayer assembly is more advantageous, since polymers with complementary barrier properties can be combined to obtain packaging materials that are highly water resistant (non-polar sheet) as well as impermeable to gas (polar sheet), thus being better adapted to different food packaging applications (Muller et al., 2017a). In this sense, PHAs have been combined with biodegradable polymers with complementary properties by using different strategies, obtaining multilayer systems with improved capacities as compared to the neat polymer monolayers (Table 6). PHB and PHBV have been used as outer layers in three-layer systems to protect the inner water-soluble sheet by electrospinning the polyester on a pre-formed layer and the subsequent compression moulding of the 
assembly (Fabra et al., 2015, Fabra et al., 2016b; Cherpinski et al., 2018) or by the co-extrusion and compression moulding of the different sheets (Thellen et al., 2013). PHAs have also been used to obtain moisture resistant protein-based films by dip coating of the PHA monolayer with a filmogenic solution based on whey protein and gelatin (de Andrade et al., 2017).

Nonetheless, when incompatible polymers are used for the different layers, additional strategies could be required for adhesion purposes. For example, Thellen et al. (2013) developed PHA tie layers, by grafting it with maleic anhydride (MA) using a dicumyl peroxide initiator to act as adhesive, thus more than doubling the peel strength with the core PVOH layer in three-layer systems. In this way, PHAs protected the water-soluble PVOH core, taking advantage of the high oxygen barrier capacity of $\mathrm{PVOH}$ as well as the biodegradable and water barrier properties of PHA materials. Likewise, a custom multilayer co-extrusion process was designed to develop PLA/PHBV multilayer films (90/10 wt\%) containing from 3 to 2049 theoretical layers, which exhibited improved ductility and barrier properties as compared to neat PLA films or melt blended films and three-layer co-extruded films. These multilayer structures presented many long, thin, crystallized lamellas of PHBV dispersed within the PLA matrix, with increased compatibility (Boufarguine et al., 2013).

Table 6. Polyhydroxyalkanoate (PHA)-based multilayer materials

\begin{tabular}{|c|c|c|c|}
\hline Polymer system & Process & Main results & Reference \\
\hline $\begin{array}{l}\mathrm{PHBV}^{\mathrm{e}} / \mathrm{WG} / \mathrm{PHBV}^{\mathrm{e}} \\
\mathrm{PHB}^{\mathrm{e}} / \mathrm{WG} / \mathrm{PHB}^{\mathrm{e}}\end{array}$ & $\begin{array}{l}\text {-WG monolayer plasticized } \\
\text { with glycerol by compression } \\
\text { moulding. } \\
\text {-Electrospinning of PHB or } \\
\text { PHBV on both sides of the WG } \\
\text { layer. } \\
\text {-Compression moulding of the } \\
\text { monolayers. }\end{array}$ & 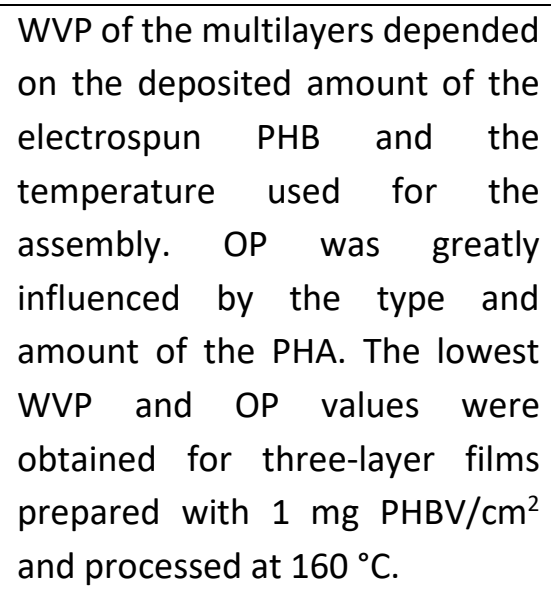 & $\begin{array}{l}\text { Fabra et al., } \\
2015\end{array}$ \\
\hline $\begin{array}{l}\text { PHBV/zeine/PHBV } \\
\text { PHB/zeine/PHB }\end{array}$ & $\begin{array}{l}\text {-PHBV and PHB monolayer by } \\
\text { compression moulding } \\
\text {-Electrospinning of zein } \\
\text { nanofibres onto the PHA films. } \\
\text {-Compression moulding of the } \\
\text { electrospun PHA monolayer } \\
\text { with an identical PHA sheet. }\end{array}$ & $\begin{array}{l}\text { WVP and OP were improved in } \\
\text { PHA multilayer systems by the } \\
\text { addition of electrospun zein } \\
\text { nanofibres. This strategy reduced } \\
\text { the film mechanical resistance } \\
\text { and improved their stretchability. }\end{array}$ & $\begin{array}{l}\text { Fabra et al., } \\
2014\end{array}$ \\
\hline
\end{tabular}




\begin{tabular}{|c|c|c|c|}
\hline Polymer system & Process & Main results & Reference \\
\hline $\mathrm{PHB}^{\mathrm{e}} / \mathrm{TPS} / \mathrm{PHB}^{\mathrm{e}}$ & $\begin{array}{l}\text {-TPS monolayer by } \\
\text { compression moulding. } \\
\text {-Electrospinning of PHB } \\
\text { fibres onto both sides of } \\
\text { the TPS monolayer. } \\
\text {-Compression moulding } \\
\text { of the monolayers. }\end{array}$ & $\begin{array}{l}\text { Improved water barrier capacity } \\
\text { compared to the neat TPS monolayer } \\
\text { by obtaining the multilayer system. }\end{array}$ & $\begin{array}{l}\text { Fabra et al., } \\
2016 \mathrm{~b}\end{array}$ \\
\hline W-G/PHA/W-G & $\begin{array}{l}\text {-PHA monolayer by } \\
\text { solvent casting. } \\
\text {-Dip the PHA monolayer } \\
\text { in a filmogenic solution } \\
\text { plasticized with glycerol. }\end{array}$ & $\begin{array}{l}\text { The hydrocolloids decreased both the } \\
\text { WVP and the opacity of the films } \\
\text { compared to the neat PHA structure. } \\
\text { Moreover, improved mechanical } \\
\text { properties were achieved due to the } \\
\text { hydrocolloids. Thermal analysis } \\
\text { proved the polymeric miscibility. }\end{array}$ & $\begin{array}{l}\text { de Andrade } \\
\text { et al., } 2017\end{array}$ \\
\hline PHB/PVOH/PHB & $\begin{array}{l}\text {-Three-layer co- } \\
\text { extrusion. } \\
\text {-Compression moulding } \\
\text { of the pre-formed layers. }\end{array}$ & $\begin{array}{l}\text { The grafted PHB improved the } \\
\text { adhesion of the PVOH layer to the PHB } \\
\text { layer. PHB protected the water-soluble } \\
\text { PVOH core and greater film barrier } \\
\text { capacities were achieved by using less } \\
\text { plasticized PVOH grade and more } \\
\text { crystalline PHB. }\end{array}$ & $\begin{array}{l}\text { Thellen et } \\
\text { al., } 2013\end{array}$ \\
\hline $\begin{array}{l}\mathrm{PHBV}^{\mathrm{e}} / \mathrm{CNF} / \mathrm{PHBV}^{\mathrm{e}} \\
\mathrm{PHB}^{\mathrm{e}} / \mathrm{CNF} / \mathrm{PHB}^{\mathrm{e}} \\
\mathrm{PHBV} / \text { LCNF/PHBV } \\
\mathrm{PHB}^{\mathrm{e}} / \mathrm{LCNF}^{\mathrm{P}} \mathrm{PHB}^{\mathrm{e}}\end{array}$ & $\begin{array}{l}\text {-Casting of the properly } \\
\text { obtained CNF and LCNF } \\
\text { solutions. } \\
\text {-Electrospinning of PHB } \\
\text { or PHBV fibres onto both } \\
\text { sides of the CNF and } \\
\text { LCNF films. } \\
\text {-Compression moulding } \\
\text { of the monolayers. }\end{array}$ & $\begin{array}{l}\text { Electrospinning coating technique } \\
\text { significantly decreased the } \\
\text { nanopapers hydrophilicity and } \\
\text { provided a more balanced mechanical } \\
\text { performance. In addition, the PHBV } \\
\text { coating enhanced the oxygen barrier } \\
\text { capacity of the LCNF films. }\end{array}$ & $\begin{array}{l}\text { Cherpinski } \\
\text { et al., } 2018\end{array}$ \\
\hline $\begin{array}{l}\text { PLA/PHBV } \\
\text { multilayer films ( } 3 \\
\text { to } 2049 \text { theoretical } \\
\text { layers) (90/10 wt\%) }\end{array}$ & $\begin{array}{l}\text {-Custom multilayer co- } \\
\text { extrusion. }\end{array}$ & $\begin{array}{l}\text { PLA/PHBV multilayer films exhibited } \\
\text { improved mechanical and barrier } \\
\text { properties compared to melt blending } \\
\text { or the three-layer co-extrusion } \\
\text { process, since the structure presented } \\
\text { many long, thin, crystallized lamellas } \\
\text { of PHBV dispersed within the PLA } \\
\text { matrix, with increased compatibility. }\end{array}$ & $\begin{array}{l}\text { Boufarguine } \\
\text { et al., } 2013\end{array}$ \\
\hline
\end{tabular}

WVP: Water vapour permeability; OP: Oxygen permeability; PVOH: polyvinyl alcohol; WG: wheat gluten; W-G: whey-gelatin; TPS: thermoplastic starch; CNFs: cellulose nanofibrils LCNFs: lignocellulose nanofibrils. e superscript means electrospun layer. 


\section{Biocomposites}

The incorporation of micro- and nano-reinforcing agents into the PHA polymer matrices to obtain biocomposites have also been considered to improve their functional properties and so their competitiveness in the food packaging sector. Biocomposites are made up of a continuous biopolymer matrix in which organic or inorganic fillers of differing geometry (fibres, flakes, spheres, particulates) are dispersed (Díez-Pascual, 2017). Natural fibres obtained from agro- and food waste have been studied as organic micro-fillers to develop PHA biocomposite films by using melt blending and compression moulding (Table 7). Lignocellulosic fibres from different food by-products, such as wheat straw (Berthet et al., 2015; Martino et al., 2015), olive mills (Berthet et al., 2015), almond shell, rice husk and seagrass (Sánchez-Safont et al., 2018) have exhibited reinforcing effects, since they led to an increase in the EM and to a decrease in both E and TS. However, these fibres negatively affected the thermal stability and water barrier capacity of PHAs, which suggested a relatively poor adhesion between the fibres and the polymeric matrix due to the more hydrophilic nature of the fibres as compared to the hydrophobic matrix. Yatigala et al. (2018) achieved improved adhesion between PHBV and wood fibres in composite films by grafting PHBV with maleic anhydride (PHBV-g-MA); this enhanced their mechanical and thermal properties, such as degradation temperature, glass transition temperature, melting temperature, and crystallinity. Moreover, the PHBV-g-MA composite showed decreased water absorption. Some other natural fibrous materials based on food-waste, such as keratin fibres from poultry feathers (Pardo-lbáñez et al., 2014) and dried distillers grains with solubles produced as a coproduct during the dry-milling process of ethanol production (Madbouly et al., 2014) have also been successfully used as fillers in PHA-based films.

Different organic fillers in the nanometric range have been studied to obtain PHA-based bionanocomposites, since nanofillers have a higher specific surface area compared to microfillers and, therefore, a larger interface and stronger interaction with the polymer matrix. For this reason, lower nanofiller loadings are required to obtain comparable results to those achieved by common concentrations of microfillers (Naffakh et al., 2013). In this sense, PHB biocomposites based on cellulose nanowhiskers (CNWs), at different concentrations, have exhibited improved functional properties as compared to the neat polymer. Fabra et al. (2016b) developed multilayer films containing bacterial CNWs (15\%wt) in all layers, the inner and the outer sheets (PHB/TPS/PHB), which exhibited improved EM and TS, as well as reduced WVP and OP. Likewise, de O Patrício et al. (2013) achieved enhanced polymer processability by using small amounts of wood pulp CNWs $(<0.75 \% w t)$ dispersed on PEG, since the biocomposites had a larger processing window than the neat PHB. Nanofillers of differing geometries, such as cellulose nanofibres (CNFs) and cellulose nanocrystals (CNCs), have also been investigated for the purposes of obtaining PHBV nanocomposites with enhanced performance (Jun et al., 2017). PHBV-CNC and PHBV-CNFs composites exhibited improved thermal stability. Both CNCs and CNFs acted as nucleating agents, thus decreasing the crystal 
size and increasing the $T_{m}$. Moreover, both nanofillers showed reinforcing effects in PHBV composites, which was greater for the CNCs at 1 wt\%. Likewise, Díez-Pascual \& Díez-Vicente (2014) reported improved thermal stability and mechanical resistance for PHB nanocomposites based on inorganic nanofillers such as zinc oxide nanoparticles (ZnONP), due to their nucleating effect and the strong matrix-ZnONP interfacial adhesion attained via hydrogen bonding interactions. In addition, PHB-ZnONP nanocomposites lowered WVP and OP values as compared to those of pure PHB films.

Chemically modified nanocomposites have also been used in order to improve the compatibility with the polymer matrix. Thus chemically modified multiple-walled carbon nanotubes (MWCNTs-COOH), have been used in PHA-g-MA matrices with improved compatibility and dispersibility of the MWCNTs within the matrix. In this case, the reaction between MA groups of PHA-g-MA and the carboxylic acid groups of the MWCNTs-COOH enhanced the thermal and mechanical properties of the material (Wu \& Liao, 2017). 


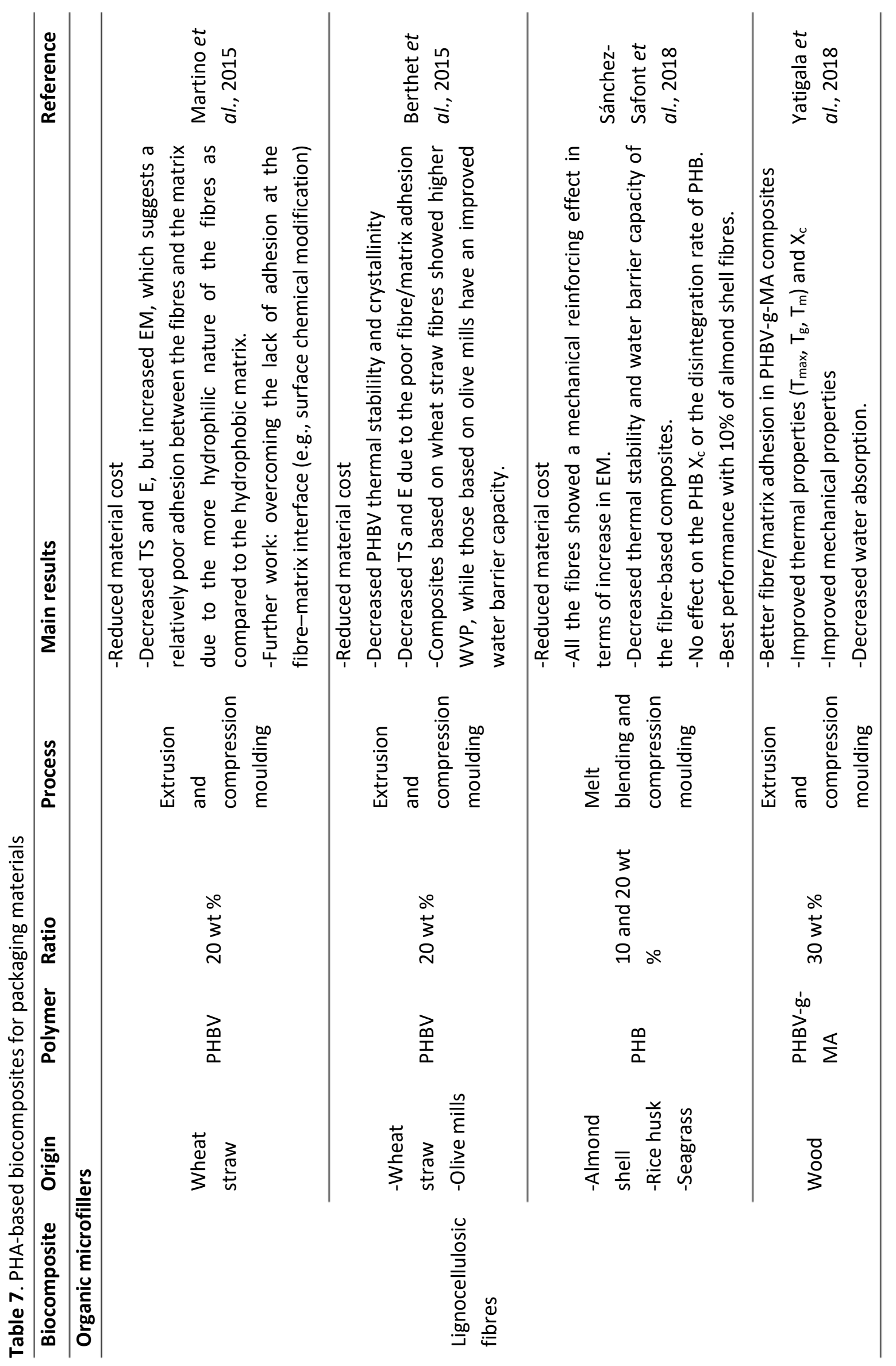




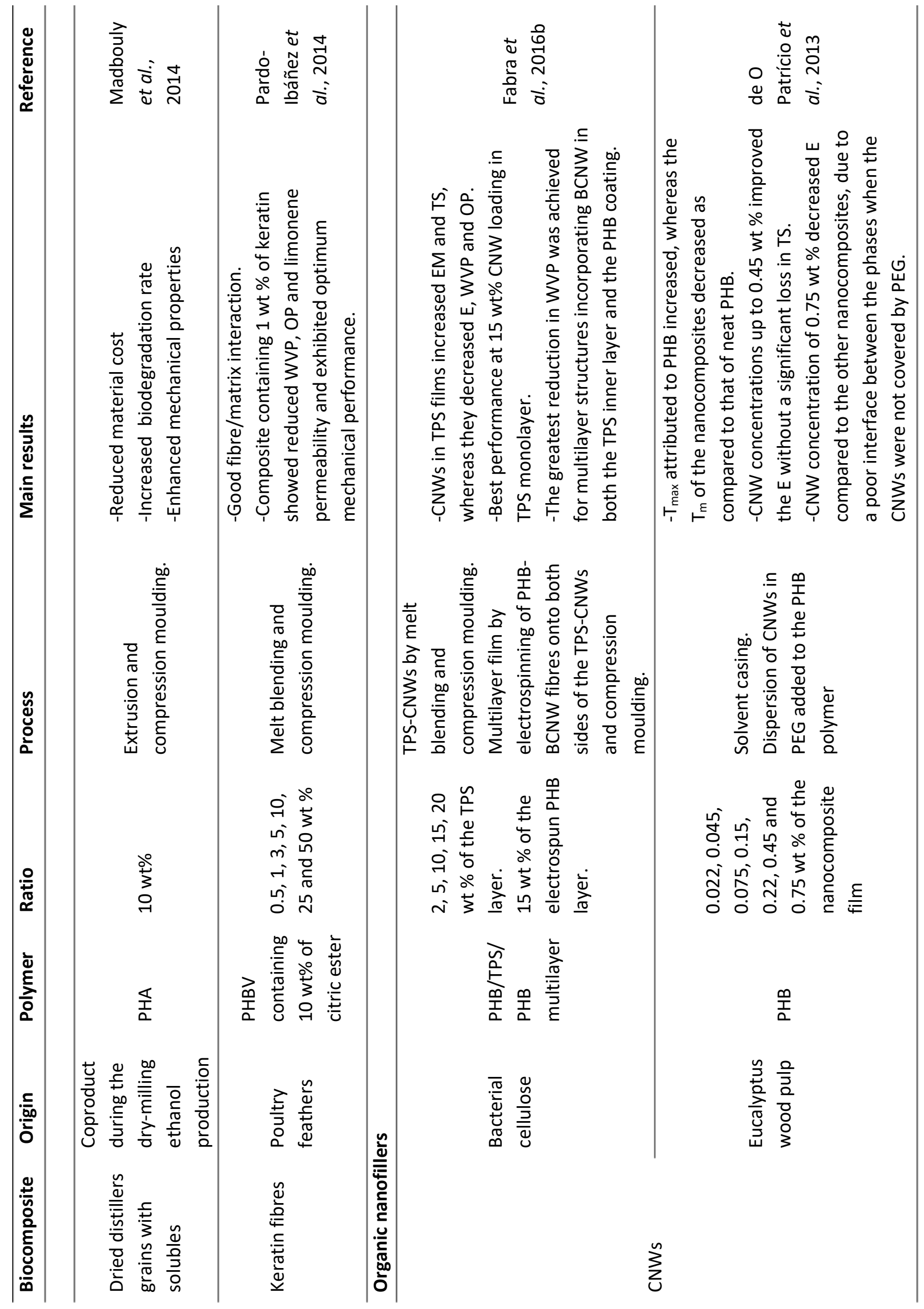




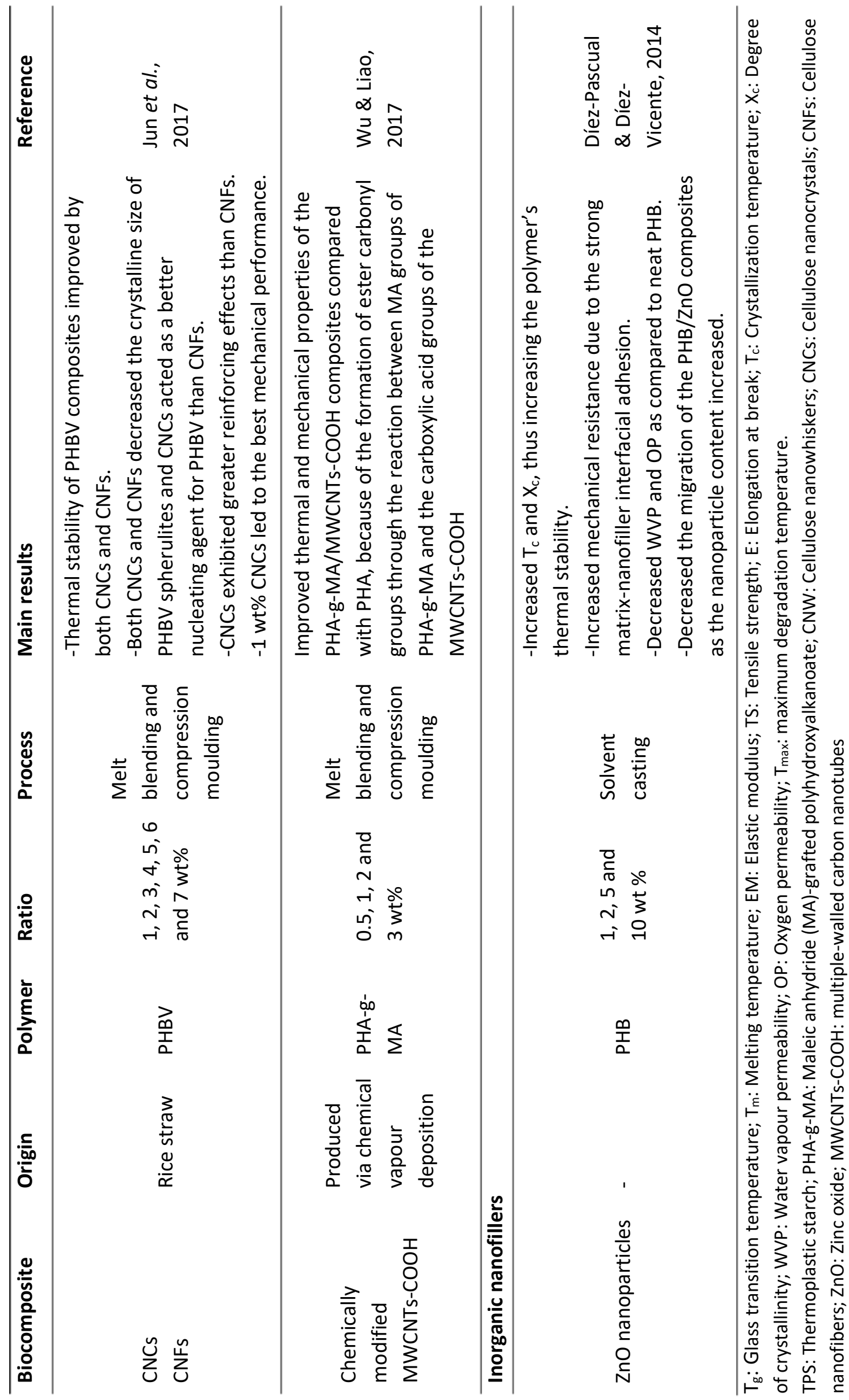




\subsection{Polylactic acid}

PLA is a linear aliphatic thermoplastic polyester derived from lactic acid, which is obtained from the fermentation of agricultural crops, such as starch, cellulose and other polysaccharides, which are 100\% renewable and biodegradable (Ma et al., 2015; Muller et al., 2017a). Due to its biodegradability, renewability, low cost, good processability and outstanding mechanical performance, PLA has been the most commonly studied biobased, biodegradable polyester for a broad range of applications. Nonetheless, its application in the food-packaging sector has been delayed due to its highly brittle nature, slow crystallization rate and poor barrier properties as compared to the synthetic polymers (Armentano et al., 2015; Ma et al., 2015).

Several strategies have been investigated as a means of improving the PLA functional properties. Enhanced PLA mechanical performance has been achieved by adding different plasticizing agents, since they decrease its $\mathrm{T}_{\mathrm{g}}$ and TS and increase the $\mathrm{E}$ of the PLA films, which are stiff and brittle (Muller et al., 2017a). Likewise, different approaches to combining PLA with biodegradable polymers with greater barrier properties, such as polymer blending or multilayer assembly, have been investigated for the purposes of improving the limited barrier capacities of PLA-based materials. As mentioned in Table 5, PLA-PHB and PLA-PHBV blend films with $20-35 \%$ of PHA have shown an improved thermal and mechanical performance, as well as greater barrier vapour capacities compared to the neat PLA films. Nonetheless, plasticizers and/or compatibilizers are commonly required in these polymer blends in order to improve the film stretchability as well as polymer compatibility in the polymer mixture. Likewise, PLA and TPS-based polymer blends have been widely studied, due to their ready availability and low cost as well as to the complementary properties of starch, as reviewed by Muller et al. (2017a). However, since both polymers are thermodynamically immiscible, due to their different natures, compatibilization strategies are required to prevent their phase separation. In this sense, compatibilizers, such as methylenediphenyl diisocyanate (Phetwarotai et al., 2012; Pivsa-Art et al., 2011; Wang et al., 2002) and MA (Huneault \& Li, 2007; Orozco et al., 2009; Zuo et al., 2014) have improved the interfacial adhesion between the polymer phases, thus enhancing their functional film properties. Similarly, PLA multilayer structures have been developed by combining PLA with either PHBV (Boufarguine et al., 2013) or TPS monolayers (Scaffaro \& Botta, 2018; Sanyang et al., 2016; Muller et al., 2017b), thus obtaining multilayer packaging materials with both an improved thermal and mechanical performance, as well as greater barrier capacity, compared to the neat polymer films. 


\subsection{Starch}

One of the most abundant natural polysaccharides is starch, which is mainly obtained from corn, cereal grain, rice and potatoes. Native starch is a renewable resource, inexpensive, biodegradable and widely available. Starch granules are composed of both amylose and amylopectin, in different ratios depending on the origin and age of the starch, which are not soluble in cold water due to the strong interaction between the starch chains (Jiménez et al., 2012). In order to use starch as plastic material, gelatinization (destructuration) and plasticization processes are required, which are commonly carried out by using water and a plasticizer, such as glycerol, thus obtaining a homogeneous blend with film-forming properties called thermoplastic starch (Jimenez et al., 2012; Parulekar \& Mohanty, 2007)

Starch-based films have proven to have several advantages, such as good oxygen barrier capacity and stretchability, as well as suitable transparency, odour and taste. However, its application as biodegradable packaging material is limited due to its highly hydrophilic nature, water sensitivity and solubility and its poor water vapour barrier capacity, as well as its low mechanical resistance (Muller et al., 2017a; Parulekar \& Mohanty, 2007). In order to overcome these drawbacks, polymer blending (Parulekar \& Mohanty, 2007) and multilayer assembly strategies with other biopolymers, such as PHAs, have been successfully carried out (Fabra et al., 2016b).

\section{Antimicrobial packaging}

One of the present-day challenges is to develop biodegradable active materials for food packaging applications in order to improve the shelf-life of food and, at the same time, reduce the environmental impacts associated with synthetic plastics. The incorporation of antimicrobial or/and antioxidant compounds into biopolymer-based materials is a good approach to obtain active films, with more competitive properties, that are useful for the purposes of extending the shelf-life of foodstuffs (Wen et al., 2016). At the same time, consumer demand is moving towards more natural foods containing lower amounts of synthetic preservatives. In this sense, naturally occurring compounds obtained from plantfood by-products are a promising option to develop active packaging materials. 


\subsection{Plant-food by-products as antimicrobials}

During the preparation and processing procedures in the fruit and vegetable industry, up to one third of the product is discarded, which is costly for the producers, as well as harmful for the environment (O'Shea et al., 2012). Research has shown that these food industry byproducts have several applications, such as the development of food additives with functional properties (gelling and water binding), nutritionally beneficial new food ingredients, such as dietary fibre, vitamins, minerals and antioxidants (Balasundram et al., 2006; Garau et al., 2007; Kammerer et al., 2014; Louli et al., 2004; O'Shea et al., 2012), as well as antimicrobial compounds for food preservation (Ayala-Zavala et al., 2010; Ayala-Zavala et al., 2011; GuilGuerrero et al., 2016; Tehranifar et al., 2011). Therefore, the valorization of these plant-food by-products allows the consumer's requirement of natural and healthy products to be met, and reduces the food waste in the agro-industry, thus increasing the economic benefits and environmental sustainability.

\subsubsection{Phenolics}

Plant phenolic compounds of differing natures, such as phenolic acids, flavonoids and tannins, have exhibited significant antimicrobial activity. Thus, mango seed kernel ethanol extracts showed a broad antimicrobial spectrum against both Gram-positive (Staphylococcus, Listeria, Salmonella, Bacillus) and Gram-negative bacteria (E. coli, Aeromonas, Pseudomonas) (Abdalla et al., 2007; Engels et al., 2009; Kabuki et al., 2000; Khammuang \& Sarnthima, 2011), which was mainly attributed to the presence of polyphenols. Likewise, a water extract of Cocos nucifera Linn. husk fibre, composed of catechin and epicatechin, together with condensed tannins, exerted both antiviral and antimicrobial effects against Staphylococcus aureus (Esquenazi et al., 2002). The antimicrobial activity of peel and pulp aqueous acetone extracts from pear, apple (Golden Delicious (GD) and Red Delicious (RD)) and quince was tested against a range of bacterial strains; $S$. aureus, Pseudomonas aeruginosa and Bacillus cereus being the most sensitive to the active extracts. Hydroxycinnamic acids, flavonols, and flavanols were the active compounds found in the fruit peels, whereas the pulps consisted of only hydroxycinnamic acids. Thus, the antimicrobial effects increased as follows: pear pulp $\approx$ pear peel $<$ GD pulp $<$ GD peel $<$ RD pulp $\approx$ quince pulp $<$ quince peel $<$ RD peel (Fattouch et al., 2008). Flavonoid-rich ethanolic extracts, obtained from the peel of Bergamot citrus fruit, exhibited significant antimicrobial activity against all the Gram-negative bacteria tested $(E$. coli, Pseudomonas putida, Salmonella enterica) and their antimicrobial effects increased after enzymatic deglycosylation (Mandalari et al., 2007). The minimum inhibitory concentrations of the fractions and the pure flavonoids, neohesperidin, hesperetin (aglycone), neoeriocitrin, eriodictyol (aglycone), naringin and naringenin (aglycone), were in the range of 200 to 800 $\mu \mathrm{g} / \mathrm{mL}$ (Mandalari et al., 2007). Similarly, berry extracts were more effective against Gram- 
negative bacteria; sea buckthorn berry and blackcurrant showing the lowest antimicrobial activity. Cloudberry, raspberry and strawberry extracts exerted greater antimicrobial effects against Salmonella (Puupponen-Pimiä et al., 2000). Freeze-dried potato peel extracts containing phenolic acids, such as chlorogenic, caffeic, gallic, and protocatechuic acids, exhibited bactericidal effects against Gram-negative bacteria at high concentrations (Sotillo et al., 1998). Antifungal effects have also been reported for methanolic extracts obtained from the peel, seeds and leaves of pomegranate against 3 post-harvest fungi (Penicillium italicum, Rhizopus stolonifer and Botrytis cinerea); the peel and seed extracts were more effective than the leaf extract due to their higher phenolic content (Tehranifar et al., 2011). Likewise, alcohol extracts from Capsicum frutescence $L$. (Chilly) and Zingier officinale L. (Ginger) were effective at controlling the microbial growth of Penicillium digitatum, Aspergillus niger and Fusarium $s p$, which are mainly responsible for the post-harvest fungal rotting of citrus (Singh et al., 2012).

\subsubsection{Essential oils}

Plant and herb extracts have been used as natural medicine for centuries, due to their proven antimicrobial activity. Essential oils (EOs) are the most widely investigated naturally-occurring antimicrobial agents in plant extracts. EOs are aromatic, oily liquids of volatile and complex nature from plant materials, such as flowers, buds, seeds, leaves, bark, fruits, etc. (AyalaZavala et al., 2011; Burt, 2004). They are formed as secondary metabolites and include volatile compounds of terpenoid or non-terpenoid origin, all being hydrocarbons and oxygenated derivatives (Ayala-Zavala et al., 2011; Guil-Guerrero et al., 2016). Terpenes or terpenoids have demonstrated antimicrobial activity against bacteria, fungi, viruses and protozoa (AyalaZavala et al., 2011). The mechanism of antibacterial action of the EOs involves several targets, since EOs can comprise more than sixty individual components. Moreover, many of these oils are generally recognized as safe (GRAS) and used in food as flavouring agents (Burt, 2004).

Of the plant-based foods, EOs are found mostly in the peels of some fruits, such as mango and citrus species. Therefore, they are also present in their by-products, representing an interesting source of antimicrobial compounds (Ayala-Zavala et al., 2011; Guil-Guerrero et al., 2016). In this sense, lemon extracts have been used as antimicrobial agents to develop antimicrobial packaging materials, which lengthened the shelf-life of Mozzarella cheeses (Conte et al., 2007). Likewise, pomegranate peel and cinnamon bark extract applied to meat products (Kanatt et al., 2010) and fresh-cut apples (Muthuswamy et al., 2008) respectively, significantly extended their shelf-life. The turmeric oil, whose main components are arturmerone, $\beta$ - trans-farnesene, turmerone and curlone, is a by-product from curcumin manufacture, which exerted significant antimicrobial effects against both Gram-positive and Gram-negative bacteria (Negi etal., 1999). 


\subsubsection{Xylans}

Worldwide, lignocellulosic materials are the most abundant organic residues and are mainly composed of cellulose, hemicellulose, lignin and other compounds. Hemicellulose is a heteropolysaccharide with xylan as the major carbohydrate and primarily involves polymers of xylose, arabinose, galactose, mannose and glucose (Carvalho et al., 2013). Although hemicellulose valorization is not as common as cellulose or starch recovery, some xylanderived products have found interesting commercial applications for the production of bioethanol, xylitol, xylooligosaccharides (XOS) and different materials such as films, coatings, gels and foams (Egüés et al., 2014). XOS are used as dietary sweeteners for low-calorie diet foods and for consumption by diabetics, since they cannot be digested by humans due to the lack of enzymes hydrolysing the $\beta$-links (Delgado et al., 2011; Nabarlatz et al., 2007; RiveroUrgell \& Santamaria-Orleans, 2001; Vazquez et al., 2000). Moreover, XOS have been shown to have prebiotic effects, since they stimulate enhanced levels of bifidobacteria (Gullón et al., 2008).

Xylans have also attracted considerable attention as natural additives for food, cosmetic and biomedical applications due to their antioxidant and/or antimicrobial activity, these being potential natural substitutes of synthetic antibiotics and antioxidants to meet the consumer demand for safer products (Melo-Silveira et al., 2011; Ruthes et al., 2017). In this sense, several cell-wall polysaccharides from a variety of sources such as almond shell biomass (Ebringerová et al., 2007), spruce pulp mill (Ebringerová et al., 2008), beechwood (Hromádková et al., 2005), Eucalyptus globulus and Pinus pinaster wood (Rivas et al., 2013), wheat bran (Hromádková et al., 2008), Fallopia species leaves (Hromádková et al., 2010)or corn cob (Melo-Silveira et al., 2011) have shown significant antioxidant activity; and antimicrobial effects against Staphylococcus aureus, Escherichia coli (Velkova et al., 2017) and Klebsiella pneumoniae (Melo-Silveira et al., 2011). 


\subsection{Biopolymers carrying essential oils for food antimicrobial packaging.} Current Organic Chemistry (2017) 21, 1-16. Raquel Requena; Lorena Atarés; María Vargas; Amparo Chiralt.

Biodegradable antimicrobial materials for food packaging applications are in great demand by the food industry and society alike for the purposes of extending food shelf life, thus reducing the environmental impacts associated with synthetic plastics. Among the natural and nontoxic active compounds available, essential oils and their major components have been widely studied due to their antioxidant and antimicrobial properties together with their GRAS status.

\subsubsection{Antimicrobial properties of essential oils}

Both EOs and several of their constituents represent a natural alternative to chemical food preservatives. EOs are complex in composition, being a source of bioactive compounds, such as terpenoids and phenolic compounds. Several antimicrobial mechanisms have been described to explain the action of EOs against microorganisms, namely membrane destabilization and disruption (Lambert et al., 2001; Neto et al., 2015); the inhibition of membrane localized metabolic events (Cox et al., 2001; Picone et al., 2013); damage in the membrane proteins (Ultee et al., 2000); the depletion of proton motive force (Ultee et al., 2001); and the leakage of cytoplasmic constituents, metabolites and ions (Alves de Azerêdo et al., 2012; Gustafson et al., 1998). Table 8 gives an overview of the current state of the art in this topic, showing some of the most recent and relevant studies dealing with the antimicrobial action of EOs and their major compounds. These studies reinforce the potential use of EOs and their major components as food preservatives due to their capacity to inhibit the growth of a wide variety of pathogenic and/or food-spoiling microorganisms.

Moreover, a synergistic effect between EOs and their major components has recurrently been observed in different studies. Ouedrhiri et al. (2016) found that the antibacterial capacity of an EOs mixture (Origanum compactum, Origanum majorana and Thymus serpyllum) was greater than that of each EO, especially against S. Aureus and E. coli. Ye et al. (2013) concluded that cinnamaldehyde and carvacrol exhibit a high degree of antibacterial activity and display synergistic antimicrobial activity for most of the bacteria tested (Table 8).

Nonetheless, the concentrations of EOs or their individual constituents required to inhibit bacteria in foods are frequently higher than what is organoleptically acceptable (de Souza, 2016; Gutierrez et al., 2009). Moreover, the highly volatile nature of these compounds, along with their great sensitivity to oxidation, which makes them prone to deterioration, limits their free-form application onto the surface of food systems. In an attempt to avoid this, what has been studied is the incorporation of EOs into the formulation of films and coatings. Table 9 summarizes recent studies of the antimicrobial activity of biopolymer films into which either 
EOs or their individual major compounds have been incorporated. A wide variety of EOs has been tested in different carrying biopolymers, and the in vitro studies, using the agar diffusion method, have proven their efficiency as antimicrobials. They mainly act against different bacteria, although they are also reported to exhibit antifungal activity (Alves-Silva et al., 2013; Perdones et al., 2014; Roselló et al., 2015; Sánchez-González et al., 2010a).

There have been fewer studies into real food systems, although several authors report an effective or limited antimicrobial action, depending on the kind of food matrix. For instance, Guerreiro et al. (2016) incorporated eugenol and/or citral into alginate or pectin films, and proved their antimicrobial activity when applied to raspberries. However, Higueras et al. (2014) could not find any notable antilisterial action of carvacrol on chicken breast, despite its proven effectiveness in in vitro studies. Interactions of active compounds and microorganisms were greatly affected by food components (Hyldgaard et al., 2014), as described below.

Table 8. Recent studies on the antimicrobial action of essential oils (EOs) and their major compounds. Minimal inhibitory concentration (MIC) ranges have been included.

\begin{tabular}{|c|c|c|c|}
\hline EO & Microorganisms tested & MIC & Reference \\
\hline $\begin{array}{l}\text { Myrcia ovata } \\
\text { Cambessedes }\end{array}$ & $\begin{array}{l}\text { Pseudomonas aeruginosa, Staphylococcus } \\
\text { aureus, Bacillus cereus, Bacillus subtilis, } \\
\text { Enterecoccus faecalis, Serratia marcescens, } \\
\text { Escherichia coli, Salmonella enteritidis }\end{array}$ & $0.78-400 \mu \mathrm{l} / \mathrm{ml}$ & $\begin{array}{l}\text { De Jesus et } \\
\text { al., } 2016\end{array}$ \\
\hline $\begin{array}{l}\text { Etlingera } \\
\text { fimbriobracteata }\end{array}$ & $\begin{array}{l}\text { Bacillus subtilis, Bacillus spizizenii, Staphylococcus } \\
\text { aureus, E. coli, Pseudomonas aeruginosa, Candida } \\
\text { albicans, Saccharomyces cerevisiae }\end{array}$ & $\mathrm{s} / \mathrm{ml}$ & $\begin{array}{l}\text { Ud-Daula } \\
\text { et al., } 2016\end{array}$ \\
\hline $\begin{array}{l}\text { Bergamot-mint } \\
\text { (Mentha citrata) }\end{array}$ & $\begin{array}{l}\text { S. aureus, Staphylococcus epidermidis, } \\
\text { Streptococcus mutans, Klebsiella pneumoniae, E. } \\
\text { coli, Salmonella typhimurium, P. aerugenosa }\end{array}$ & $\begin{array}{l}125->1000 \\
\mu \mathrm{g} / \mathrm{ml}\end{array}$ & $\begin{array}{l}\text { Verma et } \\
\text { al., } 2016\end{array}$ \\
\hline $\begin{array}{l}\text { Cinnamon bark } \\
\text { Thyme }\end{array}$ & $\begin{array}{l}\text { Listeria monocytogenes, Salmonella enterica and } \\
\text { E. coli O157:H7 }\end{array}$ & $\begin{array}{l}313-625 \mathrm{ppm} \\
313-625 \mathrm{ppm}\end{array}$ & $\begin{array}{l}\text { Ma et al., } \\
2016\end{array}$ \\
\hline $\begin{array}{l}\text { Eucalyptus } \\
\text { globulus }\end{array}$ & $\begin{array}{l}\text { S. aureus, B. subtilis, Listeria innocua, E. coli, } P \text {. } \\
\text { aerugenosa }\end{array}$ & $3-5 \mathrm{mg} / \mathrm{ml}$ & $\begin{array}{l}\text { Said et al., } \\
2016\end{array}$ \\
\hline Thymus & $\begin{array}{l}\text { Penicillium digitatum, Penicillium italicum and } \\
\text { Geotrichum citri-aurantii }\end{array}$ & $\begin{array}{l}<500->4000 \\
\mu \mathrm{g} / \mathrm{ml}\end{array}$ & $\begin{array}{l}\text { Boubaker } \\
\text { et al., } 2016\end{array}$ \\
\hline $\begin{array}{l}\text { Mustard } \\
\text { Cinnamon }\end{array}$ & $\begin{array}{l}\text { S. aureus, B. cereus, E. coli, P. aeruginosa, } \\
\text { Pseudomonas fluorescens, Pseudomonas putida, } \\
\text { Pectobacterium carotovorum, S. enterica }\end{array}$ & $\begin{array}{l}12.5-200 \mu \mathrm{g} / \mathrm{ml} \\
200-400 \mu \mathrm{g} / \mathrm{ml}\end{array}$ & $\begin{array}{l}\text { Clemente } \\
\text { et al., } 2016\end{array}$ \\
\hline
\end{tabular}




\begin{tabular}{|c|c|c|c|}
\hline EO & Microorganisms tested & MIC & Reference \\
\hline Origanum vulgare & $\begin{array}{l}\text { S. aureus, E. coli, Sarcina lutea, } B . \\
\text { cereus, } P \text {. aeruginosa, S. } \\
\text { typhimurium, E. faecalis, Candida } \\
\text { albicans }\end{array}$ & $85->512 \mu \mathrm{g} / \mathrm{ml}$ & $\begin{array}{l}\text { Sarikurkcu } \\
\text { et al., } 2015\end{array}$ \\
\hline Mentha x piperita L. & & $238-1125 \mu \mathrm{g} / \mathrm{ml}$ & $\begin{array}{l}\text { Nikolić et } \\
\text { al., } 2014\end{array}$ \\
\hline Mentha pulegium L. & $\begin{array}{l}\text { Streptococcus pyogenes, S. mutans, } \\
\text { Lactobacillus acidophilus, }\end{array}$ & $593-1192 \mu \mathrm{g} / \mathrm{ml}$ & \\
\hline $\begin{array}{l}\text { Mill. } \\
\text { Mavania angustiroila }\end{array}$ & Streptococcus salivarius, & 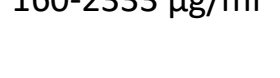 & \\
\hline Satureja montana L. & P. aeruginosa, S. aureus & $23-125 \mu \mathrm{g} / \mathrm{ml}$ & \\
\hline Salvia lavandulifolia Vahl & & $290-1208 \mu \mathrm{g} / \mathrm{ml}$ & \\
\hline Thymus numidicus & $\begin{array}{l}\text { S. aureus, K. pneumoniae, E. coli, } \\
\text { Serratia marcescens, P. aeruginosa }\end{array}$ & $\begin{array}{l}0.117-0.469 \\
\mathrm{mg} / \mathrm{ml}\end{array}$ & $\begin{array}{l}\text { Adrar et } \\
\text { al., } 2016\end{array}$ \\
\hline Salvia officinalis L. & & $3.7-15 \mathrm{mg} / \mathrm{ml}$ & \\
\hline Lime & $\begin{array}{l}\text { E. coli, S. typhinurium, B. cereus, S. } \\
\text { aureus, L. monocytogenes }\end{array}$ & $750-1500 \mathrm{mg} / \mathrm{l}$ & $\begin{array}{l}\text { Sánchez- } \\
\text { Aldana et } \\
\text { al., } 2015\end{array}$ \\
\hline Cinnamon & $\begin{array}{l}\text { L. monocytogenes, E. coli, Ps. } \\
\text { Fluorescens, Lactobacillus } \\
\text { plantarum, Lactobacillus sakei }\end{array}$ & $250-500 \mathrm{ppm}$ & $\begin{array}{l}\text { Ojagh et } \\
\text { al., } 2010\end{array}$ \\
\hline Satureja montana L. & Salmonella & & $\begin{array}{l}\text { Miladi et } \\
\text { al., } 2016\end{array}$ \\
\hline Thymus vulgaris $\mathrm{L}$. & & $0.78-1.56 \mathrm{mg} / \mathrm{ml}$ & \\
\hline Rosmarinus officinalis $L$. & & $12.5-25 \mathrm{mg} / \mathrm{ml}$ & \\
\hline $\begin{array}{l}\text { Origanum compactum } \\
\text { Origanum majorana }\end{array}$ & $\begin{array}{l}\text { S. aureus, E. coli, B. subtilis, } P \text {. } \\
\text { aeruginosa }\end{array}$ & $\begin{array}{l}0.031->4 \%(v / v) \\
0.125-2 \%(v / v)\end{array}$ & $\begin{array}{l}\text { Ouedrhiri } \\
\text { et al., } 2016\end{array}$ \\
\hline Thymus serpyllum & & $0.125->4 \%(v / v)$ & \\
\hline $\begin{array}{l}\text { Rosmarinus officinalis L. } \\
\text { (rosemary) }\end{array}$ & Clostridium perfringens & $10 \mathrm{mg} / \mathrm{ml}$ & $\begin{array}{l}\text { Radaelli et } \\
\text { al., } 2016\end{array}$ \\
\hline $\begin{array}{l}\text { Mentha } \times \text { piperita L. var. } \\
\text { Piperita (peppermint) }\end{array}$ & & $10 \mathrm{mg} / \mathrm{ml}$ & \\
\hline $\begin{array}{l}\text { Origanum majoranaL. } \\
\text { (marjoram) }\end{array}$ & & $5 \mathrm{mg} / \mathrm{ml}$ & \\
\hline $\begin{array}{l}\text { Ocimum basilicum L. } \\
\text { (basil) }\end{array}$ & & $5 \mathrm{mg} / \mathrm{ml}$ & \\
\hline Thymus vulgaris L. (thyme) & & $1.25 \mathrm{mg} / \mathrm{ml}$ & \\
\hline
\end{tabular}




\begin{tabular}{|c|c|c|c|}
\hline EO & Microorganisms tested & MIC & Reference \\
\hline $\begin{array}{l}\text { Carvacrol, eugenol, } \\
\text { resorcylic acid, trans- } \\
\text { cinnamaldehyde, thymol } \\
\text { and vanillin }\end{array}$ & E. coli 0157:H7 & - & $\begin{array}{l}\text { Kim et al., } \\
2016\end{array}$ \\
\hline Eugenol & Coliforms, Staphylococcus spp. & - & $\begin{array}{l}\text { Khare et } \\
\text { al., } 2014\end{array}$ \\
\hline $\begin{array}{l}\text { Eugenol } \\
\text { Cinnamaldehyde }\end{array}$ & E. coli, K. pneumoniae & $\begin{array}{l}249-999 \mu \mathrm{g} / \mathrm{ml} \\
0.063-0.999 \mu \mathrm{g} / \mathrm{ml} \\
122-245 \mu \mathrm{g} / \mathrm{ml}\end{array}$ & $\begin{array}{l}\text { Dhara \& } \\
\text { Tripathi, } \\
2013\end{array}$ \\
\hline $\begin{array}{l}\text { Cinnamaldehyde } \\
\text { Carvacrol }\end{array}$ & 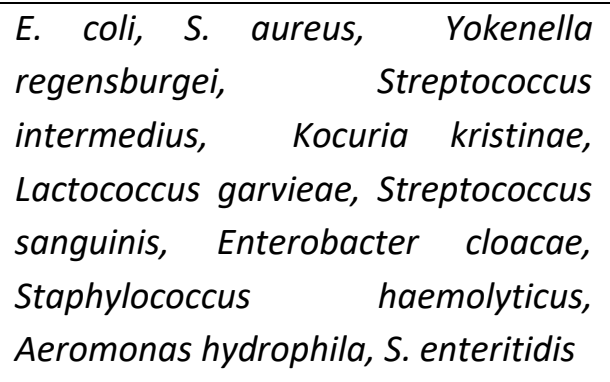 & $\begin{array}{l}0.16-0.63 \mathrm{mg} / \mathrm{ml} \\
0.16-0.31 \mathrm{mg} / \mathrm{ml}\end{array}$ & $\begin{array}{l}\text { Ye et al., } \\
2013\end{array}$ \\
\hline $\begin{array}{l}\text { Thymol } \\
\text { Carvacrol }\end{array}$ & $\begin{array}{l}\text { S. aureus, S. epidermidis, B. cereus, E. } \\
\text { coli, P. aeruginosa, E. faecalis, Vibrio } \\
\text { alginolyticus, S. typhimurium, } 12 \text { S. } \\
\text { enteritidis strains }\end{array}$ & $\begin{array}{l}32-128 \mu \mathrm{g} / \mathrm{ml} \\
64-512 \mu \mathrm{g} / \mathrm{ml}\end{array}$ & $\begin{array}{l}\text { Miladi et } \\
\text { al., } 2016\end{array}$ \\
\hline Eugenol & $\begin{array}{l}\text { L. monocytogenes, S. enterica, E. coli } \\
\text { O157:H7 }\end{array}$ & $625 \mathrm{ppm}$ & $\begin{array}{l}\text { Ma et al., } \\
2016\end{array}$ \\
\hline
\end{tabular}




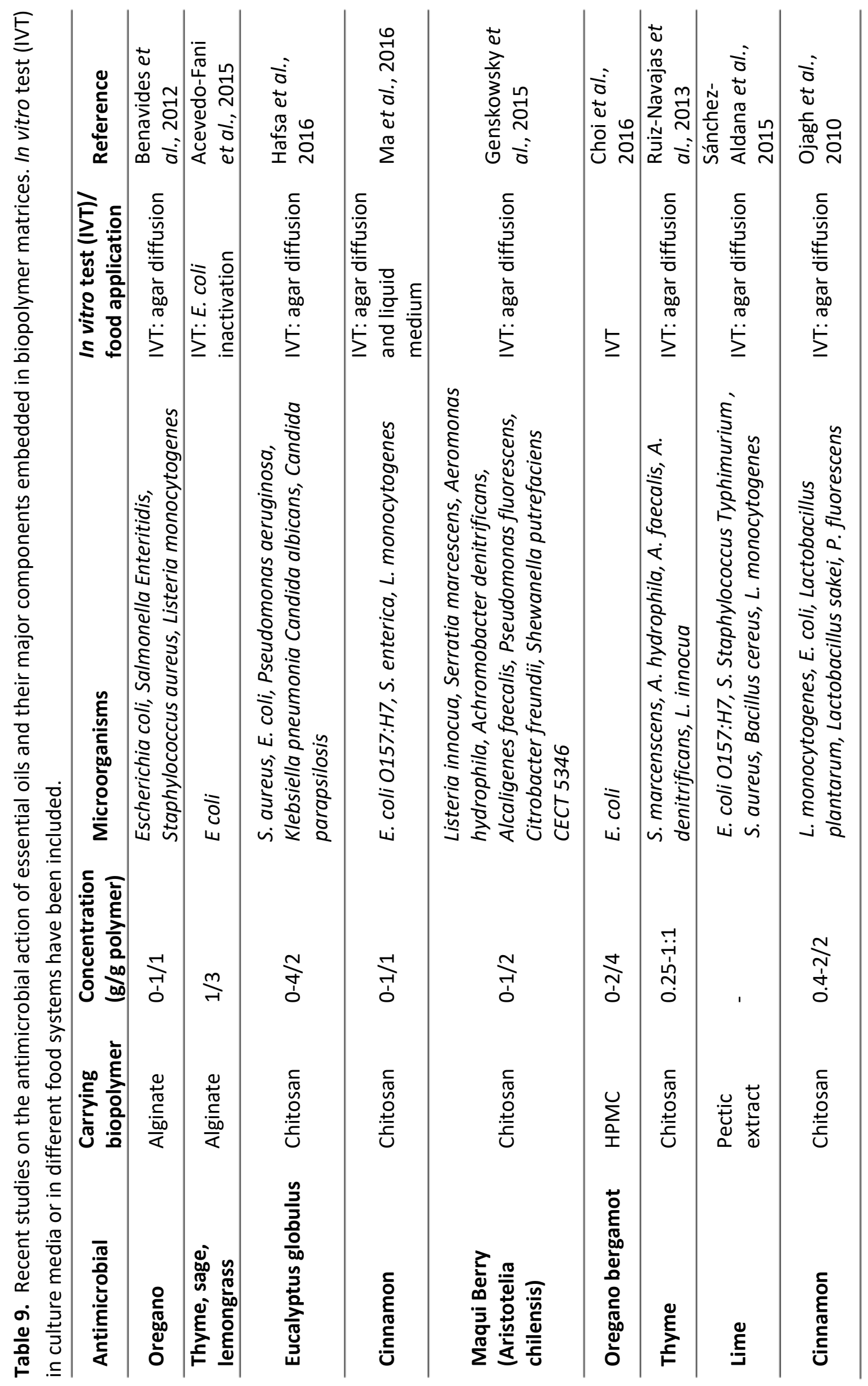




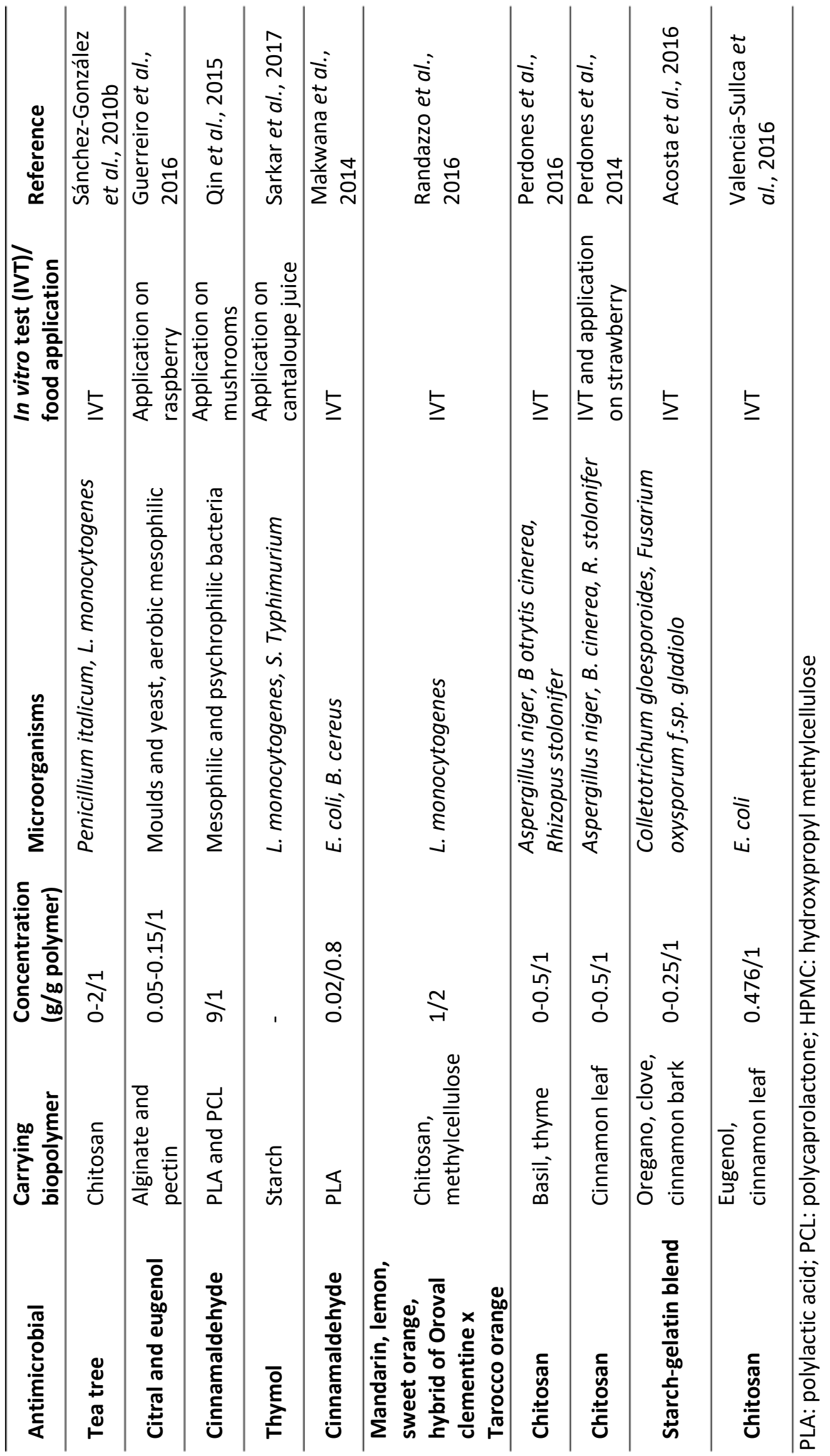




\subsubsection{Incorporation methods of essential oils into polymer matrices}

In order to develop biodegradable antimicrobial packaging systems incorporating EOs, the processability of the biopolymers and of the active ingredients should be taken into account. Casting methods or thermoplastic processing could be used to incorporate active compounds into the polymer matrices to obtain active biomaterials for packaging applications. Nevertheless, the former method has scarce industrial applicability because of the need to evaporate great amounts of solvent. In the case of aqueous systems, this is energetically nonsustainable and for organic solvents, the fact that they are toxic and dangerous to handle compromises their application. So, this kind of active compound incorporation is restricted to coating the surface of thermo-processed films with a thin layer of the active solution and carrier. Then, smaller amounts of solvent need to be evaporated, thus enhancing the process feasibility. However, the solvent casting method has been widely used to obtain biopolymer active matrices that incorporate EOs or their compounds, at a laboratory level, for the purposes of obtaining the functional properties of the biopolymer matrices and their potential use as antimicrobial/antioxidant materials (Bonilla et al., 2012a; Perdones et al., 2016; Sánchez-González et al., 2011c). Casting methods involve solving the biopolymer in an appropriate medium and adding the active ingredient under continuous stirring conditions. When using aqueous media and hydrophilic biopolymers, the solvent-polymer-EO mixture forms immiscible systems (emulsions) and requires a high degree of homogenization to achieve a good dispersion with small droplets. Rotor-stator homogenizers, sonication (Jiménez et al., 2014) or microfluidization (Bonilla et al., 2012a) has been used to this end. The latter can increase the stability of the film-forming dispersion by reducing its particle size. Finally, to obtain the active matrices, the dispersion containing the active ingredients is casted in a levelled plate and is allowed to dry under controlled conditions.

The casting/solvent evaporation method exhibits some advantages for the incorporation of active ingredients, but also significant drawbacks, depending on the nature of the polymer (polar or non-polar), its solubility in different solvents and the chemical affinity between the polymer, EO compounds and solvent. Hydrophobic non-polar biopolymers, such as biodegradable polyesters like PLA have to be solved in non-polar organic solvents, such as dichloromethane (DCM) or chloroform, which require special precautions during film processing and the use of a fume hood. In these cases, the EO compounds gain solubility and true solutions of the macromolecules and active compounds can be obtained.

Notable differences in microstructure and losses of EOs can be found in films obtained by casting method, depending on the polymer and solvent polarity, and aqueous and non-polar systems can be differentiated. Figure 4 shows the cross section of a chitosan film where droplets of the non-miscible cinnamon EO are embedded in the polymer matrix, introducing discontinuities which affect both the mechanical behaviour and mass transfer phenomenon through the film. On the other hand, EO compounds encapsulated in lecithin liposomes 
produced a laminar structure in chitosan films in line with the restructuration (phase transition) of the lecithin during the film drying step (Valencia-Sullca et al., 2016). During this step, the water loss induced the lamellar structure of the polar lipids, which alternates with the polymer layers giving rise to a high barrier material containing EO compounds inside lipid layers. On the contrary, a smooth fracture can be appreciated in PHBV films containing eugenol, due to its good miscibility with the polymer. In this way, eugenol plasticized the matrix and affected the tensile and barrier properties due to the weakening effect on the polymer network. In semicrystalline matrices, these compounds can also affect the degree of crystallinity (Requena et al., 2016).
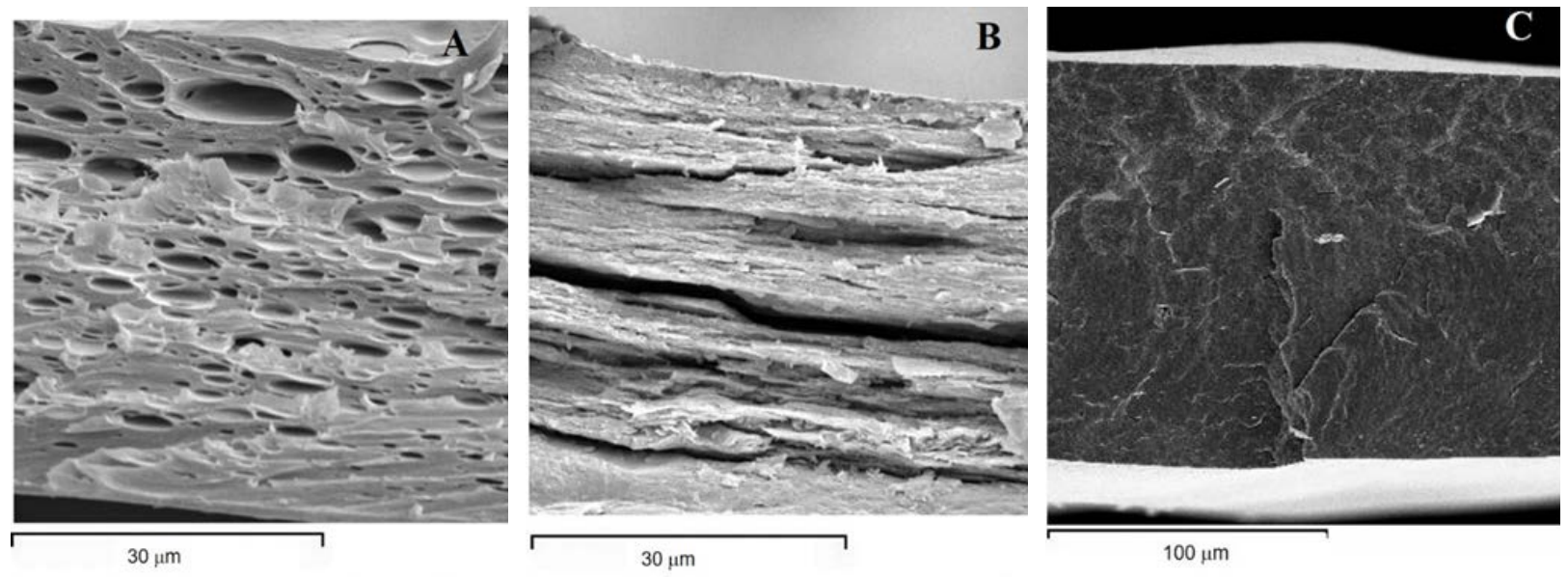

Figure 4. The film microstructure of different biopolymers containing essential oils (EO), or some of their compounds, obtained by different techniques. A: chitosan-cinnamon leaf EO film, obtained by casting. B: chitosan-lecithin encapsulated eugenol film, obtained by casting. C: PHBV-Eugenol, obtained by compression moulding.

On the other hand, using aqueous solvents leads to significant losses of the EO compounds due to a steam distillation effect at surface level during the film drying step. Throughout this step, EO droplets flocculate, coalesce and cream to the top of the drying film to a different extent, where EO compounds volatilize together with water. In this way, particular constituents of the EOs are lost depending on their relative amount in the oil. In an aqueous solvent, the major compounds can lose over $50 \%$ of the EO added to the film-forming dispersion, depending on the emulsion stability and the total lipid creaming during film drying. Smaller droplets, higher surface particle charge and the interfacial adsorption of amphiphilic molecules, such as proteins or surfactants, enhanced emulsion stability and reduced the losses of EOs during film drying (Perdones et al., 2016). Micro and nanoencapsulation of EO compounds before film preparation could be a way to minimize this problem and improve the effectiveness of active packaging containing EOs. In this sense, the use of liposomes or nanoliposomes, which can act as carrier systems of a wide range of compounds, represent an 
interesting alternative (Zhang et al., 2012). Cyclodextrins have also been very effective at entrapping EO compounds when they are incorporated into the polymer matrices. A high ratio of carvacrol could be adsorbed in chitosan films containing cyclodextrins, depending on their glycerol and moisture content, when the films are immersed in the compound (the so-called nanosponges) (Higueras et al., 2013).

Table 10 shows some examples of different methods used to incorporate EOs into biopolymer matrices in order to develop antimicrobial packaging concepts. Materials produced by thermoplastic techniques that are used industrially for the purposes of processing synthetic plastics are usually dry mixed and afterwards extruded or melt blended to obtain thermoformable packaging products.

In the first step, the biopolymer is blended with the plasticizing additives and the active ingredients by using a hot mixer. The mixing temperature depends on the melting point of the biopolymer. Blending temperatures of $155^{\circ} \mathrm{C}$ and $80^{\circ} \mathrm{C}$ have been used for PLA and PCL, respectively (Del Nobile et al., 2009). In the second step, also performed at the mixing temperature and at high pressure, a hot-plate hydraulic press can be used to obtain films or samples that are suitable for extrusion. EO compounds can also be incorporated in different zones of the screw in an extruder after polymer melting. Recently, Requena et al. (2016) have shown that the use of spraying to incorporate EOs at the interface of two thermoplastic films and the subsequent thermo-compression of the films could be an appropriate strategy with which to improve the process of obtaining active films containing EOs and reduce the loss of active compounds.

During thermal processing, a part of the EO compounds can evaporate or decompose, depending on the thermal conditions and their respective volatility and thermostability. The encapsulation of essential oils with compounds, such as cyclodextrins, can protect active ingredients against evaporation and thermal degradation, thus minimizing their loss. Cyclodextrins, which are starch derivatives with a ringed structure, are able to form inclusion complexes with volatile compounds that are held tight within the molecular structure of the cyclodextrins (Rusa et al., 2001). Loaded cyclodextrins with trans-2-hexenal were included in PLA matrices by extrusion in order to obtain antimicrobial sheets, which exhibited antifungal activity against several food spoilage fungi, despite the significant losses of antimicrobials occurring during thermal processing (Joo et al., 2012). Likewise, Wen et al. (2016) incorporated cinnamon essential oil/beta cyclodextrin inclusion complex into PLA nanofibers via electrospinning technique. The thermal stability of cinnamon EO in the PLA matrix was significantly improved due to strong interactions between beta cyclodextrin and the EO. Moreover, the electrospun nanofilm showed antimicrobial activity against both Gram-positive and Gram-negative bacteria, and prolonged the shelf life of pork meat stored at $25^{\circ} \mathrm{C}$. 
Table 10. Incorporation methods of essential oils (EOs) or EO compounds into biopolymer matrices.

\begin{tabular}{|c|c|c|c|}
\hline Method & EO/Compound & Biopolymer & Reference \\
\hline \multicolumn{4}{|c|}{ CASTING METHOD } \\
\hline $\begin{array}{l}\text { Dissolution in } \\
\text { dichloromethane }\end{array}$ & Cinnamon EO & Polylactic (PLA) & $\begin{array}{l}\text { Ahmed et al., } \\
2016\end{array}$ \\
\hline \multirow{5}{*}{ Dissolution in chloroform } & Oregano EO & PLA & $\begin{array}{l}\text { Javidi et al., } \\
2016\end{array}$ \\
\hline & Cinnamaldehyde & $\begin{array}{l}\text { PLA/Polycaprolactone } \\
\text { (PCL) }\end{array}$ & Qin et al., 2015 \\
\hline & Oregano EO & PLA & $\begin{array}{l}\text { Salmieri et al., } \\
2014\end{array}$ \\
\hline & $\begin{array}{l}\text { Cinnamaldehyde, } \\
\text { allyl isothiocyanate, }\end{array}$ & PCL & $\begin{array}{l}\text { Martínez-Abad } \\
\text { et al., } 2013\end{array}$ \\
\hline & Eugenol & Polyhydroxybutyrate & $\begin{array}{l}\text { Narayan \& } \\
\text { Ramana, } 2013 \\
\end{array}$ \\
\hline Dissolution in ethanol & Thymol & Zein & $\begin{array}{l}\text { Del Nobile \& } \\
\text { Conte, } 2008\end{array}$ \\
\hline $\begin{array}{l}\text { Emulsification in distilled } \\
\text { water }\end{array}$ & Cinnamon EO & Agar/Alginate & $\begin{array}{l}\text { Arancibia et al., } \\
2014\end{array}$ \\
\hline $\begin{array}{l}\text { Encapsulation with } \\
\text { cyclodextrin and water } \\
\text { dispersion }\end{array}$ & $\begin{array}{l}\text { Eugenol and } \\
\text { carvacrol }\end{array}$ & Whey protein isolate & $\begin{array}{l}\text { Barba et al., } \\
2015\end{array}$ \\
\hline $\begin{array}{l}\text { Encapsulation with soy oil } \\
\text { and alginate and dispersion } \\
\text { in aqueous medium }\end{array}$ & Lemongrass EO & Sodium alginate & $\begin{array}{l}\text { Matiacevich, } \\
2016\end{array}$ \\
\hline $\begin{array}{l}\text { Encapsulation in soy lecithin } \\
\text { liposomes and dispersion in } \\
1 \% \text { aqueous acetic acid }\end{array}$ & $\begin{array}{l}\text { Cinnamon leaf EO, } \\
\text { eugenol }\end{array}$ & Chitosan & $\begin{array}{l}\text { Valencia-Sullca } \\
\text { et al., } 2016\end{array}$ \\
\hline $\begin{array}{l}\text { Dispersion in } 1 \% \text { aqueous } \\
\text { acetic acid }\end{array}$ & $\begin{array}{l}\text { Bergamot, oregano, } \\
\text { basil, clove, EO, } \\
\text { carvacrol }\end{array}$ & Chitosan & $\begin{array}{l}\text { Sánchez- } \\
\text { González et } \\
\text { al.,2011b; } \\
\text { Perdones et al., } \\
\text { 2014; Bonilla et } \\
\text { al., 2012a; } \\
\text { Fernández-Pan } \\
\text { et al., 2015 }\end{array}$ \\
\hline \multicolumn{4}{|c|}{ THERMO-PROCESSING } \\
\hline $\begin{array}{l}\text { Melt blending and } \\
\text { compression moulding }\end{array}$ & Thyme EO & Wheat gluten & $\begin{array}{l}\text { Ansorena et al., } \\
2016\end{array}$ \\
\hline Melt blending and extrusion. & Thymol & $\begin{array}{l}\text { Poly (butylene } \\
\text { succinate). }\end{array}$ & $\begin{array}{l}\text { Petchwattana \& } \\
\text { Naknaen, } 2015\end{array}$ \\
\hline $\begin{array}{l}\text { Melt blending and } \\
\text { compression moulding }\end{array}$ & Thymol & PLA & $\begin{array}{l}\text { Tawakkal et al., } \\
2016\end{array}$ \\
\hline $\begin{array}{l}\text { Spraying between thermo- } \\
\text { compressed layers plus } \\
\text { thermo-compression }\end{array}$ & $\begin{array}{l}\text { Oregano EO, } \\
\text { carvacrol, clove EO, } \\
\text { eugenol }\end{array}$ & $\begin{array}{l}\text { Polyhydroxybutyrate- } \\
\text { co-valerate }\end{array}$ & $\begin{array}{l}\text { Requena et al., } \\
2016\end{array}$ \\
\hline
\end{tabular}




\subsubsection{Impact of essential oils on the film functional properties}

The EO compounds in the polymer matrices have different effects on the functional properties of the materials used for packaging purposes. The discontinuities in the matrix (droplets) or the weakening of chain interactions can provoke changes in the mechanical resistance and barrier capacity of the materials, depending on the microstructure of the film and the interactions between compounds and biopolymer.

\section{Barrier properties}

Being mainly hydrophobic mixtures/compounds, EOs may be expected to improve the water barrier properties of biopolymer films, which are frequently based on hydrophilic materials, such as carbohydrates and proteins. This trend has been observed in several studies, as reported in Table 11. However, the opposite trend has also been repeatedly reported (Table 11), which suggests that the hydrophobic-hydrophilic balance is not the only factor to be taken into account when aiming to explain the effect of EOs on the barrier properties of biopolymer films. EO incorporation in hydrophilic film matrices, such as polysaccharides or proteins, implies the occurrence of a dispersed phase disrupting the matrix homogeneity, and giving rise to an emulsified film. In fact, the water vapour transfer phenomena through the biopolymer films is strongly dependent on the droplet size distribution in heterogeneous matrices. This, in turn, is mainly determined by the initial droplet size of the film forming aqueous dispersion, under determined homogenization conditions, and the emulsion destabilization phenomena taking place during the film drying step. Other factors, such as the physical state of the lipid and the interactions with the matrix, also play an important role. Fine lipid droplets, homogenously distributed in the film matrix, are most effective as water permeability reducers (Perez-Gago \& Krochta, 2001), since the high tortuosity factor in the continuous phase creates a great resistance to mass transfer. However, interactions of the EO compounds with the polymer chains may also limit chain aggregation in the film, leading to more open polymer matrices with less mass transfer resistance (Atarés et al., 2010a; Bonilla et al., 2012a).

In less polar polymer systems, such as biodegradable polyesters, the EO compounds are more miscible and usually act as plasticizers, thus promoting all of the diffusion dependent phenomena, such as water vapour or gas permeation (Requena et al., 2016). The balance of the different effects determines the final influence of EO incorporation on the barrier properties of the biopolymer. In some cases, EO incorporation does not have a significant effect on the barrier properties of the films (Choi et al., 2016). 
Table 11. Barrier properties (water vapour -WVP- and oxygen -OP- permeability) of biopolymer films as affected by the presence of essential oils (EOs).

\begin{tabular}{|c|c|c|c|c|c|}
\hline \multirow{2}{*}{$\begin{array}{l}\text { Matrix } \\
\text { Hydroxypropyl } \\
\text { methylcellulose } \\
\text { (HPMC) }\end{array}$} & \multirow{2}{*}{$\begin{array}{l}\text { EO } \\
\begin{array}{l}\text { Oregano, } \\
\text { bergamot }\end{array}\end{array}$} & \multirow{2}{*}{$\begin{array}{l}\begin{array}{l}\text { Concentration } \\
\text { (g/g polymer) }\end{array} \\
0-0.1 / 1\end{array}$} & \multicolumn{2}{|c|}{$\begin{array}{l}\text { Main observations on the effect } \\
\text { of EO incorporation }\end{array}$} & \multirow{2}{*}{$\begin{array}{l}\text { Reference } \\
\begin{array}{l}\text { Choi et al., } \\
2016\end{array}\end{array}$} \\
\hline & & & $\begin{array}{l}\text { WVTR was not } \\
\text { significantly } \\
\text { affected }\end{array}$ & $\begin{array}{l}\text { OTR increased } \\
\text { coherently } \\
\text { with EO } \\
\text { proportion }\end{array}$ & \\
\hline HPMC & $\begin{array}{l}\text { Plai, ginger, } \\
\text { fingerroot }\end{array}$ & - & $\begin{array}{l}\text { WVP upward } \\
\text { trend }\end{array}$ & $\begin{array}{l}\text { OP upward } \\
\text { trend }\end{array}$ & $\begin{array}{l}\text { Klangmuang } \\
\text { \& } \\
\text { Sothornvit, } \\
2016\end{array}$ \\
\hline Soy protein & Carvacrol & 0.67 & $\begin{array}{l}\text { WVP upward } \\
\text { trend }\end{array}$ & - & $\begin{array}{l}\text { Otoni et al., } \\
2016\end{array}$ \\
\hline Lignocellulose & Cedarwood & $0-0.2 / 1$ & $\begin{array}{l}\text { WVP was } \\
\text { reduced }\end{array}$ & - & $\begin{array}{l}\text { Shen \& } \\
\text { Kamdem, } \\
2015 \\
\end{array}$ \\
\hline $\begin{array}{l}\text { Fish gelatin and } \\
\text { chitosan }\end{array}$ & $\begin{array}{l}\text { Origanum } \\
\text { vulgare }\end{array}$ & $0.4-1.2 \% / 1.8 \%$ & $\begin{array}{l}\text { WVP increased } \\
\text { coherently with } \\
\text { EO proportion }\end{array}$ & - & $\begin{array}{l}\text { Hosseini et } \\
\text { al., } 2015\end{array}$ \\
\hline Gelatin & $\begin{array}{l}\text { Oregano, } \\
\text { lavender }\end{array}$ & $0.04-0.12 / 1$ & $\begin{array}{l}\text { WVP not } \\
\text { affected by } \\
\text { oregano, } \\
\text { reduced by } \\
\text { lavender }\end{array}$ & - & $\begin{array}{l}\text { Martucci et } \\
\text { al., } 2015\end{array}$ \\
\hline Alginate & $\begin{array}{l}\text { Thyme, } \\
\text { lemongrass, } \\
\text { sage }\end{array}$ & $1 / 3$ & $\begin{array}{l}\text { WVP downward } \\
\text { trend or } \\
\text { reduction }\end{array}$ & - & $\begin{array}{l}\text { Acevedo- } \\
\text { Fani et al., } \\
2015\end{array}$ \\
\hline Whey protein & $\begin{array}{l}\text { Almond, } \\
\text { walnut }\end{array}$ & $0.5-1 / 8$ & $\begin{array}{l}\text { WVP was } \\
\text { reduced }\end{array}$ & $\begin{array}{l}\text { OP was } \\
\text { increased }\end{array}$ & $\begin{array}{l}\text { Galus \& } \\
\text { Kadzińska, } \\
2016\end{array}$ \\
\hline Mucilage & Oregano & $0-2 / 35$ & $\begin{array}{l}\text { WVP was } \\
\text { increased }\end{array}$ & $\begin{array}{l}\text { OP was } \\
\text { increased }\end{array}$ & $\begin{array}{l}\text { Jouki et al., } \\
2014\end{array}$ \\
\hline Alginate & Oregano & $0-1 / 1$ & $\begin{array}{l}\text { WVP was } \\
\text { reduced }\end{array}$ & - & $\begin{array}{l}\text { Benavides } \\
\text { et al., } 2012\end{array}$ \\
\hline Chitosan & Lemon & $3 / 1$ & $\begin{array}{l}\text { WVP was } \\
\text { reduced }\end{array}$ & - & $\begin{array}{l}\text { Perdones et } \\
\text { al., } 2012\end{array}$ \\
\hline $\begin{array}{l}\text { HPMC, } \\
\text { chitosan }\end{array}$ & $\begin{array}{l}\text { Bergamot, } \\
\text { lemon, tea } \\
\text { tree }\end{array}$ & $0-2 / 1$ & $\begin{array}{l}\text { WVP was } \\
\text { reduced }\end{array}$ & - & $\begin{array}{l}\text { Sánchez- } \\
\text { González et } \\
\text { al., 2011c }\end{array}$ \\
\hline Chitosan & Bergamot & $0-3 / 1$ & $\begin{array}{l}\text { WVP was } \\
\text { reduced }\end{array}$ & - & $\begin{array}{l}\text { Sánchez- } \\
\text { González et } \\
\text { al., 2010a }\end{array}$ \\
\hline Chitosan & Tea tree & $0-2 / 1$ & $\begin{array}{l}\text { WVP was } \\
\text { reduced }\end{array}$ & - & $\begin{array}{l}\text { Sánchez- } \\
\text { González et } \\
\text { al., 2010b }\end{array}$ \\
\hline HPMC & Tea tree & $0-2 / 5$ & $\begin{array}{l}\text { WVP was } \\
\text { reduced }\end{array}$ & - & $\begin{array}{l}\text { Sánchez- } \\
\text { González et } \\
\text { al., } 2009\end{array}$ \\
\hline
\end{tabular}




\begin{tabular}{llllll}
\hline Matrix & EO & $\begin{array}{l}\text { Concentration } \\
\text { (g/g polymer) }\end{array}$ & $\begin{array}{l}\text { Main observations on the effect of EO } \\
\text { incorporation }\end{array}$ & Reference \\
\hline Chitosan & Basil, thyme & $0-0.5 / 1$ & WVP was reduced & - & $\begin{array}{l}\text { Perdones } \text { et } \\
\text { al., 2016 }\end{array}$ \\
\hline Chitosan & $\begin{array}{l}\text { Cinnamon } \\
\text { leaf }\end{array}$ & $0-0.5 / 1$ & WVP was increased & $\begin{array}{l}\text { OP was } \\
\text { increased }\end{array}$ & $\begin{array}{l}\text { Perdones } \text { et } \\
\text { al., 2014 }\end{array}$ \\
\hline $\begin{array}{l}\text { Starch- } \\
\text { gelatin } \\
\text { blend }\end{array}$ & $\begin{array}{l}\text { Oregano, } \\
\text { love, } \\
\text { cinnamon } \\
\text { bark }\end{array}$ & $0-0.25 / 1$ & WVP was reduced & OP was reduced & $\begin{array}{l}\text { Acosta et } \\
\text { al., 2016 }\end{array}$ \\
\hline & $\begin{array}{l}\text { Eugenol, } \\
\text { cinnamon } \\
\text { leaf }\end{array}$ & $0.476 / 1$ & $\begin{array}{l}\text { WVP reduced by } \\
\text { eugenol }\end{array}$ & - & $\begin{array}{l}\text { Valencia- } \\
\text { Sullca et al., } \\
2016\end{array}$ \\
\hline
\end{tabular}

In general, the incorporation of EOs into the film matrix has been found to increase gas permeation. This can be mainly attributed to the greater solubility of gas molecules in the matrix, associated with the presence of more hydrophobic compounds. When EOs are incorporated, a lipid dispersed phase occurs in hydrophilic polymers, while hydrophobic matrices become more plasticized. Therefore, an increase in the gas permeability may be expected. As summarized in Table 11, this trend has been reported for several polymer-EO systems. However, as concerns oxygen permeability, films containing EOs or their compounds exhibit reduced values; this has been attributed to their antioxidant activity, which can exert an oxygen scavenging effect in the films (Bonilla et al., 2012b; Bonilla et al., 2013).

\section{Mechanical properties}

As regards the effect of EO incorporation into biopolymer films, the most frequently reported trend is a reduction in both the Elastic Modulus (EM) and Tensile Strength (TS) (Table 12), respectively associated with film stiffness and strength. The incorporation of EOs into the polymer structure leads to the partial replacement of the stronger interactions between the polymer chains by weaker polymer-oil interactions (Sánchez-González et al., 2010b; Shen \& Kamdem, 2015), thus allowing for the occurrence of structural discontinuities which reduce the mechanical resistance of the emulsified structure in hydrophilic matrices, where films tend to become less resistant to fracture and less stretchable. In hydrophobic matrices, the better compound compatibility leads to polymer plasticization, reducing both stiffness and strength, but enhancing the film extensibility. 
Table 12. Tensile properties (elastic modulus: EM, tensile strength: TS, and percentage elongation at break: \%E) of biopolymer films as affected by the presence of essential oils (EOs).

\begin{tabular}{|c|c|c|c|c|c|c|}
\hline \multirow[t]{2}{*}{ Matrix } & \multirow[t]{2}{*}{ EO } & \multirow{2}{*}{$\begin{array}{l}\text { Concentration } \\
\text { (g/g polymer) }\end{array}$} & \multicolumn{3}{|c|}{$\begin{array}{l}\text { Main observations on the effect of } \\
\text { EO incorporation }\end{array}$} & \multirow[t]{2}{*}{ Reference } \\
\hline & & & EM & TS & $\% \mathrm{E}$ & \\
\hline Soy protein & $\begin{array}{l}\text { Carvacrol, } \\
\text { cinnamaldehyde }\end{array}$ & $0.67 / 10$ & Increased & Increased & Increased & $\begin{array}{l}\text { Otoni et al., } \\
2016\end{array}$ \\
\hline Lignocellulose & Cedarwood & $0-0.2 / 1$ & Reduced & Reduced & $\begin{array}{l}\text { Slightly } \\
\text { increased }\end{array}$ & $\begin{array}{l}\text { Shen \& } \\
\text { Kamdem, } 2015\end{array}$ \\
\hline $\begin{array}{l}\text { Fish gelatin and } \\
\text { chitosan }\end{array}$ & $\begin{array}{l}\text { Origanum } \\
\text { vulgare }\end{array}$ & $\begin{array}{l}0.4- \\
1.2 \% / 1.75 \%\end{array}$ & Reduced & Reduced & No effect & $\begin{array}{l}\text { Hosseini et al., } \\
2015\end{array}$ \\
\hline Gelatin & $\begin{array}{l}\text { Oregano, } \\
\text { lavender }\end{array}$ & $0.04-0.12 / 1$ & $\begin{array}{l}\text { Non } \\
\text { reported }\end{array}$ & Reduced & No effect & $\begin{array}{l}\text { Martucci et al., } \\
2015\end{array}$ \\
\hline Alginate & $\begin{array}{l}\text { Thyme, } \\
\text { lemongrass }\end{array}$ & $1 / 3$ & $\begin{array}{l}\text { Non } \\
\text { reported }\end{array}$ & No effect & $\begin{array}{l}\text { No effect/ } \\
\text { increased }\end{array}$ & $\begin{array}{l}\text { Acevedo-Fani et } \\
\text { al., } 2015\end{array}$ \\
\hline Whey protein & Almond, walnut & $1 / 8$ & No effect & No effect & $\begin{array}{l}\text { No effect/ } \\
\text { increased }\end{array}$ & $\begin{array}{l}\text { Galus \& } \\
\text { Kadzińska, } 2016\end{array}$ \\
\hline Mucilage & Oregano & $0-2 / 35$ & Reduced & Reduced & Increased & Jouki et al.,2014 \\
\hline \multirow{2}{*}{$\begin{array}{l}\text { Soy protein } \\
\text { isolate }\end{array}$} & Cinnamon & $0.1 / 1$ & No effect & Increased & Increased & \multirow{2}{*}{$\begin{array}{l}\text { Atarés et al., } \\
2010 \mathrm{~b}\end{array}$} \\
\hline & Ginger & $0.1 / 1$ & Reduced & Reduced & No effect & \\
\hline Chitosan & Cinnamon & $0.1 / 1$ & - & Increased & Reduced & $\begin{array}{l}\text { Ojagh et al., } \\
2010\end{array}$ \\
\hline Alginate & Oregano & $0-1 / 1$ & - & Reduced & Increased & $\begin{array}{l}\text { Benavides et al., } \\
2012\end{array}$ \\
\hline Chitosan & $\begin{array}{l}\text { Bergamot, } \\
\text { lemon, tea tree }\end{array}$ & $0-2 / 1$ & Reduced & Reduced & Reduced & $\begin{array}{l}\text { Sánchez- } \\
\text { González et al., } \\
2011 c\end{array}$ \\
\hline Chitosan & Bergamot & $0-3 / 1$ & Reduced & Reduced & Reduced & $\begin{array}{l}\text { Sánchez- } \\
\text { González et al., } \\
\text { 2010a }\end{array}$ \\
\hline Chitosan & Tea tree & $0-2 / 1$ & Reduced & Reduced & Reduced & $\begin{array}{l}\text { Sánchez- } \\
\text { González et al., } \\
\text { 2010b }\end{array}$ \\
\hline $\begin{array}{l}\text { Hydroxypropyl } \\
\text { methylcellulose } \\
\text { (HPMC) }\end{array}$ & Tea tree & $0-2 / 5$ & Reduced & Reduced & No effect & $\begin{array}{l}\text { Sánchez- } \\
\text { González et al., } \\
2009\end{array}$ \\
\hline Chitosan & Basil, thyme & $0-0.5 / 1$ & Increased & Increased & Reduced & $\begin{array}{l}\text { Perdones et al., } \\
2016\end{array}$ \\
\hline Chitosan & Cinnamon leaf & $0-0.5 / 1$ & Reduced & Reduced & Increased & $\begin{array}{l}\text { Perdones et al., } \\
2014\end{array}$ \\
\hline $\begin{array}{l}\text { Starch-gelatin } \\
\text { blend }\end{array}$ & $\begin{array}{l}\text { Oregano, clove, } \\
\text { cinnamon bark }\end{array}$ & $0-0.25 / 1$ & No effect & No effect & No effect & $\begin{array}{l}\text { Acosta et al., } \\
2016\end{array}$ \\
\hline Chitosan & $\begin{array}{l}\text { Eugenol, } \\
\text { cinnamon leaf }\end{array}$ & $0.476 / 1$ & Reduced & Reduced & No effect & $\begin{array}{l}\text { Valencia-Sullca } \\
\text { et al., } 2016\end{array}$ \\
\hline
\end{tabular}


Opposite behaviour can occur for particular EO-polymer blends where specific interactions are given. In fact, several studies have reported a strengthening effect as a result of the cinnamon EO incorporation in soy protein or chitosan matrices (Atarés et al., 2010b; Ojagh et al., 2010). In these cases, EO induces the rearrangement of the polymer network and some compounds provoke chain cross-linking, thereby improving the tensile properties (Tongnuanchan et al., 2012). Consisting of numerous chemical compounds with different molecular structures, EOs could interact with the polymer matrix differently. They also affect the film-water interactions, which also play a key role in mechanical behaviour. Otoni et al. (2016) obtained soy protein films with carvacrol or cinnamaldehyde and observed a strengthening effect, which was explained by the reduction in the water adsorption capacity of the films, thus limiting their plasticizing action and making these films stiffer, under determined conditions of relative humidity.

\subsubsection{Release of essential oils from the polymer matrices into food or food simulants}

The development of active packaging involves not only the incorporation of antimicrobial and/or antioxidant substances into the materials, but also the controlled release of the active compounds so as to maintain an effective concentration in the foodstuff over a period of time (Tawakkal et al., 2016; Fernández-Pan et al., 2015). In this sense, migration studies are required in order to determine the release rate of the actives from the film into the packaged food. In general, these studies are carried out in food simulants, which are liquid systems, which emulate the different hydrophilic or lipophilic nature of real foodstuffs. These have been standardized to find out how the different factors influence the migration process and to compare the behaviour of different active compounds and polymer matrices in distinct types of more or less hydrophilic foods. Aqueous food with neutral or acid pH can be properly simulated with distilled water containing $10-50 \%$ ethanol or $3 \%$ acetic acid, whereas $95 \%$ aqueous ethanol, oil or isooctane can be used to simulate fatty foodstuffs (Comission of the European Communities, 1997; Etxabide et al., 2016).

Three coupled mechanisms are involved in the release mass transfer process: the diffusion of the food components (mainly water) into the polymer matrix, the relaxation of the macromolecular network, associated with the compound diffusion, and the diffusion of the active compound through the polymer. These mechanisms are coupled to a different extent until the thermodynamic equilibrium between film and food system phases is reached. Different models have been used to describe compound release kinetics, such first order kinetics and Fickian (Crank, 1945) or Peppas equations (Ritger \& Peppas, 1987a, 1987b). Parameters that quantify the amount of compound released at equilibrium, and its release rate, are a useful means of understanding the extent to which the release takes place and to predict its effectiveness as an active. As concerns the delivery rate of actives, constant rate 
values ( $k$ ) have been determined by applying first order kinetics equations (Biddeci et al., 2016; Tawakkal et al., 2016). Likewise, the diffusion coefficient (D) of compounds have been quantified by fitting Fick's model to the concentration of the active in the food simulant vs. time (Del Nobile \& Conte, 2008; Petchwattana \& Naknaen, 2015; Sánchez-González et al., 2011d; Tawakkal et al., 2016). The fitting of the Peppas model allows us to obtain information about the coupling of the different mechanisms involved in the process, through the value of the potential coefficient $n$. Values of $n$ in the range of 0.5 indicate a prevailing Fickian mechanism.

In the case of EO compounds embedded in polymer films, there are different factors that influence the compound migration from films to the food system: (i) the physicochemical properties of the migrant substance, such as volatility, polarity and solubility; (ii) the polymer hydrophobicity, which determines the interactions with the EO compounds and the foodstuff; (iii) the composition and properties of the packaged food, mainly the food polarity, and (iv) the storage conditions, such as temperature (Fernández-Pan et al., 2015; Higueras et al., 2014; Moradi et al., 2011; Sánchez-González et al., 2011d; Tehrany \& Desobry, 2007). All of these factors implied both complex interactions, which make controlled release predictions difficult, and also the necessity for specific studies of a determined packaging material and food system. The use of standardized food simulants can help to compare the migration of different materials, but differences in composition with respect to real foods could lead to divergent results, since particular interactions with different food components may affect migration behaviour and food quality and safety.

As previously commented on, many biopolymers with film forming properties, such as chitosan, starch, modified cellulose, alginate, whey protein or gelatin, are water soluble whereas the EO compounds are non-polar substances (Matiacevich, 2016). To promote compatibility, what has been analysed is the encapsulation of EO by means of different strategies, affecting the compound release kinetics. Table 13 and 14 summarizes previous studies into the release of actives, encapsulated or not, into different food matrices or simulants. Wu et al. (2015) reported a reduction in the release rate of cinnamon EO from fish gelatin films into corn oil as a result of their inclusion in nanoliposomes, which prolongs the activity, thus improving the antimicrobial action. In the same way, the encapsulation of carvacrol in $\beta$-cyclodextrins reduced the carvacrol release rate from whey protein isolate (WPI) films (Barba et al., 2015) and cellulose nanocrystal films (Castro et al., 2016). However, the release rate of eugenol was not significantly affected by its inclusion in $\beta$-cyclodextrin in WPI films, which was attributed to the weak interactions between the compound and cyclodextrins (Barba et al., 2015). Nanofillers, such as halloysite nanotubes, were also effective at controlling the release of peppermint EO from pectin films, increasing the EO adsorption capacity of the polymer matrix (Biddeci et al., 2016). Likewise, sepiolite nanofillers slowed down and prolonged the eugenol release from clove EO-gelatin films, through the control of the EO interactions with the polymer matrix (Giménez et al., 2012). Matiacevich et 
al. (2016) highlighted the effect of the structure of the polymer matrix on the release parameters of lemongrass EO, encapsulated in sodium caseinate microcapsules, when included in alginate films. The more ordered structure of the film greatly slowed down the release rate.

The concentration of the active compound in the film also affects release kinetics. Chen et al. (2016) reported an increase in the release rate of nanoemulsified cinnamaldehyde when its concentration rose up to a carbonyl:amino molar ratio of 1 in chitosan films. However, higher contents led to slower delivery rates, which was attributed to microstructural changes that restricted molecular diffusion through the polymer matrix.

The chemical compatibility between the active compound and the foodstuff is a decisive factor in the release of the active agent. Thus, active devices based on chitosan containing $\beta$ cyclodextrin-carvacrol complexes, placed in tight packages containing chicken samples, produced carvacrol deliveries of between $95-99 \%$ after 9 days of storage, whereas packages without chicken samples only released $35 \%$ of the active agent (Higueras et al., 2014). The great chemical affinity between the carvacrol and the chicken protein promoted carvacrol adsorption in the food, which, while limiting antimicrobial action, affected the sensory properties. Similar effects were observed for Zataria multiflora Boiss EO (ZEO) embedded in chitosan films when applied on mortadella sausages, where a fast and total release of ZEO compounds was observed due to their great affinity with the mortadella fat. Nevertheless, this was mitigated when applied in combination with grape seed extract with higher molecular weight compounds, which interact with ZEO constituents (Moradi et al., 2011). These observations have also been proven in food simulants; Petchwattana and Naknaen (2015) and Tawakkal et al. (2016) analysed the release kinetics of thymol from PBS and PLA films, respectively, and reported that the maximum release rates were observed with hydrophobic food simulants, such as $95 \%$ ethanol and isooctane, due to the greater chemical affinity between thymol and the non-polar solvents. Likewise, Sánchez-González et al. (2011d) observed a higher release at the equilibrium of limonene from chitosan films as the ethanol percentage increased in the food simulant, in line with the low polarity of limonene. However, no notable delivery of active compounds occurred in isooctane due to the lack of swelling of the polymer matrix, which tightly entraps the active.

Temperature greatly affects the kinetics of active compound delivery from a determined film in a specific medium. Temperature affects the molecular interactions in both film matrices and food systems, and therefore the chemical affinity between the active compounds and the respective substrate can change, provoking different migration behaviour. In general, low temperatures slow down migration kinetics, according to its effect on molecular diffusion, but the equilibrium status can also be modified due to the differences in the involved molecular interactions. In this sense, different authors (Bidecci et al., 2016; Wu et al., 2015) report a significant effect of temperature on the delivery kinetics of the EO active compounds 


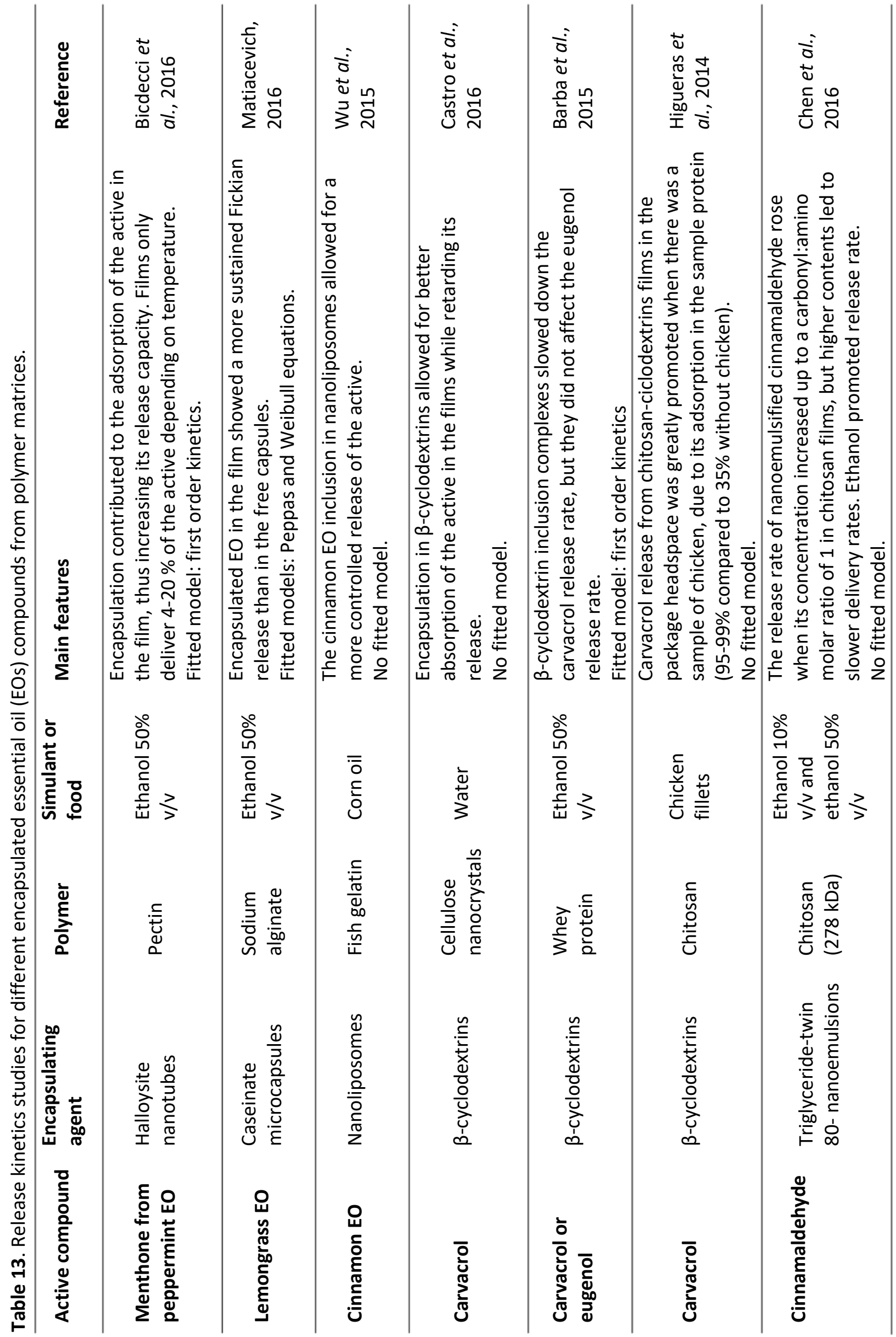




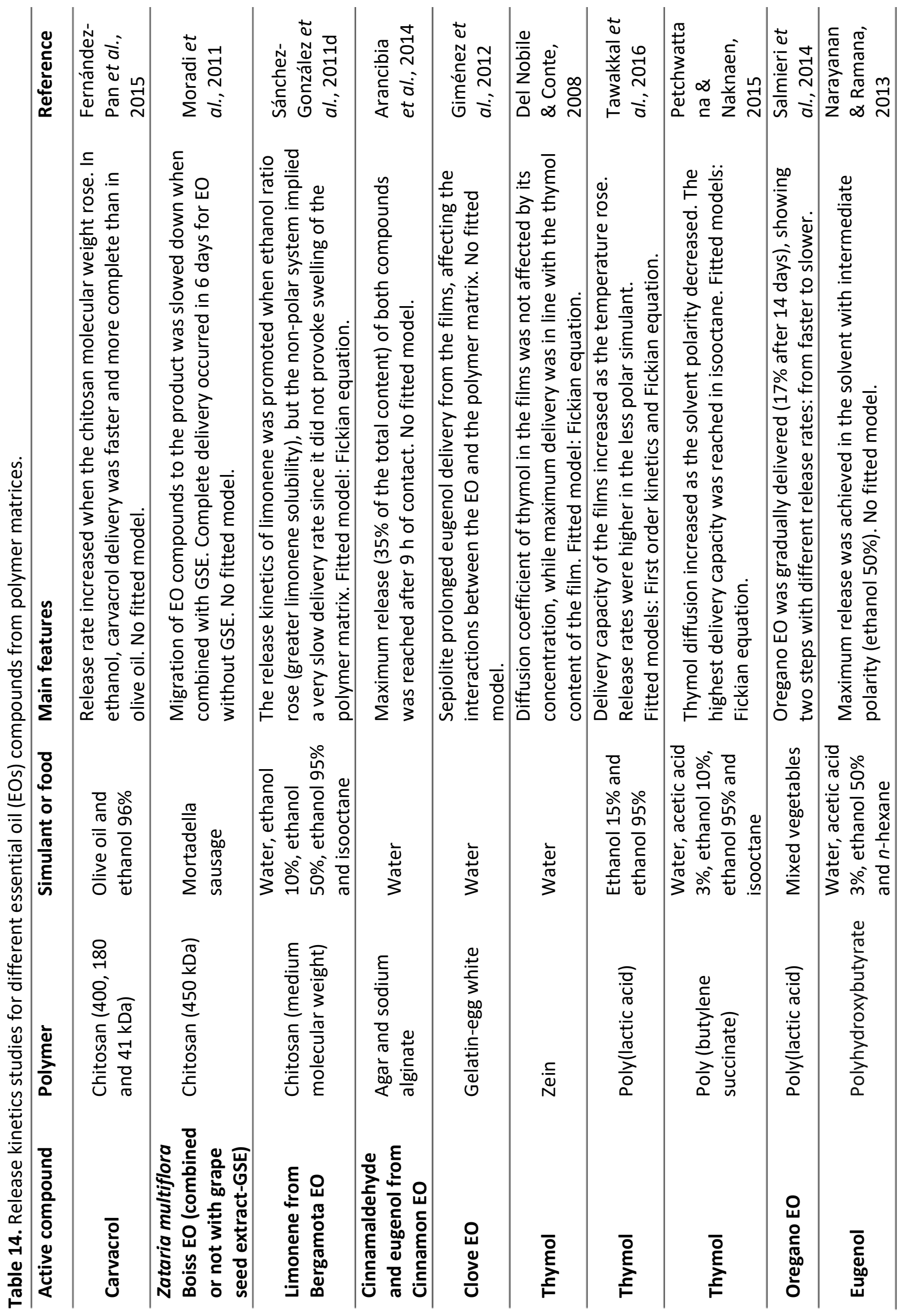




\subsubsection{Food applications of active biopolymer films containing essential oils}

During the last decade, many studies have been carried out on the use of biopolymers as carriers of EOs and their main compounds, with the aim of responding to consumer demand for preservative-free, safer products. Thus, different carbohydrate polymers, such as chitosan, cellulose derivatives, alginates, gelatin, etc., have been used both to incorporate EOs and develop film formulations for the purposes of improving the food quality and extending their shelf life. Different plant and animal proteins, such as gelatin, whey, soy and milk proteins, have also been extensively used. Table 15 summarizes several recent studies using these kinds of biopolymers. The use of other biopolymers, such as aliphatic polyesters (Petersen et al., 1999), as carriers of antimicrobials is also being investigated in order to obtain active materials for food packaging (Table 16). Among the most outstanding are PLA, PCL or PHAs, such as PHB and PHBV (Corre et al., 2012). Among the most effective compounds/EOs may be found carvacrol, thymol, cinnamaldehyde or oregano, cinnamon and clove EOs, attaining the total microbial inhibition of several foodborne pathogens. Some studies are summarized in Tables 15 and 16 and commented on below PLA films with cinnamon EO significantly reduced the bacterial growth in chicken samples inoculated with L. monocytogenes or S. typhimurium (Ahmed et al., 2016). Likewise, PLA-cinnamon EO films doubled the shelf-life of pork meat by maintaining the microbial counts below $1 \cdot 10^{7} \mathrm{CFU} / \mathrm{ml}$ for 8 days (Wen et al., 2016). Similarly, PLA films with oregano EO have been used to package rainbow trout, thus reducing the total viable counts by half after 12 days of cold storage, keeping these values below the recommended limit. At the same time, the microbial growth of psychrotrophic bacteria, lactic acid bacteria and Enterobacteriaceae was delayed as a result of the antimicrobial activity of oregano EO (Javidi et al., 2016).

Often, films based on biopolymer blends are used as carriers of these active compounds, since they usually demonstrate better physical properties. In this sense, cinnamaldehyde has been included in PLA-PCL films, which reduced the microbial growth on button mushrooms (Qin et al., 2015). Likewise, PCL-methylcellulose films with extract of rosmarinic and Asian or Italian EO mixture inhibited the microbial growth of E. coli and S. yphimurium in broccoli, while showed a bacteriostatic effect at 12 and 7 days, respectively (Takala et al., 2013). In vitro tests with PHB films containing eugenol exhibited antimicrobial activity, with a MIC of eugenol in the films of 40 and $80 \mu \mathrm{g}$ eugenol/g PHB for bacteria and fungi, respectively. A total microbial inhibition was observed with an eugenol content of over $200 \mu \mathrm{g} / \mathrm{g}$ PHB (Narayanan \& Ramana, 2013). In the same way, Requena et al., (2016) reported that PHBV films with carvacrol, eugenol or oregano EO had a fast bactericide effect against $E$. coli, whereas less, more gradual antimicrobial activity was observed against $L$. innocua. 


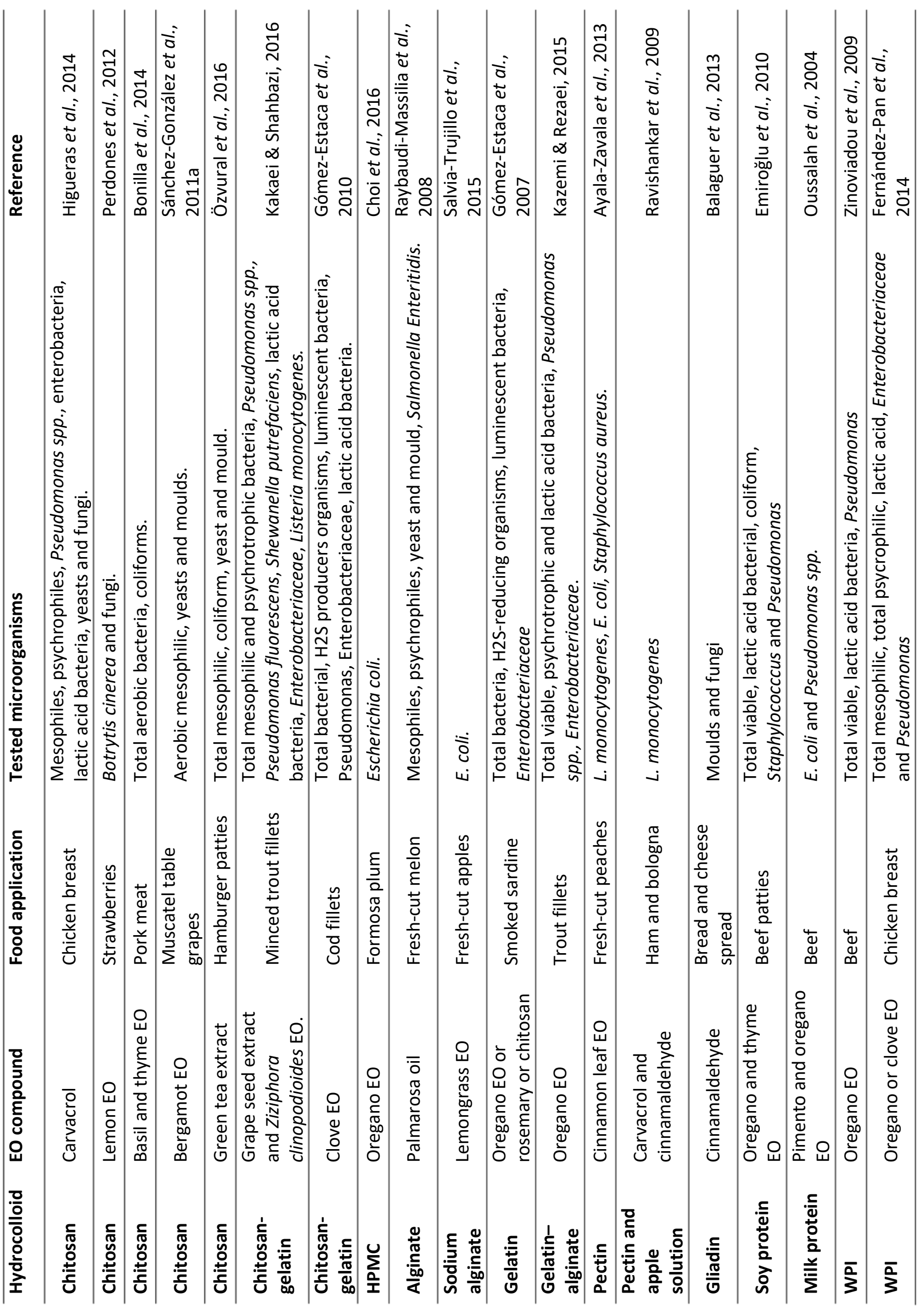


Table 16. Recent studies on applications of biodegradable polymer active films with essential oil (EO) compounds into food systems.

\begin{tabular}{|c|c|c|c|c|}
\hline $\begin{array}{l}\text { Biodegradable } \\
\text { polymer }\end{array}$ & EO compound & $\begin{array}{l}\text { Food } \\
\text { application }\end{array}$ & Microorganism tested & Reference \\
\hline $\begin{array}{l}\text { Polylactic acid } \\
\text { (PLA) }\end{array}$ & Cinnamon EO & Chicken & $\begin{array}{l}\text { Listeria monocytogenes } \\
\text { and Salmonella } \\
\text { typhimurium (in vitro and } \\
\text { in vivo) }\end{array}$ & $\begin{array}{l}\text { Ahmed et } \\
\text { al., } 2016\end{array}$ \\
\hline PLA & Oregano EO & $\begin{array}{l}\text { Rainbow } \\
\text { trout }\end{array}$ & $\begin{array}{l}\text { Staphylococcus aureus, L. } \\
\text { monocytogenes, } \\
\text { Escherichia coli and } \\
\text { Salmonella enteritidis (in } \\
\text { vitro) } \\
\text { Total viable count, } \\
\text { psychrotrophilic count, } \\
\text { lactic acid bacteria and } \\
\text { Enterobacteruaceae (in } \\
\text { vivo) }\end{array}$ & $\begin{array}{l}\text { Javidi et } \\
\text { al., } 2016\end{array}$ \\
\hline PLA & $\begin{array}{l}\text { Cinnamon EO/ } \beta- \\
\text { cyclodextrins }\end{array}$ & Pork meat & $\begin{array}{l}\text { E. coli and S. aureus (in } \\
\text { vitro) } \\
\text { Viable microbial counts } \\
\text { (in vivo) }\end{array}$ & $\begin{array}{l}\text { Wen et al. } \\
2016\end{array}$ \\
\hline $\begin{array}{l}\text { PLA, } \\
\text { polycaprolactone } \\
\text { (PCL) }\end{array}$ & Cinnamaldehyde & $\begin{array}{l}\text { Button } \\
\text { mushroom }\end{array}$ & $\begin{array}{l}\text { Mesophilic and } \\
\text { psychrophilic counts }\end{array}$ & $\begin{array}{l}\text { Qin et al., } \\
2015\end{array}$ \\
\hline $\begin{array}{l}\text { PLA, cellulose } \\
\text { nanocrystals }\end{array}$ & Oregano EO & $\begin{array}{l}\text { Mixed } \\
\text { vegetables }\end{array}$ & $\begin{array}{l}5 \text { strains of } L \text {. } \\
\text { monocytogenes HPB } \\
(2569,2558,2371,2812 \\
\text { and } 1043)\end{array}$ & $\begin{array}{l}\text { Salmieri et } \\
\text { al } 2014\end{array}$ \\
\hline $\begin{array}{l}\mathrm{PCL}, \\
\text { metylcellulose }\end{array}$ & $\begin{array}{l}\text { Two blends: (i) } \\
\text { organic acids, extract } \\
\text { of rosmarinic acid } \\
\text { and Asian EO } \\
\text { mixture; (ii) organic } \\
\text { acids, extract of } \\
\text { rosmarinic acid and } \\
\text { Italian EO mixture. }\end{array}$ & $\begin{array}{l}\text { Fresh } \\
\text { broccoli }\end{array}$ & $\begin{array}{l}\text { L. monocytogenes, } S . \\
\text { typhimurium, E. coli and } \\
\text { total aerobic microbiota. }\end{array}$ & $\begin{array}{l}\text { Takala et } \\
\text { al., } 2013\end{array}$ \\
\hline
\end{tabular}


Despite the remarkable antimicrobial activity of the EOs against most foodborne pathogens in in vitro tests, several authors have reported that higher amounts are required to achieve similar results on real foodstuffs. This fact can be explained by the interactions of some food ingredients with the EO compounds, which sequester them, thereby limiting their antimicrobial activity. In general, high contents of proteins or fats have been related with a lower bacterial sensitivity to the EOs (Aureli et al., 1992; Pandit \& Shelef et al., 1994; Shelef et al., 1984; Tassou et al., 1995), whereas this has not been observed with high carbohydrate contents (Shelef et al., 1984). In addition, the higher nutrient availability on the food, compared to the culture media, would allow for faster damage repair by bacteria (Gill et al., 2002). Thus, despite the proven antimicrobial properties of several EOs in culture media, very low or null antibacterial activity was observed for these EOs against $E$. coli in ready-to-cook chicken (Shekarforoush et al., 2007); S. typhimurium in beef (Uhart et al., 2006); Y. enterocolitica and L. monocytogenes in chicken (Firouzi et al., 2007); and L. monocytogenes in steak tartare (Veldhuizen et al., 2007). Likewise, sachets containing carvacrol inside packaged chicken breast fillets did not give rise to an efficient microbial inhibition of fungi, yeast, mesophiles and enterobacteria, because of the headspace carvacrol was adsorbed by the chicken protein matrix, thereby keeping the active compound concentration in the packaging headspace below the MIC (Higueras et al., 2014). In the same way, edible films from apple puree containing cinnamaldehyde did not exhibit antimicrobial activity against $L$. monocytogenes in ham, at different active compound concentrations and storage temperatures (Ravishankar et al., 2009). Nor did PCL-methylcellulose films containing extract of rosmarinic acid and Italian or Asian EO mixture have any effect on the $L$. monocytogenes growth in fresh broccoli (Takala et al., 2013). Therefore, although the antimicrobial activity of many EOs has been proven in in vitro studies and with some specific foodstuffs, the development of active packaging requires specific studies with a determined food product to ensure antimicrobial effectiveness and food safety. 


\section{References}

Abdalla, A. E., Darwish, S. M., Ayad, E. H., \& El-Hamahmy, R. M. (2007). Egyptian mango by-product 2: Antioxidant and antimicrobial activities of extract and oil from mango seed kernel. Food Chemistry, 103(4), 1141-1152.

Abe, H., Matsubara, I., \& Doi, Y. (1995). Physical properties and enzymic degradability of polymer blends of bacterial poly [(R)-3-hydroxybutyrate] and poly [(R, S)-3-hydroxybutyrate] stereoisomers. Macromolecules, 28(4), 844-853.

Acevedo-Fani, A., Salvia-Trujillo, L., Rojas-Graü, M. A., \& Martín-Belloso, O. (2015). Edible films from essential-oil-loaded nanoemulsions: Physicochemical characterization and antimicrobial properties. Food Hydrocolloids, 47, 168-177.

Acosta, S., Chiralt, A., Santamarina, P., Rosello, J., González-Martínez, C., \& Cháfer, M. (2016). Antifungal films based on starch-gelatin blend, containing essential oils. Food Hydrocolloids, 61, 233240.

Adrar, N., Oukil, N., \& Bedjou, F. (2016). Antioxidant and antibacterial activities of Thymus numidicus and Salvia officinalis essential oils alone or in combination. Industrial Crops and Products, 88, 112-119.

Ahmed, J., Mulla, M. Z., \& Arfat, Y. A. (2016). Thermo-mechanical, structural characterization and antibacterial performance of solvent casted polylactide/cinnamon oil composite films. Food Control, 69, 196-204.

Albuquerque, P. B., \& Malafaia, C. B. (2017). Perspectives on the production, structural characteristics and potential applications of bioplastics derived from polyhydroxyalkanoates. International Journal of Biological Macromolecules, 107, 615-625.

Aliheidari, N., Fazaeli, M., Ahmadi, R., Ghasemlou, M., \& Emam-Djomeh, Z. (2013). Comparative evaluation on fatty acid and Matricaria recutita essential oil incorporated into casein-based film. International Journal of Biological Macromolecules, 56, 69-75.

Alves de Azerêdo, G., Stamford, T. L. M., Queiroz de Figueiredo, R. C. B., \& Leite de Souza, E. (2012). The cytotoxic effect of essential oils from Origanum vulgare $L$. and/or Rosmarinus officinalis $L$. on Aeromonas hydrophila. Foodborne Pathogens and Disease, 9(4), 298-304.

Alves-Silva, J.M., Dias dos Santos, S.M., Pintado, M.E., Pérez-Álvarez J.A., Fernández-López, J., ViudaMartos, M. (2013). Chemical composition and in vitro antimicrobial, antifungal and antioxidant properties of essential oils obtained from some herbs widely used in Portugal. Food Control, 32 (2), 371-378.

Ansorena, M.R., Zubeldía, F., \& Marcovich, N.E. (2016). Active wheat gluten films obtained by thermoplastic processing. Food Science \& Technology, 69, 47-54

Arancibia, M., Giménez, B., López-Caballero, M. E., Gómez-Guillén, M. C., Montero, P. (2014). Release of cinnamon essential oil from polysaccharide bilayer films and its use for microbial growth inhibition in chilled shrimps. LWT-Food Science and Technology, 59(2), 989-995. 
Armentano, I., Fortunati, E., Burgos, N., Dominici, F., Luzi, F., Fiori, S., Jiménez, A., Yoon, K., Ahn, J., Kang, S., \& Kenny, J. M. (2015). Processing and characterization of plasticized PLA/PHB blends for biodegradable multiphase systems. Express Polymer Letters, 9(7).

Arrieta, M. P., Castro-Lopez, M. D. M., Rayón, E., Barral-Losada, L. F., López-Vilariño, J. M., López, J., \& González-Rodríguez, M. V. (2014a). Plasticized poly (lactic acid)-poly (hydroxybutyrate)(PLA-PHB) blends incorporated with catechin intended for active food-packaging applications. Journal of Agricultural and Food Chemistry, 62(41), 10170-10180.

Arrieta, M. P., Samper, M. D., López, J., \& Jiménez, A. (2014b). Combined effect of poly (hydroxybutyrate) and plasticizers on polylactic acid properties for film intended for food packaging. Journal of Polymers and the Environment, 22(4), 460-470.

Arrieta, M. P., López, J., Hernández, A., \& Rayón, E. (2014c). Ternary PLA-PHB-Limonene blends intended for biodegradable food packaging applications. European Polymer Journal, 50, 255-270.

Atarés, L., Bonilla, J., \& Chiralt, A. (2016a). Characterization of sodium caseinate-based edible films incorporated with cinnamon or ginger essential oils. Journal of Food Engineering, 100(4), 678-687.

Atarés, L., De Jesús, C., Talens, P., \& Chiralt, A. (2010b). Characterization of SPI-based edible films incorporated with cinnamon or ginger essential oils. Journal of Food Engineering, 99(3), 384-391.

Aureli, P., Costantinf, A., \& Zolea, S. (1992). Antimicrobial activity of some plant essential oils against Listeria monocytogenes. Journal of Food Protection, 55 (5), 344-348.

Ayala-Zavala, J. F., Vega-Vega, V., Rosas-Domínguez, C., Palafox-Carlos, H., Villa-Rodriguez, J. A., Siddiqui, M. W., Dávila-Aviña, J. E., \& González-Aguilar, G. A. (2011). Agro-industrial potential of exotic fruit byproducts as a source of food additives. Food Research International, 44(7), 1866-1874.

Ayala-Zavala, J. F., Silva-Espinoza, B. A., Cruz-Valenzuela, M. R., Leyva, J. M., Ortega-Ramírez, L. A., Carrazco-Lugo, D. K., \& Miranda, M. R. A. (2013). Pectin-cinnamon leaf oil coatings add antioxidant and antibacterial properties to fresh-cut peach. Flavour and Fragrance Journal, 28(1), 39-45.

Balaguer, M. P., Lopez-Carballo, G., Catala, R., Gavara, R., \& Hernandez-Munoz, P. (2013). Antifungal properties of gliadin films incorporating cinnamaldehyde and application in active food packaging of bread and cheese spread foodstuffs. International Journal of Food Microbiology, 166(3), 369-377.

Balasundram, N., Sundram, K., \& Samman, S. (2006). Phenolic compounds in plants and agri-industrial by-products: Antioxidant activity, occurrence, and potential uses. Food chemistry, 99(1), 191-203.

Barba, C., Eguinoa, A., \& Maté, J. I. (2015). Preparation and characterization of $\beta$-cyclodextrin inclusion complexes as a tool of a controlled antimicrobial release in whey protein edible films. LWT-Food Science and Technology, 64(2), 1362-1369.

Barham, P. J., \& Keller, A. (1986). The relationship between microstructure and mode of fracture in polyhydroxybutyrate. Journal of Polymer Science Part B: Polymer Physics, 24(1), 69-77. 


\section{Introduction}

Benavides, S., Villalobos-Carvajal, R., \& Reyes, J. E. (2012). Physical, mechanical and antibacterial properties of alginate film: effect of the crosslinking degree and oregano essential oil concentration. Journal of Food Engineering, 110(2), 232-239.

Berthet, M. A., Angellier-Coussy, H., Machado, D., Hilliou, L., Staebler, A., Vicente, A., \& Gontard, N. (2015). Exploring the potentialities of using lignocellulosic fibres derived from three food by-products as constituents of biocomposites for food packaging. Industrial Crops and Products, 69, 110-122.

Biddeci, G., Cavallaro, G., Di Blasi, F., Lazzara, G., Massaro, M., Milioto, S., \& Spinelli, G. (2016). Halloysite nanotubes loaded with peppermint essential oil as filler for functional biopolymer film. Carbohydrate Polymers, 152, 548-557.

Bohmert-Tatarev, K., McAvoy, S., Daughtry, S., Peoples, O. P., \& Snell, K. D. (2011). High levels of bioplastic are produced in fertile transplastomic tobacco plants engineered with a synthetic operon for production of polyhydroxybutyrate. Plant Physiology, pp-110.

Bonilla, J., Atarés, L., Vargas, M., \& Chiralt, A. (2012a). Effect of essential oils and homogenization conditions on properties of chitosan-based films. Food Hydrocolloids, 26, 9-16.

Bonilla, J., Atarés, L., Vargas, M., \& Chiralt, A. (2012b). Edible films and coatings to prevent the detrimental effect of oxygen on food quality: possibilities and limitations. Journal of Food Engineering, 110(2), 208-213.

Bonilla, J., Talón, E., Atarés, L., Vargas, M., \& Chiralt, A. (2013). Effect of the incorporation of antioxidants on physicochemical and antioxidant properties of wheat starch-chitosan films. Journal of Food Engineering, 118(3), 271-278.

Bonilla, J., Vargas, M., Atarés, L., \& Chiralt, A. (2014). Effect of chitosan essential oil films on the storage-keeping quality of pork meat products. Food Bioprocess Technology, 7(8), 2443-2450

Boubaker, H., Karim, H., El Hamdaoui, A., Msanda, F., Leach, D., Bombarda, I., \& Aoumar, A. A. B. (2016). Chemical characterization and antifungal activities of four Thymus species essential oils against postharvest fungal pathogens of citrus. Industrial Crops and Products, 86, 95-101.

Boufarguine, M., Guinault, A., Miquelard-Garnier, G., \& Sollogoub, C. (2013). PLA/PHBV films with improved mechanical and gas barrier properties. Macromolecular Materials and Engineering, 298(10), 1065-1073.

Boyandin, A. N., Prudnikova, S. V., Karpov, V. A., Ivonin, V. N., Đỗ, N. L., Nguyễn, T. H., HiệpLê, T. H., Filichev, N. L., Levin, A. L., Filipenko, M. L., Volova, T. G., \& Gitelson, I. I (2013). Microbial degradation of polyhydroxyalkanoates in tropical soils. International Biodeterioration \& Biodegradation, 83, 77-84.

Branciforti, M. C., Corrêa, M. C. S., Pollet, E., Agnelli, J. A. M., de Paula Nascente, P. A., \& Avérous, L. (2013). Crystallinity study of nano-biocomposites based on plasticized poly (hydroxybutyrate-cohydroxyvalerate) with organo-modified montmorillonite. Polymer Testing, 32(7), 1253-1260.

Bucci, D. Z., Tavares, L. B. B., \& Sell, I. (2005). PHB packaging for the storage of food products. Polymer Testing, 24(5), 564-571. 
Bugnicourt, E., Cinelli, P., Lazzeri, A., \& Alvarez, V. A. (2014). Polyhydroxyalkanoate (PHA): Review of synthesis, characteristics, processing and potential applications in packaging. Express Polymer Letters, 8(11), 791-808

Burt, S. (2004). Essential oils: their antibacterial properties and potential applications in foods-a review. International journal of food microbiology, 94(3), 223-253.

Cao, W., Wang, A., Jing, D., Gong, Y., Zhao, N., \& Zhang, X. (2005). Novel biodegradable films and scaffolds of chitosan blended with poly (3-hydroxybutyrate). Journal of Biomaterials Science, Polymer Edition, 16(11), 1379-1394.

Corre, Y.M., Bruzaud, S., Audic, J.L., \& Grohens, Y. (2012). Morphology and functional properties of commercial polyhydroxyalkanoates: a comprehensive and comparative study. Polymer Testing, 31, 226-235.

Carvalho, A. F. A., de Oliva Neto, P., Da Silva, D. F., \& Pastore, G. M. (2013). Xylo-oligosaccharides from lignocellulosic materials: chemical structure, health benefits and production by chemical and enzymatic hydrolysis. Food Research International, 51(1), 75-85.

Castro, D. O., Tabary, N., Martel, B., Gandini, A., Belgacem, N., \& Bras, J. (2016). Effect of different carboxylic acids in cyclodextrin functionalization of cellulose nanocrystals for prolonged release of carvacrol. Materials Science and Engineering: C, 69, 1018-102

Castro-Mayorga, J. L., Fabra, M. J., \& Lagaron, J. M. (2016). Stabilized nanosilver based antimicrobial poly (3-hydroxybutyrate-co-3-hydroxyvalerate) nanocomposites of interest in active food packaging. Innovative Food Science \& Emerging Technologies, 33, 524-533.

Castro-Mayorga, J. L., Fabra, M. J., Pourrahimi, A. M., Olsson, R. T., \& Lagaron, J. M. (2017). The impact of zinc oxide particle morphology as an antimicrobial and when incorporated in poly (3hydroxybutyrate-co-3-hydroxyvalerate) films for food packaging and food contact surfaces applications. Food and Bioproducts Processing, 101, 32-44.

Cerqueira, M. A., Fabra, M. J., Castro-Mayorga, J. L., Bourbon, A. I., Pastrana, L. M., Vicente, A. A., \& Lagaron, J. M. (2016). Use of electrospinning to develop antimicrobial biodegradable multilayer systems: Encapsulation of cinnamaldehyde and their physicochemical characterization. Food and Bioprocess Technology, 9(11), 1874-1884.

Chen, G. Q. (2009). A microbial polyhydroxyalkanoates (PHA) based bio-and materials industry. Chemical Society Reviews, 38(8), 2434-2446.

Chen, H., Hu, X., Chen, E., Wu, S., McClements, D. J., Liu, S., \& Li, Y. (2016). Preparation, characterization, and properties of chitosan films with cinnamaldehyde nanoemulsions. Food Hydrocolloids, 61, 662-671.

Chen, W., \& Tong, Y. W. (2012). PHBV microspheres as neural tissue engineering scaffold support neuronal cell growth and axon-dendrite polarization. Acta Biomaterialia, 8(2), 540-548. 


\section{Introduction}

Cherpinski, A., Torres-Giner, S., Vartiainen, J., Peresin, M. S., Lahtinen, P., \& Lagaron, J. M. (2018). Improving the water resistance of nanocellulose-based films with polyhydroxyalkanoates processed by the electrospinning coating technique. Cellulose, 25(2), 1291-1307

Choi, J. S., \& Park, W. H. (2004). Effect of biodegradable plasticizers on thermal and mechanical properties of poly (3-hydroxybutyrate). Polymer Testing, 23(4), 455-460.

Choi, W.S., Singh, S., \& Lee, Y.S. (2016). Characterization of edible film containing essential oils in hydroxypropyl methylcellulose and its effect on quality attributes of 'Formosa' plum (Prunus salicina L.). LWT - Food Science and Technology, 70, 213-222.

Chuah, J. A., Yamada, M., Taguchi, S., Sudesh, K., Doi, Y., \& Numata, K. (2013). Biosynthesis and characterization of polyhydroxyalkanoate containing 5-hydroxyvalerate units: effects of $5 \mathrm{HV}$ units on biodegradability, cytotoxicity, mechanical and thermal properties. Polymer Degradation and Dtability, 98(1), 331-338.

Clemente, I., Aznar, M., Silva, F., \& Nerín, C. (2016). Antimicrobial properties and mode of action of mustard and cinnamon essential oils and their combination against foodborne bacteria. Innovative Food Science \& Emerging Technologies, 36, 26-33.

Commission of the European Communities, Comission Directive 97/48/EC of 29 July amending Council Directive 82/711/EEC laying down the basic rules necessary for testing migration of the constituents of plastics materials and articles intended to come into contact with foodstuffs, Official Journal of the European Communities, 12 August 1997, no. L 222, p 10.

Conte, A., Scrocco, C., Sinigaglia, M., \& Del Nobile, M. A. (2007). Innovative active packaging systems to prolong the shelf life of mozzarella cheese. Journal of Dairy Science, 90(5), 2126-2131.

Correa, J. P., Molina, V., Sanchez, M., Kainz, C., Eisenberg, P., \& Massani, M. B. (2017). Improving ham shelf life with a polyhydroxybutyrate/polycaprolactone biodegradable film activated with nisin. Food Packaging and Shelf Life, 11, 31-39.

Cox, S. D., Mann, C. M., Markham, J. L., Gustafson, J. E., Warmington, J. R., \& Wyllie, S. G. (2001). Determining the antimicrobial actions of tea tree oil. Molecules, 6(2), 87-91.

Crank, J. T. (1975). The mathematics of diffusion. Oxford.

de Andrade, C. S., Fonseca, G. G., Mei, I., Helena, L., \& Fakhouri, F. M. (2017). Development and characterization of multilayer films based on polyhydroxyalkanoates and hydrocolloids. Journal of Applied Polymer Science, 134(6).

de Jesus, I. C., Frazão, G. G. S., Blank, A. F., \& de Aquino Santana, L. C. L. (2016). Myrcia ovata Cambessedes essential oils: A proposal for a novel natural antimicrobial against foodborne bacteria. Microbial Pathogenesis, 99, 142-147.

de O Patrício, P.S., Pereira, F. V., dos Santos, M. C., de Souza, P. P., Roa, J. P., \& Orefice, R. L. (2013). Increasing the elongation at break of polyhydroxybutyrate biopolymer: Effect of cellulose nanowhiskers on mechanical and thermal properties. Journal of Applied Polymer Science, 127(5), 36133621 
de Souza, E. L. (2016). The effects of sublethal doses of essential oils and their constituents on antimicrobial susceptibility and antibiotic resistance among food-related bacteria: A review. Trends in Food Science \& Technology, 56, 1-12.

Defoirdt, T., Sorgeloos, P., \& Bossier, P. (2011). Alternatives to antibiotics for the control of bacterial disease in aquaculture. Current Opinion in Microbiology, 14(3), 251-258.

Del Nobile, M. A., Conte, A., Incoronato, A. L., Panza, O. (2008). Antimicrobial efficacy and release kinetics of thymol from zein films. Journal of Food Engineering, 89(1), 57-63.

Del Nobile, M.A., Conte, A., Buonocore, G.G., Incoronato, A.L., Massaro, A., Panza, O. (2009). Active packaging extrusion processing of recyclable and biodegradable polymers. Journal of Food Engineering, 93, 1-6.

Delgado, G. T. C., Tamashiro, W. M. D. S. C., Junior, M. R. M., Moreno, Y. M. F., \& Pastore, G. M. (2011). The putative effects of prebiotics as immunomodulatory agents. Food Research International, 44(10), 3167-3173.

Dhar, P., Bhardwaj, U., Kumar, A., \& Katiyar, V. (2015). Poly (3-hydroxybutyrate)/cellulose nanocrystal films for food packaging applications: Barrier and migration studies. Polymer Engineering \& Science, 55(10), 2388-2395.

Dhara, L., \& Tripathi, A. (2013). Antimicrobial activity of eugenol and cinnamaldehyde against extended spectrum beta lactamase producing enterobacteriaceae by in vitro and molecular docking analysis. European Journal of Integrative Medicine, 5(6), 527-536.

Díez-Pascual, A. M. (2017). Biodegradable food packaging nanocomposites based on ZnO-reinforced polyhydroxyalkanoates. Food Packaging, 185-221.

Díez-Pascual, A. M., \& Díez-Vicente, A. L. (2014). Poly (3-hydroxybutyrate)/ZnO bionanocomposites with improved mechanical, barrier and antibacterial properties. International Journal of Molecular Sciences, 15(6), 10950-10973.

Ebringerová, A., Hromádková, Z., Koštálová, Z., \& Sasinková, V. (2007). Chemical valorization of agricultural by-products: isolation and characterization of xylan-based antioxidants from almond shell biomass. BioResources, 3(1), 60-70.

Ebringerová, A., Hromádková, Z., Hř́ibalová, V., Xu, C., Holmbom, B., Sundberg, A., \& Willför, S. (2008). Norway spruce galactoglucomannans exhibiting immunomodulating and radical-scavenging activities. International Journal of Biological Macromolecules, 42(1), 1-5.

Egüés, I., Stepan, A. M., Eceiza, A., Toriz, G., Gatenholm, P., \& Labidi, J. (2014). Corncob arabinoxylan for new materials. Carbohydrate Polymers, 102, 12-20.

Emiroğlu, Z. K., Yemiş, G. P., Coşkun, B. K., \& Candoğan, K. (2010). Antimicrobial activity of soy edible films incorporated with thyme and oregano essential oils on fresh ground beef patties. Meat Science, 86(2), 283-288. 


\section{Introduction}

Engels, C., Schieber, A., \& Gänzle, M. G. (2011). Studies on the inhibitory spectrum and mode of antimicrobial action of gallotannins from mango kernels (Mangifera indica L.). Applied and Environmental Microbiology.

Erkske, D., Viskere, I., Dzene, A., Tupureina, V., \& Savenkova, L. (2006). Biobased polymer compsites for films and coatings. Proceedings of the Estonian Academy of Sciences Chemistry, Vol. 55 (2), 70-77.

Esquenazi, D., Wigg, M. D., Miranda, M. M., Rodrigues, H. M., Tostes, J. B., Rozental, S., da Silva, A. J. R., \& Alviano, C. S. (2002). Antimicrobial and antiviral activities of polyphenolics from Cocos nucifera Linn. (Palmae) husk fiber extract. Research in microbiology, 153(10), 647-652.

Etxabide, A., Uranga, J., Guerrero, P., \& de la Caba, K. (2016). Development of active gelatin films by means of valorization of food processing waste: A review. Food Hydrocolloids, 1-7.

European Bioplastics (2017). Report - Bioplastics market data 2017.

Fabra, M. J., Lopez-Rubio, A., \& Lagaron, J. M. (2013). High barrier polyhydroxyalcanoate food packaging film by means of nanostructured electrospun interlayers of zein. Food Hydrocolloids, 32(1), 106-114.

Fabra, M. J., Lopez-Rubio, A., \& Lagaron, J. M. (2014). Nanostructured interlayers of zein to improve the barrier properties of high barrier polyhydroxyalkanoates and other polyesters. Journal of Food Engineering, 127, 1-9.

Fabra, M. J., López-Rubio, A., \& Lagaron, J. M. (2015). Three-layer films based on wheat gluten and electrospun PHA. Food and Bioprocess Technology, 8(11), 2330-2340.

Fabra, M. J., Castro-Mayorga, J. L., Randazzo, W., Lagarón, J. M., López-Rubio, A., Aznar, R., \& Sánchez, G. (2016a). Efficacy of cinnamaldehyde against enteric viruses and its activity after incorporation into biodegradable multilayer systems of interest in food packaging. Food and Environmental Virology, 8(2), 125-132.

Fabra, M. J., López-Rubio, A., Ambrosio-Martín, J., \& Lagaron, J. M. (2016b). Improving the barrier properties of thermoplastic corn starch-based films containing bacterial cellulose nanowhiskers by means of PHA electrospun coatings of interest in food packaging. Food Hydrocolloids, 61, 261-268.

Fan, X., Jiang, Q., Sun, Z., Li, G., Ren, X., Liang, J., \& Huang, T. S. (2015). Preparation and characterization of electrospun antimicrobial fibrous membranes based on polyhydroxybutyrate (PHB). Fibers and Polymers, 16(8), 1751-1758.

Fattouch, S., Caboni, P., Coroneo, V., Tuberoso, C., Angioni, A., Dessi, S., Marzouki, N., \& Cabras, P. (2008). Comparative analysis of polyphenolic profiles and antioxidant and antimicrobial activities of tunisian pome fruit pulp and peel aqueous acetone extracts. Journal of Agricultural and Food Chemistry, 56(3), 1084-1090.

Fernández-Pan, I., Carrión-Granda, X., \& Maté, J. I. (2014). Antimicrobial efficiency of edible coatings on the preservation of chicken breast fillets. Food Control, 36 (1), 69-75. 
Fernández-Pan, I., Maté, J. I., Gardrat, C., Coma, V. (2015). Effect of chitosan molecular weight on the antimicrobial activity and release rate of carvacrol-enriched films. Food Hydrocolloids, 51, 60-68.

Ferreira, B. M. P., Zavaglia, C. A. C., \& Duek, E. A. R. (2001). Films of poly (L-lactic acid)/poly (hydroxybutyrate-co-hydroxyvalerate) blends: in vitro degradation. Materials Research, 4(1), 34-42.

Firouzi, R., Shekarforoush, S. S., Nazer, A. H. K., Borumand, Z., Jooyandeh, A. R. (2007). Effects of essential oils of oregano and nutmeg on growth and survival of Yersinia enterocolitica and Listeria monocytogenes in barbecued chicken. Journal of Food Protection, 70(11), 2626-2630.

Food Packaging Forum - Food Packaging Health, Food Packaging Materials.

Galus, S., Kadzińska, J. (2016). Whey protein edible films modified with almond and walnut oils. Food Hydrocolloids, 52, 78-86.

Gao, X., Chen, J. C., Wu, Q., \& Chen, G. Q. (2011). Polyhydroxyalkanoates as a source of chemicals, polymers, and biofuels. Current Opinion in Biotechnology, 22(6), 768-774.

Garau, M. C., Simal, S., Rossello, C., \& Femenia, A. (2007). Effect of air-drying temperature on physicochemical properties of dietary fibre and antioxidant capacity of orange (Citrus aurantium v. Canoneta) by-products. Food Chemistry, 104(3), 1014-1024.

Genskowsky, E., Puente, L. A., Pérez-Álvarez, J. A., Fernandez-Lopez, J., Muñoz, L. A., \& Viuda-Martos, M. (2015). Assessment of antibacterial and antioxidant properties of chitosan edible films incorporated with maqui berry (Aristotelia chilensis). LWT-Food Science and Technology, 64(2), 1057-1062.

Geueke, B. Dossier-Bioplastics as Food Contact Materials. Food Packaging Forum, 2014.

Gill, A. O., Delaquis, P., Russo, P., \& Holley, R. A. (2002). Evaluation of antilisterial action of cilantro oil on vacuum packed ham. International journal of food microbiology, 73(1), 83-92.

Godbole, S., Gote, S., Latkar, M., \& Chakrabarti, T. (2003). Preparation and characterization of biodegradable poly-3-hydroxybutyrate-starch blend films. Bioresource Technology, 86(1), 33-37.

Gómez-Estaca, J., Montero, P., Giménez, B., \& Gómez-Guillén, M. C. (2007). Effect of functional edible films and high pressure processing on microbial and oxidative spoilage in cold-smoked sardine (Sardina pilchardus). Food Chemistry, 105(2), 511-520.

Gómez-Estaca, J., de Lacey, A. L., López-Caballero, M. E., Gómez-Guillén, M. C., \& Montero, P. (2010). Biodegradable gelatin-chitosan films incorporated with essential oils as antimicrobial agents for fish preservation. Food Microbiology, 27(7), 889-896.

Gregorova, A., Wimmer, R., Hrabalova, M., Koller, M., Ters, T., \& Mundigler, N. (2009). Effect of surface modification of beech wood flour on mechanical and thermal properties of poly (3hydroxybutyrate)/wood flour composites. Holzforschung, 63(5), 565-570.

Grillo, R., Santo Pereira, A. D. E., de Melo, N. F. S., Porto, R. M., Feitosa, L. O., Tonello, P. S., Filho, N. L., Rosa, A. H., Lima, R., \& Fraceto, L. F. (2011). Controlled release system for ametryn using polymer microspheres: preparation, characterization and release kinetics in water. Journal of Hazardous Materials, 186(2-3), 1645-1651. 
Guerreiro, A. C., Gago, C. M., Miguel, M. G., Faleiro, M. L., \& Antunes, M. D. (2016). The influence of edible coatings enriched with citral and eugenol on the raspberry storage ability, nutritional and sensory quality. Food Packaging and Shelf Life, 9, 20-28.

Guil-Guerrero, J. L., Ramos, L., Moreno, C., Zúñiga-Paredes, J. C., Carlosama-Yepez, M., \& Ruales, P. (2016). Antimicrobial activity of plant-food by-products: A review focusing on the tropics. Livestock Science, 189, 32-49.

Gullón, P., Moura, P., Esteves, M. P., Girio, F. M., Domínguez, H., \& Parajó, J. C. (2008). Assessment on the fermentability of xylooligosaccharides from rice husks by probiotic bacteria. Journal of Agricultural and Food Chemistry, 56(16), 7482-7487.

Gumel, A. M., Annuar, M. S. M., \& Chisti, Y. (2013). Recent advances in the production, recovery and applications of polyhydroxyalkanoates. Journal of Polymers and the Environment, 21(2), 580-605.

Gustafson, J. E., Liew, Y. C., Chew, S., Markham, J., Bell, H. C., Wyllie, S. G., \& Warmington, J. R. (1998). Effects of tea tree oil on Escherichia coli. Letters in applied microbiology, 26(3), 194-198.

Gutierrez, J., Barry-Ryan, C., \& Bourke, P. (2009). Antimicrobial activity of plant essential oils using food model media: efficacy, synergistic potential and interactions with food components. Food microbiology, 26(2), 142-150.

Hafsa, J., ali Smach, M., Khedher, M. R. B., Charfeddine, B., Limem, K., Majdoub, H., \& Rouatbi, S. (2016). Physical, antioxidant and antimicrobial properties of chitosan films containing Eucalyptus globulus essential oil. LWT-Food Science and Technology, 68, 356-364.

Haugaard, V. K., Danielsen, B., \& Bertelsen, G. (2003). Impact of polylactate and poly (hydroxybutyrate) on food quality. European Food Research and Technology, 216(3), 233-240.

Hazer, B., \& Steinbüchel, A. (2007). Increased diversification of polyhydroxyalkanoates by modification reactions for industrial and medical applications. Applied Microbiology and Biotechnology, 74(1), 1-12.

Hema, R., Ng, P. N., \& Amirul, A. A. (2013). Green nanobiocomposite: reinforcement effect of montmorillonite clays on physical and biological advancement of various polyhydroxyalkanoates. Polymer Bulletin, 70(3), 755-771.

Hempel, F., Bozarth, A. S., Lindenkamp, N., Klingl, A., Zauner, S., Linne, U., \& Maier, U. G. (2011). Microalgae as bioreactors for bioplastic production. Microbial Cell Factories, 10(1), 81.

Higueras, L., López-Carballo, G., Cerisuelo, J. P., Gavara, R., \& Hernández-Muñoz, P. (2013). Preparation and characterization of chitosan/HP- $\beta$-cyclodextrins composites with high sorption capacity for carvacrol. Carbohydrate polymers, 97(2), 262-268.

Higueras, L., López-Carballo, G., Hernández-Muñoz, P., Catalá, R., \& Gavara, R. (2014). Antimicrobial packaging of chicken fillets based on the release of carvacrol from chitosan/cyclodextrin films. International journal of food microbiology, 188, 53-59.

Holmes, P. A. (1988). Biologically produced (R)-3-hydroxy-alkanoate polymers and copolymers. Developments in crystalline polymers, 1-35. Springer, Dordrecht. 
Hosseini, S. F., Rezaei, M., Zandi, M., \& Farahmandghavi, F. (2015). Bio-based composite edible films containing Origanum vulgare L. essential oil. Industrial Crops and Products, 67, 403-413.

Hromádková, Z., Ebringerová, A., \& Malovíková, A. (2005). The Structural, Molecular and Functional Properties of Lignin-Containing Beechwood Glucuronoxylan. Macromolecular Symposia, Vol. 232 (1), 19-26). WILEY-VCH Verlag.

Hromádková, Z., Košt'álová, Z., \& Ebringerová, A. (2008). Comparison of conventional and ultrasoundassisted extraction of phenolics-rich heteroxylans from wheat bran. Ultrasonics Sonochemistry, 15(6), 1062-1068.

Hromádková, Z., Hirsch, J., \& Ebringerová, A. (2010). Chemical evaluation of fallopia species leaves and antioxidant properties of their non-cellulosic polysaccharides. Chemical Papers, 64(5), 663-672.

Huneault, M. A., \& Li, H. (2007). Morphology and properties of compatibilized polylactide/thermoplastic starch blends. Polymer, 48(1), 270-280.

Hyldgaard, M., Mygind, T., \& Meyer, R. L. (2014). Essential oils in food preservation: mode of action, synergies, and interactions with food matrix components. Antimicrobial compounds from natural sources, Frontiers Research topics, 36-59.

Jacquel, N., Lo, C. W., Wei, Y. H., Wu, H. S., \& Wang, S. S. (2008). Isolation and purification of bacterial poly (3-hydroxyalkanoates). Biochemical Engineering Journal, 39(1), 15-27.

Javidi, Z., Hosseini, S. F., \& Rezaei, M. (2016). Development of flexible bactericidal films based on poly (lactic acid) and essential oil and its effectiveness to reduce microbial growth of refrigerated rainbow trout. LWT-Food Science and Technology, 72, 251-260.

Jiménez, A., Fabra, M. J., Talens, P., \& Chiralt, A. (2012). Edible and biodegradable starch films: a review. Food and Bioprocess Technology, 5(6), 2058-2076.

Jiménez, A., Sánchez-González, L., Desobry, S., Chiralt, A., Tehrany, E.A. (2014). Influence of nanoliposomes incorporation on properties of film forming dispersions and films based on corn starch and sodium caseinate, Food Hydrocolloids, 35, 159-169.

Joo, M. J., Merkel, C., Auras, R., \& Almenar, E. (2012). Development and characterization of antimicrobial poly (I-lactic acid) containing trans-2-hexenal trapped in cyclodextrins. International Journal of Food Microbiology, 153(3), 297-305.

Jost, V., \& Kopitzky, R. (2015). Blending of polyhydroxybutyrate-co-valerate with polylactic acid for packaging applications-reflections on miscibility and effects on the mechanical and barrier properties. Chemical and Biochemical Engineering Quarterly, 29(2), 221-246.

Jost, V., \& Langowski, H. C. (2015). Effect of different plasticisers on the mechanical and barrier properties of extruded cast PHBV films. European Polymer Journal, 68, 302-312.

Jouki, M., Yazdi, F. T., Mortazavi, S. A., \& Koocheki, A. (2014). Quince seed mucilage films incorporated with oregano essential oil: Physical, thermal, barrier, antioxidant and antibacterial properties. Food Hydrocolloids, 36, 9-19. 
Jun, D., Guomin, Z., Mingzhu, P., Leilei, Z., Dagang, L., \& Rui, Z. (2017). Crystallization and mechanical properties of reinforced PHBV composites using melt compounding: Effect of CNCs and CNFs. Carbohydrate Polymers, 168, 255-262.

Kabuki, T., Nakajima, H., Arai, M., Ueda, S., Kuwabara, Y., \& Dosako, S. I. (2000). Characterization of novel antimicrobial compounds from mango (Mangifera indica L.) kernel seeds. Food Chemistry, 71(1), 61-66.

Kakaei, S., \& Shahbazi, Y. (2016). Effect of chitosan-gelatin film incorporated with ethanolic red grape seed extract and Ziziphora clinopodioides essential oil on survival of Listeria monocytogenes and chemical, microbial and sensory properties of minced trout fillet. LWT-Food Science and Technology, 72, 432-438.

Kammerer, D. R., Kammerer, J., Valet, R., \& Carle, R. (2014). Recovery of polyphenols from the byproducts of plant food processing and application as valuable food ingredients. Food Research International, 65, 2-12.

Kanatt, S. R., Chander, R., \& Sharma, A. (2010). Antioxidant and antimicrobial activity of pomegranate peel extract improves the shelf life of chicken products. International journal of food science \& technology, 45(2), 216-222.

Kantola, M., \& Helén, H. (2001). Quality changes in organic tomatoes packaged in biodegradable plastic films. Journal of Food Quality, 24(2), 167-176.

Kauffman, T., F. X. Brady, P. P. Puletti, and G. Raykovitz. December 1992. U.S. patent 5,169,889.

Kazemi, S. M., \& Rezaei, M. (2015). Antimicrobial effectiveness of gelatin-alginate film containing oregano essential oil for fish preservation. Journal of Food Safety, 35(4), 482-490.

Keshavarz, T., \& Roy, I. (2010). Polyhydroxyalkanoates: bioplastics with a green agenda. Current Opinion in Microbiology, 13(3), 321-326.

Khammuang, S., \& Sarnthima, R. (2011). Antioxidant and antibacterial activities of selected varieties of thai mango seed extract. Pakistan Journal of Pharmaceutical Sciences, 24(1), 37-42.

Khanna, S., \& Srivastava, A. K. (2005). Recent advances in microbial polyhydroxyalkanoates. Process Biochemistry, 40(2), 607-619.

Khare, A. K., Biswas, A. K., \& Sahoo, J. (2014). Comparison study of chitosan, EDTA, eugenol and peppermint oil for antioxidant and antimicrobial potentials in chicken noodles and their effect on colour and oxidative stability at ambient temperature storage. LWT-Food Science and Technology, 55(1), 286-293.

Kılıçay, E., Demirbilek, M., Türk, M., Güven, E., Hazer, B., \& Denkbas, E. B. (2011). Preparation and characterization of poly (3-hydroxybutyrate-co-3-hydroxyhexanoate)(PHBHHX) based nanoparticles for targeted cancer therapy. European Journal of Pharmaceutical Sciences, 44(3), 310-320.

Kim, S. A., \& Rhee, M. S. (2016). Highly enhanced bactericidal effects of medium chain fatty acids (caprylic, capric, and lauric acid) combined with edible plant essential oils (carvacrol, eugenol, $\beta$ - 
resorcylic acid, trans-cinnamaldehyde, thymol, and vanillin) against Escherichia coli O157: H7. Food Control, 60, 447-454.

Klangmuang, P., \& Sothornvit, R. (2016). Barrier properties, mechanical properties and antimicrobial activity of hydroxypropyl methylcellulose-based nanocomposite films incorporated with Thai essential oils. Food Hydrocolloids, 61, 609-616.

Koller, M., Niebelschütz, H., \& Braunegg, G. (2013a). Strategies for recovery and purification of poly [(R)-3-hydroxyalkanoates] (PHA) biopolyesters from surrounding biomass. Engineering in Life Sciences, 13(6), 549-562.

Koller, M., Sandholzer, D., Salerno, A., Braunegg, G., \& Narodoslawsky, M. (2013b). Biopolymer from industrial residues: Life cycle assessment of poly (hydroxyalkanoates) from whey. Resources, Conservation and Recycling, 73, 64-71.

Kunasundari, B., \& Sudesh, K. (2011). Isolation and recovery of microbial polyhydroxyalkanoates. Express Polymer Letters, 5(7).

Lambert, R. J. W., Skandamis, P. N., Coote, P. J., \& Nychas, G. J. (2001). A study of the minimum inhibitory concentration and mode of action of oregano essential oil, thymol and carvacrol. Journal of Applied Microbiology, 91(3), 453-462.

Laycock, B., Halley, P., Pratt, S., Werker, A., \& Lant, P. (2013). The chemomechanical properties of microbial polyhydroxyalkanoates. Progress in Polymer Science, 38(3-4), 536-583.

Lee, S. Y. (1996). Bacterial polyhydroxyalkanoates. Biotechnology and Bioengineering, 49(1), 1-14.

Levkane, V., Muizniece-Brasava, S., \& Dukalska, L. (2008). Pasteurization effect to quality of salad with meat in mayonnaise. Foodbalt, 6.

Louli, V., Ragoussis, N., \& Magoulas, K. (2004). Recovery of phenolic antioxidants from wine industry by-products. Bioresource Technology, 92(2), 201-208.

Ma, Q., Davidson, P. M., \& Zhong, Q. (2016). Antimicrobial properties of microemulsions formulated with essential oils, soybean oil, and Tween 80. International journal of food microbiology, 226, 20-25.

Ma, X., Wang, Y., Wang, J., \& Xu, Y. (2017). Effect of PBAT on property of PLA/PHB film used for fruits and vegetables. MATEC Web of Conferences, 88, 02009. EDP Sciences.

Madbouly, S. A., Schrader, J. A., Srinivasan, G., Liu, K., McCabe, K. G., Grewell, D., \& Kessler, M. R. (2014). Biodegradation behavior of bacterial-based polyhydroxyalkanoate (PHA) and DDGS composites. Green Chemistry, 16(4), 1911-1920.

Madison, L. L., \& Huisman, G. W. (1999). Metabolic engineering of poly (3-hydroxyalkanoates): from DNA to plastic. Microbiology and Molecular Biology Reviews, 63(1), 21-53.

Mäkeläinen, H., Forssten, S., Saarinen, M., Stowell, J., Rautonen, N., \& Ouwehand, A. (2009). Xylooligosaccharides enhance the growth of bifidobacteria and Bifidobacterium lactis in a simulated colon model. Beneficial Microbes, 1(1), 81-91. 


\section{Introduction}

Makwana, S., Choudhary, R., Dogra, N., Kohli, P., \& Haddock, J. (2014). Nanoencapsulation and immobilization of cinnamaldehyde for developing antimicrobial food packaging material. LWT-Food Science and Technology, 57(2), 470-476.

Malathy, A.N., Santhosh, K.S., Nidoni, U., 2014. Recent trends of biodegradable polymer: biodegradable films for food packaging and application of nanotechnology in biodegradable food packaging. Current Trends in Technology and Sciences, 3, 73-79

Mandalari, G., Bennett, R. N., Bisignano, G., Trombetta, D., Saija, A., Faulds, C. B., Gasson, M. J., \& Narbad, A. (2007). Antimicrobial activity of flavonoids extracted from bergamot (Citrus bergamia Risso) peel, a byproduct of the essential oil industry. Journal of Applied Microbiology, 103(6), 2056-2064.

Marchessault, R. H., P. F. LePoutre, and P. E. Wrist. September 1995. U.S. patent 5451456

Martínez-Abad, A., Sánchez, G., Fuster, V., Lagaron, J. M., \& Ocio, M. J. (2013). Antibacterial performance of solvent cast polycaprolactone (PCL) films containing essential oils. Food Control, 34(1), 214-220.

Martino, L., Berthet, M. A., Angellier-Coussy, H., \& Gontard, N. (2015). Understanding external plasticization of melt extruded PHBV-wheat straw fibers biodegradable composites for food packaging. Journal of Applied Polymer Science, 132(10).

Martucci, J. F., Gende, L. B., Neira, L. M., \& Ruseckaite, R. A. (2015). Oregano and lavender essential oils as antioxidant and antimicrobial additives of biogenic gelatin films. Industrial Crops and Products, 71, 205-213.

Matiacevich, S. B. Edible antimicrobial films based on microencapsulated lemongrass oil. (2016). Journal of Food Science and Technology, 53(1), 832-839.

Melo-Silveira, R. F., Fidelis, G. P., Costa, M. S. S. P., Telles, C. B. S., Dantas-Santos, N., Elias, S. D. O., \& Rocha, H. A. O. (2011). In vitro antioxidant, anticoagulant and antimicrobial activity and in inhibition of cancer cell proliferation by xylan extracted from corn cobs. International Journal of Molecular Sciences, 13(1), 409-426.

Miladi, H., Mili, D., Slama, R. B., Zouari, S., Ammar, E., \& Bakhrouf, A. (2016a). Antibiofilm formation and anti-adhesive property of three mediterranean essential oils against a foodborne pathogen Salmonella strain. Microbial Pathogenesis, 93, 22-31.

Miladi, H., Zmantar, T., Chaabouni, Y., Fedhila, K., Bakhrouf, A., Mahdouani, K., \& Chaieb, K. (2016b). Antibacterial and efflux pump inhibitors of thymol and carvacrol against food-borne pathogens. Microbial Pathogenesis, 99, 95-100.

Modi, S., Koelling, K., \& Vodovotz, Y. (2011). Assessment of PHB with varying hydroxyvalerate content for potential packaging applications. European Polymer Journal, 47(2), 179-186.

Moradi, M., Tajik, H., Razavi Rohani, S. M., \& Oromiehie, A. R. (2011). Effectiveness of Zataria multiflora Boiss essential oil and grape seed extract impregnated chitosan film on ready-to-eat mortadella-type sausages during refrigerated storage. Journal of the Science of Food and Agriculture, 91(15), 28502857. 
Muhammadi, Shabina, Afzal, M., \& Hameed, S. (2015). Bacterial polyhydroxyalkanoates-eco-friendly next generation plastic: production, biocompatibility, biodegradation, physical properties and applications. Green Chemistry Letters and Reviews, 8(3-4), 56-77.

Muizniece-Brasava, S., \& Dukalska, L. (2006). Impact of biodegradable PHB packaging composite materials on dairy product quality. Proceedings of the Latvia University of Agriculture, 16, 2006, pp. 79-87.

Muller, J., González-Martínez, C., \& Chiralt, A. (2017a). Combination of poly (lactic) acid and starch for biodegradable food packaging. Materials, 10(8), 952.

Muller, J., González-Martínez, C., \& Chiralt, A. (2017b). Poly (lactic) acid (PLA) and starch bilayer films, containing cinnamaldehyde, obtained by compression moulding. European Polymer Journal, 95, 56-70.

Muthuswamy, S., Rupasinghe, H. P. V., \& Stratton, G. W. (2008). Antimicrobial effect of cinnamon bark extract on Escherichia coli 0157: h7, Listeria innocua and fresh-cut apple slices. Journal of Food Safety, 28(4), 534-549.

Nabarlatz, D., Ebringerová, A., \& Montané, D. (2007). Autohydrolysis of agricultural by-products for the production of xylo-oligosaccharides. Carbohydrate Polymers, 69(1), 20-28.

Naffakh, M., Díez-Pascual, A. M., Marco, C., Ellis, G. J., \& Gómez-Fatou, M. A. (2013). Opportunities and challenges in the use of inorganic fullerene-like nanoparticles to produce advanced polymer nanocomposites. Progress in Polymer Science, 38(8), 1163-1231.

Narayanan, A., \& Ramana, K. V. (2013). Synergized antimicrobial activity of eugenol incorporated polyhydroxybutyrate films against food spoilage microorganisms in conjunction with pediocin. Applied Biochemistry and Biotechnology, 170(6), 1379-1388.

Negi, P. S., Jayaprakasha, G. K., Jagan Mohan Rao, L., \& Sakariah, K. K. (1999). Antibacterial activity of turmeric oil: a byproduct from curcumin manufacture. Journal of Agricultural and Food Chemistry, 47(10), 4297-4300.

Neto, N. J. G., Magnani, M., Chueca, B., García-Gonzalo, D., Pagán, R., \& de Souza, E. L. (2015). Influence of general stress-response alternative sigma factors $\sigma \mathrm{S}$ (RpoS) and $\sigma \mathrm{B}$ (SigB) on bacterial tolerance to the essential oils from Origanum vulgare L. and Rosmarinus officinalis L. and pulsed electric fields. International Journal of Food Microbiology, 211, 32-37.

Neufeld, L., Stassen, F., Sheppard, R., \& Gilman, T. (2016). The new plastics economy: rethinking the future of plastics. World Economic Forum.

Nikolić, M., Jovanović, K. K., Marković, T., Marković, D., Gligorijević, N., Radulović, S., \& Soković, M. (2014). Chemical composition, antimicrobial, and cytotoxic properties of five Lamiaceae essential oils. Industrial Crops and Products, 61, 225-232.

O'Shea, N., Arendt, E. K., \& Gallagher, E. (2012). Dietary fibre and phytochemical characteristics of fruit and vegetable by-products and their recent applications as novel ingredients in food products. Innovative Food Science \& Emerging Technologies, 16, 1-10. 


\section{Introduction}

Ojagh, S. M., Rezaei, M., Razavi, S. H., \& Hosseini, S. M. H. (2010). Development and evaluation of a novel biodegradable film made from chitosan and cinnamon essential oil with low affinity toward water. Food Chemistry, 122(1), 161-166.

Orozco, V. H., Brostow, W., Chonkaew, W., \& Lopez, B. L. (2009). Preparation and characterization of poly (Lactic acid)-g-maleic anhydride+ starch blends. Macromolecular symposia, Vol. 277 (1), 69-80. WILEY-VCH Verlag.

Orts, W. J., Marchessault, R. H., Bluhm, T. L., \& Hamer, G. K. (1990). Observation of strain-induced $\beta$ form in poly ( $\beta$-hydroxyalkanoates). Macromolecules, 23(26), 5368-5370.

Otoni, C. G., Avena-Bustillos, R. J., Olsen, C. W., Bilbao-Sainz, C., \& McHugh, T. H. (2016) Mechanical and water barrier properties of isolated soy protein composite edible films as affected by carvacrol and cinnamaldehyde micro and nanoemulsions. Food Hydrocolloids, 57, 72-79.

Ouedrhiri, W., Balouiri, M., Bouhdid, S., Moja, S., Chahdi, F. O., Taleb, M., \& Greche, H. (2016). Mixture design of Origanum compactum, Origanum majorana and Thymus serpyllum essential oils: Optimization of their antibacterial effect. Industrial Crops and Products, 89, 1-9.

Oussalah, M., Caillet, S., Salmiéri, S., Saucier, L., \& Lacroix, M. (2004). Antimicrobial and antioxidant effects of milk protein-based film containing essential oils for the preservation of whole beef muscle. Journal of Agricultural and Food Chemistry, 52(18), 5598-5605.

Özvural, E. B., Huang, Q., \& Chikindas, M. L. (2016). The comparison of quality and microbiological characteristic of hamburger patties enriched with green tea extract using three techniques: Direct addition, edible coating and encapsulation. LWT-Food Sci. Technol., 68, 385-390.

Pandit, V. A., \& Shelef, L. A. (1994). Sensitivity of Listeria monocytogenes to rosemary (Rosmarinus officinalis L.). Food Microbiology, 11 (1), 57-63.

Pardo-Ibáñez, P., Lopez-Rubio, A., Martínez-Sanz, M., Cabedo, L., \& Lagaron, J. M. (2014). Keratinpolyhydroxyalkanoate melt-compounded composites with improved barrier properties of interest in food packaging applications. Journal of Applied Polymer Science, 131(4).

Parulekar, Y., \& Mohanty, A. K. (2007). Extruded biodegradable cast films from polyhydroxyalkanoate and thermoplastic starch blends: fabrication and characterization. Macromolecular Materials and Engineering, 292(12), 1218-1228.

Peelman, N., Ragaert, P., De Meulenaer, B., Adons, D., Peeters, R., Cardon, L., \& Devlieghere, F. (2013). Application of bioplastics for food packaging. Trends in Food Science \& Technology, 32(2), 128-141.

Perdones, A., Sánchez-González, L., Chiralt, A., \& Vargas, M. (2012). Effect of chitosan-lemon essential oil coatings on storage-keeping quality of strawberry. Postharvest Biology and Technology, 70, 32-41.

Perdones, A., Vargas, M., Atarés, L., \& Chiralt, A. (2014). Physical, antioxidant and antimicrobial properties of chitosan-cinnamon leaf oil films as affected by oleic acid. Food Hydrocolloids, 36, 25664. 
Perdones, A., Chiralt, A., \& Vargas, M. (2016). Properties of film-forming dispersions and films based on chitosan containing basil or thyme essential oil. Food Hydrocolloids, 57, 271-279

Perez-Gago, M. B., \& Krochta, J. M. (2001). Lipid particle size effect on water vapor permeability and mechanical properties of whey protein-beeswax emulsion films. Journal of Agricultural and Food Chemistry, 49(2), 996-1002.

Petchwattana, N., \& Naknaen, P. (2015). Utilization of thymol as an antimicrobial agent for biodegradable poly (butylene succinate). Materials Chemistry and Physics, 163, 369-375.

Petersen, K., Nielsen, P. V., Bertelsen, G., Lawther, M., Olsen, M. B., Nilsson, N. H., \& Mortensen, G. (1999). Potential of biobased materials for food packaging. Trends in Food Science \& Technology, 10(2), 52-68.

Phetwarotai, W., Potiyaraj, P., \& Aht-Ong, D. (2012). Characteristics of biodegradable polylactide/gelatinized starch films: Effects of starch, plasticizer, and compatibilizer. Journal of Applied Polymer Science, 126(S1).

Picone, G., Laghi, L., Gardini, F., Lanciotti, R., Siroli, \& L.Capozzi, F. (2013). Evaluation of the effect of carvacrol on the Escherichia coli 555 metabolome by using HNMR spectroscopy. Food Chemistry, 41, 4367-4374.

Piergiovanni, L., \& Limbo, S. (2016). Food packaging materials. Springer.

Pimentel, T., Pizzuti, L., Fakhouri, F. M., Mei, L. H. I., \& Fonseca, G. G. (2018). Development of Multilayer Films Obtained From Epoxidized Methyl Esters, Polyhydroxyalkanoates and Their Combinations. Journal of Polymers and the Environment, 26(4), 1661-1672.

Pires, C., Ramos, C., Teixeira, B., Batista, I., Nunes, M. L., \& Marques, A. (2013). Hake proteins edible films incorporated with essential oils: physical, mechanical, antioxidant and antibacterial properties. Food Hydrocolloids, 30(1), 224-231.

Pivsa-Art, W., Pavasupree, S., Narongchai, O., Insuan, U., Jailak, P., \& Pivsa-Art, S. (2011). Preparation of Polymer Blends between Poly (L-lactic acid), Poly (butylene succinate-co-adipate) and Poly (butylene adipate-co-terephthalate) for Blow Film Industrial Application. Energy Procedia, 9, 581-588.

PlasticsEurope (2017). Plastics - The Facts 2017

Porter, M. M., Lee, S., Tanadchangsaeng, N., Jaremko, M. J., Yu, J., Meyers, M., \& McKittrick, J. (2013). Porous hydroxyapatite-polyhydroxybutyrate composites fabricated by a novel method via centrifugation. Mechanics of Biological Systems and Materials, Vol. 5, 63-71. Springer, New York, NY.

Pristov, J. B., Mitrović, A., \& Spasojević, I. (2011). A comparative study of antioxidative activities of cellwall polysaccharides. Carbohydrate Research, 346(14), 2255-2259.

Puupponen-Pimiä, R., Nohynek, L., Meier, C., Kähkönen, M., Heinonen, M., Hopia, A., \& OksmanCaldentey, K. M. (2001). Antimicrobial properties of phenolic compounds from berries. Journal of Applied Microbiology, 90(4), 494-507. 


\section{Introduction}

Qin, Y., Liu, D., Wu, Y., Yuan, M., Li, L., \& Yang, J. (2015). Effect of PLA/PCL/cinnamaldehyde antimicrobial packaging on physicochemical and microbial quality of button mushroom (Agaricus bisporus). Postharvest Biology and Technology, 99, 73-79.

Radaelli, M., Silva, B. P. D., Weidlich, L., Hoehne, L., Flach, A., Costa, L. A. M. A. D., \& Ethur, E. M. (2016). Antimicrobial activities of six essential oils commonly used as condiments in Brazil against Clostridium perfringens. Brazilian Journal of Microbiology, 47(2), 424-430.

Rai, R., \& Roy, I. (2011). Polyhydroxyalkanoates: the emerging new green polymers of choice. $A$ Handbook of Applied Biopolymer Technology, 79-101. RSC Publishing

Randazzo, W., Jiménez-Belenguer, A., Settanni, L., Perdones, A., Moschetti, M., Palazzolo, E., \& Moschetti, G. (2016). Antilisterial effect of citrus essential oils and their performance in edible film formulations. Food Control, 59, 750-758.

Ravishankar, S., Zhu, L., Olsen, C. W., McHugh, T. H., \& Friedman, M. (2009). Edible apple film wraps containing plant antimicrobials inactivate foodborne pathogens on meat and poultry products. Journal of Food Science, 74(8), M440-M445.

Raybaudi-Massilia, R. M., Mosqueda-Melgar, J., \& Martín-Belloso, O. (2008). Edible alginate-based coating as carrier of antimicrobials to improve shelf-life and safety of fresh-cut melon. International Journal of Food Microbiology, 121(3), 313-327.

Raza, Z. A., Abid, S., \& Banat, I. M. (2018). Polyhydroxyalkanoates: Characteristics, production, recent developments and applications. International Biodeterioration \& Biodegradation, 126, 45-56.

Requena, R., Jiménez, A., Vargas, M., \& Chiralt, A. (2016). PHBV active bilayer films obtained by compression-molding applying essential oils at the interface. Polymer International, 65, 883-891.

Ritger, P.L., \& Peppas, N.A. (1987a). A simple equation for description of solute release I. Fickian and non-fickian release from non-swellable devices in the form of slabs, spheres, cylinders or discs. Journal of controlled release, 5(1), 23-36.

Ritger, P.L., \& Peppas, N.A. (1987b). A simple equation for description of solute release II. Fickian and anomalous release from swellable devices. Journal of controlled release, 5(1), 37-42.

Rivas, S., Conde, E., Moure, A., Domínguez, H., \& Parajó, J. C. (2013). Characterization, refining and antioxidant activity of saccharides derived from hemicelluloses of wood and rice husks. Food Chemistry, 141(1), 495-502.

Rivero-Urgell, M., \& Santamaria-Orleans, A. (2001). Oligosaccharides: application in infant food. Early Human Development, 65, S43-S52.

Roselló, J., Semperea, F., Sanz-Berzosa, I., Chiralt, A., \& Santamarina, P. (2015). Antifungal activity and potential use of essential oils against Fusarium culmorum and Fusarium verticillioides. Journal of Essential Oil Bearing Plants, 18(2), 359-367

Ross, G., Ross, S., \& Tighe, B. J. (2017). Bioplastics: new routes, new products. Brydson's Plastics Materials, 631-652. 
Ruiz-Navajas, Y., Viuda-Martos, M., Sendra, E., Perez-Alvarez, J. A., Fernández-López, J. (2013). In vitro antibacterial and antioxidant properties of chitosan edible films incorporated with Thymus moroderi or Thymus piperella essential oils. Food Control, 30(2), 386-392.

Rusa, C.C., Luca, C., \& Tonelli, A.E. (2001). Polymer-cyclodextrin inclusion compounds: Towards new aspects of their inclusion mechanism. Macromolecules, 34, 1318-1322.

Ruthes, A. C., Martínez-Abad, A., Tan, H. T., Bulone, V., \& Vilaplana, F. (2017). Sequential fractionation of feruloylated hemicelluloses and oligosaccharides from wheat bran using subcritical water and xylanolytic enzymes. Green Chemistry, 19(8), 1919-1931.

Said, Z. B. O. S., Haddadi-Guemghar, H., Boulekbache-Makhlouf, L., Rigou, P., Remini, H., Adjaoud, A., \& Madani, K. (2016). Essential oils composition, antibacterial and antioxidant activities of hydrodistillated extract of Eucalyptus globulus fruits. Industrial Crops and Products, 89, 167-175.

Salmieri, S., Islam, F., Khan, R. A., Hossain, F. M., Ibrahim, H. M., Miao, C., \& Lacroix, M. (2014). Antimicrobial nanocomposite films made of poly (lactic acid)-cellulose nanocrystals (PLA-CNC) in food applications-part B: effect of oregano essential oil release on the inactivation of Listeria monocytogenes in mixed vegetables. Cellulose, 21(6), 4271-4285.

Salvia-Trujillo, L., Rojas-Graü, M. A., Soliva-Fortuny, R., \& Martín-Belloso, O. (2015). Use of antimicrobial nanoemulsions as edible coatings: Impact on safety and quality attributes of fresh-cut Fuji apples. Postharvest Biology and Technology, 105, 8-16.

Sánchez-Aldana, D. S., Andrade-Ochoa, S., Aguilar, C. N., Contreras-Esquivel, J. C., \& NevárezMoorillón, G. V. (2015). Antibacterial activity of pectic-based edible films incorporated with Mexican lime essential oil. Food Control, 50, 907-912

Sanchez-Garcia, M. D., Lagaron, J. M., \& Hoa, S. V. (2010a). Effect of addition of carbon nanofibers and carbon nanotubes on properties of thermoplastic biopolymers. Composites Science and Technology, 70(7), 1095-1105.

Sanchez-Garcia, M. D., Lopez-Rubio, A., \& Lagaron, J. M. (2010b). Natural micro and nanobiocomposites with enhanced barrier properties and novel functionalities for food biopackaging applications. Trends in Food Science \& Technology, 21(11), 528-536.

Sánchez-González, L., Vargas, M., González-Martínez, C., Chiralt, A., \& Cháfer, M. (2009). Characterization of edible films based on hydroxypropylmethylcellulose and tea tree essential oil. Food Hydrocolloids, 23(8), 2102-2109.

Sánchez González, L., Cháfer, M., Chiralt, A., \& González-Martínez, C. (2010a). Physical properties of edible chitosan films containing bergamot essential oil and their inhibitory action on Penicillium italicum. Carbohydrate Polymers, 82 (2) 277-283.

Sánchez-González, L., González-Martínez, C., Chiralt, A., \& Cháfer, M. (2010b). Physical and antimicrobial properties of chitosan-tea tree essential oil composite films. Journal of Food Engineering, 98(4), 443-452. 
Sánchez-González, L., Chiralt, A., González-Martínez, C., \& Cháfer, M. (2011a). Effect of essential oils on properties of film forming emulsions and films based on hydroxypropylmethylcellulose and chitosan. Journal of Food Engineering, 105(2), 246-253.

Sánchez-González, L., Pastor, C., Vargas, M., Chiralt, A., González-Martínez, C., \& Cháfer, M. (2011b). Effect of hydroxypropylmethylcellulose and chitosan coatings with and without bergamot essential oil on quality and safety of cold-stored grapes. Postharvest Biology and Technology, 60(1), 57-63.

Sánchez-González, L., Cháfer, M., Hernández, M., Chiralt, A., \& González-Martínez, C. (2011c). Antimicrobial activity of polysaccharide films containing essential oils. Food Control, 22(8), 1302-1310.

Sánchez-González, L., Cháfer, M., González-Martínez, C., Chiralt, A., Desobry, S. (2011d). Study of the release of limonene present in chitosan films enriched with bergamot oil in food simulants. Journal of Food Engineering, 105(1), 138-143.

Sánchez-Safont, E. L., Aldureid, A., Lagarón, J. M., Gámez-Pérez, J., \& Cabedo, L. (2018). Biocomposites of different lignocellulosic wastes for sustainable food packaging applications. Composites Part B: Engineering, 145, 215-225.

Sanyang, M. L., Sapuan, S. M., Jawaid, M., Ishak, M. R., \& Sahari, J. (2016). Development and characterization of sugar palm starch and poly (lactic acid) bilayer films. Carbohydrate Polymers, 146, 36-45.

Sarikurkcu, C., Zengin, G., Oskay, M., Uysal, S., Ceylan, R., \& Aktumsek, A. (2015). Composition, antioxidant, antimicrobial and enzyme inhibition activities of two Origanum vulgare subspecies (subsp. vulgare and subsp. hirtum) essential oils. Industrial Crops and Products, 70, 178-184.

Sarkar, P., Bhunia, A. K., \& Yao, Y. (2017). Impact of starch-based emulsions on the antibacterial efficacies of nisin and thymol in cantaloupe juice. Food Chemistry, 217, 155-162.

Savenkova, L., Gercberga, Z., Bibers, I., \& Kalnin, M. (2000). Effect of 3-hydroxy valerate content on some physical and mechanical properties of polyhydroxyalkanoates produced by Azotobacter chroococcum. Process Biochemistry, 36(5), 445-450.

Scaffaro, R., Sutera, F., \& Botta, L. (2018). Biopolymeric bilayer films produced by co-extrusion film blowing. Polymer Testing, 65, 35-43.

Sevastianov, V. I., Perova, N. V., Shishatskaya, E. I., Kalacheva, G. S., \& Volova, T. G. (2003). Production of purified polyhydroxyalkanoates (PHAs) for applications in contact with blood. Journal of Biomaterials Science, Polymer Edition, 14(10), 1029-1042.

Shekarforoush, S. S., Nazer, A. H. K., Firouzi, R., \& Rostami, M. (2007). Effects of storage temperatures and essential oils of oregano and nutmeg on the growth and survival of Escherichia coli O157: $\mathrm{H7}$ in barbecued chicken used in Iran. Food Control, 18(11), 1428-1433.

Shelef, L. A., Jyothi, E. K., \& Bulgarellii, M. A. (1984). Growth of enteropathogenic and spoilage bacteria in sage-containing broth and foods. Journal of Food Science, 49 (3), 737-740. 
Shen, Z., \& Kamdem, D. P. (2015). Antimicrobial activity of sugar beet lignocellulose films containing tung oil and cedarwood essential oil. Cellulose, 22(4), 2703-2715.

Shishatskaya, E. I., Nikolaeva, E. D., Vinogradova, O. N., \& Volova, T. G. (2016). Experimental wound dressings of degradable PHA for skin defect repair. Journal of Materials Science: Materials in Medicine, 27(11), 165.

Singh, H., Al-samarai, G., \& Syarhabil, M. (2012). Exploitation of natural products as an alternative strategy to control postharvest fungal rotting of citrus. International Journal of Scientific and Research Publications, 2(3), 1-4.

Siracusa, V., Rocculi, P., Romani, S., \& Dalla Rosa, M. (2008). Biodegradable polymers for food packaging: a review. Trends in Food Science \& Technology, 19(12), 634-643.

Snell, K. D., \& Peoples, O. P. (2002). Polyhydroxyalkanoate polymers and their production in transgenic plants. Metabolic Engineering, 4(1), 29-40.

Solaiman, D. K., Ashby, R. D., Zerkowski, J. A., Krishnama, A., \& Vasanthan, N. (2015). Control-release of antimicrobial sophorolipid employing different biopolymer matrices. Biocatalysis and Agricultural Biotechnology, 4(3), 342-348.

Sotillo, D. R., Hadley, M., \& Wolf-Hall, C. (1998). Potato peel extract a nonmutagenic antioxidant with potential antimicrobial activity. Journal of Food Science, 63(5), 907-910.

Steel, M. L., and P. Norton-Berry. July 1986. U.S. patent 4,603,070.

Sudesh, K., Abe, H., \& Doi, Y. (2000). Synthesis, structure and properties of polyhydroxyalkanoates: biological polyesters. Progress in Polymer Science, 25(10), 1503-1555.

Sun, S., Liu, P., Ji, N., Hou, H., \& Dong, H. (2017a). Effects of low polyhydroxyalkanoate content on the properties of films based on modified starch acquired by extrusion blowing. Food Hydrocolloids, 72, 81-89.

Sun, S., Liu, P., Ji, N., Hou, H., \& Dong, H. (2017b). Effects of various cross-linking agents on the physicochemical properties of starch/PHA composite films produced by extrusion blowing. Food Hydrocolloids, 77, 964-975.

Takala, P. N., Salmieri, S., Boumail, A., Khan, R. A., Vu, K. D., Chauve, G., \& Lacroix, M. (2013). Antimicrobial effect and physicochemical properties of bioactive trilayer polycaprolactone/methylcellulose-based films on the growth of foodborne pathogens and total microbiota in fresh broccoli. Journal of Food Engineering, 116(3), 648-655.

Tassou, C. C., Drosinos, E. H., \& Nychas, G. J. E. (1995). Effects of essential oil from mint (Mentha piperita) on Salmonella enteritidis and Listeria monocytogenes in model food systems at 4 and 10 ${ }^{\circ} \mathrm{C}$. Journal of Applied Bacteriology, 78 (6), 593-600.

Tawakkal, I. S., Cran, M. J., \& Bigger, S. W. (2016). Release of thymol from poly (lactic acid)-based antimicrobial films containing kenaf fibres as natural filler. LWT-Food Science and Technology, 66, 629637. 


\section{Introduction}

Tehranifar, A., Selahvarzi, Y., Kharrazi, M., \& Bakhsh, V. J. (2011). High potential of agro-industrial byproducts of pomegranate (Punica granatum L.) as the powerful antifungal and antioxidant substances. Industrial Crops and Products, 34(3), 1523-1527.

Tehrany, E. A., \& Desobry, S. (2007). Partition coefficient of migrants in food simulants/polymers systems. Food Chemistry, 101(4), 1714-1718

Thellen, C., Coyne, M., Froio, D., Auerbach, M., Wirsen, C., \& Ratto, J. A. (2008). A processing, characterization and marine biodegradation study of melt-extruded polyhydroxyalkanoate (PHA) films. Journal of Polymers and the Environment, 16(1), 1-11.

Thellen, C., Cheney, S., \& Ratto, J. A. (2013). Melt processing and characterization of polyvinyl alcohol and polyhydroxyalkanoate multilayer films. Journal of Applied Polymer Science, 127(3), 2314-2324.

Tongnuanchan, P., Benjakul, S., \& Prodpran, T. (2012). Properties and antioxidant activity of fish skin gelatin film incorporated with citrus essential oils. Food Chemistry, 134(3), 1571-1579.

Ud-Daula, A. S., Demirci, F., Salim, K. A., Demirci, B., Lim, L. B., Baser, K. H. C., \& Ahmad, N. (2016). Chemical composition, antioxidant and antimicrobial activities of essential oils from leaves, aerial stems, basal stems, and rhizomes of Etlingera fimbriobracteata (K. Schum.) R.M.Sm. Industrial Crops and Products, 84, 189-198.

Uhart, M., Maks, N., \& Ravishankar, S. (2006). Effect of spices on growth and survival of Salmonella typhimurium DT 104 in ground beef stored at 4 and $8{ }^{\circ} \mathrm{C}$. Journal of Food Safety, 26(2), 115-125.

Ultee, A., Kets, E. P., Alberda, M., Hoekstra, F. A., \& Smid, E. J. (2000). Adaptation of the food-borne pathogen Bacillus cereus to carvacrol. Archives of Microbiology, 174(4), 233-238.

Ultee, A., \& Smid, E. J. Influence of carvacrol on growth and toxin production by Bacillus cereus (2001). International journal of food microbiology, 64(3), 373-378.

Valappil, S. P., Misra, S. K., Boccaccini, A. R., \& Roy, I. (2006). Biomedical applications of polyhydroxyalkanoates, an overview of animal testing and in vivo responses. Expert Review of Medical Devices, 3(6), 853-868.

Valappil, S. P., Boccaccini, A. R., Bucke, C., \& Roy, I. (2007). Polyhydroxyalkanoates in Gram-positive bacteria: insights from the genera Bacillus and Streptomyces. Antonie Van Leeuwenhoek, 91(1), 1-17.

Valencia-Sullca, C., Jiménez, M., Jiménez, A., Atarés, L., Vargas, M., Chiralt, A. (2016). Influence of liposome encapsulated essential oils on properties of chitosan films. Polymer International, 65, 979987.

Vazquez, M. J., Alonso, J. L., Domınguez, H., \& Parajo, J. C. (2000). Xylooligosaccharides: manufacture and applications. Trends in Food Science \& Technology, 11(11), 387-393.

Veldhuizen, E. J., Creutzberg, T. O., Burt, S. A., \& Haagsman, H. P. (2007). Low temperature and binding to food components inhibit the antibacterial activity of carvacrol against Listeria monocytogenes in steak tartare. Journal of Food Protection, 70(9), 2127-2132. 
Velkova, N., Zemljic, L. F., Saake, B., \& Strnad, S. (2017). Adsorption of cationized xylans onto polyethylene terephthalate fabrics for antimicrobial medical textiles. Textile Research Journal, 0040517517748512.

Verma, S. K., Goswami, P., Verma, R. S., Padalia, R. C., Chauhan, A., Singh, V. R., \& Darokar, M. P. (2016). Chemical composition and antimicrobial activity of bergamot-mint (Mentha citrata Ehrh.) essential oils isolated from the herbage and aqueous distillate using different methods. Industrial Crops and Products, 91, 152-160.

Vieira, M. G. A., da Silva, M. A., dos Santos, L. O., \& Beppu, M. M. (2011). Natural-based plasticizers and biopolymer films: A review. European Polymer Journal, 47(3), 254-263.

Volova, T. G. (2004). Polyhydroxyalkanoates--plastic materials of the 21st century: production, properties, applications. Nova publishers.

Volova, T. G., Prudnikova, S. V., Vinogradova, O. N., Syrvacheva, D. A., \& Shishatskaya, E. I. (2017). Microbial Degradation of Polyhydroxyalkanoates with Different Chemical Compositions and Their Biodegradability. Microbial Ecology, 73(2), 353-367.

Wang, H., Sun, X., \& Seib, P. (2002). Mechanical properties of poly (lactic acid) and wheat starch blends with methylenediphenyl diisocyanate. Journal of Applied Polymer Science, 84(6), 1257-1262.

Wang, Z., Wu, H., Chen, J., Zhang, J., Yao, Y., \& Chen, G. Q. (2008a). A novel self-cleaving phasin tag for purification of recombinant proteins based on hydrophobic polyhydroxyalkanoate nanoparticles. Lab On a Chip, 8(11), 1957-1962.

Wang, S., Ma, P., Wang, R., Wang, S., Zhang, Y., \& Zhang, Y. (2008b). Mechanical, thermal and degradation properties of poly (d, I-lactide)/poly (hydroxybutyrate-co-hydroxyvalerate)/poly (ethylene glycol) blend. Polymer Degradation and Stability, 93(7), 1364-1369.

Wang, S. Y., Wang, Z., Liu, M. M., Xu, Y., Zhang, X. J., \& Chen, G. Q. (2010). Properties of a new gasoline oxygenate blend component: 3-hydroxybutyrate methyl ester produced from bacterial poly-3hydroxybutyrate. Biomass and Bioenergy, 34(8), 1216-1222.

Webb, H. K., Arnott, J., Crawford, R. J., \& Ivanova, E. P. (2012). Plastic degradation and its environmental implications with special reference to poly (ethylene terephthalate). Polymers, 5(1), 118.

Wen, P., Zhu, D. H., Feng, K., Liu, F. J., Lou, W. Y., Li, N., Zong, M-H., \& Wu, H. (2016). Fabrication of electrospun polylactic acid nanofilm incorporating cinnamon essential oil/ $\beta$-cyclodextrin inclusion complex for antimicrobial packaging. Food Chemistry, 196, 996-1004.

Wille, M., De Schryver, P., Defoirdt, T., Bossier, P., \& Sorgeloos, P. (2010). The effect of poly $\beta$ hydroxybutyrate on larviculture of the giant freshwater prawn Macrobrachium rosenbergii. Aquaculture, 302(1-2), 76-81

Wu, J., Liu, H., Ge, S., Wang, S., Qin, Z., Chen, L., \& Zhang, Q. (2015). The preparation, characterization, antimicrobial stability and in vitro release evaluation of fish gelatin films incorporated with cinnamon essential oil nanoliposomes. Food Hydrocolloids, 43, 427-435. 
Wu, C. S., \& Liao, H. T. (2017). Interface design of environmentally friendly carbon nanotube-filled polyester composites: Fabrication, characterisation, functionality and application. Express Polymer Letters, 11(3), 187.

Xavier, J. R., Babusha, S. T., George, J., \& Ramana, K. V. (2015). Material properties and antimicrobial activity of polyhydroxybutyrate (PHB) films incorporated with vanillin. Applied Biochemistry and Biotechnology, 176(5), 1498-1510.

Xiao, X. Q., Zhao, Y., \& Chen, G. Q. (2007). The effect of 3-hydroxybutyrate and its derivatives on the growth of glial cells. Biomaterials, 28(25), 3608-3616.

Xu, J., \& Guo, B. H. (2010). Plastics from Bacteria Natural Functions and Applications. Microbiology Monographs, Vol. 14. Springer-Verlag, Berlin Heidelberg

Xu, P., Zeng, Q., Cao, Y., Ma, P., Dong, W., \& Chen, M. (2017). Interfacial modification on polyhydroxyalkanoates/starch blend by grafting in-situ. Carbohydrate Polymers, 174, 716-722.

Yalpani, M. July 1993b. U.S. patent 5,229,158.

Yalpani, M. July 1993a. U.S. patent 5,225,227.

Yao, Y. C., Zhan, X. Y., Zhang, J., Zou, X. H., Wang, Z. H., Xiong, Y. C., Chen, J., \& Chen, G. Q. (2008). A specific drug targeting system based on polyhydroxyalkanoate granule binding protein PhaP fused with targeted cell ligands. Biomaterials, 29(36), 4823-4830.

Yatigala, N. S., Bajwa, D. S., \& Bajwa, S. G. (2018). Compatibilization improves physico-mechanical properties of biodegradable biobased polymer composites. Composites Part A: Applied Science and Manufacturing, 107, 315-325.

Ye, H., Shen, S., Xu, J., Lin, S., Yuan, Y., \& Jones, G. S. (2013). Synergistic interactions of cinnamaldehyde in combination with carvacrol against food-borne bacteria. Food Control, 34(2), 619-623.

Yoshie, N., Nakasato, K., Fujiwara, M., Kasuya, K., Abe, H., Doi, Y., \& Inoue, Y. (2000). Effect of low molecular weight additives on enzymatic degradation of poly (3-hydroxybutyrate). Polymer, 41(9), 3227-3234.

Zhang, X., Luo, R., Wang, Z., Deng, Y., \& Chen, G. Q. (2009). Application of (R)-3-hydroxyalkanoate methyl esters derived from microbial polyhydroxyalkanoates as novel biofuels. Biomacromolecules, 10(4), 707-711.

Zhang, H.Y., Tehrany, E.A., Kahn, C.J.F., Ponçot, M., Linder, M., \& Cleymand, F. (2012). Effects of nanoliposomes based on soya, rapeseed and fish lecithins on chitosan thin films designed for tissue engineering, Carbohydrate polymers, 88, 618-627

Zhang, M., \& Thomas, N. L. (2011). Blending polylactic acid with polyhydroxybutyrate: the effect on thermal, mechanical, and biodegradation properties. Advances in Polymer Technology, 30(2), 67-79.

Zhang, X., Wei, C., He, Q., \& Ren, Y. (2010). Enrichment of chlorobenzene and o-nitrochlorobenzene on biomimetic adsorbent prepared by poly-3-hydroxybutyrate (PHB). Journal of Hazardous Materials, 177(1-3), 508-515. 
Zhijiang, C., \& Guang, Y. (2011). Optical nanocomposites prepared by incorporating bacterial cellulose nanofibrils into poly (3-hydroxybutyrate). Materials Letters, 65(2), 182-184.

Zhou, J., Peng, S. W., Wang, Y. Y., Zheng, S. B., Wang, Y., \& Chen, G. Q. (2010). The use of poly (3hydroxybutyrate-co-3-hydroxyhexanoate) scaffolds for tarsal repair in eyelid reconstruction in the rat. Biomaterials, 31(29), 7512-7518.

Zinoviadou, K. G., Koutsoumanis, K. P., \& Biliaderis, C. G. (2009). Physico-chemical properties of whey protein isolate films containing oregano oil and their antimicrobial action against spoilage flora of fresh beef. Meat Science, 82(3), 338-345.

Zou, X. H., Li, H. M., Wang, S., Leski, M., Yao, Y. C., Yang, X. D., \& Chen, G. Q. (2009). The effect of 3hydroxybutyrate methyl ester on learning and memory in mice. Biomaterials, 30(8), 1532-1541.

Zuo, Y., Gu, J., Yang, L., Qiao, Z., Tan, H., \& Zhang, Y. (2014). Preparation and characterization of dry method esterified starch/polylactic acid composite materials. International Journal of Biological Macromolecules, 64, 174-180. 



\section{OBJECTIVES}



The general objective of this Doctoral Thesis was to develop biodegradable active materials for food packaging applications mainly based on PHBV, combined with other biopolymers (PLA and starch) and using different antimicrobial compounds, such as essential oil compounds or active xylan fractions from rice husk.

\section{Specific objectives}

1. To improve the properties of PHBV films by using different plasticizers (polyethylenglycol with different molecular weight 200, 1000 and 4000, as well as lauric and stearic acid), and active compounds (oregano and clove essential oils, as well as their respective main compounds, carvacrol and eugenol), by considering the functional properties as packaging materials (structural, thermal, optical, mechanical and water vapor barrier properties), the antimicrobial activity and the release kinetics in different food simulants.

2. To analyse the potential synergy between different essential oil compounds and their applications to different food real systems when incorporated into PHBV films.

3. To develop multilayer antimicrobial films combining polar (starch) and less-polar (polyester) sheets, and incorporating carvacrol, to optimise the material functionality: barrier and mechanical properties, the active release kinetics and antimicrobial action.

4. To obtain xylans and cellulosic fractions, useful for food packaging applications, from rice husk by-product, using sequential subcritical water extraction. 

CHAPTERS 



\section{Improving properties of PHBV films}

I. Effect of plasticizers on thermal and physical properties of compression-moulded poly[(3hydroxybutyrate)-co-(3-hydroxyvalerate)] films

II. Poly[(3-hydroxybutyrate)-co-(3-hydroxyvalerate)] active bilayer films obtained by compression moulding and applying essential oils at the interface

III. Release kinetics of carvacrol and eugenol from poly(hydroxybutyrate-cohydroxyvalerate) (PHBV) films for food packaging applications

CHAPTER 2

Antimicrobial activity of EO compounds. Application to food systems

IV. Study of the potential synergistic antibacterial activity of essential oil components using the thiazolyl blue tetrazolium bromide (MTT) assay

V. Eugenol and carvacrol migration from PHBV films and antibacterial action in different food matrices

CHAPTER 3

Improving functionality of packaging films with multilayer assemblies

VI. Obtaining antimicrobial bilayer starch and polyester-blend films with carvacrol.

\section{CHAPTER 4}

\section{Rice husk valorization for obtaining products with packaging application}

VII. Valorization of rice husk into bioactive xylans and cellulose nanocrystals by using sequential subcritical water extraction. 



\section{Effect of plasticizers on thermal and physical properties of compression-moulded poly[(3- hydroxybutyrate)-co-(3-hydroxyvalerate)] films}

Raquel Requena; Alberto Jiménez; María Vargas; Amparo Chiralt

Polymer Testing (2016) 56, 45-53.

Institute of Food Engineering for Development, Universitat Politècnica de València, Valencia, Spain 



\begin{abstract}
Poly[(3-hydroxybutyrate)-co-(3-hydroxyvalerate)] (PHBV) is a promising bio-based, biodegradable polymer for replacing synthetic polymers, but its brittleness limits its application range. With the aim of improving the mechanical properties of PHBV films, different plasticizers (polyethylene glycol (PEG 200, 1000 and 4000), lauric acid (LA) and stearic acid (SA)) were incorporated into the film formulation at $10 \mathrm{wt} \%$. All plasticized films showed lower melting temperature and crystallization degree than pure PHBV films. All plasticizers, except SA, reduced film stiffness and resistance to break, and increased the films' water sorption capacity and solubility as well as their water vapour permeability, but only PEG1000 yielded more extensible films. PEG1000 and PEG4000 gave rise to the most heat-resistant plasticized films while LA and SA highly promoted the heat-sensitivity of PHBV. PEG1000 was the most effective at plasticizing PHBV films, and it was the only plasticizer that partially mitigated the ageing effects.
\end{abstract}

Keywords: Tensile properties, ageing, PHBV, crystallization, thermal stability. 


\section{INTRODUCTION}

In recent years, numerous research works have focused on the valorization of biodegradable polymers obtained from organic waste. Materials derived from renewable sources containing polysaccharides, lipids and proteins can be consumed by microorganisms, especially by bacteria, in order to obtain monomers such as hydroxyalkanoic acids (with many structural variations), and D- and L-lactic acid [1]. These monomers have been used to produce polyhydroxyalkanoates (PHAs) and polylactic acid (PLA) respectively, two of the most important biodegradable polymers derived from renewable sources [2,3].

PHAs are a family of linear polyesters of 3, 4, 5 and 6-hydroxyacids synthesised by a wide variety of bacteria, including strains of Pseudomonas, Bacillus, Ralstonia, Aeromonas or Rhodobacter [4]. These polymers are present in the cells as cytoplasmic inclusions, which are used as energy reserves [5,6]. Depending on polymer composition, a wide range of PHAs with desirable properties can be obtained, from polymers which are stiff and crystalline to others that are flexible and rubbery [7].

Poly-hydroxybutyrate (PHB) is one the most widely studied PHAs. The physical properties of $\mathrm{PHB}$ are often compared to those of isotactic polypropylene because they have similar melting points, degrees of crystallinity and glass transition temperatures [8]. PHB presents good processability, and it yields materials with a high degree of transparency and stiffness. Even if PHB has many interesting properties, its inherent brittleness, relatively low thermal stability, ageing behaviour and high cost of production restrict its range of applications [9]. PHB's great fragility is described as a result of different factors, which also contribute to its ageing behaviour: (1) secondary crystallization of the amorphous phase since its glass transition is close to room temperature; (2) low nucleation density, which leads to "large" spherulites or the appearance of cracks in the inter-spherulitic confinements that worsen the film's mechanical properties [10-12]. In order to reduce the brittleness and thermal instability of $\mathrm{PHB}$, copolymers with hydroxyvalerate (known as poly-hydroxybutyrate-co- hydroxyvalerate (PHBV)) have been obtained. As reported by Savenkova, Gercberga, [13], these copolymers give rise to much less brittle materials, with higher extensibility, than the homopolymers; the higher the hydroxyvalerate content, the more flexible the material is.

Additionally, in order to reduce PHBV brittleness different plasticizers have been used. These reduce the intermolecular forces along polymer chains, which improve the flexibility and chain mobility, at the same time that they provoke a decrease in glass transition temperature and changes in the crystallization behaviour. The effect of different kinds of plasticizers on the mechanical and thermal properties of PHBV matrices has been studied. Some of these are polyols, such as propylene glycol (PG) or glycerol (G) [14]; citrates, such as triethyl citrate (TEC) [14] and acetyl butyl citrate (ATBC) [10]; polyolefins, such as polyisobutylene [13]; dibutilphtalate (DBP) [15]; dibutyl sebacate [13]; oils and triglycerides, such as castor oil, 
soybean oil and epoxidised soybean oil (ESO) [14]; surfactants like sophorolipid [16] or polyethylene-glycol with medium molecular weight (PEG1000) [14]. In general, medium molecular weight substances with oxygen atoms (e.g. ethers or ketones), which are accessible for interactions with the polymer matrix, such as PEG1000, TEC or DBP, have effectively improved the films' stretchability [14]. The addition of some plasticizers hindered the PHB and PHBV crystallization in line with the interruption of interactions among the polymer chains $[10,11,16]$. However, some plasticizers, such as PG, PEG1000 or ESO, promoted molecular mobility thus favouring the crystallization process [14].

PEGs of different molecular weight have been already used as effective plasticizers in different polymers [17-19], and could be a good alternative for PHBV matrices. No previous studies into the effect of the molecular weight of this compound on its plasticizing effectiveness in PHBV films have been found. Likewise, although surfactants, such as fatty acids, have been used as plasticizers in different matrices [20-22] their potential for PHBV plasticization has not been analysed either.

In this study, the effect of the addition of PEG with different molecular weight and two fatty acids (lauric acid or stearic acid) on crystallization behaviour and thermal stability, tensile properties and water affinity of PHBV films was characterized. In addition, the films were analysed in terms of their microstructural and optical properties, and the impact of storage under controlled conditions (ageing process) on film properties was also evaluated.

\section{MATERIALS AND METHODS}

\subsection{Materials}

Poly(3-hydroxybutyrate-co-3-hydroxyvalerate) (PHBV) with $8 \%$ of hydroxyvalerate (HV) content was provided in pellet form by NaturePlast (Caen, France). Polyethylenglycol 200 (PEG200), polyethylenglycol 950-1050 (PEG1000), polyethylenglycol 4000 (PEG4000) and lauric acid (LA) were supplied by Sigma-Aldrich (Sigma-Aldrich Chemie, Steinheim, Germany). Stearic acid (SA) was obtained from Panreac Química, S.A. (Castellar del Vallès, Barcelona, Spain).

\subsection{Preparation of films}

PHBV films were prepared by melt blending and compression-moulding. PHBV was mixed with a constant amount of PEG200, PEG1000, PEG4000, LA or SA (10 \% w/w) on a two-roll mill (Model LRM-M-100, Labtech Engineering, Thailand) at $180{ }^{\circ} \mathrm{C}$ and $15 \mathrm{rpm}$ for $10 \mathrm{~min}$. Pure PHBV without plasticizer, used as control film, was processed under the same conditions. Films were obtained by pressing $3.5 \mathrm{~g}$ of each blend by using a hydraulic press (Model LP20, Labtech 
Engineering, Thailand). Steel sheets were pre-heated for $5 \mathrm{~min}$ and then, compression was performed at $180^{\circ} \mathrm{C}$ for $4 \mathrm{~min}$ at $100 \mathrm{bar}$, followed by a cooling cycle to $60^{\circ} \mathrm{C}$ for $3 \mathrm{~min}$. The obtained films were conditioned at $25^{\circ} \mathrm{C}$ and $53 \% \mathrm{RH}$ for 1 or 5 weeks (initial and final times respectively) prior to testing. In this way, six kinds of samples were obtained: without plasticizer (PHBV) and with the different plasticizers (PHBV-PEG200, PHBV-PEG1000, PHBVPEG4000, PHBV-LA and PHBV-SA).

\subsection{Film characterization}

\subsubsection{Film thickness}

Film thickness was measured to the nearest $0.0025 \mathrm{~mm}$ with a Palmer digital micrometer at six random positions.

\subsubsection{Scanning electron microscopy (SEM)}

The cross-section of the samples was observed using a Scanning Electron Microscope (JEOL JSM-5410, Japan). Conditioned film samples were immersed in liquid $\mathrm{N}_{2}$, cryofractured, fixed on copper stubs, gold coated, and observed using an accelerating voltage of $10 \mathrm{kV}$.

\subsubsection{Optical properties}

The transparency of films was studied by applying the Kubelka-Munk theory for multiple scattering to the reflection spectra [23]. The surface reflectance spectra of the films were obtained from 400 to $700 \mathrm{~nm}$ using a spectrocolorimeter CM-3600d (Minolta Co., Tokyo, Japan) on both a white and a black background. The internal transmittance $\left(T_{i}\right)$ was obtained by applying Eq. (1), where $R_{0}$ is the reflectance of the film on an ideal black background. Parameters $a$ and $b$ were calculated by Eqs. (2) and (3), where $R$ is the reflectance of the sample layer backed by a known reflectance $\left(R_{g}\right)$. Measurements were taken in triplicate for each sample.

$$
\begin{aligned}
& T_{i}=\sqrt{\left(a-R_{0}\right)^{2}}-b^{2}(1) \\
& a=\frac{1}{2} \cdot\left(R+\frac{R_{0}-R+R_{g}}{R_{0} \cdot R_{g}}\right)(2) \\
& b=\left(a^{2}-1\right)^{\frac{1}{2}}
\end{aligned}
$$


The reflectance of an infinitely thick layer of the material $\left(R_{\infty}\right)$ was also determined by means of Eq. (4) in order to obtain the CIE L*a*b* colour coordinates: Lightness $\left(\mathrm{L}^{*}\right)$, Chroma $\left(\mathrm{C}_{\mathrm{ab}}{ }^{*}\right)$ (Eq. (5)) and Hue ( $\left.\mathrm{hab}^{*}{ }^{*}\right)$ (Eq. (6)), using D65 illuminant/10 observer, as reference. The colour difference (Eq. (7)) between the different films and the control film was determined.

$$
\begin{aligned}
& R_{\infty}=a-b(4) \\
& C_{a b}^{*}=\sqrt{\left(a^{* 2}+b^{* 2}\right)}(5) \\
& h_{a b}^{*}=\operatorname{arctg}\left(\frac{b^{*}}{a^{*}}\right)(6) \\
& \Delta E=\sqrt{\left(\Delta L^{*}\right)^{2}+\left(\Delta a^{*}\right)^{2}+\left(\Delta b^{*}\right)^{2}}
\end{aligned}
$$

\subsubsection{Moisture content}

Conditioned films (for 1 or 5 weeks) were dried for $24 \mathrm{~h}$ at $60{ }^{\circ} \mathrm{C}$ in a convection oven (J.P. Selecta, S.A. Barcelona, Spain) and finally placed in a vacuum oven to complete film drying. Measurements were taken in triplicate.

\subsubsection{Water vapour permeability}

Water vapour permeability (WVP) was determined at $25^{\circ} \mathrm{C}$, according to the ASTM E-96-95 [24] gravimetric method, as described by Vargas, Albors [25]. Distilled water was placed in Payne permeability cups ( $3.5 \mathrm{~cm}$ diameter, Elcometer SPRL, Hermelle/s Argenteau, Belgium) to obtain $100 \% \mathrm{RH}$ on one side of the film, while an oversaturated magnesium nitrate solution was used to control the relative humidity on the other side of the film. In order to reduce resistance to water vapour transport, a fan was placed on the top of the cup. The slopes of the steady state period of the curves of weight loss as a function of time were determined by linear regression in order to calculate WVTR, Eq. (8). WVP measurements Eq. (9) were taken in quadruplicate for each type of film.

$$
\begin{aligned}
& W V T R=\frac{J}{A}(8) \\
& W V P=\frac{W V T R}{P_{w 1}-P_{w 2}} \cdot L(9)
\end{aligned}
$$

Where:

WVTR is water vapour transmission rate, $\mathrm{g} \cdot \mathrm{h}^{-1} \cdot \mathrm{m}^{-2}$ $J$ is slope of the plotting of weight loss vs. time, $g \cdot h^{-1}$. 
$A$ is area of the film, $\mathrm{m}^{2}$

$P_{\mathrm{w} 1}$ is partial pressure of water vapour on the film's underside, $\mathrm{Pa}$

$P_{\mathrm{w} 2}$ is partial pressure of water on the film's upper surface, $\mathrm{Pa}$

$L$ is film thickness, $m$.

\subsubsection{Tensile properties}

Mechanical performance of the films was studied according to ASTM standard method D882 [26]. A Universal Testing Machine (TA.XTplus model, Stable Micro Systems, Haslemere, England) was used to obtain the stress-strain curves of the samples. From these curves, tensile strength (TS), elastic modulus (EM), and percentage of elongation at break (\% E) of the films were obtained. Film samples $(2.5 \times 10 \mathrm{~cm})$ were placed in film-extension grips and stretched until breaking at $50 \mathrm{~mm} \mathrm{~min}^{-1}$. Measurements (eight replicates per formulation) were considered after film conditioning.

\subsubsection{Film water solubility}

Film solubility was determined in triplicate for each film sample by placing it in bidistilled water at a film:water ratio of 1:100 for $72 \mathrm{~h}$. Then, the film samples were dried in a convection oven (J.P. Selecta, S.A., Barcelona, Spain) for $24 \mathrm{~h}$ at $60{ }^{\circ} \mathrm{C}$ and finally dried in a vacuum oven to complete film drying. Solubility was expressed as the percentage of dissolved solid mass with respect to the total film solids.

\subsubsection{Water sorption isotherms}

Film samples were placed in a desiccator with $\mathrm{P}_{2} \mathrm{O}_{5}$ to complete drying. Afterwards, film samples, in triplicate, were placed at $25{ }^{\circ} \mathrm{C}$ in hermetic chambers containing saturated salt solutions with different water activity $\left(a_{\mathrm{w}}\right)$ : $\mathrm{LiCl}(0.11), \mathrm{CH}_{3} \mathrm{COO}_{2} \mathrm{~K}(0.23), \mathrm{MgCl}_{2}(0.33), \mathrm{K}_{2} \mathrm{CO}_{3}$ (0.43), $\mathrm{Mg}\left(\mathrm{NO}_{3}\right)_{2}$ (0.53), $\mathrm{CuCl}_{2}$ (0.68), $\mathrm{NaCl}$ (0.75), $\mathrm{KCl}$ (0.84). Samples were weighed periodically until constant weight $(\Delta m \approx 0.00001 \mathrm{~g})$, when the equilibrium was assumed [27]. Then, the equilibrium moisture content was determined by drying them in a vacuum oven at $60{ }^{\circ} \mathrm{C}$ and $6.7 \mathrm{KPa}$ for 2 days. The GAB model (Eq. (10)) [28] was applied to fit the sorption data by using a non-linear procedure with the solver tool of Microsoft Excel $2013^{\circledR}$.

$$
W_{e}=\frac{W_{0} \cdot C \cdot K \cdot a_{w}}{\left(1-K \cdot a_{w}\right) \cdot\left(1+(C-1) \cdot K \cdot a_{w}\right.}(10)
$$


Where $W_{\mathrm{e}}$ is the equilibrium moisture content on dry basis, $a_{\mathrm{w}}$ is water activity, $W_{0}$ is the monolayer moisture content, $C$ and $K$ are equation parameters, both being temperature dependent and related to the water sorption energy of the film.

\subsubsection{Differential scanning calorimetry (DSC)}

DSC analyses were carried out by using a differential scanning calorimeter (Star ${ }^{\mathrm{e}}$ System, Mettler-Toledo, Inc., Switzerland). Film samples $(7 \mathrm{mg}$ ) were weighed in aluminium pans and sealed. Samples were analysed using a double scan: a first heating step from $-60^{\circ} \mathrm{C}$ to $200{ }^{\circ} \mathrm{C}$ at $10{ }^{\circ} \mathrm{C} / \mathrm{min}$, then cooling to $-60{ }^{\circ} \mathrm{C}$ at $50{ }^{\circ} \mathrm{C} / \mathrm{min}$ and a second heating step at $10^{\circ} \mathrm{C} / \mathrm{min}$ to $200{ }^{\circ} \mathrm{C}$. An empty aluminium pan was used as reference. Measurements were taken in duplicate for each sample under a nitrogen stream of $20 \mathrm{~mL} / \mathrm{min}$. The crystallinity degree of the polymer in the films was estimated by using Eq. (11) from the melting enthalpy values $(\Delta \mathrm{H})$ of the samples (J/g PHBV) and the melting enthalpy of $100 \%$ crystalline $\mathrm{PHB}\left(\Delta \mathrm{H}^{0}{ }_{\mathrm{PHB}}=-132 \mathrm{~J} / \mathrm{g}\right.$ polymer) [29], by assuming that only PHB crystals are formed in PHBV.

$$
X C(\%)=\frac{\Delta H}{\Delta H_{P H B}^{0}} \cdot 100
$$

Pure plasticizers were also analysed in terms of their melting properties. Thus, a cooling scan at $10{ }^{\circ} \mathrm{C} / \mathrm{min}$, followed by $10 \mathrm{~min}$ at isothermal conditions $\left(10^{\circ} \mathrm{C}\right.$ below the melting temperature) and a subsequent heating scan at the same heating rate was applied.

\subsubsection{Thermogravimetric analysis (TGA)}

A thermogravimetric analyser (Star ${ }^{\mathrm{e}}$ System, Mettler-Toledo, Inc., Switzerland) was used to measure the thermal weight loss of each type of film in duplicate in a temperature range between $25^{\circ} \mathrm{C}$ and $600{ }^{\circ} \mathrm{C}$ at a heating speed of $10{ }^{\circ} \mathrm{C} / \mathrm{min}$ under a nitrogen stream of 20 $\mathrm{mL} / \mathrm{min}$.

\subsubsection{Statistical analysis}

Statgraphics Centurion XVI (Manugistics Corp., Rockville, MD) was used to carry out statistical analyses of data through analysis of variance (ANOVA). Fisher's least significant difference (LSD) was used at the $95 \%$ confidence level. 


\section{RESULTS AND DISCUSSION}

\subsection{Microstructure and thermal behaviour of plasticized and non-plasticized films.}

Figure 1 shows the SEM micrographs of the cross-sections of the different films. Nonplasticized PHBV films showed quite a homogeneous structure, exhibiting the typical brittle fracture in most of the observed areas, as previously reported by other authors [30]. Nevertheless, plastic deformation and a few threads of a deformed material are discernible on the fracture surface of plasticized films between the brittle zones, as has been described for semicrystalline polymers [31], which was promoted by the plasticizing effect of the amorphous regions in the films. Whereas no notable microstructural effect was observed when PEGs were incorporated to the films, the addition of fatty acids (LA and SA) enhanced the roughness of the surface fracture, thus indicating a different rearrangement of the polymer molecules due to the specific interactions with these less polar plasticizers. In all cases, brittle and plastic deformation regions were observed in the micrographs, with different frequency, depending on the observation area. This is typical of semicrystalline structures such as PHBV films.

To quantify the crystallinity degree in the different films, as affected by plasticizers, DSC analysis was carried out. Table 1 shows melting temperature $\left(T_{m}\right)$ and melting enthalpy $\left(\Delta H_{m}\right)$ of PHBV obtained from both first and second heating scans. The values of the first scan revealed the actual crystalline state of PHBV in the obtained thermo-compressed films, whereas for values of the second scan revealed that the thermal history was deleted. Crystallinity degree $\left(X_{c}\right)$ was determined from the melting enthalpy values of first heating step and are also shown in Table 1. As it has been previously observed for PHBV films plasticized with ATBC [10], plasticizers reduced the crystallization degree of the polymers while decreased melting temperature, without notable differences among the different compounds. Crystallization temperature $\left(T_{c}\right)$ and crystallization enthalpy $\left(\Delta H_{c}\right)$ of the polymer were also obtained from the cooling scan (Table 1 ). $\Delta H_{c}$ values were lower than the corresponding $\Delta \mathrm{H}_{\mathrm{m}}$ values, according to the supercooling effects. These values reflect the crystallization inhibition provoked by plasticizers (lower $\Delta H_{c}$ values in plasticized films). Plasticisers also decreased $T_{c}$ with respect to the pure polymer, although supercooling effects were similar in all cases; difference between $T_{c}$ and $T_{m}$ was $67^{\circ} \mathrm{C}$ for net PHVB vs. $72-75^{\circ} \mathrm{C}$ for most of the plasticized films, except for LA $\left(66^{\circ} \mathrm{C}\right)$. This also agrees with the PHBV crystallization inhibition induced by plasticizers. In general, the melting temperature reflected the lamella thickness [15]. The obtained results suggested that in all plasticized films thinner lamellae were obtained as compared to net PHBV. 

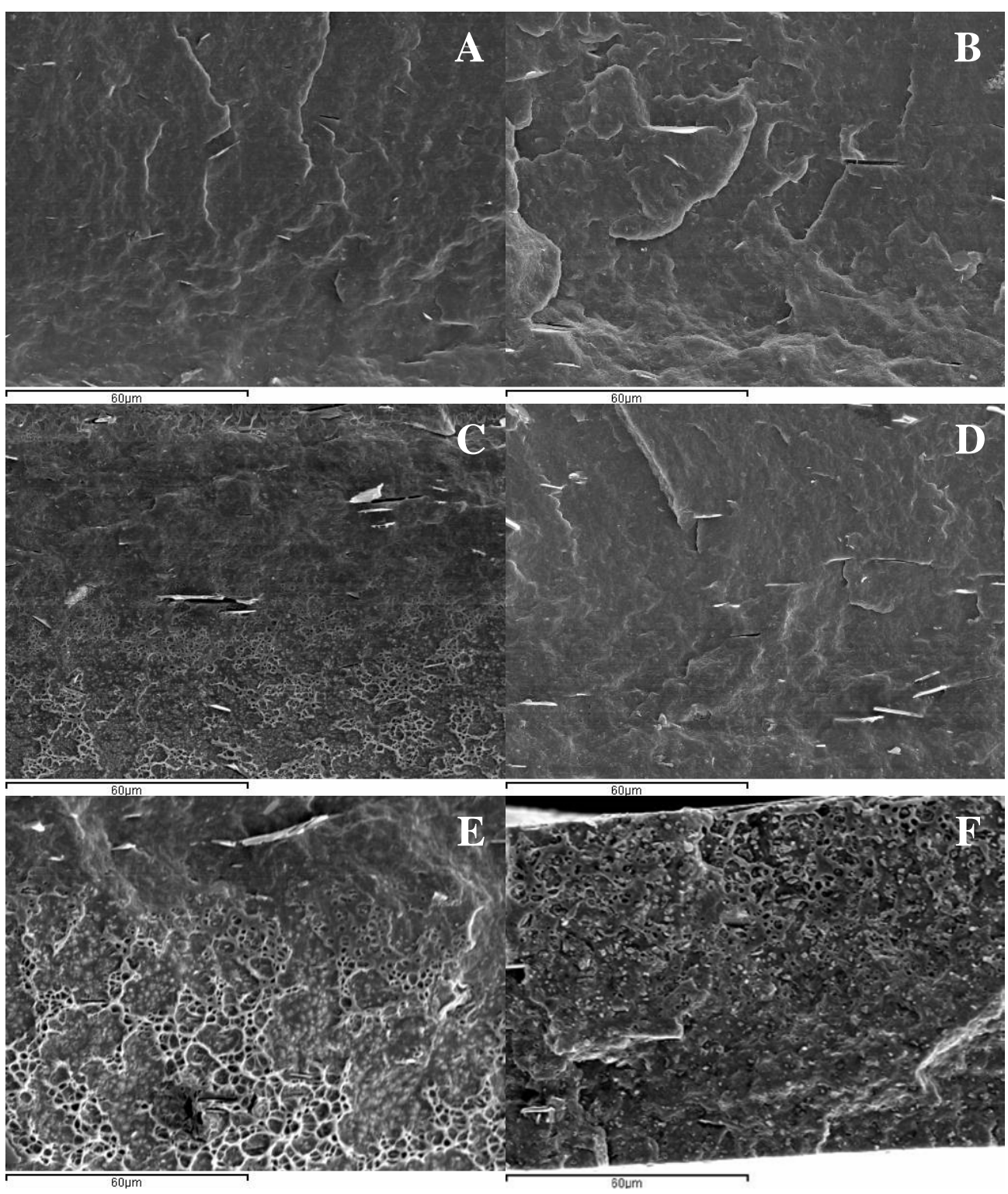

Figure 1. SEM images of the cross-sections of PHBV based films. A: pure PHBV, B: PHBV-PEG200, C: PHBV-PEG1000, D: PHBV-PEG4000, E: PHBV-LA, F: PHBV-SA.

Glass transition temperature $\left(\mathrm{T}_{\mathrm{g}}\right)$ of the amorphous phase of the polymer was also analysed in the first heating scan. All film formulations showed glass transition at $7{ }^{\circ} \mathrm{C}$, without significant differences between samples, which is not coherent with the expected effect of plasticizers in the amorphous phase [10]. This suggests a lack of integration of these compounds within the polymer amorphous region. In this sense, phase separation of plasticizers could lead to their crystallization in the films. In order to know their melting properties, DSC analysis was carried out and Table 2 shows the melting temperature and enthalpy obtained for pure plasticizers. In all cases, melting temperature was within the temperature range considered for the DSC analyses, except PEG200 which is liquid in the whole interval. Nevertheless, there was no PEG or LA crystallization in PHBV films as deduced 
from DSC curves (Figure 2), where the corresponding melting peaks were not observed. Therefore, no clear phase separation of these compounds in the films can be assumed. On the contrary, there was no complete integration of SA in the polymer matrix, since the DCS thermograms (Figure 2) exhibited a melting endotherm at $69{ }^{\circ} \mathrm{C}\left(\Delta \mathrm{H}_{\mathrm{m}}: 9.7 \mathrm{~J} / \mathrm{g}\right.$ film) attributed to SA melting. According to the enthalpy value, and taking into account both the melting enthalpy of totally crystallized SA $\left(\Delta \mathrm{H}_{\mathrm{m}}: 230 \mathrm{~J} / \mathrm{g}\right)$ and its mass fraction in the film, it was estimated that $42 \%$ of added SA was in crystalline form in the films, thus evidencing phase separation of this compound. After ageing for 5 weeks, a progress in SA crystallization was observed $\left(\Delta \mathrm{H}_{\mathrm{m}}=14.2 \mathrm{~J} / \mathrm{g}\right.$ film), which means a $62 \%$ of crystallization degree for SA in the films. This suggests that SA was not compatible with the PHBV matrix and that it is progressively separated, crystallizing in a different phase.

Table 2. Melting point $\left(T_{m}\right)$, melting enthalpy $\left(\Delta \mathrm{H}_{m}\right)$ of the pure plasticizers. Mean values \pm standard deviation.

\begin{tabular}{lcc}
\hline Plasticizer & $\mathbf{T}_{\mathrm{m}}\left({ }^{\circ} \mathrm{C}\right)$ & $\Delta \mathbf{H}_{\mathrm{m}}(\mathrm{J} / \mathrm{g})$ \\
\hline PEG200 & $-83.9 \pm 0.2$ & $21 \pm 2$ \\
PEG1000 & $35.4 \pm 0.3$ & $173 \pm 4$ \\
PEG4000 & $59.2 \pm 0.2$ & $206 \pm 5$ \\
LA & $43.8 \pm 0.4$ & $193 \pm 3$ \\
SA & $69.2 \pm 0.2$ & $230 \pm 3$ \\
\hline
\end{tabular}

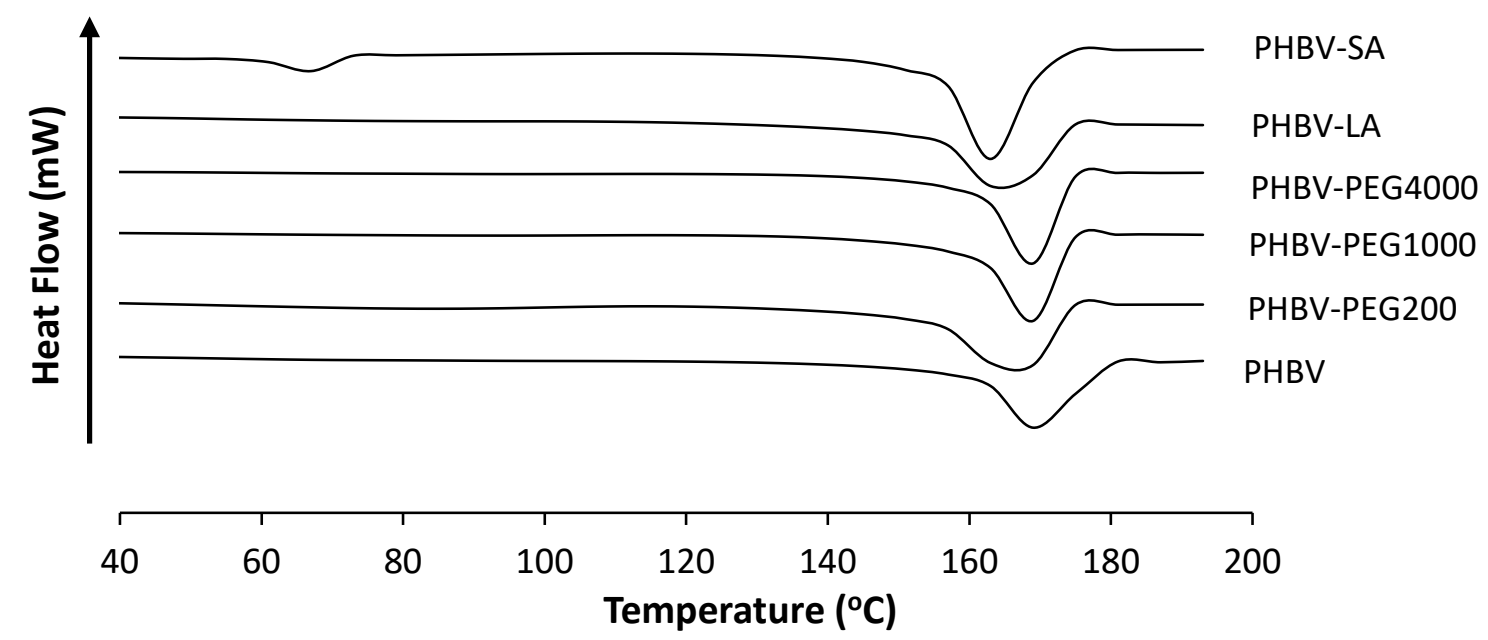

Figure 2. Thermograms for pure PHBV films and films containing $10 \%$ of plasticizer: PEG200, PEG1000, PEG4000, lauric acid (LA) and stearic acid (SA). 
The values of all PHVB crystallization/melting parameters after 5 weeks of storage were not included in Table 1 since there were not significant differences with respect to the initial values. Thus, no progress in crystallization of polymer throughout storage can be deduced neither in non-plasticized nor in plasticized PHBV. Fabra, López-Rubio [32] also observed that the post-processing time did not alter the $T_{m}$ or $X_{c}$, in PHBV-PEG1000 multilayer films. Branciforti, Corrêa [10], also reported similar behaviour for PHBV (18 \% HV) plasticized with ATBC, although changes in the crystalline forms occurred, as deduced from the changes in the wide-angle X-ray diffraction patterns. After 15 storage days, the mean size of the crystalline domains of the spherulites increased in plasticized films (recrystallization), although it was not associated with an increase in the crystalline volume fraction of the copolymer.

Incorporation of plasticizers slightly affected thermal degradation behaviour of PHBV films, as can be observed in Figure 3. The temperature values corresponding to the onset of decomposition ( $T_{\text {onset }}$ ) and to the maximum degradation rate ( $\left.T_{\text {peak }}\right)$ for the different film formulations are shown in Table 3. A significant decrease in both $T_{\text {onset }}$ and $T_{\text {peak }}$ of the films occurred for samples plasticized with PEG 200, LA and SA, whereas films plasticized with PEG1000 and 4000 exhibited similar temperature values to pure PHBV. A second degradation step at higher temperatures was observed in films with PEG1000 and 4000, as reported for commercial PHA matrices containing additives and plasticizers, which could be associated to the formation of degradation products involving both polymer and plasticizer, with different thermal behaviour.

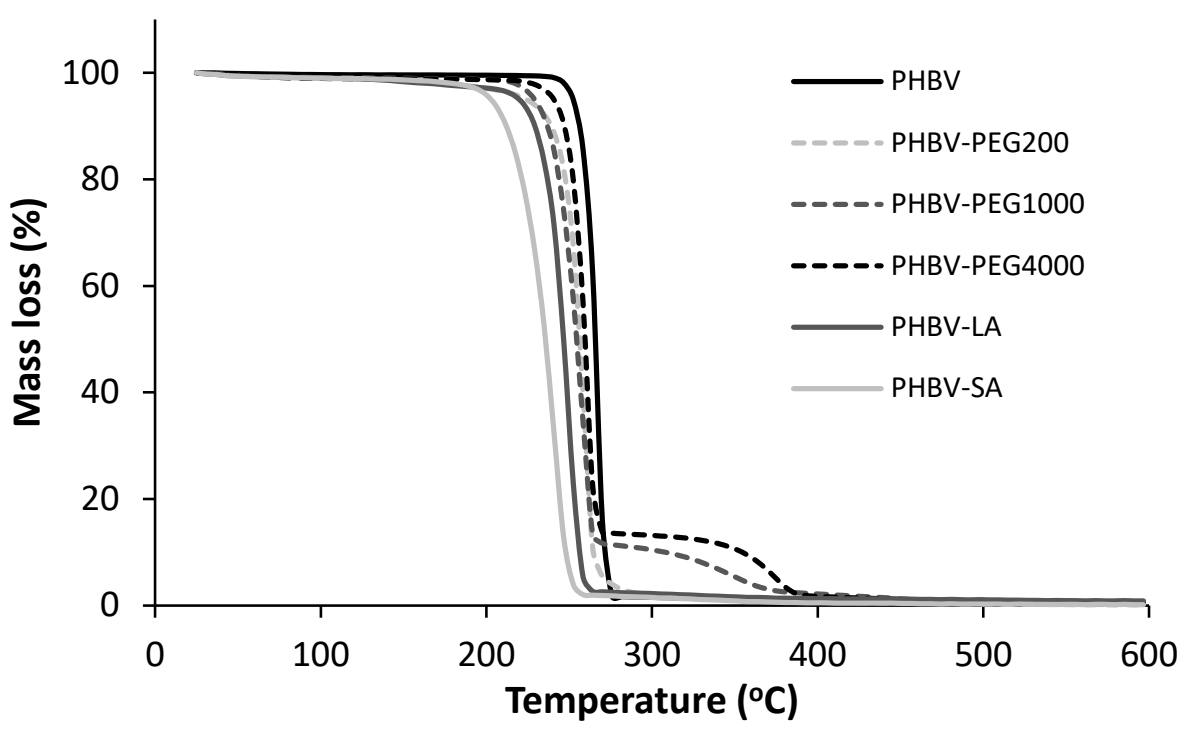

Figure 3. Thermogravimetric curves for pure PHBV films and containing $10 \%$ of plasticizer: PEG200, PEG1000, PEG4000, lauric acid (LA) and stearic acid (SA). 

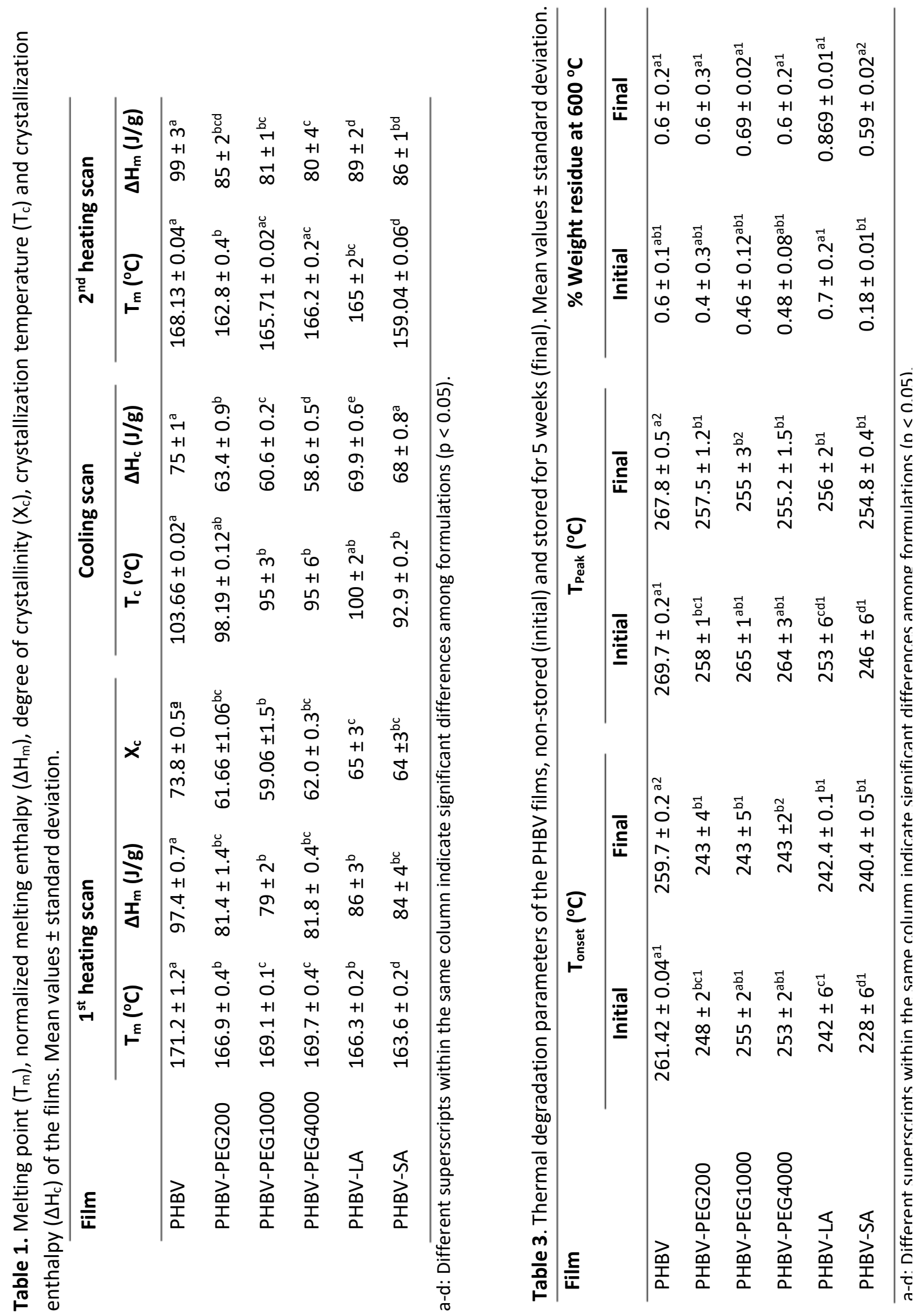


\subsection{Effect of plasticizers on tensile properties of the films}

Table 4 shows elastic modulus (EM), tensile strength (TS) and elongation at break (E\%) of pure PHBV films and the PHBV films containing plasticizers. Both EM and TS significantly decreased when LA and PEG of different molecular weights were added to the matrix, as previously observed for other plasticizers in PHBV matrices $[10,14,15]$. Nevertheless, SA enhanced the film's stiffness without notable reduction of its resistance to break. In terms of the elongation at break, PEG (especially PEG1000) was the only plasticizer that yielded more extensible films (32\% increment). The observed behaviour suggests that, although inter-chain forces were weakened by the incorporation of PEG or LA in the film, as deduced by the reported decrease in the film stiffness, not enough promotion of the film extensibility was obtained to extend the polymer applications to determined packaging requirements. The particular effect of SA could be explained by its crystallization in the films, which could contribute to the observed hardening effect; the films become more brittle, harder and less flexible.

Table 4. Elastic modulus (EM), tensile strength (TS) and elongation at break (E\%) of the PHBV films, non-stored (initial) and stored for 5 weeks (final). Mean values \pm standard deviation.

\begin{tabular}{|c|c|c|c|c|c|c|}
\hline \multirow[b]{2}{*}{ Film } & \multicolumn{2}{|c|}{ EM (MPa) } & \multicolumn{2}{|c|}{ TS (MPa) } & \multicolumn{2}{|c|}{$E(\%)$} \\
\hline & Initial & Final & Initial & Final & Initial & Final \\
\hline PHBV & $1690 \pm 90^{\mathrm{a} 1}$ & $1760 \pm 40^{a 1}$ & $37 \pm 3^{\mathrm{a} 1}$ & $35 \pm 2^{\mathrm{a} 1}$ & $3.4 \pm 0.3^{\mathrm{a} 1}$ & $2.5 \pm 0.2^{\mathrm{a} 2}$ \\
\hline PHBV-PEG200 & $1320 \pm 60^{\mathrm{b} 1}$ & $1500 \pm 60^{\mathrm{b} 2}$ & $27 \pm 2^{\mathrm{b} 1}$ & $27 \pm 2^{\mathrm{b} 1}$ & $3.7 \pm 0,6^{\mathrm{a} 1}$ & $2.9 \pm 0.2^{\mathrm{b} 2}$ \\
\hline PHBV-PEG1000 & $1260 \pm 70^{\mathrm{b} 1}$ & $1220 \pm 90^{c 1}$ & $26 \pm 2^{b 1}$ & $22 \pm 3^{\mathrm{c} 1}$ & $4.5 \pm 0.6^{\mathrm{b} 1}$ & $3.3 \pm 0.4^{\mathrm{c} 2}$ \\
\hline PHBV-PEG4000 & $1340 \pm 90^{b 1}$ & $1230 \pm 90^{c 2}$ & $26 \pm 2^{b 1}$ & $21 \pm 2^{c 2}$ & $3.7 \pm 0.2^{\mathrm{a} 1}$ & $2.8 \pm 0.2^{\mathrm{ab} 2}$ \\
\hline PHBV-LA & $1460 \pm 70^{d 1}$ & $1560 \pm 50^{\mathrm{b} 2}$ & $28 \pm 2^{\mathrm{b} 1}$ & $29 \pm 2^{\mathrm{b} 1}$ & $2.8 \pm 0.3^{\mathrm{c} 1}$ & $2.6 \pm 0.2^{\mathrm{a} 1}$ \\
\hline PHBV-SA & $1830 \pm 60^{c 1}$ & $1380 \pm 50^{d 2}$ & $33 \pm 2^{\mathrm{c} 1}$ & $22 \pm 2^{c 2}$ & $2.5 \pm 0.3^{\mathrm{c} 1}$ & $1.8 \pm 0.1^{\mathrm{d} 2}$ \\
\hline
\end{tabular}

a-d: Different superscripts within the same column indicate significant differences among formulations $(p<0.05)$. 1-2: Different superscripts within the same row indicate significant differences among non-stored and stored films $(p<0.05)$.

After 5 weeks of storage, practically all samples became harder and more brittle; EM increased while the elongation at break decreased, as observed by other authors in PHBV films $[2,10,11,13,30,33]$. These changes have been attributed to the secondary crystallization of the spherulites, although no notable increase in the crystallization degree has been observed [10], as previously commented on. The lack of adequate solubility of plasticizers in the polymer matrix could also contribute to the development of tensile properties throughout storage (progressive separation) as well as their relative low plasticization effect in terms of the 
promotion of film extension [14]. A greater solubility of plasticizer in PHBV would increase the film extensibility [15], whereas phase separation, due to low solubility, could promote film brittleness in line with the reduction of overall cohesion forces of the polymer network due to the matrix interruption.

\subsection{Effect of plasticizers on water affinity of the films}

Figure 4 shows the sorption isotherms at $25^{\circ} \mathrm{C}$ for pure PHBV films and for plasticized PHBV films. The sorption isotherm of pure PHBV films exhibited the typical shape of type III isotherms, where the equilibrium water content remained constant until water activity values of 0.7 , from which the water content sharply increased. The addition of the plasticizers, except for SA, increased the water sorption capacity of the PHBV matrices especially at $a_{w}$ values above 0.4. This behaviour is coherent with the higher hydrophilic character of PEG and LA, which enhanced the overall water affinity of the film matrix.

GAB model fits the experimental data accurately, as can be seen in Figure 4. The monolayer moisture contents $\left(W_{0}\right)$ of the plasticized films were significantly higher than that of pure PHBV films, especially for the different PEGs, although no changes occurred with SA, which did not notably modify the water affinity of the matrix.

Coherently with these results, the water solubility of the plasticized films increased with respect to the non-plasticized PHBV (Table 5). All of this revealed the different hydrophilichydrophobic balance of polymer and plasticizers, which also pointed to possible phase separation. No significant changes in the film solubility occurred after ageing for 5 weeks (values not included).

Likewise, the water vapour permeability (WVP) values of PHBV films (Table 5) notably increased in plasticized films, except for SA where no differences were observed. Pure PHBV films showed WVP values similar to those obtained by Corre, Bruzaud [2] for PHBV with $8 \%$ HV. The increase in the free volume of the polymeric structure, provoked by plasticisation, enhances diffusion rate of water molecules and then permeation rate [34]. Similarly, water solubility is also promoted in the more polar plasticized regions, which also contributes to the increase in permeability values. This effect was not expected for SA, according to its water affinity, and so, its addition did not induce changes in the WVP of the films. In PEG-containing films, WVP increased with the decrease in the molecular weight of the plasticizer, according to the greatest hydrophilic character of low molecular weight PEG. In general, the WVP of the films did not significantly change during film ageing, although some tendency to decrease was observed in plasticized films, which could be attributed to the rearrangement of the matrix components previously described, such as secondary crystallization or possible phase separation. 

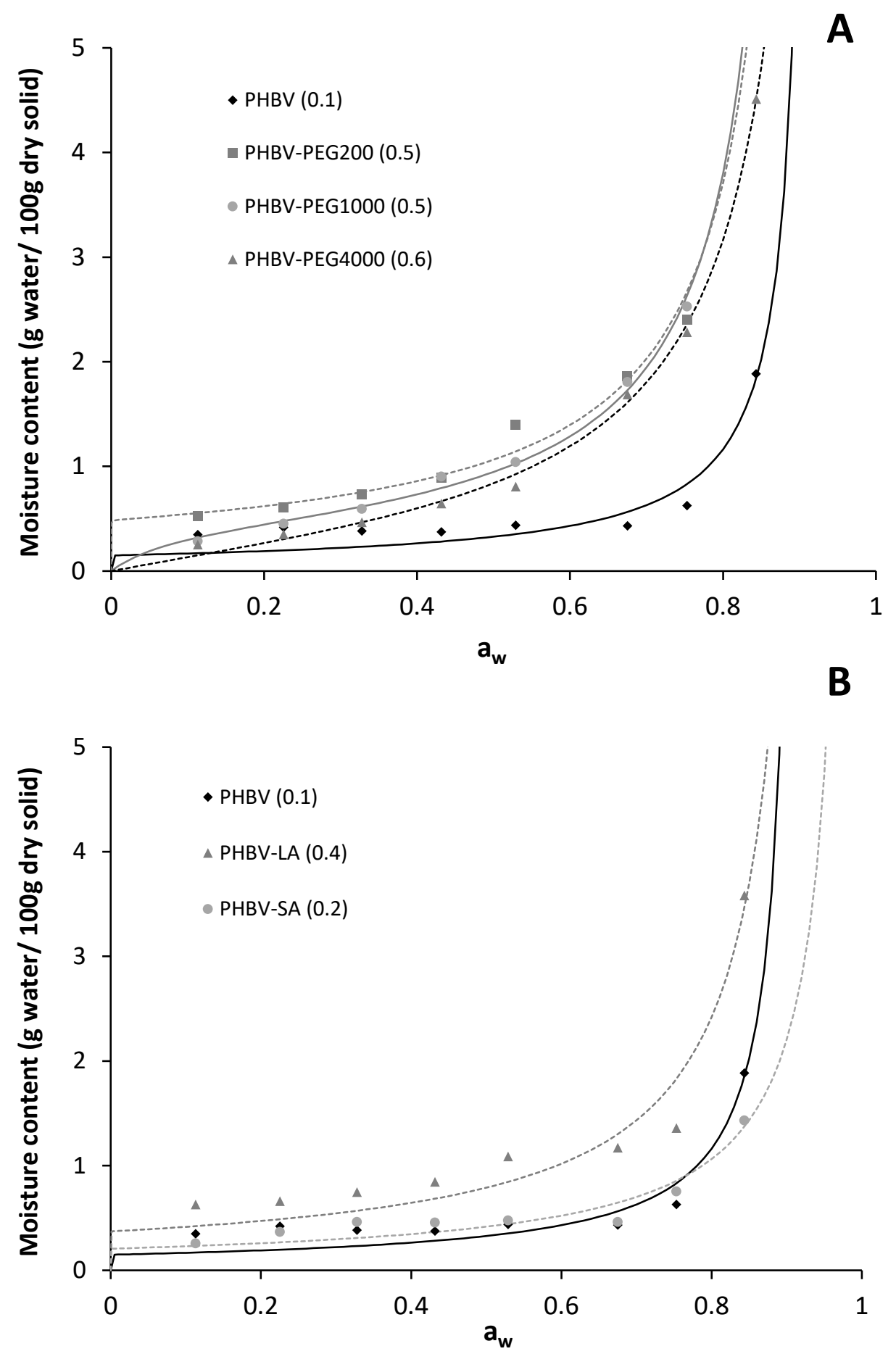

Figure 4. Water sorption isotherms of (A) pure PHBV film and PHBV films containing $10 \%$ of PEG200, PEG1000, PEG4000, and (B) control film and PHBV films containing $10 \%$ lauric acid (LA) and stearic acid (SA). Experimental points and GAB fitted model (lines). Values of the monolayer moisture content ( $W_{0}$, $\mathrm{g} / 100 \mathrm{~g}$ solids) are shown for each film in brackets. 
Table 5. Water vapour permeability (WVP) and solubility (mg solubilized film/g initial dried film) of the films, non-stored (initial) and stored for 5 weeks (final). Mean values \pm standard deviation.

\begin{tabular}{|c|c|c|c|}
\hline \multirow[b]{2}{*}{ Film } & \multicolumn{2}{|c|}{ WVP. $10^{12}(\mathrm{~g} / \mathrm{m} \cdot \mathrm{s} \cdot \mathrm{Pa})$} & \multirow{2}{*}{$\frac{\text { Solubility }(\mathrm{mg} / \mathrm{g})}{\text { Initial }}$} \\
\hline & Initial & Final & \\
\hline PHBV & $5.7 \pm 0.4^{\mathrm{a} 1}$ & $4.4 \pm 1.4^{\mathrm{a} 1}$ & $<0.001^{a}$ \\
\hline PHBV-PEG200 & $17 \pm 2^{\mathrm{b} 1}$ & $14.7 \pm 1.2^{\mathrm{b} 1}$ & $21.2 \pm 1.7^{b}$ \\
\hline PHBV-PEG1000 & $11.7 \pm 1.1^{\mathrm{c} 1}$ & $13 \pm 3^{\mathrm{b} 1}$ & $34.2 \pm 1.4^{c}$ \\
\hline PHBV-PEG4000 & $9.7 \pm 0.2^{\mathrm{d} 1}$ & $8.2 \pm 0.3^{\mathrm{c} 2}$ & $25 \pm 2^{d}$ \\
\hline PHBV-LA & $8.6 \pm 0.6^{\mathrm{d} 1}$ & $5.7 \pm 0.3^{\mathrm{a} 2}$ & $3.2 \pm 0.9^{e}$ \\
\hline PHBV-SA & $5 \pm 0.8^{\mathrm{a} 1}$ & $6.1 \pm 0.8^{\mathrm{a} 1}$ & $<0.001^{\mathrm{a}}$ \\
\hline
\end{tabular}

a-e: Different superscripts within the same column indicate significant differences among formulations $(p<0.05)$. 1-2: Different superscripts within the same raw indicate significant differences among non-stored and stored films $(p<0.05)$.

\subsection{Optical properties of plasticized and non-plasticized films}

Internal transmittance ( $\mathrm{Ti}$ ) of the films and colour parameters are shown in Table 6. High values of Ti are related with highly homogeneous and transparent films. The Ti values at 550 $\mathrm{nm}$ (the wavelength at which the highest differences were observed) evidenced that while films containing PEG or LA were more transparent than control films, and that the addition of SA significantly reduced the film's transparency. This agrees with the above mentioned crystallization of SA in the film, which promotes light dispersion with the corresponding increase in opacity. In agreement with the changes in the film's light transmission properties when plasticizers were incorporated, the colour parameters, lightness $\left(L^{*}\right)$, chroma $\left(C_{a b}{ }^{*}\right)$ and hue $\left(\mathrm{h}_{\mathrm{ab}}{ }^{*}\right)$, also changed. Nevertheless, the total colour differences $(\Delta \mathrm{E})$ were below 2.4 units, which are in the limit of the human eye perception [35]. Thus, these differences are not relevant to develop packaging materials. Optical parameters after 5 weeks of storage did not show significant differences with respect to the initial values and thus the values were not included.

Table 6. Internal transmittance at $550 \mathrm{~nm}(\mathrm{Ti})$, Lightness $\left(\mathrm{L}^{*}\right)$, Chroma $\left(\mathrm{C}_{\mathrm{ab}}{ }^{*}\right)$, hue $\left(\mathrm{h}_{\mathrm{ab}}{ }^{*}\right)$ and Colour difference $(\Delta \mathrm{E})$ of the plasticized films with respect to pure PHBV films. Mean values \pm standard deviation.

\begin{tabular}{lccccc}
\hline Film & Ti $550 \mathbf{n m}$ & L $^{*}$ & C $^{*}$ & $\mathbf{h}^{*}$ & $\mathbf{\Delta E}$ \\
\hline PHBV & $65.2 \pm 2.4^{\mathrm{a}}$ & $77.2 \pm 0.3^{\mathrm{a}}$ & $19.2 \pm 0.4^{\mathrm{a}}$ & $82.7 \pm 0.2^{\mathrm{a}}$ & - \\
PHBV-PEG200 & $68.4 \pm 0.9^{\mathrm{b}}$ & $75.1 \pm 0.2^{\mathrm{b}}$ & $20.4 \pm 0.2^{\mathrm{b}}$ & $80.7 \pm 0.13^{\mathrm{b}}$ & 2.5 \\
PHBV-PEG1000 & $67.9 \pm 0.5^{\mathrm{b}}$ & $76.3 \pm 0.2^{\mathrm{c}}$ & $20.3 \pm 0.2^{\mathrm{b}}$ & $80.9 \pm 0.14^{\mathrm{bc}}$ & 1.5 \\
PHBV-PEG4000 & $66.7 \pm 0.6^{\mathrm{ab}}$ & $76,1 \pm 0.2^{\mathrm{c}}$ & $20.1 \pm 0.2^{\mathrm{b}}$ & $81.1 \pm 0.2^{\mathrm{c}}$ & 1.6 \\
PHBV-LA & $66.6 \pm 0,9^{\mathrm{ab}}$ & $77.02 \pm 0.07^{\mathrm{a}}$ & $18.9 \pm 0.11^{\mathrm{a}}$ & $82.8 \pm 0.11^{\mathrm{a}}$ & 0.3 \\
PHBV-SA & $63 \pm 0.8^{\mathrm{c}}$ & $78.6 \pm 0.4^{\mathrm{d}}$ & $18.1 \pm 0.3^{\mathrm{c}}$ & $83.7 \pm 0.3^{\mathrm{d}}$ & 1.8 \\
\hline
\end{tabular}

a-d: Different superscripts within the same column indicate significant differences among formulations $(p<0.05)$. 


\section{CONCLUSIONS}

The used plasticizers led to apparently homogeneous PHBV-based matrices, as supported by DSC analyses, but crystallization of SA in the films occurred. Although the addition of PEG and LA significantly decreased the stiffness and the resistance to break of PHBV films, only PEG1000 yielded more extensible films. PEG1000 was also the only plasticizer that partially mitigated ageing effects. All plasticizers, except SA, increased the water affinity of the films, promoting an increase in WVP and water solubility. All plasticizers slightly decreased the thermal stability of the films. PEG1000 and PEG4000 gave rise to the most heat-resistant plasticized films while LA and SA highly promoted the heat-sensitivity of PHBV. Among the studied compounds, PEG1000 was the most effective at plasticizing PHBV films, although a greater ratio would be required to adapt PHBV mechanical properties to certain packaging requirements.

\section{Acknowledgements}

The authors thank the Ministerio de Economía y Competitividad - Government of Spain for the financial support provided through AGL2013-42989-R Project. Author Raquel Requena thanks the Ministry of Education, Cultura and Sport - Government of Spain for a FPU Grant. 


\section{REFERENCES}

[1] G.Q. Chen, M.K. Patel, Plastics derived from biological sources: present and future: a technical and environmental review, Chem. Rev. 112 (4) (2011), p. 2082.

[2] Y.M. Corre, S. Bruzaud, J.L. Audic, Y. Grohens, Morphology and functional properties of commercial polyhydroxyalkanoates: a comprehensive and comparative study, Polym. Test. 31 (2) (2012), p. 226.

[3] L. Jiang, J. Zhang, Biodegradable polymers and polymer blends. In Handbook of Biopolymers and Biodegradable Plastics: Properties, Processing and Applications (2012), pp. 109-128.

[4] I. Chodak, Polyhydroxyalkanoates: origin, properties and applications. In Monomers, Polymers and Composites from Renewable Resources (2008), pp. 451-477.

[5] S. Chardron, S. Bruzaud, B. Lignot, A. Elain, O. Sire, Characterization of bionanocomposites based on medium chain length polyhydroxyalkanoates synthesized by Pseudomonas oleovorans, Polym. Test. 29 (8) (2010), p. 966.

[6] S. Philip, T. Keshavarz, I. Roy, Polyhydroxyalkanoates: biodegradable polymers with a range of applications, J. Chem. Technol. Biot. 82 (3) (2007), p. 233..

[7] P.A. Holmes, Biologically produced (R)-3-hydroxy-alkanoate polymers and copolymers. In Developments in crystalline polymers, Springer, Netherlands (1988), pp. 1-65

[8] M. Hakkarainen, Aliphatic polyesters: abiotic and biotic degradation and degradation products. In Degradable Aliphatic Polyesters, Springer, Heidelberg, Berlin (2002), pp. 113-138

[9] H. Alata, T. Aoyama, Y. Inoue, Effect of aging on the mechanical properties of poly (3hydroxybutyrate-co-3-hydroxyhexanoate), Macromolecules 40 (13) (2007), p. 4546.

[10] M. C. Branciforti, M. C. S. Corrêa, E. Pollet, J. A. M. Agnelli, P. A. de Paula Nascente, L. Avérous, Crystallinity study of nano-biocomposites based on plasticized poly (hydroxybutyrate-cohydroxyvalerate) with organo-modified montmorillonite. Polym. Test. 32(7) (2013), p. 1253.

[11] A. El-Hadi, R. Schnabel, E. Straube, G. Müller, S. Henning, Correlation between degree of crystallinity, morphology, glass temperature, mechanical properties and biodegradation of poly (3hydroxyalkanoate) PHAs and their blends, Polym. Test. 21(6) (2002), p. 665.

[12] R.S. Kurusu, C.A. Siliki, É. David, N.R. Demarquette, C. Gauthier, J. M. Chenal, Incorporation of plasticizers in sugarcane-based poly (3-hydroxybutyrate) (PHB): Changes in microstructure and properties through ageing and annealing, Ind. Crop. Prod. 72 (2015), p. 166.

[13] L. Savenkova, Z. Gercberga, I. Bibers, M. Kalnin, Effect of 3-hydroxy valerate content on some physical and mechanical properties of polyhydroxyalkanoates produced by Azotobacter chroococcum, Process Biochem. 36(5) (2000), p. 445.

[14] V. Jost, H. C. Langowski, Effect of different plasticisers on the mechanical and barrier properties of extruded cast PHBV films, Eur. Polym. J. 68 (2015), p. 302. 
[15] J.S. Choi, W.H. Park, Effect of biodegradable plasticizers on thermal and mechanical properties of poly (3-hydroxybutyrate). Polym. Test. 23 (4) (2004), p. 455.

[16] D. K. Solaiman, R. D. Ashby, J.A. Zerkowski, A. Krishnama, N. Vasanthan, Control-release of antimicrobial sophorolipid employing different biopolymer matrices. Biocatalysis and Agricultural Biotechnology, 4 (3) (2005), p. 342.

[17] M. Baiardo, G. Frisoni, M. Scandola, M. Rimelen, D. Lips, K. Ruffieux, E. Wintermantel, Thermal and mechanical properties of plasticized poly (L-lactic acid), J. Appl. Polym. Sci. 90 (7) (2003), p. 1731.

[18] N. Cao, X. Yang, Y. Fu, Effects of various plasticizers on mechanical and water vapor barrier properties of gelatin films., Food Hydrocolloid, 23 (3) (2009), p. 729.

[19] R. Sothornvit, J.M. Krochta, Plasticizer effect on mechanical properties of $\beta$-lactoglobulin films, J. Food Eng. 50 (3) (2001), p. 149.

[20] L.C Bertan, P.S. Tanada-Palmu, A.C. Siani, C.R.F. Grosso, Effect of fatty acids and 'Brazilian elemi' on composite films based on gelatin, Food Hydrocolloid, 19 (1) (2005), p. 73.

[21] F.X. Budi Santosa, G.W. Padua, Tensile properties and water absorption of zein sheets plasticized with oleic and linoleic acids, J. Agr. Food Chem. 47 (5) (1999), p. 2070.

[22] M. Pommet, A. Redl, M.H. Morel, S. Guilbert, Study of wheat gluten plasticization with fatty acids, Polymer, 44 (1) (2003), p. 115.

[23] J.B. Hutchings, Food and colour appearance, Chapman and Hall food Science Book, second ed., Aspen Publication, Gaithersburg, MD (1999).

[24] ASTM. Standard test method for water vapour transmission of materials, in Standards Designations: E96-95, Annual Book of American Standard Testing Methods, American Society for Testing and Materials, Philadelphia, PA (1995), pp. 406-413.

[25] M. Vargas, A. Albors, A. Chiralt, C. González-Martínez, Water interactions and microstructure of chitosan-methylcellulose composite films as affected by ionic concentration, LWT-Food Sci. Technol. 44 (10) (2011), p. 2290.

[26] ASTM, Standard test method for tensile properties of thin plastic sheeting, in Standard D882, Annual Book of American Standard Testing Methods, American Society for Testing and Materials, Philadelphia, PA (2011), pp. 162-170.

[27] W.E.L. Spiess, W.R. Wolf, Results of the COST 90 Project on water activity in: Jowitt, R., Escher, F., Hallstrom, B., Meffert, H.F.Th., Spiess, W.E.L., Vos, G. (Eds.), Physical Properties of Foods, Applied Science Publishers, London and New York, (1983), pp 65-91.

[28] C. Van Den Berg, Description of water activity of foods for engineering purposes by means of the GAB model of sorption in: B.M. McKenna (Ed.), Engineering and food, Elsevier Applied Science Publishers, London (1984), pp. 311-321. 
[29] O. Miguel, J.L. Egiburu, J.J. Iruin, Blends of bacterial poly (3-hydroxybutyrate) with synthetic poly (3-hydroxybutyrate) and poly (epichlorohydrin): transport properties of carbon dioxide and water vapour, Polymer. 42 (3) (2001), p. 953.

[30] M.J. Fabra, G. Sánchez, A. López-Rubio, J.M. Lagaron, Microbiological and ageing performance of polyhydroxyalkanoate-based multilayer structures of interest in food packaging, LWT-Food Sci. Technol. 59 (2) (2014), p. 760.

[31] K. Sungsanit, N. Kao, S.N. Bhattacharya, Properties of linear poly (lactic acid)/polyethylene glycol blends, Polym. Eng. Sci. 52 (1) (2012), p. 108.

[32] M.J. Fabra, A. Lopez-Rubio, J.M. Lagaron, Nanostructured interlayers of zein to improve the barrier properties of high barrier polyhydroxyalkanoates and other polyesters, J. Food Eng. 127 (2014), p. 1.

[33] W.V. Srubar, Z.C. Wright, A. Tsui, A.T. Michel, S.L. Billington, C.W. Frank, Characterizing the effects of ambient aging on the mechanical and physical properties of two commercially available bacterial thermoplastics. Polym. Degrad. Stabil. 97 (10) (2012), p. 1922.

[34] G. Wypych, Handbook of plasticizers, ChemTec Publishing, Ontario, Canada, 2004.

[35] M. Mahy, L. Eycken, A. Oosterlinck, Evaluation of uniform color spaces developed after the adoption of CIELAB and CIELUV, Color Res. App. 19 (2) (1994), p. 105. 


\section{Poly[(3-hydroxybutyrate)-co-(3-hydroxyvalerate)] active bilayer films obtained by compression moulding and applying essential oils at the interface}

Raquel Requena; Alberto Jiménez; María Vargas; Amparo Chiralt

Polymer International (2016) 65, 883-891

Institute of Food Engineering for Development, Universitat Politècnica de València, Valencia, Spain 



\section{ABSTRACT}

Four active components, oregano essential oil (OR) and its respective main compound carvacrol (CA) and clove essential oil (CLO) and its respective main compound eugenol (EU), were used separately to obtain, using compression moulding, poly[(3-hydroxybutyrate)-co-(3hydroxyvalerate)] (PHBV) bilayer films with antimicrobial activity. The active compounds were sprayed (13\% w/w, polymer to active compound ratio) at the interface between two layers of PHBV, which were joined using thermo-compression. Tensile, barrier and optical properties, as well as thermal behaviour, of the films were characterized after one week at $25^{\circ} \mathrm{C}$ and 53 $\%$ relative humidity. Likewise, the antimicrobial activity of the films was evaluated against Escherichia coli and Listeria innocua. Although the tensile properties of the films were not improved with respect to pure PHBV films by the addition of the active compounds, more transparent materials with better water vapour barrier capacity were obtained. Thermogravimetric analyses showed that CA and EU slightly decreased the polymer thermal stability, while OR and CLO led to more thermally resistant material. Miscibility of actives with the polymer was assessed through the promoted decrease in melting temperature and degree of crystallinity. PHBV films allowed the release of the active compounds in adequate amounts and at adequate rates into culture media to control the microbial growth of the two tested bacteria. The films were significantly more effective against $E$. coli than against $L$. innocua. Both bacteria were more sensitive to $O R$ and to its main compound, $C A$, due to the greater antimicrobial effectiveness of these components.

Keywords: poly[(3-hydroxybutyrate)-co-(3-hydroxyvalerate)] (PHBV); carvacrol; eugenol; oregano; clove; Listeria innocua; Escherichia coli; antimicrobial. 


\section{INTRODUCTION}

The packaging industry is the main consumer of plastic materials, most of them oil-based. In this context, the food sector is the main producer of packaging waste, since packaging plays an essential role in the transport and preservation of food. Nevertheless, the increasing concern about the environmental impact generated by packaging waste has promoted the search for biodegradable alternatives. ${ }^{1,2}$ One of the promising options in biomaterial development for packaging are polyhydroxyalkanoates (PHAs), which are completely biodegradable linear polyesters that are produced by bacteria. ${ }^{3}$ These biopolymers can be synthetized from renewable resources such as sucrose, starch, cellulose, etc. ${ }^{1}$ Within this large family of PHAs, poly(3-hydroxybutyrate) is the most studied, since it shows properties similar to those of some synthetic thermoplastic polymers such as polypropylene. ${ }^{4}$ However, the high crystallinity of its structure makes it yield rigid and brittle materials, thus limiting its application range. ${ }^{5,6}$ In order to solve these drawbacks, copolymers such as poly[(3hydroxybutyrate)-co-(3-hydroxyvalerate)] (PHBV) have been developed. ${ }^{7,8}$

In order to compensate for the drawbacks of biodegradable materials in comparison to conventional synthetic packaging systems, an increased functionality of the former is required. In this regard, biodegradable films with antioxidant and antimicrobial properties have the advantage of reducing or inhibiting the microbial growth and the oxidative processes in foods. ${ }^{9}$ Natural compounds used in the formulation of biodegradable films, such as essential oils (EOs), have shown antioxidant and antimicrobial activity and have been recognized as safe by the US Food and Drug Administration. ${ }^{10,11}$ EOs are oily, aromatic and volatile liquids of complex composition with two or three major components, which can represent up to $85 \%$ of the total. There are other minor components present in trace amounts. ${ }^{12-14}$ Oregano essential oil (OR) and clove essential oil (CLO) are among the most effective EOs in controlling microbial growth. ${ }^{15}$ The antimicrobial activity of these oils is mainly attributed to their major components, carvacrol (CA) and eugenol (EU), respectively. ${ }^{13}$ Nevertheless, some studies have concluded that the whole EO has greater antibacterial activity than the mixture of its major components, ${ }^{16,17}$ which suggests that the minor components are critical for the activity and may have a synergistic or potentiating effect. ${ }^{13}$

The incorporation of EOs as active compounds in biodegradable films involves high losses of volatiles when the films are made, both in extension and drying of the film-forming dispersions (casting), as in the thermo-processing (extrusion or melt blending). The incorporation of EOs by spraying them on one side of a film and the subsequent thermo-compression of two films, obtaining a bilayer film with the active compounds at the interface, could be an appropriate strategy for improving the process of obtaining such films. In this way, the release of the active compounds would occur progressively from the package to the food surface or to the headspace of the packaging. This approach would avoid the direct application of the active compounds on the food, which has been previously found to have serious drawbacks. ${ }^{18}$ 
The aim of the work presented here was to develop bilayer PHBV films incorporating OR or $\mathrm{CLO}$ and their major components, CA or EU. The resulting films were evaluated for their antimicrobial and functional properties

\section{MATERIALS AND METHODS}

\subsection{Materials}

Poly(3-hydroxybutyrate-co-3-hydroxyvalerate) (PHBV) with $8 \%$ of hydroxyvalerate (HV) content was provided in pellet form by NaturePlast (Caen, France). OR and CLO were obtained from Herbes del Molí (Alicante, Spain). Poly(ethylene glycol) 1000 (PEG1000), used to plasticize the polymer, CA, EU and UV methanol were supplied by Sigma-Aldrich (Steinheim, Germany).

\subsection{Preparation of films}

\subsubsection{Preparation of PHBV films}

PHBV films were obtained by compression moulding. To this end, PHBV was mixed with $10 \%$ (w/w) PEG1000 in a two-roll mill (LRM-M-100, Labtech Engineering, Thailand) at $180{ }^{\circ} \mathrm{C}$ and $15 \mathrm{rpm}$ for $10 \mathrm{~min}$. Afterwards, the pellets were compression-moulded using a hydraulic press (LP20, Labtech Engineering, Thailand). Then, $3.5 \mathrm{~g}$ of pellets was put onto steel sheets and preheated on the heating unit for $5 \mathrm{~min}$. Next, compression was performed at $160{ }^{\circ} \mathrm{C}$ for $4 \mathrm{~min}$ at $10 \mathrm{MPa}$ followed by a cooling cycle of $3 \mathrm{~min}$.

\subsubsection{Incorporation of active compounds into bilayer structures}

The obtained PHBV monolayers were sprayed with a constant amount of active compound (OR, CLO, CA, EU) of $13 \%(\mathrm{w} / \mathrm{w})$ with respect to the polymer matrix (polymer plus plasticizer) and were covered with another monolayer. Finally, in order to obtain bilayer films, the ensemble monolayers were compressed at $160{ }^{\circ} \mathrm{C}$ for $2 \mathrm{~min}$ at a pressure of $7 \mathrm{MPa}$ followed by a cooling cycle of $3 \mathrm{~min}$. Thus, five kinds of films were obtained: pure polymer bilayer films without active compounds (PHBV), as a control, and films with active compounds (PHBV-CA, PHBV-EU, PHBV-OR, PHBV-CLO). 


\subsection{Film characterization}

\subsubsection{Retention of active compounds}

Quantification of the active compound retention in the films was carried out using two different methods. The first was to weigh the film before and after the pressing process. Thus, the retention percentage can be estimated by the difference in weight. The second was to extract the active compound with UV methanol, followed by spectrophotometric quantification using a UV-visible spectrophotometer (Evolution 201, Thermo Scientific). This was performed to determine the retention percentage in PHBV bilayer films with pure CA or EU. To this end, film samples of $100 \mathrm{mg}$ were cut in strips, as thin as possible to promote the total release of the active compounds from the polymer matrix. The strips were placed in flasks with $10 \mathrm{~mL}$ of UV methanol, which were kept stirring at $20{ }^{\circ} \mathrm{C}$ for $24 \mathrm{~h}$. After that, samples were filtered and appropriately diluted to obtain absorbance values between 0.2 and 0.8. Then, CA and EU were quantified through absorbance measurements at 275 and $282 \mathrm{~nm}$, respectively. In order to ensure total extraction of active compounds, the solvent was replaced by new solvent after $24 \mathrm{~h}$, and samples were kept stirring at $20^{\circ} \mathrm{C}$ for $72 \mathrm{~h}$ more. Then, samples were analysed spectrophotometrically in the same way. PHBV bilayer films without active compounds were also submitted to the same extraction procedure in order to use their methanol extract as blank solution. Measurements were taken in quintuplicate per formulation and all absorbance measurements were taken in triplicate. Standard calibration curves for CA and EU were obtained to determine their concentration from the absorbance values by using an initial solution with $500 \mu \mathrm{g} \cdot \mathrm{mL}^{-1}$ and subsequent dilutions.

\subsubsection{Scanning electron microscopy (SEM)}

Microstructure of cross-sections of the films was observed using SEM (JEOL JSM-5410, Japan). Film samples were cryofractured by immersion in liquid nitrogen, fixed on copper stubs and gold coated. Then the images were captured using an accelerating voltage of $10 \mathrm{kV}$.

\subsubsection{Optical properties}

The surface reflectance spectra of the films was determined from 400 to $700 \mathrm{~nm}$ using a spectro-colorimeter (CM-3600d, Minolta Co., Tokyo, Japan). The measurements were taken in duplicate in three films of each formulation. Transparency of the films was evaluated by applying the Kubelka-Munk theory for multiple scattering to the reflection spectra (Eq. (13)): ${ }^{19}$ 
$a=\frac{1}{2} \cdot\left(R+\frac{R_{0}-R+R_{g}}{R_{0} \cdot R_{g}}\right)$

$b=\left(a^{2}-1\right)^{\frac{1}{2}}$

$T_{i}=\sqrt{\left(a-R_{0}\right)^{2}}-b^{2}$

Where $R_{0}$ is the reflectance of the film on an ideal black background and $R$ is the reflectance of the sample layer backed by a known reflectance $\left(R_{\mathrm{g}}\right)$.

The reflectance of an infinitely thick layer of the material $\left(R_{\infty}\right)$ was calculated by means of Eq. (4), in order to obtain the colour coordinates: lightness $\left(L^{*}\right)$, chroma (Cab*) and hue (hab*) using illuminant D65 and $10^{\circ}$ observer.

$$
\begin{aligned}
& R_{\infty}=a-b \\
& C_{a b}^{*}=\sqrt{\left(a^{* 2}+b^{* 2}\right)} \\
& h_{a b}^{*}=\operatorname{arctg}\left(\frac{b^{*}}{a^{*}}\right)
\end{aligned}
$$

Moreover, to evaluate the colour differences between the various films and the control film (PHBV), the following equation was used:

$$
\Delta E=\sqrt{\left(\Delta L^{*}\right)^{2}+\left(\Delta a^{*}\right)^{2}+\left(\Delta b^{*}\right)^{2}}
$$

\subsubsection{Tensile properties}

Tensile properties of the films were evaluated using a universal testing machine (TA.XTplus model, Stable Micro Systems, Haslemere, UK) according to ASTM D882 standard method. ${ }^{20}$ The typical mechanical parameters used in this kind of analysis, tensile strength (TS), elastic modulus (EM) and elongation at break $(E)$, were obtained from the stress-strain curves of the various samples. To this end, film strips $(2.5 \mathrm{~cm} \times 10 \mathrm{~cm})$ were placed in film-extension grips and stretched until breaking at $50 \mathrm{~mm} \cdot \mathrm{min}^{-1}$. Measurements were taken in eight replicates per formulation in films conditioned at $25{ }^{\circ} \mathrm{C}$ and $53 \%$ relative humidity (RH) for one week. 


\subsubsection{Water vapour permeability (WVP)}

The WVP was determined in quadruplicate in films conditioned at $25^{\circ} \mathrm{C}$ and $53 \% \mathrm{RH}$ for one week, according to gravimetric method ASTM E-96-95. ${ }^{21}$ For this purpose, the film samples were placed on Payne permeability cups $(3.5 \mathrm{~cm}$ in diameter, Elcometer SPRL, Hermelle/s Argenteau, Belgium) with distilled water inside to get $100 \% \mathrm{RH}$ on one side of the film. Each cup was placed in a desiccator at $25{ }^{\circ} \mathrm{C}$ with an oversaturated solution of magnesium nitrate (53\% RH). In order to reduce the resistance to transport of water vapour, a fan was placed above each cup. The cups were weighed periodically over four days and the WVP was calculated from the slopes of the curves of weight loss versus time. ${ }^{22}$

\subsubsection{Thermal properties}

A thermogravimetric analyser (StareSystem, Mettler Toledo Inc., Switzerland) was used to evaluate the thermal stability of the various types of films. Measurements of the thermal weight loss of each type of film were performed in duplicate in a temperature range between 25 and $600^{\circ} \mathrm{C}$ at a heating speed of $10^{\circ} \mathrm{C} \cdot \mathrm{min}^{-1}$ under a nitrogen stream of $20 \mathrm{~mL} \mathrm{~min}{ }^{-1}$.

DSC analyses were performed with a differential scanning calorimeter (Stare System, Mettler Toledo Inc., Switzerland). Film samples (ca $10 \mathrm{mg}$ ) were weighed, placed into aluminium pans and analysed using a multiple scan. Firstly, a scan was conducted from 25 to $-60^{\circ} \mathrm{C}$ at a rate of $10{ }^{\circ} \mathrm{C} \cdot \mathrm{min}^{-1}$. Then, samples were heated to $200{ }^{\circ} \mathrm{C}$ and cooled to $-60{ }^{\circ} \mathrm{C}$ at the same rate. Lastly, a second heating scan was performed $\left(10^{\circ} \mathrm{C} \cdot \mathrm{min}^{-1}\right)$. All measurements were taken in duplicate under a nitrogen stream of $20 \mathrm{~mL} \mathrm{~min}^{-1}$.

The sample crystallinity was calculated from the enthalpy of melting of $100 \%$ crystalline poly(3-hydroxybutyrate) $\left(\Delta H_{\mathrm{PHB}}^{0}=-132 \mathrm{~J} \cdot \mathrm{g}^{-1} \text { polymer }\right)^{23,24}$ and the measured melting enthalpy of the various samples $(\Delta H)$ :

$X_{C}(\%)=\left(\Delta \mathrm{H} / \Delta H_{P H B}^{0}\right) \times 100(8)$

\subsubsection{Antimicrobial activity}

The methodology followed for the determination of the antimicrobial activity of the films was adapted from Jiménez et al. ${ }^{25}$ Listeria innocua (CECT 910) and Escherichia coli (CECT 101) were supplied by the Spanish Type Culture Collection (CECT, Burjassot, Spain). These bacterial cultures were regenerated (from a culture stored at $-25^{\circ} \mathrm{C}$ ) by transferring a loopful into 10 $\mathrm{mL}$ of tryptone soy broth (TSB; Scharlab, Barcelona, Spain) and incubating at $37^{\circ} \mathrm{C}$ for $24 \mathrm{~h}$. From this culture, a $10 \mu \mathrm{L}$ aliquot was again transferred into $10 \mathrm{~mL}$ of TSB and grown at $37{ }^{\circ} \mathrm{C}$ 
for $24 \mathrm{~h}$ more in order to obtain a culture in exponential phase of growth. Afterwards, this bacterial culture was appropriately diluted in TSB tubes to get a target inoculum of $10^{5}$ $\mathrm{CFU} \cdot \mathrm{mL}^{-1}$. Circular samples of $55 \mathrm{~mm}$ in diameter, obtained from the various film formulations, were placed in inoculated tubes and incubated for 13 days at $10^{\circ} \mathrm{C}$. Immediately after the inoculation and after 2, 6, 9 and 13 days, the microbial counts on tryptone soy agar (TSA; Scharlab, Barcelona, Spain) plates were examined. To this end, serial dilutions were made and poured onto TSA dishes which were incubated for $24 \mathrm{~h}$ at $37^{\circ} \mathrm{C}$. All tests were performed in duplicate.

The amounts of CA and EU that migrated from the films to the culture media at the various times were estimated from the release kinetics of these compounds in food simulants (data not shown). To this end, film samples of $500 \mathrm{mg}$ were placed in flasks with $100 \mathrm{~mL}$ of solvent and stirred at $20^{\circ} \mathrm{C}$. The released compound was analysed at various contact times. Simulant A ( $10 \%$ ethanol) was selected for the release studies after considering its similar composition to that of the culture media.

\subsubsection{Statistical analysis}

Analysis of variance with Fisher's least significant difference at 95\% confidence level was performed to analyse the data statistically Statgraphics Centurion XVI (Manugistics Corp., Rockville, MD, USA) was used.

\section{RESULTS AND DISCUSSION}

\subsection{Active compound retention in films}

The weight losses of the films after thermo-compression were quantified in order to determine the loss of the active compounds from a simple approach. The weight loss of the films with active compounds ranges between 3 and $6 \%$ with respect of the initial mass, showing great variability, which does not allow us to obtain significant differences between formulations. This loss must be mainly attributed to volatilization of actives, since the moisture content of the PHBV films is $0.9 \%$ and no significant water loss can be assumed. Based on the weight loss, 20-44\% of the incorporated amount of actives could be lost by volatilization during thermo-compression, although the weight measurements could imply notable errors. 
On the other hand, CA and EU contents in PHBV-CA and PHBV-EU films, determined using methanol extraction and spectrophotometric quantification, are $11.5 \pm 1.3$ and $8.1 \pm 1.4 \mathrm{~g}$ per $100 \mathrm{~g}$ of polymer matrix, respectively. Comparison of these values with the incorporated amount (15 g per $100 \mathrm{~g}$ of polymer matrix) leads to retention percentages of $80 \pm 6 \%$ for CA and $58 \pm 6 \%$ for EU. Significant differences in the retention level of both compounds and the similarity in their boiling points ( 237.7 and $253.2^{\circ} \mathrm{C}$, respectively) suggest that some EU could be more strongly bonded to the polymer matrix and that no total extraction in methanol of this compound from the films could be obtained. In this sense, the extraction procedure is limited by the bonding of actives to the polymer matrix, and greater amounts of these (not extractable) could be present in the film.

\subsection{Film microstructure}

Figure 1 shows SEM micrographs of cross-sections of PHBV bilayer films without and with the various active compounds. No layer separation is observed in control films (PHBV), which indicates a good join of the layers after the thermo-pressing process. In the same way, the micrographs of the bilayer films with active compounds showed no separation between the layers, which proves the good miscibility of the active compounds in the polymer matrix. The micrographs reveal that active compounds diffuse from the interface to the matrix sinus, where they are retained in a homogeneous way. Thermo-compression leads to a good incorporation of active compounds in the bilayer films, as deduced from the homogeneity of the films and the complete adhesion of the two polymer layers containing actives in between.

\subsection{Optical properties}

Table 1 summarizes the optical properties evaluated for each formulation. High values of $T_{i}$ are indicative of very good film homogeneity and transparency. On the contrary, lower values of $T_{i}$ are typical of more opaque films. Incorporation of the studied active compounds at the interface of PHBV bilayer films gives rise to films with significantly higher $T_{i}$ values at $550 \mathrm{~nm}$ (where the spectra showed the biggest difference), meaning that the PHBV films with active compounds are slightly more transparent than the control film (pure PHBV). According to the SEM micrographs, these results reflect again the good miscibility of the active compounds in the polymer layers, where they diffuse from the interface. This diffusion could affect the polymer interchain forces, decreasing the matrix compactness, which would give rise to more transparent films. This effect would have an impact on the film mechanical behaviour, giving rise to lower TS and EM values, as commented on below. 


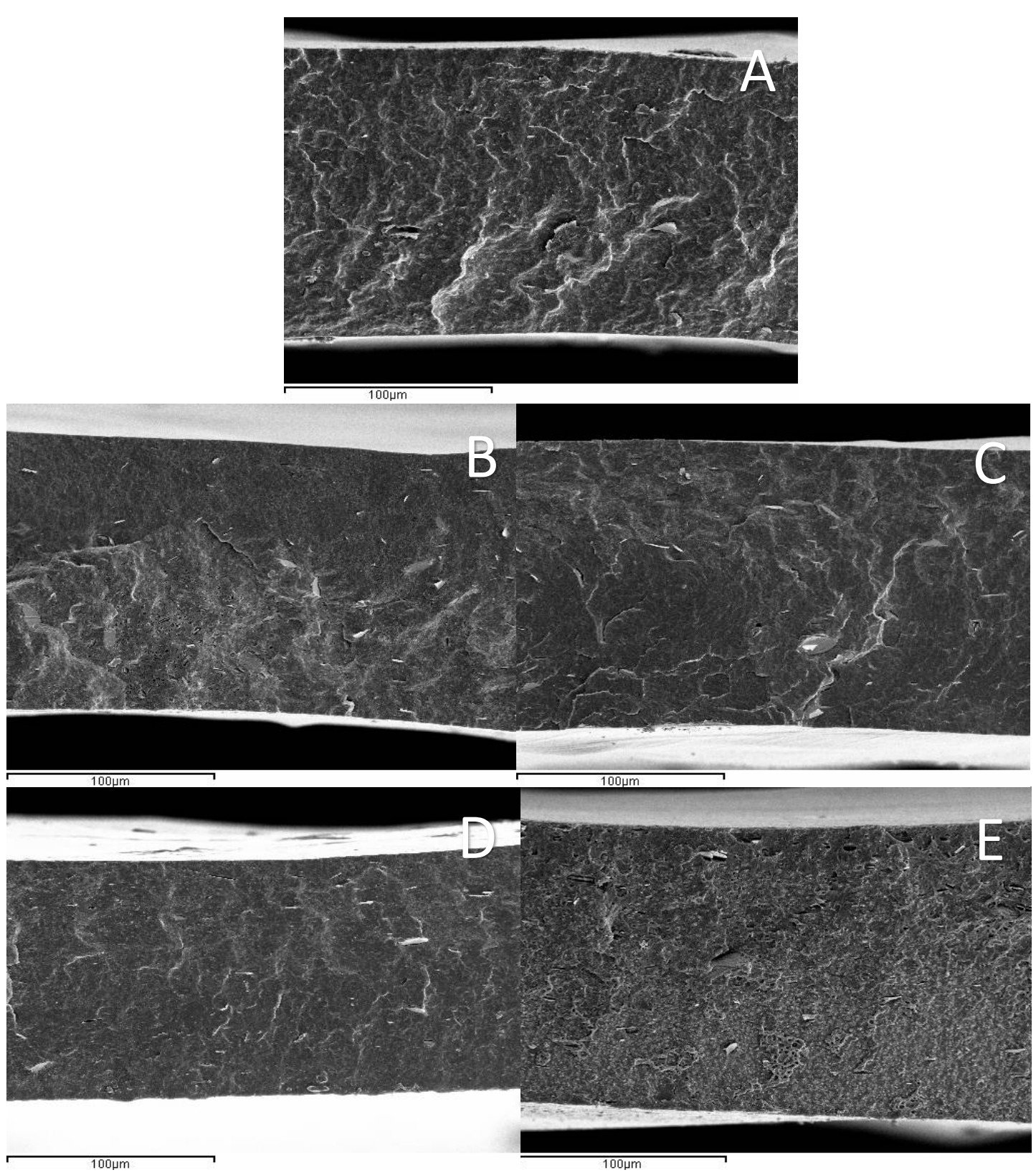

Figure 1. SEM micrographs of cross-sections of PHBV bilayer films (A) without and with active compounds: (B) carvacrol; (C) eugenol; (D) oregano and (E) clove essential oil. 
Table1. Internal transmittance $\left(T_{i}\right)$ at $550 \mathrm{~nm}$ and colour parameters of PHBV bilayer films with various active compounds (carvacrol (CA); eugenol (EU); oregano (OR) and clove essential oil (CLO)) and without them. Mean values \pm standard deviation.

\begin{tabular}{lccccc}
\hline Formulation & $\mathbf{T}_{\mathbf{i}}(\mathbf{5 5 0} \mathbf{\mathbf { n m }})$ & $\mathbf{L}^{*}$ & $\mathbf{C}^{*}$ & $\mathbf{h}^{*}$ & $\boldsymbol{\Delta}$ \\
\hline PHBV & $50.2 \pm 0.8^{\mathrm{a}}$ & $75.7 \pm 0.2^{\mathrm{a}}$ & $20.8 \pm 0.2^{\mathrm{a}}$ & $80.3 \pm 0.1^{\mathrm{a}}$ & - \\
PHBV-CA & $60 \pm 2^{\mathrm{b}}$ & $76.1 \pm 0.3^{\mathrm{a}}$ & $19.3 \pm 0.4^{\mathrm{b}}$ & $81.8 \pm 0.2^{\mathrm{b}}$ & 1.64 \\
PHBV-EU & $58.8 \pm 0.4^{\mathrm{b}}$ & $75.8 \pm 0.3^{\mathrm{a}}$ & $20.2 \pm 0.2^{\mathrm{c}}$ & $80.3 \pm 0.1^{\mathrm{a}}$ & 0.56 \\
PHBV-OR & $58 \pm 2^{\mathrm{b}}$ & $75.8 \pm 0.6^{\mathrm{a}}$ & $20.0 \pm 0.4^{\mathrm{ac}}$ & $81.2 \pm 0.5^{\mathrm{b}}$ & 0.47 \\
PHBV-CLO & $58 \pm 2^{\mathrm{b}}$ & $75.58 \pm 0.1^{\mathrm{a}}$ & $20.3 \pm 0.2^{\mathrm{ac}}$ & $80.7 \pm 0.1^{\mathrm{a}}$ & 0.50 \\
\hline
\end{tabular}

a-c: Different superscripts within the same column indicate significant differences among formulations $(p<0.05)$.

Regarding the film colour, the addition of the various active compounds does not provoke significant differences in film lightness, as has been reported by Martucci et al. ${ }^{26}$ When CA or EU is incorporated, the film chroma significantly decreases, whereas the addition of EOs does not modify this parameter as reported by Muriel-Galet et al. ${ }^{27}$ and Teixeira et al. ${ }^{28}$ for ethylene-vinyl alcohol copolymer and fish protein films containing OR. Film hue is significantly affected by the incorporation of both OR and its main component, CA. Unlike these, CLO and its main component, EU, have no significant effect on this parameter. Films with CA show the highest colour differences with respect to control films. However, these differences are not relevant in practical terms since colour differences below 2.4 can not be perceived by the human eye. ${ }^{29}$

\subsection{Tensile properties}

Table 2 summarizes the tensile parameters, i.e. EM, TS and $E$, for each film formulation. The incorporation of the studied active compounds in PHBV bilayer films significantly decreases the EM, TS and $E$ values. Although the addition of all compounds reduces the material stretchability, CA gives rise to films that are more extensible than those containing EU, OR or CLO. Films containing EU, OR or CLO do not show significant differences among them in terms of mechanical behaviour. Previous studies have shown similar results due to the addition of CLO, OR or EU in fish protein and thermoplastic flour films. ${ }^{28,30}$ On the contrary, other studies performed with CA and OR incorporated in triticale protein, polypropylene and alginate films found that the films were more extensible than the pure polymer films. ${ }^{31-34}$ In the same way, the decrease in the EM and TS values due to the incorporation of these active compounds has also been described for EU, OR and CA by Woranuch and Yoksan, ${ }^{30}$ Aguirre et al. ${ }^{31}$ and Ramos et al., ${ }^{33}$ respectively. Given the poor stretchability of the obtained PHBV films, their application would be limited to packaging uses, where ductility is not required, such as preformed trays or lids. 
Table 2. Tensile properties (elastic modulus (EM), tensile strength (TS) and elongation at break (E)) and water vapour permeability (WVP) $(\mathrm{g} / \mathrm{m} \cdot \mathrm{s} \cdot \mathrm{Pa}$ ) of bilayer films with various active compounds (carvacrol (CA); eugenol (EU); oregano (OR) and clove essential oil (CLO)) and without them. Mean values \pm standard deviation.

\begin{tabular}{lcccc}
\hline Formulation & EM (MPa) & TS (MPa) & E (\%) & WVPx10 $^{\mathbf{1 2}}$ \\
\hline PHBV & $1140 \pm 10^{\mathrm{a}}$ & $27.6 \pm 0.6^{\mathrm{a}}$ & $5.3 \pm 0.4^{\mathrm{a}}$ & $21 \pm 4^{\mathrm{a}}$ \\
PHBV-CA & $780 \pm 90^{\mathrm{b}}$ & $17.6 \pm 1.1^{\mathrm{b}}$ & $4.4 \pm 0.6^{\mathrm{b}}$ & $9 \pm 1^{\mathrm{b}}$ \\
PHBV-EU & $770 \pm 120^{\mathrm{b}}$ & $17.0 \pm 1.9^{\mathrm{b}}$ & $3.8 \pm 0.4^{\mathrm{c}}$ & $15 \pm 2^{\mathrm{c}}$ \\
PHBV-OR & $770 \pm 70^{\mathrm{b}}$ & $17.3 \pm 0.6^{\mathrm{b}}$ & $3.8 \pm 0.4^{\mathrm{c}}$ & $12 \pm 2^{\mathrm{bd}}$ \\
PHBV-CLO & $800 \pm 90^{\mathrm{b}}$ & $18.2 \pm 1.2^{\mathrm{b}}$ & $3.9 \pm 0.4^{\mathrm{c}}$ & $21 \pm 6^{\mathrm{a}}$ \\
\hline
\end{tabular}

$a-d$ : Different superscripts within the same column indicate significant differences among formulations $(p<0.05)$.

The disparity in the effect of actives on the film tensile behaviour can be due both to the different quantity of active compound incorporated in the polymer matrix and to the different interactions between components. When active compounds are incorporated at the interface between two layers, these are not directly included in the sinus of the polymer matrix. As a result, these compounds could provoke a discontinuity between both layers that could affect the mechanical behaviour of the layer assembly. However, this discontinuity is not observed in the microstructural images, and thus it is possible to assume that the active compounds diffuse fast into the polymer matrix. Therefore, the balance of molecular interactions between the active compounds and the polymer chains near the interface will affect the overall cohesion forces of the polymer network. Given the good adhesion between PHBV layers, interactions between added compounds and polymer chains will govern the resulting mechanical properties of the films. In this sense, no relevant differences in tensile behaviour are observed for active bilayers. The only remarkable fact is the lower reduction in the film stretchability when CA is used, which could be attributed to its effect at the interfacial level, increasing the layer adhesion forces. The molecules that diffuse into the PHBV matrix could provoke a weakening effect of the chain forces of the polymer, making chain slippage easier during tensile testing. Other phenols of the tested actives could promote some crosslinking effect in the matrix, thus lowering the ductility of the material, as deduced from the film thermal behaviour commented on below. 


\subsection{Water vapour permeability}

The WVP values of PHBV bilayer films are given in Table 2. The incorporation of active compounds in PHBV bilayer films gives rise to significantly lower values of WVP, except for CLO that shows no differences with respect to the control film. OR and its main component, $\mathrm{CA}$, are the most effective at decreasing WVP. Analogously, Woranuch and Yoksan ${ }^{30}$ and Benavides et al. ${ }^{32}$ reported a higher water barrier capacity in thermoplastic flour and alginate films after the incorporation of EU and OR, respectively. However, other studies reported the opposite effect. ${ }^{28,31,34}$ As previously mentioned, these differences can be attributed both to the different quantities of active compound incorporated in the polymer matrix and to the different interactions between components that define the matrix strength.

The differences in chemical composition and molecular polarity of the matrix components can explain the different WVP values of the bilayer films with active compounds, since water vapour transfer through a film is greatly affected by the hydrophilic-lipophilic balance of film components. ${ }^{28}$ In this sense, all active compounds significantly increase the water vapour barrier capacity of the films since they are all hydrophobic substances. Among them, the most effective in promoting the water barrier capacity is $\mathrm{CA}$, followed by $\mathrm{OR}$, the main component of which is CA.

\subsection{Thermal behaviour}

Figure 2 shows the degradation patterns of pure PHBV films and of those containing the various active compounds. Pure films show a degradation pattern with two main thermal events. The first one corresponds to PHBV degradation, while the second one corresponds to plasticizer degradation as can be observed in Figure 2(A), where the behaviour of the polymer without plasticizer is included. Likewise, the effect of the second compression step on bilayer films can also be observed. A decrease in the thermal resistance of the polymer is promoted by this second compression, which indicates that the thermal treatment induced structural changes in the polymer network. When the active compounds are added, a weight loss starts at about $150{ }^{\circ} \mathrm{C}$ due to the progressive volatilization of actives from the film (boiling points of CA and EU are 237.7 and $253.2{ }^{\circ} \mathrm{C}$, respectively). ${ }^{35} \mathrm{In}$ fact, the losses of the active compounds overlap with the degradation step of PHBV, which does not permit the estimation of their release from the film using TGA. 

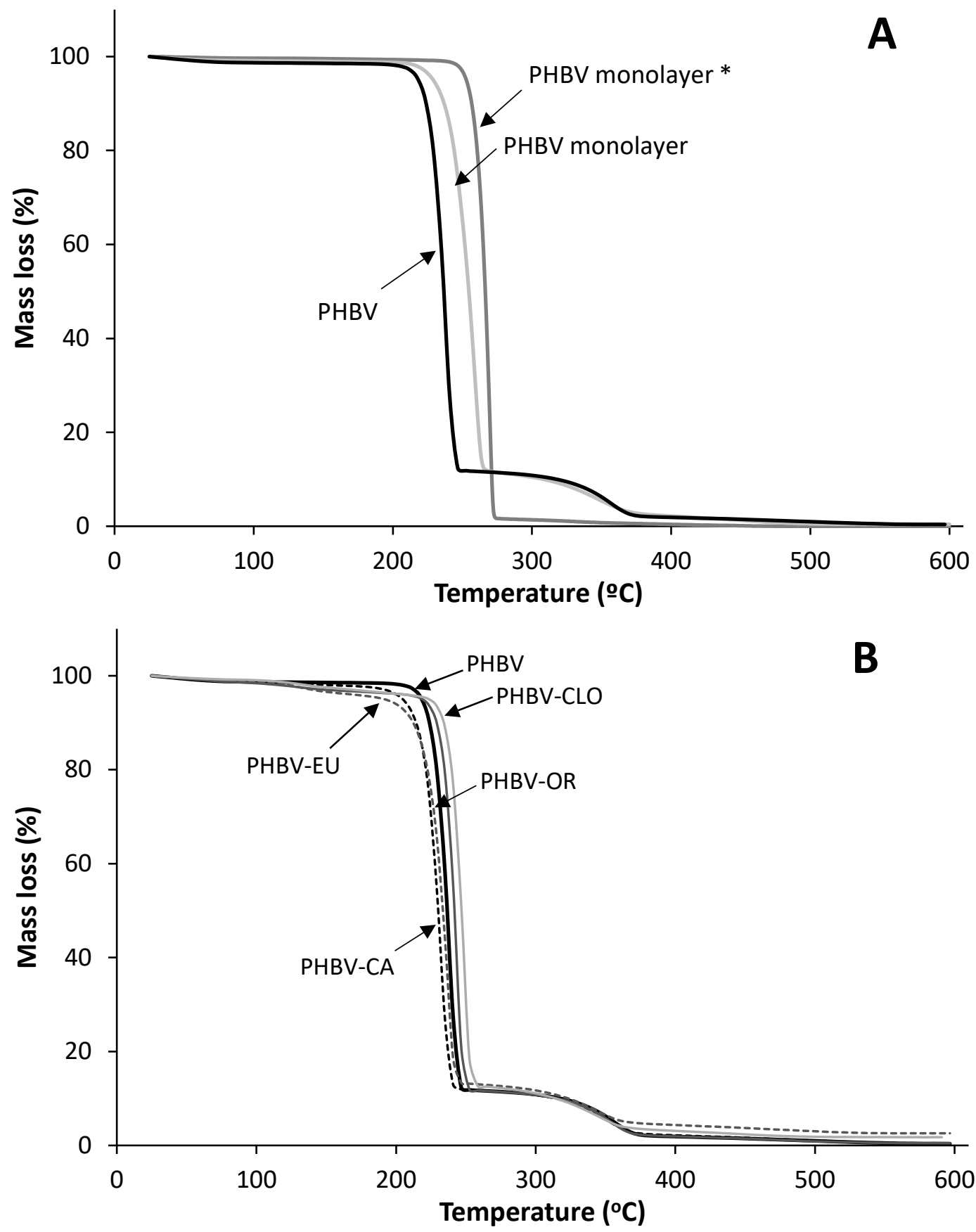

Figure 2. TGA curves of PHBV films. (A) PHBV monolayer and bilayer films containing or not containing $\left({ }^{*}\right)$ plasticizer. (B) PHBV bilayer films with active compounds: carvacrol (CA); eugenol (EU); oregano (OR) and clove essential oil (CLO). 
Table 3 gives the onset and peak temperatures for the main degradation step of the polymer for the various films. The incorporation of pure CA or EU enhances the thermal sensitivity of PHBV, decreasing the onset and peak of degradation temperature, whereas the whole essential oils (OR and CLO) slightly promote the thermal stability of the polymer. Incorporation of some additives to polymer matrices usually results in a reduction of the thermal resistance of the network due to the weakening effect of the chain bonds. ${ }^{36}$ Nevertheless, some authors ${ }^{37,38}$ reported an increase in the polymer thermal resistance when some essential oils are added. Among all formulations, the film with CLO is the most thermally resistant, which could be associated with stronger interactions between PHBV and some components of the $E O$, thus reinforcing the polymer network. This is coherent with the lower extraction capacity for EU from the films using methanol, which suggests the strong bonding of a part of this compound to the polymer network.

Figure 3 shows the DSC thermograms for the first heating scan and the cooling scan of control PHBV films and those containing active compounds. Likewise, monolayer (pressed once) PHBV films with and without plasticizers were also analysed to evaluate the effect of processing. Table 4 summarizes the peak temperature values for melting (first and second heating scans) and crystallization (cooling scan) for the various samples, as well as the corresponding enthalpy values of these transitions. Glass transition temperature $\left(T_{\mathrm{g}}\right)$ of the amorphous phase of polymer was also determined in the first heating scan. Plasticizer addition slightly reduces both temperature and enthalpy associated with either melting or crystallization process of PHBV, whereas plasticizer does not significantly affect $T_{\mathrm{g}}$. This indicates that PEG interacts with the polymer lattice, affecting crystallization behaviour and reducing the degree of crystallization of PHBV from 99 to $60 \%$. However, the application of a second thermocompression step in bilayer formation promotes crystallization of the polymer (Table 4) in line with the increase in the molecular mobility during the heating step. As expected, this effect disappears in the second heating scan where the thermal history of the samples has been eliminated. The addition of active compounds modifies the thermal behaviour of PHBV in agreement with their miscibility with the polymer. Both crystallization and melting peaks are shifted to lower temperature values when any of the active components is present in the film. Likewise, all of them provoke a reduction in the degree of crystallinity of polymer in the film (Table 4). This effect is more pronounced for the whole EOs, and especially for CLO. This indicates that other components of EOs interact with polymer chains to a greater extent, thus affecting thermal behaviour. This effect of EOs on the crystallinity of polymers was also reported for polypropylene films with CA and thymol by Ramos et al. ${ }^{33}$ The film thermal properties obtained from the first and the second heating scans are very similar, which indicates no sensitivity of the polymer to the different thermal history. On the other hand, the differences between $T_{\mathrm{c}}$ and $T_{\mathrm{m}}$ are about $50^{\circ} \mathrm{C}$ in all cases, which indicates that the same supercooling effect occurs in all cases and so any of the added compounds show nucleating action, but only a depressing effect on the melting point according to the miscibility effects. 
All samples show a small glass transition at $T_{\mathrm{g}}$ of about $7{ }^{\circ} \mathrm{C},{ }^{39}$ without significant differences between them. The thermal response of the films agrees with that observed in TGA where the whole EOs seem to have greater impact on the polymer structure than pure CA or EU.

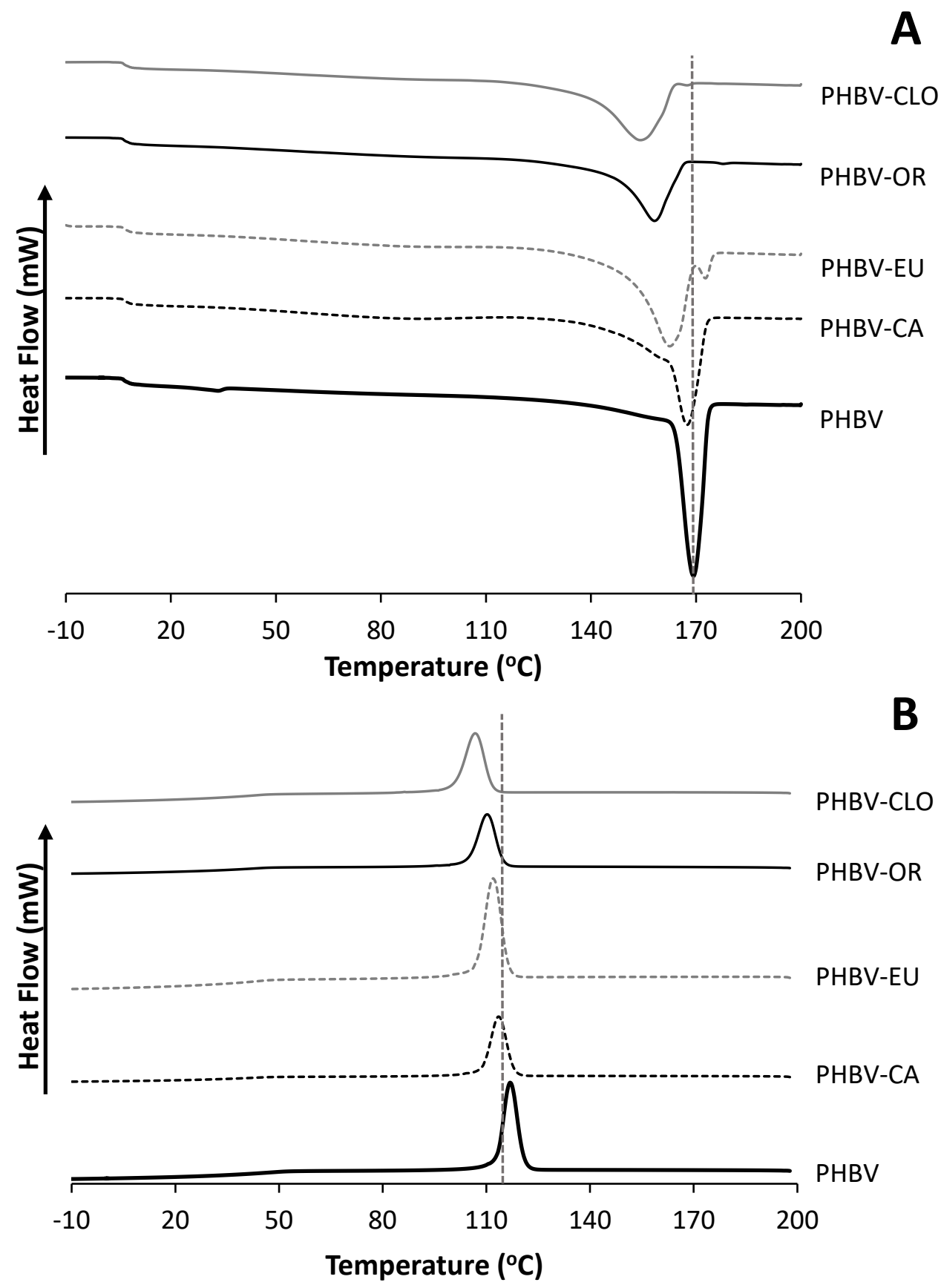

Figure 3. DSC thermograms for (A) first heating scan and (B) the cooling scan of control PHBV film and films with active compounds: carvacrol (CA); eugenol (EU); oregano (OR) and clove essential oil (CLO). 

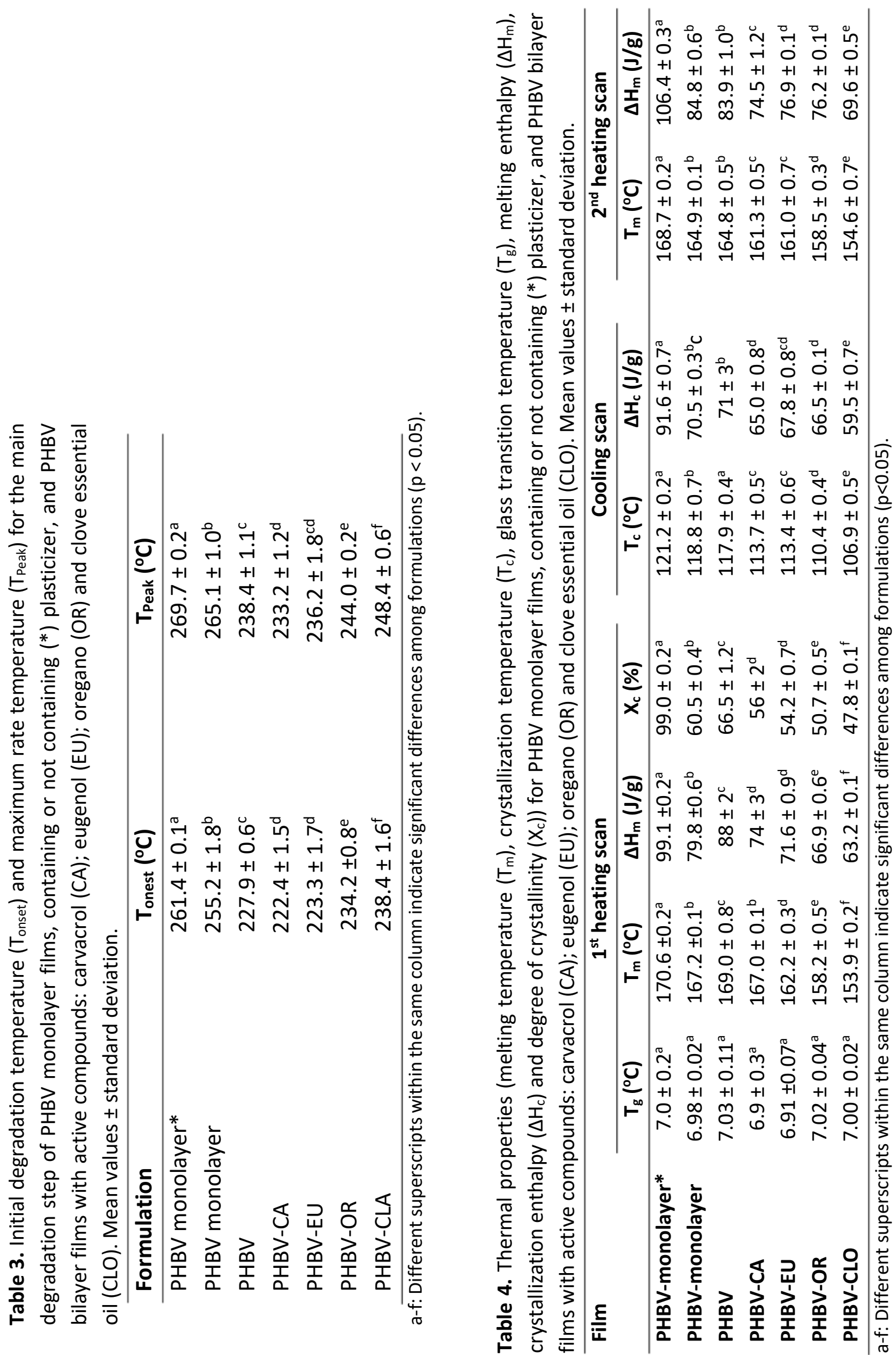


\subsection{Antimicrobial properties}

Figure 4 shows the microbial counts at different incubation times for the various films in contact with culture media with $L$. innocua and $E$. coli. The respective amounts $\left(\mathrm{g} \mathrm{mL}^{-1}\right.$ ) of CA and EU released from the film to the culture media, assuming the same kinetic release as in simulant A, are also shown for films containing CA or EU. Films without active compounds have no effect on growth of both bacteria, which indicates that the antimicrobial effect cannot be attributed to the polymer. The incorporation of active compounds in PHBV bilayer films, regardless of their nature, significantly decreases the growth of L. innocua and of E. coli. L. innocua is more sensitive to OR and its main component (CA) than to CLO and its main component (EU). Similar results were reported by Teixeira et al. ${ }^{28}$ Although EU is more retained within the polymer matrix when methanol extraction is performed, the available ratio of $E U$ is released faster into simulant $A$, reaching an equilibrium value higher than that obtained for CA. In this way, at every measurement time, the EU concentration in the media is significantly higher than the CA level. Therefore, the greater antimicrobial activity of CA in the films must be attributed to its higher effectiveness as reported by Burt. ${ }^{13}$ The main inhibition mechanism of this type of active, as reported by other authors, ${ }^{40-42}$ is the disturbance of the cytoplasmic membrane of cells, disrupting the proton motive force, electron flow, active transport and coagulation of cell contents. Nevertheless, a different intensity of the effects must be expected as a function of the molecular structure of the active. Films containing CA or OR show similar antimicrobial effect at 2 and 13 days. However, they have a different antimicrobial effect within this period. While CA leads to a gradual decrease in the L. innocua population, OR shows higher antimicrobial activity from day 2. A faster kinetic release of OR from the films, or a synergic effect of CA with the other compounds present in the oil, which lend it higher activity, could explain this behaviour. Films containing EU are more effective against $L$. innocua than those with CLO throughout the first 9 days. Nevertheless, the effect is reversed after 13 days. This behaviour suggests the delayed release of active components of CLO.

In general, E. coli is more sensitive than L. innocua to all tested compounds, since a total inhibition is rapidly observed when E.coli is cultured in presence of films containing CA, EU or OR. Previous studies of films with OR and CA have reported similar antimicrobial activities against E. coli. ${ }^{26,31,33,43,44}$ For both bacteria, PHBV-CLO films are the least effective, showing higher activity against $E$. coli. This behaviour agrees with the possible crosslinking effect of oil compounds into the polymer matrix, as deduced from TGA, which could inhibit their effective release to the culture media, thus decreasing their antimicrobial action. At all contact times, the estimated CA concentrations in the media are significantly higher than the minimum inhibitory concentrations (MICs) reported for L. innocua $\left(3.7 \times 10^{-4} \mathrm{~g} \cdot \mathrm{mL}^{-1}\right)^{13}$ and E. coli $(3.1 \times$ $\left.10^{-4} \mathrm{~g} \cdot \mathrm{mL}^{-1}\right),{ }^{45}$ as deduced from the found antimicrobial activity. In the same way, the EU concentrations are also higher than the respective MICs reported for L. innocua $\left(1.5 \times 10^{-3}\right.$ 
$\left.\mathrm{g} \cdot \mathrm{mL}^{-1}\right)^{46}$ and $E$. coli $\left(1.2 \times 10^{-3} \mathrm{~g} \cdot \mathrm{mL}^{-1}\right) .{ }^{45}$ The obtained results reveal that PHBV is an adequate matrix as a carrier of EU or CA to obtain antimicrobial films against Gram-positive or Gramnegative bacteria such as $E$. coli or $L$. innocua. The studied active agents are more effective against Gram-negative bacteria, E. coli, than against Gram-positive bacteria, L. innocua. On the contrary, other studies performed with antimicrobial films containing the same active compounds showed higher antimicrobial activity against Gram-positive cells, without an outer membrane. ${ }^{13,28,31-33,36,47}$ However, Aldana et al. ${ }^{48}$ have also observed a higher antimicrobial activity of films with lime EO against Gram-negative bacteria. This fact indicates that the nature and structural characteristics of the matrix from which the EO is released, as well as the film formation method, could greatly affect the film antimicrobial properties. ${ }^{44}$
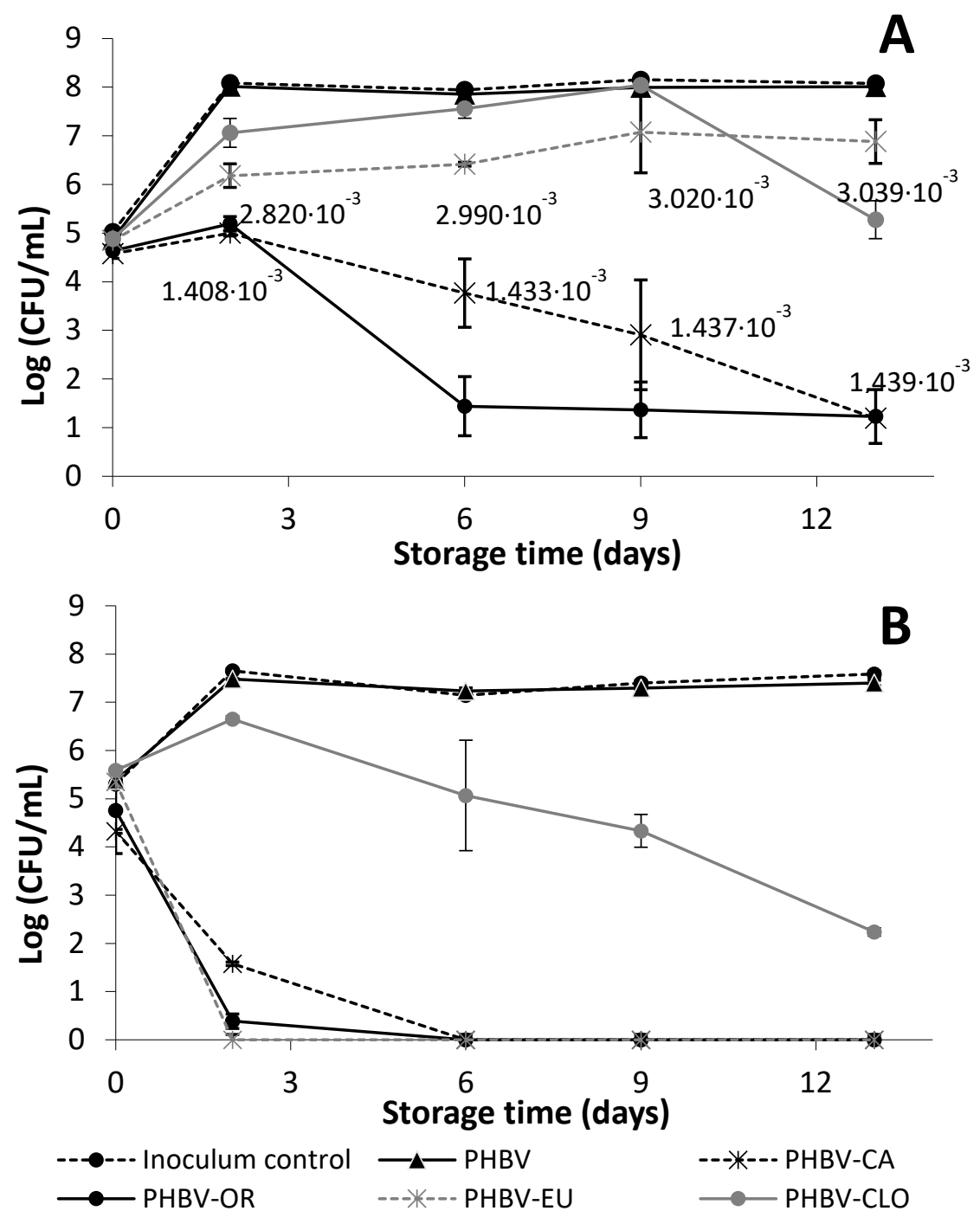

Figure 4. Effect of various PHBV bilayer films on growth and survival of (A) L. innocua and (B) E. coli at $10{ }^{\circ} \mathrm{C}$. The released amounts ( $\mathrm{g} \cdot \mathrm{mL}^{-1}$ of media, assuming the same release kinetics as in simulant $\mathrm{A}$ ) of $\mathrm{CA}$ and $\mathrm{EU}$ at the various contact times are indicated. 


\section{CONCLUSIONS}

PHBV bilayer films with active compounds incorporated at the interface between the layers were obtained by compression moulding, with a good layer adhesion and homogeneous structure. This method produced antimicrobial films with appropriate tensile, optical and water vapour barrier properties, and with good thermal stability, even if the incorporation of active compounds significantly affected the physical properties of the films. Although the studied actives did not improve the tensile properties of the films, more transparent materials with better water vapour barrier capacity were obtained. As regards thermal stability, while $\mathrm{CA}$ and EU gave rise to a slight decrease in the thermal stability of the polymer matrix, OR and CLO led to more thermally resistant materials. The compound miscibility into the polymer matrix was confirmed by DSC analyses, where a notable decrease in the polymer melting temperature and crystallinity was observed when active compounds, especially whole EOs, were incorporated. The release of the active ingredients from the films was adequate to control the growth of E. coli and L. innocua in culture media. Active films were significantly more effective against $E$. coli than against $L$. innocua, and both bacteria were more sensitive to $\mathrm{OR}$ and its main compound, CA. The greater antimicrobial activity of films containing CA was attributed to the higher effectiveness of $C A$, since the amount of EU released from the film was higher than the amount of CA released. Therefore, incorporation of natural antimicrobials such as those studied, especially CA and OR, into bilayer films of PHBV could be a promising option for the development of active biodegradable films.

\section{Acknowledgements}

The authors thank the Ministerio de Economía y Competitividad- Government of Spain for financial support provided through AGL2013-42989-R Project. RR thanks the Ministerio de Educación, Cultura y Deporte - Government of Spain for an FPU Grant. 


\section{REFERENCES}

1 Reddy CSK, Ghai R and Kalia V, Bioresour Technol 87:137-146 (2003).

2 Shah AA, Hasan F, Hameed A and Ahmed S, BiotechnolAdv 26:246-265 (2008).

3 Catoni SE, Trindade KN, Gomes CA, Schneider AL, Pezzin A and Soldi V, Polímeros 23:320-325 (2013).

4 Sudesh K, Abe H and Doi Y, Prog PolymSci 25:1503-1555 (2000).

5 Fabra MJ, Sánchez G, López-Rubio A and Lagaron JM, LWT Food Sci Technol 59:760-767 (2014).

6 Modi S, Koelling K and Vodovotz Y, Eur PolymJ 47:179-186 (2011).

7 Keshavarz T and Roy I, Curr OpinMicrobiol 13;321-326 (2010).

8 RaySSandBousminaM, ProgMater Sci 50:962-1079 (2005).

9 Falguera V, Quintero JP, Jiménez A, Muñoz JA and Ibarz A, Trends Food Sci Technol 22:292-303 (2011).

10 López P, Sánchez C, Batlle R and Nerín C, J Agric Food Chem 55:8814-8824 (2007).

11 Sánchez-González L, Cháfer M, Hernández M, Chiralt A and González-Martínez C, Food Control 22:1302-1310 (2011).

12 Bakkali F, Averbeck S, Averbeck D and Idaomar M, Food Chem Toxicol 46:446-475 (2008).

13 Burt S, Int J FoodMicrobiol 94:223-253 (2004).

14 Gutierrez J, Barry-Ryan C and Bourke P, Int J FoodMicrobiol 124:91-97 (2008).

15 Calo JR, Crandall PG, O’Bryan CA and Ricke SC, Food Control 54:111-119 (2015).

16 GillAO,Delaquis P, Russo P and Holley RA, Int J FoodMicrobiol 73:83-92 (2002).

17 Mourey A and Canillac N, Food Control 13:289-292 (2002).

18 Ben Arfa A, Preziosi-Belloy L, Chalier P and GontardN, JAgric FoodChem 55:2155-2162 (2007).

19 Hutchings JB, Food Colour and Appearance, 2nd edition. Aspen Publishers, Gaithersburg, MD (1999). 20 American Society for Testing and Materials, Annual Book of American Standard Testing Methods. Standard test method for tensile properties of thin plastic sheeting. Standard D882. ASTM, Philadelphia, PA, pp. 162-170 (2001).

21 American Society for Testing and Materials, Annual Book of American Standard Testing Methods. Standard test method for water vapour transmission of materials. ASTM E96/E96M. ASTM, Philadelphia, PA, pp. 406-413 (1995).

22 Vargas M, Albors A, Chiralt A and González-Martínez C, LWT Food Sci Technol 44:2290-2295 (2011). 23 Miguel O, Egiburu JL and Iruin JJ, Polymer 42:953-962 (2001). 
24 Dai Y, Lambert L, Yuan Z and Keller J, J Biotechnol 134:137-145 (2008).

25 Jiménez A, Sánchez-González L, Desobry S, Chiralt A and Tehrany EA, Food Hydrocoll 35:159-169 (2014).

26 Martucci JF, Gende LB, Neira LM and Ruseckaite RA, Ind Crops Prod 71:205-213 (2015).

27 Muriel-Galet V, Cran MJ, Bigger SW, Hernández-Muñoz P and Gavara R, J Food Eng 149:9-16 (2015).

28 Teixeira B, Marques A, Pires C, Ramos C, Batista I, Saraiva JA et al., LWT Food Sci Technol 59:533539 (2014).

29 Mahy M, Eycken L and Oosterlinck A, Color Res Appl 19:105-121 (1994).

30 Woranuch S and Yoksan R, Carbohydr Polym 96:586-592 (2013).

31 Aguirre A, Borneo R and León AE, Food Biosci 1:2-9 (2013).

32 Benavides S, Villalobos-Carvajal R and Reyes JE, J Food Eng 110:232-239 (2012).

33 Ramos M, Jiménez A, Pletzer M and Garrigós MC, J Food Eng 109:513-519 (2012).

34 Rojas-Graü MA, Avena-Bustillos RJ, Olsen C, Friedman M, Henika PR, Martín-Belloso O et al., J Food Eng 81:634-641 (2007).

35 Lide DR, CRC Handbook of Chemistry and Physics, 89th edition. CRC Press, New York (2001).

36 Arrieta MP, Peltzer MA, del Carmen Garrigós M and Jiménez A, J Food Eng 114:486-494 (2013).

37 Sanuja S, Agalya A and Umapathy MJ, Int J Biol Macromol 74:76-84 (2015).

38 Shen Z and Kamdem DP, Int J Biol Macromol 74:289-296 (2015).

39 Tao J, Song C, Cao M, Hu D, Liu L, Liu N et al., Polym Degrad Stab 94:575-583 (2009).

40 Denyer SP and Hugo WB, Soc Appl Bacteriol Techn Ser 27:331-334 (1991).

41 Davidson PM, Chemical preservatives and natural antimicrobial compounds, in Food Microbiology: Fundamentals and Frontiers ed. By Doyle MP, Beuchat LR and Montville TJ. ASM Press, Washington, DC, pp. 520-556 (1997).

42 Sikkema J, De Bont JAM and Poolman B, Microbiol Rev 59:201-222 (1995).

43 Debiagi F, Kobayashi RKT, Nakazato G, Panagio LA andMali S, Ind Crops Prod 52:664-670 (2014).

44 Hosseini SF, Rezaei M, Zandi M and Farahmandghavi F, Ind Crops Prod 67:403-413 (2015).

45 Ye H, Shen S, Xu J, Lin S, Yuan Y and Jones GS, Food Control 34:619-623 (2013).

46 Shah B, Davidson PM and Zhong Q, Int J Food Microbiol 161:53-59 (2013).

47 Muppalla SR, Kanatt SR, Chawla SP and Sharma A, Food Packag Shelf Life 2:51-58 (2014).

48 Aldana DS, Andrade-Ochoa S, Aguilar CN, Contreras-Esquivel JC and Nevárez-Moorillón GV, Food Control 50:907-912 (2015). 



\title{
Release kinetics of carvacrol and eugenol from poly(hydroxybutyrate-co-hydroxyvalerate) (PHBV) films for food packaging applications
}

\author{
Raquel Requena, María Vargas, Amparo Chiralt
}

European Polymer Journal (2017) 92, 185-193

Institute of Food Engineering for Development, Universitat Politècnica de València, Valencia, Spain 



\section{ABSTRACT}

Poly(hydroxybutyrate-co-hydroxyvalerate) (PHBV) films, plasticized with PEG, incorporating $13 \% \mathrm{w} / \mathrm{w}$ of active compounds (carvacrol-CA, eugenol-EU) were obtained by spraying the active between PHBV layers and their subsequent adhesion. Release kinetics of CA and EU in food simulants of different polarity was analysed and the films' antimicrobial activity was predicted, taking the minimal inhibitory concentration against some foodborne pathogens into account. Overall migration values were also determined. At equilibrium, an almost total release of both CA and EU occurred in $50 \%$ ethanol, about 20 and $50 \%$ of CA and EU, respectively, was delivered in the more aqueous simulants and $65-70 \%$ in fatty systems. The release rate increased when the polarity of aqueous simulants decreased, but it fell markedly in fatty systems. EU was released faster than CA in the less polar simulants, but more slowly in the more aqueous systems.

Keywords: Release kinetics, carvacrol, eugenol, diffusion, antimicrobial effect, partition coefficient. 


\section{INTRODUCTION}

The use of active films for food packaging applications represents a good option for the purposes of lengthening the food shelf life while maintaining quality [1,2]. The use of active films mitigates the drawbacks associated with the direct application of the antimicrobials on the food products, usually carried out by spraying or dipping, such as the rapid neutralization of active compounds or the fast diffusion from the surface into the product [3]. The use of films as carriers of antimicrobials allows for a progressive release of the active into the product surface where it effectively acts for longer, thus improving the antimicrobial effectiveness and enhancing food safety and quality throughout the storage $[4,5]$.

Biopolymers present several advantages over oil-based polymers, such as their biodegradability and the use of renewable resources [6]. In this context, the polyhydroxyalkanoates are a promising option in the food packaging field; specifically poly(hydroxybutyrate-co-hydroxyvalerate) (PHBV), which leads to less brittle and more stretchable materials than poly(hydroxybutyrate) $[7,8]$.

Of the antimicrobial compounds that can potentially be used in the active film formulations, natural substances, such as the essential oils (EOs); enzymes, such as lysozyme; bacteriocins, such as nisin or organic acids, such as sorbic acid, can be found [3]. EOs have exhibited antimicrobial activity against many foodborne pathogens, which have often been attributed to their main components. Oregano essential oil (OR) and clove essential oil (CLO) are two of the most effective EOs at controlling microbial growth [9]. The antimicrobial effectiveness of both OR and CLO, as well as their respective main components, carvacrol (CA) and eugenol (EU), have been demonstrated in different biodegradable matrices [10-14]. However, the effectiveness of the films as carriers of antimicrobial compounds does not only depend on the nature of the active compounds, but also on the capacity of the film to release an adequate concentration of the active to the food at a determined contact time and at equilibrium (partition coefficient). This, in turn, depends on the active's interactions with the polymer matrix and its solubility in the food system. The release kinetics of the active compound into the food throughout the storage time is, therefore, a crucial factor when guaranteeing antimicrobial effectiveness and food safety $[15,16]$. In this sense, several mathematical models, such as first order kinetics [17-19], Peppas and Weibull models [20], or the Fickian model $[19,21-23]$ have been used to determine the compound release rate from the films, and the concentration reached in the food system. In this way, the time needed to reach a concentration level of active in the food greater than the minimum inhibitory concentration (MIC) must be predicted in order to ensure the food safety, thus providing useful information about the active packaging's ability to exert the antimicrobial function in real foodstuffs. 
PHBV thermoprocessed films with $13 \% \mathrm{w} / \mathrm{w}$ CA, EU, OR or CLO have exhibited effective antimicrobial activity against Gram + and Gram - bacteria in in vitro studies with tryptic soy broth medium, thus indicating the effective release of actives in this polar substrate [24]. Nevertheless, in order to be applied in different real foods, the active release kinetics should be known in systems with different polarities, simulating different kinds of foods. In this sense, the use of normalized food simulants [25] for the purposes of analysing release kinetics, allows for adequate predictions of release in different real foods.

Thus, the aim of this work was to analyse the release kinetics of CA and EU from PHBV active films obtained by compression moulding in polar and non-polar food simulants and to model the experimental data by fitting different kinetic models. Likewise, predictions of the active concentration in a model packaged liquid food with different polarity were made in order to predict the effectiveness of active films, according to the MIC values for several foodborne pathogens. The overall migration of film components in the different simulants was also determined in order to know how the film fits the legal limits as a function of food polarity.

\section{MATERIALS AND METHODS}

\subsection{Materials}

Poly(3-hydroxybutyrate-co-3-hydroxyvalerate) (PHBV) with $8 \%$ of hydroxyvalerate was supplied in pellet form by NaturePlast (Caen, France). Polyethylenglycol 1000 (PEG1000), used as plasticizer; carvacrol (CA), eugenol (EU); and UV grade solvents: methanol, ethanol, acetic acid and isooctane were from Sigma-Aldrich (Sigma-Aldrich Chemie, Steinheim, Germany).

\subsection{Film preparation}

\subsubsection{PHBV monolayer films}

PHBV monolayer films were prepared by melt blending and compression-moulding as described by Requena et al. [24]. Briefly, PHBV was mixed with PEG1000 (10 \% w/w) in a tworoll mill (Model LRM-M-100, Labtech Engineering, Thailand) at $180{ }^{\circ} \mathrm{C}$ and compressionmoulded using a hydraulic press (Model LP20, Labtech Engineering, Thailand) at $10 \mathrm{MPa}$ and $180^{\circ} \mathrm{C}$ for $4 \mathrm{~min}$.

\subsubsection{Active PHBV bilayer films}

PHBV bilayer films with different active compounds were obtained by spraying a constant amount (15 g of active per $100 \mathrm{~g}$ polymer matrix) of each active compound as reported by 
Requena et al. [24]. Thus, PHBV monolayers were sprayed with CA or EU, covered with another monolayer and compressed together using the hydraulic press. In this way, three kinds of films were obtained: bilayer films without active compounds (PHBV), as a control, and films with the different active compounds (PHBV-CA and PHBV-EU).

\subsection{Analysis of the retention of active compound in the films}

Two different methods were carried out to quantify the CA and EU content in PHBV films. Thus, the weight loss of the films after the bilayer compression was assessed to estimate the mass loss occurring in the process attributed to losses of actives caused by volatilization. Additionally, the CA and EU retention in the PHBV bilayer films was determined by methanol extraction followed by spectrophotometric quantification. To this end, film samples were kept under stirring for $24 \mathrm{~h}$ at $20^{\circ} \mathrm{C}$, using a methanol:film ratio of $100: 1$. The extract was filtered and quantitatively diluted to measure the absorbance using a UV-visible spectrophotometer (Evolution 201, Thermo Scientific). In this way, the CA and EU content in PHBV films could be determined by the absorbance measurements at 275 and $282 \mathrm{~nm}$, respectively, using the methanol extract of active-free PHBV bilayer films as blank solution. All analyses were carried out in samples from five different positions of five different films, in order to analyse the degree of homogeneity of the active distribution throughout the film.

\subsection{Kinetics of CA and EU release in food simulants}

In order to determine the release rate of CA and EU from the PHBV bilayer films into different food systems, four types of food simulants were considered. Thus, A (ethanol $10 \%(\mathrm{v} / \mathrm{v})$ ) and $B$ (acetic acid $3 \%(w / v)$ ) food simulants were selected to imitate aqueous food and aqueous food with $\mathrm{pH}$ values lower than 4.5 , respectively, whereas D1 (ethanol $50 \%(\mathrm{v} / \mathrm{v})$ ) was selected to imitate alcoholic food and oil-in water emulsions and D2 (isooctane) was used to simulate food with a fatty continuous phase [26]. In this way, film samples of $500 \mathrm{mg}$ were weighed and placed in flasks with $100 \mathrm{~mL}$ of the corresponding simulant. Thereby, each film formulation-food simulant system was kept under stirring at $20^{\circ} \mathrm{C}$ throughout the assay time. After the different contact times up to equilibrium, the samples were taken from the flasks, and the absorbance was measured. Thus, the CA and EU profile concentration in each simulant over time could be determined by the absorbance measurements using the corresponding standard calibration curve. All analyses were performed in triplicate for three different flasks containing the different film samples. The liquid phase in contact with the active-free PHBV films was used as blank for the absorbance measurements, for each simulant and time. 


\subsubsection{Mathematical modelling of CA and EU release.}

The Peleg model [27] was applied to the data regarding the CA or EU content in the food simulant at the different times in order to estimate the amount of active released at equilibrium $\left(\mathrm{M}_{\infty}\right)$, as well as the partition coefficient of the active compounds in the different food simulant. Eq. 1 relates the data of the active concentration in the simulant and time.

$\frac{t}{M_{t}}=k_{1}+k_{2} t$ (Eq. 1)

Where:

$\mathrm{M}_{\mathrm{t}}$ : mass of active compound released into the simulant after contact time $\mathrm{t}$.

$k_{1}$ and $k_{2}$ : model constants, where $k_{1}$ is inversely related with the release rate and $k_{2}$ with the asymptotic value of the curve or mass of active released at equilibrium $\left(M_{\infty}=1 / k_{2}\right)$.

Likewise, experimental data were also fitted using the Korsmeyer-Peppas model [28] (Eq. 2), to investigate the mechanisms involved in the active release process and the possible coupling of the relaxation of the polymer in contact with the solvent with the diffusion of the active compound through the polymer matrix.

$\frac{M_{t}}{M_{\infty}}=k t^{n}($ Eq. 2)

Where $M_{t} / M_{\infty}$ is the fraction of active compound released at time $t, k$ is the rate constant incorporating characteristics of the matrix related to the diffusion process, and $n$ is the diffusional exponent that provides information about the mechanisms involved in the release process. Thus, a $\mathrm{n}$ value of 0.5 means that the release takes place through Fickian diffusion, whereas if the $n$ value is higher than 0.5 , known as anomalous transport, the diffusion and the polymer relaxation rates are coupled. If the $n$ value is lower than 0.5 , a quasi-Fickian diffusion for the active release can be considered [28].

Lastly, Fick's second law was considered to model the diffusion process of CA and EU in the PHBV bilayer films towards the food simulants. Film samples can be considered as infinite plane sheets with the half thickness as a characteristic dimension, where the active compound diffuses only in an axial direction. The diffusional long-time equation for an infinite plane sheet [29] with ten terms was used to determine the values of diffusion coefficient (D) of CA and EU 
into the different solvents (Eq. 3), by using the Solver tool (Microsoft Excel 2013 ${ }^{\circledR}$ ) to optimize the D values, by minimizing the Sum of Squared Errors (SSE), and considering the following boundary conditions:

$$
\begin{array}{lcll}
t=0 & 0<x<L & c=c_{0} \\
t>0 & x=0 \quad x=L \quad c=0 \\
M_{t}=M_{\infty}\left(\frac{8}{\pi^{2}} \sum_{n=0}^{\infty}\left[\frac{1}{(2 n+1)^{2}} \exp \left\{\frac{-\pi^{2} D(2 n+1)^{2} t}{L^{2}}\right\}\right]\right)
\end{array}
$$

where:

Mt: mass of compound released at time $t$.

$M_{\infty}$ : mass of compound released at equilibrium.

L: half thickness of film.

\subsubsection{Prediction of antimicrobial action of the films from release kinetics.}

Along with the obtained parameters, Peleg's equation, was used to predict the amount of CA or EU released throughout time into different types of foodstuffs, simulated by the considered simulants; this was compared with the MIC values reported for different bacteria in order to determine whether these values are reached in the food system in a reasonable time. To this end, a theoretical mass ratio of active packaging and food of 12:1000 was considered, corresponding to a $1 \mathrm{~kg}$ of product packaged in a $15 \times 10 \times 6 \mathrm{~cm}$ pack with a film area of $450 \mathrm{~cm}^{2}$. In this way, the length of time necessary to reach the active's MIC of some foodborne bacteria has been predicted depending on the kind of packaged food.

\subsection{Overall migration of active PHBV bilayer films}

An important issue in the field of food contact materials is the migration of the packaging constituents into the food. The OM2 overall migration test was carried out, according to Regulation 10/2011/EC [26], in order to determine the overall migration of the PHBV films with and without the different actives (CA or EU). The OM2 test determines the migration of a specific packaging material in $A, B$ and $D 2$ food simulants for 10 days at $40^{\circ} \mathrm{C}$; this simulates a long food storage period at room temperature or lower, including heating at $70^{\circ} \mathrm{C}$ for $2 \mathrm{~h}$ or heating at $100{ }^{\circ} \mathrm{C}$ for $15 \mathrm{~min}$. To this end, five film samples of $23 \mathrm{~mm}$ diameter were placed in tubes with $69 \mathrm{~mL}$ of corresponding solvent and kept at $40{ }^{\circ} \mathrm{C}$ for 10 days. Afterwards, the solvent was transferred to cups and evaporated at $105^{\circ} \mathrm{C}$ until a constant weight was reached. 
Thus, the overall migration of each film formulation was determined as the weight of residue after drying and expressed as $\mathrm{mg} / \mathrm{dm}^{2}$ of film, according to the regulation. All analyses were carried out in duplicate.

\subsection{Statistical analysis}

Statgraphics Centurion XVI (Manugistics Corp., Rockville, MD) was used to carry out statistical analyses of data through analysis of variance (ANOVA). Fisher's least significant difference (LSD) was used at the $95 \%$ confidence level.

\section{RESULTS AND DISCUSSION}

\subsection{Concentration of active compounds in the films}

The final mass ratio of the active compounds in the films after compression moulding was estimated through the weight loss of the films in this step. It was about $2.5 \%$ with respect to the initial mass of the film, regardless of the type of active. The weight loss of the films can be attributed to the active compound volatilization and moisture loss $(0.9 \%)$, which represents a final content of active in the films of about $11-12 \mathrm{~g}$ of active/100 $\mathrm{g}$ film, and a retention percentage with respect to the amount initially incorporated of nearly $90 \%$. Nevertheless, the methanol extraction of CA and EU from PHBV-CA and PHBV-EU films and the subsequent quantification by the spectrophotometric method yielded $10.3 \pm 1.0$ and $5.7 \pm 0.9 \mathrm{~g}$ per $100 \mathrm{~g}$ of film, respectively for $C A$ and $E U$, without significant differences between samples from different films and film zones. Thus, a reproducible and homogenous distribution of the actives in the film can be assumed, while, as compared with the theoretical active content in the films (13 g per $100 \mathrm{~g}$ film), the retention percentages would be $80 \pm 6 \%$ and $43 \pm 4 \%$ for CA and EU, respectively. Nevertheless, taking into account the similar boiling points of CA (234-236 $\left.{ }^{\circ} \mathrm{C},[30]\right)$ and $\mathrm{EU}\left(253^{\circ} \mathrm{C},[31]\right)$, no total extraction could be carried out from the active PHBV films in methanol, especially for EU, due to an inadequate partition coefficient associated with the compounds' particular interactions with the polymer matrix and their solubility in the extraction solvent. So, about $11-12 \mathrm{~g}$ of active/100 $\mathrm{g}$ film could be assumed in the films with CA or EU.

\subsection{Release kinetics of CA and EU in food simulants}

Release mass of CA and EU at different contact times with simulants have been determined and Figure 1 shows the mean values, referred to the maximum value (at equilibrium) for each case. This ratio represented the fraction of active released at each time with respect to the 
final amount released at equilibrium in each simulant. Table 1 shows the maximum values $\left(M_{\infty}\right)$, referred per mass unit of the initial film, and estimated by applying Peleg's model to the experimental data for CA and EU release. The values of $1 / k_{1}$ parameter, related to the release rate, were also included in Table 1. A good fitting of the model was achieved in all cases $\left(R^{2}>0.97\right)$. Both release rate and asymptotic value were greatly affected by the polarity of the food simulant, yielding different values for each active. The fastest release of both CA and EU was observed in $50 \%$ ethanol (D1 simulant), whereas the slowest delivery occurred in the non-polar solvent (D2: isooctane). Likewise, the maximum active release occurred in D1 simulant for both compounds, without any significant differences in the $M_{\infty}$ values. Similar amounts of both compounds were also delivered at equilibrium in the non-polar simulant (D2). This behaviour agrees with that reported by other authors for the EO compounds' delivery, which increased when the ethanol ratio rose in the food simulant, according to the promotion of the active compound solubility in the aqueous system when the ethanol ratio rose $[19,23,23,32]$. In the more polar simulants of different $\mathrm{pH}(\mathrm{A}$ and $\mathrm{B})$, greater amounts of EU than CA were released, since EU is more soluble $(2460 \mathrm{mg} / \mathrm{L},[33])$ than CA (1250 mg/L, [33]) in water. Nevertheless, EU was released at a slower rate. Thus, the maximum expected release of CA and EU will occur in less polar foodstuffs, such as alcoholic beverages or oil-inwater emulsions (sauces, dressings or high fat dairy products), whereas in more aqueous foods a lower release would be expected. Table 1 also shows the maximum delivery ratio $\left(M_{\infty} / M_{0}\right)$ for each compound, related with its partition coefficient (defined as the mass of active released at equilibrium in the simulant $\left(M_{\infty}\right)$ with respect to the corresponding residual mass of the active in the film $\left.\left(M_{0}-M_{\infty}\right)\right)$. This ratio was referred to the $M_{0}$ value of the theoretical amount incorporated in the initial film and also to the amount determined by methanol extraction. Values higher than $100 \%$ can be observed for the second approach, thus indicating that methanol extraction was not complete, especially for EU, as previously commented on. A practically total release of the retained compound occurred in films in contact with D1 simulant, where about $95 \%$ of the theoretical amount incorporated was released. Then, only about $5 \%$ of the incorporated active compounds were lost during the film thermocompression process, as deduced from the weight loss analyses, and a final concentration of 11-12 $\mathrm{g}$ of active/100 g film could be assumed.

Table 2 shows the diffusion values and the Kormeyer\&Peppas parameters for CA and EU release in each simulant. The values of $n$ coefficient were not significantly higher than 0.5 in any case for the active compound release and so, Fickian or quasi-Fickian diffusion can be predicted for both actives in the PHBV matrix, as reported by other authors for different EO compounds from different matrices. Particularly, a diffusional mechanism has been reported for thymol release in different polyester films, such as poly(butylene succinate) [22] and poly(lactic acid) [19], lemongrass EO in sodium alginate films [20] and Satureja hortensis EO in alginate microparticles [34]. Therefore, the relaxation of the polymer in contact with the solvents was not coupled with the compound diffusion and three steps can be assumed for 
the release process: a) the solvent diffusion into the polymer matrix, b) the network relaxation in line with solvation and plasticization, and c) the diffusion of the compound through the relaxed polymer network until the thermodynamic equilibrium between phases (polymer/food system) is reached. At equilibrium, the compound affinity with the solvated polymer and its solubility in the liquid food system will determine the partition coefficient for the delivered compound. The compound diffusion through the matrix will be affected by the solvent impregnation into the polymer network and the interactions established among the components.

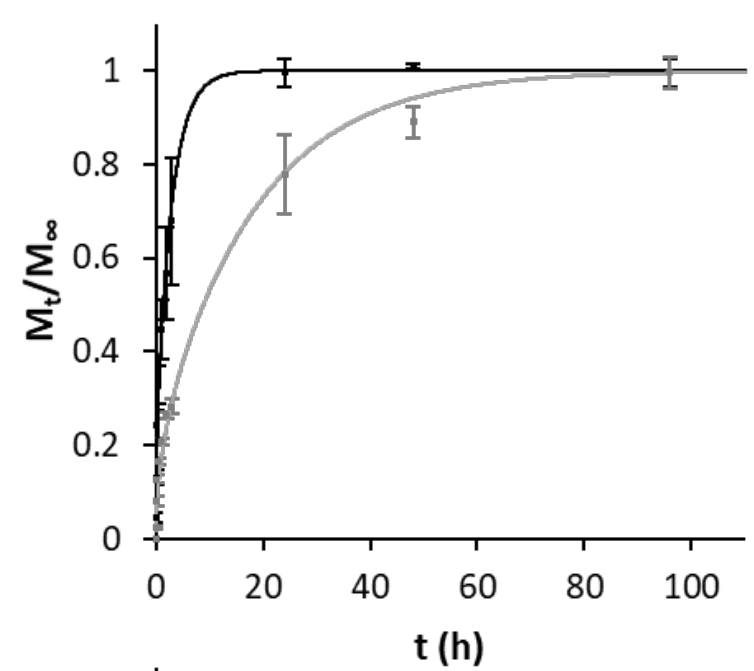

A

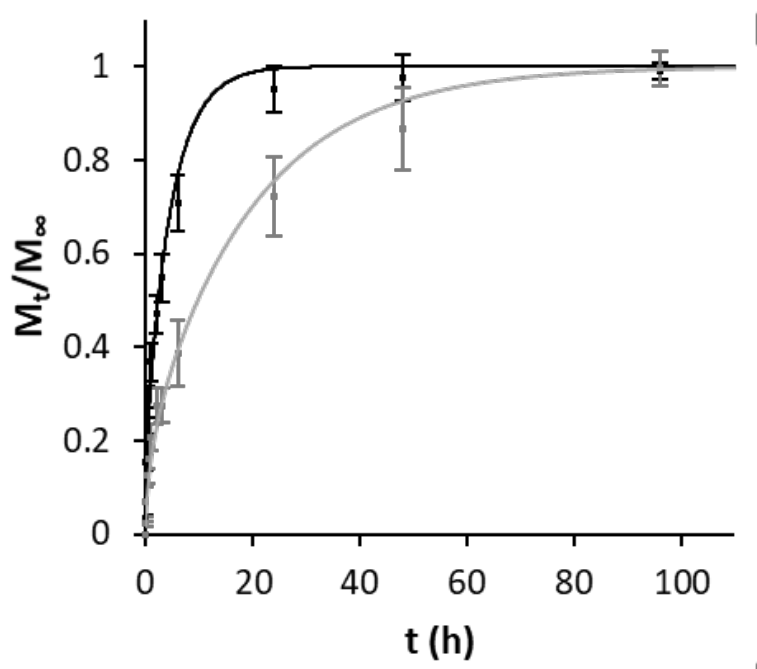

B

C

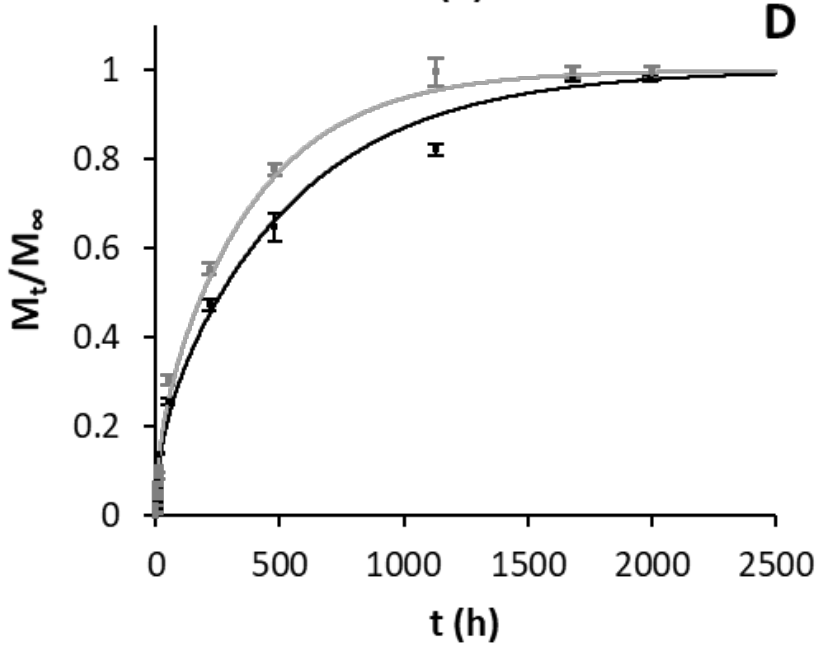

Figure 1. Ratio of the active compound released in each food simulant, with respect to that of the equilibrium value, as a function of contact time (points) and fitted Fick's model (lines). CA ( - ) and EU $(-)$. A: ethanol $10 \%(v / v), B$ : acetic acid $3 \%(w / v), D 1$ : ethanol $50 \%(v / v)$, and D2: isooctane. 
Table 1. Parameters of Peleg's model: amount of active compound released at equilibrium in $100 \mathrm{ml}$ of simulant $\left(\mathrm{M}_{\infty}\right)\left(\mathrm{g}\right.$ active $/ 100 \mathrm{~g}$ film) and its release rate $\left(1 / \mathrm{k}_{1}\right)(\mu \mathrm{g}$ active/s), and maximum release ratio $\left(M_{\infty} / M_{0}\right)$ : mass of active released at equilibrium in the simulant related to the initial mass of the active in the film (expressed with respect to the theoretical incorporated amount $\left({ }^{1}\right)$ and with respect to the amount determined by methanol extraction $\left({ }^{2}\right)$.

\begin{tabular}{llccccc}
\hline Active & Simulant & $\mathbf{1 / \mathbf { k } _ { 1 }}$ & $\mathbf{M}_{\infty}=1 / \mathbf{k}_{\mathbf{2}}$ & $\mathbf{M}_{\infty} / \mathbf{M}_{\mathbf{0}}(\%)^{\mathbf{1}}$ & $\mathbf{M}_{\infty} / \mathbf{M}_{\mathbf{0}}(\%)^{\mathbf{2}}$ & $\mathbf{R}^{\mathbf{2}}$ \\
\hline \multirow{4}{*}{ Carvacrol } & A & $3.5 \pm 1.1^{\mathrm{c}}$ & $2.9 \pm 0.2^{\mathrm{e}}$ & $22 \pm 2^{\mathrm{e}}$ & $28 \pm 2^{\mathrm{f}}$ & 0.980 \\
& B & $2.8 \pm 1.0^{\mathrm{c}}$ & $2.9 \pm 0.8^{\mathrm{e}}$ & $23 \pm 6^{\mathrm{e}}$ & $29 \pm 8^{\mathrm{f}}$ & 0.997 \\
& D1 & $7.2 \pm 0.7^{\mathrm{b}}$ & $12.5 \pm 0.2^{\mathrm{a}}$ & $96 \pm 2^{\mathrm{a}}$ & $122 \pm 2^{\mathrm{c}}$ & 0.995 \\
& D2 & $0.15 \pm 0.02^{\mathrm{e}}$ & $8.4 \pm 0.4^{\mathrm{c}}$ & $65 \pm 3^{\mathrm{c}}$ & $82 \pm 4^{\mathrm{e}}$ & 0.973 \\
\hline \multirow{3}{*}{ Eugenol } & A & $1.9 \pm 0.3^{\mathrm{cd}}$ & $6.1 \pm 0.3^{\mathrm{d}}$ & $47 \pm 2^{\mathrm{d}}$ & $107 \pm 5^{\mathrm{d}}$ & 0.999 \\
& B & $2.0 \pm 0.7^{\mathrm{cd}}$ & $6.7 \pm 0.1^{\mathrm{d}}$ & $52 \pm 1^{\mathrm{d}}$ & $118 \pm 2^{\mathrm{c}}$ & 0.999 \\
& D1 & $19.0 \pm 2.0^{\mathrm{a}}$ & $11.9 \pm 0.2^{\mathrm{a}}$ & $92 \pm 2^{\mathrm{a}}$ & $210 \pm 4^{\mathrm{a}}$ & 0.977 \\
& D2 & $0.30 \pm 0.03^{\mathrm{de}}$ & $9.3 \pm 0.3^{\mathrm{b}}$ & $71 \pm 3^{\mathrm{b}}$ & $163 \pm 6^{\mathrm{b}}$ & 0.982 \\
\hline
\end{tabular}

a-g: different letters in the same column indicate significant differences $(P<0.05)$ between samples

Table 2. Diffusion coefficient (D) and parameters of the Korsmeyer-Peppas model (rate constant (k) and diffusional exponent ( $\mathrm{n})$ ).

\begin{tabular}{llcccc}
\hline Active & Simulant & $\mathbf{D x 1 0 ^ { 1 3 }}\left(\mathbf{m}^{\mathbf{2}} / \mathbf{s}\right)$ & $\mathbf{n}$ & $\mathbf{k}\left(\mathbf{h}^{-\mathbf{n}}\right)$ & $\mathbf{R}^{\mathbf{2}}$ \\
\hline \multirow{4}{*}{ Carvacrol } & A & $3.2 \pm 0.4^{\mathrm{d}}$ & $0.450 \pm 0.020^{\mathrm{d}}$ & $0.27 \pm 0.02^{\mathrm{bc}}$ & 0.990 \\
& B & $4.8 \pm 0.4^{\mathrm{e}}$ & $0.354 \pm 0.008^{\mathrm{a}}$ & $0.37 \pm 0.03^{\mathrm{cd}}$ & 0.999 \\
& D1 & $1.2 \pm 0.2^{\mathrm{b}}$ & $0.508 \pm 0.006^{\mathrm{e}}$ & $0.25 \pm 0.02^{\mathrm{bc}}$ & 0.975 \\
& D2 & $0.017 \pm 0.002^{\mathrm{a}}$ & $0.510 \pm 0.014^{\mathrm{e}}$ & $0.060 \pm 0.001^{\mathrm{a}}$ & 0.989 \\
\hline \multirow{3}{*}{ Eugenol } & A & $0.50 \pm 0.10^{\mathrm{ab}}$ & $0.383 \pm 0.006^{\mathrm{ab}}$ & $0.17 \pm 0.06^{\mathrm{ab}}$ & 0.982 \\
& B & $0.50 \pm 0.12^{\mathrm{ab}}$ & $0.390 \pm 0.030^{\mathrm{b}}$ & $0.20 \pm 0.03^{\mathrm{ab}}$ & 0.992 \\
& D1 & $5.5 \pm 0.4^{\mathrm{d}}$ & $0.549 \pm 0.012^{\mathrm{f}}$ & $0.43 \pm 0.03^{\mathrm{d}}$ & 0.996 \\
& D2 & $0.023 \pm 0.0013^{\mathrm{a}}$ & $0.383 \pm 0.004^{\mathrm{ab}}$ & $0.068 \pm 0.003^{\mathrm{a}}$ & 0.997
\end{tabular}

a-f: different letters in the same column indicate significant differences $(P<0.05)$ between samples

Figure 1 shows the experimental points in terms of the ratio of released compound with respect to the equilibrium value and the fitted Fick's model for CA and EU diffusion, in each simulant. The good fitting of the model can be observed in all cases ( $\mathrm{SSE}<0.04$ ) as well as the different pattern of the curves depending on the simulant and the released compound. Whereas the CA release in aqueous simulants ( $A$ and $B$ ) was significantly faster than that of EU, significantly slower CA release occurred in the less polar simulants (D1 and D2), as 
compared to EU. The values of diffusion coefficients (Table 2) were coherent with the commented release rates of each compound in the different simulants. In this sense, it is remarkable that diffusion of EU in the matrix when it is in contact with the most polar simulants was greatly reduced, with respect to that of CA. This suggests stronger interactions of EU with the solvated PHBV matrix, which reduced its migration rate through the network, although higher amounts were delivered at equilibrium in these simulants where this compound is more soluble. On the contrary, when solvent polarity was reduced, and a less polar solvent is entrapped in the matrix, the EU diffusion, and its release rate, increased with respect to that of $\mathrm{CA}$, the matrix releasing similar amounts of the compounds at equilibrium, near to the initial total content of the film (13 g/100 g film). Tawakkal et al. [19] and Petchwattana and Naknaen [22] also reported an increase in the diffusion coefficient of thymol in poly(lactic acid) and poly(butylene succinate) films, respectively, when the polarity of the simulant decreased (higher ethanol/water ratio), in agreement with that observed for EU in PHBV films, but contrary to CA behavior. Nevertheless, the obtained D values were in the range of those obtained by other authors $[19,22]$ for thymol release from polyester films to water/ethanol mixtures, at similar temperatures $\left(0.1-3.0 \cdot 10^{-13} \mathrm{~m}^{2} / \mathrm{s}\right)$. The differences can be explained in terms of the respective interactions of the active with the solvated polymer matrix and its solubility in the liquid phase, depending on its polarity.

The slowest diffusion of both active compounds was obtained in the least polar system (isooctane), probably due to the fact that the polymer matrix swells to a lower extent with this solvent, which supposes a reduction in the free volume of polymer chains, thus limiting the diffusion process, as reported by other authors [21-23]. A more closed network implies a more restricted compound mobility, thus inhibiting molecular diffusion.

\subsection{Active release prediction over the storage time.}

On the basis of the kinetic analysis, the active release concentration vs. time was predicted assuming bulk diffusion into the food mass (e.g packaged liquid food), for a packaged food with a food-film mass ratio of 1000:12, (e.g. $1 \mathrm{~kg}$ product in a $15 \times 10 \times 6$ pack with $450 \mathrm{~cm}^{2}$ area) and the kinetic equations obtained for the different simulants, using both film formulations, PHBV-CA and PHBV-EU. Figures 2 and 3 show the concentration values of CA and EU, respectively, reached in the food system as a function of time, where the range of values for the MIC for several foodborne pathogens were also shown. As deduced from kinetic analysis, CA would be quickly delivered in aqueous foods, achieving a limited maximum concentration after $24 \mathrm{~h}$. On the contrary, the CA release will be higher and more gradual in non-polar systems (D2). Almost $44 \mathrm{~h}$ will be needed for fatty foods to reach the required concentration for the antimicrobial action, taking into account the MIC values of CA against some foodborne pathogens such as Staphylococcus aureus $\left(1.7 \cdot 10^{-4} \mathrm{~g} / \mathrm{mL}\right)$, Bacillus cereus $\left(1.8 \cdot 10^{-4} \mathrm{~g} / \mathrm{mL}\right)$, 
Salmonella typhimurium $\left(2.2 \cdot 10^{-4} \mathrm{~g} / \mathrm{mL}\right)$, Escherichia coli $\left(2.2 \cdot 10^{-4} \mathrm{~g} / \mathrm{mL}\right)$ and Listeria monocytogenes $\left(3.7 \cdot 10^{-4} \mathrm{~g} / \mathrm{mL}\right)$ [35]. In contrast, in aqueous foods, MICs for most bacteria would be reached after short contact times (between 2 and $24 \mathrm{~h}$ depending on the bacteria) and, therefore, a fast microbial growth inhibition could be expected. In contrast, for foods with alcohol content higher than $20 \%$ or oil in water emulsions (D1 simulant), only $1 \mathrm{~h}$ would be required to achieve these MIC values.

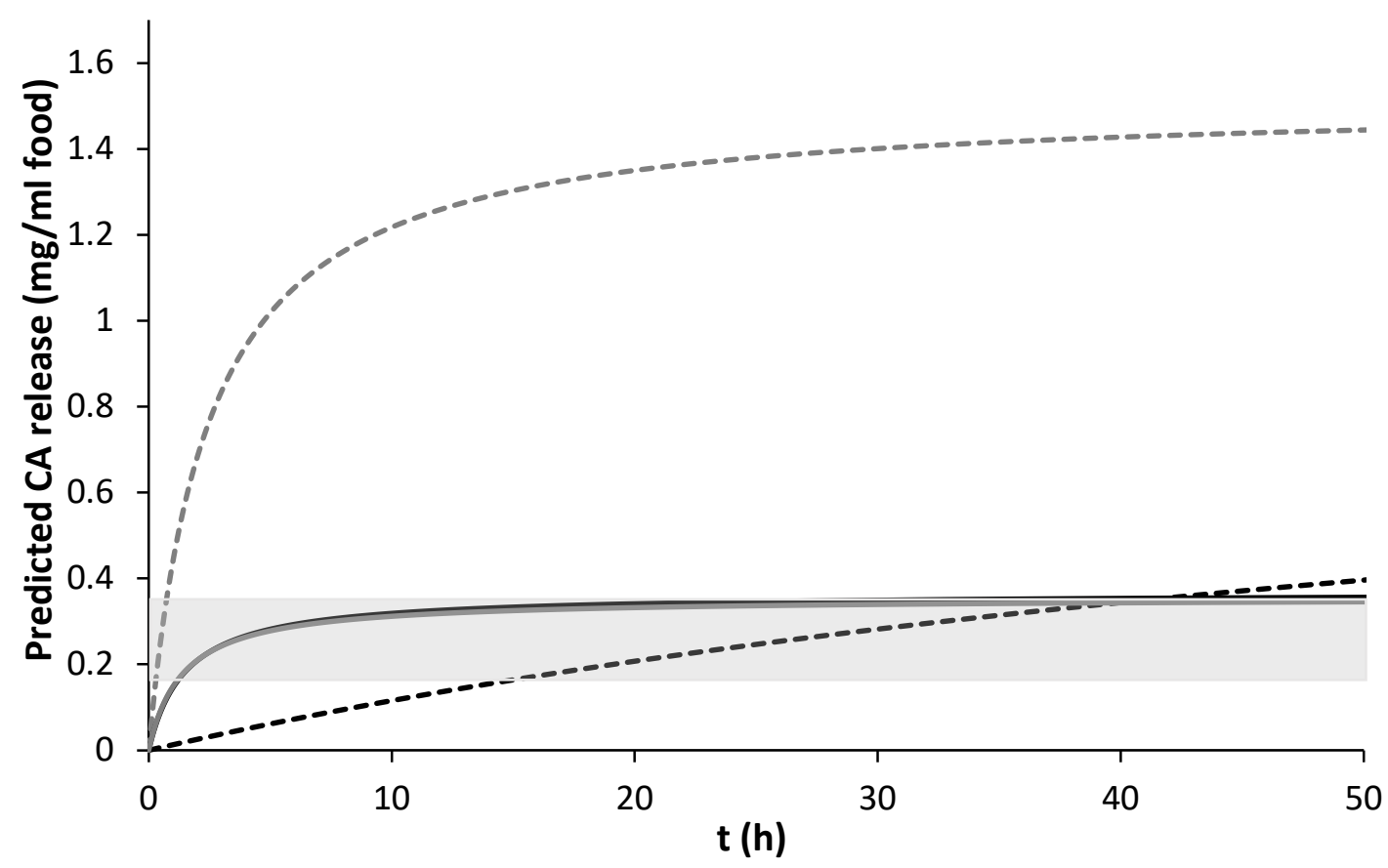

Figure 2. Predicted concentration of released CA versus time in different types of food or food simulants: $10 \%$ ethanol (-), $3 \%$ acetic acid (-), $50 \%$ ethanol (--) and isooctane (---). Shaded area corresponds to the range of minimum inhibitory concentration of CA against different bacteria.

Figure 3 shows the predicted concentration of EU released in the different types of foods (simulants) compared with the MIC values of several bacteria. Since the bacteria show different sensitivity to EU than to $C A$, different EU amounts will be necessary to inhibit their microbial growth. The reported MIC values of EU were $1.6 \cdot 10^{-5} \mathrm{~g} / \mathrm{mL}$ for $B$. cereus [36], $1 \cdot 10^{-4}$ $\mathrm{g} / \mathrm{mL}$ for S. aureus [37], $5 \cdot 10^{-4} \mathrm{~g} / \mathrm{mL}$ for S. typhimurium [35], $1 \cdot 10^{-3} \mathrm{~g} / \mathrm{mL}$ for E. coli [35] or $1 \cdot 10^{-}$ ${ }^{3} \mathrm{~g} / \mathrm{mL}$ for L. monocytogenes [35]. Thus, in some cases, longer contact times between the active film and the foodstuffs would be required, according to the EU release rates. Then, whereas in aqueous foods the MIC of EU would be achieved after $5 \mathrm{~min}-8 \mathrm{~h}$, for some of the above mentioned bacteria, the MIC for $E$. coli and L. monocytogenes would not be reached at any time, since the maximum expected EU release ranges between $7 \cdot 10^{-4}-8 \cdot 10^{-4} \mathrm{~g} / \mathrm{ml}$ in the polar food model. On the contrary, all the MIC values would be reached in less polar foodstuffs 
at different times, depending on the food continuous phase. Thus, in oil-in-water foods, such as some dairy products, only $2 \mathrm{H}$ would be necessary to reach the MIC of EU against E. coli and L. monocytogenes, while 15 days would be required in foodstuffs with a fatty continuous phase.

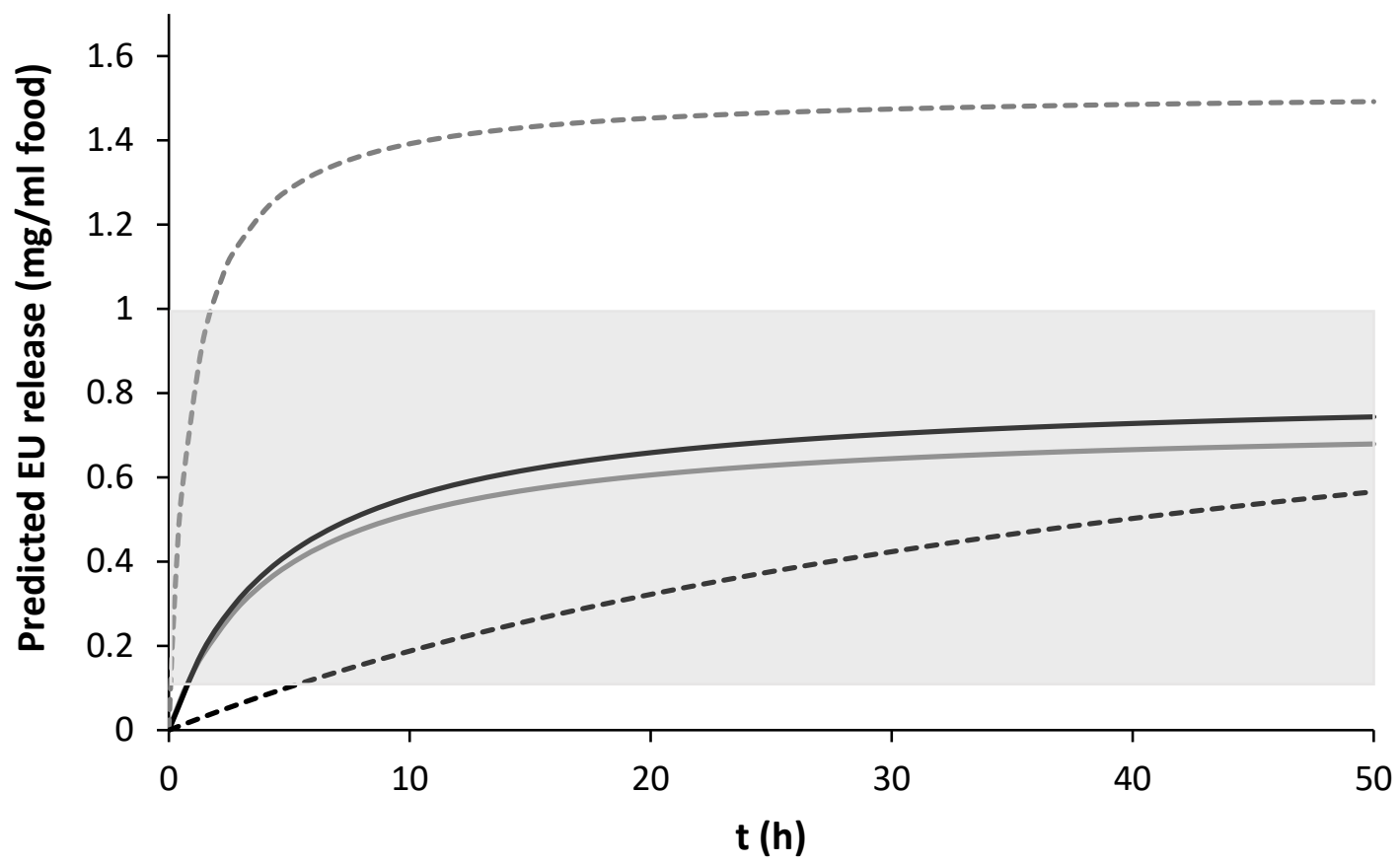

Figure 3. Predicted concentration of released EU versus time in each different type of food or food simulants: $10 \%$ ethanol (-), $3 \%$ acetic acid (-), $50 \%$ ethanol (---) and isooctane (---). Shaded area corresponds to the minimum inhibitory concentration of EU against different bacteria.

\subsection{Overall migration of active PHBV bilayer films}

Overall migration of the obtained films was also assessed to determine how they fit the European Regulation in terms of the overall migration limit (OML). All the films maintained their integrity after the contact time at $40{ }^{\circ} \mathrm{C}$ in all the food simulants tested. According to the Regulation 10/2011/EC [26], the OML for plastic materials and articles must not exceed $10 \mathrm{mg}$ of total constituents delivered per $\mathrm{dm}^{2}$ of food contact surface. Nevertheless, also according to the regulation for active materials intended to come into contact with foodstuffs, the active substances released should not be included in the overall migration [38]. Moreover, as reported by Balaguer et al. [39], the volatile substances, such as the EOS and their main compounds, are not considered in the overall migration values, since the possibly migrated compounds evaporate with the solvents and do not contribute to the final residue weight. This is especially true when aqueous solvents are used and the steam drag effect favors the 
compound evaporation. Then, the determined migration values do not include the active compounds and it is assumed that they correspond to a fraction of the polymer matrix (polymer plus plasticizer).

Figure 4 shows the values of the overall migration, expressed in $\mathrm{mg} / \mathrm{dm}^{2}$ of the film, for the different film samples and simulants. Active-free PHBV films exceeded the OML in both neutral and acid polar simulants, without significant differences due to $\mathrm{pH}$, while no migration occurred in isooctane. Most of the residue found in polar solvents could be mainly attributed to plasticizer migration, due to its more hydrophilic nature and water solubility, since, in all cases, the overall migration values were lower than the PEG concentration in the films (107 $\left.\mathrm{mg} / \mathrm{dm}^{2}\right)$.

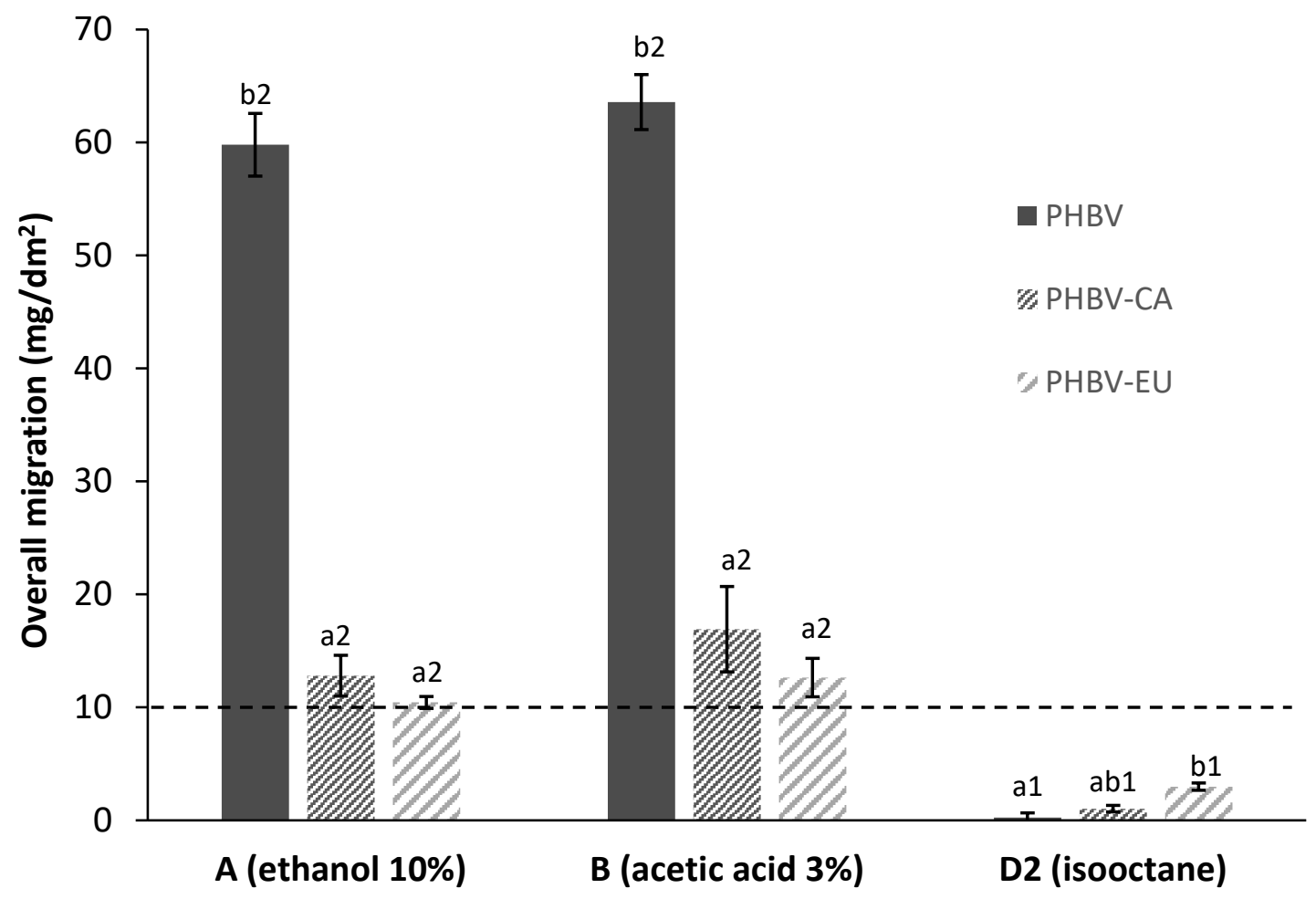

Figure 4. Overall migration in different food simulants of active-free PHBV films and those containing different active components: carvacrol (PHBV-CA) and eugenol (PHBV-EU). Different letters $(a, b, .$. indicate significant differences between samples for a determined simulant and different numbers $(1,2, .$.$) significant differences between simulants for a determined film sample. Overall migration limit$ $(--)$. 
However, PHBV films with active compounds showed significantly lower overall migration values than active-free PHBV films in both neutral and acid polar simulants. This suggests that interactions between actives and plasticizer could lead to linking reactions (e.g. PEG can act as Lewis acceptor of phenolic protons through the oxygen electron pairs of ether groups), thus reducing the water solubility of PEG, which contributes to its greater retention in the matrix. No significant differences in overall migration in $10 \%$ ethanol and $3 \%$ acetic acid were observed for PHBV films containing CA or EU. On the contrary, in non-polar solvents such as isooctane, PHBV films with the active compounds led to slightly higher migration values than the active-free PHBV films, although in every case the values of the overall migration were lower than in polar simulants and below the OML. When using this solvent, the evaporation of actives before determining the weight of residue could occur to a lesser extent, since no steam drag effects would occur in the absence of water. Then, the potentially released active compounds could contribute to the total amount of migrated mass determined.

Under the extreme conditions tested, the water affinity of the plasticizer used (PEG) leads to the OML being exceeded in most of the cases in polar systems. Nevertheless, overall migration values within the permitted range could be achieved in less extreme environmental conditions [39]. Plasticizer seems to be retained in the polymer matrix when the phenolic active compounds are present in the films.

\section{CONCLUSION}

PEG plasticized PHBV active films with CA and EU could be obtained by incorporating them between two polymer layers by spraying the active, and subsequent compression moulding. Although $15 \mathrm{~g}$ of actives per $100 \mathrm{~g}$ polymer matrix were incorporated, about $5 \%$ of these were lost during thermal compression and the bilayer films contain about $12 \mathrm{~g}$ of actives per $100 \mathrm{~g}$ of film. This method simulates incorporating actives and adhesive at the same time during the industrial production of multilayer films. CA and EU diffused through the polymer layers and were effectively released into different food simulants. At equilibrium, a total release of both CA and EU occurred in 50\% ethanol (simulating high fat content, oil-in-water foods), whereas around 20 and $50 \%$ of the content, for CA and EU respectively, was delivered in the more aqueous systems, regardless of the $\mathrm{pH}$. In fatty systems, $65-70 \%$ of the active content was delivered at equilibrium. The release rate was enhanced when the polarity of aqueous systems decreased (50\% ethanol), but it fell markedly in fatty systems (isooctane). The delivery of EU from PHBV films plasticized with PEG was slower than that of CA in aqueous systems, but this tendency was inverted when the polarity of the medium decreased. On the basis of the release kinetics, the antimicrobial activity against some foodborne pathogens could be predicted, taking the reported minimal inhibitory concentration of each compound into account. This 
concentration was reached for CA in every simulant tested at different times, which permits its effective antimicrobial action to be predicted. Nevertheless, EU did not reach the antimicrobial levels of some pathogens in neutral and acid aqueous systems or in fatty foods. However, antimicrobial in vivo tests are required to assess the antimicrobial effectiveness of these kinds of materials in real foods.

\section{Acknowledgements}

The authors thank the Ministerio de Economía y Competitividad (Spain) for the financial support provided through Project AGL2013-42989-R and AGL2016-76699-R. Author Raquel Requena thanks the Ministry of Education, Culture and Sport (Spain) for the FPU (FPU13/03444) Grant. 


\section{REFERENCES}

[1] C. Chervin, A. El-Kereamy, P. Rache, A. Tournaire, B. Roger, P. Westercamp, R. Holmes, Ethanol vapours to complement or replace sulfur dioxide fumigation of table grapes, in: 26th International Horticultural Congress: Issues and Advances in Postharvest Horticulture, Toronto, 2013.

[2] J.A. Torres, M. Motoki, M. Karel, Microbial stabilization of intermediate moisture food surfaces I. Control of surface preservative concentration, J. Food Process. Pres. 9(2) (1985) 75-92.

[3] A. Ben Arfa, L. Preziosi-Belloy, P. Chalier, N. Gontard, Antimicrobial paper based on a soy protein isolate or modified starch coating including carvacrol and cinnamaldehyde, J. Agr. Food Chem. 55(6) (2007) 2155-2162.

[4] E. Chollet, I. Sebti, A. Martial-Gros, P. Degraeve, Nisin preliminary study as a potential preservative for sliced ripened cheese: $\mathrm{NaCl}$, fat and enzymes influence on nisin concentration and its antimicrobial activity, Food Control. 19 (10) (2008) 982-989.

[5] P. Suppakul, J. Miltz, K. Sonneveld, S.W. Bigger, Active packaging technologies with an emphasis on antimicrobial packaging and its applications, J. Food Sci. 68(2) (2003) 408-420.

[6] S. Tunç, O. Duman, Preparation of active antimicrobial methyl cellulose/carvacrol/montmorillonite nanocomposite films and investigation of carvacrol release, LWT-Food Sci. Technol. 44(2) (2011) 465472.

[7] V. Jost, H. C. Langowski, Effect of different plasticisers on the mechanical and barrier properties of extruded cast PHBV films, Eur. Polym. J. 68 (2015) 302-312.

[8] S.S. Ray, M. Bousmina, Biodegradable polymers and their layered silicate nanocomposites: in greening the 21st century materials world, Prog. Mater. Sci. 50(8) (2005) 962-1079.

[9] J.R. Calo, P.G. Crandall, C.A. O'Bryan, S. C. Ricke, Essential oils as antimicrobials in food systems-A review, Food Control. 54 (2015) 111-119.

[10] A. Aguirre, R. Borneo, A.E. León, Antimicrobial, mechanical and barrier properties of triticale protein films incorporated with oregano essential oil, Food Bioscience. 1 (2013) 2-9.

[11] D. Alkan, A. Yemenicioğlu, Potential application of natural phenolic antimicrobials and edible film technology against bacterial plant pathogens, Food Hydrocolloid. 55 (2016) 1-10.

[12] M.P. Arrieta, M.A. Peltzer, M. del Carmen Garrigós, A. Jiménez, Structure and mechanical properties of sodium and calcium caseinate edible active films with carvacrol, J. Food Eng. 114(4) (2013) 486-494.

[13] S. Benavides, R. Villalobos-Carvajal, J. E. Reyes, Physical, mechanical and antibacterial properties of alginate film: Effect of the crosslinking degree and oregano essential oil concentration, J. Food Eng. $110(2)(2012) 232-239$. 
[14] B. Teixeira, A. Marques, C. Pires, C. Ramos, I. Batista, J.A. Saraiva, M.L. Nunes, Characterization of fish protein films incorporated with essential oils of clove, garlic and origanum: Physical, antioxidant and antibacterial properties, LWT-Food Sci. Technol. 59(1) (2014) 533-539.

[15] I. Fernández-Pan, J. I. Maté, C. Gardrat, V. Coma, Effect of chitosan molecular weight on the antimicrobial activity and release rate of carvacrol-enriched films, Food Hydrocolloid. 51 (2015) 60-68.

[16] E.A. Tehrany, S. Desobry, Partition coefficient of migrants in food simulants/polymers systems, Food Chem. 101(4) (2007) 1714-1718

[17] C. Barba, A. Eguinoa, J.I. Maté, Preparation and characterization of $\beta$-cyclodextrin inclusion complexes as a tool of a controlled antimicrobial release in whey protein edible films, LWT-Food Sci. Technol. 64(2) (2015) 1362-1369.

[18] G. Biddeci, G. Cavallaro, F. Di Blasi, G. Lazzara, M. Massaro, S. Milioto, ..., G. Spinelli, Halloysite nanotubes loaded with peppermint essential oil as filler for functional biopolymer film, Carbohyd. Polym. 152 (2016) 548-557.

[19] I.S. Tawakkal, M. J. Cran, S.W. Bigger, Release of thymol from poly (lactic acid)-based antimicrobial films containing kenaf fibres as natural filler, LWT-Food Sci. Technol. 66 (2013) 629-637.

[20] S.B. Matiacevich, Edible antimicrobial films based on microencapsulated lemongrass oil, Journal of food science and technology, 53(1) (2016) 832-839.

[21] M. A. Del Nobile, A. Conte, A. L. Incoronato, O. Panza, Antimicrobial efficacy and release kinetics of thymol from zein films, J. Food Eng. 89(1) (2008) 57-63.

[22] N. Petchwattana, P. Naknaen, Utilization of thymol as an antimicrobial agent for biodegradable poly (butylene succinate), Mater. Chem. Phys. 163 (2015) 369-375.

[23] L. Sánchez-González, M. Cháfer, C. González-Martínez, A. Chiralt, S. Desobry, Study of the release of limonene present in chitosan films enriched with bergamot oil in food simulants, J. Food Eng. 105(1) (2011) 138-143.

[24] R. Requena, A. Jiménez, M. Vargas, A. Chiralt, Poly [(3-hydroxybutyrate)-co-(3-hydroxyvalerate)] active bilayer films obtained by compression moulding and applying essential oils at the interface, Polym. Int. 65(8) (2016) 883-891.

[25] COMMISSION DIRECTIVE 97/48/EC of 29 July 1997 amending for the second time Council Directive $82 / 711 /$ EEC laying down the basic rules necessary for testing migration of the constituents of plastic materials and articles intended to come into contact with foodstuffs (text with EEA relevance).

[26] Commission Regulation (EU) No 10/2011 of 14 January 2011 on plastic materials and articles intended to come into contact with food.

[27] M. Peleg, An Empirical Model for the Description of Moisture Sorption Curves, J. Food Sci. 53(4) (1988) 1216-1217.

[28] J. Siepmann, N. A. Peppas, Higuchi equation: derivation, applications, use and misuse, Int. J. Pharm. 418(1) (2011) 6-12. 
[29] J. Crank, The Mathematics of Diffusion, second ed. Oxford University Press, 1975.

[30] G. A. Leeke, R. Santos, M. B. King, Vapor-liquid equilibria for the carbon dioxide+ carvacrol system at elevated pressures, J. Chem. Eng. Data. 46(3) (2001) 541-545.

[31] H. M. El-Tahawi, R. G. Craig, Thermal analysis of zinc oxide-eugenol cements during setting, J. Dent. Res, 50(2) (1971) 430-5.

[32] ANarayanan, K. V. Ramana, Synergized antimicrobial activity of eugenol incorporated polyhydroxybutyrate films against food spoilage microorganisms in conjunction with pediocin, Appl. Biochem. Biotech. 170(6) (2013) 1379-1388.

[33] S.H. Yalkowsky, Y. He, P. Jain, Handbook of Aqueous Solubility Data, second ed. CRC Press, Florida, 2010.

[34] S.M. Hosseini, H. Hosseini, M.A. Mohammadifar, J.B. German, A.M. Mortazavian, A. Mohammadi, K. Khosravi-Darani, R. Khaksar, Incorporation of essential oil in alginate microparticles by multiple emulsion/ionic gelation process, Int. J. Biol. Macromol. 62 (2013) 582-588.

[35] S. Burt, Essential oils: their antibacterial properties and potential applications in foods-a review, Int. J. Food Microbiol. 94(3) (2004) 223-253.

[36] M. J. Mohammed, F.A. Al-Bayati, Isolation and identification of antibacterial compounds from Thymus kotschyanus aerial parts and Dianthus caryophyllus flower buds, Phytomedicine. 16(6) (2009) 632-637.

[37] S.E. Walsh, J.Y. Maillard, A.D. Russell, C.E. Catrenich, D.L. Charbonneau, R.G. Bartolo, Activity and mechanisms of action of selected biocidal agents on Gram-positive and-negative bacteria, J. Appl. Microbiol. 94(2) (2003) 240-247.

[38] Commission Regulation (EC) No 450/2009 of 29 May 2009 on active and intelligent materials and articles intended to come into contact with food (Text with EEA relevance)

[39] M.P. Balaguer, M. Borne, P. Chalier, N. Gontard, M.H. Morel, S. Peyron,..., P. Hernandez-Munoz, Retention and release of cinnamaldehyde from wheat protein matrices, Biomacromolecules. 14(5) (2013) 1493-1502. 



\section{Study of the potential synergistic antibacterial activity of essential oil components using the thiazolyl blue tetrazolium bromide (MTT) assay}

Raquel Requena; María Vargas; Amparo Chiralt

Submited to Applied and Environmental Microbiology

Institute of Food Engineering for Development, Universitat Politècnica de València, Valencia, Spain 



\section{ABSTRACT}

A thiazolyl blue tetrazolium bromide (MTT) assay was used to study in a rapid and easy way the potential interactions between several active compounds extracted from plant essential oils (carvacrol, eugenol, cinnamaldehyde, thymol and eucalyptol) that were used as antibacterial agents against Escherichia coli and Listeria innocua. The minimum inhibitory concentration (MIC) of each active compound and the fractional inhibitory concentration (FIC) index for the binary combinations of essential oil compounds were determined. According to FIC index values, some of the compound binary combinations showed an additive effect, but others, such as carvacrol-eugenol and carvacrol-cinnamaldehyde exhibited a synergistic effect against $L$. innocua and $E$. coli, which was affected by the compound ratios. Some eugenolcinnamaldehyde ratios exhibit an antagonistic effect against $E$. coli, but a synergistic effect against $L$. innocua. The most remarkable synergistic effect was observed for carvacrolcinnamaldehyde blends for both $E$. coli and $L$. innocua, but using different compound ratios (1:0.1 and 0.5:4 respectively for each bacteria).

Keywords: antimicrobial synergy, Listeria innocua, Escherichia coli, MIC, FIC index. 


\section{INTRODUCTION}

Foodborne pathogens and spoilage bacteria are the major concerns of food companies, since they produce a large amount of food waste with the consequent economic losses, as well as causing important foodborne illnesses, which is one of the major global health preoccupations [1]. Synthetic preservatives have been widely used for decades to maintain quality, extend the shelf life and ensure the safety of foodstuffs [2]. However, their repeated applications have led to chemical residue accumulation in the food chain and the development of microbial resistance and side effects for human health [3]. For these reasons, consumer preferences are changing toward safer, natural food preservatives. In this context, essential oils (EOs) and several of their constituents represent a natural, safe alternative to chemical food preservatives, due to their capacity to inhibit the growth of a wide variety of pathogenic and food-spoiling microorganisms including bacteria, fungi and yeasts $[1,4,5]$. Thus, carvacrol, which is the main compound of oregano EO, has been effective at inhibiting the growth and survival of several foodborne and spoilage bacteria, such as Listeria monocytogenes, Aeromonas hydrophila, Pseudomonas fluorescens [6] and different strains of Escherichia coli [7], as well as some important foodborne fungal pathogens [8]. Carvacrol is also present in thyme EO, where thymol is the most abundant active compound. Several in vivo studies demonstrated that thymol exhibits antimicrobial activity against a broad spectrum of Gram negative or Gram-positive bacteria [9] and fungi [8]. Eugenol is the main compound of cinnamon leaf EO (70-95\%), which also contains cinnamaldehyde in a proportion of 1 to $5 \%$ [10]. Both active compounds have exhibited significant antimicrobial effects in in vitro tests against different foodborne pathogens, such as Staphylococcus sp., Micrococcus sp., Bacillus sp., Enterobacter sp. [11], E. coli [12] and Helicobacter pylori [13]. Eucalyptol, which occurs in different active aromatic plants such as oregano, rosemary, thyme and ginger, also has proven broad-spectrum antimicrobial activity that includes the inhibition of both Gram-positive ( $L$. monocytogenes, Staphylococcus aureus, Bacillus cereus and Enterococcus faecalis) and Gramnegative bacteria (E. coli, A. hydrophila, Pseudomonas aeruginosa and fluorescens, Klebsiella pneumoniae and Moraxella catarrhalis) [14, 15]. However, the concentrations of the EOs or their constituents required to inhibit bacterial growth in foods can modify the taste or exceed the acceptable flavour threshold of food products [16]. In this sense, the potential synergistic activity of these EO compounds has appeared as an alternative means of reducing the active doses needed to achieve antimicrobial effects in food, since several authors have demonstrated some synergistic interactions against several foodborne pathogens in in vitro studies combining carvacrol, thymol, eugenol, cinnamaldehyde and eucalyptol $[6,12,15,17$, 18]. Nevertheless, it is very difficult to compare the published results for the same EO compounds, since there are several factors that influence their antimicrobial effects. The most important variable is the antimicrobial test method, including incubation temperature, inoculum size and test microorganisms $[19,20]$. Therefore, it is necessary to standardize the antimicrobial activity assessment in order to obtain comparable and reproducible results. 
Diffusion methods (agar disk diffusion and agar well diffusion) have been widely used to screen the antimicrobial activity of EOs and their main compounds (Huang et al., 2012) [7, 21]; however, these tests do not permit the quantification of their bioactivity in terms of minimum inhibitory concentration (MIC), since they are qualitative tests [22]. Likewise, methods in vapour-phase, such as the disk volatilization assay, have been used in many studies for the antimicrobial evaluation of EOs in vapour-phase, but they only allow us to identify the most effective compound from several active ingredients $[23,24]$. Moreover, these tests are not able to perform a large-scale screening with many different active compounds at different concentrations. Some other methods used to determine the EO compounds' antimicrobial activity, such as the agar-plate method for total microbial count, are resource-intensive and time-consuming [25], and more sophisticated studies, such as flow cytometry or tests based on absorbance measurement, require special equipment which is not commonly available [26, 27]. The thiazolyl blue tetrazolium bromide (MTT) colorimetric assay is one of the most useful methods for the evaluation of in vitro cell viability using microtiter plate design or the broth microdilution method [24], which has been used to study EO antimicrobial susceptibility [24, 28], as well as drug interactions against bacteria [29] and fungi [30]. This checkerboard experiment avoids the need for culturing procedures and allows us to distinguish between bacteriostatic and bactericidal effects and, therefore, obtain an easy and rapid quantitative determination of the MIC of large numbers of samples [22], unlike the antimicrobial susceptibility methods based on colony counting by decimal dilution and agar plating, which are not able to check many different active compounds and concentrations within a short time [12]. Moreover, the MTT assay is an inexpensive and reproducible test, which can be used for a wide variety of microorganisms, since the use of the MTT reagent as a colorimetric indicator avoids the need for a spectrophotometric plate reader. Nonetheless, EO compounds can alter the results of microplate toxicity assays, due to their volatile nature [31]. Thus, it is advisable to use an effective vapour barrier, such as a sealer mat made of non-reactive rubber, to avoid vapour transmission between adjacent wells [24, 29].

To the best of our knowledge, the potential use of the MTT assay as a tool with which to determine the possible interactions between different active compounds of essential oils at controlling microbial growth has been little explored. The aim of this study was to analyse the potential synergistic activity of the most effective antimicrobial compounds from EOs (carvacrol, eugenol, cinnamaldehyde, thymol and eucalyptol) against E. coli and L. innocua using MTT assay. E. coli was chosen as model for pathogenic Gram-negative bacteria [32], whereas $L$. innocua was selected as representative strain of L. monocytogenes (model Grampositive bacteria), because of its non-pathogenicity to humans [33] and similar sensitivity to EO compounds [34]. 


\section{MATERIALS AND METHODS}

\subsection{Reagents and bacterial strains}

Carvacrol, eugenol, cinnamaldehyde, thymol, eucalyptol and MTT reagent were supplied by Sigma-Aldrich (Steinheim, Germany). Dimethyl sulfoxide (DMSO) was purchased from Panreac (Barcelona, Spain), whereas Phosfate Buffered Saline (PBS), Tryptone Soy Broth (TSB) and Tryptone Soy Agar (TSA) were supplied by Scharlab (Barcelona, España).

Listeria innocua (CECT 910) and Escherichia coli (CETC 101) lyophilized strains were supplied by the Spanish Type Culture Collection (CECT, Universitat de València, Spain), and stored at $-25^{\circ} \mathrm{C}$ with $30 \%$ glycerol. Active cultures were regenerated by inoculating the microbial stock suspensions into TSB followed by their incubation at $37^{\circ} \mathrm{C}$ for $24 \mathrm{~h}$. The inoculums were properly diluted to obtain bacterial suspensions of $10^{5} \mathrm{CFU} / \mathrm{mL}$.

\subsection{MIC assessment and combined antimicrobial effects}

A MTT colorimetric assay was carried out by using a 96-well microtiter plate design in order to determine the MIC of the different EO compounds (Figure 1). Stock solutions of each EO compound $(10 \mathrm{mg} / \mathrm{mL}$ ) were obtained using DMSO as emulsifier. Diluted EO solutions (2.5 to $0.05 \mathrm{mg}$ active/ $\mathrm{mL}$ ) were prepared from the stock solutions using TSB medium as solvent and aliquots of $100 \mu \mathrm{l}$ of each dilution were placed in their corresponding wells. Then, plates were inoculated with $100 \mu \mathrm{l}$ of the $10^{5} \mathrm{CFU} / \mathrm{mL}$ bacterial suspension and covered with a sealer mat as an effective vapour barrier to prevent the volatile compounds from contaminating the adjoining wells. Sterility and bacterial growth control were also prepared with non-inoculated and inoculated culture media, whereas the outer wells were left empty to prevent edge effect.

After $24 \mathrm{~h}$ incubation at $37^{\circ} \mathrm{C}, 10 \mu \mathrm{l}$ of MTT reconstituted in PBS at $5 \mathrm{mg} / \mathrm{mL}$ were added to each well and incubated for $4 \mathrm{~h}$ at $37{ }^{\circ} \mathrm{C}$. MTT is a yellow tetrazolium salt, which is reduced to a purple formazan by dehydrogenases of a live cell. Thus, the formazan amount produced is directly proportional to the number of live cells and the MIC of the EO compounds can be assessed by the naked eye [28]. In this way, the MIC values were determined as the lowest concentration of active compound at which no purple colour was observed. All the experiments were carried out in duplicate. 


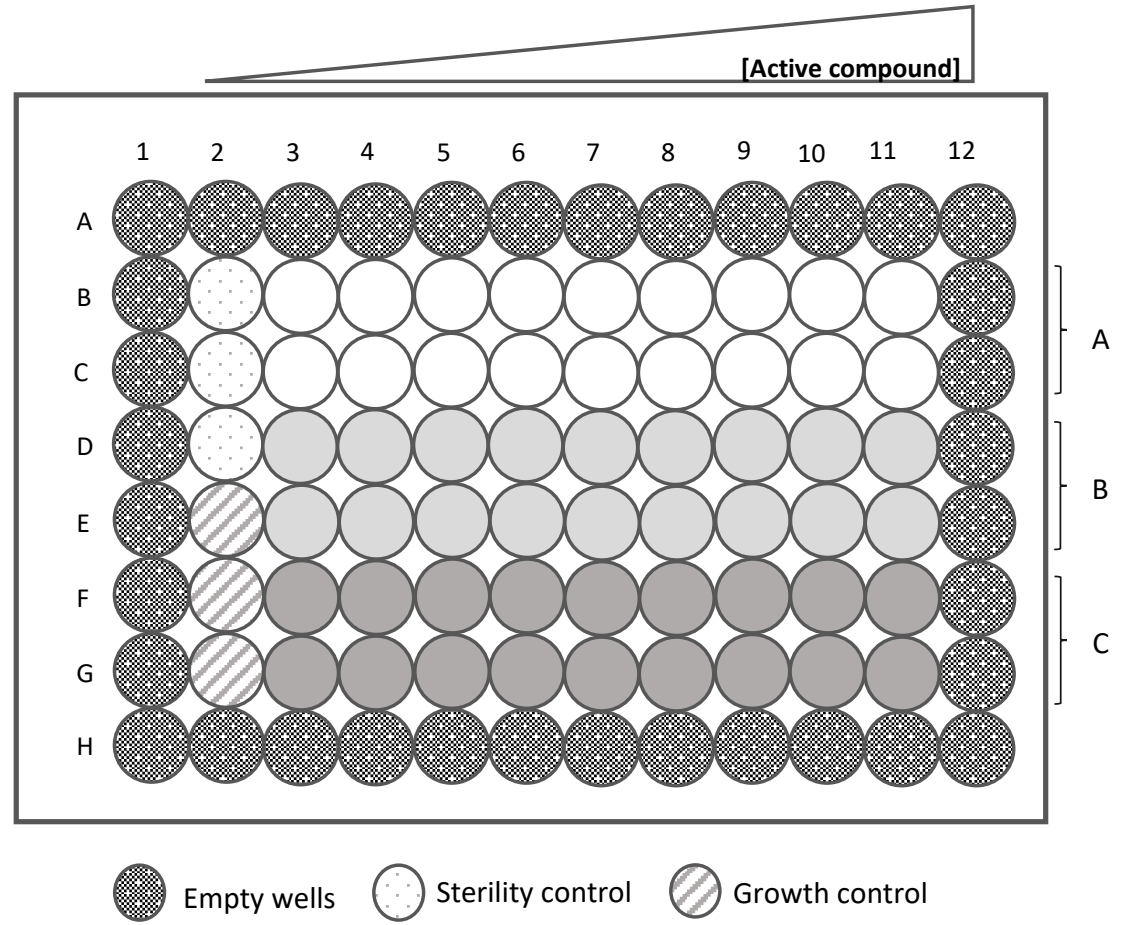

Figure 1. Experimental design for the determination of the minimum inhibitory concentration (MIC) of three different active compounds (A, B and C). Sterility and growth control were prepared with noninoculated and inoculated culture media, whereas the outer wells were left empty to avoid edge effect.

The potential synergistic effects of binary combinations of the different EO compounds were also tested by the chequerboard method. EO compound stock solutions were prepared in DMSO and properly diluted in TSB to obtain binary combinations with final concentrations of each active compound that ranged from the MIC values determined to 1:100 dilution below the corresponding MIC. The microtiter plate design allowed the concentrations of each antimicrobial to be varied along the different axes, thus ensuring that each well of the plate represents a different combination (Figure 2). The antimicrobial effects of each binary combination were evaluated by calculating the fractional inhibitory concentration (FIC) index, following Eq. (1). As shown in the theoretical isobologram (Figure 3), it was considered to be a synergistic action when the FIC index was lower than 1, additivity when the FIC was 1 , and an antagonistic effect when the FIC was higher than $1[12,27,35]$.

$\mathrm{FIC}_{\text {index }}=\mathrm{FIC}_{\mathrm{A}}+\mathrm{FIC}_{\mathrm{B}}$

Where,

$\mathrm{FIC}_{\mathrm{A}}=\mathrm{MIC}_{\mathrm{A} \text { in presence of } \mathrm{B}} / \mathrm{MIC}_{\mathrm{A} \text { alone }}$

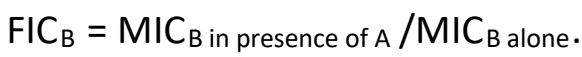




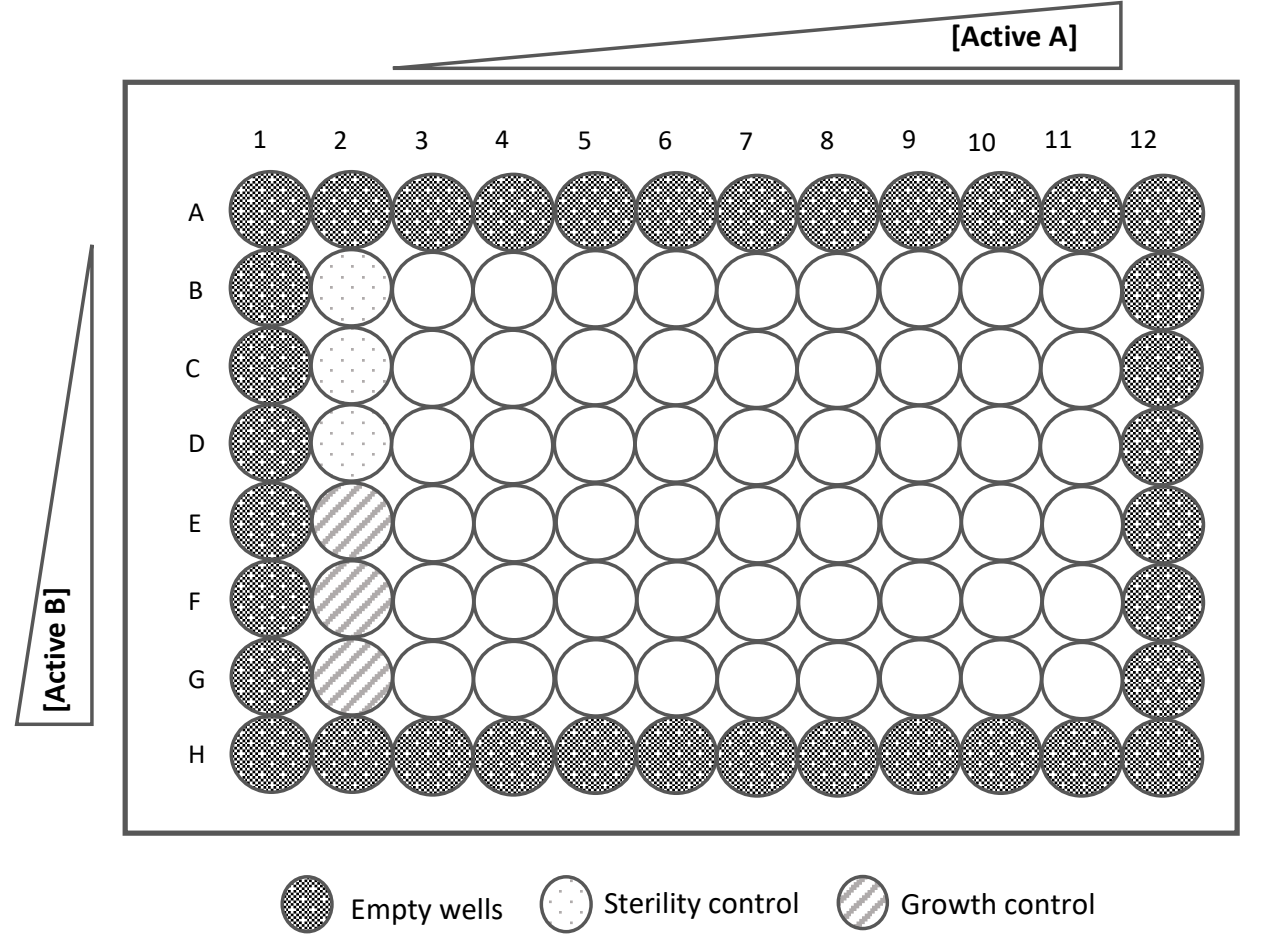

Figure 2. Experimental design for the determination of the fractional inhibitory concentration (FIC) for each active compound in a binary mixture. Sterility and growth control were prepared with noninoculated and inoculated culture media, whereas the outer wells were left empty to avoid edge effect.

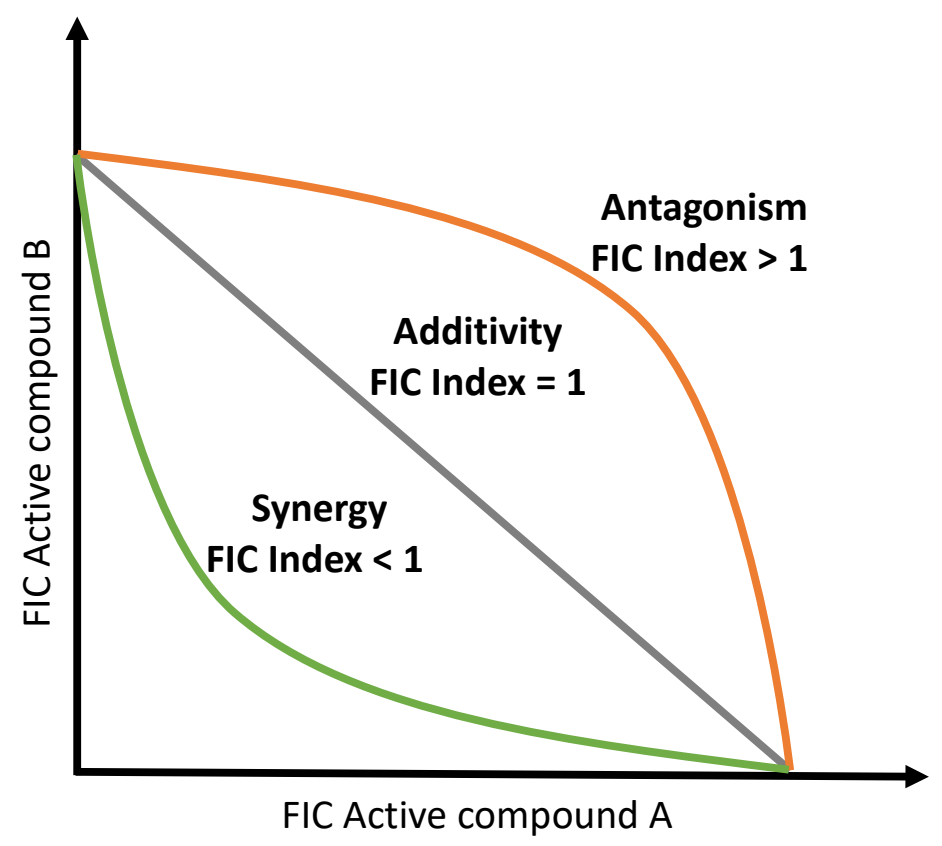

Figure 3. Theoretical isobolograms displaying the three types of possible effects (additivity, antagonism and synergy), according to the fractional inhibitory concentration (FIC) index values. 


\section{RESULTS AND DISCUSSION}

\subsection{Minimum inhibitory concentration}

All the active components evaluated exhibited antibacterial activity against $E$. coli and $L$. innocua, with values of MIC ranging from 0.5 to $1.75 \mathrm{mg} / \mathrm{mL}$ (Table 1). Cinnamaldehyde was the most effective at inhibiting the growth of both bacteria (lowest MIC), and the reported MIC was similar to that found by other authors $[18,28]$. As reported de Sousa et al. [6] and Van Vuuren \& Viljoen [15] for L. monocytogenes and E. coli, respectively, eucalyptol was the least effective at inhibiting bacterial growth, E. coli being more resistant. Likewise, in accordance with the MIC reported by Pei et al. [12] and Hill et al. [18] for E. coli and L. innocua, respectively, eugenol showed lower values as compared to cinnamaldehyde, carvacrol and thymol, being more effective against $L$. innocua.

Carvacrol and thymol, with very similar molecular structures (Table 1), showed similar MIC values for both bacteria, E. coli being more affected than $L$. innocua. This coincides with that obtained in previous studies, although the MIC values were slightly lower $[17,36]$. The differences in terms of the MIC values for the same active component and bacterial strain can be explained by the different methodology applied, the culture media used, inoculum size, $\mathrm{pH}$, incubation time and temperature [12].

Table 1. Minimum inhibitory concentration (MIC) of the different active compounds against Escherichia coli and Listeria innocua.

Active compound




\subsection{Interactions between components in binary active compound mixtures}

The potential synergistic antibacterial effect of all binary combinations of the compounds were determined quickly and easily by calculating the fractional inhibitory concentration (FIC) index, thus obtaining the isobolograms for the different active binary mixtures against $L$. innocua (Figure 4) and E. coli (Figure 5). It was considered to be a synergistic action when the FIC index was lower than 1, additivity when the FIC index was 1, and an antagonistic effect when the FIC index was higher than $1[12,27,35]$. The binary combinations that exhibit a synergistic effect with the lowest FIC index values are given in Table $\mathbf{2}$ for both $E$. coli and $L$. innocua.

Carvacrol/cinnamaldehyde combinations exhibited a synergistic effect against $E$. coli for almost all combination ratios (Figure 5), but the synergistic effect against L. innocua (Figure 4) was only observed when cinnamaldehyde was the major component in the mixture. Ye el al. [28] also reported strong synergistic activity for carvacrol/cinnamaldehyde combinations against 7 kinds of bacteria, including E. coli. In contrast, almost all the eugenol/cinnamaldehyde combinations exhibited an antagonistic effect against $E$. coli and $L$. innocua. On the contrary, Pei et al. [12] found a synergistic action between eugenol and cinnamaldehyde against $E$. coli and only an additive effect between carvacrol and cinnamaldehyde for the same bacteria.

Every ratio of eugenol/carvacrol combinations showed an antagonistic effect against $L$. innocua, whereas either synergistic or additive effects were observed against $E$. coli, depending on the ratio of both components. Similarly, no synergistic effects were observed for different ratios of eugenol/carvacrol combinations against L. innocua by García-García et al. [37].

As concerns carvacrol/thymol combinations, an antagonistic effect was observed for $E$. coli at every ratio while a mild synergistic action was detected for L. innocua at the highest carvacrol ratio (Table 2). In contrast, Pei et al. [12] observed a synergistic activity of these compounds against $E$. coli. However, other authors [38, 39] did not find that positive interactions between these compounds improved their antibacterial action, suggesting a similar mechanism of action associated with their similar molecular structure.

Despite the different molecular structure of carvacrol and eucalyptol, which could promote a different mechanism of action, antimicrobial activity was not promoted in the carvacrol/eucalyptol mixtures, in contrast with that reported by de Sousa et al. [6] and de Oliveira et al. [14]. In fact, binary combinations with eucalyptol were the least effective in most cases, in line with its higher MIC value for both bacteria. So, its antibacterial activity was the lowest, both alone or combined with other, more active compounds. Only when combined with a small proportion of thymol, was the FIC index value lower than 1 for L. innocua (Table 2). 
Compound combinations, given in Table 2, allow for greater antibacterial action than that achieved with the respective, pure compounds, using a lower total amount of actives. It is remarkable that wider synergistic spectrum was obtained for $L$. innocua than for $E$. coli, which could be related with the different bacteria cell envelope of Gram-positive and Gram-negative bacteria. Gram-positive bacteria surrounded by layers of peptidoglycan many times thicker than is found in E. coli could be more sensitive to the combined action of different compounds that are able to interact with the bacteria cell envelope to a different extent. The compound combination that was best at controlling the growth of $E$. coli was carvacrol/cinnamaldehyde (1:0.1 ratio), whose MIC value was $0.55 \mathrm{mg} / \mathrm{mL}$. This combination was also the most effective against $L$. innocua (MIC value $0.45 \mathrm{mg} / \mathrm{mL}$ ), but when using a caravacrol/cinnamaldehyde ratio of 0.5:4.

Table 2. Binary combinations with the highest synergistic effect (lowest fractional inhibitory concentration index) against Listeria innocua and Escherichia coli.

\begin{tabular}{lcccc} 
& \multicolumn{2}{c}{ E. coli } & \multicolumn{2}{c}{ L. innocua } \\
\hline Synergistic combination (A/B) & $\mathbf{A ~ ( m g / m L )}$ & $\mathbf{B ~ ( m g / m L )}$ & $\mathbf{A ~ ( m g / m L ) ~}$ & B (mg/mL) \\
\hline Carvacrol/Cinnamaldehyde & 0.50 & 0.05 & 0.05 & 0.40 \\
Carvacrol/Thymol & - & - & 0.60 & 0.10 \\
Eugenol/Carvacrol & 0.40 & 0.45 & 0.90 & 0.10 \\
Eugenol/Cinnamaldehyde & 0.80 & 0.10 & 0.20 & 0.40 \\
Eugenol/Thymol & - & - & 0.90 & 0.05 \\
Eucalyptol/Thymol & - & - & 1.00 & 0.05 \\
Eucalyptol/Cinnamaldehyde & - & - & 1.00 & 0.10 \\
Thymol/Cinnamaldehyde & - & - & 0.45 & 0.10 \\
\hline
\end{tabular}



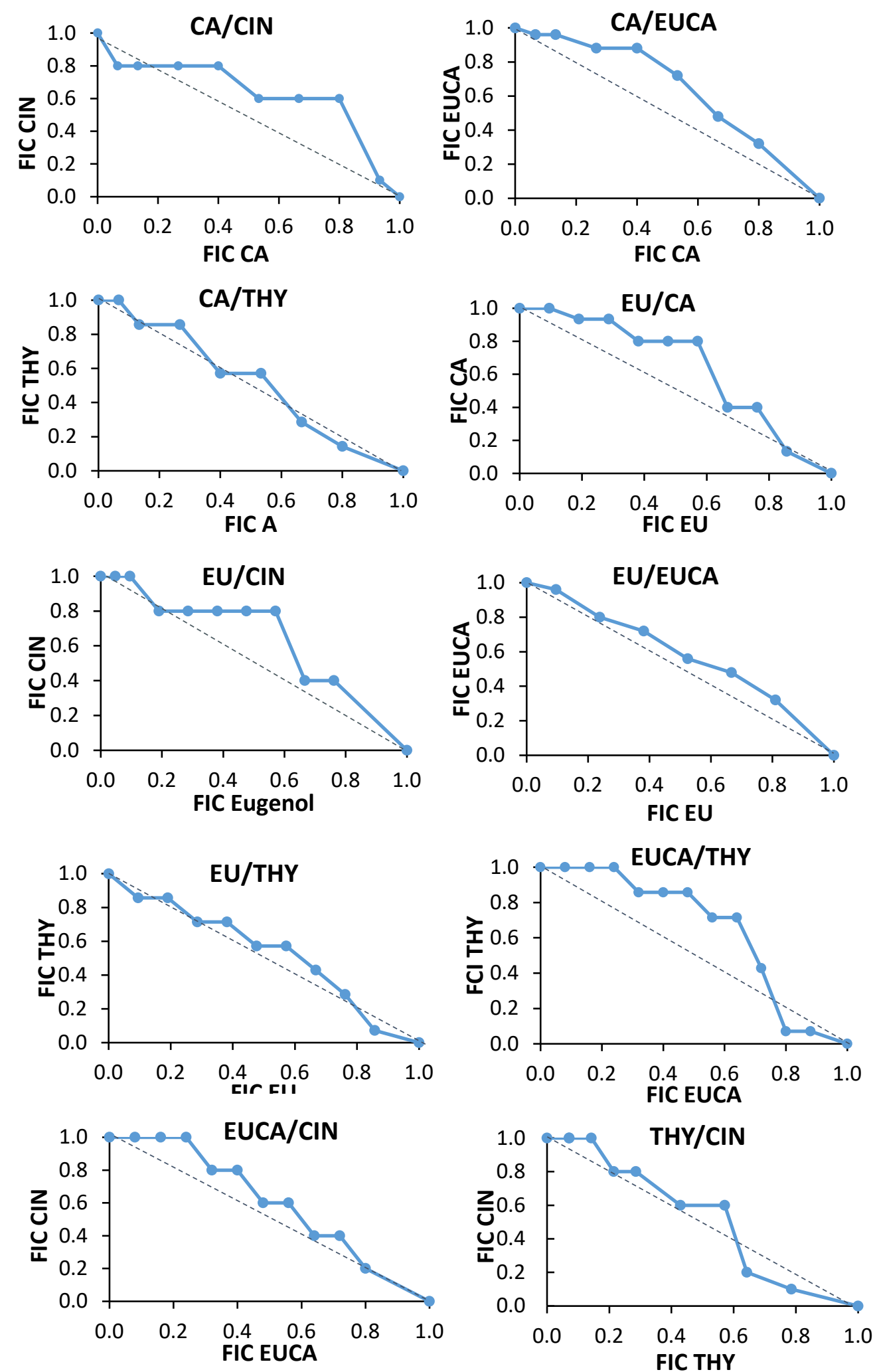

Figure 4. Isobolograms showing the fractional inhibitory concentration (FIC) for the binary combinations of the active compounds (carvacrol (CA), eugenol (EU), cinnamaldehyde (CIN), thymol (THY), eucalyptol (EUCA)) against L. innocua. 

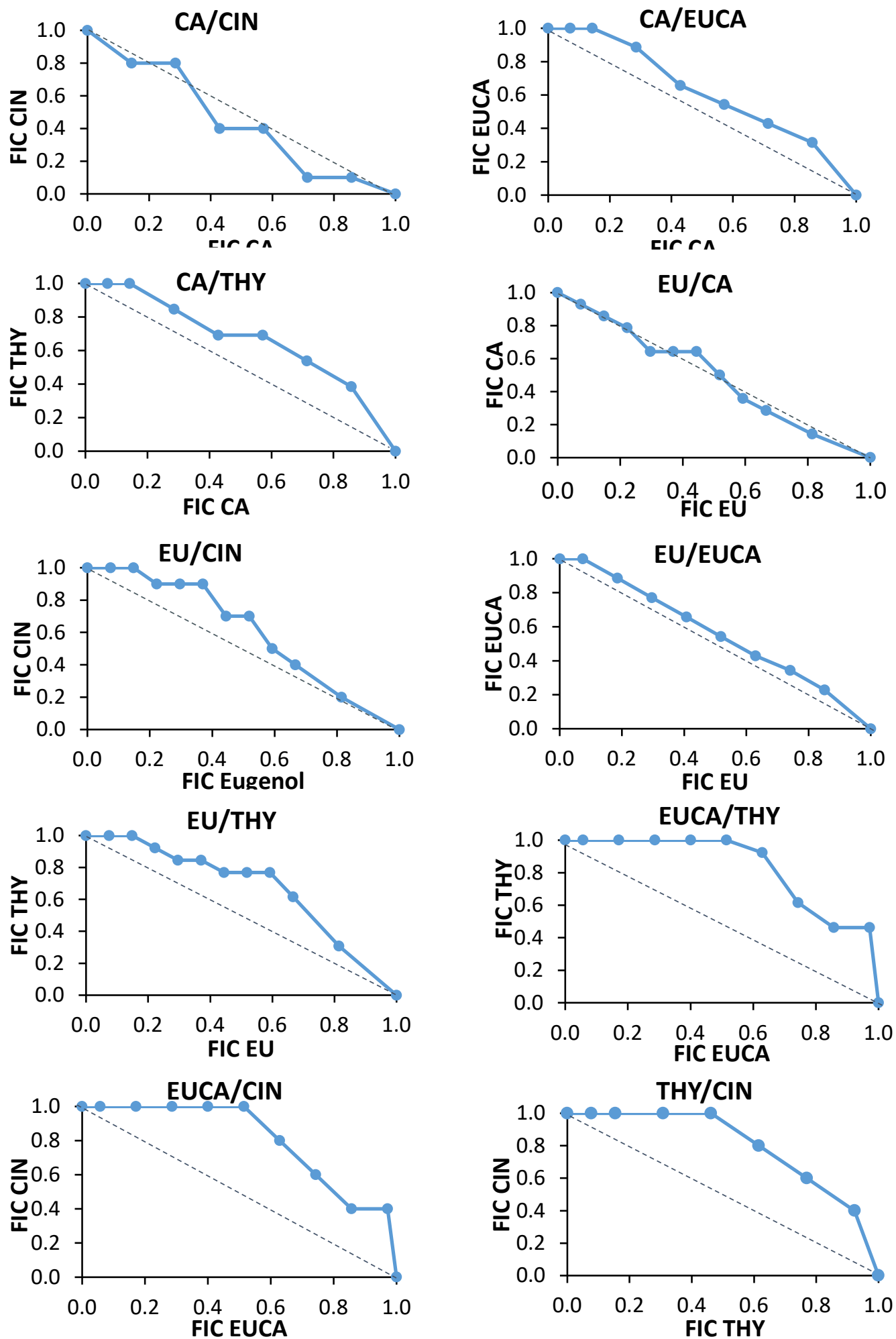

Figure 5. Isobolograms showing the fractional inhibitory concentration (FIC) for the binary combinations of the active compounds (carvacrol (CA), eugenol (EU), cinnamaldehyde (CIN), thymol (THY), eucalyptol (EUCA)) against E. coli. 


\section{CONCLUSIONS}

The MTT method was effective at evaluating the potential synergistic antibacterial effect simply and quickly through the FIC index assessment of blends of active components from essential oils, which can be easily standardized. This method provided reliable MIC values of the active compounds, as well as the FIC index value of their binary combinations over a wide concentration range below the respective MICs. The most remarkable synergistic effect was observed for carvacrol/cinnamaldehyde blends for both $E$. coli and $L$. innocua, but using different compound ratios (1:0.1 and 0.5:4 respectively for each bacteria). In general, the obtained results concerning the synergistic effects of the EO components agree with those reported by other authors, although some discrepancies were obtained that are attributable to the antimicrobial susceptibility method used (temperature, culture media, $\mathrm{pH}$, bacterial strain). Likewise, the MTT method allows for a wide range of concentrations to be tested, which better permits the estimation of the optimal ratio of active compounds with which to obtain the maximum synergy. The synergistic effect was more notable in the Gram-positive bacteria than in the Gram-negative, which could be attributed to the different bacterial cell envelope. The obtained results allowed the dose of active compounds used for food application purposes to be optimized, thus minimizing their sensory impact.

\section{Acknowledgments}

The authors thank the Ministerio de Economía y Competitividad (Spain) for the financial support provided through Project AGL2016-76699-R. Author Raquel Requena thanks the Ministry of Education, Culture and Sport (Spain) for the FPU (FPU13/03444) Grant. 


\section{REFERENCES}

[1] Ghabraie M, Vu KD, Tata L, Salmieri S, Lacroix M. Antimicrobial effect of essential oils in combinations against five bacteria and their effect on sensorial quality of ground meat. LWT-Food Sci Technol 2016; 66:332-339.

[2] Jaiswal AK, Jaiswal S. Modelling the effects of natural antimicrobials as food preservatives. Handbook of natural antimicrobials for food safety and quality, 2014; 259-284.

[3] Akinyemi KO, Oluwa OK, Omomigbehin EO. Antimicrobial activity of crude extracts of three medicinal plants used in south-west Nigerian folk medicine on some food borne bacterial pathogens. Afr J of Tradit Complem 2006; 3(4):13-22.

[4] Conner D, Beuchat LR. Effects of essential oils from plants on growth of food spoilage yeasts. J Food Sci 1984; 49(2): 429-434.

[5] Wilson CL, Solar JM, El Ghaouth A, Wisniewski ME. Rapid evaluation of plant extracts and essential oils for antifungal activity against Botrytis cinerea. Plant Dis 1997; 81(2):204-210.

[6] De Sousa JP, de Azerêdo GA, de Araújo Torres R, da Silva Vasconcelos MA, da Conceição ML, de Souza EL. Synergies of carvacrol and 1, 8-cineole to inhibit bacteria associated with minimally processed vegetables. Int J Food Microbiol 2012; 154(3):145-151.

[7] Stratakos AC, Sima F, Ward P, Linton M, Kelly C, Pinkerton L, Stef L, Pet I, Corcionivoschi N. The in vitro effect of carvacrol, a food additive, on the pathogenicity of $\mathrm{O} 157$ and non- $\mathrm{O} 157$ Shiga-toxin producing Escherichia coli. Food Control 2018; 84:290-296.

[8] Abbaszadeh S, Sharifzadeh A, Shokri H, Khosravi AR, Abbaszadeh A. Antifungal efficacy of thymol, carvacrol, eugenol and menthol as alternative agents to control the growth of food-relevant fungi. Journal of Medical Mycology 2014; 24(2): 51-56.

[9] Moon H, Rhee MS. Synergism between carvacrol or thymol increases the antimicrobial efficacy of soy sauce with no sensory impact. Int J Food Microbiol 2016; 217:35-41.

[10] Vangalapati M, Satya SN, Prakash SDV, Avanigadda S. A review on pharmacological activities and clinical effects of cinnamon species. Research Journal of pharmaceutical, biological and chemical sciences 2012; 3(1):653-663.

[11] Moleyar V, Narasimham P. Antibacterial activity of essential oil components. Int J Food Microbiol 1992; 16(4): 337-342.

[12] Pei RS, Zhou F, Ji BP, Xu J. Evaluation of combined antibacterial effects of eugenol, cinnamaldehyde, thymol, and carvacrol against E. coli with an improved method. J Food Sci 2009; 74(7).

[13] Ali SM, Khan AA, Ahmed I, Musaddiq M, Ahmed KS, Polasa H, Rao LV, Habibullah CM, Sechi LA, Ahmed N. Antimicrobial activities of Eugenol and Cinnamaldehyde against the human gastric pathogen Helicobacter pylori. Ann Clin Microb Anti 2005; 4(1):20. 
[14] De Oliveira KÁR, de Sousa JP, da Costa Medeiros JA, de Figueiredo RCBQ, Magnani M, de Siqueira Júnior JP, de Souza EL. Synergistic inhibition of bacteria associated with minimally processed vegetables in mixed culture by carvacrol and 1, 8-cineole. Food Control 2015; 47:334-339.

[15] Van Vuuren SF, Viljoen AM. Antimicrobial activity of limonene enantiomers and 1, 8-cineole alone and in combination. Flavour Frag J 2007; 22(6):540-544.

[16] Gutierrez J, Barry-Ryan C, Bourke P. The antimicrobial efficacy of plant essential oil combinations and interactions with food ingredients. Int J Food Microbiol 2008; 124(1):91-97.

[17] Guarda A, Rubilar JF, Miltz J, Galotto MJ. The antimicrobial activity of microencapsulated thymol and carvacrol. Int J Food Microbiol 2011; 146(2):144-150.

[18] Hill LE, Gomes C, Taylor TM. Characterization of beta-cyclodextrin inclusion complexes containing essential oils (trans-cinnamaldehyde, eugenol, cinnamon bark, and clove bud extracts) for antimicrobial delivery applications. LWT-Food Sci Technol 2013; 51(1):86-93.

[19] Lambert R, Pearson J. Susceptibility testing: accurate and reproducible minimum inhibitory concentration (MIC) and non-inhibitory concentration (NIC) values. J Appl Microbiol 2000; 88(5):784790.

[20] Nostro A, Germano MP, D'angelo V, Marino A, Cannatelli, MA. Extraction methods and bioautography for evaluation of medicinal plant antimicrobial activity. Lett Appl Microbiol 2000; 30(5):379-384.

[21] Huang $\mathrm{TH}$, Chen $\mathrm{CL}$, Hung $\mathrm{CJ}$, Kao CT. Comparison of antibacterial activities of root-end filling materials by an agar diffusion assay and Alamar blue assay. J Dent Sci 2012; 7(4):336-341.

[22] Ncube NS, Afolayan AJ, Okoh Al. Assessment techniques of antimicrobial properties of natural compounds of plant origin: current methods and future trends. Afr J Biotechnol 2008; 7(12).

[23] Bueno J. Models of evaluation of antimicrobial activity of essential oils in vapour phase: a promising use in healthcare decontamination. Natural Volatiles \& Essential Oils 2015; 2(2).

[24] Houdkova M, Rondevaldova J, Doskocil I, Kokoska L. Evaluation of antibacterial potential and toxicity of plant volatile compounds using new broth microdilution volatilization method and modified MTT assay. Fitoterapia 2017; 118:56-62.

[25] Clark FE. Agar-Plate Method for Total Microbial Count 1. Methods of Soil Analysis. Part 2. Chemical and Microbiological Properties, (methodsofsoilanb) 1965; 1460-1466.

[26] Gunasekera TS, Attfield PV, Veal DA. A flow cytometry method for rapid detection and enumeration of total bacteria in milk. Appl Environ Microb 2000; 66(3):1228-1232.

[27] Krepker M, Shemesh R, Poleg YD, Kashi Y, Vaxman A, Segal E. Active food packaging films with synergistic antimicrobial activity. Food Control 2017; 76:117-126.

[28] Ye H, Shen S, Xu J, Lin S, Yuan Y, Jones GS. Synergistic interactions of cinnamaldehyde in combination with carvacrol against food-borne bacteria. Food Control 2013; 34(2):619-623. 
[29] Rondevaldova J, Novy P, Urban J, Kokoska L. Determination of anti-staphylococcal activity of thymoquinone in combinations with antibiotics by checkerboard method using EVA capmat ${ }^{\mathrm{TM}}$ as a vapor barrier. Arab J Chem 2017; 10(4):566-572.

[30] Te Dorsthorst DTA, Verweij PE, Meis JFGM, Punt NC, Mouton JW. Comparison of fractional inhibitory concentration index with response surface modeling for characterization of in vitro interaction of antifungals against itraconazole-susceptible and -resistant Aspergillus fumigatus isolates. Antimicrobial Agents Ch 2002; 46(3):702-707.

[31] Novy P, Kloucek P, Rondevaldova J, Havlik J, Kourimska L, Kokoska L. Thymoquinone vapor significantly affects the results of Staphylococcus aureus sensitivity tests using the standard broth microdilution method. Fitoterapia 2014; 94:102-107.

[32] Sondi I, Salopek-Sondi B. Silver nanoparticles as antimicrobial agent: a case study on E. coli as a model for Gram-negative bacteria. J Colloid Interf Sci 2004; 275(1):177-182.

[33] Coma V, Sebti I, Pardon P, Deschamps A, Pichavant FH. Antimicrobial edible packaging based on cellulosic ethers, fatty acids, and nisin incorporation to inhibit Listeria innocua and Staphylococcus aureus. J Food Protect 2001; 64(4):470-475.

[34] Teixeira B, Marques A, Ramos C, Neng NR, Nogueira JM, Saraiva JA, Nunes ML. Chemical composition and antibacterial and antioxidant properties of commercial essential oils. Ind Crop Prod 2013; 43:587-595.

[35] Bell A. Antimalarial drug synergism and antagonism: mechanistic and clinical significance. FEMS Microbiol Lett 2005; 253(2):171-184.

[36] Du E, Gan L, Li Z, Wang W, Liu D, Guo Y. In vitro antibacterial activity of thymol and carvacrol and their effects on broiler chickens challenged with Clostridium perfringens. J Anim Sci Biotechno 2015; 6(1):58.

[37] García-García R, López-Malo A, Palou E. Bactericidal action of binary and ternary mixtures of carvacrol, thymol, and eugenol against Listeria innocua. J Food Sci 2011; (2).

[38] Gallucci MN, Oliva M, Casero C, Dambolena J, Luna A, Zygadlo J, Demo M. Antimicrobial combined action of terpenes against the food-borne microorganisms Escherichia coli, Staphylococcus aureus and Bacillus cereus. Flavour Frag J 2009; 24(6):348-354.

[39] Rivas L, McDonnell MJ, Burgess CM, O'Brien M, Navarro-Villa A, Fanning S, Duffy G. Inhibition of verocytotoxigenic Escherichia coli in model broth and rumen systems by carvacrol and thymol. Int J Food Microbiol 2010; 139(1-2):70-78. 



\title{
Eugenol and carvacrol migration from PHBV films and antibacterial action in different food matrices
}

\author{
Raquel Requena; María Vargas; Amparo Chiralt
}

\author{
Submited to Food Chemistry
}

Institute of Food Engineering for Development, Universitat Politècnica de València, Valencia, Spain 



\section{ABSTRACT}

The antibacterial effect of PHBV films with oregano or clove essential oil, or their main compounds, carvacrol (CA) and eugenol (EU), respectively, was analysed in food matrices (cheese, chicken breast, pumpkin and melon) and in in vitro test for Escherichia coli and Listeria innocua. The migration of CA and EU in the different food matrices was determined to analyse the food matrix effect on the film's antimicrobial effectiveness. The antimicrobial activity in foods was less remarkable than in in vitro test. Despite the antilisterial effect in the in vitro test, this was not noticed in any food matrix. The most significant antibacterial effects against $E$. coli were observed in cheese and pumpkin, whereas the highest migration of both CA and UE took place in melon. This lack of correlation reflected that many compositional factors affect the active compound's availability to exert its antibacterial action in a specific food.

Keywords: PHBV films, essential oils, carvacrol, eugenol, migration, antibacterial activity, food applications. 


\section{INTRODUCTION}

Nowadays, the microbial contamination of perishable products is the main reason for food spoilage and foodborne diseases, since they are transported and stored for a long time until consumption (Pavlath \& Orts, 2009). In this context, active packaging has appeared as a novel strategy for the control of microbial growth, thereby increasing food quality and safety of the packaged foodstuffs (Wen et al., 2016). In turn, consumer demand is moving towards more natural foods containing lower amounts of synthetic preservatives. In this sense, naturally occurring compounds, such as essential oils (EOs) and their main compounds, which are considered as flavoring substances by the European Regulation 1999/217/CE and Generally Recognized As Safe (GRAS) substances by the Food and Drug Administration (FDA), have been widely studied as to their antimicrobial properties against spoilage and pathogenic microorganisms and constitute an effective alternative to synthetic preservatives (Jaiswal, \& Jaiswal, 2015).

EOs are complex mixtures of volatile compounds where two or three major components can constitute up to $85 \%$ of the oil, the phenolic compounds being mainly responsible for their antimicrobial properties. However, minor compounds are reported to have an important effect on the EO antimicrobial activity, possibly due to synergistic effects (Burt, 2004; Gutierrez, Barry-Ryan, \& Bourke, 2008). Of the EOs, oregano (OR) and clove essential oil (CLO) are two of the most effective at inhibiting microbial growth of food-borne pathogens and spoilage microorganisms (Burt, 2004) and much research has focused on the development of antimicrobial films containing these actives. Whey protein films containing OR have inhibited the microbial growth of Listeria innocua, Salmonella enteritidis and Staphylococcus aureus (Royo, Fernández-Pan, \& Maté, 2010), whereas starch-chitosan films with OR exhibited antimicrobial properties against Bacillus cereus, Escherichia coli, S. enteritidis and S. aureus (Pelissari, Grossmann, Yamashita, \& Pineda, 2009). Likewise, Muppalla, Kanatt, Chawla, \& Sharma (2014) have reported significant antimicrobial effects against $S$. aureus and $B$. cereus by incorporating CLO into carboxymethyl cellulose-polyvinyl alcohol films. Similar results were obtained with pectin films containing CLO for S. aureus, E. coli and Listeria monocytogenes (Nisar et al., 2018). The antimicrobial properties of both OR and CLO have mainly been attributed to their major compounds, carvacrol (CA) and eugenol (EU), respectively (Burt, 2004). Many in vitro studies with active biodegradable matrices containing CA (Requena, Jiménez, Vargas \& Chiralt, 2016; Rojas-Graü et al., 2007) or EU (Narayan \& Ramana, 2013; Requena et al., 2016) demonstrated their effectiveness as antimicrobial agents against a broad spectrum of microorganisms. However, significantly higher EO amounts are required to achieve similar antimicrobial effects when applied to food matrices, probably due to the interactions between the active compounds and different food components, which could limit their effectiveness as antimicrobials (Burt, 2004; Gutierrez et al., 2008). In this sense, some authors reported that high fat and protein contents in the food matrix can inhibit the 
antimicrobial activity of the EOs, which was attributed to the protective action of these food components for the bacteria (Canillac \& Mourey, 2004; Gutierrez et al., 2008; Higueras, LópezCarballo, Hernández-Muñoz, Catalá, \& Gavara, 2014; Kim, Ruengwilysup, \& Fung, 2004; Shelef, Jyothi, \& Bulgarellii, 1984; Veldhuizen, Creutzberg, Burt, \& Haagsman, 2007). Thus, no significant antimicrobial activity has been reported against several foodborne pathogens after applying chitosan films with CA on chicken samples. The scavenging effect of chicken protein on the CA gave rise to a very low available active concentration (Higueras et al., 2014). Likewise, EOs were less effective in full-fat products than in their corresponding low-fat alternative, such as was observed in cheese (Smith-Palmer, Stewart, \& Fyfe, 2001) or hotdogs (Singh, Singh, Bhunia, \& Singh, 2003). One of the main hypotheses for the higher microbial resistance to EOs in high protein and fat foods, compared to in vitro tests, is the greater nutrient availability in the food, which allows bacteria to repair their damage faster than in the culture medium (Gill, Delaquis, Russo, \& Holley, 2002; Veldhuizen et al., 2007). Some authors also suggested that, due to their lipophilic nature, EOs generally dissolve in the fatlipid phase of food, thus being less available to interact with the bacteria present in the aqueous phase (Mejlholm \& Dalgaard, 2002; Veldhuizen et al., 2007). Moreover, phenolic compounds, the main antimicrobial agents in EOs can react with fatty free radicals, resulting from autoxidation in fatty products, thus obtaining reaction products less effective than the original phenolic compounds (Kim et al., 2004). On the contrary, high salt and water levels in the food are reported to increase the bacterial sensitivity to EOs (Shelef et al., 1984). As regards the carbohydrate content of foods, Gutierrez et al. (2008) reported that EO antimicrobial activity was reduced at high starch concentrations, in contrast to that observed by Shelef et al. (1984). Therefore, it is clear that the development of active films for food packaging applications require antimicrobial in vivo tests performed with the specific microorganisms inoculated into the food matrix where the films containing EOs should be applied, in order to assess whether food safety requirements are met.

As concerns film composition, the increasing environmental awareness advises the replacement of conventional plastic materials for more environmentally-friendly, biodegradable ones obtained from natural sources. In this context, biopolymers obtained from renewable resources through bacterial action, such as the polyhydroxyalkanoates (PHAs), are a promising option for food packaging applications, since they can be produced by 300 species of Gram-positive and Gram-negative bacteria as well as a wide range of archaea and are completely biodegradable (Laycock, Halley, Pratt, Werker, \& Lant, 2013). Poly(3hydroxybutyrate-co-3-hydroxyvalerate) (PHBV) is one of the most common PHAs, since this biopolymer has physical properties comparable to some synthetic polymers, such as polypropylene and polyethylene, although PHBV leads to more brittle materials with lower elongation at break (Laycock et al., 2013). PHA films have been previously used as carriers of the different EO compounds to obtain biodegradable active materials, whose antimicrobial 
activity has been proved in in vitro tests (Narayan \& Ramana, 2013; Requena et al., 2016; Xavier, Babusha, George, \& Ramana, 2015).

The aim of this study was to assess the antibacterial effect of PHBV films containing OR or CLO, as well as their main compounds, CA and EU respectively, in several food matrices of distinct composition, in order to determine the food matrix effect on the film antimicrobial properties.

\section{MATERIALS AND METHODS}

\subsection{Materials and reagents}

PHBV ( $8 \%$ of hydroxyvalerate) was provided in pellet form by NaturePlast (Caen, France). The polyethyleneglycol 950-1050 Da (PEG1000) used as plasticizer, as well as carvacrol (CA) and eugenol (EU), and UV-grade methanol were supplied by Sigma-Aldrich (Steinheim, Germany). Oregano (OR) and clove essential oils (CLO) were obtained from Herbes del Molí (Alicante, Spain). Gas chromatography standard 2-pentanol was purchased from Sigma-Aldrich Corp. (St. Louis, MO).

\subsection{Film preparation}

PHBV monolayer films were prepared by melt blending and compression-moulding as described by Requena et al. (2016). Briefly, PHBV in pellet form was blended with PEG1000 $(10 \% \mathrm{w} / \mathrm{w})$ in a two-roll mill (Model LRM-M-100, Labtech Engineering, Thailand) at $180^{\circ} \mathrm{C}$ and thermo-compressed by using a hot plate hydraulic press (Model LP20, Labtech Engineering, Thailand) at $10 \mathrm{MPa}$ and $180{ }^{\circ} \mathrm{C}$ for $4 \mathrm{~min}$. Then, PHBV active films with different active compounds were obtained by spraying a constant amount $(13 \% \mathrm{w} / \mathrm{w}$, in the film) of each active compound (OR, CLO, CA or EU) as reported by Requena et al. (2016). To sum up, PHBV monolayers were sprayed with the corresponding active compound, covered with another PHBV sheet and compressed using the hydraulic press. Thus, five kinds of films were obtained: control films without active compounds (PHBV), and films with the corresponding active compounds (PHBV-OR, PHBV-CLO, PHBV-CA, PHBV-EU).

\subsection{Physicochemical analysis of raw materials}

Physicochemical properties of foods directly related with the microbial growth sensitivity, such as $\mathrm{pH}$ and water activity $\left(\mathrm{a}_{\mathrm{w}}\right)$, were analysed in each of the food matrices by using a $\mathrm{pH}$ puncture electrode (Seven Easy ${ }^{\mathrm{TM}} \mathrm{pH}$, Mettler Toledo, Switzerland) and an $\mathrm{a}_{\mathrm{w}}$ meter (Aqualab 4TE, METER FOOD, USA), respectively. The ${ }^{\circ}$ Brix were also determined in fruit samples 
(pumpkin and melon), as ripeness indicator, by using a refractometer (ATAGO ${ }^{\text {TM }}$ NAR-3T Abbe, Japan). For $\mathrm{a}_{\mathrm{w}}$ measurements, all samples were peeled and cut into small pieces, whereas for the determination of the total soluble solids in the fruit, the sample juice was obtained by liquefying. All measurements were taken in triplicate.

\subsection{Antibacterial effectiveness of active films: in vitro and in vivo tests}

\subsubsection{Processing of food matrices}

The antibacterial activity of the different active films was tested in food matrices with high protein or fat content (fresh cheese and chicken breast) and high carbohydrate content (freshcut pumpkin and melon), in order to study the food composition effect on the film antimicrobial activity. All the food was purchased from a local market, transported to the laboratory immediately and handled in a laminar flow cabinet in sterile conditions. The chicken breasts were cut into thin fillets and the fresh cheese was prepared in slices. Both vegetable matrices were superficially disinfected by dipping them in sodium hypochlorite $1 \%$ $(\mathrm{v} / \mathrm{v})$ solution for $1 \mathrm{~min}$, peeled and also cut into thin slices. $10 \mathrm{~g}$ samples of $55 \mathrm{~mm}$ in diameter were obtained from each food matrix and placed in petri dishes.

\subsubsection{Antibacterial activity assessment}

Listeria innocua (CECT 910) and Escherichia coli (CETC 101) lyophilized strains were supplied by the Spanish Type Culture Collection (CECT, Universitat de València, Spain), and stored at $-25{ }^{\circ} \mathrm{C}$ with $30 \%$ glycerol. Bacterial cultures on exponential growth phase were prepared by inoculating the microbial stock suspensions into TSB, followed by their incubation at $37{ }^{\circ} \mathrm{C}$ for $24 \mathrm{~h}$. The inoculums were properly diluted to obtain bacterial suspensions of $10^{6} \mathrm{CFU} / \mathrm{mL}$.

Tryptic Soy Agar (TSA, Scharlab, Barcelona, Spain) culture medium, used for in vitro tests, and the different food samples placed in petri dishes (55 $\mathrm{mm}$ in diameter) were inoculated with $100 \mu \mathrm{L}$ of $L$. innocua or $E$. coli suspension and covered with the different active film samples of the same diameter. Both samples covered with active-free PHBV films and those noncovered were also tested as film control and inoculum control, respectively. Petri dishes were closed with their lids, sealed with Parafilm ${ }^{\mathrm{TM}}$ and incubated for 6 days. Incubation was carried out at $10^{\circ} \mathrm{C}$ in all cases. TSA culture media and fresh cheese samples were also previously tested at $4{ }^{\circ} \mathrm{C}$. Microbial counts in each sample were performed in duplicate after inoculation and after 6 incubation days. To this end, each sample was homogenized in buffer peptone water (Scharlab, Barcelona, Spain) for $3 \mathrm{~min}$, by using a Stomacher Lab-blender (Masticator, IUL Instruments, Barcelona, Spain) and properly diluted. The plate counts of L. innocua were performed on Palcam agar base (Scharlab, Barcelona, Spain) containing Palcam selective 
supplement for Listeria (Scharlab, Barcelona, Spain), after incubation at $37{ }^{\circ} \mathrm{C}$ for $48 \mathrm{~h}$, whereas the plate counts of E. coli were performed on Fecal Coliforms agar (Scharlab, Barcelona, Spain) dyed with 1\% Rosolic acid solution (Scharlab, Barcelona, Spain) after preincubation at $37{ }^{\circ} \mathrm{C}$ for $2 \mathrm{~h}$ and transferred to $44^{\circ} \mathrm{C}$ for $22 \mathrm{~h}$. Counts were expressed as log CFU/g food matrix or TSA.

\section{6. $\mathrm{CA}$ and EU migration to the food matrices}

\subsubsection{Quantification in the films by methanol extraction}

The active amount that migrated from the films to the different matrices during incubation time was estimated indirectly by determining the active compound remaining in the films after the contact time, through methanol extraction and subsequent spectrophotometric quantification. Thus, after 6 days at $10^{\circ} \mathrm{C}$ and prior to the extraction, PHBV-CA and PHBV-EU films were detached from the different matrices and kept in phosphorus pentoxide $\left(a_{w}=0\right)$ for $24 \mathrm{~h}$ to remove adsorbed water. Then, methanol extraction of the active compounds was carried out using $10 \mathrm{mg}$ film in $1 \mathrm{~mL}$ solvent in contact for $72 \mathrm{~h}$. The resulting extracts were filtered and properly diluted to obtain absorbance values between 0.2 and 0.8 . In this way, CA and EU amounts in the extracts were quantified through absorbance measurements at 275 and $282 \mathrm{~nm}$, respectively, by using an UV-visible spectrophotometer (Evolution 201, Thermo Scientific). PHBV bilayer films without active compounds in contact with samples for 6 days and submitted to the same extraction procedure were used to obtain the background solutions. All the determinations were run in triplicate. CA and EU standard calibration curves were previously obtained to convert absorbance values to active content. The active amount that migrated from the active films to the different matrices was estimated by subtracting the active mass remaining in the films after the incubation from the initial active amount in the films, which was assessed using the same extraction procedure.

\subsubsection{Analyses in the food matrices by Gas chromatography-mass spectrometry (GC-MS)}

The active compounds that migrated from the active films to the different food matrices were extracted by purge and trap thermal desorption (Perdones, Escriche, Chiralt, \& Vargas, 2016). $100 \mu \mathrm{l}$ of the internal standard 2-pentanol $(10 \mathrm{mg} / \mathrm{L})$ and $10 \mathrm{~g}$ of food purée, properly diluted with water, were placed into a purging flask and kept in a water bath under the extraction conditions shown in Table 1, previously optimized for each food matrix. Throughout the extraction time, purified nitrogen $(100 \mathrm{~mL} / \mathrm{min})$ flowed through the glass frit at the bottom of the flask. Thus, volatile compounds were dragged by the nitrogen stream, which passed 
through the sample and were adsorbed in a $100 \mathrm{mg}$ porous polymer (Tenax ${ }^{\circledR} \mathrm{TA}, 20-35$ mesh) packed into a glass tube placed at the end of the system.

Table 1. Optimum extraction conditions established for each food matrix for the purge and trap method.

\begin{tabular}{lccc}
\hline Matrix & Sample:Water & Time $(\mathbf{m i n})$ & Temperature $\left({ }^{\circ} \mathbf{C}\right)$ \\
\hline Cheese & $1: 1$ & 25 & 70 \\
Chicken & $1: 1$ & 15 & 40 \\
Pumpkin & $1: 2$ & 25 & 50 \\
Melon & $1: 0$ & 25 & 50 \\
\hline
\end{tabular}

The adsorbed volatile extract was thermally desorbed by a direct thermal desorber (TurboMatrix TD, Perkin-Elmer TM, CT-USA). Desorption was performed under a $10 \mathrm{~mL} / \mathrm{min}$ helium flow at $220^{\circ} \mathrm{C}$ for $10 \mathrm{~min}$, and the volatiles were cryofocused in a cold trap at $30^{\circ} \mathrm{C}$. After $1 \mathrm{~min}$, the cold trap was heated up to $250^{\circ} \mathrm{C}$ (at a rate of $99^{\circ} \mathrm{C} / \mathrm{min}$ ) and volatiles were directly transferred onto the head of the capillary column. The GC-MS analysis was performed using a Finnigan TRACE ${ }^{\text {TM }}$ MS (ThermoQuest, Austin, USA). Volatile compounds were separated using a DB-WAX capillary column (1.0 $\mu \mathrm{m} \times 0.32 \mathrm{~mm} \times 60 \mathrm{~m}$, SGE, Australia). Helium was used as carrier gas at a constant flow rate of $1 \mathrm{~mL} / \mathrm{min}$. The oven was kept at an initial temperature of $40^{\circ} \mathrm{C}$ for $2 \mathrm{~min}$. Then, the temperature was increased to $190^{\circ} \mathrm{C}$ at a rate of 4 ${ }^{\circ} \mathrm{C} / \mathrm{min}$, maintained for $5 \mathrm{~min}$ and finally increased to $230^{\circ} \mathrm{C}$ at $10^{\circ} \mathrm{C} / \mathrm{min}$. The MS interface and source temperatures were 250 and $200^{\circ} \mathrm{C}$, respectively. Electron impact mass spectra were recorded in impact ionisation mode at $70 \mathrm{eV}$ and with a mass range of $m / z 33-433$. At least five extracts were obtained for each food sample. The identification of CA and EU was performed by comparing their mass spectra with spectral data from the National Institute of Standards and Technology 2002 library as well as the published retention indices. The CA and EU quantification was carried out after calibration following the standard addition method, in order to avoid the food matrix composition effect. $10 \mathrm{~g}$ of food purée, homogenised with 100 $\mu \mathrm{l}$ of internal standard 2-pentanol $(10 \mathrm{mg} / \mathrm{L})$ and 5 different concentrations of CA or EU were tested in quadruplicate, following the procedure already described.

\subsection{Statistical analyses}

Experimental data were analysed by analysis of variance (ANOVA) using Fisher's Least Significant Difference (LSD) test at $95 \%$ confidence level. To this end, Statgraphics Centurion XVIs for Windows 5.1 (Manugistics Corp., Rockville, MD, USA) was used. 


\section{RESULTS AND DISCUSSION}

\subsection{Characterization of raw materials}

Moisture content is not directly related with the microbial spoilage of foods, since foodstuffs with the same moisture content can deteriorate to a different extent, whereas the water activity $\left(a_{w}\right)$, or free water available for the microbial growth, has been widely used as an indicator of microbial spoilage sensitivity. All foodstuffs are suitable substrates for bacterial development in terms of $a_{w}$, since all matrices show $a_{w}$ values (Table 2) above the required threshold for bacterial growth (0.9) (Beuchat, 1981). The $\mathrm{pH}$ can also be used as a predictor of the bacterial growth, since it generally occurs optimally at $\mathrm{pH}$ values in the range 6-7 and falls as the $\mathrm{pH}$ moves away from this region (Adams \& Nicolaides, 1997). Similarly to that reported for $\mathrm{a}_{\mathrm{w}}$ values, all the food products showed $\mathrm{pH}$ values in the optimal range for bacterial growth (Table 2). Therefore, the physicochemical properties of the foodstuffs did not hinder the bacterial growth in any case. As regards the soluble solid content of the plant foodstuffs, the melon samples showed higher values, which could mean more nutritious media for the bacterial development.

Table 2. Water activity $\left(\mathrm{a}_{\mathrm{w}}\right)$ and $\mathrm{pH}$ values, and Brix level of the different food matrices. Mean value \pm standard deviation.

\begin{tabular}{lccc}
\hline Matrix & $\mathrm{pH}$ & $\mathrm{a}_{\mathrm{w}}$ & Brix level $\left({ }^{\circ}\right)$ \\
\hline Cheese & $6.61 \pm 0.02$ & $0.985 \pm 0.002$ & - \\
Chicken & $5.98 \pm 0.02$ & $0.991 \pm 0.001$ & - \\
Pumpkin & $5.79 \pm 0.02$ & $0.991 \pm 0.001$ & $11.7 \pm 0.2$ \\
Melon & $6.17 \pm 0.04$ & $0.988 \pm 0.001$ & $12.7 \pm 0.2$ \\
\hline
\end{tabular}

\subsection{Antibacterial effect of active films at $4{ }^{\circ} \mathrm{C}$}

Microbial counts of $L$. innocua and $E$. coli in TSA culture media performed at $4{ }^{\circ} \mathrm{C}$ are shown in Table 3. At this temperature, the lack of bacterial growth in the culture medium after incubation was remarkable for both bacteria, especially for $E$. coli where a decrease in the initial counts was observed. Likewise, no significant differences in the microbial counts of either bacteria were observed after 6 days of incubation for any sample covered with PHBV films without actives, in comparison with the non-covered samples $\left(C_{6}\right)$. Therefore, the antibacterial activity of the films with active compounds was attributed to the incorporation of active compounds. Both PHBV-CA and PHBV-OR films exerted a significant bactericidal effect against $L$. innocua, as reported by Requena et al., (2016) in TSB liquid media. However, no antilisterial activity of the PHBV-EU or PHBV-CLO films was observed, which agrees with the higher minimum inhibitory concentration (MIC) of EU for $L$. innocua $(1.05 \mathrm{mg} / \mathrm{mL})$ 
compared to the corresponding MIC value of CA $(0.75 \mathrm{mg} / \mathrm{mL}$ ) (Requena, Vargas, \& Chiralt, 2018). However, the total inhibition of $E$. coli was observed with all the active films, excluding PHBV-CLO, despite the higher EU MIC value against E. coli $(1.35 \mathrm{mg} / \mathrm{mL})$ (Requena et al., 2018) compared to the corresponding value against L. innocua. This could be attributed to the different combined effect of the low temperature $\left(4{ }^{\circ} \mathrm{C}\right)$ and actives on both bacteria: bacteriostatic for Listeria and bactericidal for E. coli. Although EU is the main compound in $\mathrm{CLO}$, the EU content in the PHBV-CLO films could be below its MIC against $E$. coli at $4^{\circ} \mathrm{C}$ (Burt, 2004).

In contrast to the results of the in vitro test, significant microbial growth of L. innocua was observed in fresh cheese samples after 6 days of incubation at $4{ }^{\circ} \mathrm{C}$ (Table 3). This may be due to the composition of the dairy product, which makes it very sensitive to the growth of Listeria (Gutierrez et al., 2008). In contrast with the Listeria's capacity to grow at temperatures as low as $4{ }^{\circ} \mathrm{C}$ (Al-Nabulsi et al., 2015), the mesophilic status of E. coli did not allow its growth (Francis \& O'Beirne, 2001). PHBV films containing active compounds did not show any remarkable effects on the growth of $L$. innocua and $E$. coli inoculated into fresh cheese samples, unlike the effects observed in in vitro tests; this is likely due to the combined bacteriostatic or bactericidal effect of the low temperature, which could mask the antibacterial action of the active PHBV films. Thus, additional tests were conducted at $10^{\circ} \mathrm{C}$ in order better to reflect the role of the active compounds.

Table 3. Microbial counts of Listeria innocua and Escherichia coli on inoculated TSA agar and fresh cheese (log CFU/g sample) after the film contact for 6 days at $4{ }^{\circ} \mathrm{C}$. Inoculated, non-covered samples were also considered before $\left(C_{0}\right)$ and after the incubation time $\left(C_{6}\right)$.

\begin{tabular}{|c|c|c|c|c|c|c|c|}
\hline Matrix & $\mathrm{C}_{0}$ & $\mathrm{C}_{6}$ & PHBV & PHBV-CA & PHBV-EU & PHBV-OR & PHBV-CLO \\
\hline & \multicolumn{7}{|c|}{ Listeria innocua } \\
\hline Agar & $3.2 \pm 0.1^{\mathrm{b}}$ & $3.4 \pm 0.1^{\mathrm{a}}$ & $3.3 \pm 0.1^{\mathrm{ab}}$ & $2.8 \pm 0.1^{c}$ & $3.5 \pm 0.3^{\mathrm{a}}$ & $2.6 \pm 0.2^{c}$ & $3.5 \pm 0.1^{\mathrm{a}}$ \\
\hline \multirow[t]{2}{*}{ Cheese } & $3.6 \pm 0.1^{d}$ & $5.7 \pm 0.2^{\mathrm{a}}$ & $5.3 \pm 0.2^{c}$ & $5.4 \pm 0.4^{\mathrm{bc}}$ & $5.4 \pm 0.1^{\mathrm{abc}}$ & $5.6 \pm 0.1^{\mathrm{abc}}$ & $5.6 \pm 0.2^{\mathrm{ab}}$ \\
\hline & \multicolumn{7}{|c|}{ Escherichia coli } \\
\hline Agar & $3.6 \pm 0.1^{a}$ & $2.8 \pm 0.2^{c}$ & $2.8 \pm 0.2^{c}$ & nd & nd & nd & $3.0 \pm 0.2^{b}$ \\
\hline Cheese & $4.7 \pm 0.1^{\mathrm{a}}$ & $4.9 \pm 0.5^{\mathrm{a}}$ & $4.1 \pm 0.2^{b}$ & $3.8 \pm 0.7^{b}$ & $4.6 \pm 0.1^{\mathrm{a}}$ & $4.7 \pm 0.1^{\mathrm{a}}$ & $4.6 \pm 0.1^{\mathrm{a}}$ \\
\hline
\end{tabular}

a-c: Different letters in the same line show significant differences between film formulations $(p<0.05)$. nd: nondetected microbial growth. 


\subsection{Antibacterial effect of active films at $10^{\circ} \mathrm{C}$}

Due to the potential combined antimicrobial effect of the low temperature, the antimicrobial tests were carried out at $10^{\circ} \mathrm{C}$, within the limits of cold preservation. The in vivo test was performed to obtain the microbial counts of L. innocua and E. coli in two kinds of high-protein foods (fresh cheese and chicken breast) and in two kinds of vegetable matrices (fresh-cut pumpkin and melon), previously inoculated and stored at $10{ }^{\circ} \mathrm{C}$ for 6 days. No bacteriostatic effects were observed for $L$. innocua and $E$. coli at this storage temperature, whose population increased more than 4 log after 6 days in the TSA culture medium (Figure 1). The microbial growth of both bacteria was quite similar, with small differences depending on the foodstuff that are associated with the different food composition.

In line with the in vitro results at $4{ }^{\circ} \mathrm{C}$, PHBV films with $\mathrm{CA}$ or $\mathrm{OR}$ significantly reduced the microbial counts of $L$. innocua and $E$. coli, thus showing an antibacterial effect against both bacteria, although those counts were always higher than the initial inoculum (grey dotted lines). Both bacteria were more affected by PHBV films containing CA than by those containing OR, as reported by Rojas-Grau et al. (2007) in in vitro studies for alginate-apple puree films and $E$. coli, since the OR antimicrobial activity has been mainly attributed to CA, which only represents $46 \%$ of this EO (Perdones, Tur, Chiralt, \& Vargas, 2016). In contrast with that obtained in the in vitro test at $4{ }^{\circ} \mathrm{C}, \mathrm{PHBV}$-EU and PHBV-CLO films significantly reduced both bacterial growths, with no significant differences between formulations. Similar reductions were reported at $10{ }^{\circ} \mathrm{C}$ for L. monocytogenes and E.coli by Alboofetileh, Rezaei, Hosseini, \& Abdollahi (2014) with alginate films containing CLO.

\subsubsection{Antibacterial effect of active films in high-protein food}

The microbial counts of $L$. innocua and $E$. coli obtained in fresh cheese and chicken breast samples coated with the different films are shown in Figure 1. It is remarkable that no significant growth reduction of $L$. innocua was observed in fresh cheese samples with any film formulation, in contrast with that obtained in the in vitro test (Figure 1). This lack of antilisterial activity could be due to the protective effect of the fats and proteins present in the cheese exert on bacteria, which inhibited any potential antimicrobial effect of the EO compounds, as reported by several authors (Canillac \& Mourey, 2004; Gutierrez et al., 2008; Higueras et al., 2014; Kim et al., 2004; Shelef et al., 1984; Veldhuizen et al., 2007). SmithPalmer et al. (2001) and Singh et al. (2003) reported significantly greater antilisterial effect of the EO on low-fat cheese and hotdogs than in the corresponding full-fat products. However, all the active film formulations exhibited significant antimicrobial activity against $E$. coli, in line with the greater sensitivity of $E$. coli to these active compounds (Raybaudi-Massilia, Mosqueda-Melgar, \& Martin-Belloso, 2006; Requena et al., 2018; Teixera et al., 2013). However, despite the higher sensitivity of E. coli to CA compared to the other studied actives 
(Burt, 2004; Pei, Zhou, Ji, \& Xu, 2009), the PHBV films containing CA gave rise to the lowest microbial reduction $(1.5 \mathrm{log})$, followed by PHBV-OR $(2.5 \mathrm{log})$. As reported by several authors, the whole EOs are often more effective than their pure main compounds; this is because there are some other minor compounds that could be critical in the antimicrobial activity (Gill et al., 2002; Mourey \& Canillac, 2002), which, to a different extent, can also be affected by the presence of the cheese components. Notwithstanding the lower antimicrobial effect of EU against E. coli when compared to CA and OR (Burt, 2004; Pei et al., 2009), PHBV films containing EU or CLO inhibited the microbial growth by $3 \mathrm{log}$, with no significant differences between either. The different behaviour observed for active films in cheese with respect to that exhibited in the in vitro test suggests that the antimicrobial activity of OR and CA could be inhibited by the interaction with the fats or proteins present in the cheese, whereas EU and CLO could be more available in the fatty-protein matrix to act against bacteria. Therefore, as reported by Glass \& Johnson (2004), higher amounts of antimicrobials are often required when they are applied to real systems, since some compounds present in the foodstuffs can interfere with both the microorganism's viability and the potential antimicrobial activity of the active compounds.

Significant differences were observed in the L. innocua counts for chicken breast samples incubated with and without active PHBV films, although without any remarkable reductions in practical terms (> $1 \mathrm{log}$ ). Nevertheless, the PHBV-EU films resulted in significant growth inhibitions of $E$. coli (2 log) in chicken samples. Likewise, PHBV films containing CLO or CA also led to significant bacterial growth reductions, but to a lesser extent, whereas no antimicrobial activity was observed by applying PHBV-OR films. In the same way, Shekarforoush, Nazer, Firouzi, \& Rostami (2007) reported a significant antimicrobial effect of OR against E. coli in in vitro studies, but no effect was observed when this EO was applied to roast chicken. Differences between the in vitro and in vivo tests in chicken samples could again be explained by the scavenging effect of the protein matrix on the active, probably due to their high chemical compatibility (Higueras et al., 2014).

\subsubsection{Antibacterial effect of active films in plant food}

Antimicrobial studies were also performed on two matrices with high carbohydrate content and low fat and protein content in order to compare the antimicrobial activity of the active films depending on the food matrix composition. Figure 1 shows the microbial counts of $L$. innocua and $E$. coli in inoculated fresh-cut pumpkin and melon, incubated for 6 days at $10^{\circ} \mathrm{C}$, in contact with the different films. The initial population of L. innocua increased 4 log in both products, whereas the microbial growth of E. coli was food matrix-dependent; counts increased 5 log in pumpkin samples and less than 3 log in melon samples, highlighting the importance of the food matrix in the bacterial growth. 
As regards the antimicrobial activity of the active films, no film formulation led to important growth inhibitions (> $1 \mathrm{log}$ ) of $L$. innocua in either of the two vegetable matrices. Similarly, no antilisterial activity was observed in fresh broccoli packaged in plastic bags containing an active trilayer film based on a mixture of organic acids, extract of rosmarinic acid and Italian or Asian EO (Takala et al., 2013). However, all the active films had a significant antimicrobial effect against $E$. coli in fresh-cut pumpkin samples, but not in fresh-cut melon samples, in all likelihood because of the active interaction with some of the melon components.

The growth inhibition effects of the studied active films on the different food matrices, in terms of the reduction in log CFU, with respect to the corresponding inoculum control, are shown in Table 4. In in vitro studies with TSA culture medium, a significant growth inhibition of both bacteria was observed (between 1 and 4 log depending on the film formulation), whereas in in vivo tests, the antimicrobial effects were less remarkable in every case with the exception of the antimicrobial effect against E. coli of PHBV-EU and PHBV-CLO films, which were more effective in cheese, chicken meat and pumpkin samples. The greater antimicrobial effect of these actives in the food matrices suggests that the presence of some matrix compounds strengthen the mechanism of antibacterial action. The most significant antimicrobial effects against $E$. coli were obtained in fresh cheese and fresh-cut pumpkin. PHBV-EU and PHBV-CLO films were more effective in cheese, while PHBV-CA and PHBV-OR films exerted a greater effect in pumpkin samples. Despite the antilisterial effects observed in the in vitro tests, particularly in the case of CA, these were not noticed in any of the food matrices studied $(<1 \mathrm{log})$. The presence of nutrients that have a protective, nutritious effect on bacteria, as well as the interactions of the actives with the food compounds, significantly decreased their potential antilisterial effect. In this sense, noteworthy results were obtained for the plant foods, where, despite the low content of fat and protein in the matrix, a marked reduction in the antilisterial activity was observed for all the films. In this sense, Gutierrez et al. (2008) also reported that starch concentrations of $5 \%$ and $10 \%$ had a negative effect on the OR efficacy against L. monocytogenes. In general, the active compound was more effective against E. coli than L. innocua when applied to the food matrices, as well as in the culture medium, which may also be attributed to the higher MIC values of the active compounds for Listeria, which, in turn, will be affected by the substrate of growth (Pei et al., 2009; RaybaudiMassilia et al., 2006; Requena et al., 2018; Teixera et al., 2013). The lack of any significant antibacterial effect of active films on melon is remarkable, where very low values of growth inhibition were observed for both E. coli and L. innocua. Likewise, no inhibition of the $L$. innocua growth was observed in cheese samples. 


\section{L. innocua}

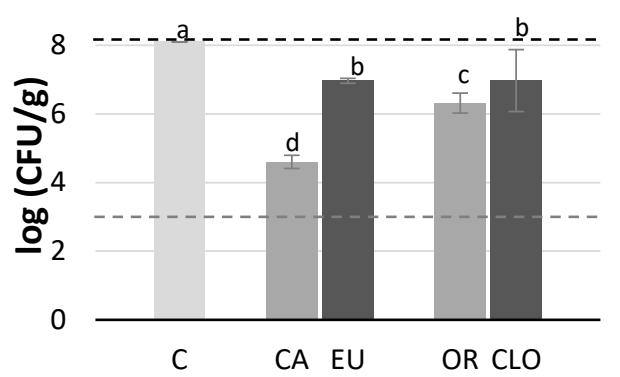

8

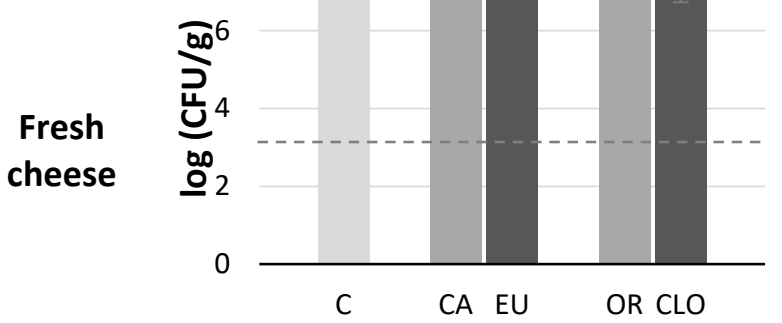

$$
8
$$
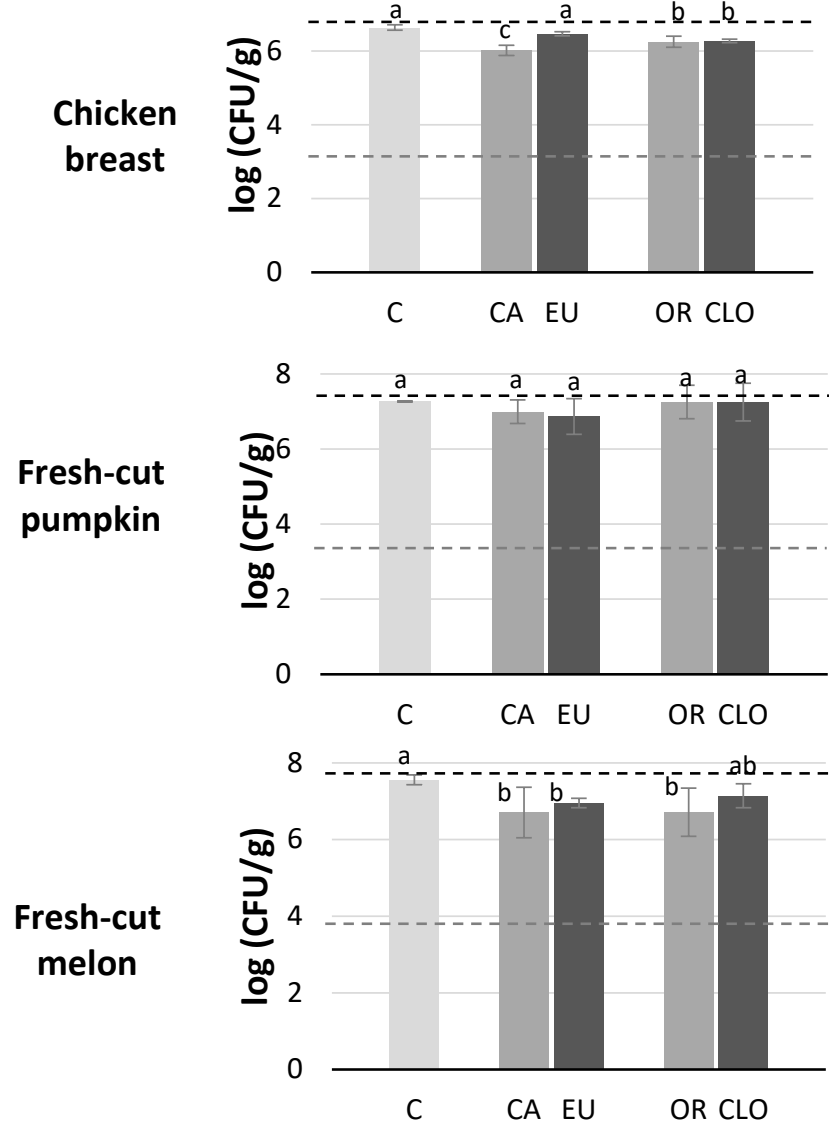

E. coli
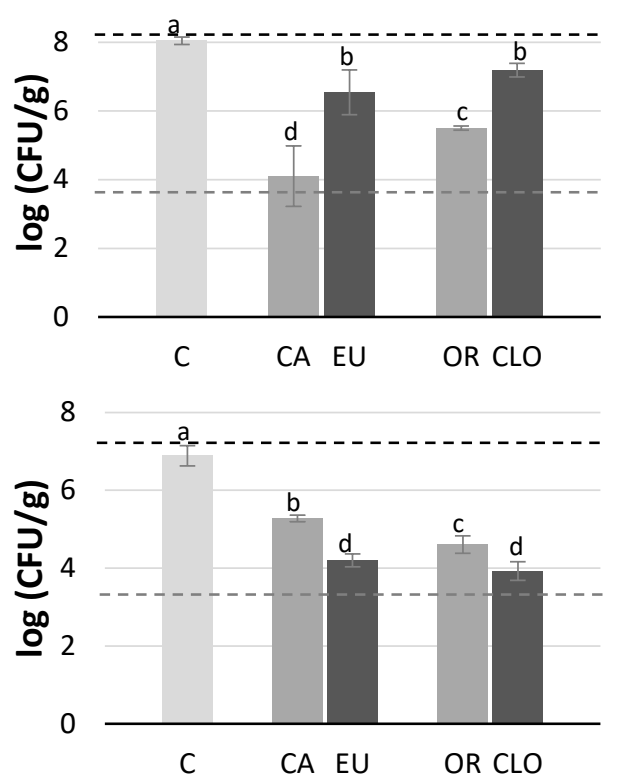

8
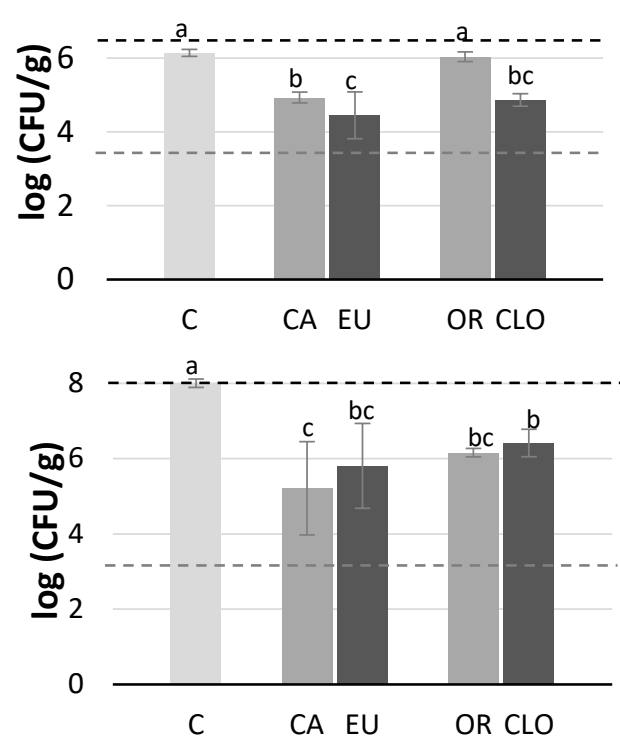

8

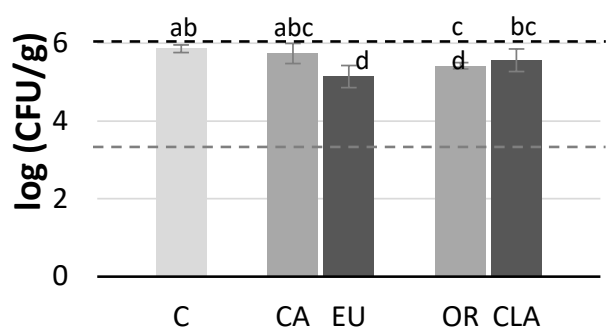

Figure 1. Microbial counts for Listeria innocua and Escherichia coli, obtained after 6 days of incubation at $10^{\circ} \mathrm{C}$ in TSA culture media (in vitro test) and different food matrices covered with films containing carvacrol (CA), eugenol (EU), oregano (OR) or clove essential oil (CLO) and without actives (C). Dotted lines show the microbial count of the inoculum before (grey) and after 6 days of incubation (black). Different letters above the error bars of the histogram show homogeneous sample groups $(p<0.05)$. 


\subsection{Cuantification of CA and EU migration to the food matrices}

The total migration of actives from the films to the food systems was analysed to better understand the differences in their antibacterial effect. This was carried out for CA and EU in the case of PHBV-CA and PHBV-EU films. In this sense, the remaining CA and EU content in the active films was analysed after 6 days in contact with each matrix, under the same conditions given in the antimicrobial assays, as well as the active content present in the respective food matrix, as described in section 2.6. Table 5 shows the contents of CA and EU in the film after 6 contact days, and the estimated amount delivered (\% respect to the initial content in the film: $107 \pm 7 \mathrm{mg} \mathrm{CA} / \mathrm{g}$ film or $61 \pm 6 \mathrm{mg} \mathrm{EU} / \mathrm{g}$ film) to the food system, as well as the content determined in the food matrix, using both the data obtained from the remaining content in the films ( 1 subscript) and that quantified in the food matrix ( 2 subscript). Although the amount of actives released into the food matrices by both methods did not coincide completely, the tendencies observed were quite coherent; this is except for the case of EU in chicken meat samples, where no significant release was detected through the analyses of the remaining content in the films. Nevertheless, a direct analysis in the food matrix would offer more reliable values since film manipulation throughout the extraction process could imply uncontrolled losses of the actives.

Melon was the food system in which the highest migration of both CA and UE occurred, whereas the pumpkin samples and the culture medium exhibited the lowest content of actives. Likewise, except for the pumpkin samples, the percentages of released CA and EU led to active contents in the food matrices higher than the MIC (CA: $0.75 \mathrm{mg} / \mathrm{mL}$ for L. innocua and $0.70 \mathrm{mg} / \mathrm{mL}$ for E. coli; EU: $1.05 \mathrm{mg} / \mathrm{mL}$ for L. innocua and $1.35 \mathrm{mg} / \mathrm{mL}$ for E.coli; Requena et al., 2018). However, no remarkable antimicrobial effects were observed on the melon samples coated with PHBV-CA or PHBV-EU films, which could be attributed to a scavenging effect of the melon components on the actives or to their fast diffusion into the internal tissue, provoking a dilution effect on the sample surface where the bacteria grow. In contrast, despite the scarce CA and EU migration into the pumpkin samples, it was sufficient to reduce the microbial growth of $E$. coli by 2.8 or $2.3 \mathrm{log}$, respectively. Likewise, very low CA or EU concentrations were estimated in the agar medium, when compared to food matrices, while the most significant antibacterial effect was obtained in this culture medium. This suggests that both CA and EU were more concentrated at the sample surface, with minor internal diffusion, which allowed for a more effective antibacterial action. On the other hand, although no significant differences between the migration of CA and EU into the chicken or cheese samples were observed, the migration values were higher in the chicken breast. However, a more marked growth inhibition of $E$. coli was observed in the cheese samples for both active compounds. 

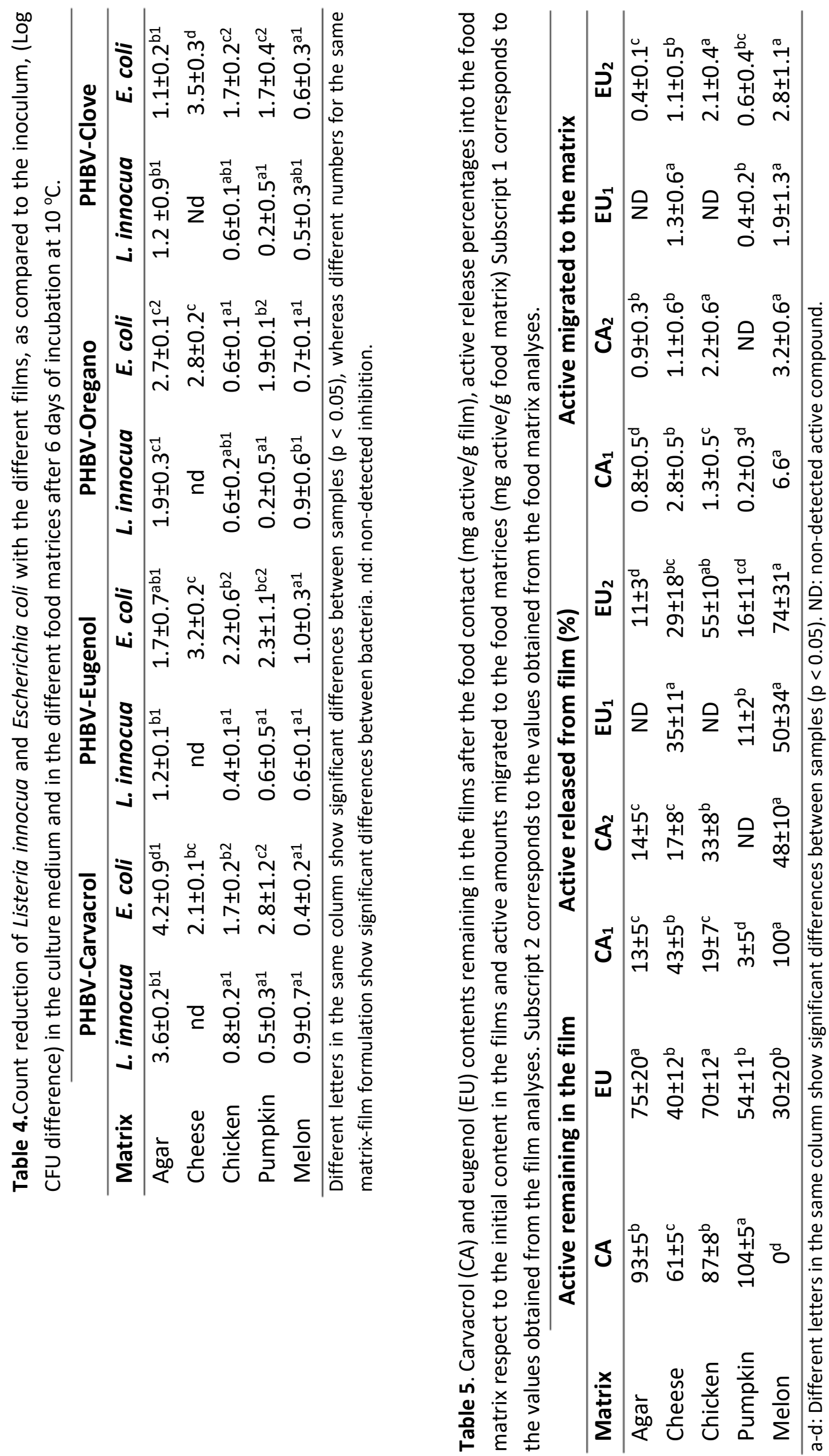
The lack of coherence between the active migration from the films into the food matrices and the antibacterial action observed in the different cases make a specific antimicrobial analysis necessary for each food to prove the effectiveness of a determined antimicrobial material. Many factors affect the availability of the potentially active compounds to exert their action. The interactions of actives with the food components, which can provoke a scavenging effect of the compound (Higueras et al., 2014), their specific diffusion into the internal part of the food matrix and the subsequent dilution effects on the contaminated surface or the reinforced vitality of bacteria induced by food components, compromise the antimicrobial effectiveness of the potentially active compounds included in a determined packaging material. On the other hand, a study of the release kinetics of the active compounds in food simulants did not give the same values of compound migration than those obtained in real foods or culture medium. Previous studies (Requena et al. 2017) with the same films containing CA or EU in food simulants A ( $10 \%$ ethanol aqueous solution) and D1 (50\% ethanol aqueous solution), which could emulate less fatty foods (chicken breast, melon and pumpkin samples or agar culture medium) and more fatty systems (cheese), respectively, would permit the estimation of the migration values of these components in the less and more fatty systems. The estimated values were 1.8 and $7.7 \mathrm{mg} \mathrm{CA} / \mathrm{g}$ matrix and 3.8 and $7.4 \mathrm{mg}$ EU/g matrix, respectively, for less and more fatty systems. These values differ noticeably from those obtained in the real foods, where specific components play an important role in both the active compound migration and availability and the bacterial vitality. Then, studies into the real foods are required to ensure that the potential antibacterial material can exert adequate protection against bacterial proliferation.

\section{CONCLUSION}

PHBV films with active essential oil compounds were highly effective against $L$. innocua and $E$. coli in in vitro tests, but they were much less effective in the real foods tested, with the exception of the effect against $E$. coli in cheese samples coated with PHBV-EU or PHBV-CLO films. No antilisterial effect was observed in any food matrices. The most significant antimicrobial effects against $E$. coli were observed in fresh cheese, for PHBV-EU and PHBVCLO films, and fresh-cut pumpkin, for PHBV-CA and PHBV-OR films. In general, although the percentages of CA and EU migration led to active contents in the food matrices that were higher than their MICs, they were not always effective. The highest migration of both CA and UE took place in melon, whereas the lowest migration was quantified in pumpkin samples and in the culture medium. In contrast, no significant antimicrobial activity of the films was observed in melon, while they were very effective against $E$. coli in the culture medium and the pumpkin samples. The lack of correlation between the amount of active that migrated to the food and the antibacterial effect observed in the different matrices reflected the fact that many compositional factors affect the active compound's availability to exert its antibacterial 
action on a specific food composition, which, in turn, has a different nutritious/protective effect on the bacteria. Therefore, antimicrobial analyses are required that are specific to the food in question to ensure the effectiveness of a particular antimicrobial packaging material.

\section{Acknowledgements}

The authors thank the Ministerio de Economía y Competitividad (Spain) for the financial support provided through Project AGL2016-76699-R. Author Raquel Requena thanks the Ministry of Education, Culture and Sport (Spain) for the FPU (FPU13/03444) Grant. 


\section{REFERENCES}

Adams, M. R., \& Nicolaides, L. (1997). Review of the sensitivity of different foodborne pathogens to fermentation. Food Control, 8(5), 227-239.

Al-Nabulsi, A. A., Osaili, T. M., Shaker, R. R., Olaimat, A. N., Jaradat, Z. W., Elabedeen, N. A. Z., \& Holley, R. A. (2015). Effects of osmotic pressure, acid, or cold stresses on antibiotic susceptibility of Listeria monocytogenes. Food Microbiology, 46, 154-160.

Alboofetileh, M., Rezaei, M., Hosseini, H., \& Abdollahi, M. (2014). Antimicrobial activity of alginate/clay nanocomposite films enriched with essential oils against three common foodborne pathogens. Food Control, 36(1), 1-7.

Beuchat, L. R. (1981). Microbial stability as affected by water activity. Cereal Foods World, 26(7), 345349.

Burt S. (2004). Essential oils: their antibacterial properties and potential applications in foods-a review. International Journal of Food Microbiology, 94(3), 223-253.

Canillac, N., \& Mourey, A. (2004). Effects of several environmental factors on the anti-Listeria monocytogenes activity of an essential oil of Picea excelsa. International Journal of Food Microbiology, 92(1), 95-103.

Francis, G. A., \& O'beirne, D. (2001). Effects of vegetable type, package atmosphere and storage temperature on growth and survival of Escherichia coli O157: $\mathrm{H7}$ and Listeria monocytogenes. Journal of Industrial Microbiology and Biotechnology, 27(2), 111-116.

Gill, A. O., Delaquis, P., Russo, P., \& Holley, R. A. (2002). Evaluation of antilisterial action of cilantro oil on vacuum packed ham. International Journal of Food Microbiology, 73(1), 83-92.

Glass KA, Johnson EA. (2004). Antagonistic effect of fat on the antibotulinal activity of food preservatives and fatty acids. Food Microbiology, 21, 675-682.

Gutierrez, J., Barry-Ryan, C., \& Bourke, P. (2008). The antimicrobial efficacy of plant essential oil combinations and interactions with food ingredients. International Journal of Food Microbiology, 124(1), 91-97.

Higueras, L., López-Carballo, G., Hernández-Muñoz, P., Catalá, R., \& Gavara, R. (2014). Antimicrobial packaging of chicken fillets based on the release of carvacrol from chitosan/cyclodextrin films. International Journal of Food Microbiology, 188, 53-59.

Kim, S., Ruengwilysup, C., \& Fung, D. Y. C. (2004). Antibacterial effect of water-soluble tea extracts on foodborne pathogens in laboratory medium and in a food model. Journal of Food Protection, 67(11), 2608-2612

Laycock, B., Halley, P., Pratt, S., Werker, A., \& Lant, P. (2013). The chemomechanical properties of microbial polyhydroxyalkanoates. Progress in Polymer Science, 38(3-4), 536-583. 
Mejlholm, O., \& Dalgaard, P. (2002). Antimicrobial effect of essential oils on the seafood spoilage micro-organism Photobacterium phosphoreum in liquid media and fish products. Letters in Applied Microbiology, 34(1), 27-31.

Mourey, A., \& Canillac, N. (2002). Anti-Listeria monocytogenes activity of essential oils components of conifers. Food Control, 13(4), 289-292.

Muppalla, S. R., Kanatt, S. R., Chawla, S. P., \& Sharma, A. (2014). Carboxymethyl cellulose-polyvinyl alcohol films with clove oil for active packaging of ground chicken meat. Food Packaging and Shelf Life, $2(2), 51-58$.

Narayanan, A., \& Ramana, K. V. (2013). Synergized antimicrobial activity of eugenol incorporated polyhydroxybutyrate films against food spoilage microorganisms in conjunction with pediocin. Applied Biochemistry and Biotechnology, 170(6), 1379-1388.

Nisar, T., Wang, Z. C., Yang, X., Tian, Y., Iqbal, M., \& Guo, Y. (2018). Characterization of citrus pectin films integrated with clove bud essential oil: Physical, thermal, barrier, antioxidant and antibacterial properties. International Journal of Biological Macromolecules, 106, 670-680.

Pandit, V. A., \& Shelef, L. A. (1994). Sensitivity of Listeria monocytogenes to rosemary (Rosmarinus officinalis L.). Food Microbiology, 11 (1), 57-63.

Pavlath, A. E., \& Orts, W. (2009). Edible Films and Coatings: Why, What, and How?. In Edible Films and Coatings for Food Applications (1-23). Springer New York.

Pei, R. S., Zhou, F., Ji, B. P., \& Xu, J. (2009). Evaluation of combined antibacterial effects of eugenol, cinnamaldehyde, thymol, and carvacrol against E. coli with an improved method. Journal of Food Science, 74(7).

Pelissari, F. M., Grossmann, M. V., Yamashita, F., \& Pineda, E. A. G. (2009). Antimicrobial, mechanical, and barrier properties of cassava starch- chitosan films incorporated with oregano essential oil. Journal of Agricultural and Food Chemistry, 57 (16), 7499-7504.

Perdones, Á., Escriche, I., Chiralt, A., \& Vargas, M. (2016). Effect of chitosan-lemon essential oil coatings on volatile profile of strawberries during storage. Food Chemistry, 197, 979-986.

Perdones, Á., Tur, N., Chiralt, A., \& Vargas, M. (2016). Effect on tomato plant and fruit of the application of biopolymer-oregano essential oil coatings. Journal of the Science of Food and Agriculture, 96(13), 4505-4513.

Ravishankar, S., Zhu, L., Olsen, C. W., McHugh, T. H., \& Friedman, M. (2009). Edible apple film wraps containing plant antimicrobials inactivate foodborne pathogens on meat and poultry products. Journal of Food Science, 74(8), M440-M445.

Raybaudi-Massilia, R. M., Mosqueda-Melgar, J., \& Martin-Belloso, O. (2006). Antimicrobial activity of essential oils on Salmonella enteritidis, Escherichia coli, and Listeria innocua in fruit juices. Journal of Food Protection, 69(7), 1579-1586. 
Requena, R., Jiménez, A., Vargas, M., \& Chiralt, A. (2016). Poly [(3-hydroxybutyrate)-co-(3hydroxyvalerate)] active bilayer films obtained by compression moulding and applying essential oils at the interface. Polymer International, 65(8), 883-891.

Requena, R., Vargas, M., \& Chiralt, A. (2017). Release kinetics of carvacrol and eugenol from poly (hydroxybutyrate-co-hydroxyvalerate) (PHBV) films for food packaging applications. European Polymer Journal, 92, 185-193.

Requena, R., Vargas, M., \& Chiralt, A. (2018, unpublished results). Study of the potential synergistic antibacterial activity of essential oil components using the thiazolyl blue tetrazolium bromide (MTT) assay.

Rojas-Graü, M. A., Avena-Bustillos, R. J., Olsen, C., Friedman, M., Henika, P. R., Martín-Belloso, O., Pan, Z., \& McHugh, T. H. (2007). Effects of plant essential oils and oil compounds on mechanical, barrier and antimicrobial properties of alginate-apple puree edible films. Journal of Food Engineering, 81(3), 634641.

Royo, M., Fernández-Pan, I., \& Maté, J. I. (2010). Antimicrobial effectiveness of oregano and sage essential oils incorporated into whey protein films or cellulose-based filter paper. Journal of the Science of Food and Agriculture, 90 (9), 1513-1519.

Shekarforoush, S. S., Nazer, A. H. K., Firouzi, R., \& Rostami, M. (2007). Effects of storage temperatures and essential oils of oregano and nutmeg on the growth and survival of Escherichia coli O157: $\mathrm{H7}$ in barbecued chicken used in Iran. Food Control, 18(11), 1428-1433.

Shelef, L. A., Jyothi, E. K., \& Bulgarellii, M. A. (1984). Growth of enteropathogenic and spoilage bacteria in sage-containing broth and foods. Journal of Food Science, 49 (3), 737-740.

Singh, A., Singh, R. K., Bhunia, A. K., \& Singh, N. (2003). Efficacy of plant essential oils as antimicrobial agents against Listeria monocytogenes in hotdogs. LWT-Food Science and Technology, 36(8), 787-794.

Smith-Palmer, A., Stewart, J., \& Fyfe, L. (2001). The potential application of plant essential oils as natural food preservatives in soft cheese. Food Microbiology, 18(4), 463-470.

Takala, P. N., Salmieri, S., Boumail, A., Khan, R. A., Vu, K. D., Chauve, G., Bouchard, J., \& Lacroix, M. (2013). Antimicrobial effect and physicochemical properties of bioactive trilayer polycaprolactone/methylcellulose-based films on the growth of foodborne pathogens and total microbiota in fresh broccoli. Journal of Food Engineering, 116(3), 648-655.

Teixeira, B., Marques, A., Ramos, C., Serrano, C., Matos, O., Neng, N. R., Nogueria, J.M.F., Saraiva, J.A., \& Nunes, M. L. (2013). Chemical composition and bioactivity of different oregano (Origanum vulgare) extracts and essential oil. Journal of the Science of Food and Agriculture, 93(11), 2707-2714.

Veldhuizen, E. J., Creutzberg, T. O., Burt, S. A., \& Haagsman, H. P. (2007). Low temperature and binding to food components inhibit the antibacterial activity of carvacrol against Listeria monocytogenes in steak tartare. Journal of Food Protection, 70(9), 2127-2132. 
Wen, P., Zhu, D. H., Feng, K., Liu, F. J., Lou, W. Y., Li, N., Zong, M-H., \& Wu, H. (2016). Fabrication of electrospun polylactic acid nanofilm incorporating cinnamon essential oil/ $\beta$-cyclodextrin inclusion complex for antimicrobial packaging. Food Chemistry, 196, 996-1004.

Xavier, J. R., Babusha, S. T., George, J., \& Ramana, K. V. (2015). Material properties and antimicrobial activity of polyhydroxybutyrate (PHB) films incorporated with vanillin. Applied Biochemistry and Biotechnology, 176(5), 1498-1510. 



\title{
Obtaining antimicrobial bilayer starch and polyester- blend films with carvacrol
}

\author{
Raquel Requena; María Vargas; Amparo Chiralt
}

Food Hydrocolloids (2018) 83, 188-133.

Institute of Food Engineering for Development, Universitat Politècnica de València, Valencia, Spain 



\begin{abstract}
Bilayer films using polyester blends (P) and starch (S) were obtained and characterized, incorporating carvacrol as active compound. Carvacrol was incorporated by spraying it between melt blended and compression moulded sheets or through its incorporation into the chloroform P solution used to obtain P cast films. Different PLA-PHBV ratios (75:25 and 65:35) were tested, with and without PEG1000, whereas the 75:25 ratio with PEG was only used for cast sheets, based on its better overall properties. Mono and bilayers were characterised as to their tensile and water vapour barrier properties and thermal behaviour. Release kinetics of carvacrol in different food simulants and in in vitro antibacterial activity against Listeria innocua and Escherichia coli were also analysed. Incorporating carvacrol by spraying it between the polyester and starch sheets was not effective at retaining the compound in the bilayers. However, the incorporation of carvacrol into cast $P$ films, and the subsequent formation of bilayers with the $S$ sheets, was highly effective at providing practically total carvacrol retention. These active bilayers exhibited highly improved tensile and water vapour barrier capacity with respect to the S monolayer ( $87 \%$ reduction in WVP, 840\% increase in elastic modulus) and inhibited the growth of $L$. innocua and $E$. coli from both $\mathrm{P}$ or $\mathrm{S}$ contact sides of bilayers, depending on the internal diffusion of carvacrol through the bilayer and its adequate release of the compound into the culture medium.
\end{abstract}

Keywords: starch; poly(lactic acid), poly(hydroxybutyrate-co-hydroxyvalerate), carvacrol, packaging properties, antibacterial properties. 


\section{INTRODUCTION}

With society's growing concern for the environment and the great dependence on fossil fuels for plastic production, there is a need to find suitable environmentally-friendly solutions to the outbreak of plastic-based packaging. In this context, bio-based and biodegradable polymers such as poly(lactic acid) (PLA) and polyhydroxyalkanoates (PHAs) have emerged as suitable green solutions (Avérous, 2004; Corre, Bruzaud, Audic, \& Grohens, 2012). The relatively widespread use of PLA on the market is due to its adequate physical properties, similar to polystyrene and poly(ethylene terephthalate) (Siracusa, Rocculi, Romani, \& Dalla Rosa 2008), and its better features compared to other biopolymers, such as higher transparency, processability, printability and rate of composability (Arrieta et al., 2014b; Auras, Harte, \& Selke, 2004). However, PLA application in flexible films has been hindered due to its inherent brittle nature and its limited gas barrier properties (Muller, González-Martínez, \& Chiralt, 2017b). Other biodegradable polyester with good barrier capacity, such as poly(hydroxybutyrate-co-hydroxyvalerate) (PHBV), have emerged, whose blend with PLA could improve the properties of the material. PHBV is an entirely biodegradable polyester synthesised by a wide variety of bacteria whose degree of crystallinity and melting point decrease as the hydroxyvalerate content increases (Savenkova, Gercberga, Bibers, \& Kalnin, 2000). Blending strategies between both polyesters and/or with plasticizers have recently been applied in order to obtain materials with different functionality, thus obtaining product blends with interesting physical, thermal and mechanical properties compared to the neat polymers (Armentano et al., 2015a,b; Arrieta, López, Ferrándiz, \& Peltzer, 2013; Arrieta, Samper, López, \& Jiménez 2014a; Arrieta et al., 2014b; Jost \& Kopitzky, 2015). Jost \& Kopitzky (2015) reported a water vapour permeability reduction of $46 \%$ and a $40 \%$ lower oxygen permeability for a 75:25 PL-PHBV ratio, compared to the pure PLA films. Arrieta et al. (2014a) and Armentano et al. (2015b) also highlighted the enhancement of the film barrier properties by combining PLA and poly(hydroxybutyrate) (PHB). Likewise, the addition of plasticizers, such as acetyl tributyl citrate, limonene, PEG300 and oligomer lactic acid, has been proposed as a means of improving the stretchability of both PLA and PHB films (Arrieta et al., 2013; Arrieta et al., 2014a; Armentano et al., 2015a, b).

Developing multilayer structures where materials with complementary properties are combined in the same sheet could also be an interesting approach to overcome the shortcomings of these promising polyesters (Martucci \& Ruseckaite, 2010). Starch, obtained from different natural resources, is a polymer which is widely available at low cost and provides biodegradable films with great oxygen barrier capacity (Ortega-Toro, Muñoz, Talens, $\&$ Chiralt, 2016). Nevertheless, it is not more widely applied in the field of food packaging due to its high water sensitivity and water vapour permeability and its relatively low tensile strength (Souza, Goto, Mainardi, Coelho, \& Tadini, 2013; Acosta, Jiménez, Cháfer, GonzálezMartínez, \& Chiralt, 2015; Versino, López, \& García, 2015). Combining PLA-PHBV blend films 
with starch films in bilayer structures could represent a good option to obtain materials with improved mechanical and barrier properties more suited to food packaging applications. Polyester layers would contribute to strengthening the bilayer while reducing water vapour permeability and the starch layer would help to control the oxygen and gas barrier capacity of the layer assembly. The multilayer strategy has usually been applied in synthetic plastic to obtain materials with better functionality, although there are few reported studies into biodegradable polymers. In this sense, PLA films have recently been combined in multilayer structures with MaterBi (commercial starch-based thermoplastic polymer) and sugar palm starch films (Scaffaro, Sutera, \& Botta, 2018; Sanyang, Sapuan, Jawaid, Ishak, \& Sahari, 2016); fish and bovine hide gelatin layers (Nilsuwan, Benjakul, \& Prodpran, 2017; Martucci \& Ruseckaite, 2010); soy protein films (González \& Igarzabal, 2013) and cassava starch films (Muller, González-Martínez, \& Chiralt, 2017a). The multilayer assemblies exhibited lower WVP and better mechanical performance than the hydrocolloid-based films, and better oxygen barrier capacity and film stretchability than neat PLA films. Likewise, the incorporation of active compounds, such as essential oils or their main constituents, could also provide added value to these polyester-starch bilayers (antimicrobial or antioxidant materials), since these natural and non-toxic compounds could inhibit the growth of foodborne bacteria and pathogenic microorganisms in the food packaging applications (Burt, 2004; Friedman, Henika, Levin, \& Mandrell, 2004; Fratianni et al., 2010). In this sense, numerous studies have shown that carvacrol (CA), the main compound of the Labiatae family, including Origanum, Satureja, Thymbra, Thymus, and Coridothymus (Babili et al., 2011; Xu, Zhou, Ji, Pei, \& Xu, 2008), exhibits a wide-spectrum antimicrobial activity (Requena et al., 2017a). Moreover, CA has been recognized as GRAS by the FDA and, therefore, approved as a safe food preservative in the USA and Europe.

The aim of this work was to obtain antimicrobial bilayer films with carvacrol, combining sheets of PLA-PHBV blends and thermoplastic starch, and characterize them as to their antimicrobial and functional properties and carvacrol release kinetics. PLA-PHBV blends were obtained by both melt blending and compression moulding or casting from their chloroform solutions. Two different strategies were used to incorporate carvacrol into bilayers: spraying the compound dose at the bilayer interface or incorporating it in the polyester-casting solution.

\section{MATERIALS AND METHODS}

\subsection{Materials and reagents}

Cassava starch, poly(3-hydroxybutyrate-co-3-hydroxyvalerate) (PHBV) with $8 \%$ of hydroxyvalerate and amorphous PLA 4060D with density of $1.24 \mathrm{~g} / \mathrm{cm}^{3}$, supplied respectively by Asia CO., LDT (Kalasin, Thailand), NaturePlast (Caen, France) and Natureworks (U.S.A), were 
used to obtain bilayer films. The plasticizer poly(ethylene glycol) with molecular weight of 1000 Da (PEG1000) was purchased from Sigma-Aldrich (Steinheim, Germany), whereas the glycerol was obtained from Panreac Química S.L.U. (Castellar del Vallés, Barcelona, Spain). Carvacrol (CA) and the different UV grade solvents, chloroform, methanol, ethanol, acetic acid and isooctane, were supplied by Sigma-Aldrich (Steinheim, Germany). Magnesium nitrate $\left(\mathrm{Mg}\left(\mathrm{NO}_{3}\right)_{2}\right)$, used to reach $53 \%$ relative humidity $(\mathrm{RH})$ during the film conditioning, was supplied by Vidra Foc S.A. (Barcelona, Spain).

For the antimicrobial activity analysis, stock cultures of Escherichia coli (CECT 101) and Listeria innocua (CECT 910) were supplied by the Spanish Type Culture Collection (CECT, Burjassot, Spain). Tryptone Soy Broth, Agar Bacteriological and Tryptone Phosphate Water were provided by Scharlab (Barcelona, Spain).

\subsection{Film preparation}

Thermo-processed polyester films were prepared by melt blending and compressionmoulding using different PLA:PHBV ratios, and PEG1000 as plasticizer, in order to optimise the PLA-PHBV ratio in the polyester blends, according to their functional properties. Afterwards, the best blend formulation was also obtained by casting incorporating or not CA in the film forming dispersion (FFD). Thus, these polyester monolayer films (compression moulded or cast) were combined with cassava starch (S) monolayer films to obtain polyester/starch bilayers, with or without CA.

\subsubsection{Preparation of polyester monolayer films by thermo-compression (T-PLA:PHBV:PEG)}

Pure PLA and PHBV films, as well as PLA-PHBV blend films were obtained at two different PHBV ratios (25 and 35 wt.\%) in the polymer blend. In addition, PEG1000 was used as plasticizer in both pure and blend films in a constant proportion ( $15 \mathrm{~g} / 100 \mathrm{~g}$ polymer). Thus, the film components were melt-blended in a two-roll mill (Model LRM-M-100, Labtech Engineering, Thailand) at $200{ }^{\circ} \mathrm{C}$ and $12 \mathrm{rpm}$ for $10 \mathrm{~min}$, except in the case of the pure PHBV formulation which was processed at $180^{\circ} \mathrm{C} .2 .5 \mathrm{~g}$ of the resulting pellets were compression moulded in a hydraulic press (Model LP20, Labtech Engineering, Thailand) in a three-step process. First, the steel sheets were pre-heated at $200{ }^{\circ} \mathrm{C}$ for $5 \mathrm{~min}$. Then, the compression was performed at $200{ }^{\circ} \mathrm{C}$ and 100 bars for $4 \mathrm{~min}$, followed by a cooling cycle for 3 min until the temperature reached about $70{ }^{\circ} \mathrm{C}$. The resulting films were stored at $53 \% \mathrm{RH}$ and $25{ }^{\circ} \mathrm{C}$ until further analysis or their use to obtain bilayer films. 


\subsubsection{Preparation of polyester monolayer films by casting (C-75:25:15 and C-75:25:15-CA)}

PLA-PHBV blend monolayers were obtained by casting in a ratio of 75:25 with and without CA, using PEG1000 (15 g/100 g polymer) as a plasticizer, on the basis of results obtained from the thermoprocessed monolayers. The PLA, PHBV and PEG1000 blend was dissolved in chloroform at $5.88 \%(\mathrm{w} / \mathrm{w})$ by boiling under reflux for $4 \mathrm{~h}$. Then, the FFD was cooled until room temperature, adjusting the total weight with chloroform and incorporating, or not, the CA at $25 \mathrm{~g} \mathrm{CA} / 100 \mathrm{~g}$ polymer matrix (polyesters and plasticizer). The resulting FFDs were poured into $15 \mathrm{~cm}$ diameter Teflon plates (1.98 g solids per plate) and the solvent was evaporated overnight in a fume hood. When FFD contained CA, its content was $2.8 \mathrm{mg} \mathrm{CA} / \mathrm{cm}^{2}$ of film, similar to that applied by spraying between layers using the processing method. The dried films were peeled off the casting surface and stored at $53 \% \mathrm{RH}$ and $25^{\circ} \mathrm{C}$ until further analysis or their use to obtain bilayer films.

\subsubsection{Preparation of starch monolayer films by compression-moulding (S)}

Cassava starch (S) monolayer films were prepared with a S:water:glycerol:PEG1000 ratio of 100:55:30:0.5. Thermoplastic starch pellets were obtained in a two-roll mill (Model LRM-M100 , Labtech Engineering, Thailand) at $160{ }^{\circ} \mathrm{C}$ and $12 \mathrm{rpm}$ for $20 \mathrm{~min}$. The resulting pellets were conditioned at $25{ }^{\circ} \mathrm{C}$ and $53 \% \mathrm{RH}$ for 10 days, by using an oversaturated $\mathrm{Mg}\left(\mathrm{NO}_{3}\right)_{2}$ solution. $4 \mathrm{~g}$ of conditioned pellets were placed onto steel sheets and preheated in a hydraulic press (Model LP20, Labtech Engineering, Thailand) at $160{ }^{\circ} \mathrm{C}$ for $1 \mathrm{~min}$. Then, compression moulding was performed at the same temperature, applying 50 bars for $2 \mathrm{~min}$, followed by 100 bars for 6 min. Finally, a cooling cycle was applied for 3 min until the temperature reached about $70^{\circ} \mathrm{C}$. The resulting films were stored at $53 \% \mathrm{RH}$ and $25^{\circ} \mathrm{C}$ until further analysis or their use to obtain bilayer films

\subsubsection{Preparation of active starch-polyester bilayer films (TP-S, TP-CA-S, CP-S, CP(CA)-S)}

According to the best functional properties as packaging material, the T-75:25:15 film formulation was chosen among the different thermoprocessed polyester (TP) formulations to obtain bilayers with $\mathrm{S}$ films. To this end, CA was sprayed at the interface between both thermo-compressed films in the same ratio used in the cast polyester films $\left(2.8 \mathrm{mg} / \mathrm{cm}^{2}\right.$ of film). Then, both monolayers, with and without CA at the interface, were compression moulded in a hydraulic press (Model LP20, Labtech Engineering, Thailand) at $160{ }^{\circ} \mathrm{C}$ and 100 bar for $2 \mathrm{~min}$ and cooled down until $80^{\circ} \mathrm{C}$ in $2 \mathrm{~min}$, thus obtaining TP-CA-S and TP-S films respectively, with a nominal mass fraction of TP film in the bilayers of about 0.38 . 
Likewise, bilayer films were also obtained through thermo-compression of both the $S$ monolayer and the cast polyester monolayer (CP) with and without $C A$, thus obtaining $C P(C A)$ $\mathrm{S}$ and $\mathrm{CP}-\mathrm{S}$ films respectively, with a nominal mass fraction of CP film in the bilayers of about 0.33 .

\subsection{Film characterization}

\subsubsection{Analysis of the CA retention in the films}

CA distribution was analysed in newly prepared active films (TP-CA-S, CP(CA) and CP(CA)-S), and others stored for 6 days, by methanol extraction and spectrophotometric quantification. Three different films were divided into four concentric circular sections: internal circles of 3 $\mathrm{cm}$ radius and circular crowns of internal-external radii of 3-5, 5-7 and 7-7.5 cm. Film samples $(0.2 \mathrm{~g})$ of each section were kept in $\mathrm{P}_{2} \mathrm{O}_{5}(0 \% \mathrm{HR})$ for $24 \mathrm{~h}$ and extracted in $10 \mathrm{~mL}$ of methanol under constant stirring for $72 \mathrm{~h}$ at $20^{\circ} \mathrm{C}$. The methanol extracts were filtered, properly diluted and their absorbance was measured using UV-visible spectrophotometer (Thermo Scientific Evolution 201, EEUU) at $275 \mathrm{~nm}$ (maximum of absorption of the CA in methanol), using as the blank solution the methanol extract of the corresponding control film without $C A$ in each case. The absorbance measurements were transformed into CA concentration values (g CA/100 g film) using the corresponding calibration curve. All measurements were taken in triplicate.

\subsubsection{Thermal behaviour}

Differential scanning calorimetry (DSC) analyses were performed using a DSC (Stare System, Mettler Toledo Inc., Switzerland). Film samples (about $10 \mathrm{mg}$ ) were placed into aluminium pans (Seiko Instruments, P/N SSC000C008) and analysed using a multiple scan. Firstly, samples were heated from room temperature to $180^{\circ} \mathrm{C}$ at $10^{\circ} \mathrm{C} / \mathrm{min}$. Then, samples were cooled to $30{ }^{\circ} \mathrm{C}$ at $-50^{\circ} \mathrm{C} / \mathrm{min}$ and heated again to $180^{\circ} \mathrm{C}$ at $10^{\circ} \mathrm{C} / \mathrm{min}$. All measurements were taken in duplicate under a nitrogen stream of $20 \mathrm{~mL} / \mathrm{min}$.

A thermogravimetric analyser (TGA/SDTA 851e, Mettler Toledo, Schwarzenbach, Switzerland) was used to determine the thermal stability of the different film formulations. Measurements of the thermal weight loss of each type of film were taken in duplicate in a temperature range between 25 and $600{ }^{\circ} \mathrm{C}$ at $10^{\circ} \mathrm{C} / \mathrm{min}$ under a nitrogen stream of $20 \mathrm{~mL} / \mathrm{min}$. 


\subsubsection{Tensile properties}

The tensile behaviour of the films was determined following the ASTM D882 standard method by using a texture analyser (TA-XTplus, Stable Micro Systems, Surrey, United Kingdom). A hand-held digital micrometer (Electronic Digital Micrometer, Comecta S.A., Barcelona, Spain) was used to measure film thickness to the closest $0.001 \mathrm{~mm}$, at six random positions around the film. Then, film strips ( $25 \mathrm{~mm}$ wide, $100 \mathrm{~mm}$ long) were mounted in the tensile grips (5 $\mathrm{mm}$ of film between grips) and stretched at $50 \mathrm{~mm} / \mathrm{min}$ until breaking. The elastic modulus (EM), tensile strength at break (TS) and percentage of elongation at break (\% E) were obtained from stress-strain curves. Measurements (eight replicates per formulation) were taken in films conditioned at $25{ }^{\circ} \mathrm{C}$ and $53 \% \mathrm{RH}$ for one week.

\subsubsection{Water vapour permeability}

The water vapour permeability (WVP) of the films was determined according to the ASTM E96-95 gravimetric method. Round film samples ( $35 \mathrm{~mm}$ diameter) of each formulation were placed on Payne permeability cups $(3.5 \mathrm{~cm}$ in diameter, Elcometer SPRL, Hermelle/s Argenteau, Belgium) at $25{ }^{\circ} \mathrm{C}$ and a 53-100 \% RH gradient, which was created with an oversaturated $\mathrm{Mg}\left(\mathrm{NO}_{3}\right)_{2}$ solution and distilled water, respectively. In order to reduce the resistance to transport of water vapour, a fan was placed above each cup. The cups were weighed periodically using an analytical balance ( $\pm 0.00001 \mathrm{~g}$ ), until the steady state was reached and the WVP was calculated from the slope of the curves of weight loss versus time. Measurements (in quadruplicate per formulation) were taken in films conditioned for one week at $25^{\circ} \mathrm{C}$ and $53 \% \mathrm{RH}$.

\subsubsection{Release kinetics of CA in food simulants}

The release kinetic study was carried out only for the CP(CA) monolayer and the CP(CA)-S bilayer films due to the poor CA retention obtained for the TP-CA-S bilayer films. The release kinetics of CA from these films was studied in four different food simulants according to the Commission regulation (EU) 2015/174 amending and correcting Regulation (EU) No 10/2011 on plastic materials and articles intended to come into contact with food. Thus, aqueous food with neutral and acid $\mathrm{pH}$ were simulated with $10 \%$ ethanol $(\mathrm{v} / \mathrm{v})(\mathrm{A})$ and $3 \%$ acetic acid $(\mathrm{w} / \mathrm{v})$ (B), respectively, whereas fatty foods were simulated with $50 \%$ ethanol (v/v) (D1) and isooctane (D2). Film samples of $500 \mathrm{mg}$ were placed in contact with $100 \mathrm{~mL}$ of each simulant and kept under stirring at $20^{\circ} \mathrm{C}$ throughout the time. The absorbance of the different solutions was measured at different contact times up to equilibrium, thus obtaining the CA profile concentration in each simulant over time using standard calibration curves previously obtained in each simulant. All analyses were performed in triplicate and the corresponding 
extracts of films without CA were used as blank solutions for the absorbance measurements, for each simulant and time.

The CA amount released into the simulants at each time $\left(M_{t}\right)$ was fitted to Peleg's model (Eq. 1) (Peleg, 1988), and the constants $k_{1}$ (inversely related to the initial release rate) and $k_{2}$ (related to the asymptotic release value) were determined. The amount of active released at equilibrium $\left(\mathrm{M}_{\infty}\right)$ was calculated from $\mathrm{k}_{2}$ (Eq. 2).

$$
\begin{aligned}
& \frac{t}{M_{t}}=k_{1}+k_{2} \cdot t \\
& M_{\infty}=\frac{1}{k_{2}} \quad \text { (Eq. 2) }
\end{aligned}
$$

Fick's second law was fitted to the experimental data to obtain the diffusion coefficient of CA from the films towards the food simulants. Film samples were considered as infinite plane sheets with the half thickness as the characteristic dimension, where the active compound diffuses only in an axial direction. The diffusional long-time equation with ten terms for an infinite plane sheet (Crank, 1975) was used to determine the diffusion coefficient (D) values of CA for the different solvents (Eq. 3), where $M_{t}$ is the mass of compound released at time $t$, $M_{\infty}$ is the mass of compound released at equilibrium and $L$ is the half thickness of film. The Solver tool (Microsoft Excel $2013^{\circledR}$ ) was used to optimize the D values, by minimizing the Sum of Squared Errors (SSE), considering the following boundary conditions:

$$
\begin{array}{lcc}
t=0 & 0<x<L & c=c_{0} \\
t>0 & x=0 \quad x=L \quad c=0 \\
M_{t}=M_{\infty}\left(\frac{8}{\pi^{2}} \sum_{n=0}^{\infty}\left[\frac{1}{(2 n+1)^{2}} \exp \left\{\frac{-\pi^{2} D(2 n+1)^{2} t}{L^{2}}\right\}\right]\right)
\end{array}
$$

\subsubsection{Antibacterial activity assessment}

Listeria innocua (CECT 910) and Escherichia coli (CECT 101) were regenerated (from a culture stored at $-25^{\circ} \mathrm{C}$ with $30 \%$ glycerol) by transferring an aliquot into $10 \mathrm{~mL}$ of TSB and incubating at $37^{\circ} \mathrm{C}$ for $24 \mathrm{~h}$. A $10 \mu \mathrm{L}$ aliquot was transferred from this culture into $10 \mathrm{~mL}$ of TSB and grown again at $37^{\circ} \mathrm{C}$ for $24 \mathrm{~h}$, thus obtaining a culture in the stage of exponential growth. Petri dishes with $10 \mathrm{~g}$ of TSA were properly inoculated to obtain an inoculum concentration of $10^{4} \mathrm{CFU} / \mathrm{g}$. Circular samples of $55 \mathrm{~mm}$ in diameter, obtained from the different kinds of films, were placed on inoculated TSA plates and incubated for 6 days at $10{ }^{\circ} \mathrm{C}$. Then, the microbial counts were 
examined by serial dilutions and plating technique with TSA incubated for $24 \mathrm{~h}$ at $37^{\circ} \mathrm{C}$. All tests were performed in duplicate and the corresponding films without CA were used as control samples. In the case of the bilayer films, the antimicrobial test was carried out on both sides of the films, by placing each one in contact with the culture media. Thus, the microbial counts were reported for both analyses: the polyester layer or the S layer in contact with the culture media.

\subsubsection{Statistical analyses}

Statistical analysis of variance with Fisher's least significant difference at $95 \%$ confidence level was performed using Statgraphics Centurion XVI (Manugistics Corp., Rockville, MD, USA).

\section{RESULTS AND DISCUSSION}

\subsection{Properties of the polyester blend monolayer films}

\subsubsection{Physical properties}

Table 1 includes the tensile properties (elastic modulus (EM), tensile strength (TS) and elongation at break (E)) of the polyester monolayers obtained by thermo-compression (T) or casting $(C)$ with different PLA:PHBV:PEG ratios. Neat PLA and PHBV films were highly resistant and stiff, with values of tensile parameters in the range of those previously reported by other authors (Chen, Hao, Guo, Song, \& Zhang, 2002; Courgneau et al., 2012; Muller et al., 2017a). The incorporation of $15 \%$ of PEG significantly increased the PLA film stretchability, which was twenty times higher than that of the neat PLA film, coherent with the decrease in the glass transition temperature (commented on below) and the subsequent increase in the polymer chain mobility, as also observed by Sheth, Kumar, Davé, Gross, \& McCarthy (1997). On the other hand, the addition of PHBV (25 or $35 \%$ ) to PLA films led to less resistant materials than pure PLA films, with low stretchability values. This can be attributed to the lack of total polymer miscibility which led to discontinuities in the PLA network, including PHBV domains, which favoured the film break (Gérard, Budtova, Podshivalov, \& Bronnikov, 2014). When PHBV was included in the PEG-plasticized PLA matrix, a significant reduction in both the film stretchability and resistance was observed. This effect was more pronounced for the highest proportion of PHBV, which gave rise to an extremely brittle material. However, the T-75:25:15 formulation showed global mechanical properties that could meet some food packaging requirements. Therefore, this thermo-processed monolayer formulation was selected to obtain active bilayer films with $\mathrm{S}$ sheets and CA sprayed at the interface. This ratio was also used to obtain polyester monolayer films by casting with and without $C A$, whose tensile properties are also summarized in Table 1. 
No significant differences were observed in the thickness of monolayers obtained by the different methods, since a similar surface solid density was used in both cases. However, the film formation processes significantly affected the mechanical behaviour of the polyester blend films. Cast polyester blend films (C-75:25:15) were more resistant, stiffer and less extensible than those obtained by compression moulding. As reported by Fakhouri et al. (2013) and Moreno, Díaz, Atarés, \& Chiralt (2016), during the solvent evaporation in the casting process, the polymer chains can interact more effectively than during melt blending, thus giving rise to more compact matrices. Incorporating CA into cast polyester films (C75:25:15-CA) significantly reduced the EM and enhanced stretchability due to the random distribution of the CA molecules between the polymer chains, which increases their free volume, provoking a plasticizing effect and reducing the matrix strength. The plasticizing effect of CA in different polymer matrices has also been reported in neat PHBV films (Requena, Jiménez, Vargas, \& Chiralt, 2016a), polypropylene (Ramos, Jiménez, Peltzer, \& Garrigós, 2012), alginate-apple puree (Rojas-Graü et al., 2007) or Gelidium Corneum films (Lim, Hong, Song, 2010).

As Jost \& Kopitzky (2015) reported, pure PLA films showed significantly higher WVP values than PHBV films (Table 1). The water vapour barrier capacity of PLA and PHBV films decreased when $15 \%$ of PEG was included in the film formulation due to the polymer matrix rearrangement that results in higher free volume which facilitates molecular diffusion (Byun, Kim, \& Whiteside 2010). The incorporation of PHBV into PLA matrices enhanced water vapour barrier capacity of the films, which was significantly notable with 35\% PHBV, when a reduction in the WVP of $50 \%$ was obtained. As occurred in the pure polymer films, PEG addition to PLAPHBV blends enhanced the film WVP, in line with its plasticizing effect and the subsequent promotion of molecular mobility and diffusion. However, in PEG-plasticized blends, samples with the highest PHBV content exhibited higher WVP values than those of the sample with the lowest PHBV content. This suggests different PEG interactions with both polymers in the blend, giving rise to a non-equivalent partition of the plasticizer between PLA and PHVB domains. In fact, the plasticizing effect of PEG on pure PLA matrices was much more effective than on PHBV films (commented on below). The increase in the PHBV ratio in the blend would imply a greater amount of PEG available for the PLA domains, thus provoking greater molecular mobility in these regions of the film, which enhanced water diffusion through the PLA phase.

Polyester monolayers obtained by casting had worse water vapour barrier capacity than the corresponding monolayers obtained by thermo-processing, contrary to what is expected from the effect observed on the tensile properties, which suggested a more compact polymer arrangement in the matrix with better cohesion forces (Table 1). In this sense, the different degree of crystallinity of the polymers in the matrix could play an important role in both the tensile behaviour and barrier capacity of the films. The addition of CA significantly improved the water vapour barrier capacity, in line with the enhancement of the hydrophobic nature of 
the matrix, thus limiting the solubility of the water molecules (Woranuch \& Yoksan, 2013; Benavides, Villalobos-Carvajal \& Reyes, 2012; Requena et al., 2016a). The effect of CA on polymer crystallization could also affect both the tensile and barrier properties of the films.

Table 1.Tensile properties (elastic modulus (EM), tensile strength (TS) and elongation at break (E)), thickness and water vapour permeability (WVP: g/m.s.Pa) of the polyester monolayers obtained by thermo-compression $(\mathrm{T})$ and casting $(\mathrm{C})$ with different PLA:PHBV:PEG ratios. Mean values \pm standard deviations.

\begin{tabular}{|c|c|c|c|c|c|}
\hline Formulation & EM (MPa) & TS (MPa) & E (\%) & Thickness ( $\mu \mathrm{m})$ & WVP $\times 10^{12}$ \\
\hline $\mathrm{T}-100: 0: 0$ & $1670 \pm 70^{b}$ & $49 \pm 2^{a}$ & $3.2 \pm 0.1^{d}$ & $124 \pm 8^{b}$ & $3.3 \pm 0.3^{d}$ \\
\hline T-100:0:15 & $570 \pm 90^{e}$ & $17 \pm 1^{\mathrm{e}}$ & $57.2 \pm 5.5^{b}$ & $107 \pm 4^{f}$ & $5.4 \pm 0.4^{c}$ \\
\hline T-0:100:0 & $1760 \pm 50^{\mathrm{a}}$ & $33 \pm 2^{b}$ & $2.6 \pm 0.3^{\mathrm{de}}$ & $131 \pm 8^{a}$ & $1.2 \pm 0.4^{e}$ \\
\hline T-0:100:15 & $1300 \pm 40^{d}$ & $28 \pm 2^{c}$ & $3.7 \pm 0.4^{d}$ & $109 \pm 7^{f}$ & $3.6 \pm 1.4^{d}$ \\
\hline$T-65: 35: 0$ & $1490 \pm 40^{c}$ & $32 \pm 1^{b}$ & $2.2 \pm 0.1^{\mathrm{de}}$ & $120 \pm 5^{d}$ & $1.8 \pm 0.1^{\mathrm{e}}$ \\
\hline T-65:35:15 & $510 \pm 40^{\mathrm{ef}}$ & $4 \pm 1^{g}$ & $0.8 \pm 0.3^{e}$ & $124 \pm 8^{b}$ & $9.1 \pm 1.8^{b}$ \\
\hline$T-75: 25: 0$ & $1470 \pm 30^{c}$ & $31 \pm 2^{b}$ & $2.2 \pm 0.2^{\mathrm{de}}$ & $126 \pm 2^{b}$ & $3.1 \pm 0.1^{d}$ \\
\hline T-75:25:15 & $460 \pm 40^{f}$ & $9 \pm 1^{f}$ & $7.1 \pm 1.8^{c}$ & $116 \pm 9^{e}$ & $4.2 \pm 0.3^{\mathrm{cd}}$ \\
\hline C-75:25:15 & $1270 \pm 20^{d}$ & $22 \pm 1^{d}$ & $2.1 \pm 0.2^{\text {de }}$ & $116 \pm 5^{e}$ & $11.9 \pm 0.6^{a}$ \\
\hline$C-75: 25: 15-C A$ & $520 \pm 80^{\text {ef }}$ & $21 \pm 2^{d}$ & $130.1 \pm 1.9^{a}$ & $141 \pm 9^{a}$ & $9.6 \pm 1.2^{b}$ \\
\hline
\end{tabular}

a-f: Different superscripts within the same column indicate significant differences among film samples $(p<$ $0.05)$.

\subsubsection{Thermal behaviour}

The DSC analyses were carried out in order to determine the blending compound effects on the glass transition $\left(T_{g}\right)$, crystallization $\left(T_{c}\right)$ and melting $\left(T_{m}\right)$ processes of the PLA-PHBV-based monolayers. Figure 1 shows the thermograms of the different polyester monolayers obtained by both thermo-compression and casting in the first heating scan. The PLA monolayers, both with and without PEG, only exhibited glass transition, in line with their amorphous nature. However, for the PHBV films, with and without plasticizer, only the melting of the crystalline polymer fraction was observed. There was no PEG crystallization in either the PLA or PHBV films, since the corresponding melting peak, at around $35^{\circ} \mathrm{C}$, was not observed (Requena et al., 2016a). This suggests that PEG was interacting strongly in the matrix, without phase separation, thus inhibiting its crystallization. Likewise, monolayers containing PLA-PHBV blends exhibited PLA glass transition and PHVB melting, although an exothermic crystallization could be observed at around $100{ }^{\circ} \mathrm{C}$ during the heating scan $(\Delta \mathrm{Hc}: 10.5 \pm 0.3$ and $4.7 \pm 0.3 \mathrm{~J} / \mathrm{g}$ PLA for blends containing 25 and $35 \%$ PHBV, respectively). This must be attributed to the PLA recrystallization, as reported by Muller et al. (2017a) and Armentano et al. (2015a,b), since two melting peaks were observed in these cases with peak temperatures near to those of the PLA and PHBV, respectively. This indicates that the PHBV promotes the PLA crystallization 
during heating after its glass transition (Arrieta et al., 2014a; Zhang \& Thomas, 2013), due to its ability to act as a nucleating agent (Furukawa et al., 2005). In the multi-step melting process, the peak at a lower temperature (about $160^{\circ} \mathrm{C}$ ) was attributed to the crystallized PLA ( $\left.\mathrm{T}_{\mathrm{m} \text { PLA }}\right)$, and the peak at a higher temperature (about $170^{\circ} \mathrm{C}$ ), was attributed to the crystallized PHBV ( $T_{m}$ PHBv $)$. This behaviour agrees with the lack of total miscibility between both polymers, as reported by Armentano et al. (2015a,b) and the nucleating effect of PHBV (Furukawa et al., 2005).

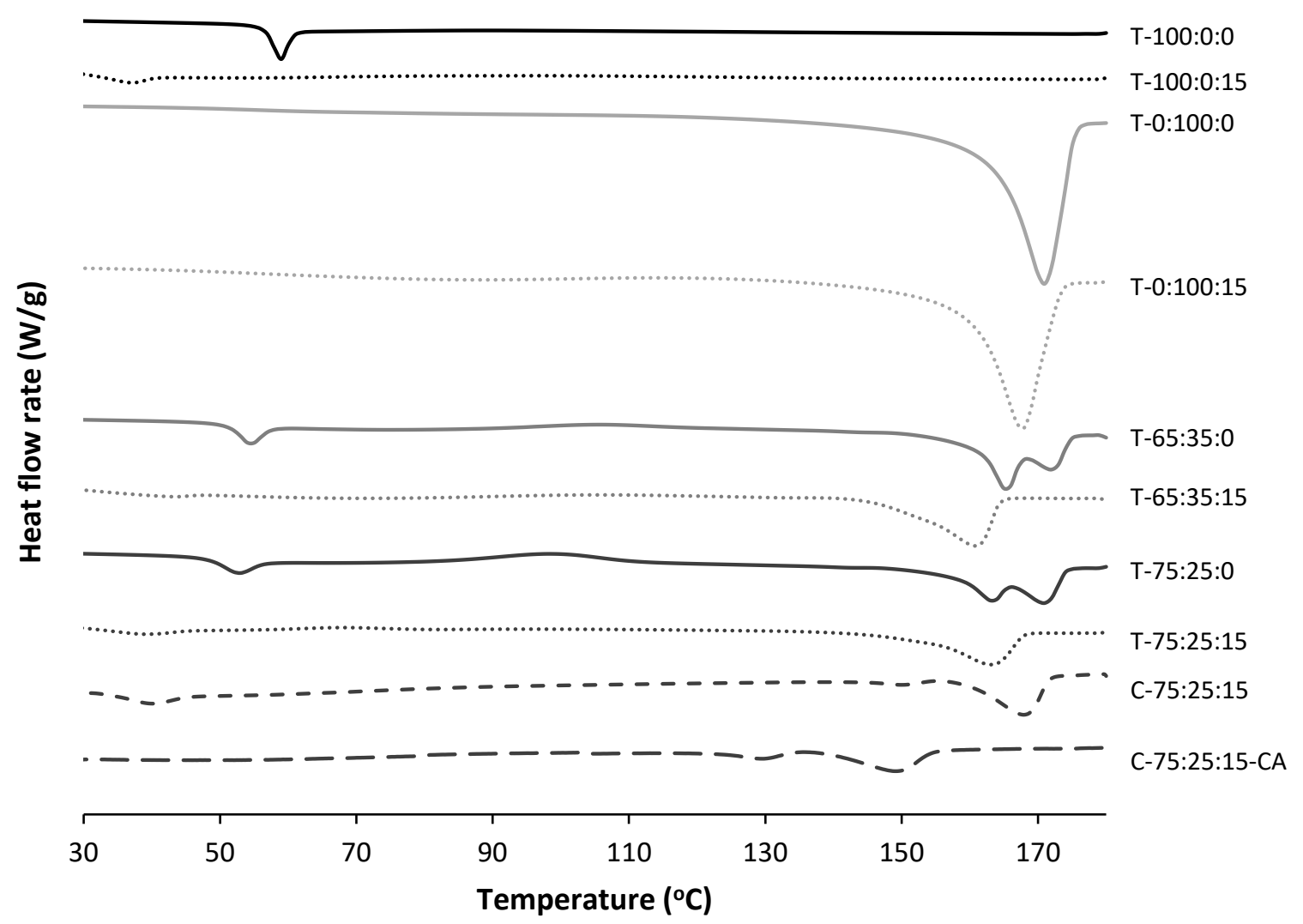

Figure 1. DSC thermograms of the polyester monolayers obtained by thermo-compression $(T)$ and casting $(C)$ at different PLA:PHBV:PEG ratios from the first heating scan.

Table 2 shows the thermal parameters from the first and second heating scans, where the previous thermal history of the samples has been deleted, as well as the crystallization temperatures $\left(T_{c}\right)$ obtained from the cooling step for the different polyester monolayers, obtained by both thermo-compression and casting. During the cooling steps, only one crystallization peak was observed at the applied cooling rate $\left(50^{\circ} \mathrm{C} / \mathrm{min}\right)$. The addition of PEG to the PLA films exerted a strong plasticizing effect, thus bringing down its $\mathrm{T}_{\mathrm{g}}$ from $57^{\circ} \mathrm{C}$ to 39 
${ }^{\circ} \mathrm{C}$, whereas adding it to PHBV films led to less crystalline materials, since the plasticizer decreased the crystallization and melting enthalpies $\left(\Delta \mathrm{H}_{m}\right.$ and $\left.\Delta \mathrm{H}_{c}\right)$, as well as the $T_{m}$ and $T_{c}$ values, as previously reported by Requena, Jímenez, Vargas, \& Chiralt (2016b). The $\mathrm{T}_{\mathrm{g}}$ corresponding to the PHBV amorphous phase, expected at around $-1{ }^{\circ} \mathrm{C}$ according to some authors (Martelli et al. 2012; Ferreira, Zavaglia, \& Duek, 2002), could not be evaluated with the used heating rate as reported (Gerard \& Budtova, 2012). In addition to the nucleating PHBV effect on the PLA crystallization, PHBV led to a significant shift in the $T_{g}$ of PLA to lower temperatures in PLA-PHBV blends, which suggests a partial miscibility of both polyesters. Conversely, PLA inhibited the PHBV crystallization, thus reducing both the $\Delta \mathrm{H}_{\mathrm{m}}$ and $\Delta \mathrm{H}_{\mathrm{c}}$ values of PHBV. No PLA recrystallization, or subsequent separated melting, was observed during the first heating scan when films contained PEG (Figure 1), although the observed melting temperature was lower than that obtained for pure PHBV or PEG-plasticized PHBV, which could indicate the co-crystallization of both polymers to some extent. Both polyester blend films showed lower PLA $T_{g}$ values when they contained PEG, thus demonstrating its plasticizing effect, which was more noticeable for the PLA:PHBV ratio of 65:35. This suggests that a major proportion of PEG was in the PLA phase when the PHBV ratio increased, thus enhancing its plasticization, as could be deduced from the film water vapour barrier properties, commented on above. However, the extensibility of this PEG-plasticized film with a higher proportion of PHBV was much more limited, probably due to the more dispersed phase of PHBV, which promoted film fracture.

The polyester blend monolayer obtained by casting (C-75:25:15) exhibited a similar thermal behaviour to the corresponding thermoprocessed formulation, but no PLA crystallization was clearly detected during the first heating scan. However, two separate melting peaks were observed corresponding to each polymer (Figure 1), which indicates that PLA crystallised to some extent during the casting process, thus giving rise to two different crystalline domains. In this sense, it is remarkable that the crystallized PLA in cast blend films exhibited a lower melting temperature, which suggests greater polymer miscibility when the chains interact in the casting solution. This was also supported by the lower degree of crystallinity of both polymers ( $X_{c}$ values) when blend films were obtained by casting. As expected, $C A$ addition in C-75:25:15 films had a significant plasticizing effect, since a clear reduction in the PLA $T_{g}$ was observed. The plasticizing effect of carvacrol and other essential oil compounds on PLA matrices was also reported by Armentano et al. (2015a) for PLA:PHBV blends with carvacrol, Arrieta, López, Hernández, \& Rayón (2014c) for limonene or by Muller et al. (2017a) for cinnamaldehyde. Supercooling effects (difference between $T_{c}$ and $T_{m}$ ) were noticed in every case. All the polyester blend formulations exhibited lower $T_{c}$ than the neat PHBV formulation and supercooling was about $40{ }^{\circ} \mathrm{C}$ for the neat PHBV and $50{ }^{\circ} \mathrm{C}$ for all the polyester blends. This is coherent with the blending effect which delays and inhibits the crystallization process. 
Table 2. Thermal properties of the polyester monolayers obtained by thermo-compression $(T)$ and casting $(C)$ at different PLA:PHBV:PEG ratios from the first and the second heating scan: melting temperature $\left(T_{m}\right)$, crystallization temperature $\left(T_{c}\right)$, glass transition temperature $\left(T_{g}\right)$, melting enthalpy $\left(\Delta \mathrm{H}_{\mathrm{m}}\right)\left(\mathrm{J} / \mathrm{g}\right.$ polymer), and degree of crystallinity $\left(\mathrm{X}_{\mathrm{c}}\right)$ of each polymer considering the separate integration of each melting endotherm and the polymer mass fraction in the blend. Mean values \pm standard deviation.

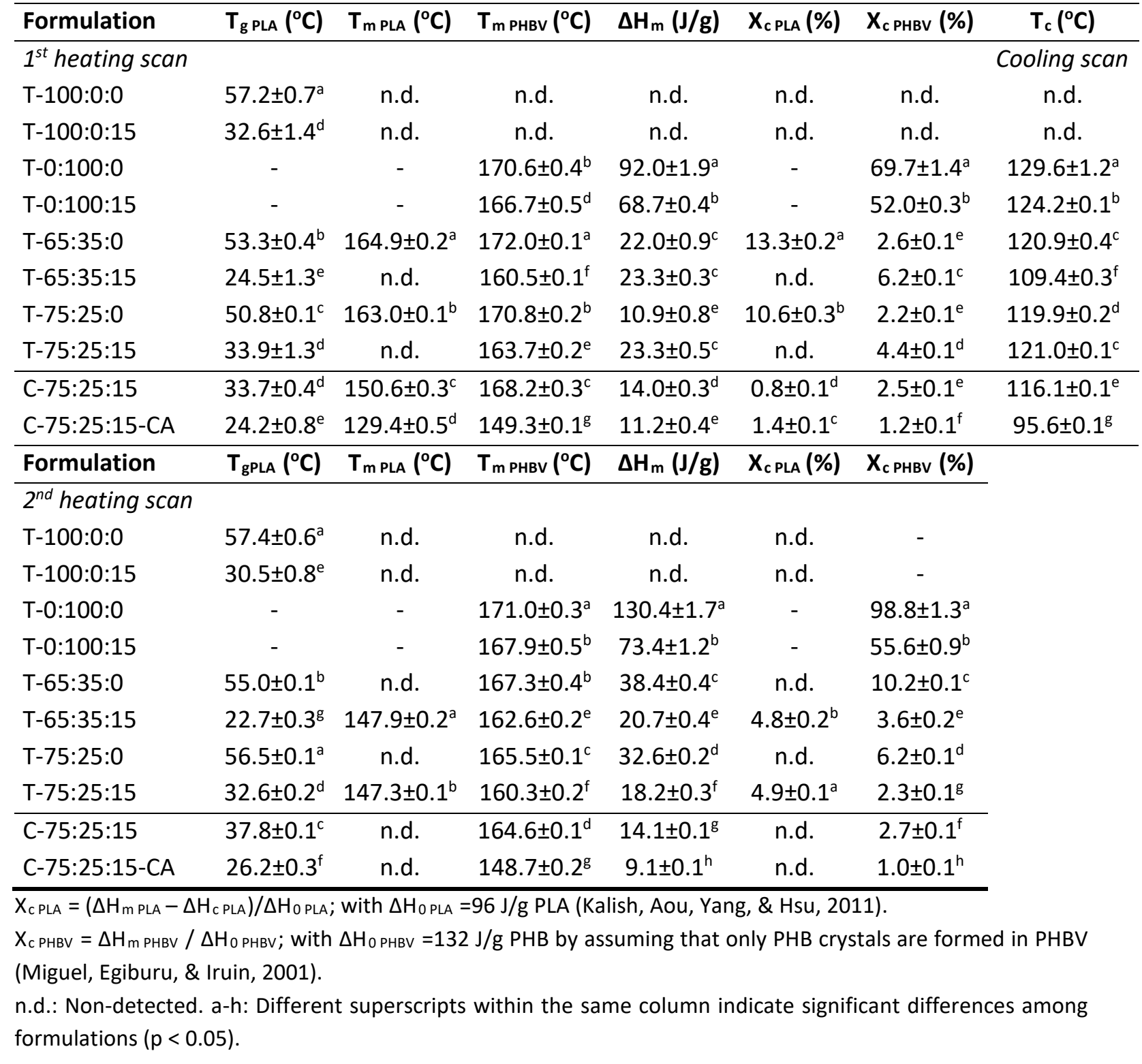

Thermal parameters were also obtained from the second heating scan when the thermal history of the polymers was deleted (Table 2). No PLA crystallization was noticed during the second heating scan for the T-65:35:0 and T-75:25:0 films, unlike that observed during the first heating step, and only plasticized blends obtained by thermo-compression ( $T-65: 35: 15$ and T75:25:15) showed multiple-melting peaks. This is coherent with the influence of thermal history on the polymer crystallization and reflects that, under the thermal conditions of DSC 
analysis, PLA only crystallized when it was plasticised with PEG according to the enhancement of molecular mobility enabling the chain rearrangement in crystalline domains under the more extreme cooling rate $\left(50^{\circ} \mathrm{C} / \mathrm{min}\right)$ applied in DSC analysis.

Table 3 shows the initial degradation temperature ( $T_{\text {onset }}$ ) and the temperature at the maximum degradation rate ( $\left.T_{\text {peak }}\right)$ for the different degradation steps of the polyester monolayers, either thermo-processed or cast. PLA with $\mathrm{T}_{\text {peak PLA }}$ of $329 \pm 2{ }^{\circ} \mathrm{C}$ was more thermostable than PHBV with $\mathrm{T}_{\text {peak PHBV }} 233.2 \pm 0.1^{\circ} \mathrm{C}$, as reported by Ferreira et al. (2002) and Zhao, Cui, Sun, Turng, \& Peng (2013). The plasticizer induced a significant decrease in the PLA's thermal stability, whereas no significant differences were observed in the PHBV-15PEG formulation with respect to the non-plasticized PHBV film. However, as reported by Requena et al. (2016b), PHBV showed a second degradation step at higher temperatures associated with the PEG degradation, which overlapped to a greater extent with the main peak in the plasticized PLA films (Figure 2). This peak was not present in 75:25 PLA-PHBV blends, which suggests a better integration of the plasticizer in this matrix. The PLA-PHBV blend formulations exhibited two different degradation steps corresponding to both polyesters, according to the lack of polymer miscibility. However, the degradation temperatures in the blends were lower than those corresponding to the pure polymer, which suggests their partial miscibility. The addition of both $25 \%$ and $35 \%$ of PHBV provoked a remarkable decrease in the PLA thermal stability, as reported by Ferreira et al. (2002) and Modi, Koelling, \& Vodovotz (2012) for PLAPHBV mixtures. This effect was more marked when blends contained PEG. In contrast, the changes in the temperature of thermal degradation were not significant in the PHBV phase.

The TGA analysis also demonstrated that the film formation process significantly affected the thermal stability of polymers. Casting led to polyester blend monolayers with significantly greater thermal stability than the corresponding thermo-processed formulation, probably due to some thermal degradation that previously took place during thermoprocessing. Cast films containing CA exhibited a progressive weight loss up to about $250{ }^{\circ} \mathrm{C}\left(\mathrm{T}_{\text {peak }}=175{ }^{\circ} \mathrm{C}\right)$, associated with the compound volatilization; however, no remarkable change in the peak temperatures of polymers was observed, while the separate peak associated with PEG was also present in these films, as opposed to that observed for the same formulation obtained by casting. Again, the influence of the processing method on the interactions established between the polymer chains was reflected.

DSC and TGA reveal polymer-phase separation in the polyester blend films, with a partial miscibility, containing different domains richer in PLA or in PHBV. A lower degree of PHBV crystallinity was observed in the blends ( $\mathrm{X}_{\mathrm{C}}$ PHBV $)$, whereas PLA crystallization was observed, despite the amorphous nature of the polymer used, induced by PHBV. In the same sense, Mofokeng \& Luyt (2015) reported PLA-PHBV (70:30) blend micrographs where PHBV appears dispersed in spherical domains in a continuous PLA phase. In contrast, Modi et al. (2011) 
reported a partial compatibility between both polymers in PLA-PHBV blends, associated with the decrease in the PLA $T_{g}$, and no phase separation was observed by SEM.

Table 3. Initial degradation temperature $\left(T_{\text {onset }}\right)$, maximum rate temperature $\left(T_{\text {peak }}\right)$ for the main degradation steps of the polyester monolayers obtained by thermo-compression $(T)$ and casting $(C)$ at different PLA:PHBV:PEG ratios. Mean values \pm standard deviation.

\begin{tabular}{lccc}
\hline Formulation & $\mathbf{T}_{\text {onset }}$ & $\mathbf{T}_{\text {peak PHBV }}$ & $\mathbf{T}_{\text {peak PLA }}$ \\
\hline T-100:0:0 & $309 \pm 2^{\mathrm{a}}$ & - & $329 \pm 2^{\mathrm{a}}$ \\
T-100:0:15 & $281 \pm 4^{\mathrm{b}}$ & - & $314 \pm 3^{\mathrm{c}}$ \\
T-0:100:0 & $233 \pm 1^{\mathrm{d}}$ & $243 \pm 1^{\mathrm{c}}$ & - \\
T-0:100:15 & $229 \pm 3^{\text {de }}$ & $241 \pm 3^{\mathrm{c}}$ & - \\
T-65:35:0 & $226 \pm 7^{\text {def }}$ & $241 \pm 1^{\mathrm{c}}$ & $300 \pm 1^{\mathrm{e}}$ \\
T-65:35:15 & $216 \pm 3^{\mathrm{f}}$ & $239 \pm 4^{\mathrm{c}}$ & $286 \pm 8^{\mathrm{f}}$ \\
T-75:25:0 & $225 \pm 1^{\text {def }}$ & $240 \pm 2^{\mathrm{c}}$ & $306 \pm 3^{\mathrm{d}}$ \\
T-75:25:15 & $219 \pm 7^{\text {ef }}$ & $235 \pm 5^{\mathrm{c}}$ & $297 \pm 1^{\mathrm{e}}$ \\
\hline C-75:25:15 & $236 \pm 1^{\mathrm{c}}$ & $254 \pm 1^{\mathrm{b}}$ & $317 \pm 2^{\mathrm{bc}}$ \\
C-75:25:15-CA & $92 \pm 1^{\mathrm{g}}$ & $257 \pm 1^{\mathrm{a}}$ & $320 \pm 1^{\mathrm{b}}$ \\
\hline
\end{tabular}

a-g: Different superscripts within the same column indicate significant differences among formulations $(p<0.05)$. 
A

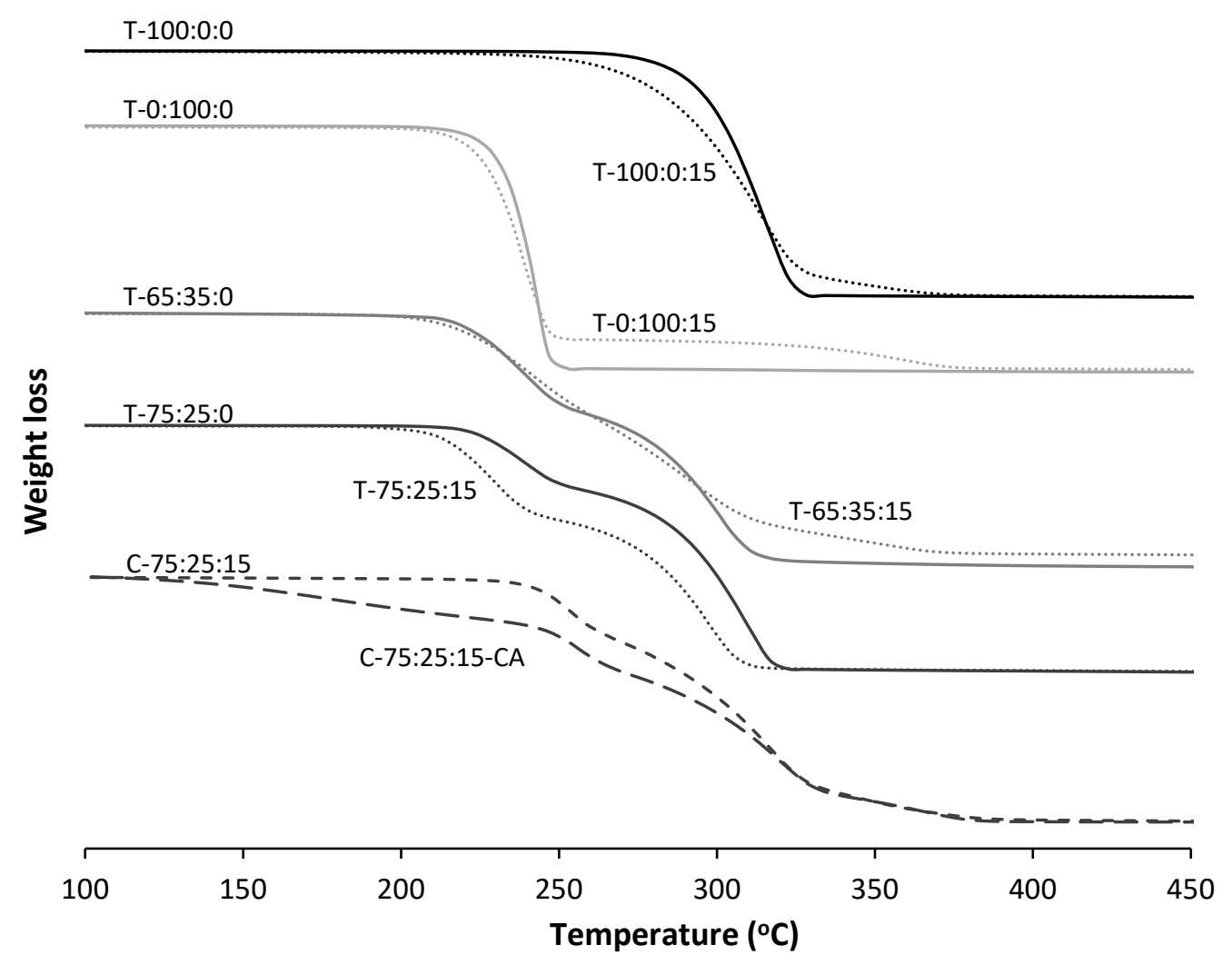

B

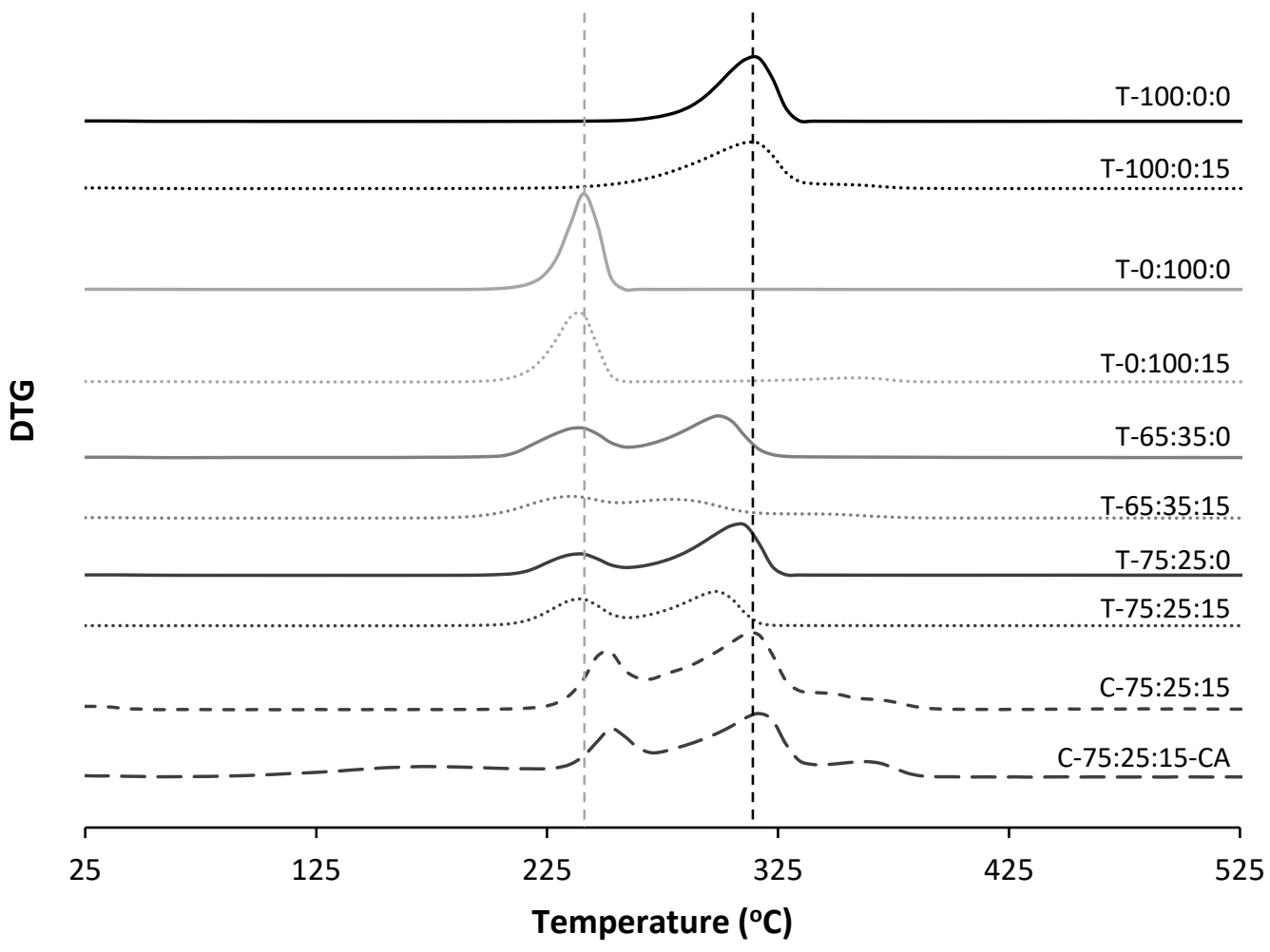

Figure 2. Relative weight loss ( $\mathrm{g} / \mathrm{g}$ sample) curves $(\mathrm{A})$ and derivative curves $(\mathrm{B})$ of the polyester monolayers obtained by thermo-compression $(T)$ and casting $(C)$ at different PLA:PHBV:PEG ratios 


\subsection{Characterization of polyester-starch bilayer films}

\subsection{1. $C A$ retention in bilayer films}

Gravimetric determinations, for the bilayer films with CA sprayed at the interface of thermoprocessed monolayers (TP-CA-S) before and after the second thermo-compression step, showed a mass loss of $33 \pm 3 \%$ due to the partial polymer (mainly starch) radial flow during compression, which was enhanced by the plasticizing effect of the CA. Thus, significant losses of the active compound incorporated in the bilayer could occur during this step. Then, the radial distribution of the CA in both newly-prepared films (D0) and those stored for 6 days (D6) was analysed (Table 4). CA was heterogeneously distributed according to the film radius, the outer area $(7.0-7.5 \mathrm{~cm})$ being the richest in $\mathrm{CA}$ in both the newly prepared and stored films. This confirmed the radial flow of the sprayed active compound during thermo-compression and the CA resistance to the internal diffusion inside the matrix both during the compression step and the film storage. Therefore, and given that the circular crown from 7.0 to $7.5 \mathrm{~cm}$ was discarded for both physical and antimicrobial analysis, the mean CA concentration estimated in the bilayer films was $1.2 \mathrm{~g} \mathrm{CA} / 100 \mathrm{~g}$ of film with a heterogeneous distribution.

Table 4. Carvacrol (CA) distribution in newly-prepared TP-CA-S bilayer films (D0) and after 6 days of storage at $53 \% \mathrm{HR}$ (D6). Mean values \pm standard deviation.

\begin{tabular}{ccc}
\hline Sample radius $(\mathrm{cm})$ & D0 $(\mathrm{g} \mathrm{CA} / 100 \mathrm{~g}$ film$)$ & D6 $(\mathrm{g} \mathrm{CA} / \mathbf{1 0 0} \mathrm{g}$ film $)$ \\
\hline 0 to $3.0 \mathrm{~cm}$ & $0.9 \pm 0.3^{\mathrm{a} 1}$ & $0.7 \pm 0.2^{\mathrm{a} 1}$ \\
3.0 to $5.0 \mathrm{~cm}$ & $0.9 \pm 0.1^{\mathrm{a} 1}$ & $1.4 \pm 0.5^{\mathrm{a} 1}$ \\
5.0 to $7.0 \mathrm{~cm}$ & $1.5 \pm 0.3^{\mathrm{b} 1}$ & $1.2 \pm 0.2^{\mathrm{a} 1}$ \\
7.0 to $7.5 \mathrm{~cm}$ & $3.4 \pm 0.4^{\mathrm{c} 1}$ & $4.2 \pm 1.4^{\mathrm{b} 1}$ \\
\hline
\end{tabular}

a-c: Different superscripts within the same column indicate significant differences among samples $(p<0.05)$. 1-2: Different superscripts within the same line indicate significant differences for the same sample at different storage time $(p<0.05)$.

In cast films (CP(CA)), a homogenous distribution of CA was assumed, since loaded monolayer comes from a solution, and the extraction with methanol gave $19.8 \pm 0.3 \mathrm{~g} \mathrm{CA} / 100 \mathrm{~g}$ monolayer. Likewise, a homogenous distribution was assumed in the $\mathrm{CP}(\mathrm{CA})$-S bilayer where methanol extraction led to $8.2 \pm 0.2 \mathrm{~g} \mathrm{CA} / 100 \mathrm{~g}$ bilayer. Both analysed CA contents were very close to the theoretical values ( $8.3 \mathrm{~g} \mathrm{CA} / \mathrm{g}$ bilayer and $19.9 \mathrm{CA} / 100 \mathrm{~g}$ monolayer), which indicates that no significant losses in CA occurred during the monolayer casting process or bilayer thermocompression. 


\subsubsection{Physical properties}

Both polyester-starch bilayer structures, TP-S and CP-S, were less stiff and resistant than the respective polyester monolayer, with elongation percentages in the range of their corresponding polyester monolayer (Table 5). However, both of them were significantly stiffer and more resistant than the $\mathrm{S}$ monolayer, although much less extensible. The kind of polyester processing affected the tensile behaviour of bilayer films. Thus, cast polyester sheets led to stiffer bilayer films (CP-S and CP(CA)-S), due to their contribution to the overall stiffness of the bilayer film because of the greater resistance and stiffness of cast polyester. Nevertheless, TPCA-S films were significantly more extensible than the rest of the bilayers, probably due to the CA diffusion in both $S$ and $P$ layers from the interface, thus plasticizing them and enhancing their stretchability, especially in the polymeric material near to the interface, where the break mainly occurs.

Coherently with the respective WVP of TP and CP monolayers, TP-S bilayer films exhibited lower WVP values than CP-S. Although the bilayer assemblies always had higher WVP than their corresponding polyester sheets, both CA-free bilayers, TP-S and CP-S, had reduced WVP values (95\% and $89 \%$ reduction, respectively) with respect to the $S$ monolayer. No significant differences were noticed between the WVP values of the CP-S and CP(CA)-S bilayers, whereas spraying CA at the interface significantly increased the WVP of the TP-S bilayers. This proves once again the great impact of the processing method on the functional properties of both mono and bilayer assemblies, in particular, differing interactions of CA with the polymer matrices could be deduced from the contrasting effect it had on the bilayer properties. Similar tendencies were obtained when materials with different water vapour barrier capacity were combined in multilayer structures, such as gluten-PE (Irissin-Mangata, Boutevin, \& Bauduin, 1999), gelatine-PLA (Martucci \& Ruseckaite, 2010) or starch-PCL (Ortega-Toro, Morey, Talens, $\&$ Chiralt, 2015). As concerns the barrier properties, the controlling layer of the mass transport is always the one which offers the highest barrier capacity. The polyester-starch bilayers obtained by the different methods were fully effective at controlling the water vapour permeation, due to the barrier capacity of the polyester sheets, whereas a good oxygen barrier capacity was expected owing to the barrier effect of the $S$ sheet (oxygen permeability: $0.123 \cdot 10^{-12} \mathrm{~cm}^{3} / \mathrm{m}$ s Pa (Muller et al., 2017a)).

Although no significant differences were observed in the monolayer thickness regardless of the processing method, TP-S bilayers were significantly thinner than CP-S, due to the radial flow of both monolayers during the thermo-compression step. This indicates the greater flowability of TP as compared to CP; this was significantly enhanced when CA was sprayed at the interface (TP-CA-S), since all the active compound and polymer monolayers flowed radially because of the pressure action, as previously commented on. 
Table 5. Tensile properties (elastic modulus (EM), tensile strength (TS) and elongation at break (E)), thickness and water vapour permeability (WVP: g/m.s.Pa) of starch monolayer (S) and the different bilayer films with and without carvacrol (CA). TP-S: thermo-processed polyester-starch bilayer; CP-S: cast polyester-starch bilayer. Mean values \pm standard deviation.

\begin{tabular}{lccccc}
\hline Formulation & EM (MPa) & TS (MPa) & E (\%) & Thickness $(\mu \mathrm{m})$ & WVP $\times 10^{12}$ \\
\hline TP-S & $290 \pm 40^{\mathrm{c}}$ & $5.0 \pm 0.7^{\mathrm{b}}$ & $3 \pm 2^{\mathrm{c}}$ & $174 \pm 10^{\mathrm{c}}$ & $14 \pm 2^{\mathrm{c}}$ \\
TP-CA-S & $180 \pm 40^{\mathrm{d}}$ & $5.2 \pm 0.7^{\mathrm{b}}$ & $25 \pm 4^{\mathrm{b}}$ & $161 \pm 12^{\mathrm{cd}}$ & $57 \pm 7^{\mathrm{e}}$ \\
\hline CP-S & $760 \pm 30^{\mathrm{a}}$ & $9.2 \pm 1.3^{\mathrm{a}}$ & $1.4 \pm 0.4^{\mathrm{c}}$ & $251 \pm 7^{\mathrm{a}}$ & $32 \pm 5^{\mathrm{d}}$ \\
CP(CA)-S & $480 \pm 50^{\mathrm{b}}$ & $5.2 \pm 1.6^{\mathrm{b}}$ & $1.2 \pm 0.6^{\mathrm{c}}$ & $216 \pm 16^{\mathrm{b}}$ & $38 \pm 5^{\mathrm{d}}$ \\
\hline $\mathrm{S}$ & $50 \pm 10^{\mathrm{e}}$ & $4.1 \pm 0.3^{\mathrm{b}}$ & $75 \pm 7^{\mathrm{a}}$ & $155 \pm 8^{\mathrm{d}}$ & $283 \pm 6^{\mathrm{f}}$ \\
\hline
\end{tabular}

a-f: Different superscripts within the same column indicate significant differences among formulations $(p<$ $0.05)$.

\subsubsection{Thermal properties}

The TGA analysis of the starch-polyester bilayers revealed thermal behaviour similar to that of the $\mathrm{S}$ monolayer (Figure 3 ), thus showing an initial mass loss associated with the water linked to the starch and the subsequent degradation of the polymeric material. The higher mass fraction of the $\mathrm{S}$ monolayer in the bilayer (61.50\%) and the greater proportion of PLA in the polyester monolayer (63.75 \%) make the PHBV a minor compound (6.54 \% of the bilayer) and its thermal degradation was barely appreciable. Both PLA and starch exhibited similar degradation temperatures, which overlap in the TGA curve. However, the CP-S bilayer films exhibited a shoulder in the DTG curves at higher temperatures attributable to the end of PLA degradation, due to the greater thermal stability of PLA in cast monolayers, as previously commented on. As regards the CA mass loss in starch-polyester systems containing CA (TPCA-S and CP(CA)-S), significant differences could be observed. Despite the fact that the same initial amount of CA was incorporated into the bilayers, CP(CA)-S films exhibited a higher mass loss associated with the CA volatilization than the TP-CA-S, in agreement with the greater retention of the compound during bilayer processing, as previously commented on. The $T_{\text {peak }}$ for CA volatilization in bilayers was $125{ }^{\circ} \mathrm{C}$ compared to $175{ }^{\circ} \mathrm{C}$ found in the CA-loaded P monolayer. This difference could be attributed to the partial diffusion of CA into the starch sheet, which could release CA at lower temperatures, in line with its residual water content (steam drag effect), which was lost up to about $100^{\circ} \mathrm{C}$. 

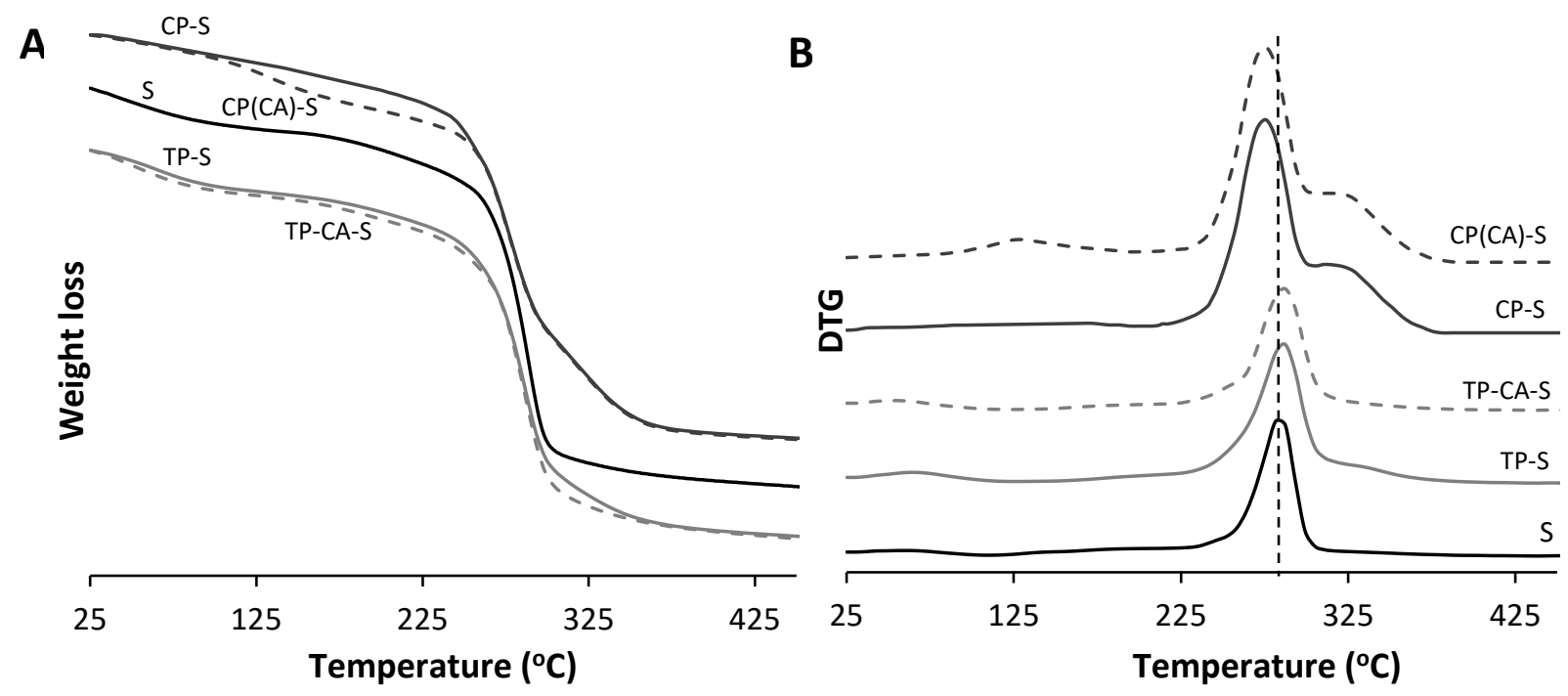

Figure 3. Relative weight loss (g/g sample) curves (A) and derivative curves (B) of the starch monolayer (S) and the different bilayer films with and without carvacrol (CA). TP-S: thermo-compressed polyesterstarch bilayer; CP-S: cast polyester-starch bilayer.

\subsubsection{Release kinetics of CA and antimicrobial activity}

The antimicrobial properties of the different monolayer and bilayer films were analysed against Gram + (L. innocua) and Gram - bacteria (E. coli). No significant microbial growth reductions $(<1 \mathrm{log})$ were observed when CA was sprayed at the interface between thermoprocessed polyester and starch sheets, in contrast with that reported in previous studies using active PHBV bilayers with CA sprayed at the interface (Requena et al., 2016a). Whereas PHBV bilayer films permitted an appropriate CA retention in the films and, therefore, significant antibacterial activity, the TP-CA-S bilayers did not result in an effective assembly from the antimicrobial point of view, due to the insufficient CA retention, associated with the radial flow of the material during thermocompression. The amount of CA released from the film into the culture medium after 6 contact days was estimated from the difference between the CA content in the films after this period and the initial content, both determined by methanol extraction. Thus, the amount of active compound released from the film into the culture medium $\left(9 \cdot 10^{-5} \mathrm{~g} / \mathrm{mL}\right)$ was significantly lower than the MIC of this active compound for $L$. innocua $\left(3.7 \cdot 10^{-4} \mathrm{~g} / \mathrm{mL}\right)$ and E. coli $\left(3.1 \cdot 10^{-4} \mathrm{~g} / \mathrm{mL}\right)$ (Burt, 2004; Ye et al., 2013), which explains the lack of antimicrobial activity of this bilayer assembly.

Figure 4 shows microbial counts of E. coli and L. innocua (CFU/g) for both active films (cast polyester monolayer containing carvacrol: $\mathrm{CP}(\mathrm{CA})$; bilayer film with starch: $\mathrm{CP}(\mathrm{CA})-\mathrm{S})$ and the corresponding control formulations (CP and S) after incubating for 6 days. In the case of the bilayers, two different tests were carried out: the CP or the S layers in contact with the 
inoculated agar plate ( $C P(C A)-S$ and S-CP(CA), respectively). Unlike the results obtained for TPCA-S, when CA was incorporated into the polyester casting solution, the resulting bilayer structure exhibited significant antimicrobial activity, in line with the greater CA retention. This fact reveals the importance of the method used to develop active films. CP control samples had no significant effects on the microbial growth of either bacteria, whereas $\mathrm{S}$ control samples slightly increased both microbial counts, since starch is a potential growth substrate for bacteria. Therefore, the antimicrobial activity observed for both bilayers containing CA must be attributed to its antimicrobial activity and to an adequate release of the active compound into the culture medium. Both $\mathrm{CP}(\mathrm{CA})$ and $\mathrm{CP}(\mathrm{CA})-\mathrm{S}$ films significantly reduced the microbial growth of both bacteria ( 9 and $5 \log$ CFU, respectively), with $E$. coli being more sensitive, as reported by Requena et al. (2016a). Likewise, microbial growth reductions of 5 and 6 log CFU were reported against L. monocytogenes and Salmonella typhimurium, respectively, in chicken samples with cast PLA films containing $25 \%$ of cinnamon (Ahmed, Mulla, \& Arfat, 2016). The bilayers were always less effective than the CA-loaded monolayers (despite having the same CA content per surface unit of film), whose application leads to a total growth inhibition of $E$. coli. The fact that the bilayers are less effective could be attributed to a more limited CA release due to the internal diffusion of the compound into a thicker structure; this represents a longer pathway for molecular diffusion and, therefore, more time needed for a determined amount to be released.

Although no significantly different antimicrobial action was observed between the CA-loaded bilayer for $S$ contact (S-CP(CA)) or CP contact (CP(CA)-S) with the culture medium against $E$. coli, more marked antilisterial effects were observed when the $S$ layer was in contact with the culture media. This could be attributed to the greater water affinity of the S layer, which promoted the swelling of the polymer matrix in contact with the culture medium, which, in turn, accelerated the release of the active compound. The obtained results also proved that the active compound diffused into both $\mathrm{CP}$ and $\mathrm{S}$ sheets, giving rise to antimicrobial activity through both sides of the bilayers. The active amount released and its release rate through each layer will influence how effective each side of the bilayer is at controlling the microbial growth inhibition. Hence, the incorporation of CA dissolved in the polyester casting solution and the formation of an active layer by casting was effective at developing antimicrobial polyester-starch bilayer films, with improved tensile and barrier properties as compared to the neat starch films. 

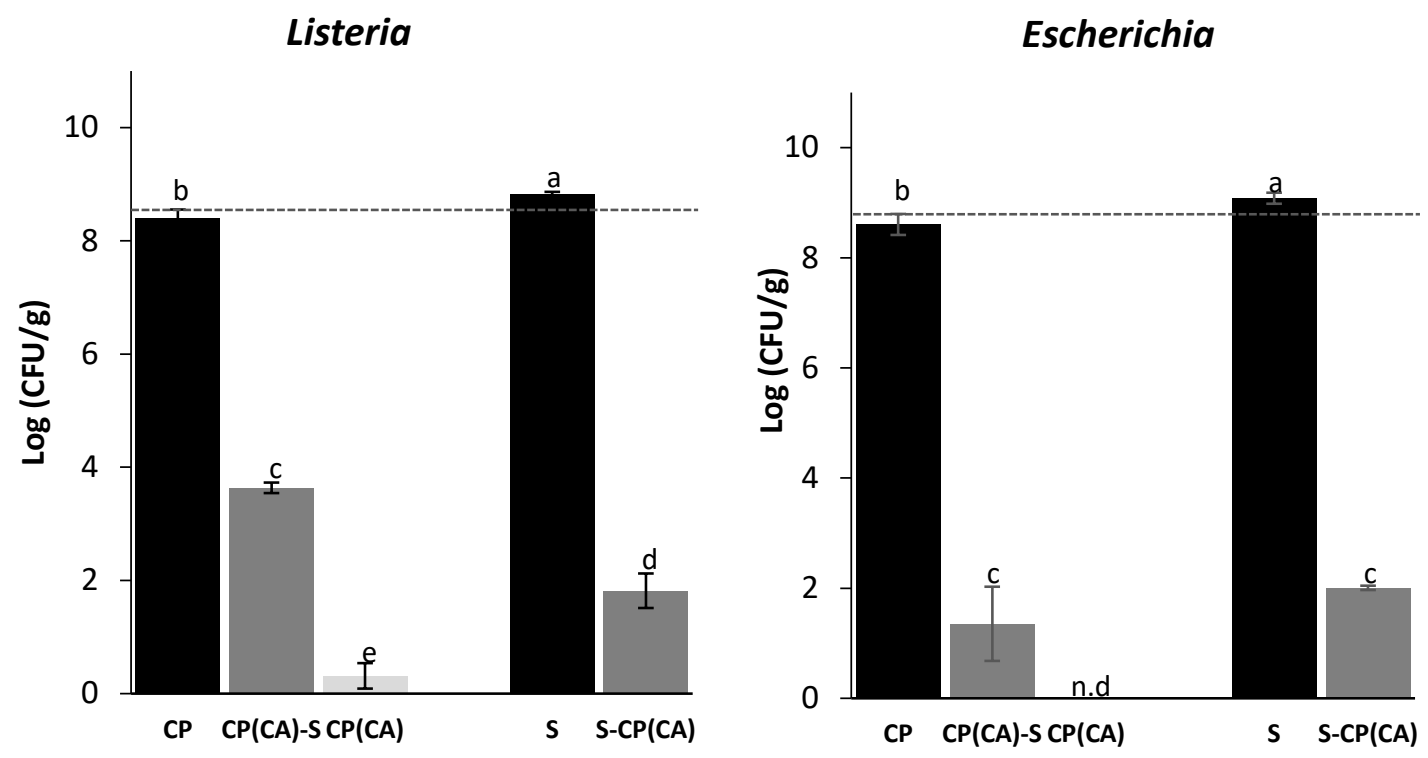

Figure 4. Effect of the cast polyester (CP) and starch (S) monolayers and bilayer structure with CA on the microbial growth of Listeria innocua and Escherichia coli, after incubating for 6 days at $10^{\circ} \mathrm{C}$. Two different tests for the bilayer films: the polyester (CP(CA)-S) and the starch layer (S-CP(CA)) in contact with the inoculated agar plate. The dotted lines show the microbial count of the inoculum after incubating for 6 days at $10{ }^{\circ} \mathrm{C}$. a-d: Different superscripts within the chart indicate significant differences among formulations $(p<0.05)$. n.d: non detected

Based on the above-mentioned results from the CA retention and the resulting antimicrobial activity, CA release kinetic studies were only carried out for the cast polyester monolayer (CP(CA)) and the corresponding bilayer with starch (CP(CA)-S). This was studied in four food simulants with different polarities. Aqueous ( $A: 10 \%$ ethanol $(\mathrm{v} / \mathrm{v})$ and $\mathrm{B}: 3 \%$ acetic acid $(\mathrm{w} / \mathrm{v})$ ) and less polar simulants (D1: $50 \%$ ethanol (v/v) and D2: isooctane) were considered. The CA released into the simulants at different contact times was determined, thus obtaining Figure 5 , which shows the mean values of the amount of released CA referred to the initial amount of CA in the films (points). These data were fitted to Peleg's model (lines) in order to determine the maximum amount of $C A$ delivered at equilibrium $\left(M_{\infty}\right)$, referred per mass unit of the initial film, in each simulant (Table 6). The values of the $1 / k_{1}$ parameter, related to the initial release rate of the compound, are also summarized in Table 6. A good fit of the model was achieved in every case $\left(R_{2}>0.97\right)$. Both Peleg's parameters were significantly affected by the food simulant's polarity and the fastest CA release was achieved in $50 \%$ ethanol (D1 simulant) for both mono and bilayer films, as previously reported by Requena, Vargas, \& Chiralt (2017b) for CA-loaded PHBV bilayers. In contrast, the highest CA amount released at equilibrium $\left(\mathrm{M}_{\infty}\right)$ from the polyester monolayer occurred in the less polar simulants (isooctane or $50 \%$ ethanol), whereas for the bilayer this occurred in the D1 (50\% ethanol) solvent, while the $\mathrm{M}_{\infty}$ value in isooctane was much lower than in $50 \%$ ethanol. This could be related with the role of the 
starch sheet in the bilayer's CA delivery, with the greater affinity with the more polar simulant, which contributed to the swelling of the polymer and faster compound diffusion. In both cases, the amount of CA released at equilibrium was significantly lower in the polar simulants ( $A$ and $B$ ). This agrees with what was previously reported by other authors for the release of essential oil compounds form polymer matrices, which was enhanced as the ethanol ratio in the solvent increased, due to the greater solubility of the active compound in the solvent (Narayanan \& Ramana, 2013; Sánchez-González, Cháfer, González-Martínez, Chiralt, \& Desobry, 2011; Tawakkal, Cran, \& Bigger, 2016). Thus, the maximum expected delivery of CA from the $\mathrm{CP}(\mathrm{CA})$ films would occur in non-polar food, those containing free fats on the surface, whereas the maximum expected released from CP(CA)-S bilayer films would be expected in foodstuffs of intermediate polarity, such as alcoholic beverages or oil-in-water emulsions (sauces, dressings or high fat dairy products). Conversely, a lower CA delivery would be expected when applied to aqueous food packaging.

Two different steps can be noticed as regards the CA release from monolayer films into $3 \%$ acetic acid, probably due to the partial polyester hydrolysis induced by the acid medium during the first contact period which could open the film's microstructure, favouring the subsequent compound release (Figure 5). This pattern was not observed for the CA release from the bilayer film in the same solvent, probably due to the greater contribution of the starch sheet to the CA release in this aqueous solvent. However, this two-step behaviour can also be distinguished for the CA release from bilayer films in $50 \%$ ethanol, which suggests a different release rate of CA from the different polymer sheets in this solvent. This effect would be expected in any case since each polymer exhibited a different chemical affinity with CA and the solvent, establishing a different partition coefficient in each case. However, the experimental points did not permit the decoupling of the CA release from each sheet in every case and the overall behaviour was analysed.

Table 6 also shows the maximum release ratio of $C A\left(M_{\infty} / M_{0}\right)$ from the monolayer and the bilayer structures, defined as the mass of $C A$ released at equilibrium in the simulant related to the initial amount in the film. Thus, practically the entire amount of CA was delivered in isooctane for the monolayer $\mathrm{CP}(\mathrm{CA})$ film $(85.9 \pm 0.5 \%)$ and total delivery was achieved in 50 $\%$ ethanol for the bilayer CP(CA)-S $(112 \pm 14 \%)$. The largest quantity of CA released at equilibrium from the bilayer in the simulant of intermediate polarity coincided with the internal diffusion of CA towards the starch sheet, with weaker interactions with CA, and with less tendency to retain it against delivery into the food simulant in the second step of the release period. Nevertheless, both monolayer and bilayer films showed a maximum release ratio of about $20 \%$ in aqueous systems ( $A$ and $B$ simulants), with no significant differences between them. All these aspects reflect the different solvent interactions with both polymer sheets which, in turn, affect the final partition coefficient of CA between the two polymer layers and the solvent. In this sense, three coupled mechanisms are involved in the release 
process of the active compounds from the films: the solvent diffusion into the polymer matrix, the relaxation of the macromolecular network and the diffusion of the active compound through the relaxed polymer matrix, until the thermodynamic equilibrium between film and food system is reached (Requena et al., 2017a). Different factors influence the compound release, such as the polarity and solubility of the migrant and the polymer-compound affinity, which determine their interactions, and the solubility of the compound in the food system or simulant. Thus, in the case of bilayer films, both polymer matrices (starch and polyester blend layers) are expected to interact differently with both migrant and solvent and so they contribute to differing extents to the release rate and final partition of the compound. Nonetheless, a general tendency was observed in the behaviour of the CA released from bilayer films.

Table 6. Diffusion coefficient (D) values and parameters of Peleg's model for the carvacrol release from the cast polyester monolayer (CP(CA)) and the corresponding bilayer with starch (CP(CA)-S): CA release rate $\left(1 / \mathrm{k}_{1}\right)$; amount of $C A$ released at equilibrium in $100 \mathrm{~mL}$ of simulant $\left(1 / \mathrm{k}_{2}=\mathrm{M}_{\infty}\right)$; maximum release ratio $\left(M_{\infty} / M_{0}\right)$ : mass of $C A$ released at equilibrium in the simulant related to the theoretical incorporated amount. Mean values \pm standard deviation.

\begin{tabular}{|c|c|c|c|c|c|c|}
\hline Simulant & Film & $\begin{array}{c}1 / k_{1} \\
(\mu g / s)\end{array}$ & $\begin{array}{c}1 / k_{2}=M_{\infty} \\
\left(\mathrm{mg} \mathrm{CA} / \mathrm{cm}^{2} \text { film }\right)\end{array}$ & $\begin{array}{c}1 / k_{2}=M_{\infty} \\
(g C A / 100 \text { g film })\end{array}$ & $\begin{array}{c}M_{\infty} / M_{0} \\
(\%)\end{array}$ & $\begin{array}{l}D \times 10^{14} \\
\left(\mathrm{~m}^{2} / \mathrm{s}\right)\end{array}$ \\
\hline \multirow{2}{*}{ 3\% Acetic acid } & $\mathrm{CP}(\mathrm{CA})$ & $1.0 \pm 0.2^{\mathrm{de}}$ & $0.71 \pm 0.07^{d}$ & $5.1 \pm 0.5^{d}$ & $25 \pm 3^{d}$ & $2 \pm 1^{d}$ \\
\hline & $C P(C A)-S$ & $0.6 \pm 0.3^{\mathrm{ef}}$ & $0.32 \pm 0.05^{f}$ & $1.1 \pm 0.2^{\mathrm{g}}$ & $11 \pm 2^{\mathrm{e}}$ & $15 \pm 6^{b}$ \\
\hline \multirow{2}{*}{$10 \%$ Ethanol } & $\mathrm{CP}(\mathrm{CA})$ & $6.0 \pm 2.0^{\mathrm{bcd}}$ & $0.53 \pm 0.03^{e}$ & $3.8 \pm 0.2^{\mathrm{e}}$ & $19 \pm 1^{d}$ & $30 \pm 10^{b}$ \\
\hline & $C P(C A)-S$ & $0.6 \pm 0.1^{f}$ & $0.60 \pm 0.06^{\text {de }}$ & $2.2 \pm 0.2^{f}$ & $22 \pm 2^{d}$ & $5 \pm 1^{c}$ \\
\hline \multirow{2}{*}{$50 \%$ Ethanol } & $\mathrm{CP}(\mathrm{CA})$ & $220 \pm 10^{a}$ & $2.10 \pm 0.20^{\mathrm{ab}}$ & $15.3 \pm 1.3^{b}$ & $76 \pm 7^{c}$ & $280 \pm 30^{\mathrm{a}}$ \\
\hline & $C P(C A)-S$ & $3.2 \pm 0.2^{c}$ & $3.20 \pm 0.40^{\mathrm{a}}$ & $11.3 \pm 1.4^{c}$ & $110 \pm 10^{\mathrm{a}}$ & $5 \pm 1^{c}$ \\
\hline \multirow{2}{*}{ Isooctane } & $\mathrm{CP}(\mathrm{CA})$ & $9.1 \pm 2.0^{\mathrm{b}}$ & $2.41 \pm 0.01^{b}$ & $17.2 \pm 0.1^{\mathrm{a}}$ & $86 \pm 1^{b}$ & $6 \pm 1^{c}$ \\
\hline & $C P(C A)-S$ & $0.6 \pm 0.2^{\mathrm{ef}}$ & $1.87 \pm 0.40^{c}$ & $6.7 \pm 1.4^{d}$ & $70 \pm 10^{c}$ & $2 \pm 1^{d}$ \\
\hline
\end{tabular}

a-f: Different superscripts within the same column indicate significant differences among tests $(p<0.05)$.

No coupling of the polymer relaxation and compound diffusion was reported for similar compounds in different polymer matrices, the diffusion being the controlling mechanism of the active compound release as reported by some authors in the case of limonene in chitosan films (Sánchez-González et al., 2011) or thymol in zein (Del Nobile, Conte, Incoronato, \& Panza, 2008), PLA (Tawakkal et al., 2016) and PBS films (Petchwattana \& Naknaen, 2015). Then, the overall diffusion coefficient (D) of CA in both mono and bilayers was estimated in each simulant. Figure 6 shows the values of $\left(\mathrm{M}_{\mathrm{t}} / \mathrm{M}_{\infty}\right)$ vs. contact time (points) and Fick's model fitted to the experimental data in each simulant (lines). A good fit of the model can be observed in every case (SSE < 0.04 ), as well as the different pattern of the curves depending 
on the simulant and the film. Nevertheless, the two expected steps could be observed for the CA delivery from CP(CA)-S bilayer films into $10 \%$ and $50 \%$ ethanol, due to the different contribution of both layers in the release process throughout the contact time (Figure 6), depending on the relative affinity of the matrix with the solvent and diffusing compound. This agrees with the different antibacterial activity observed for the bilayer in contact with the culture medium in its different layer, whose CA release differed depending on the polymer in contact with the culture medium.

The CA D values of the monolayer in the different simulants are in line with the release rates estimated from Peleg's model; the highest D values were obtained in $50 \%$ ethanol (Table 6). Similar results have been reported by Tawakkal et al. (2016) and Petchwattana \& Naknaen (2015) for thymol diffusion from PLA and PBS films, respectively. In contrast, the values of the CA diffusion were lower in the bilayers in every simulant except for $3 \%$ acetic acid, where it reached the highest value. The internal diffusion of CA in the bilayer assembly and the establishment of different interactions with both polymer sheets hid the compound's ability to diffuse towards the simulant, which is also dependent on the respective polymer relaxation with the solvent diffusion.

From the release kinetics, and assuming a bulk diffusion into the culture medium, which could be simulated by simulant $A$ ( $10 \%$ ethanol), the amount of CA released after 6 contact days ( $\mathrm{M}_{\infty}$, since the equilibrium has already been reached at that time) from the monolayer and bilayer films could be estimated. These amounts were $1.2 \cdot 10^{-3} \mathrm{~g} / \mathrm{mL}$ and $1.3 \cdot 10^{-3} \mathrm{~g} / \mathrm{mL}$ for mono and bilayer, respectively, which are significantly higher than the MIC of this active compound against L. innocua $\left(3.7 \cdot 10^{-4} \mathrm{~g} / \mathrm{mL}\right.$ ) and E. coli $\left(3.1 \cdot 10^{-4} \mathrm{~g} / \mathrm{mL}\right.$ ) (Burt, 2004; Ye et al., 2013), coherent with the observed antibacterial effect. 


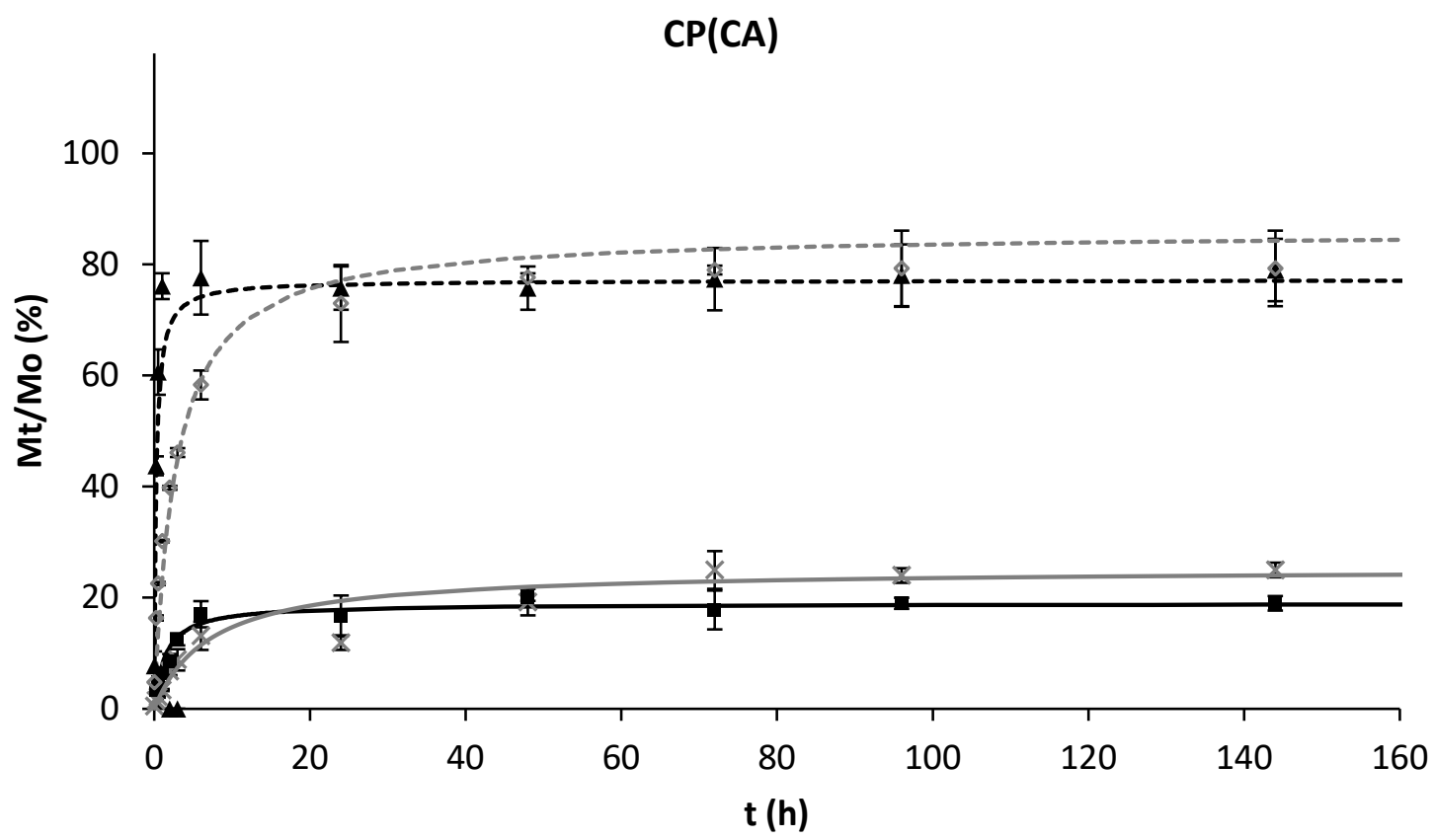

CP(CA)-S

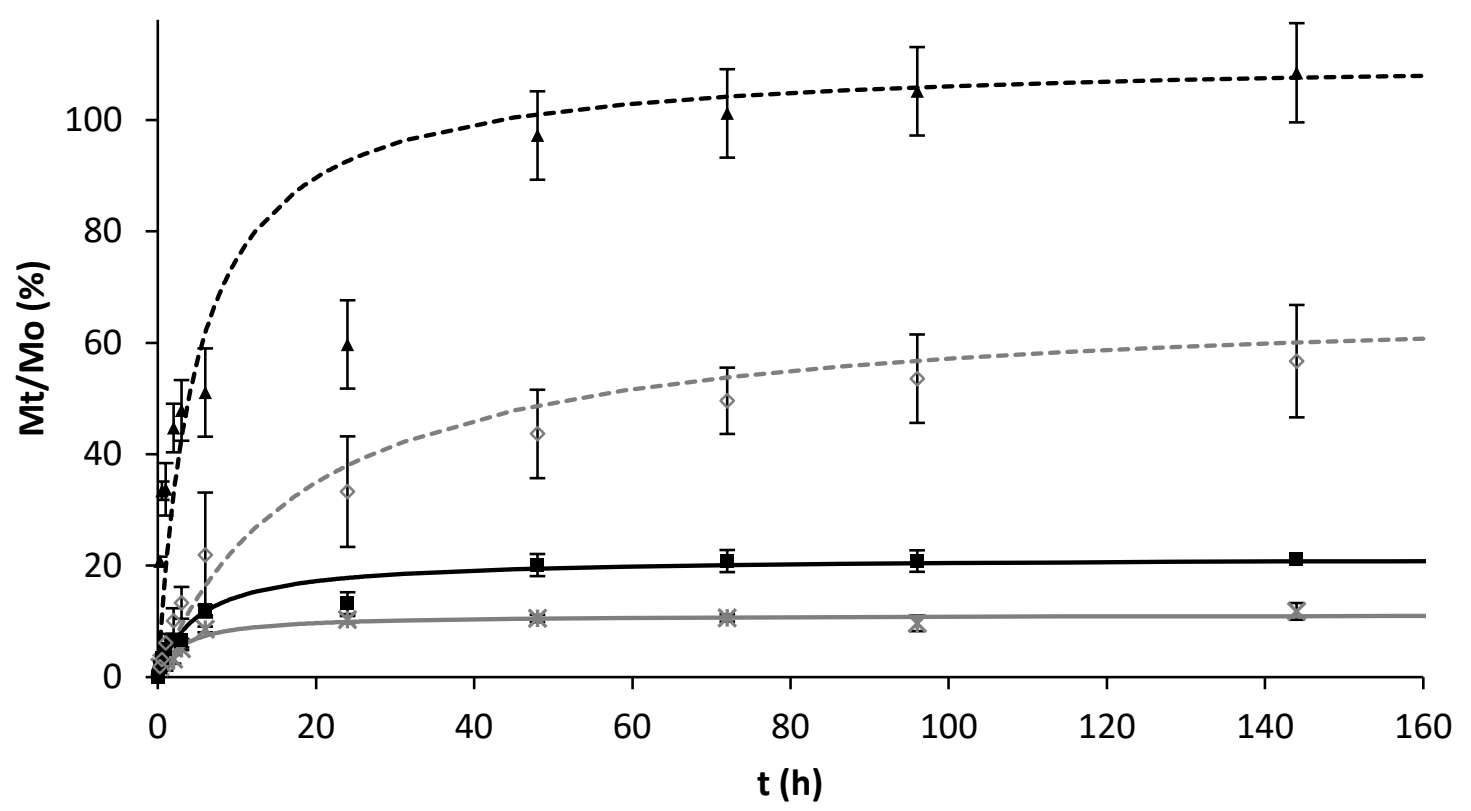

$10 \%$ Ethanol

$3 \%$ Acetic acid

-----50\% Ethanol

Isooctane

Figure 5. The ratio of the active compound delivered from the cast polyester monolayer $(\mathrm{CP}(\mathrm{CA}))$ and the corresponding bilayer with starch (CP(CA)-S) in each simulant, with respect to the theoretical initial amount, as a function of the contact time (points) and Peleg's fitted model (lines). 

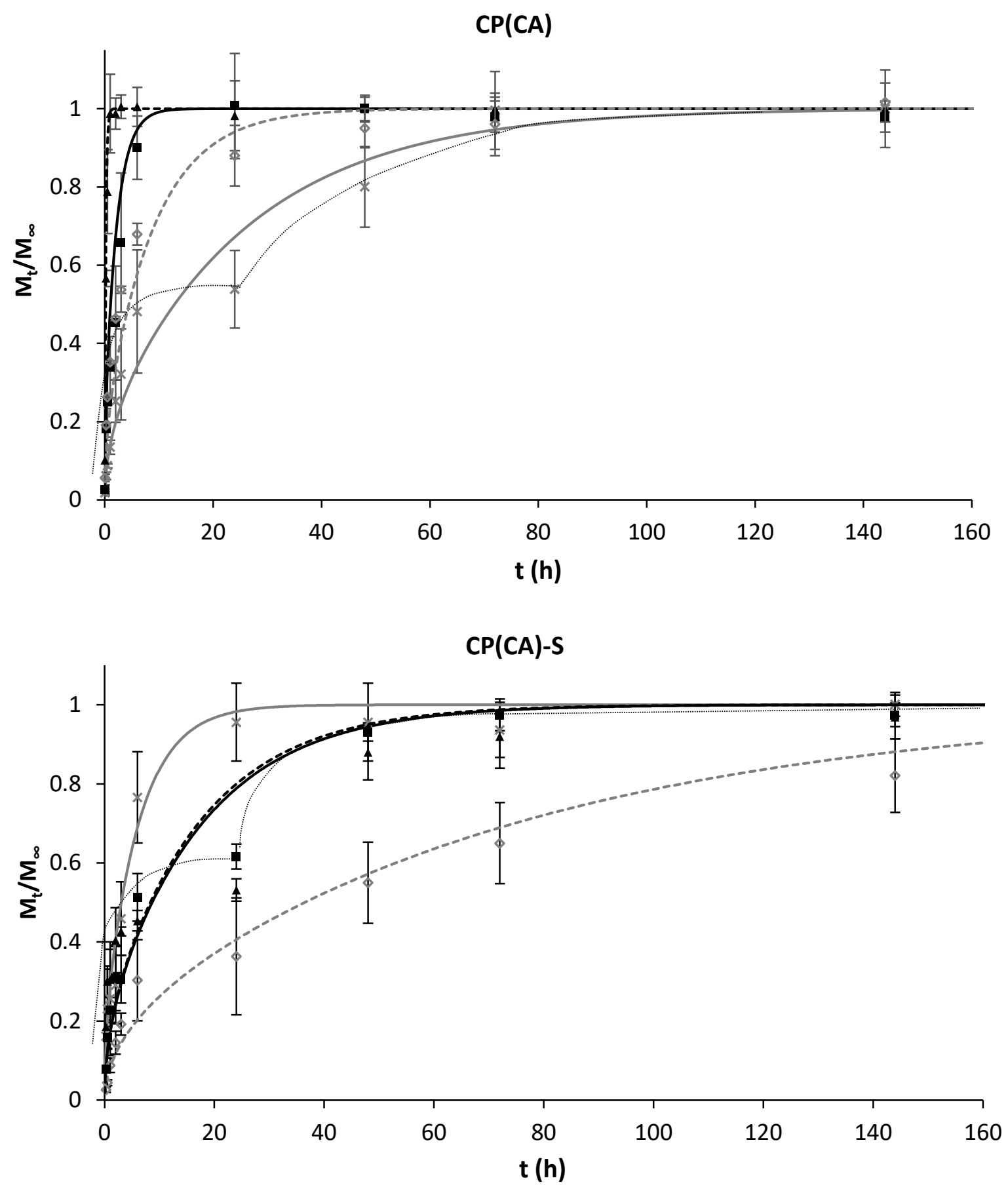

- 10\% Ethanol —3\% Acetic acid -----50\% Ethanol ------Isooctane

Figure 6. Ratio of the active compound delivered from the cast polyester monolayer ( $C P(C A))$ and the corresponding bilayer with starch (CP(CA)-S) in each simulant, with respect to the equilibrium value, as a function of contact time (points) and Fick's fitted model (lines). The thin grey curve shows the actual two-step tendency observed for the CP(CA) monolayer in 3\% acetic acid and the CP(A)-S bilayer in 10 or $50 \%$ ethanol. 


\section{CONCLUSION}

The properties of thermoprocessed PLA-PHBV blends were affected by the polymer proportion and the presence of PEG as plasticizer. The PLA glass transition and crystallinity of both polymers changed in the different blends, indicating the presence of different domains richer in either PLA or PHBV, with limited partial miscibility, all of which is affected by the different PEG plasticization of such domains. The 75:25 PLA-PHBV formulation with PEG exhibited the best overall properties in terms of extensibility and water vapour permeability and, thus, was used to be the carrier of carvacrol by casting. This formulation was stiffer and less stretchable when obtained by casting, although carvacrol incorporation into cast films greatly enhanced their extensibility, reducing the stiffness and water vapour permeability. The incorporation of carvacrol by spraying between the polyester and starch sheets was not effective at retaining the compound in the bilayers, mainly due to the radial flow promoted by the compound (especially in the starch layer) during thermocompression, which dragged a large proportion of the active to the film's edge. In contrast, the incorporation of carvacrol into cast polyester blend films, and the subsequent formation of bilayers with the starch sheets by means of thermo-compression, was highly effective at providing the practically total retention of carvacrol in both mono and bilayers. These active bilayers not only exhibited highly improved tensile and water vapour barrier capacity with respect to the starch monolayer ( $87 \%$ reduction in WVP, $840 \%$ increase in elastic modulus) but also antibacterial properties against $L$. innocua and E. coli from both contact sides (polyester or starch) of the bilayer, depending on the internal diffusion of carvacrol through the bilayer and the adequate release of the compound into the culture medium. Then, cast PLA-PHBV blend films can be used as carriers of carvacrol for the purposes of obtaining well-adhered bilayers films with starch by means of thermocompression, with adequate tensile and barrier properties and antibacterial activity due to the good retention of the active during the film processing and its adequate release into food systems of differing polarities. 


\section{REFERENCES}

Acosta, S., Jiménez, A., Cháfer, M., González-Martínez, C., \& Chiralt, A. (2015). Physical properties and stability of starch-gelatin based films as affected by the addition of esters of fatty acids. Food Hydrocolloids, 49, 135-143.

Ahmed, J., Mulla, M. Z., \& Arfat, Y. A. (2016). Thermo-mechanical, structural characterization and antibacterial performance of solvent casted polylactide/cinnamon oil composite films. Food Control, 69, 196-204.

Armentano, I., Fortunati, E., Burgos, N., Dominici, F., Luzi, F., Fiori, S., Jiménez, A., Yoon, K., Ahn, J., Kang, S., \& Kenny, J. M. (2015a). Bio-based PLA_PHB plasticized blend films: Processing and structural characterization. LWT-Food Science and Technology, 64(2), 980-988.

Armentano, I., Fortunati, E., Burgos, N., Dominici, F., Luzi, F., Fiori, S., Jiménez, A., Yoon, K., Ahn, J., Kang, S., \& Kenny, J. M. (2015b). Processing and characterization of plasticized PLA/PHB blends for biodegradable multiphase systems. Express Polymer Letters, 9(7).

Arrieta, M. P., López, J., Ferrándiz, S., \& Peltzer, M. A. (2013). Characterization of PLA-limonene blends for food packaging applications. Polymer Testing, 32(4), 760-768.

Arrieta, M. P., Samper, M. D., López, J., \& Jiménez, A. (2014a). Combined effect of poly (hydroxybutyrate) and plasticizers on polylactic acid properties for film intended for food packaging. Journal of Polymers and the Environment, 22(4), 460-470.

Arrieta, M. P., Fortunati, E., Dominici, F., Rayón, E., López, J., \& Kenny, J. M. (2014b). PLA-PHB/cellulose based films: Mechanical, barrier and disintegration properties. Polymer Degradation and Stability, 107, 139-149.

Arrieta, M. P., López, J., Hernández, A., \& Rayón, E. (2014c). Ternary PLA-PHB-Limonene blends intended for biodegradable food packaging applications. European Polymer Journal, 50, 255-270.

Auras, R., Harte, B., \& Selke, S. (2004). An overview of polylactides as packaging materials. Macromolecular Bioscience, 4(9), 835-864.

Avérous, L. (2004). Biodegradable multiphase systems based on plasticized starch: a review. Journal of Macromolecular Science, Part C: Polymer Reviews, 44(3), 231-274.

Babili, F. E., Bouajila, J., Souchard, J. P., Bertrand, C., Bellvert, F., Fouraste, I., Moulis, C., \& Valentin, A. (2011). Oregano: chemical analysis and evaluation of its antimalarial, antioxidant, and cytotoxic activities. Journal of Food Science, 76(3).

Benavides, S., Villalobos-Carvajal, R., \& Reyes, J. E. (2012). Physical, mechanical and antibacterial properties of alginate film: Effect of the crosslinking degree and oregano essential oil concentration. Journal of Food Engineering, 110(2), 232-239.

Burt, S. (2004). Essential oils: their antibacterial properties and potential applications in foods-a review. International Journal of Food Microbiology, 94(3), 223-253. 
Byun, Y., Kim, Y. T., \& Whiteside, S. (2010). Characterization of an antioxidant polylactic acid (PLA) film prepared with $\alpha$-tocopherol, BHT and polyethylene glycol using film cast extruder. Journal of Food Engineering, 100(2), 239-244.

Chen, G. X., Hao, G. J., Guo, T. Y., Song, M. D., \& Zhang, B. H. (2002). Structure and mechanical properties of poly (3-hydroxybutyrate-co-3-hydroxyvalerate)(PHBV)/clay nanocomposites. Journal of Materials Science Letters, 21(20), 1587-1589.

Corre, Y. M., Bruzaud, S., Audic, J. L., \& Grohens, Y. (2012). Morphology and functional properties of commercial polyhydroxyalkanoates: a comprehensive and comparative study. Polymer Testing, 31(2), 226-235.

Courgneau, C., Domenek, S., Lebossé, R., Guinault, A., Avérous, L., \& Ducruet, V. (2012). Effect of crystallization on barrier properties of formulated polylactide. Polymer International, 61(2), 180-189.

Crank, J. (1975). Diffusion in a cylinder. The Mathematics of Diffusion, 69-88.

Del Nobile, M. A., Conte, A., Incoronato, A. L., \& Panza, O. (2008). Antimicrobial efficacy and release kinetics of thymol from zein films. Journal of Food Engineering, 89(1), 57-63.

Fakhouri, F. M., Costa, D., Yamashita, F., Martelli, S. M., Jesus, R. C., Alganer, K., Collares-Queiroz, F. P., \& Innocentini-Mei, L. H. (2013). Comparative study of processing methods for starch/gelatin films. Carbohydrate Polymers, 95(2), 681-689.

Ferreira, B. M. P., Zavaglia, C. A. C., \& Duek, E. A. R. (2002). Films of PLLA/PHBV: thermal, morphological, and mechanical characterization. Journal of Applied Polymer Science, 86(11), 28982906.

Fratianni, F., De Martino, L., Melone, A., De Feo, V., Coppola, R., \& Nazzaro, F. (2010). Preservation of chicken breast meat treated with thyme and balm essential oils. Journal of Food Science, 75(8).

Friedman, M., Henika, P. R., Levin, C. E., \& Mandrell, R. E. (2004). Antibacterial activities of plant essential oils and their components against Escherichia coli O157: H7 and Salmonella enterica in apple juice. Journal of Agricultural and Food Chemistry, 52(19), 6042-6048.

Furukawa, T., Sato, H., Murakami, R., Zhang, J., Duan, Y. X., Noda, I., Ochiai, S., \& Ozaki, Y. (2005). Structure, dispersibility, and crystallinity of poly (hydroxybutyrate)/poly (L-lactic acid) blends studied by FT-IR microspectroscopy and differential scanning calorimetry. Macromolecules, 38(15), 6445-6454.

Gerard, T., \& Budtova, T. (2012). Morphology and molten-state rheology of polylactide and polyhydroxyalkanoate blends. European Polymer Journal, 48(6), 1110-1117.

Gérard, T., Budtova, T., Podshivalov, A., \& Bronnikov, S. (2014). Polylactide/poly (hydroxybutyrate-cohydroxyvalerate) blends: Morphology and mechanical properties. Express Polymer Letters, 8(8), 609617.

González, A., \& Igarzabal, C. I. A. (2013). Soy protein-Poly (lactic acid) bilayer films as biodegradable material for active food packaging. Food Hydrocolloids, 33(2), 289-296. 
Irissin-Mangata, J., Boutevin, B., \& Bauduin, G. (1999). Bilayer films composed of wheat gluten and functionalized polyethylene: Permeability and other physical properties. Polymer Bulletin, 43(4-5), 441-448.

Jost, V., \& Kopitzky, R. (2015). Blending of polyhydroxybutyrate-co-valerate with polylactic acid for packaging applications-reflections on miscibility and effects on the mechanical and barrier properties. Chemical and Biochemical Engineering Quarterly, 29(2), 221-246.

Kalish, J. P., Aou, K., Yang, X., \& Hsu, S. L. (2011). Spectroscopic and thermal analyses of $\alpha^{\prime}$ and $\alpha$ crystalline forms of poly (I-lactic acid). Polymer, 52(3), 814-821.

Lim, G. O., Hong, Y. H., \& Song, K. B. (2010). Application of Gelidium corneum edible films containing carvacrol for ham packages. Journal of Food Science, 75(1).

Marais, A., Kochumalayil, J. J., Nilsson, C., Fogelström, L., \& Gamstedt, E. K. (2012). Toward an alternative compatibilizer for PLA/cellulose composites: Grafting of xyloglucan with PLA. Carbohydrate Polymers, 89(4), 1038-1043.

Martelli, S. M., Sabirova, J., Fakhoury, F. M., Dyzma, A., De Meyer, B., \& Soetaert, W. (2012). Obtention and characterization of poly (3-hydroxybutyricacid-co-hydroxyvaleric acid)/mcl-PHA based blends. LWT-Food Science and Technology, 47(2), 386-392.

Martucci, J. F., \& Ruseckaite, R. A. (2010). Three-layer sheets based on gelatin and poly (lactic acid), part 1: Preparation and properties. Journal of Applied Polymer Science, 118(5), 3102-3110.

Miguel, O., Egiburu, J. L., \& Iruin, J. J. (2001). Blends of bacterial poly (3-hydroxybutyrate) with synthetic poly (3-hydroxybutyrate) and poly (epichlorohydrin): transport properties of carbon dioxide and water vapour. Polymer, 42(3), 953-962.

Modi, S., Koelling, K., \& Vodovotz, Y. (2012). Miscibility of poly (3-hydroxybutyrate-co-3hydroxyvalerate) with high molecular weight poly (lactic acid) blends determined by thermal analysis. Journal of Applied Polymer Science, 124(4), 3074-3081.

Mofokeng, J. P., \& Luyt, A. S. (2015). Dynamic mechanical properties of PLA/PHBV, PLA/PCL, PHBV/PCL blends and their nanocomposites with $\mathrm{TiO}_{2}$ as nanofiller. Thermochimica Acta, 613, 41-53.

Moreno, O., Díaz, R., Atarés, L., \& Chiralt, A. (2016). Influence of the processing method and antimicrobial agents on properties of starch-gelatin biodegradable films. Polymer International, 65(8), 905-914.

Muller, J., González-Martínez, C., \& Chiralt, A. (2017a). Poly (lactic) acid (PLA) and starch bilayer films, containing cinnamaldehyde, obtained by compression moulding. European Polymer Journal, 95, 56-70.

Muller, J., González-Martínez, C., \& Chiralt, A. (2017b). Combination of poly (lactic) acid and starch for biodegradable food packaging. Materials, 10(8), 952.

Narayanan, A., \& Ramana, K. V. (2013). Synergized antimicrobial activity of eugenol incorporated polyhydroxybutyrate films against food spoilage microorganisms in conjunction with pediocin. Applied Biochemistry and Biotechnology, 170(6), 1379-1388. 
Nilsuwan, K., Benjakul, S., \& Prodpran, T. (2017). Physical/thermal properties and heat seal ability of bilayer films based on fish gelatin and poly (lactic acid). Food Hydrocolloids, 77, 248-256.

Ortega-Toro, R., Morey, I., Talens, P., \& Chiralt, A. (2015). Active bilayer films of thermoplastic starch and polycaprolactone obtained by compression molding. Carbohydrate Polymers, 127, 282-290.

Ortega-Toro, R., Muñoz, A., Talens, P., \& Chiralt, A. (2016). Improvement of properties of glycerol plasticized starch films by blending with a low ratio of polycaprolactone and/or polyethylene glycol. Food Hydrocolloids, 56, 9-19.

Peleg, M. (1988). An empirical model for the description of moisture sorption curves. Journal of Food science, 53(4), 1216-1217.

Petchwattana, N., \& Naknaen, P. (2015). Utilization of thymol as an antimicrobial agent for biodegradable poly (butylene succinate). Materials Chemistry and Physics, 163, 369-375.

Ramos, M., Jiménez, A., Peltzer, M., \& Garrigós, M. C. (2012). Characterization and antimicrobial activity studies of polypropylene films with carvacrol and thymol for active packaging. Journal of Food Engineering, 109(3), 513-519.

Requena, R., Jiménez, A., Vargas, M., \& Chiralt, A. (2016a). Poly [(3-hydroxybutyrate)-co-(3hydroxyvalerate)] active bilayer films obtained by compression moulding and applying essential oils at the interface. Polymer International, 65(8), 883-891.

Requena, R., Jiménez, A., Vargas, M., \& Chiralt, A. (2016b). Effect of plasticizers on thermal and physical properties of compression-moulded poly [(3-hydroxybutyrate)-co-(3-hydroxyvalerate)] films. Polymer Testing, 56, 45-53.

Requena, R., Vargas, M., Atarés, L., \& Chiralt, A. (2017a). Biopolymers carrying essential oils, or their compounds, for food antimicrobial packaging. Current Organic Chemistry, 21, 1-16.

Requena, R., Vargas, M., \& Chiralt, A. (2017b). Release kinetics of carvacrol and eugenol from poly (hydroxybutyrate-co-hydroxyvalerate) (PHBV) films for food packaging applications. European Polymer Journal, 92, 185-193.

Rojas-Graü, M. A., Avena-Bustillos, R. J., Olsen, C., Friedman, M., Henika, P. R., Martín-Belloso, O., Pan, Z., \& McHugh, T. H. (2007). Effects of plant essential oils and oil compounds on mechanical, barrier and antimicrobial properties of alginate-apple puree edible films. Journal of Food Engineering, 81(3), 634641.

Sánchez-González, L., Cháfer, M., González-Martínez, C., Chiralt, A., \& Desobry, S. (2011). Study of the release of limonene present in chitosan films enriched with bergamot oil in food simulants. Journal of Food Engineering, 105(1), 138-143.

Sanyang, M. L., Sapuan, S. M., Jawaid, M., Ishak, M. R., \& Sahari, J. (2016). Development and characterization of sugar palm starch and poly (lactic acid) bilayer films. Carbohydrate Polymers, 146, 36-45. 
Savenkova, L., Gercberga, Z., Bibers, I., \& Kalnin, M. (2000). Effect of 3-hydroxy valerate content on some physical and mechanical properties of polyhydroxyalkanoates produced by Azotobacter chroococcum. Process Biochemistry, 36(5), 445-450.

Scaffaro, R., Sutera, F., \& Botta, L. (2018). Biopolymeric bilayer films produced by co-extrusion film blowing. Polymer Testing, 65, 35-43.

Sheth, M., Kumar, R. A., Davé, V., Gross, R. A., \& McCarthy, S. P. (1997). Biodegradable polymer blends of poly (lactic acid) and poly (ethylene glycol). Journal of Applied Polymer Science, 66(8), 1495-1505.

Siracusa, V., Rocculi, P., Romani, S., \& Dalla Rosa, M. (2008). Biodegradable polymers for food packaging: a review. Trends in Food Science \& Technology, 19(12), 634-643.

Souza, A. C., Goto, G. E. O., Mainardi, J. A., Coelho, A. C. V., \& Tadini, C. C. (2013). Cassava starch composite films incorporated with cinnamon essential oil: Antimicrobial activity, microstructure, mechanical and barrier properties. LWT-Food Science and Technology, 54(2), 346-352.

Tawakkal, I. S., Cran, M. J., \& Bigger, S. W. (2016). Release of thymol from poly (lactic acid)-based antimicrobial films containing kenaf fibres as natural filler. LWT-Food Science and Technology, 66, 629637.

Versino, F., López, O. V., \& García, M. A. (2015). Sustainable use of cassava (Manihot esculenta) roots as raw material for biocomposites development. Industrial Crops and Products, 65, 79-89.

Woranuch, S., \& Yoksan, R. (2013). Eugenol-loaded chitosan nanoparticles: II. Application in bio-based plastics for active packaging. Carbohydrate Polymers, 96(2), 586-592.

Xu, J., Zhou, F., Ji, B. P., Pei, R. S., \& Xu, N. (2008). The antibacterial mechanism of carvacrol and thymol against Escherichia coli. Letters in Applied Microbiology, 47(3), 174-179.

Ye, H., Shen, S., Xu, J., Lin, S., Yuan, Y., \& Jones, G. S. (2013). Synergistic interactions of cinnamaldehyde in combination with carvacrol against food-borne bacteria. Food Control, 34(2), 619-623.

Zhang, M., \& Thomas, N. L. (2011). Blending polylactic acid with polyhydroxybutyrate: the effect on thermal, mechanical, and biodegradation properties. Advances in Polymer Technology, 30(2), 67-79.

Zhao, H., Cui, Z., Sun, X., Turng, L. S., \& Peng, X. (2013). Morphology and properties of injection molded solid and microcellular polylactic acid/polyhydroxybutyrate-valerate (PLA/PHBV) blends. Industrial \& Engineering Chemistry Research, 52(7), 2569-2581 


\section{Valorization of rice husk into bioactive xylans and cellulose nanocrystals, using sequential subcritical water extraction}

Raquel Requena1; Amparo Jiménez-Quero²; Rosana Moriana³ ${ }^{3}$ María Vargas; Amparo Chiralt ${ }^{1}$; Francisco Vilaplana ${ }^{2}$

Submitted to Bioresources Technology

${ }^{1}$ Institute of Food Engineering for Development, Universitat Politècnica de València, Valencia, Spain. ${ }^{2}$ Division of Glycoscience, School of Biotechnology, KTH Royal Institute of Technology, Stockholm, Sweden.

${ }^{3}$ School of Chemical Science and Engineering Department of Fibre and Polymer Technology, KTH Royal Institute of Technology, Stockholm, Sweden. 



\section{ABSTRACT}

The feasibility of obtaining high value products such as bioactive compounds and cellulosic reinforcing agents from rice husk (an important agricultural by-product) has been studied, by using sequential subcritical water extraction (SWE) prior to the bleaching and acid hydrolysis to obtain cellulose nanocrystals (CNCS). SWE is a green process step intended to substitute the common alkali pre-treatment, which can better preserve bioactivity of the hemicellulose fractions. The yields and properties of the obtained fractions were compared to those found using the alkali pre-treatment. Thus, the proposed hydrothermal approach for the rice husk valorization allowed for obtaining bioactive hemicellulose fractions, with antioxidant and antibacterial activity, useful as additives for food or food packaging, at the same time that it supposes a more eco-friendly process, avoiding the use of alkali solutions. Despite the fact that it was less effective at purifying the cellulosic fraction, the subsequent bleaching and acid hydrolysis mitigate this apparent drawback, thus obtaining CNCs with a high aspect ratio which confer them very good reinforcing capacity to obtain improved composites. Moreover, this alternative process would allow for the silica recovery, which was extracted in the alkali step, and maintained in the SWE.

Key words: rice husk; subcritical water extraction; xylans; cellulose nanocrystals; valorization. 


\section{INTRODUCTION}

Rice husk is a widely available food industry by-product, mainly composed of cellulose (40\%), hemicellulose (30\%), lignin (10\%) and silica (20\%) (Battegazzore 2014; Hessien et al. 2009). Different studies have proposed several strategies for rice husk valorization considering its abundance, composition and cheap cost. In the field of plant biomass valorization, the biorefinery approach for the production of a range of useful products including chemicals, energy and materials has been gaining more and more attention in recent years. The major advantages of biorefineries are the generation of multiple products with complete utilization of biomass with zero waste generation. Moreover, the process can be economically viable when it targets low volume high value products, in addition to high volume low value products, like bioethanol (Abraham et al. 2016). Rice husk has been proposed as renewable fuel in cogenerating plants, due to its high calorific power (Ebrahimi et al., 2017; Tsai et al. 2007) or as partial replacement for building materials, because of its high silica content (Hamzeh et al.2013; Prasad \& Pandey 2012; Torkaman et al., 2014). The application of rice husk as a partial substitute in biopolymer films based on polylactic acid (Yussuf et al., 2010; Tran et al., 2014), polydroxyalkanoate (Wu, 2014) and polycaprolactone (Zhao et al., 2008) has also been studied, since these natural fibres are highly biodegradable, while allowing for a reduction in the cost of the resulting biobased materials. Given the high cellulose content of rice husk, these fibres can be deemed as a widely available cellulose source from agricultural crop wastes, and can be used as a cheap raw material for developing cellulose-based products, such as highly crystalline rod-shaped cellulose regions, called cellulose nanocrystals (CNCs), of great potential as reinforcing agents for different composites (Johar \& Ahmad, 2012). The isolation of CNCs from plan biomass occurs in two stages. The first one consists of a pretreatment of the raw material, which involves the complete or partial removal of matrix materials such as hemicelluloses, lignin, etc., as well as the isolation of the cellulosic fibres. The second step is a controlled chemical treatment, commonly hydrolysis with $\mathrm{H}_{2} \mathrm{SO}_{4}$, whose objective is to remove the amorphous regions of the cellulose polymer (Brinchi et al., 2013). Different approaches have been reported for cost-effective pre-treatments of lignocellulosic biomass. Physical methods such as comminution including dry, wet, and vibratory ball milling, as well as compression milling were sometimes used to favour the subsequent extraction stages. Physicochemical processes such as steam, ammonia or carbon dioxide explosion have been used to promote the hemicellulose degradation and lignin transformation due to high temperature, thus increasing the potential of cellulose hydrolysis. Likewise, different chemical pre-treatments, such as ozonolysis, alkaline hydrolysis with $\mathrm{NaOH}$ and oxidative delignification have been applied to enhance the cellulose isolation (Kumar et al., 2009; Mosier et al., 2005).

The exploitation of the high hemicellulose fraction of rice husk, which is mainly made up of substituted arabinoxylans, also offers interesting possibilities. Although hemicellulose valorization is not as common as cellulose or starch recovery, some xylan-derived products 
have found commercial applications for the production of bioethanol, xylitol, xylooligosaccharides and other different materials, such as films, coatings, gels and foams (Egüés et al., 2014). Xylans have also attracted considerable attention as natural additives for food, cosmetics and biomedical applications due to their antioxidant and/or antimicrobial activity. This makes them potential natural substitutes for synthetic antibiotics or antioxidants, which satisfies the consumer demand for safer products (Melo-Silveira et al., 2012; Ruthes et al., 2017). In fact, several cell-wall polysaccharides, including xylan, 4-Omethyl-D-glucurono-D-xylan, galactomannan and galactoglucomannan from a variety of sources, exhibited antioxidant activity (Ebringerová et al., 2007; Ebringerová et al., 2008; Hromádková et al., 2005; Hromádková et al., 2008; Hromádková et al., 2010; Melo-Silveira et al., 2012; Pristov et al., 2011), as well as antimicrobial effects against Staphylococcus aureus, Escherichia coli (Velkova et al., 2017) and Klebsiella pneumoniae (Melo-Silveira et al., 2012).

A common process applied to extract the hemicellulose fraction from plant by-products is based on severe alkali treatments (Egüés et al., 2014; Zhang et al., 2014). Nonetheless, these conditions promote the removal of the chain-linked acetyl, uronic acid and phenolic compounds, which leads to a loss in the hemicelluloses' functionality (Ruthes et al., 2017; Zhou et al., 2010). Other treatments, including acid extraction (Zhang et al., 2014), enzyme extraction (Zhang et al., 2014) and different mechanical-chemical extraction treatments, such as microwave-assisted extraction (Rose \& Inglett, 2010), ultrasound-assisted extraction (Ebringerová et al., 1998; Hromadkova et al., 1999) and steam explosion extraction (Allen et al., 2001; Zhang et al., 2014), have also been applied for hemicellulose valorization from cereal by-products. The low hemicellulose extraction yields of the water extraction process has been improved by combining it with mechanical treatments (Zhang et al., 2014). Subcritical water extraction (SWE) emerges as a promising green technique for the isolation of hemicellulose fractions with preserved molecular functionalities and high molecular weight (Ruthes et al., 2017). SWE is a potential reaction medium for the conversion of lignocellulosic biomass, since water under subcritical conditions (temperature below critical point at pressure high enough to maintain liquid state) promotes mass transfer during the extraction process (Hanim et al., 2012; Prado et al., 2014; Ruthes et al., 2017; Toor et al., 2011, Martinez-Abad et al., 2018). Compared to conventional treatments (acid, alkali and enzymatic hydrolysis), SWE has numerous advantages, of which the main one is the use of non-toxic solvents. Moreover, this technique does not require pre-treatments, is faster and more targeted, saves on both raw material and energy, and presents a lower degree of sugar degradation, compared to conventional methods (Hanim et al., 2012; Prado et al., 2014; Prado et al., 2016). The high effectiveness of SWE to extract hemicelluloses from plant by-products has been demonstrated by several authors (Kilpeläinen et al., 2014; Prado et al., 2014; Rivas et al., 2013; Ruthes 2017)

In this study, a more integral valorization of the rice husk was analysed to obtain bioactive hemicelluloses and CNCs using sequential SWE prior to the bleaching and acid hydrolysis to obtain the cellulosic materials. The yields and properties of the obtained fractions were 
compared to those found using the common alkali process. In this way, polymeric hemicelluloses (xylans) with bioactive properties and CNCs, useful as reinforcing agents, could be obtained.

\section{MATERIALS AND METHODS}

\subsection{Materials and reagents}

The rice husk was kindly provided by Dacsa Group (Valencia, Spain), dried at room temperature for one week and milled with a Wiley Mill Acm 82302 (Acmas Technocracy Pvt. Ltd, Germany) to a 20 mesh. Sodium hydroxide $(\mathrm{NaOH})$, sodium chlorite, sodium acetate, acetyl chloride, methanol, sulphuric acid (96 wt\%), ethanol (99\%), methyl iodide $\left(\mathrm{CH}_{3} \mathrm{l}\right)$, dimethyl sulfoxide (DMSO), dichloromethane, trifluoroacetic acid (TFA), sodium borohydride $\left(\mathrm{NaBH}_{4}\right)$, pyridine, acetic anhydride and ethyl acetate were all analytical grade from SigmaAldrich (Steinheim, Germany) and were used without further purification. Ultrapure water (Milli-Q, Millipore, MA) was used in all cases. Spectra/Por 1 and 3 Dialysis Membrane, 6-8 kDa and 3.5 kDa MWCO were purchased from SpectrumLabs (Breda, The Netherlands).

2,2-Diphenyl-1-pikryl-hydrazyl (DPPH) was from Sigma-Aldrich (Spain). Phosfate Buffered Saline (PBS), Tryptone Soy Broth (TSB) and Tryptone Soy Agar (TSA) were supplied by Scharlab (Barcelona, España) and MTT reagent was supplied by Sigma-Aldrich (Steinheim, Germany). Listeria innocua (CECT 910) and Escherichia coli (CETC 101) lyophilized strains were supplied by the Spanish Type Culture Collection (CECT, Universitat de València, Spain), and stored at $-25^{\circ} \mathrm{C}$ with $30 \%$ glycerol. Active cultures were regenerated by inoculating the microbial stock suspensions into TSB followed by their incubation at $37^{\circ} \mathrm{C}$ for $24 \mathrm{~h}$. The inoculums were properly diluted to obtain bacterial suspensions of $10^{5} \mathrm{CFU} / \mathrm{mL}$.

\subsection{Bioprocess design}

\subsubsection{Hemicellulose isolation}

\section{a) Subcritical water extraction}

SWE of the milled rice husk samples was performed by pressurized hot water using a laboratory accelerated solvent extraction Dionex ${ }^{\mathrm{TM}} \mathrm{ASE}^{\mathrm{TM}} 350$ at $160{ }^{\circ} \mathrm{C}$ and $\mathrm{pH} 7$ on the basis of the higher xylan yields reported by Ruthes et al. (2017) for wheat bran. Extractions were performed using $2 \mathrm{~g}$ of milled sample under sequential cycles of 5, 10,15 and 30 min, resulting in four extracts (E-SWE5, E-SWE15, E-SWE30 and E-SWE60) and a insoluble fraction (RH-SWE). The extracts and residue were freeze-dried for $72 \mathrm{~h}$ for further analyses. 


\section{b) Alkali treatment}

For comparison purposes, the hemicellulose alkaline extraction from rice husk was also performed following the procedure described by Moriana et al. (2016). Milled rice husk (4 wt \%) was successively treated three times with a $\mathrm{NaOH}$ solution $(4.5 \% \mathrm{w} / \mathrm{v})$ at $80{ }^{\circ} \mathrm{C}$ for $2 \mathrm{~h}$ under mechanical stirring. After each treatment the lignocellulosic material was filtered and washed until the chemical removal. The alkali extracts (E-A1, E-A2, E-A3) obtained after each alkali treatment and the insoluble fraction ( $\mathrm{RH}-\mathrm{A})$ were dialyzed for $48 \mathrm{~h}$ using a $3.5 \mathrm{kDa}$ membrane to eliminate alkali residue and freeze-dried for $72 \mathrm{~h}$ for further analyses. Three different batches were considered.

\subsubsection{Isolation of cellulose nanocrystals}

\subsubsection{Bleaching treatment}

The insoluble fraction coming from the SWE (RH-SWE) and the alkaline (RH-A) extraction were subjected to five consecutive bleaching treatments in order to remove the lignin and residual hemicellulose following the methodology previously described by Le Normand et al. (2014). Dried residues (4 wt \%) were treated with bleaching solutions consisting of equal parts of acetate buffer $(2 \mathrm{M}, \mathrm{pH} 4.8)$, aqueous chlorite $(1.7 \% \mathrm{w} / \mathrm{v})$ and water, at $80^{\circ} \mathrm{C}$ for $4 \mathrm{~h}$ under mechanical stirring. After each treatment, the bleached material was filtered and washed until the chemicals were removed, and dried at room temperature, thus obtaining the two different kinds of bleached samples, those coming from the RH-A sample (RH-A-B) and those coming from the RH-SWE (RH-SWE-B).

\subsubsection{Acid hydrolysis and purification}

The acid hydrolysis was conducted after the bleaching treatment on both kind of fibres (RHA-B and RH-SWE-B) by using the methodology described by Moriana et al. (2016). Both bleached residues ( $4 \mathrm{wt} \%$ ) were treated with $65 \mathrm{wt} \%$ sulphuric acid (preheated) at $45^{\circ} \mathrm{C}$ for 40 min under continuous stirring. The reactions was stopped by adding ice cubes and the hydrolysed material was washed with water by successive centrifugations at $25000 \mathrm{~g}$ for 20 min (Rotofix 32A Hettich Zentrifugen, Germany), until the supernatant reached constant pH. Then, the residue was water suspended and dialysed against distilled water for several days, using a 6-8 KDa membrane, until constant $\mathrm{pH}$ in the range of 5-6 was reached. The resulting suspensions were sonicated for $10 \mathrm{~min}$ at $7.125 \mathrm{~W} / \mathrm{mL}$, while cooling in an ice bath, centrifuged at $4500 \mathrm{rpm}$ for $10 \mathrm{~min}$ to remove the higher particles (mostly silica, which could be valorised) and kept at $4{ }^{\circ} \mathrm{C}$ for further analyses. 


\subsection{Characterization of the materials obtained throughout the valorization processes}

\subsubsection{Characterization of the alkali and SWE soluble extracts}

\subsubsection{Carbohydrate composition}

Methanolysis with $\mathrm{HCl}$ in methanol (2M) was performed on the extracts resulting from SWE (E-SWE5, E-SWE15, E-SWE30 and E-SWE60) and alkali extraction (E-A1, E-A2 and E-A3) (1mg of freeze-dried material), at $100{ }^{\circ} \mathrm{C}$ for $5 \mathrm{~h}$, followed by hydrolysis with TFA $2 \mathrm{M}$ at $120{ }^{\circ} \mathrm{C}$ for 1 $\mathrm{h}$. The hydrolysed monosaccharides from methanolysis were separated and quantified in triplicate runs by HPAEC-PAD on an ICS3000 system (Dionex, Sunnyvale, CA) using a Dionex CarboPac PA1 column at $30^{\circ} \mathrm{C}$ at a flow rate of $1 \mathrm{~mL} / \mathrm{min}$. Two different gradients were applied for the analysis of neutral sugars (fucose, arabinose, rhamnose, galactose, glucose, xylose, mannose), and uronic acids (galacturonic and glucuronic acid), respectively, as previously reported by McKee et al. (2016)

\subsubsection{Molar mass distributions by Size-Exclusion Chromatography (SEC)}

The molar mass distributions of the different hemicellulose extracts were analysed by sizeexclusion chromatography (SECcurity 1260, Polymer Standard Services, Mainz, Germany) coupled to a refractive index detector (SECcurity 1260, Polymer Standard Services, Mainz, Germany) in an eluent system consisting of dimethyl sulfoxide (DMSO, HPLC grade, Scharlab, Sweden) with $0.5 \% \mathrm{w} / \mathrm{w} \mathrm{LiBr}$ (ReagentPlus) at $60^{\circ} \mathrm{C}$, following the procedure reported by Ruthes et al. (2017). In brief, 2-3 g/L of the hemicellulose fractions were dissolved in the SEC eluent, and SEC separation was performed with a flow rate of $0.5 \mathrm{~mL} / \mathrm{min}$ using a column set consisting of a GRAM PreColumn, 30 and 10000 analytical columns (PSS, Mainz, Germany). Standard calibration of apparent molar masses was performed using pullulan standards (PSS, Mainz, Germany).

\subsubsection{Antioxidant activity of the extracts}

The antioxidant activity of the hemicellulosic extracts was measured in triplicate by using the 2,2-Diphenyl-1-pikryl-hydrazyl (DPPH) reduction method, following the methodology described by Brand-Williams, Cuvelier, \& Berset (1995). These measurements were carried out only for the SWE and alkali extracts with the highest xylan contents, E-SWE60 and E-A3, respectively. Briefly, aliquots of the different properly diluted samples were mixed with a methanol solution of $\mathrm{DPPH}^{\cdot}(0.0255 \mathrm{~g} / \mathrm{L})$ at a final ratio ranging from $0.025: 1$ to $0.3: 1$. The absorbance of the resulting solutions was measured at $515 \mathrm{~nm}$ every $15 \mathrm{~min}$, until the reaction 
reached the steady state, by using a spectrophotometer (ThermoScientific spectrophotometer Evolution 201 UV-vis).

The DPPH concentration ( $\mathrm{mM}$ ) in the reaction medium was calculated from the calibration curve (Eq. 1), whereas the percentage of remaining $\mathrm{DPPH}^{\cdot}\left(\% \mathrm{DPPH}^{\circ}{ }_{\text {rem}}\right)$ was calculated following Eq. 2.

$$
\begin{aligned}
& A b s 515_{\mathrm{nm}}=10.7617 \cdot\left[\mathrm{DPPH}^{\cdot}\right]+0.0031 \quad(\text { Eq 1.) } \\
& \left.\% \mathrm{DPPH}_{\text {rem }}=\left(\left[\mathrm{DPPH}^{\cdot}\right] \mathrm{t}_{\text {steady }}\right] /\left[\mathrm{DPPH}^{\cdot}\right] \mathrm{t}_{0}\right) \cdot 100
\end{aligned}
$$

Where, [DPPH'] $\mathrm{t}_{\text {steady }}$ is the concentration of $\mathrm{DPPH}^{\cdot}$ at steady state and [DPPH'] $\mathrm{t}_{0}$ is the concentration at the beginning of the reaction.

The parameter $\mathrm{EC}_{50}$ was determined by plotting the $\% \mathrm{DPPH}^{-}$rem versus the mass ratio of extract to DPPH (mg extract/mg DPPH), which indicates the amount of extract required to reduce the initial concentration of $\mathrm{DPPH}^{-}$to $50 \%$ once the stability of the reaction was reached (Talón et al., 2017).

\subsubsection{Antibacterial activity of the extracts by MTT assay}

A MTT colorimetric assay was carried out by using a 96-well microtiter plate design in order to study the potential antimicrobial activity of the hemicellulosic SWE and alkali extracts with the highest xylan contents, E-SWE60 and E-A3, respectively. Diluted solutions (150 to $10 \mathrm{mg}$ extract $/ \mathrm{mL}$ ) were prepared from the freeze-dried extracts using TSB broth medium as solvent and aliquots of $100 \mu \mathrm{l}$ of each dilution were placed in their corresponding wells. Then, plates were inoculated with $100 \mu \mathrm{l}$ of the $10^{5} \mathrm{CFU} / \mathrm{mL}$ bacterial suspension of L. innocua or E. coli, and covered with a sealer mat to avoid contaminations between the adjoining wells. Sterility and bacterial growth control were also prepared with non-inoculated and inoculated culture media, whereas the outer wells were left empty to prevent edge effect.

After $24 \mathrm{~h}$ incubation at $37{ }^{\circ} \mathrm{C}, 10 \mu \mathrm{l}$ of MTT reconstituted in PBS $(5 \mathrm{mg} / \mathrm{mL})$ were added to each well and incubated for $4 \mathrm{~h}$ at $37^{\circ} \mathrm{C}$. MTT is a yellow tetrazolium salt, which is reduced to a purple formazan by dehydrogenases of a live cell. The antimicrobial activity of the extracts as well as their corresponding minimum inhibitory concentrations (MICs) can be assessed by the naked eye, since the formazan amount produced is directly proportional to the number of live cells (Requena et al., 2018). Thus, the MIC values were determined as the lowest concentration of active compound at which no purple colour was observed. All the experiments were carried out in duplicate. 


\subsubsection{Characterization of the insoluble fractions from macro to nano dimensions}

\subsubsection{Chemical composition analyses}

The chemical composition of the insoluble fractions was analysed at each process step. The dry content of the different samples was measured by using a Mettler Toledo HB43 moisture analyser (Columbus, $\mathrm{OH}$ ). The Klason lignin of each residue was estimated following the Tappi test method T222 om-06 (TAPPI, 2006), while the total amount of soluble extractives in water and ethanol on the raw residue was determined by Soxhlet extraction, according to NREL's LAP (NREL, 2005). The ash content of the samples was determined by thermogravimetric analysis (TGA) using a Mettler-Toledo 851 (TGA/SDTA) module (Mettler Toledo, Columbus, $\mathrm{OH}$ ) following the method previously published by Zhang et al. (2015) and Gordobil et al. (2016). Thermogravimetric method consisted of a heating ramp at $50{ }^{\circ} \mathrm{C} / \mathrm{min}$ from $25^{\circ} \mathrm{C}$ to a 3 min isothermal stage at $120^{\circ} \mathrm{C}$, followed by a heating ramp until $950^{\circ} \mathrm{C}$ at $100{ }^{\circ} \mathrm{C} / \mathrm{min}$ under $\mathrm{O}_{2}$ atmosphere.

The monosaccharide composition was analysed by high-pH anion exchange chromatography with pulsed amperometric detection (HPAEC-PAD) in triplicate runs in the pre-treated samples. Conventional two-step sulphuric acid hydrolysis Saeman et al. (1954) was employed for the milled rice husk and the insoluble fractions resulting from the alkali extraction and the SWE, as well as the corresponding bleached and hydrolysed samples. In brief, $4 \mathrm{mg}$ of the freeze-dried sample was pre-hydrolysed at room temperature for $3 \mathrm{~h}$, diluted until a final concentration of $1 \mathrm{M} \mathrm{H}_{2} \mathrm{SO}_{4}$, and then subjected to the second hydrolysis step at $100{ }^{\circ} \mathrm{C}$ for 3 h. The hydrolysed monosaccharides were separated and quantified by HPAEC-PAD on an ICS3000 system (Dionex, Sunnyvale, CA) using a Dionex CarboPac PA1 column at $30{ }^{\circ} \mathrm{C}$ at a flow rate of $1 \mathrm{~mL} / \mathrm{min}$. Two different gradients were applied for the analysis of neutral sugars (fucose, arabinose, rhamnose, galactose, glucose, xylose, mannose), and uronic acids (galacturonic and glucuronic acid), respectively, as previously reported by McKee et al. (2016).

\subsubsection{Gravimetric analysis}

The gravimetric yield of the SWE, alkali and bleaching treatment was assessed by weighting the samples before and after each treatment, taking into account their dry content.

\subsubsection{Scanning Electron Microscopy (SEM)}

The surface morphology of the rice husk fibres was analysed using a Tabletop TM-1000 scanning electron microscope (SEM) (Hitachi, Japan) at $15 \mathrm{kV}$. The effect of the different treatments was assessed by comparison of the untreated, SWE, alkali treated, and bleached 
fibres. No metal coating of the samples was required, due to observation under variable pressure vacuum.

\subsubsection{Atomic Force Microscopy (AFM)}

The morphology of the CNCs was imaged in the dry state with tapping-mode AFM (Multimode V, Bruker, Santa Barbara, CA) following the same experimental methodology previously reported for the CNCs from residual biomass (Le Normand et al., 2014). Images in height and phase modes were recorded with an E-scanner in a scan assist mode. RTESP silica cantilevers (Bruker) having a tip with a radius of $8 \mathrm{~nm}$ and a spring constant of $20-80 \mathrm{~N} / \mathrm{m}$ oscillated at its fundamental resonance frequencies between 306 and $366 \mathrm{kHz}$. The $\mathrm{CNC}$ samples were prepared using the layer-by-layer technique: silicon wafers were used as substrates for adsorption after of being cleaned in an air plasma cleaner (Model PDC 002, Harrick Scientific Corporation, NY) for $4 \mathrm{~min}$ at $30 \mathrm{~W}$; the silicon wafers were introduced into a cationic polymer for $5 \mathrm{~min}$, washed and dried; and finally, they were rinsed with diluted CNC solutions. The distribution of particle lengths and diameters were obtained from printouts of several height mode AFM images, using the section analysis tool of the NanoScope Analysis software (Bruker, version 1.40). More than a hundred individual CNCs were randomly selected and measured to determine their average length and diameter.

\subsubsection{Fourier Transform Infrared Spectrometry (FTIR) with Attenuated Total Reflection (ATR)}

The rice husk and the samples obtained at the different steps of the process were characterized regarding their chemical structure in order to identify changes in their functional groups throughout the process. To this end, FTIR spectra of the samples were recorded on a FTIR spectrometer Spectrum 2000 (Perkin Elmer, Wellesley, MA, USA), equipped with a Golden single-reflection accessory for Attenuated Total Reflection (ATR) measurements. Background scanning and correction were performed before testing the samples. Each spectrum was collected after 16 scans between 4000 and $600 \mathrm{~cm}^{-1}$ at intervals of $1 \mathrm{~cm}^{-1}$, with a resolution of $4 \mathrm{~cm}^{-1}$. The FTIR spectra were fitted by an automatic base line correction using OMNIC 4.0 software. The measurements were repeated seven times for each sample.

\subsubsection{X-Ray Diffraction Analysis (XRD)}

The rice husk, alkaline and SWE samples together with the bleached ones and the CNCs were analysed in an X-ray diffractometer (X'Pert PRO MPD PANalytical, The Netherlands) at environment temperatures. A monochromatic CuKa radiation $\left(k=1.54 \mathrm{~A}^{\circ}\right)$ in the range of $2 \theta$ varying from $10^{\circ}$ to $60^{\circ}$ at a scan rate of $1^{\circ} / \mathrm{min}$. X-ray diffraction data were processed and 
analysed using HighScore Plus 3.0 software (PANalytical, Inc.). The crystalline index (Crl) of the different samples was determined by referring to diffraction intensity of crystalline and amorphous regions according with the Segal empirical method (Segal et al., 1959) after subtraction of the background signal.

\subsubsection{Thermogravimetric Analysis (TGA)}

The thermal behaviour of the raw rice husk and the insoluble fractions obtained after each step of the process was determined by dynamic thermogravimetric analysis (TGA) using a Mettler-Toledo TGA/SDTA 851 (Columbus, OH). Approximately $6 \mathrm{mg}$ of each sample was heated between $25^{\circ} \mathrm{C}$ and $600^{\circ} \mathrm{C}$ at a heating rate of $10^{\circ} \mathrm{C} / \mathrm{min}$ under a nitrogen atmosphere flow of $50 \mathrm{~mL} / \mathrm{min}$. The thermogravimetric (TG) and the derivative thermogravimetric (DTG) curves were obtained using STAR ${ }^{\mathrm{e}}$ Evaluation Software (Mettler-Toledo, Columbus, OH). The maximum degradation temperature $\left(T_{\max }\right)$ peaks at which the maximum degradation rate took place were determined by the DTG curves, while the mass loss percentages of each thermal degradation stage and the residue at the end of the test were calculated from the TG curves. The initial degradation temperature ( $\left.T_{\text {onset }}\right)$ was determined by extrapolating the slope of the DTG curve in correspondence with the first local maximum in the second derivative thermogravimetric (D2TG) curve and down to the zero level of the DTG axis (Moriana et al., 2014b). All measurements were run in triplicate

\section{RESULTS AND DISCUSSION}

The biorefinery process proposed to the rice husk valorization was studied to isolate hemicellulosic fractions by the sequential SWE, in comparison to the usual alkali extraction, at the same time that the resulting insoluble fractions were profited to obtain CNCs in a cascade process based on bleaching treatments and acid hydrolysis.

Figure 1 shows the different process steps for each overall process applied to rice husk to obtain CNCs. The product appearance after each treatment, as well as the respective yields, obtained from mass balances, are also included. The alkali treatment provoked a colour change in the rice husk samples to brownish-orange, according to the removal of a great deal of the non-cellulosic components ( $46 \%$ ) such as hemicellulose, lignin and pectin present in the husk, as reported by García-García et al. (2018) for the pine cone residue submitted to the same alkali treatment. The colour changes were less noticeable along the hydrothermal approach, which suggests a less effective extraction of the amorphous components in terms of quantity, as deduced from the lower yield of the alkali treatment (54\%) compared to the SWE yield (69\%), due to the milder conditions of the SWE. However, the extracted hemicellulosic fractions could be purer and better preserved, with more active properties. 
The more aggressive conditions of the alkali treatment enhanced the release of the amorphous phase, thus leading to purer cellulosic materials after the bleaching treatment (whiter residues). Higher yields were reported for the same alkali treatment for forest residues, whereas significantly lower yields were achieved for the bleaching treatments, which can be explained by the differences in the plant tissue structure with different sensitivity to the chemical agents (García-García et al., 2018; Moriana et al., 2016). Similar alkali and bleaching treatments applied to rice husk led to slightly higher yields for the alkali treatment and lower yields for the bleaching steps, probably due to small differences in the process conditions and the raw material (Collazo-Bigliardi et al., 2018).

As concerns the soluble extract, SWE was more suitable, since the total efficiency was $27.0 \%$ soluble solids, whereas the alkali treatments yield $23.6 \%$ after the alkali elimination by dialysis, where some small solutes could also be lost (Figure 1). It is worthy to note that these yields take into account the amorphous soluble components of rice husk such as hemicelluloses, lignin or ashes. Comparable extraction yields (22.3\%) were reported by Ruthes et al. (2017) using SWE at $160^{\circ} \mathrm{C}$ and $\mathrm{pH}$ 7.0.

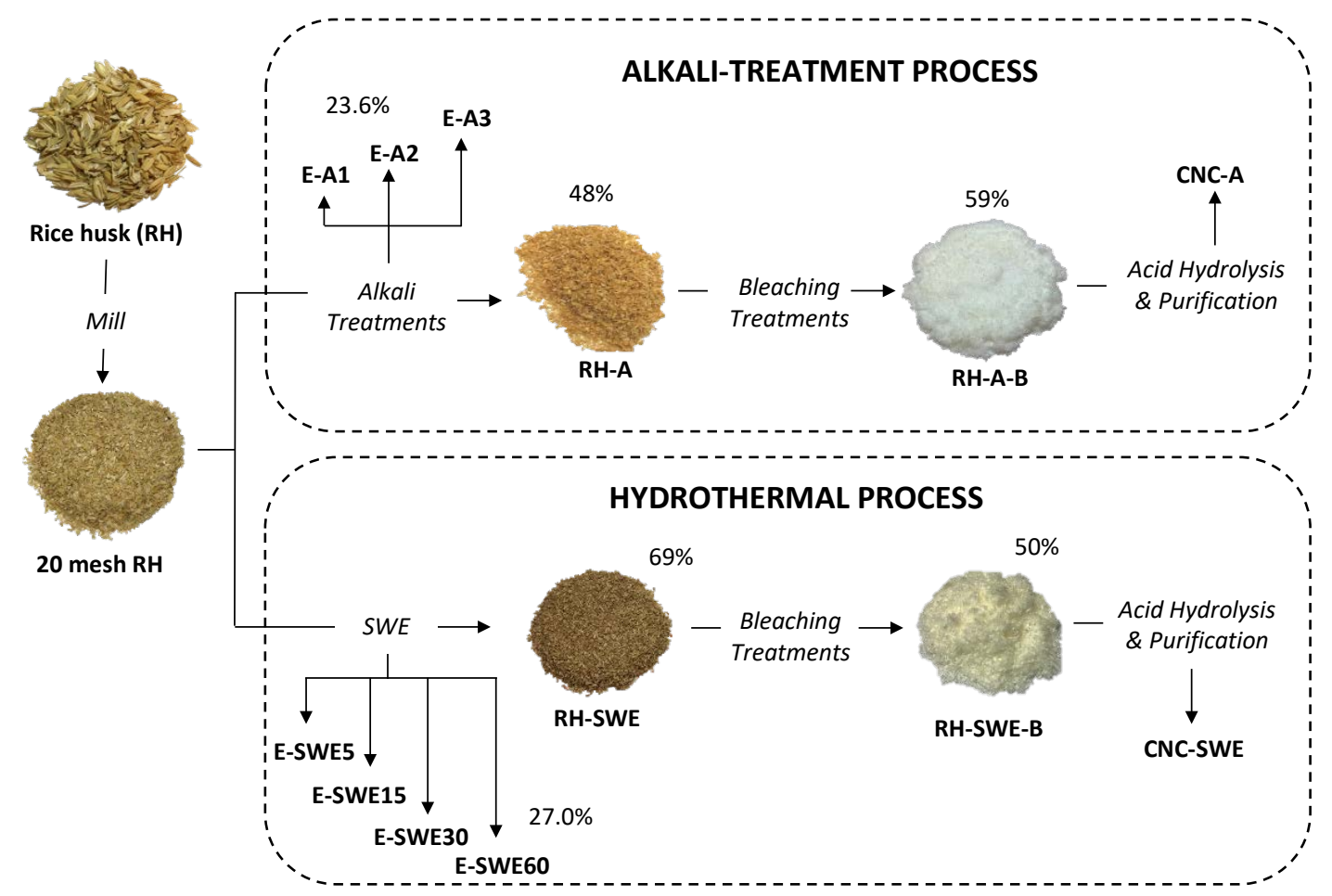

Figure 1. Schematic representation of rice husk valorization through two different approaches, common alkali-treatment process and an alternative hydrothermal process. The gravimetric yields for each treatment were calculated based on the total dry weight of the previous step. 


\subsection{Characterization of extracts}

\subsubsection{Chemical composition of the hemicellulosic extracts}

The alkaline and SWE extracts were compared in terms of the monosaccharide composition, in order to monitor the evolution of the extraction processes in terms of purity and to further correlate the potential functionality of the extracts from both extraction processes in terms of the xylan content and bioactive properties (antioxidant and antimicrobial capacity). The first 5 min SWE extracts contained mainly glucose (> $80 \mathrm{wt} \%$ ) (Figure 2a), probably due to the presence of residual starch coming from the rice husking process. However, in the next process steps, the xylan content in the extracts progressively increased as a result of the higher hemicellulose extraction, reaching a xylan content of $84 \%$ in the $60 \mathrm{~min}$ extract (Table 1). Likewise, the xylan content was higher in the second and the third alkaline extraction compared to the first one, although the fractions obtained by SWE at 30 and 60 min were richer on xylans ( $69 \%$ and $84 \%$, respectively) than those obtained by alkali extraction.

Table 1. Monosaccharide composition (in \% wt), number-average molar mass $\left(\mathrm{M}_{\mathrm{n}}\right)$ and weight-average molar mass $\left(\mathrm{M}_{\mathrm{w}}\right)$ of the rice husk extracts resulting from sequential fractionation by subcritical water extraction (E-SWE) and the three consecutive alkaline extractions (E-A).

\begin{tabular}{lccccccc} 
& \multicolumn{3}{c}{ Hydrothermal process } & \multicolumn{3}{c}{ Alkaline process } \\
\cline { 2 - 8 } & E-SWE5 & E-SWE15 & E-SWE30 & E-SWE60 & E-A1 & E-A1 & E-A1 \\
\hline Ara & $1.7 \pm 0.1$ & $12.8 \pm 0.9$ & $12.1 \pm 1.0$ & $7.6 \pm 0.5$ & $5.2 \pm 2.1$ & $8.5 \pm 0.9$ & $6.7 \pm 2.0$ \\
Gal & $<0.1$ & $3.2 \pm 0.1$ & $4.8 \pm 0.4$ & $4.2 \pm 0.2$ & $2.8 \pm 2.1$ & $1.6 \pm 0.1$ & $1.3 \pm 0.3$ \\
Glc & $80.4 \pm 11.4$ & $42.8 \pm 5.0$ & $6.1 \pm 1.3$ & $2.8 \pm 0.3$ & $38.5 \pm 6.5$ & $2.9 \pm 0.4$ & $4.0 \pm 2.4$ \\
Xyl & $2.1 \pm 0.2$ & $18.3 \pm 0.7$ & $53.6 \pm 6.8$ & $73.2 \pm 0.9$ & $33.6 \pm 5.5$ & $60.4 \pm 2.6$ & $47.0 \pm 9.6$ \\
MeGIcA & $<0.1$ & $<0.1$ & $2.3 \pm 0.4$ & $2.2 \pm 0.3$ & $0.6 \pm 0.2$ & $2.9 \pm 0.4$ & $2.7 \pm 1.0$ \\
GalA & $<0.1$ & $<0.1$ & $<0.1$ & $<0.1$ & $0.3 \pm 0.1$ & $0.6 \pm 0.1$ & $0.3 \pm 0.1$ \\
GlcA & $<0.1$ & $<0.1$ & $0.8 \pm 0.1$ & $0.7 \pm 0.1$ & $0.4 \pm 0.1$ & $0.6 \pm 0.1$ & $0.5 \pm 0.1$ \\
Xylan (\%) & $3.8 \pm 0.3$ & $31 \pm 2$ & $69 \pm 7$ & $83.7 \pm 1.4$ & $40 \pm 5$ & $72 \pm 4$ & $57 \pm 13$ \\
Ara:Xyl ratio & $0.82 \pm 0.08$ & $0.70 \pm 0.03$ & $0.23 \pm 0.04$ & $0.10 \pm 0.01$ & $0.15 \pm 0.07$ & $0.14 \pm 0.01$ & $0.14 \pm 0.01$ \\
Total & $85.5 \pm 11.6$ & $77.0 \pm 6.3$ & $79.7 \pm 8.9$ & $90.7 \pm 1.7$ & $81.3 \pm 10.2$ & $77.5 \pm 3.9$ & $62.4 \pm 10.6$ \\
carbohydrates & & & & & & & \\
$M_{n}$ & 36810 & 4291 & 3254 & 2705 & 12150 & 8784 & 8128 \\
$M_{w}$ & 691700 & 250600 & 59990 & 6499 & 271700 & 35970 & 35230 \\
\hline
\end{tabular}

a The xylan content was calculated as the sum of the Xyl+Ara+GlcA+MeGlcA populations.

Values for fucose, rhamnose and mannose were not detected $(<0.1)$. 
(a)

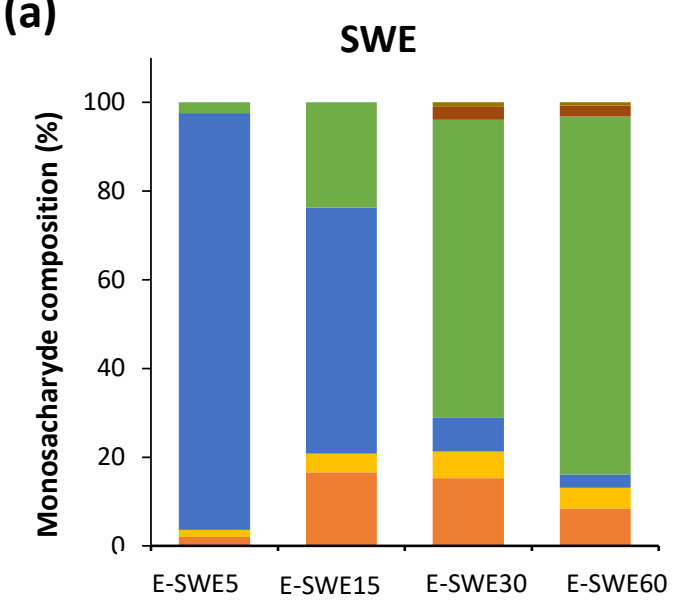

(b)

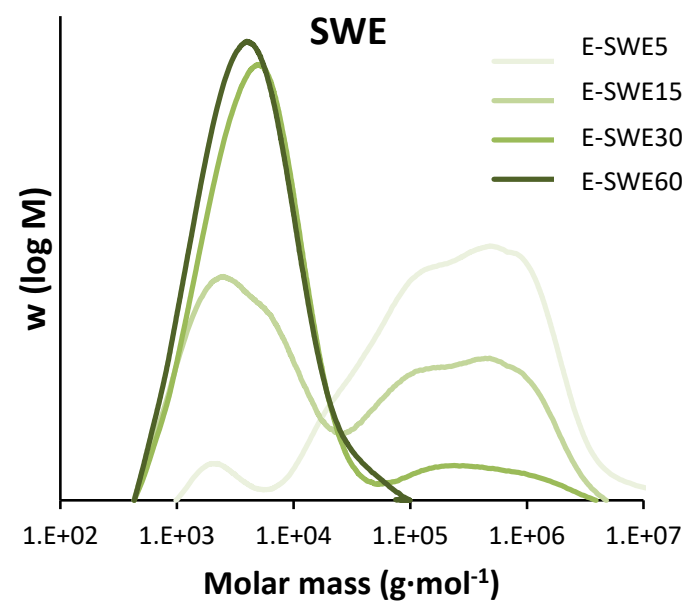

Molar mass $\left(\mathrm{g} \cdot \mathrm{mol}^{-1}\right)$

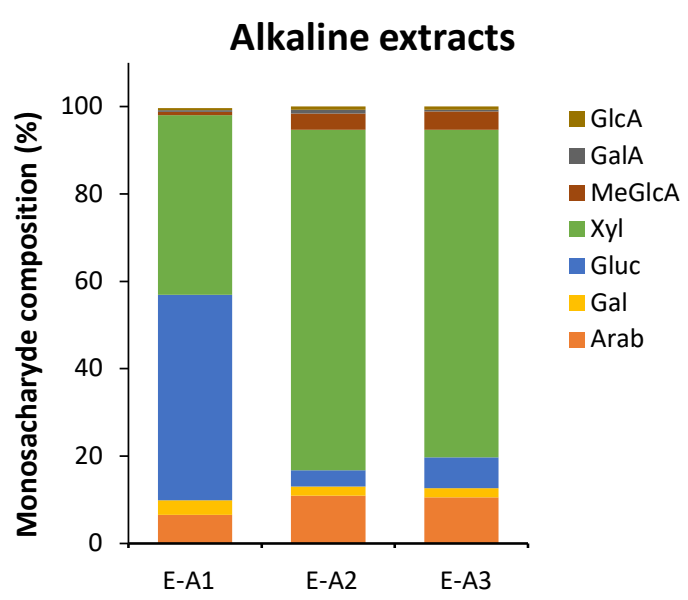

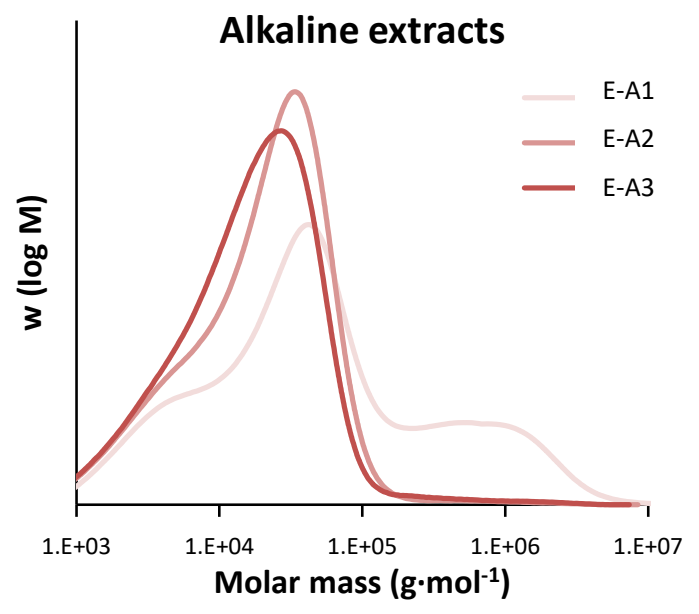

Figure 2. Monosaccharide composition in the carbohydrate fraction (a) and molar mass distributions (b) of the rice husk extracts resulting from sequential fractionation by subcritical water extraction (ESWE) and the three consecutive alkaline extractions (E-A). Values for fucose, rhamnose and mannose were not detected $(<0.1)$.

The molar mass distributions and average molecular weights of the polymeric fractions were determined by SEC analyses (Figure $\mathbf{2} \mathbf{b}$ and Table $\mathbf{1}$ ). The first alkali extract and the sequential SWE for 5, 15 and 30 min showed bimodal molar mass distributions with two main populations, a high molar mass polymeric fraction $\left(10^{5}-10^{6} \mathrm{~g} \cdot \mathrm{mol}^{-1}\right)$ and a low molar mass fraction $\left(10^{3}-10^{4} \mathrm{~g} \cdot \mathrm{mol}^{-1}\right)$, whereas the second and the third alkali extracts and the SWE for 60 min exhibited monomodal distributions $\left(10^{3}-10^{4} \mathrm{~g} \cdot \mathrm{mol}^{-1}\right)$ (Figure $\mathbf{2 b}$ ). The fraction with higher molar mass could be attributed to the presence of starch residues that are removed during the first steps of the extraction processes, whereas the lower molecular mass molecules correspond to hemicelluloses.

The polysaccharides in the second and the third alkali extracts exhibited higher molar mass $\left(3.5 \cdot 10^{4} \mathrm{~g} \cdot \mathrm{mol}^{-1}\right)$ than those of the $60 \mathrm{~min}$ SWE $\left(6.5 \cdot 10^{3} \mathrm{~g} \cdot \mathrm{mol}^{-1}\right)$, as shown in Table 1. As 
previously reported Ruthes et al. (2017) for wheat bran, these differences can be attributed to the different extractability of the macromolecular populations of both extraction processes. The more severe conditions of the alkali treatment lead to the break of the ferulic crosslinks in the rice husk, thus liberating arabinoxylans with higher molar weigh, but without the covalently attached phenolic functionalities. In contrast, arabinoxylan fractions with lower molar mass, with better preserved chemical functionalities (e.g. acetylations, feruloylations) are usually obtained by SWE. This results points to the lower efficiency of the SWE process to purify the cellulosic fraction of rice husk, but with better preservation capacity of the functional properties of the extract, as discussed in the next section.

\subsubsection{Functional properties of the hemicellulosic extracts}

The radical scavenging activity of the alkaline and SWE extracts with the highest xylan content was assessed against the DPPH', which is widely used. This method consist of the reduction of a coloured oxidant as a result of the electron transfer. The DPPH scavenging activity of the extracts was reported as the percentage of the remaining $\mathrm{DPPH}^{*}$ when the reaction reached the steady state (Figure $\mathbf{3}$ ). Thus, the lower amount of the extract required to reduce the percentage of remaining $\mathrm{DPPH}^{\prime}$ radical the stronger its antioxidant activity. SWE reacted within a moderate rate with the DPPH; reaching the steady state after $1 \mathrm{~h}$, whereas the alkaline extract reacted much more slowly and reached the steady state within $5 \mathrm{~h}$. Moreover, SWE extract showed significant scavenging activity with an $\mathrm{EC}_{50}$ value (50\% reduction of the remaining $\mathrm{DPPH}^{*}$ ) of $9.6 \pm 0.6 \mathrm{mg} / \mathrm{mg} \mathrm{DPPH}^{\prime}$, whereas the alkaline extract showed a significantly lower scavenging activity than the SWE extract, with $\mathrm{EC}_{50}$ value of $170 \pm 21 \mathrm{mg} / \mathrm{mg} \mathrm{DPPH}$, which represents a 18-fold lower antioxidant capacity (Figure 3).

Butsat et al. (2009) reported a good correlation between total phenolic content and antioxidant activity of rice husk extracts, where the soluble phenolic content was lower than the fraction esterified to the cell wall polysaccharides and lignin. The most abundant phenolic compounds in rice husk are $\mathrm{p}$-coumaric acid followed by ferulic acid, with $\mathrm{EC}_{50}$ values of 0.2 $\mathrm{mg} / \mathrm{mg} \mathrm{DPPH}^{\cdot}$ and $20.8 \mathrm{mg} / \mathrm{mg} \mathrm{DPPH}^{\prime}$, respectively (Brand-Williams et al., 1995), whereas syringic, vanillic, and p-hydroxybenzoic acid are in trace amounts. Moreover, the extracts with bound phenolic acids exhibited radical scavenging activities slightly higher than the extracts containing free phenolic acids. Therefore, it is reasonable to obtain significantly lower antioxidant activity when using alkali extraction, since these harsh conditions are reported to remove the xylans' phenolic substituents (Ruthes et al., 2017). Closed dialysis and membrane ultrafiltration have been applied to fractionate the low molar mass (oligosaccharides) from the high molar mass population (polysaccharides) in order to obtain high molecular weight fractions enriched in feruloylated arabinoxylan with enhanced radical scavenging activity (Ruthes et al., 2017). 

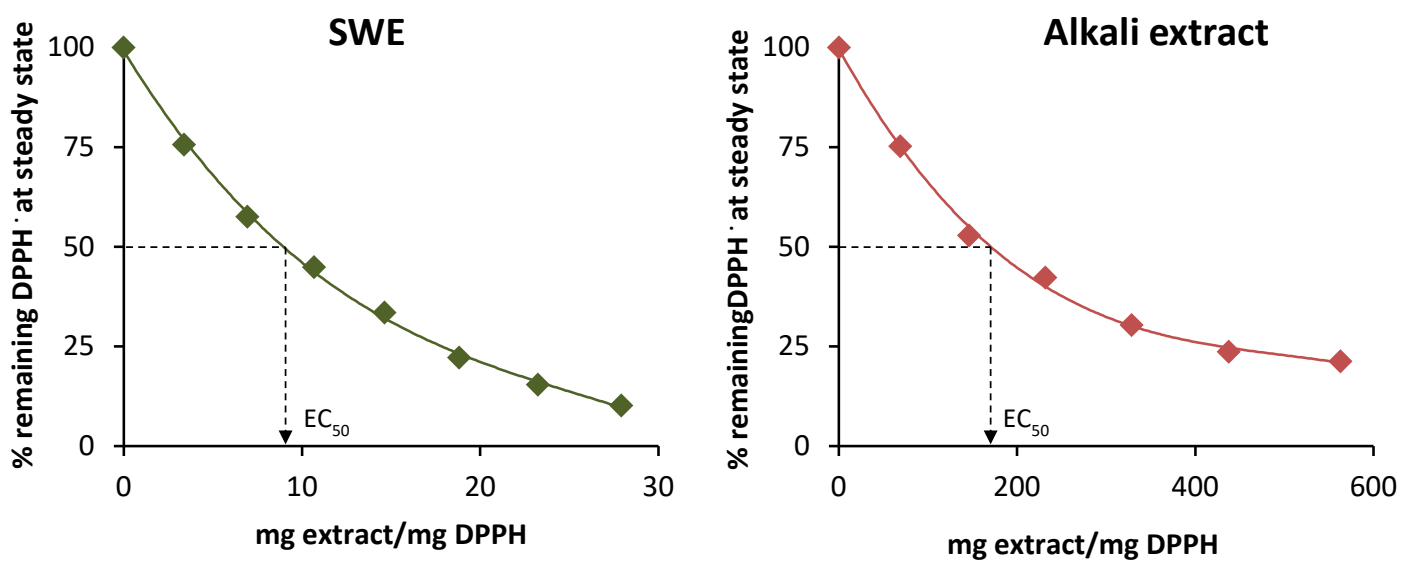

Figure 3. Percentage of DPPH' remaining at the steady state versus the mass ratio of extract to DPPH' (mg extract/mg DPPH) for the rice husk extracts resulting from de subcritical water extraction (ESWE60) and the alkaline treatment (E-A3) showing the parameter $\mathrm{EC}_{50}$.

The hemicellulosic extract obtained from the last step of the SWE (E-SWE60) inhibited the microbial growth of $L$. innocua and $E$. coli, the Gram-negative bacteria being significantly more resistant (MIC $=95 \pm 2.5 \mathrm{mg} / \mathrm{mL}$ ) than the Gram-positive bacteria (MIC $=55 \pm 2.5 \mathrm{mg} / \mathrm{mL}$ ). Despite the antimicrobial activity reported for the SWE extract, the MIC values were significantly lower to the MIC reported for arabinoxylans from oat spelt against Staphylococcus aureus and Escherichia coli (Velkova et al., 2017). Unlike for SWE extract, no antimicrobial effects were observed for the extract obtained from the last alkali treatment (EA3), which confirm the negative effect of the alkali treatments on the hemicelluloses' functionality (Ruthes et al., 2017; Zhou et al., 2010).

The obtained results confirm the best efficiency of SWE at preserving the structure and functionality of the xylan fractions of rice husk, although it seems less effective at purifying the cellulosic residue. Nevertheless, the subsequent bleaching and acid hydrolysis could mitigate this aspect, giving rise to final cellulose products with adequate properties, avoiding a non-green step such as the alkali treatment. 


\subsection{Characerization of the insoluble fraction from macro to nano dimensions}

\subsubsection{Chemical composition of the insoluble fractions}

The chemical composition of the rice husk, both raw and submitted to the different process steps for the alkali-treatment process and the hydrothermal process was determined as to carbohydrate composition, ash content, Klason lignin and extractives (only for raw material) and the weight percentages of each fraction are shown in Table 2 . The relative content of cellulose was initially estimated from the percentage of glucose (without taking into account the presence of glucose in xyloglucan, mixed-linkage $\beta$-glucan and glucomannan), whereas the hemicellulose/pectin content was considered as the percentage of the remaining sugars. Thus, the raw rice husk contained 35.1 wt \% cellulose, 19.3 wt \% hemicelluloses, 16.8 wt \% lignin, and $17.0 \mathrm{wt} \%$ ash, in the range of those previously reported by Collazo-Bigliardi et al. (2018) for rice husk (33.8 wt \% cellulose, $17.1 \mathrm{wt} \%$ hemicelluloses, $21.5 \mathrm{wt} \%$ lignin, and 16.5 wt \% ash). Johar et al. (2012) also reported similar chemical composition for this material, with the exception of the hemicellulose content, which was significantly higher (33 wt \%). Differences in rice husk composition can be caused by the type of paddy, climate and geographical conditions, sample preparation and analysis method.

As expected, the cellulose content progressively increased in the insoluble fraction throughout both processes due to the removal of the non-cellulosic materials. Nonetheless, significant differences were observed between both processes. The alkali treatment removed the main part of the inorganic silica (ashes), as well as a part of the lignin and hemicellulose/pectin content as previously reported by Collazo-Bigliardi et al. (2018). SWE was particularly selective to isolate the hemicelluloses, but it did not alter the Klason lignin content of the husk. The most significant reduction in Klason lignin was achieved during the bleaching treatments, their contents being $9 \%$ and $25 \%$, respectively in the RH-A-B and RH-SWE-B samples. The high ash content in the RH-SWE-B samples (16.6\%) is also remarkable, in contrast with RH-A-B samples

(3.5\%). These differences could attributed to the lower effectiveness of the SWE at disrupting the structure of the plant tissue and deliver the bonded compounds, such as lignin, and the neutral conditions, which limit the silica extraction (main constituent of ashes) which are much more soluble in the alkaline medium as silicic acid.

During the hydrolytic treatment with sulphuric acid, hemicelluloses and pectin of the solid residue were hydrolysed together with the amorphous part of the cellulose and became soluble as reported by Moriana et al. (2015), thus obtaining cellulosic fractions with hemicellulose content lower than $1 \%$ in both cases. The CNC purification process consisting of 1-week dialysis, sonication and final centrifugation to remove the highest particles allowed for obtaining crystalline cellulose fractions with high cellulose content in both processes (>95\%). In the case of the bleached sample resulting from the SWE process (RH-SWE-B sample), which showed high ash content (16.6\%), the hydrolysis stage for the CNC isolation 
could also include the silica recovery, since it is a valuable by-product with numerous applications in the glass, foundries, construction, ceramics and the chemical industry. Moreover, it is also used as functional filler for paints, plastics, rubber, and as silica sand in water filtration and agriculture.

Table 2. Chemical composition (in \% wt) of rice husk and the samples obtained after the different process steps to obtain CNCs.

\begin{tabular}{|c|c|c|c|c|c|c|c|}
\hline & \multirow[t]{2}{*}{ Rice Husk } & \multicolumn{3}{|c|}{ Alkali-treatment process } & \multicolumn{3}{|c|}{ Hydrothermal process } \\
\hline & & Alkaline step & Bleaching & Hydrolysis & SWE & Bleaching & Hydrolysis ${ }^{(1)}$ \\
\hline Ara & $1.8 \pm 0.1$ & $2.16 \pm 0.03$ & $1.35 \pm 0.05$ & $<0.1$ & $0.4 \pm 0.1$ & $0.4 \pm 0.1$ & $<0.1$ \\
\hline Gal & $0.9 \pm 0.2$ & $0.69 \pm 0.02$ & $0.20 \pm 0.03$ & $<0.1$ & $<0.1$ & $<0.1$ & $<0.1$ \\
\hline Glc & $35.1 \pm 0.4$ & $59.82 \pm 2.21$ & $73.52 \pm 0.10$ & $96 \pm 5$ & $41.3 \pm 0.8$ & $60 \pm 2$ & $95 \pm 6$ \\
\hline Xyl & $16.7 \pm 1.4$ & $12.20 \pm 0.15$ & $17.00 \pm 0.36$ & $1.03 \pm 0.11$ & $11.1 \pm 0.2$ & $15 \pm 3$ & $<0.1$ \\
\hline $\begin{array}{l}\text { Total } \\
\text { carbohydrates }\end{array}$ & $54.5 \pm 1.3$ & $74.87 \pm 2.41$ & $92.01 \pm 0.20$ & $96 \pm 5$ & $52.9 \pm 0.8$ & $60 \pm 2$ & $95 \pm 6$ \\
\hline Cellulose & $35.1 \pm 0.4$ & $59.82 \pm 2.21$ & $73.52 \pm 0.10$ & $96 \pm 5$ & $41.3 \pm 0.8$ & $60 \pm 2$ & $95 \pm 6$ \\
\hline Hemicellulose & $19.4 \pm 1.7$ & $15.0 \pm 0.2$ & $18.4 \pm 0.3$ & $1.03 \pm 0.11$ & $11.6 \pm 0.2$ & $15 \pm 3$ & $<0.1$ \\
\hline Klason lignin & 33.8 & 20.5 & 9.0 & N/A & 39.5 & 25.0 & N/A \\
\hline Ash & $17.0 \pm 0.2$ & $5.8 \pm 1.2$ & $3.5 \pm 0.2$ & n.d & $17.4 \pm 0.7$ & $16.6 \pm 0.1$ & $0.4 \pm 0.2$ \\
\hline Extractives & $5.46 \pm 0.01$ & - & - & - & - & - & - \\
\hline
\end{tabular}

Fucose, rhamnose, mannose, galacturonic and glucuronic acid were not detected (<0.1). N/A: non applicable.

${ }^{(1)}$ After centrifugation of the CNC suspension for silica separation.

\subsubsection{Micro and nano-structural analyses}

Figure 4 shows the SEM micrographs of the raw rice husk and the different samples obtained throughout both valorization processes to monitor their morphological changes. The fibre bundles of the rice husk remained after alkali extraction and SWE, which indicates the retention of the cementing lignin material, which acts as a binder in the fibre components and preserves the bundle shape during both treatments. Nonetheless, during the alkali treatment a great part of the pectin and hemicellulose fraction was removed, thus opening the cell walls, as reported by Collazo-Bigliardi et al. (2018) and Johar et al. (2012) for the alkali treatment of rice husk. In line with the chemical composition and the above mentioned observed appearance of the insoluble fractions, most of the lignin was removed after the bleaching treatments, liberating the cellulosic fibres. However, the bleached SWE materials showed the presence of some fibre bundles and undisrupted tissue fragments, due to the lower effectiveness of SWE at quantitatively removing the non-cellulosic material. In contrast, sodium hydroxide is reported to decrease the degree of polymerization and bonding of the residue components, interrupts the lignin structure and increase the internal surface of cellulose fibres (Singh et al., 2014), thus promoting the penetration of the chemicals into the structure during the bleaching treatment (Kallel et al., 2016). 

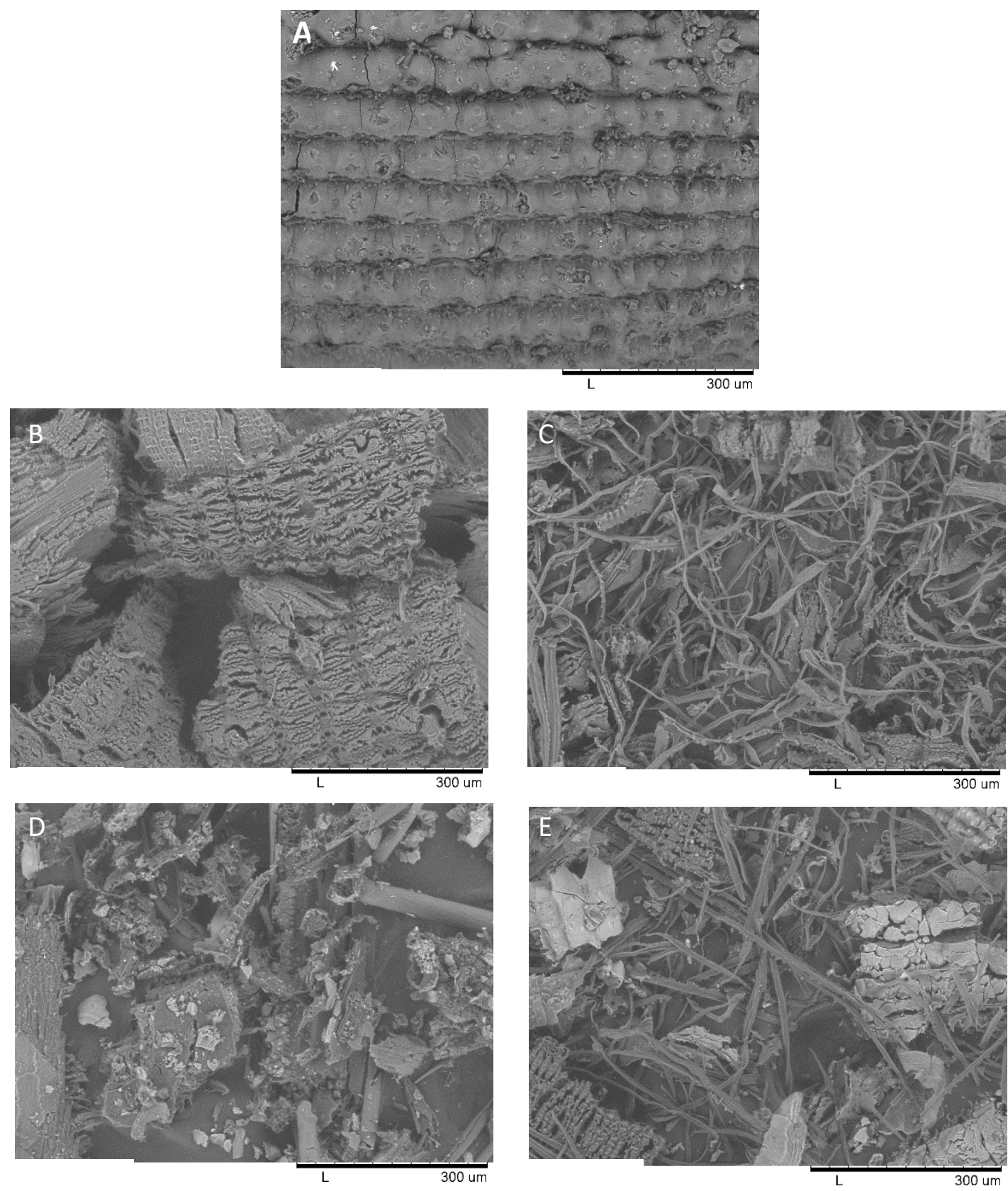

Figure 4. Scanning electron micrographs of different solid fractions of the samples (A) untreated (B) alkali treated, (C) alkali-bleached treated, (D) SWE-treated and (E) SWE-bleached treated.

The morphology and size distribution of CNCs obtained throughout both valorization processes were studied by AFM. Figure 5 shows the AFM image of the isolated CNCs from rice husk, as well as the distribution of the particle diameters (D) and lengths (I) of the CNCS obtained by applying alkali-treatment or hydrothermal processes. The obtained CNCs had the typical rod-like aspect and some crystal aggregates are usually in the dried state, mainly due to the strong hydrogen bonds established between them (Le Normand et al. 2014). 
(a)

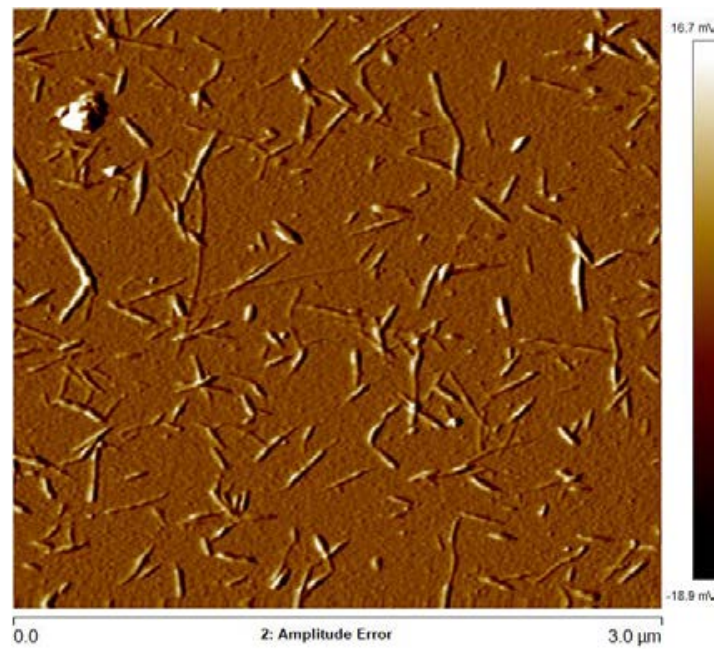

(b)

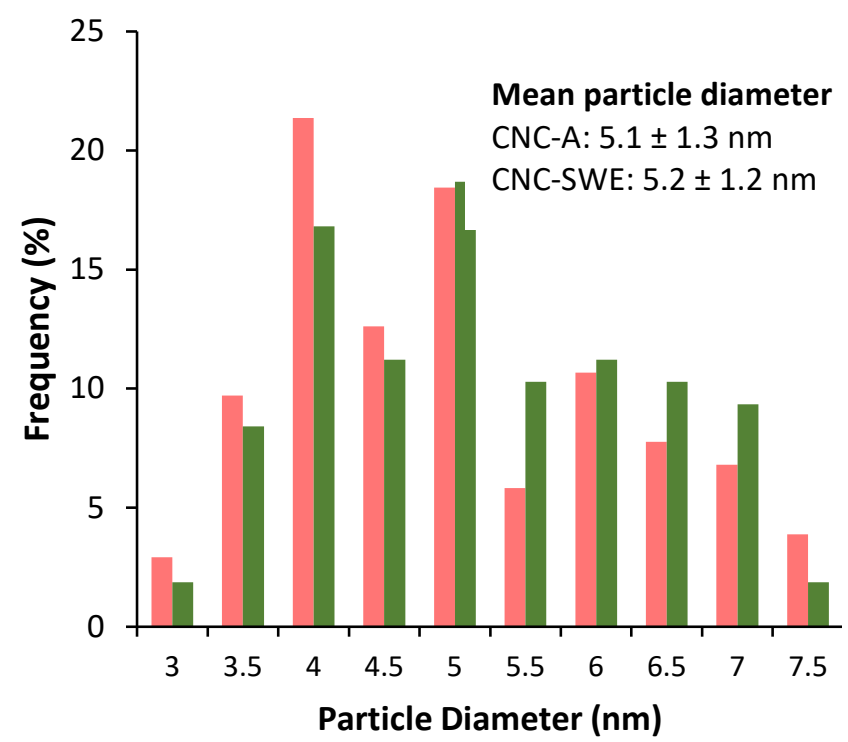

(c)

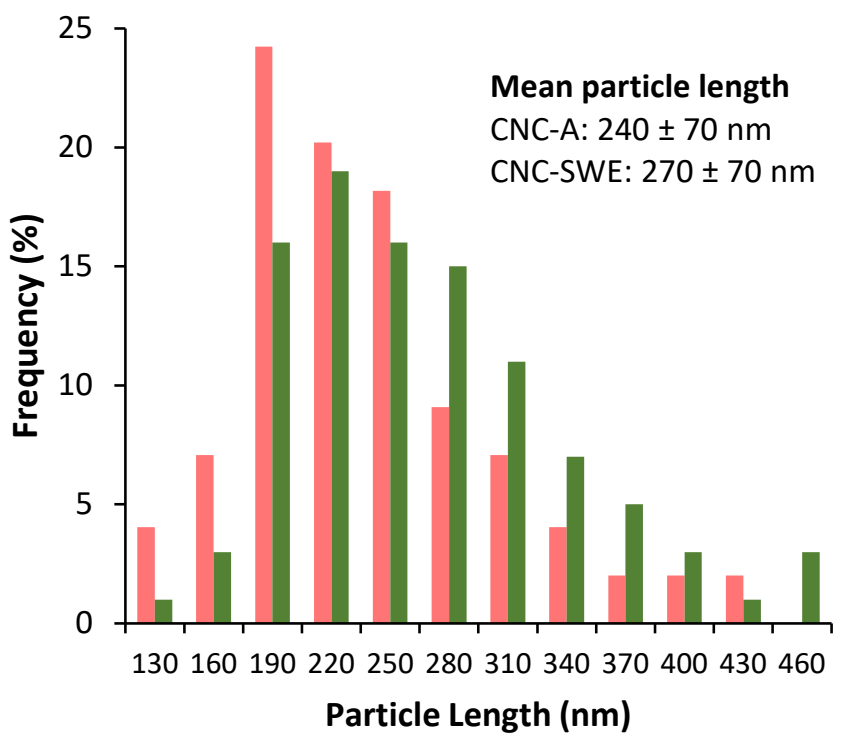

Figure 5. AFM image of the cellulose nanocrystals (CNCs) isolated from rice husk in a amplitude mode (a), diameter (b) and length distributions (c) of CNCs obtained in the alkali-treatment process (red bars) (CNC-A) and the hydrothermal process (green bars) (CNC-W). Mean particle diameter and length are also shown from the analyses of 100 individual CNC particles using AFM by image analyses.

As expected, the length and diameter of the CNCs from rice husk were similar for both processes, with values in the common range (diameter: 2-20 nm and length: 100-600 nm) reported by (Moriana, Vilaplana, \& Ek, 2016). Therefore, the aspect ratio (I/D) was also similar 
in CNCs obtained by both processes, in the range of 30-75. According to Silvério et al. (2013), CNCs can be considered as good reinforcing materials if their aspect ratio is higher than 10 . Collazo-Bigliardi et al. (2018) and Johar et al. (2012) reported higher diameter values (15-50) and lower aspect ratio (10-20) for the CNCs isolated from rice husk, since these parameters can be affected by the nature of the lignocellulosic raw material, mechanical process, pretreatment and conditions of the acid hydrolysis and purification steps (Chauve et al.,2013). Similar aspect ratio was obtained for CNCs from pine cones by using the same CNC isolation procedure (Moriana et al., 2016). The rice husk CNCs obtained by both processes can potentially provide very high reinforcing effects as deduced from their high aspect ratio, enhancing both mechanical and thermal properties of composite materials when used as fillers at low loadings (Eichhorn et al., 2010).

\subsubsection{Crystalline structure analysis}

Figure 6 shows the X-ray diffraction patterns of the untreated rice husk and the different samples obtained after each step of both processes for CNC isolation. In all samples, the typical crystalline peaks of type I cellulose (20: $15-16^{\circ}$ [110], $22^{\circ}$ [200]) were observed as reported by other authors (Collazo-Bigliardi et al., 2018; Johar et al., 2012; Moriana et al., 2016). As expected, these peaks become more defined along the conversion from macro- to nano-dimension, due to the progressive removal of the amorphous phase. This increase resulted in a higher degree of crystallinity as the CNC isolation processes progressed (Figure 6) (Bettaieb et al., 2015; Le Normand et al., 2014; Sheltami et al., 2012).

During the alkaline treatment, the highest $\mathrm{Cr}$ increment was observed, in line with the higher increase in the cellulose content of this insoluble fraction. Significantly lower $\mathrm{Crl}$ values have been reported for alkaline treated rice husk, probably due to differences in the conditions used for this process step (Collazo-Bigliardi et al., 2018; Johar et al., 2012). Nonetheless, similar results were reported for pine needles by Moriana et al. (2016) using the same alkaline treatment conditions. In contrast, SWE yield less crystalline samples, due to its lower effectiveness at removing the amorphous components of the rice husk, commented on above. From the bleached to the hydrolysed samples, slightly higher increment in crystallinity was found for the alkali-treatment process than for the hydrothermal process. This difference could be attributed to the presence of some contaminating amorphous silica in the CNC fraction, despite the applied centrifugation step to separate the remaining silica in the hydrolysate. In fact, although no significant differences in the total cellulose content of both CNC fractions were observed, the obtained variability can justify the Crl difference between the small-size samples used for the XRD analyses. 

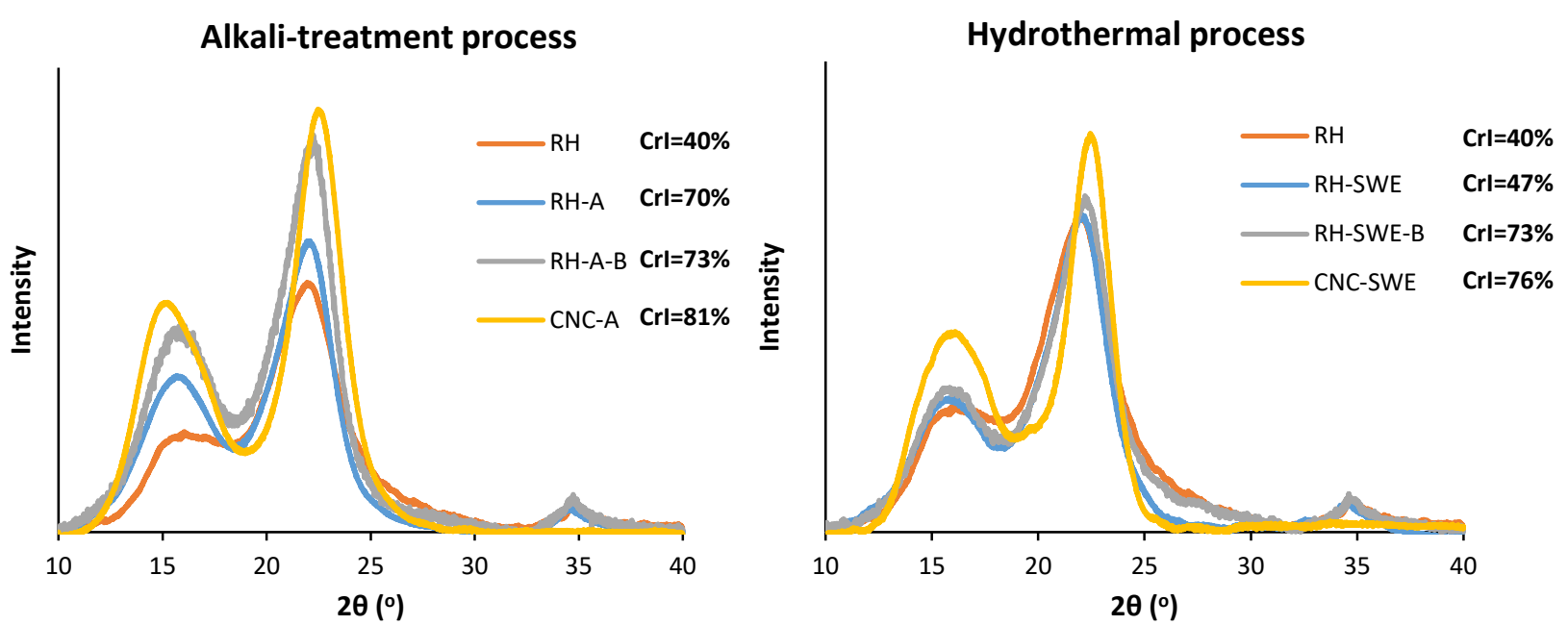

Figure 6. X-ray diffraction patterns of the rice husk $(\mathrm{RH})$ and the different samples obtained along the alkali-treatment process (RH-A: alkali treated; RH-A-B: alkali-bleached treated; CNC-A: cellulose nanocrystals) and the hydrothermal process (RH-SWE: SWE treated; RH-SWE-B: SWE-bleached treated; CNC-SWE: cellulose nanocrystals). Their corresponding crystalline index (Crl) are shown.

\subsubsection{Chemical structure analysis}

FTIR was performed to evaluate the expected chemical changes induced by the different treatments. The FTIR spectra of the untreated rice husk and the different samples obtained throughout both CNC isolation processes are shown in Figure 7. The alkali-treated samples and the corresponding bleached and hydrolysed samples showed a higher peak in the region related to the stretching vibrations of $\mathrm{OH}$ groups of the cellulose $\left(3330 \mathrm{~cm}^{-1}\right)$ (Reddy \& Rhim 2014), when compared to the untreated rice husk, due to the relative increase in the hydrogen bond strength, because of the removal of the amorphous components present in the untreated material with the subsequent increased crystallinity (Johar et al., 2012; Moriana et al., 2016). This change in FTIR spectra was less noticeable in the samples obtained from the hydrothermal process, due to the presence of higher amounts of remaining amorphous components, as previously commented on, associated with the lower effectiveness of the SWE process to disrupt the tissue structure and release the different amorphous components. The peaks at approximately 1700-1590 (carboxylic acid), 1509 (acetyl group) and $1250 \mathrm{~cm}^{-1}$ (methyl ester group), which are related to the lignin structure, were also disappearing along the conversion from macro- to nano-dimension, thus proving the removal of most of noncellulosic material (Johar et al., 2012; Moriana et al., 2016). 

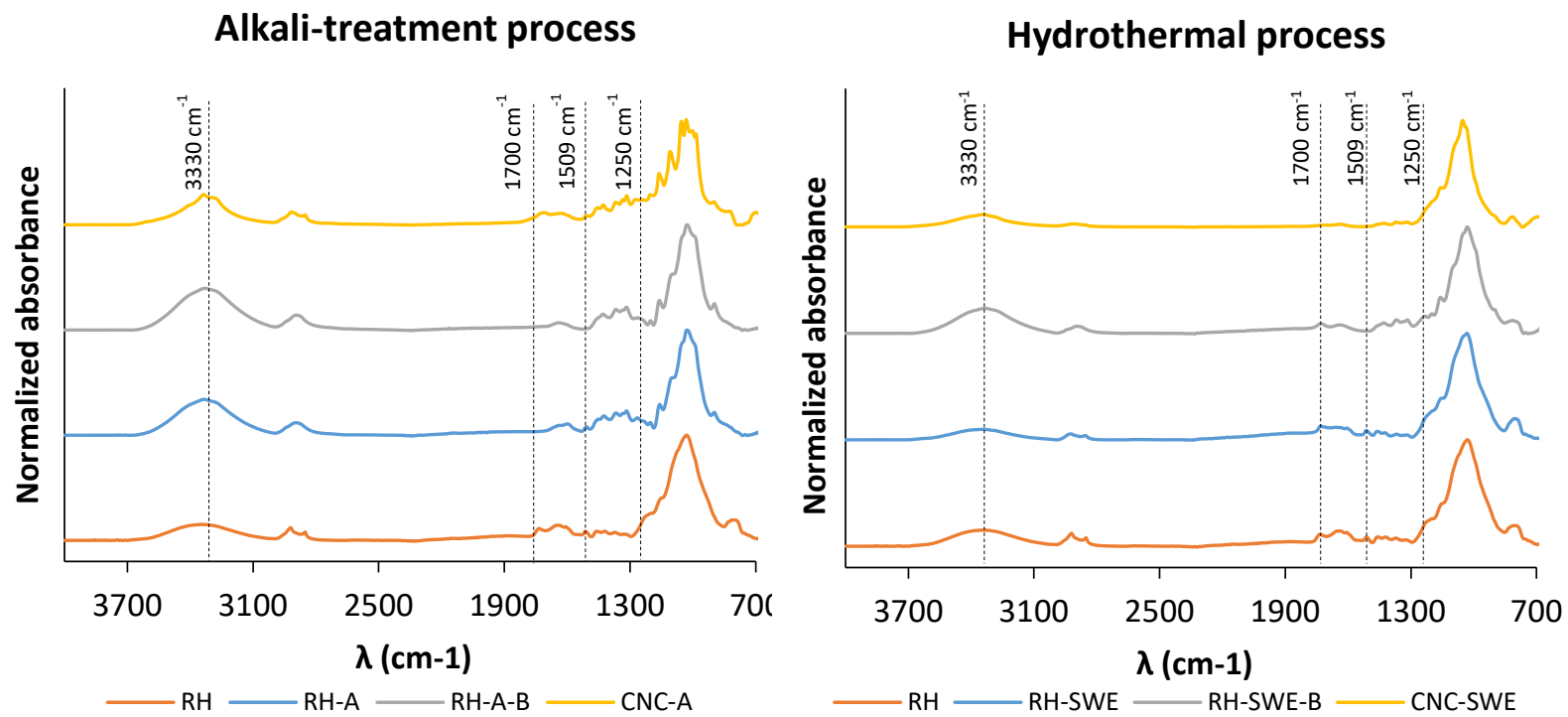

Figure 7. FTIR spectra for the rice husk $(\mathrm{RH})$ and the different samples obtained along the alkalitreatment process (RH-A: alkali treated; $\mathrm{RH}-\mathrm{A}-\mathrm{B}$ : alkali-bleached treated; $\mathrm{CNC}-\mathrm{A}$ : cellulose nanocrystals) and the hydrothermal process (RH-SWE: SWE treated; RH-SWE-B: SWE-bleached treated; CNC-SWE: cellulose nanocrystals).

\subsubsection{Thermogravimetric analysis}

Thermogravimetric analyses were carried out to determine the thermal stability of the rice husk fibres and the different samples obtained along both processes. Figure 8 shows the TG and DTG curves obtained for the different samples, where two main mass loss steps at higher and lower temperatures are distinguished, excluding the CNC samples. The mass loss step $<<$ $3 \%)$ at lower temperature $\left(25-150^{\circ} \mathrm{C}\right)$ is attributed to the loss of the absorbed water, whereas the main step (>55\%) at temperatures between $180^{\circ} \mathrm{C}$ and $550^{\circ} \mathrm{C}$ is assigned to the thermal degradation of the sample components, where the degradation of the main compounds (cellulose, hemicellulose and lignin) occurred. The TGA also validated the extraction of the amorphous components during the alkaline and bleaching treatments, since the main degradation peak showed smaller shoulders at lower temperature (attributes to the amorphous fraction) on the DTG curve. These amorphous components have a lower degradation temperatures compared to cellulose and their progressive removal implied higher thermal stability of the material (Johar et al., 2012). Thus, the materials resulting from the different treatments degraded within a narrower temperature range and showed better thermal stability than the raw material (Table $\mathbf{3}$ ). The hydrolysis reaction gave rise to more thermosensitive samples, due to the surface sulphation resulting from the sulphuric acid treatment (Fahma et al., 2010; Johar et al., 2012). CNCs coming from the alkali-treatment process (CNC-A) were more thermostable than those from the hydrothermal process (CNC- 
SWE), which could be related with the lower crystallinity of this fraction. Both kind of CNCS exhibited a degradation pattern where three overlapping steps can be distinguished: the first one at lower temperature associated with the sulphate groups that catalyse the dehydration process of cellulose; the second one related to the breakdown of the more accessible region in the crystal interior; and the last one at higher temperature associated with the less accessible crystal interior of the CNCs as reported by (Moriana et al. (2016).

(b)

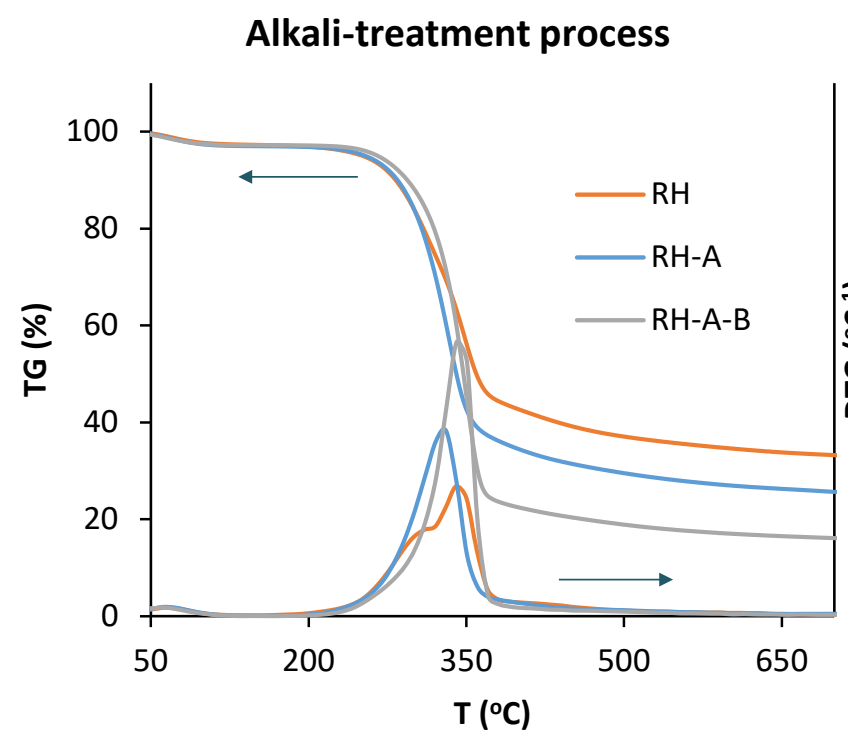

CNCs

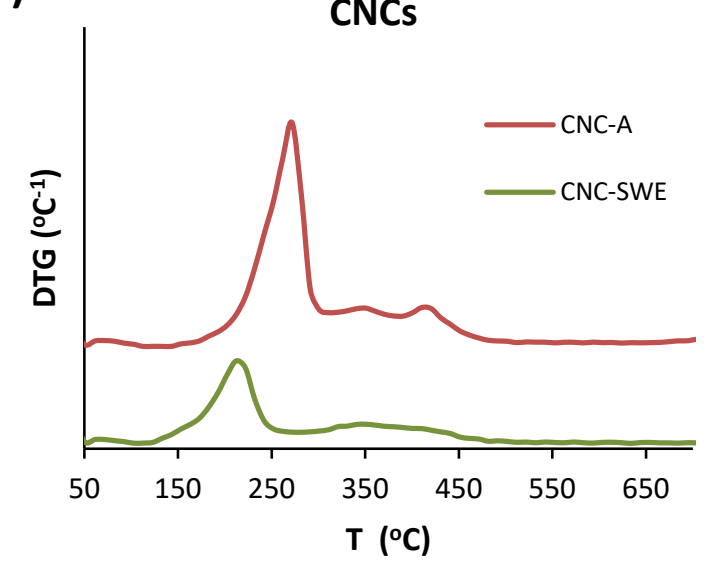

Hydrothermal process

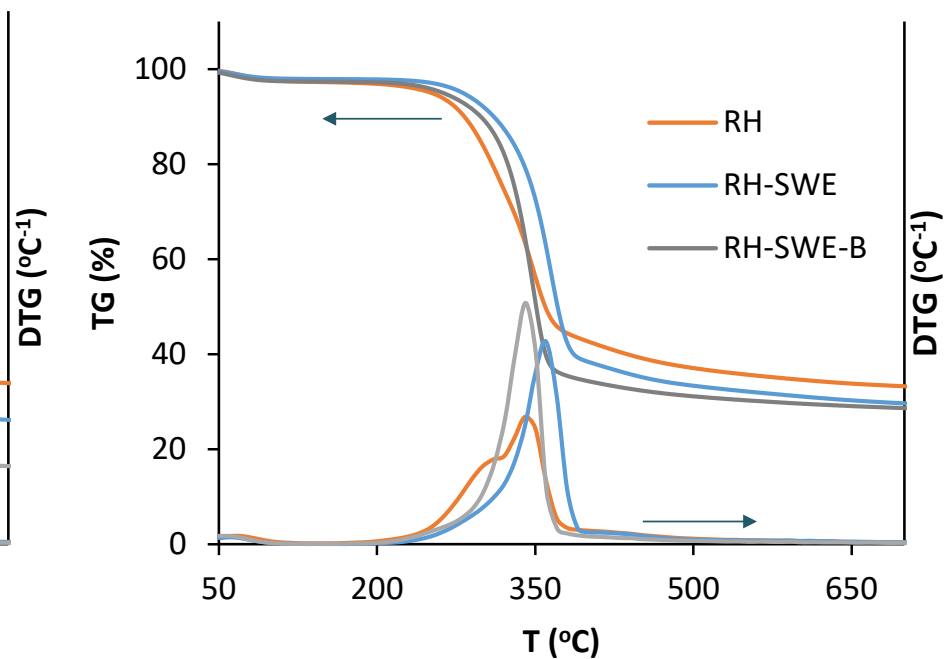

Figure 8. (a) Derivative curves (DTG) curves of cellulose nanocrystals (CNCs) obtained from both alkalitreatment process (CNC-A) and hydrothermal process (CNC-SWE). (b) Thermogravimetric (TG) and DTG curves for rice husk $(\mathrm{RH})$ and the different materials resulting from the alkali treatment process (RH-A: alkali treated; RH-A-B: alkali-bleached treated) and the hydrothermal process (RH-SWE: SWE treated; RH-SWE-B: SWE-bleached treated). 
Table 3. Thermogravimetric parameters of the raw rice husk $(\mathrm{RH})$ and the different samples obtained along the alkali-treatment process (RH-A: alkali treated; RH-A-B: alkali-bleached treated; CNC-A: cellulose nanocrystals) and the hydrothermal process (RH-SWE: SWE treated; RH-SWE-B: SWEbleached treated; CNC-SWE: cellulose nanocrystals).

\begin{tabular}{|c|c|c|c|c|c|c|}
\hline \multirow[t]{2}{*}{ Sample } & \multicolumn{2}{|c|}{$[25-150]^{\circ} \mathrm{C}$} & \multicolumn{3}{|c|}{$[180-550]^{\circ} \mathrm{C}$} & \multirow{2}{*}{$\begin{array}{l}\text { Residue } \\
\text { Mass (\%) }\end{array}$} \\
\hline & Mass loss (\%) & $\mathrm{T}_{\max }\left({ }^{\circ} \mathrm{C}\right)$ & $\mathrm{T}_{\text {onset }}\left({ }^{\circ} \mathrm{C}\right)$ & Mass loss (\%) & $\mathrm{T}_{\max }\left({ }^{\circ} \mathrm{C}\right)$ & \\
\hline $\mathrm{RH}$ & $2.77 \pm 0.04$ & $70.3 \pm 0.9$ & $252.3 \pm 1.3$ & $55.0 \pm 0.4$ & $345.4 \pm 0.8$ & $32.6 \pm 0.2$ \\
\hline $\mathrm{RH}-\mathrm{A}$ & $3.01 \pm 0.05$ & $67.2 \pm 2.1$ & $274.6 \pm 0.5$ & $63.6 \pm 1.3$ & $330.8 \pm 0.1$ & $23.8 \pm 1.7$ \\
\hline RH-A-B & $2.86 \pm 0.09$ & $60.5 \pm 4.2$ & $303.0 \pm 0.3$ & $74.7 \pm 0.2$ & $346.8 \pm 0.1$ & $15.9 \pm 0.2$ \\
\hline CNC-A & - & - & $223.1 \pm 3.2$ & $50.2 \pm 2.8$ & $\begin{array}{c}271 \pm 6 / 315 \\
\pm 6 / 416 \pm 5\end{array}$ & $35.8 \pm 3.3$ \\
\hline RH-SWE & $2.13 \pm 0.10$ & $59.3 \pm 0.4$ & $318.3 \pm 0.3$ & $59.9 \pm 0.3$ & $363.8 \pm 0.5$ & $28.9 \pm 0.4$ \\
\hline RH-SWE-B & $2.63 \pm 0.01$ & $55.0 \pm 0.6$ & $301.8 \pm 1.3$ & $63.5 \pm 0.4$ & $344.4 \pm 0.1$ & $27.9 \pm 0.6$ \\
\hline CNC-SWE & - & - & $173.9 \pm 2.4$ & $45.3 \pm 0.4$ & $\begin{array}{c}216 \pm 1 / 354 \\
\pm 2 / 421 \pm 1\end{array}$ & $39.9 \pm 0.5$ \\
\hline
\end{tabular}

\section{CONCLUSION}

As concerns the rice husk valorization to obtain high value products such as bioactive compounds and cellulosic reinforcing agents, SWE process allows for obtaining better preserved hemicellulose fractions, with antioxidant and antibacterial activity, useful as additives for food or food packaging, at the same time that it supposes a more eco-friendly process, avoiding the use of alkali solutions. Despite the fact that it was less effective at purifying the cellulosic fraction, the subsequent bleaching and acid hydrolysis mitigate this apparent drawback, at the same time that gave additional value to the process due to the fact that would allow for the silica recovery, which was extracted in the alkali step, and maintained in the SWE. This fraction of high value could be separated from the SWE-hydrolysate fraction which also contains the CNCs. The CNCs obtained from rice husk exhibited a high aspect ratio which confer them very good reinforcing capacity to obtain improved composites. 


\section{REFERENCES}

Abraham, A., Mathew, A. K., Sindhu, R., Pandey, A., \& Binod, P. (2016). Potential of rice straw for biorefining: an overview. Bioresource technology, 215, 29-36.

Allen, S. G., Schulman, D., Lichwa, J., Antal, M. J., Laser, M., \& Lynd, L. R. (2001). A comparison between hot liquid water and steam fractionation of corn fiber. Industrial \& Engineering Chemistry Research, 40(13), 2934-2941.

Battegazzore, D., Bocchini, S., Alongi, J., Frache, A., \& Marino, F. (2014). Cellulose extracted from rice husk as filler for poly (lactic acid): preparation and characterization. Cellulose, 21(3), 1813-1821.

Bettaieb, F., Khiari, R., Hassan, M. L., Belgacem, M. N., Bras, J., Dufresne, A., \& Mhenni, M. F. (2015). Preparation and characterization of new cellulose nanocrystals from marine biomass Posidonia oceanica. Industrial Crops and Products, 72, 175-182.

Brand-Williams, W., Cuvelier, M. E., \& Berset, C. L. W. T. (1995). Use of a free radical method to evaluate antioxidant activity. LWT-Food science and Technology, 28(1), 25-30.

Brienzo, M., Carvalho, A. F. A., de Figueiredo, F. C., \& de Oliva Neto, P. (2016). Sugarcane bagasse hemicellulose properties, extraction technologies and xylooligosaccharides production. In Food Waste: Practices, Management and Challenges (pp. 155-188). Nova Science Publishers New York.

Brinchi, L., Cotana, F., Fortunati, E., \& Kenny, J. M. (2013). Production of nanocrystalline cellulose from lignocellulosic biomass: technology and applications. Carbohydrate Polymers, 94(1), 154-169.

Chauve, G., Fraschini, C., \& Jean, B. (2013). Separation of cellulose nanocrystals. In K. Oksman, A. P. Mathew, A. Bismark, O. Rojas, \& M. Sain (Eds.). Handbook of green materials: Processing technologies, properties and applications (pp. 73-87). World Scientific Publishing Co.

Ciucanu, I., \& Kerek, F. (1984). A simple and rapid method for the permethylation of carbohydrates. Carbohydrate Research, 131(2), 209-217.

Collazo-Bigliardi, S., Ortega-Toro, R., \& Boix, A. C. (2018). Isolation and characterisation of microcrystalline cellulose and cellulose nanocrystals from coffee husk and comparative study with rice husk. Carbohydrate Polymers, 191, 205-215.

Delgado, G. T. C., Tamashiro, W. M. D. S. C., Junior, M. R. M., Moreno, Y. M. F., \& Pastore, G. M. (2011). The putative effects of prebiotics as immunomodulatory agents. Food Research International, 44(10), 3167-3173.

Ebringerová, A., Hromádková, Z., Alfödi, J., \& Hř́balová, V. (1998). The immunologically active xylan from ultrasound-treated corn cobs: extractability, structure and properties. Carbohydrate Polymers, $37(3), 231-239$.

Ebrahimi, M., Villaflores, O. B., Ordono, E. E., \& Caparanga, A. R. (2017). Effects of acidified aqueous glycerol and glycerol carbonate pretreatment of rice husk on the enzymatic digestibility, structural characteristics, and bioethanol production. Bioresource Technology, 228, 264-271.

Ebringerová, A., Hromádková, Z., Koštálová, Z., \& Sasinková, V. (2007). Chemical valorization of agricultural by-products: isolation and characterization of xylan-based antioxidants from almond shell biomass. BioResources, 3(1), 60-70. 
Ebringerová, A., Hromádková, Z., Hř́balová, V., Xu, C., Holmbom, B., Sundberg, A., \& Willför, S. (2008). Norway spruce galactoglucomannans exhibiting immunomodulating and radical-scavenging activities. International Journal of Biological Macromolecules, 42(1), 1-5.

Egüés, I., Stepan, A. M., Eceiza, A., Toriz, G., Gatenholm, P., \& Labidi, J. (2014). Corncob arabinoxylan for new materials. Carbohydrate Polymers, 102, 12-20.

García-García, D., Balart, R., Lopez-Martinez, J., Ek, M., \& Moriana, R. Optimizing the yield and physicochemical properties of pine cone cellulose nanocrystals by different hydrolysis time. Cellulose, 1-14

Gordobil, O., Moriana, R., Zhang, L., Labidi, J., \& Sevastyanova, O. (2016). Assesment of technical lignins for uses in biofuels and biomaterials: Structure-related properties, proximate analysis and chemical modification. Industrial Crops and Products, 83, 155-165.

Grootaert, C., Delcour, J. A., Courtin, C. M., Broekaert, W. F., Verstraete, W., \& Van de Wiele, T. (2007). Microbial metabolism and prebiotic potency of arabinoxylan oligosaccharides in the human intestine. Trends in Food Science \& Technology, 18(2), 64-71.

Gullón, P., Moura, P., Esteves, M. P., Girio, F. M., Domínguez, H., \& Parajó, J. C. (2008). Assessment on the fermentability of xylooligosaccharides from rice husks by probiotic bacteria. Journal of agricultural and food chemistry, 56(16), 7482-7487.

Hamzeh, Y., Ziabari, K. P., Torkaman, J., Ashori, A., \& Jafari, M. (2013). Study on the effects of white rice husk ash and fibrous materials additions on some properties of fiber-cement composites. Journal of Environmental Management, 117, 263-267.

Hanim, S. S., Norsyabilah, R., Suhaila, M. N., Noraishah, A., \& Kartina, A. S. (2012). Effects of temperature, time and pressure on the hemicelluloses yield extracted using subcritical water extraction. Procedia Engineering, 42, 562-565.

Hessien, M. M., Rashad, M. M., Zaky, R. R., Abdel-Aal, E. A., \& El-Barawy, K. A. (2009). Controlling the synthesis conditions for silica nanosphere from semi-burned rice straw. Materials Science and Engineering: $B, 162(1), 14-21$.

Hromadkova, Z., Kováčiková, J., \& Ebringerová, A. (1999). Study of the classical and ultrasound-assisted extraction of the corn cob xylan. Industrial Crops and Products, 9(2), 101-109.

Hromádková, Z., Ebringerová, A., \& Malovíková, A. (2005). The Structural, Molecular and Functional Properties of Lignin-Containing Beechwood Glucuronoxylan. In Macromolecular Symposia (Vol. 232, No. 1, pp. 19-26). WILEY-VCH Verlag.

Hromádková, Z., Košt'álová, Z., \& Ebringerová, A. (2008). Comparison of conventional and ultrasoundassisted extraction of phenolics-rich heteroxylans from wheat bran. Ultrasonics Sonochemistry, 15(6), 1062-1068.

Hromádková, Z., Hirsch, J., \& Ebringerová, A. (2010). Chemical evaluation of fallopia species leaves and antioxidant properties of their non-cellulosic polysaccharides. Chemical Papers, 64(5), 663-672.

Johar, N., Ahmad, I., \& Dufresne, A. (2012). Extraction, preparation and characterization of cellulose fibres and nanocrystals from rice husk. Industrial Crops and Products, 37(1), 93-99. 
Johar, N., \& Ahmad, I. (2012). Morphological, thermal, and mechanical properties of starch biocomposite films reinforced by cellulose nanocrystals from rice husks. BioResources, 7(4), 54695477.

Kallel, F., Bettaieb, F., Khiari, R., García, A., Bras, J., \& Chaabouni, S. E. (2016). Isolation and structural characterization of cellulose nanocrystals extracted from garlic straw residues. Industrial Crops and Products, 87, 287-296.

Kilpeläinen, P. O., Hautala, S. S., Byman, O. O., Tanner, L. J., Korpinen, R. I., Lillandt, M. K., ... \& Ilvesniemi, H. S. (2014). Pressurized hot water flow-through extraction system scale up from the laboratory to the pilot scale. Green Chemistry, 16(6), 3186-3194.

Kumar, P., Barrett, D. M., Delwiche, M. J., \& Stroeve, P. (2009). Methods for pretreatment of lignocellulosic biomass for efficient hydrolysis and biofuel production. Industrial \& Engineering Chemistry Research, 48(8), 3713-3729.

Le Normand, M., Moriana, R., \& Ek, M. (2014). Isolation and characterization of cellulose nanocrystals from spruce bark in a biorefinery perspective. Carbohydrate Polymers, 111, 979-987.

Martínez-Abad, A., Giummarella, N., Lawoko, M., \& Vilaplana, F. (2018). Differences in extractability under subcritical water reveal interconnected hemicellulose and lignin recalcitrance in birch hardwoods. Green Chemistry, 20, 2534-2546.

McKee, L. S., Sunner, H., Anasontzis, G. E., Toriz, G., Gatenholm, P., Bulone, V., \& Olsson, L. (2016). A GH115 $\alpha$-glucuronidase from Schizophyllum commune contributes to the synergistic enzymatic deconstruction of softwood glucuronoarabinoxylan. Biotechnology for Biofuels, 9(1), 2.

Melo-Silveira, R. F., Fidelis, G. P., Costa, M. S. S. P., Telles, C. B. S., Dantas-Santos, N., Elias, S. D. O., \& Rocha, H. A. O. (2011). In vitro antioxidant, anticoagulant and antimicrobial activity and in inhibition of cancer cell proliferation by xylan extracted from corn cobs. International Journal of Molecular Sciences, 13(1), 409-426.

Moriana, R., Vilaplana, F., \& Ek, M. (2016). Cellulose nanocrystals from forest residues as reinforcing agents for composites: A study from macro-to nano-dimensions. Carbohydrate Polymers, 139, 139149.

Mosier, N., Wyman, C., Dale, B., Elander, R., Lee, Y. Y., Holtzapple, M., \& Ladisch, M. (2005). Features of promising technologies for pretreatment of lignocellulosic biomass. Bioresource Technology, 96(6), 673-686.

Nabarlatz, D., Ebringerová, A., \& Montané, D. (2007). Autohydrolysis of agricultural by-products for the production of xylo-oligosaccharides. Carbohydrate Polymers, 69(1), 20-28.

NREL: Determination of Extractives in Biomass (2005). Laboratory Analytical Procedure. Golden, CO: NREL.

Prado, J. M., Forster-Carneiro, T., Rostagno, M. A., Follegatti-Romero, L. A., Maugeri Filho, F., \& Meireles, M. A. A. (2014). Obtaining sugars from coconut husk, defatted grape seed, and pressed palm fiber by hydrolysis with subcritical water. The Journal of Supercritical Fluids, 89, 89-98. 
Prado, J. M., Lachos-Perez, D., Forster-Carneiro, T., \& Rostagno, M. A. (2016). Sub-and supercritical water hydrolysis of agricultural and food industry residues for the production of fermentable sugars: a review. Food and Bioproducts Processing, 98, 95-123

Prasad, R., \& Pandey, M. (2012). Rice husk ash as a renewable source for the production of value added silica gel and its application: an overview. Bulletin of Chemical Reaction Engineering \& Catalysis, 7(1).

Pristov, J. B., Mitrović, A., \& Spasojević, I. (2011). A comparative study of antioxidative activities of cellwall polysaccharides. Carbohydrate Research, 346(14), 2255-2259.

Reddy, J. P., \& Rhim, J. W. (2014). Isolation and characterization of cellulose nanocrystals from garlic skin. Materials Letters, 129, 20-23.

Requena, R., Vargas, M., \& Chiralt, A. (2018). Eugenol and carvacrol migration from PHBV films and antibacterial action in different food matrices. Food Chemistry (Under review).

Rivero-Urgell, M., \& Santamaria-Orleans, A. (2001). Oligosaccharides: application in infant food. Early Human Development, 65, S43-S52.

Rose, D. J., \& Inglett, G. E. (2010). Production of feruloylated arabinoxylo-oligosaccharides from maize (Zea mays) bran by microwave-assisted autohydrolysis. Food Chemistry, 119(4), 1613-1

Ruthes, A. C., Martínez-Abad, A., Tan, H. T., Bulone, V., \& Vilaplana, F. (2017). Sequential fractionation of feruloylated hemicelluloses and oligosaccharides from wheat bran using subcritical water and xylanolytic enzymes. Green Chemistry, 19(8), 1919-1931.

Saeman, J. F., Moore, W. E., Mitchell, R. L., \& Millett, M. A. (1954). Techniques for the determination of pulp constituents by quantitiative paper chromatography. Tappi Journal, 37(8), 336-343.

Segal, L. G. J. M. A., Creely, J. J., Martin Jr, A. E., \& Conrad, C. M. (1959). An empirical method for estimating the degree of crystallinity of native cellulose using the $\mathrm{X}$-ray diffractometer. Textile Research Journal, 29(10), 786-794.

Sheltami, R. M., Abdullah, I., Ahmad, I., Dufresne, A., \& Kargarzadeh, H. (2012). Extraction of cellulose nanocrystals from mengkuang leaves (Pandanus tectorius). Carbohydrate Polymers, 88(2), 772-779.

Silvério, H. A., Neto, W. P. F., Dantas, N. O., \& Pasquini, D. (2013). Extraction and characterization of cellulose nanocrystals from corncob for application as reinforcing agent in nanocomposites. Industrial Crops and Products, 44, 427-436.

Singh, R., Shukla, A., Tiwari, S., \& Srivastava, M. (2014). A review on delignification of lignocellulosic biomass for enhancement of ethanol production potential. Renewable and Sustainable Energy Reviews, 32, 713-728.

Talón, E., Trifkovic, K. T., Nedovic, V. A., Bugarski, B. M., Vargas, M., Chiralt, A., \& González-Martínez, C. (2017). Antioxidant edible films based on chitosan and starch containing polyphenols from thyme extracts. Carbohydrate Polymers, 157, 1153-1161.

TAPPI (2006). Acid insoluble lignin in wood and pulp, T 222 om-06; 2006. US. Technical Association of Pulp and Paper Industry).

Toor, S. S., Rosendahl, L., \& Rudolf, A. (2011). Hydrothermal liquefaction of biomass: a review of subcritical water technologies. Energy, 36(5), 2328-2342. 
Torkaman, J., Ashori, A., \& Momtazi, A. S. (2014). Using wood fiber waste, rice husk ash, and limestone powder waste as cement replacement materials for lightweight concrete blocks. Construction and Building Materials, 50, 432-436.

Tran, T. P. T., Bénézet, J. C., \& Bergeret, A. (2014). Rice and Einkorn wheat husks reinforced poly (lactic acid)(PLA) biocomposites: effects of alkaline and silane surface treatments of husks. Industrial Crops and Products, 58, 111-124.

Tsai, W. T., Lee, M. K., \& Chang, Y. M. (2007). Fast pyrolysis of rice husk: Product yields and compositions. Bioresource Technology, 98(1), 22-28.

Vazquez, M. J., Alonso, J. L., Domınguez, H., \& Parajo, J. C. (2000). Xylooligosaccharides: manufacture and applications. Trends in Food Science \& Technology, 11(11), 387-393.

Vegas, R., Alonso, J. L., Domínguez, H., \& Parajó, J. C. (2004). Processing of rice husk autohydrolysis liquors for obtaining food ingredients. Journal of Agricultural and Food Chemistry, 52(24), 7311-7317.

Wang, J., Yuan, X., Sun, B., Cao, Y., Tian, Y., \& Wang, C. (2009). On-line separation and structural characterisation of feruloylated oligosaccharides from wheat bran using HPLC-ESI-MSn. Food Chemistry, 115(4), 1529-1541.

$\mathrm{Wu}$, C. S. (2014). Preparation and characterization of polyhydroxyalkanoate bioplastic-based green renewable composites from rice husk. Journal of Polymers and the Environment, 22(3), 384-392.

Yussuf, A. A., Massoumi, I., \& Hassan, A. (2010). Comparison of polylactic acid/kenaf and polylactic acid/rise husk composites: the influence of the natural fibers on the mechanical, thermal and biodegradability properties. Journal of Polymers and the Environment, 18(3), 422-429.

Zhao, Q., Tao, J., Yam, R. C., Mok, A. C., Li, R. K., \& Song, C. (2008). Biodegradation behavior of polycaprolactone/rice husk ecocomposites in simulated soil medium. Polymer Degradation and Stability, 93(8), 1571-1576.

Zhang, Z., Smith, C., \& Li, W. (2014). Extraction and modification technology of arabinoxylans from cereal by-products: a critical review. Food Research International, 65, 423-436. 618.

Zhang, X., Zhang, H., \& Na, Y. (2015). Transformation of sodium during the ashing of Zhundong coal. Procedia Engineering, 102, 305-314.

Zhou, S., Liu, X., Guo, Y., Wang, Q., Peng, D., \& Cao, L. (2010). Comparison of the immunological activities of arabinoxylans from wheat bran with alkali and xylanase-aided extraction. Carbohydrate Polymers, 81(4), 784-789. 



\section{GENERAL DISCUSSION}


Development of environmentally friendly alternatives such as bio-based and/or biodegradable food packaging materials is one of the current research trends that face the environmental problems associated to the high consumption of synthetic plastics. Active packaging materials also constitute an adequate strategy to extend food shelf-life, and better maintain food quality and safety. Of the different biodegradable polymers, PHAs are those gaining attention due to the broad chemical variety of their radicals, which provides physical properties as good as the ones exhibited by conventional polymers. Moreover, some PHA packaging materials offer good resistance to moisture, because of their hydrophobic nature and gas barrier properties comparable to some synthetic polymers such as PVC and PET, with the advantage of being completely biodegradable. Compared to polysaccharide-based materials, PHAs films exhibit much better moisture barrier properties, whereas the gas barrier capacity is inferior. Nevertheless, they have some drawbacks related with their use. Specifically, PHBV films are brittle, stiff, relatively permeable to oxygen and expensive. In this sense, different strategies such as the addition of plasticizers and/or active compounds, polymer blends, multilayer systems and composites can be implemented in order to enhance their functional properties as packaging materials. In the present Doctoral Thesis, the development of active biomaterials for food packaging applications was addressed by using PHBV combined with other biopolymers (PLA and starch) and using different antimicrobial agents, such as essential oil compounds. In this sense, different PHBV-based multiphase materials were obtained.

The first strategy used, analysed in Chapter 1. I, was to develop more extensible PHBV films by using different plasticizers, since they are reported to reduce the intermolecular forces along polymer chains, which improve the flexibility and chain mobility, at the same time that they provoke changes in the crystallization behaviour. Thus, PHBV films were obtained by compression moulding, adding five different plasticizers (polyethylenglycol (PEG) with different molecular weight 200, 1000 and 4000, as well as stearic (SA) and lauric acid (LA) in a constant amount $(10 \% \mathrm{w} / \mathrm{w})$ to obtain a more extensible material. Plasticizers hindered the PHBV crystallization and decreased the melting temperature, which suggests a thinner lamella in the plasticized films as compared to the neat PHBV films. PEG1000 and PEG4000 gave rise to the most heat-resistant plasticized films while LA and SA highly promoted the heatsensitivity of PHBV. The polymers inter-chain forces were weakened by the incorporation of PEG or LA in the film, as deduced by the reported decrease in the film stiffness and resistance, but only PEG1000 yielded more extensible films and partially mitigated the aging effects. Likewise, the increase in the free volume of the polymeric structure provoked by plasticisation enhanced the diffusion rate of water molecules and then the permeation rate. Based on these results, PEG1000 was selected to develop PHBV based films for the subsequent studies in the Doctoral Thesis. 
In Chapter 1. II, the challenge was to obtain PHBV active films by applying essential oils (EOs) to reduce or inhibit the microbial growth and the oxidative processes in foods, since EOs have shown antioxidant and antimicrobial activity and have been recognized as safe by the US Food and Drug Administration.

The incorporation of EOs as active compounds into biodegradable films involves high losses of volatiles when the films are made, both by extension and drying of the film-forming dispersions (casting) and by thermo-processing (extrusion or melt blending). Conversely, the incorporation of EOs by spraying them on one side of a film and the subsequent thermocompression of two films, obtaining a bilayer film with the active compounds at the interface, could be an appropriate strategy for improving the process of obtention of active films. In this way, the release of the active compounds would occur progressively from the package to the food surface or to the headspace of the packaging. This approach would avoid the direct application of the active compounds on the food, which has been previously found to have serious drawbacks. In this sense, multilayer assembly were developed by spraying the active compound (oregano essential oil, clove essential oil and their respective main compounds carvacrol and eugenol), at the interface between two layers of PHBV. The effect of the active components on the resulting functional properties (tensile, barrier and optical properties, as well as thermal behaviour) of PHBV bilayer films and their antimicrobial activity against Escherichia coli and Listeria innocua was also analysed in in vitro tests. Although the tensile properties of the films were not improved with respect to the control bilayer films (without active compunds), the incorporation of the active compounds produced more transparent materials with better water vapour barrier capacity, in line with their hydrophobic nature. Moreover, PHBV active films controlled the microbial growth of the two tested bacteria in in vitro tests, oregano EO and its main compound, carvacrol, being the most effective antimicrobials. Therefore, they would allow the foodstuffs to be better preserved against microbial decay, thus contributing to extend their shelf-life.

The effectiveness of the films as carriers of antimicrobial compounds does not only depend on the nature of the actives, but also on the capacity of the film to release an adequate concentration of the active to the food at a given contact time or at equilibrium (partition coefficient). Likewise, the antimicrobial effectiveness depends on the interactions between the active and the polymer matrix and its solubility in the food system. Therefore, the release kinetics of the active compound into the food throughout the storage time is a crucial factor for guaranteeing the film antimicrobial effectiveness and food safety. In order to predict the antimicrobial activity of these active films in foods, Chapter 1 . III studies the release kinetics of carvacrol (CA) and eugenol (EU) in food simulants of different polarity. The release rate increased when the polarity of aqueous simulants decreased, but it fell markedly in fatty systems. Thus, at equilibrium, the almost total release of both CA and EU occurred in $50 \%$ ethanol; in the more aqueous simulants about 20 and $50 \%$ of CA and EU, respectively, was delivered and $65-70 \%$ was released in fatty systems. Likewise, EU was released faster than CA 
in the less polar simulants, but more slowly in the more aqueous systems. In this way, the time needed to reach a concentration level of active in the food higher than the minimum inhibitory concentration (MIC) can be predicted in order to ensure the food safety, thus providing useful information about the ability of the active packaging to exert the antimicrobial function in real foodstuffs.

The concentration of EOs or their constituents required to inhibit bacterial growth in foods can modify the taste, reducing the acceptability of food products. In this sense, the potential synergistic activity of EO compounds can be harnessed as an alternative means of reducing the active doses needed to achieve antimicrobial effects in food. Thus, the purpose of Chapter 2. IV was to analyse the potential interactions between CA, EU, cinnamaldehyde, thymol and eucalyptol, against $E$. coli and $L$. innocua by determining the minimum inhibitory concentration of each active compound and the fractional inhibitory concentration index for the binary combinations of EO compounds. The most remarkable synergistic effect was observed for CA-cinnamaldehyde blends for both $E$. coli and L. innocua, but using different compound ratios (1:0.1 and 0.5:4, respectively for each bacteria). Nonetheless, significantly higher EO amounts were required to achieve antimicrobial effects when applied to food matrices, due to the interactions between the active compounds and different food components that could limit their effectiveness as antimicrobials. Thus, in Chapter 2. $\mathbf{V}$ the antibacterial effect of PHBV films containing different EO compounds (Chapter 1.II) was analysed in food matrices of different composition (cheese, chicken breast and pumpkin and melon slices). Moreover, the migration of CA and EU in the different food matrices was determined to analyse the food matrix effect on the antimicrobial effectiveness of the films. The microbial growth reduction in foods was less remarkable than in in vitro test by using the active films. In fact, although significant antilisterial effects were shown in vitro, they were not observed in any food matrix. The most significant antibacterial effects against $E$. coli were reported in cheese and pumpkin, whereas the highest migration of both CA and EU took place in melon. This lack of correlation between the antimicrobial activity and the migration of the active compounds reflected that many compositional factors affect the availability of the active compounds to exert its antibacterial action in a specific food.

Developing multilayer structures where materials with complementary properties are combined in the same sheet is also an interesting approach to overcome the shortcomings of the PHBV films. In this sense, starch is widely available at low cost and provides biodegradable films with great oxygen barrier capacity, whereas PHBV films have good water vapour barrier and high tensile strength. Therefore, the combination of both biopolymers could offer packaging materials with interesting properties due to their complementary characteristics. Nonetheless, the lack of compatibility between both polymers hindered their combination either by blending or in a bilayer structures (lack of adhesion). Based on the greater compatibility between PLA and starch, PLA-PHBV blends previously optimized in terms of mechanical, barrier and thermal properties, were used to develop bilayer structures with 
starch monolayers in order to obtain films with improved performance (Chapter 3. VI). The 75:25 PLA-PHBV formulation with PEG100 (PLA $75:$ PHBV $_{25}-\mathrm{PEG)}$ ) exhibited the best overall properties in terms of extensibility and water vapour permeability and, thus, was used to be the carrier of carvacrol by casting. This formulation was stiffer and less stretchable when obtained by casting, although carvacrol incorporation into casted films greatly enhanced their extensibility, reducing the stiffness and water vapour permeability. Two different approaches were considered to obtain active bilayer films with carvacrol, based on starch and $\mathrm{PLA}_{75}$ :PHBV 25 -PEG monolayers. The incorporation of carvacrol by spraying it between the melt blended and compression moulded polyester and starch sheets was not effective at retaining the compound in the film, mainly due to the radial flow promoted by the compound (especially in the starch layer) during thermo-compression, which dragged a large proportion of the active to the edges of the film. However, the incorporation of CA into casted polyester films and subsequent thermo-compression with starch sheets, was highly effective at providing practically total CA retention in both mono and bilayers. These active bilayers exhibited highly improved tensile and water vapour barrier capacity with respect to the starch monolayer and inhibited the growth of L. innocua and E. coli from both polyester or starch contact sides of bilayers, depending on the internal diffusion of carvacrol through the bilayer and its adequate release of the compound into the culture medium. Therefore, cast PLA-PHBV blend films can be used as carriers of carvacrol for the purpose of obtaining well-adhered bilayers by thermocompression with starch, with adequate tensile and barrier properties and antibacterial activity due to the good retention of the active during the film processing and its adequate release into food systems of differing polarities.

Alternative active agents to EOs have been considered in order to obtain active packaging materials without impact on the sensory profile of the packed foodstuffs. In this context, bioactive xylans obtained from lignocellulosic by-products can be potential natural substitutes of synthetic antibiotics and antioxidants, thus meeting the consumer demand for safer products. In addition, the high cellulose content of the lignocellulosic biomass can be exploited to obtain cellulosic based materials such as cellulose nanocrystals (CNCs), which can be used as fillers to develop biocomposites with enhanced mechanical performance. In this sense, the feasibility of obtaining high value products, such as bioactive compounds and cellulosic reinforcing agents, from rice husk (an important agricultural by-product) have been studied by using sequential subcritical water extraction (SWE) prior to bleaching and acid hydrolysis (Chapter 4. VII). SWE is a green process intended to substitute the common alkali pretreatment, which can better preserve bioactivity of the hemicellulose fractions. The yields and properties of the obtained fractions were compared to those found using the alkali pretreatment. Thus, the proposed hydrothermal approach for the rice husk valorization allowed for obtaining bioactive hemicellulose fractions, with antioxidant and antibacterial activity, useful as additives for food or food packaging, at the same time that it supposes an ecofriendly process, avoiding the use of alkali solutions. Despite the fact that it was less effective 
at purifying the cellulosic fraction, the subsequent bleaching and acid hydrolysis mitigate this apparent drawback, thus obtaining CNCs with a high aspect ratio, which confer them very good reinforcing capacity to obtain improved composites. Moreover, this alternative process would allow for the silica recovery, which was extracted in the alkali step, and maintained in the SWE.

The following figures summarize the main functional properties of all films obtained in this doctoral thesis, for a better understanding of the main results. In order to compare the main effects of the film composition and the film processing strategy on the outcoming parameters, the results have been brought together taking into account the different chapters of the thesis, as described in Table 1.

Figure 1 shows the correlation EM (Elastic Modulus, MPa) -TS (Tensile Strength, MPa) map where of all the films are located. As it can be observed, PHBV monolayer films (blue square) showed high rigidity and resistance to break, close to some conventional plastics such as PP and with better performance than LDPE and HDPE materials. Likewise, pure PLA films (grey square) were significantly more resistant than those materials based on PHBV. As commented on above, the polymer inter-chain forces were weakened by the incorporation of plasticizers in both PHBV and PLA films, as deduced by the decrease in the film stiffness (EM) and resistance (TS). Nonetheless, plasticized PHBV films were stiffer and more resistant than plasticized PLA films. Thermo-compressed PLA-PHBV films without plasticizer showed a mechanical behaviour similar to that of plasticized PHBV films, but less rigid and resistant materials were obtained by incorporating PEG1000 in thermo-processed polyester blend films. As concerns the plasticized polyester blend films obtained by casting, significant differences were observed by incorporating carvacrol. In this sense, those films without carvacrol showed mechanical properties similar to plasticized PHBV films, whereas those containing carvacrol were more similar to the PHBV bilayer films containing EOs (orange dots), which showed intermediate tensile properties. Stiffer and more resistant materials were obtained by combining starch and polyester sheets (yellow dots) as compared to $S$ films (yellow square), the bilayers with casted polyester monolayer being more suitable.

In general, the materials obtained in the different chapters were less extensible than the commercial synthetic polymers. Slightly more stretchable films were obtained by incorporating PEG1000 into PHBV films, as compared to the neat PHBV films. Nonetheless, the PEG addition in the PLA matrix yielded plasticized materials with significantly higher stretchability (57\%). Likewise, the incorporation of CA in a polyester casting solution yielded PLA:PHBV-PEG-CA $c$ films with greatly enhanced extensibility (130\%). As concerns the thermoprocessed bilayer assemblies, the greatest stretchability $(25 \%)$ was obtained by spraying CA at the interface between the polyester and the starch layers. 


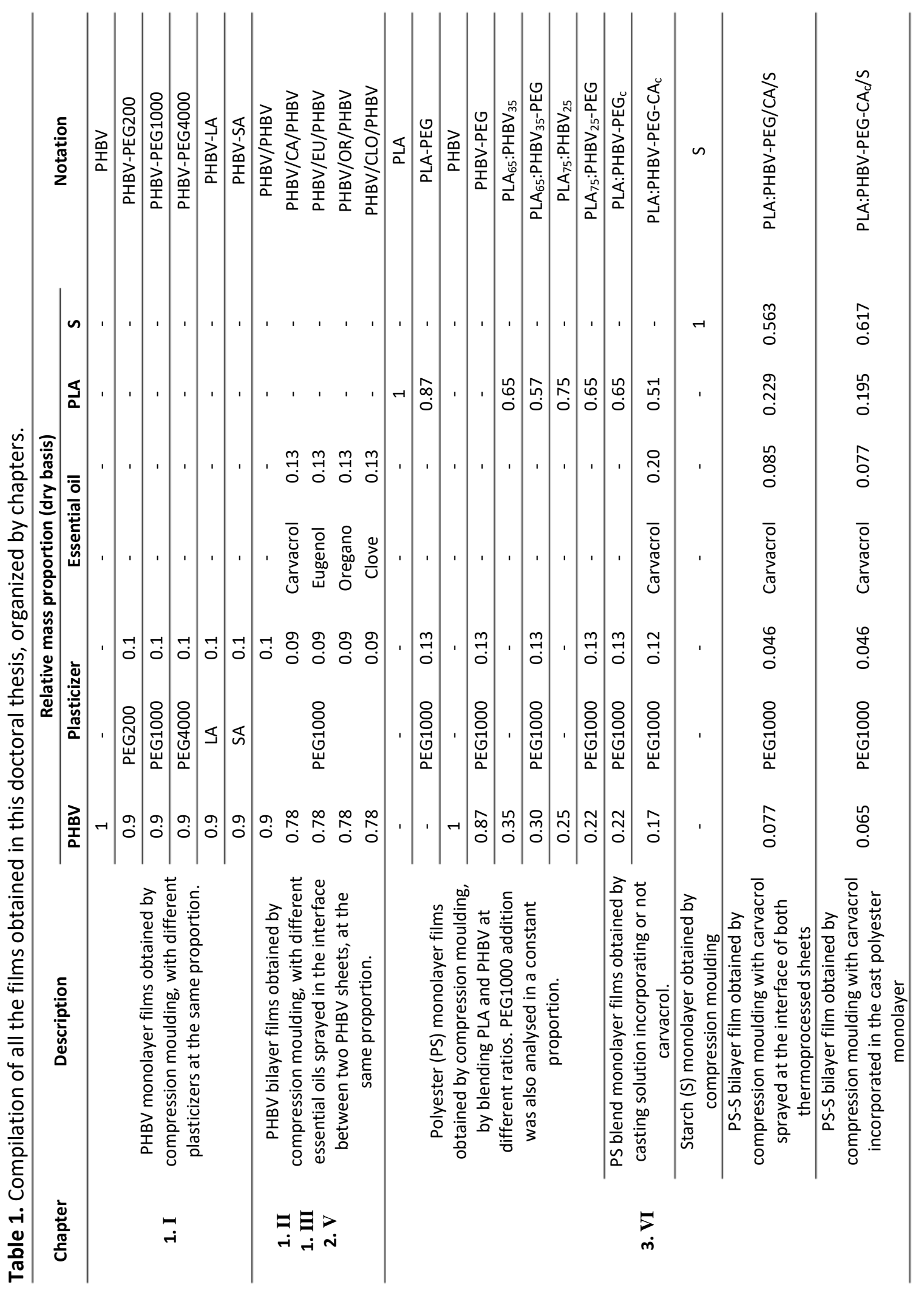




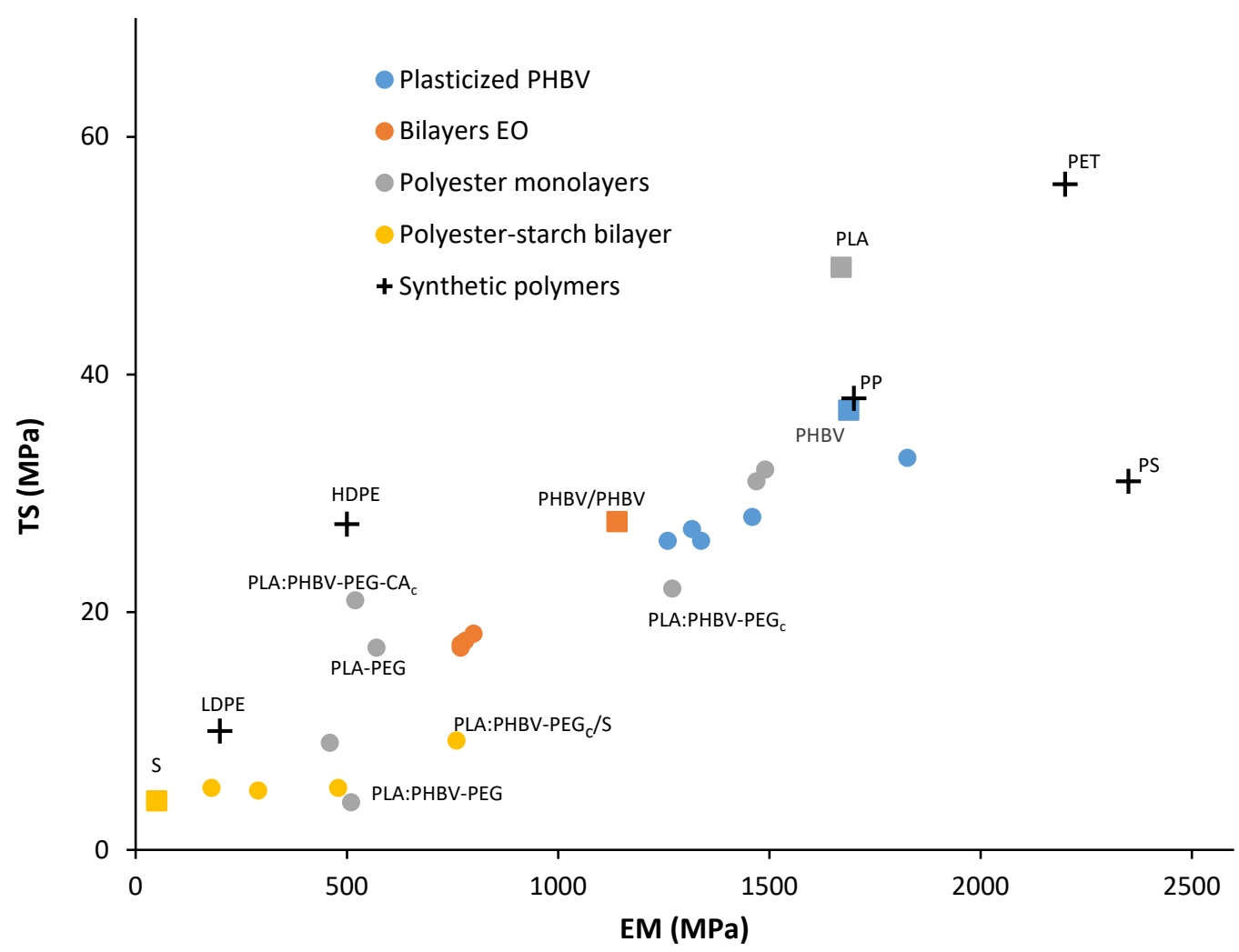

Figure 1. Map of mechanical properties (Tensile Strength vs. Elastic Modulus) showing the location of the different film formulations and some synthetic plastics commonly used in food packaging (HDPE, LDPE, PET, PP, PS, Cho et al., 1998; Shudesh et al., 2000; Plackett, 2012).

One of the most important parameters for food packaging is the barrier capacity of the materials in terms of water vapour, since these small molecules are able to move from the internal or external environment through the polymer package wall, resulting in possible negative changes in the product quality and shelf-life. In Figure 1, the water vapour permeability (WVP) of the studied film formulations can be observed, together with the values of some synthetic polymers. The water vapour barrier capacity of the PHBV films was worsened by the plasticizer addition, whereas EO compounds yielded slightly lower WVP values as compared to the neat PHBV bilayer (PHBV/PHBV). In any case, all PHBV-based formulations showed water barrier properties that were similar to those of synthetic plastics. Likewise, PLA and PLA-PHBV based materials showed WVP values in the range of commercial polymers for food packaging applications. Although slightly lower water vapour barrier capacity was obtained for the polyester-starch bilayer structures, all these formulations led to materials with greatly enhanced water vapour permeability compared to the starch sheets, while starch layer provides high barrier capacity to oxygen and other gases. 
As concerns the release of the actives from the studied film, Table $\mathbf{2}$ summarizes the maximum percentage of released compound $\left(\mathrm{M}_{\infty} / \mathrm{M}_{0}\right)$ from the films, with respect to the initial content in the films, for different food simulants. As can be observed, this ratio depended on the type of active used, solvent polarity, swelling capacity and relaxation of the polymer matrix on each solvent, the presence of interactions among components and the method used to prepare the films, among other factors.

At equilibrium, a total release of both active compounds, CA and EU, occurred in $50 \%$ ethanol (simulating high fat content, oil-in-water foods) from the PHBV bilayers (Chapter 1. III), whereas significantly lower amounts were delivered in the more aqueous systems, regardless of the $\mathrm{pH}$. In fatty systems, $65-70 \%$ of the active content was delivered at equilibrium. The release rate was enhanced when the polarity of aqueous systems decreased ( $50 \%$ ethanol). Similar CA release ratios were obtained in Chapter 3. VII from casted polyester monolayers and its corresponding bilayer assembly with starch sheets, which showed significantly higher release ratio in non-polar simulants.

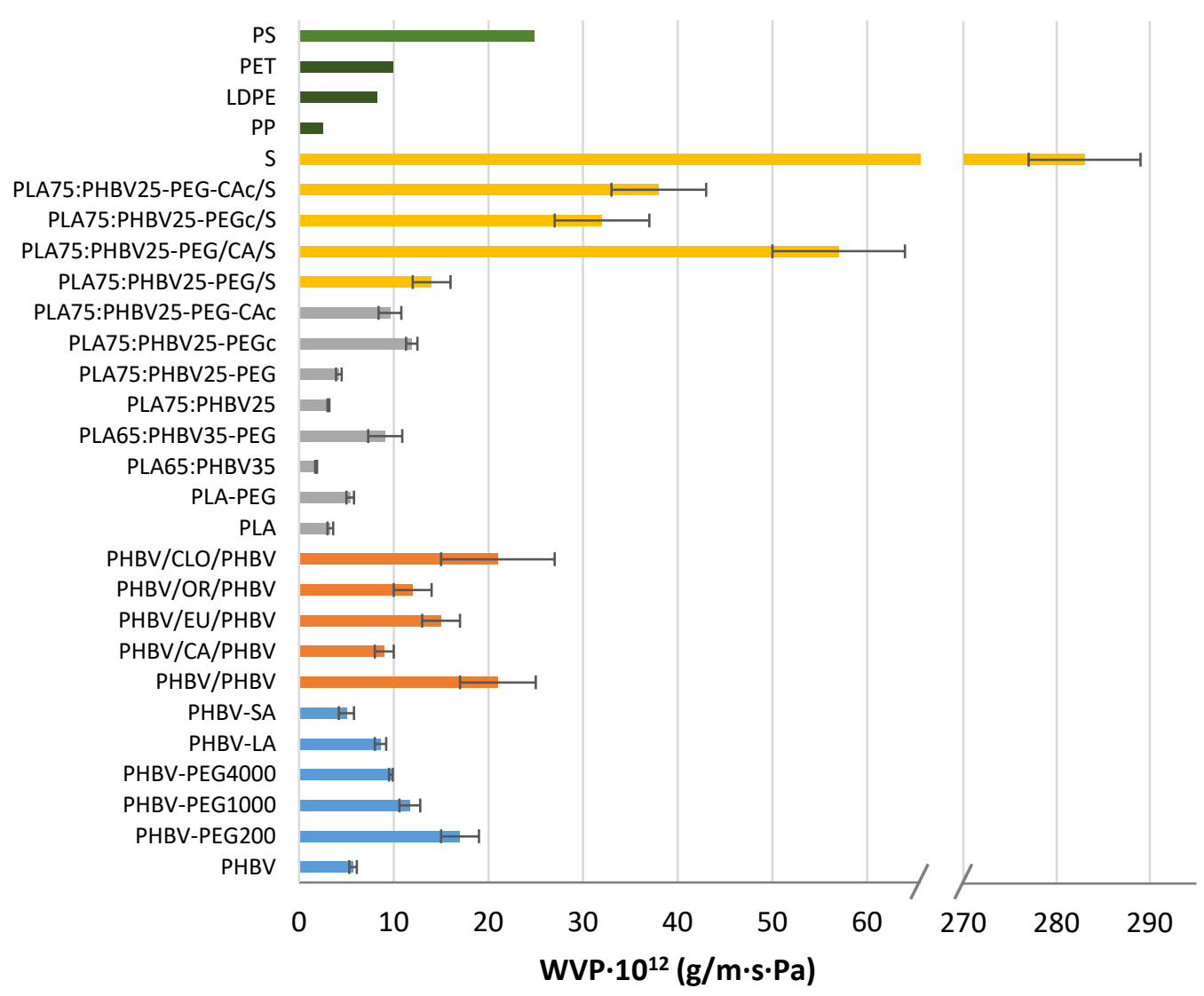

Figure 2. Water vapour permeability values of the different film formulations and some synthetic plastics commonly used in food packaging (PP, LDPE, PET and PS, green, Plackett, 2012). Chapter 1. I (blue); Chapter 1. II (orange); polyester monolayers in Chapter 3. VI (grey) and polyester-starch bilayers in Chapter 3. VI (yellow). 
Table 2. Mass of active released at equilibrium in the simulant related to the theoretical incorporated amount $\left(M_{\infty} / M_{0}(\%)\right)$ for the active films formulations whose release kinetic was studies.

\begin{tabular}{lcccc}
\hline \multirow{2}{*}{ Simulant } & \multicolumn{2}{c}{ Chapter 1.III } & \multicolumn{3}{c}{ Chapter 3.VI } \\
\cline { 2 - 6 } & PHBV/CA/PHBV & PHBV/EU/PHBV & PLA:PHBV-PEG-CA & PLA:PHBV-PEG-CA $/$ CA/S \\
\hline 3\% Acetic acid & 23 & 52 & 25 & 11 \\
10\% Ethanol & 22 & 47 & 19 & 22 \\
50\% Ethanol & 96 & 92 & 76 & 110 \\
Isooctane & 65 & 71 & 86 & 70 \\
\hline
\end{tabular}

The antimicrobial capacity of the active films was affected by the film composition and the processing method. Table 3 summarizes the reduction in microbial counts for $E$. coli with the different active films, as compared to the inoculum in in vitro test (agar) and in the different food matrices after 6 days of incubation at $10^{\circ} \mathrm{C}$. Although significant antimicrobial activity was observed against L. innocua in the in vitro test for all PHBV bilayers with EO compounds, no antimicrobial effects were detected in any food matrix. Conversely, these active bilayers inhibited the bacterial growth of $E$. coli in almost all the tested foodstuffs to a greater or lesser extent. It is worthy to mention that by using the same active amount per surface unit of film, a greatly improved antimicrobial activity of CA was obtained for both casted polyester monolayer and its corresponding polyester-starch bilayer, against both bacteria in the in vitro studies.

Table 3. Count reduction of Escherichia coli with the different active films, as compared to the inoculum, (Log CFU difference) in the in vitro test and in the different food matrices after 6 days of incubation at $10^{\circ} \mathrm{C}$.

\begin{tabular}{lcccccc}
\hline \multirow{2}{*}{ Matrix } & \multicolumn{4}{c}{ Chapter 2.V } & \multicolumn{2}{c}{ Chapter 3.VI } \\
\cline { 2 - 7 } & PHBV/CA/PHBV & PHBV/EU/PHBV & PHBV/OR/PHBV & PHBV/CLO/PHBV & PLA:PHBV-PEG-CAc & PLA:PHBV-PEG-CAc/CA/S \\
\hline Agar & 4.2 & 1.7 & 2.7 & 1.1 & 8.8 & $7.5-6.8$ \\
Cheese & 2.1 & 3.2 & 2.8 & 3.5 & N/A & N/A \\
Chicken & 1.7 & 2.2 & - & 1.7 & N/A & N/A \\
Pumpkin & 2.8 & 2.3 & 1.9 & 1.7 & N/A & N/A \\
Melon & - & 1.0 & - & - & N/A \\
\hline
\end{tabular}

N/A: non applicable 
As main conclusion, we can mention that PHBV exhibited adequate properties to obtain biodegradable active films for food packaging applications when plasticised with PEG1000, which can be modulated by incorporating essential compounds, such as eugenol or carvacrol, which confer antimicrobial properties to the material at the same time that positively modify barrier properties of the films. Blending PHBV with PLA also enhanced the film functionality, allowing for obtaining bilayer films with thermoplastic starch, with good mechanical properties and adequate barrier capacity for water vapour and oxygen. The PHBV-PLA monolayer can carry the non-polar active compounds, which effectively diffuse through the bilayer assembly and, thus, it can act as antimicrobial material from the different contact sides, depending on the kind of food application. In this sense, the films exhibited adequate release capacity of the active compounds, which favour their antimicrobial properties. Incorporating hemicellulose active fractions obtained by SWE and cellulosic materials from rice husk, to the obtained films could also improve the properties of PHBV-based materials or bilayer assemblies, avoiding the potential sensory impact of the essential oil compounds. 

CONCLUSIONS 
1. The used plasticizers led to apparently homogeneous PHBV-based matrices, as supported by DSC analyses, but crystallization of SA in the films occurred. Although the addition of PEG and LA significantly decreased the stiffness and the resistance to break of PHBV films, only PEG1000 yielded more extensible films. PEG1000 was also the only plasticizer that partially mitigated ageing effects. All plasticizers, except SA, increased the water affinity of the films, promoting an increase in WVP and water solubility. Likewise, all plasticizers slightly decreased the crystallinity degree and the thermal stability of the films. PEG1000 and PEG4000 gave rise to the most heat-resistant plasticized films while LA and SA highly promoted the heatsensitivity of PHBV. Among the studied compounds, PEG1000 was the most effective at plasticizing PHBV films, although additional strategies would be required to adapt PHBV mechanical properties to certain packaging requirements.

2. PHBV bilayer films with active compounds incorporated at the interface between the layers were obtained by compression moulding, with a good layer adhesion and homogeneous structure. This method produced antimicrobial films with appropriate tensile, optical and water vapour barrier properties, and with good thermal stability, even if the incorporation of active compounds significantly affected the physical properties of the films. Although the studied actives did not improve the tensile properties of the films, more transparent materials with better water vapour barrier capacity were obtained. As regards thermal stability, while $\mathrm{CA}$ and EU gave rise to a slight decrease in the thermal stability of the polymer matrix, OR and CLO led to more thermally resistant materials. The compound miscibility into the polymer matrix was confirmed by DSC analyses, where a notable decrease in the polymer melting temperature and crystallinity was observed when active compounds, especially whole EOs, were incorporated. The release of the active ingredients from the films was adequate to control the growth of E. coli and L. innocua in culture media. Active films were significantly more effective against $E$. coli than against $L$. innocua, and both bacteria were more sensitive to $\mathrm{OR}$ and its main compound, $\mathrm{CA}$. The greater antimicrobial activity of films containing CA was attributed to the higher effectiveness of $C A$, since the amount of EU released from the film was higher than the amount of CA released. Therefore, incorporation of natural antimicrobials such as those studied, especially CA and OR, into bilayer films of PHBV could be a promising option for the development of active biodegradable films

3. PEG plasticized PHBV active films with CA and EU could be obtained by incorporating them between two polymer layers by spraying the active, and subsequent compression moulding. Although $15 \mathrm{~g}$ of actives per $100 \mathrm{~g}$ polymer matrix were incorporated, about $5 \%$ of these were lost during thermal compression and the bilayer films contain about $12 \mathrm{~g}$ of actives per $100 \mathrm{~g}$ of film. This method simulates incorporating actives and adhesive at the same time during the industrial production of multilayer films. CA and EU diffused through the polymer layers and were effectively released into different food simulants. At equilibrium, a total release of both CA and EU occurred in $50 \%$ ethanol (simulating high fat content, oil-in-water foods), whereas around 20 and $50 \%$ of the content, for CA and EU respectively, was delivered in the more 
aqueous systems, regardless of the $\mathrm{pH}$. In fatty systems, $65-70 \%$ of the active content was delivered at equilibrium. The release rate was enhanced when the polarity of aqueous systems decreased ( $50 \%$ ethanol), but it fell markedly in fatty systems (isooctane). The delivery of EU from PHBV films plasticized with PEG was slower than that of CA in aqueous systems, but this tendency was inverted when the polarity of the medium decreased. On the basis of the release kinetics, the antimicrobial activity against some foodborne pathogens could be predicted, taking the reported minimal inhibitory concentration of each compound into account. This concentration was reached for CA in every simulant tested at different times, which permits its effective antimicrobial action to be predicted. Nevertheless, EU did not reach the antimicrobial levels of some pathogens in neutral and acid aqueous systems or in fatty foods. However, antimicrobial in vivo tests are required to assess the antimicrobial effectiveness of these kinds of materials in real foods.

4. The MTT method was effective at evaluating the potential synergistic antibacterial effect simply and quickly through the FIC index assessment of blends of active components from essential oils, which can be easily standardized. This method provided reliable MIC values of the active compounds, as well as the FIC index value of their binary combinations over a wide concentration range below the respective MICs. The most remarkable synergistic effect was observed for carvacrol/cinnamaldehyde blends for both E. coli and L. innocua, but using different compound ratios (1:0.1 and 0.5:4 respectively for each bacteria). In general, the obtained results concerning the synergistic effects of the EO components agree with those reported by other authors, although some discrepancies were obtained that are attributable to the antimicrobial susceptibility method used (temperature, culture media, $\mathrm{pH}$, bacterial strain). Likewise, the MTT method allows for a wide range of concentrations to be tested, which better permits the estimation of the optimal ratio of active compounds with which to obtain the maximum synergy. The synergistic effect was more notable in the Gram-positive bacteria than in the Gram-negative, which could be attributed to the different bacterial cell envelope. The obtained results allowed the dose of active compounds used for food application purposes to be optimized, thus minimizing their sensory impact.

5. PHBV films with active essential oil compounds were highly effective against $L$. innocua and $E$. coli in in vitro tests, but they were much less effective in the real foods tested, with the exception of the effect against $E$. coli in cheese samples coated with PHBV-EU or PHBV-CLO films. No antilisterial effect was observed in any food matrices. The most significant antimicrobial effects against $E$. coli were observed in fresh cheese, for PHBV-EU and PHBVCLO films, and fresh-cut pumpkin, for PHBV-CA and PHBV-OR films. In general, although the percentages of $\mathrm{CA}$ and EU migration led to active contents in the food matrices that were higher than their MICs, they were not always effective. The highest migration of both CA and UE took place in melon, whereas the lowest migration was quantified in pumpkin samples and in the culture medium. In contrast, no significant antimicrobial activity of the films was observed in melon, while they were very effective against $E$. coli in the culture medium and 
the pumpkin samples. The lack of correlation between the amount of active that migrated to the food and the antibacterial effect observed in the different matrices reflected the fact that many compositional factors affect the active compound's availability to exert its antibacterial action on a specific food composition, which, in turn, has a different nutritious/protective effect on the bacteria. Therefore, antimicrobial analyses are required that are specific to the food in question to ensure the effectiveness of a particular antimicrobial packaging material.

6. The properties of thermoprocessed PLA-PHBV blends were affected by the polymer proportion and the presence of PEG as plasticizer. The PLA glass transition and crystallinity of both polymers changed in the different blends, indicating the presence of different domains richer in either PLA or PHBV, with limited partial miscibility, all of which is affected by the different PEG plasticization of such domains. The 75:25 PLA-PHBV formulation with PEG exhibited the best overall properties in terms of extensibility and water vapour permeability and, thus, was used to be the carrier of carvacrol by casting. This formulation was stiffer and less stretchable when obtained by casting, although carvacrol incorporation into cast films greatly enhanced their extensibility, reducing the stiffness and water vapour permeability. The incorporation of carvacrol by spraying between the polyester and starch sheets was not effective at retaining the compound in the bilayers, mainly due to the radial flow promoted by the compound (especially in the starch layer) during thermocompression, which dragged a large proportion of the active to the film's edge. In contrast, the incorporation of carvacrol into cast polyester blend films, and the subsequent formation of bilayers with the starch sheets by means of thermo-compression, was highly effective at providing the practically total retention of carvacrol in both mono and bilayers. These active bilayers not only exhibited highly improved tensile and water vapour barrier capacity with respect to the starch monolayer ( $87 \%$ reduction in WVP, $840 \%$ increase in elastic modulus) but also antibacterial properties against $L$. innocua and E. coli from both contact sides (polyester or starch) of the bilayer, depending on the internal diffusion of carvacrol through the bilayer and the adequate release of the compound into the culture medium. Then, cast PLA-PHBV blend films can be used as carriers of carvacrol for the purposes of obtaining well-adhered bilayers films with starch by means of thermocompression, with adequate tensile and barrier properties and antibacterial activity due to the good retention of the active during the film processing and its adequate release into food systems of differing polarities.

7. As concerns the rice husk valorization to obtain high value products such as bioactive compounds and cellulosic reinforcing agents, SWE process allows for obtaining better preserved hemicellulose fractions, with antioxidant and antibacterial activity, useful as additives for food or food packaging, at the same time that it supposes a more eco-friendly process, avoiding the use of alkali solutions. Despite the fact that it was less effective at purifying the cellulosic fraction, the subsequent bleaching and acid hydrolysis mitigate this apparent drawback, at the same time that gave additional value to the process due to the fact 
that would allow for the silica recovery, which was extracted in the alkali step, and maintained in the SWE. This fraction of high value could be separated from the SWE-hydrolysate fraction which also contains the CNCS. The CNC obtained from rice husk exhibited a high aspect ratio which confer them very good reinforcing capacity to obtain improved composites.

As main conclusion, we can mention that PHBV exhibited adequate properties to obtain biodegradable active films for food packaging applications when plasticised with PEG1000, which can be modulated by incorporating essential compounds, such as eugenol or carvacrol, which confer antimicrobial properties to the material at the same time that positively modify barrier properties of the films. Blending PHBV with PLA also enhanced the film functionality, allowing for obtaining bilayer films with thermoplastic starch, with good mechanical properties and adequate barrier capacity for water vapour and oxygen. The PHBV-PLA monolayer can carry the non-polar active compounds, which effectively diffuse through the bilayer assembly and, thus, it can act as antimicrobial material from the different contact sides, depending on the kind of food application. In this sense, the films exhibited adequate release capacity of the active compounds, which favour their antimicrobial properties. Incorporating hemicellulose active fractions obtained by SWE and cellulosic materials from rice husk, to the obtained films could also improve the properties of PHBV-based materials or bilayer assemblies, avoiding the potential sensory impact of the essential oil compounds. 